\title{
Historic Landscape Inventory for Knoxville National Cemetery
}

Susan I. Enscore, Adam D. Smith, and Megan W. Tooker

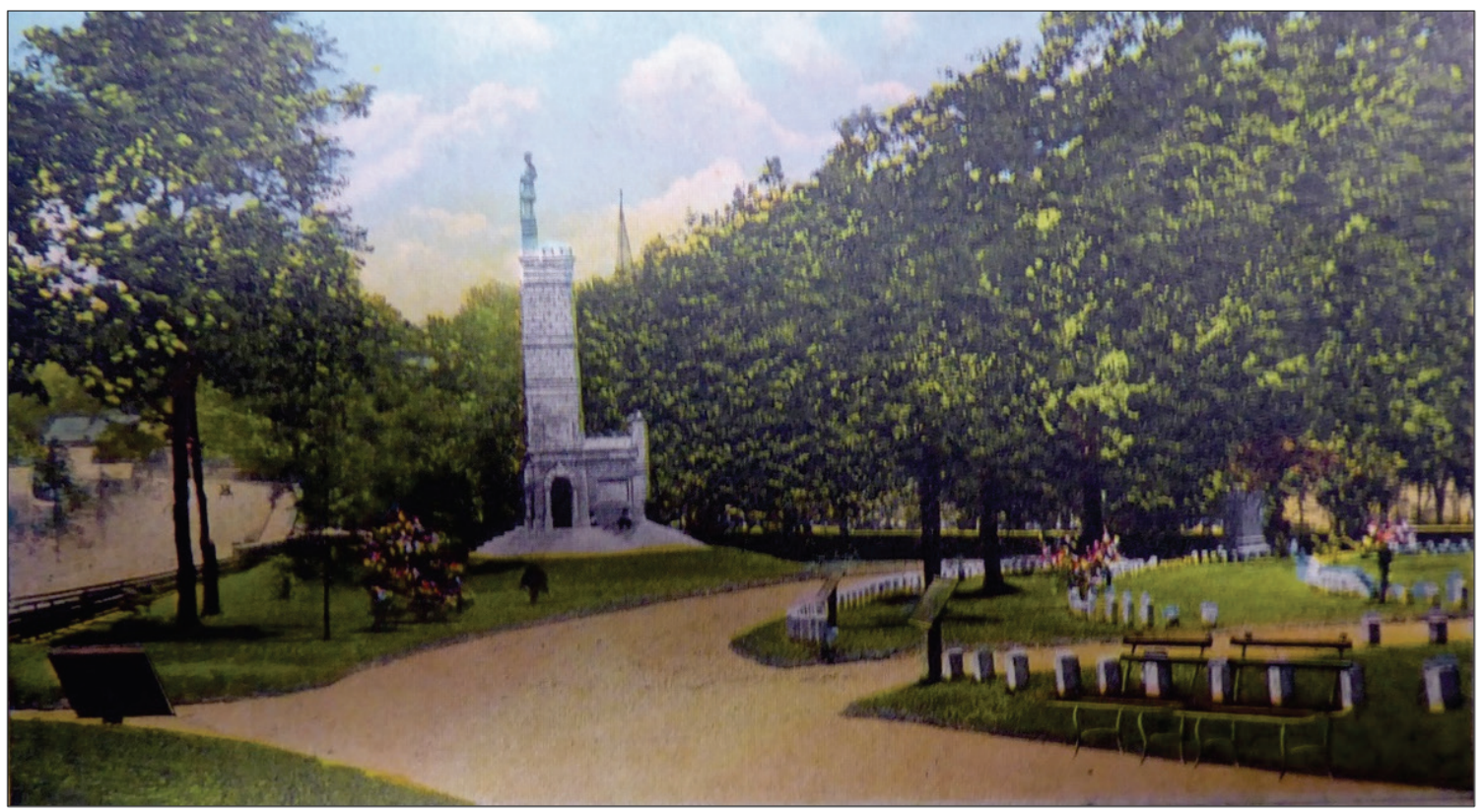


The U.S. Army Engineer Research and Development Center (ERDC) solves the nation's toughest engineering and environmental challenges. ERDC develops innovative solutions in civil and military engineering, geospatial sciences, water resources, and environmental sciences for the Army, the Department of Defense, civilian agencies, and our nation's public good. Find out more at www.erdc.usace.army.mil.

To search for other technical reports published by ERDC, visit the ERDC online library at https://erdclibrary.on.worldcat.org/discovery. 


\title{
Historic Landscape Inventory for Knoxville National Cemetery
}

\author{
Susan I. Enscore, Adam D. Smith, and Megan W. Tooker
}

U.S. Army Engineer Research and Development Center (ERDC)

Construction Engineering Research Laboratory (CERL)

2902 Newmark Dr.

Champaign, IL 61824

Final

Approved for public release; distribution is unlimited.

Prepared for U.S. Department of Veterans Affairs

National Cemetery Administration

Washington, DC 20420

Under Project 467132: "Cultural Landscape Survey for Knoxville National Cemetery, Tennessee" 


\section{Abstract}

This project was undertaken to provide the U.S. Department of Veterans Affairs National Cemetery Administration with a cultural landscape survey of Knoxville National Cemetery. The 9.8-acre cemetery is located within the city limits of Knoxville, Tennessee, and contains more than 9,00o burials. Knoxville National Cemetery was placed on the National Register of Historic Places on 12 September 1996, as part of a multiple-property submission for Civil War Era National Cemeteries.

The National Cemetery Administration tasked the U.S. Army Engineer Research and Development Center-Construction Engineering Research Laboratory (ERDC-CERL) to inventory and assess the cultural landscape at Knoxville National Cemetery through creation of a landscape development context, a description of current conditions, and an analysis of changes over time to the cultural landscape. All landscape features were included in the survey because according to federal policy on National Cemeteries, all national cemetery landscape features are considered to be contributing elements.

DISCLAIMER: The contents of this report are not to be used for advertising, publication, or promotional purposes. Citation of trade names does not constitute an official endorsement or approval of the use of such commercial products. All product names and trademarks cited are the property of their respective owners. The findings of this report are not to be construed as an official Department of the Army position unless so designated by other authorized documents. 


\section{Contents}

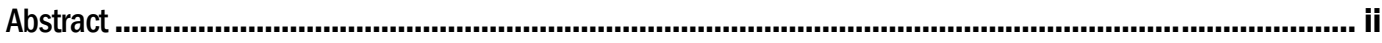

Figures and Tables...........................................................................................................................................vi

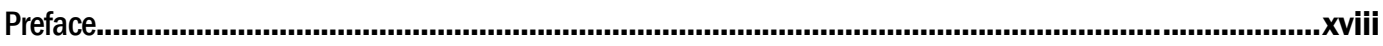

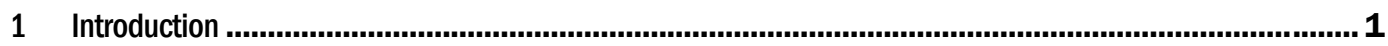

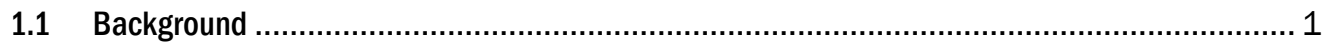

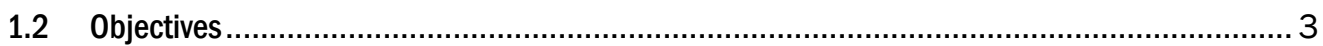

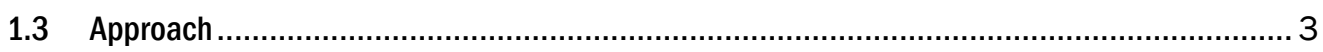

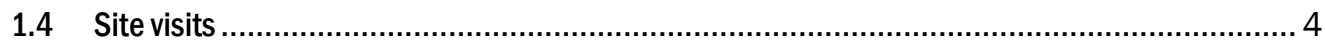

1.4.1 Knoxville National Cemetery .............................................................................................. 4

1.4.2 Archival repositories....................................................................................................... 4

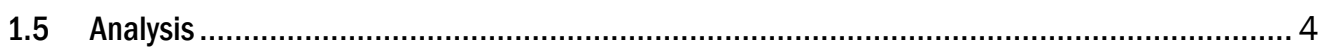

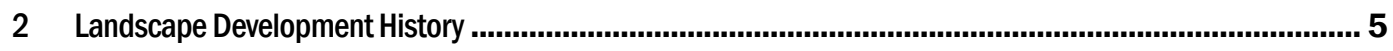

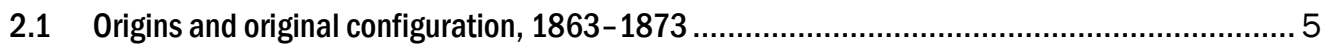

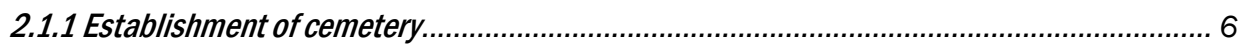

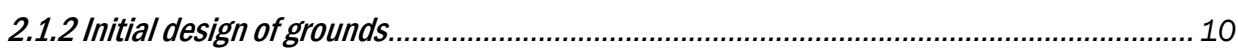

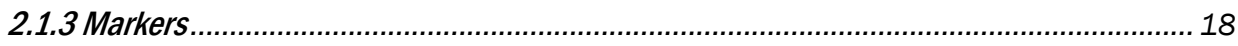

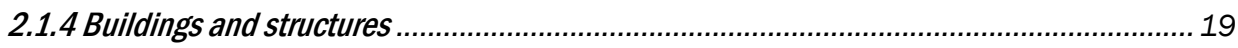

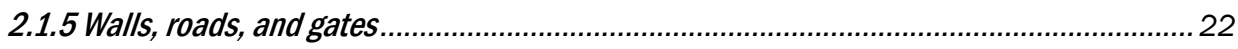

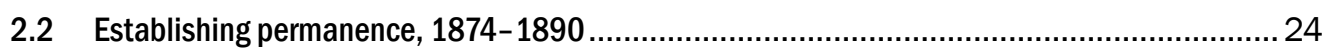

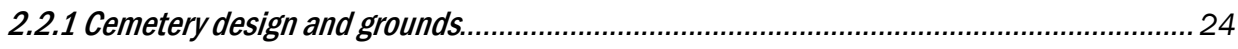

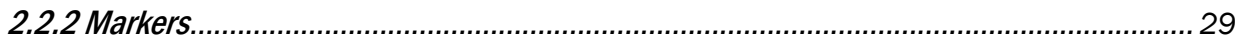

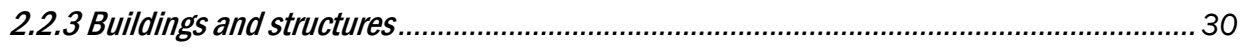

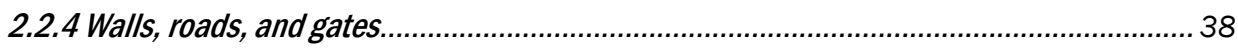

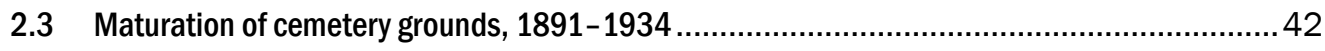

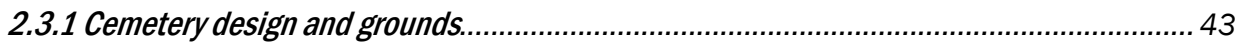

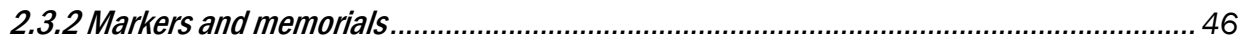

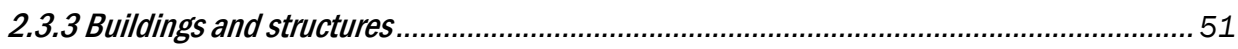

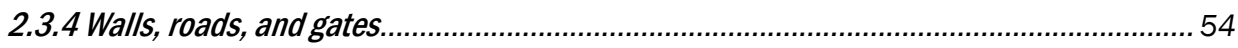

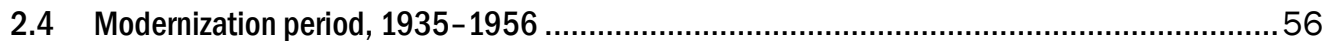

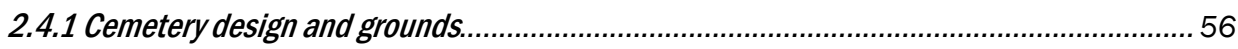

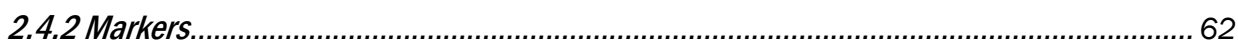

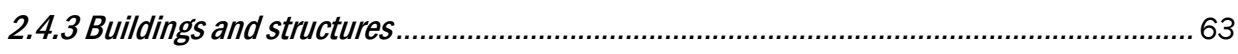

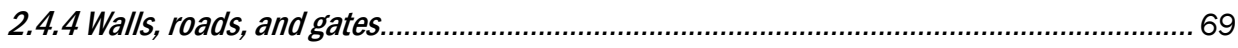

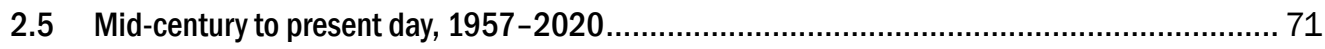

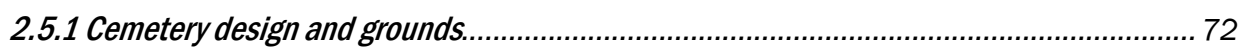

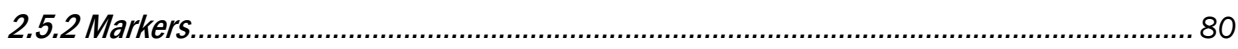

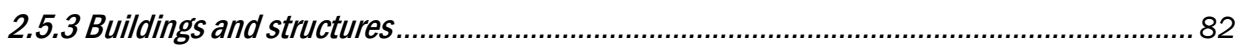

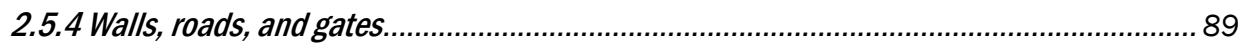




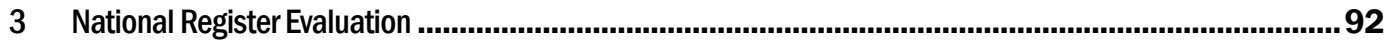

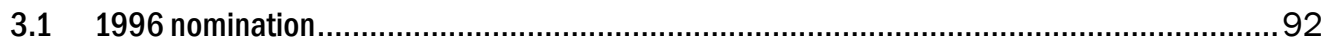

3.2 National Register Eligibility of National Cemeteries - A Clarification Policy (9/8/2011) ........116

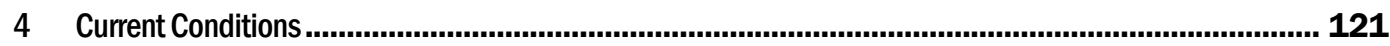

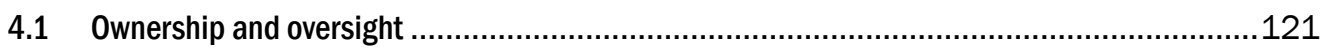

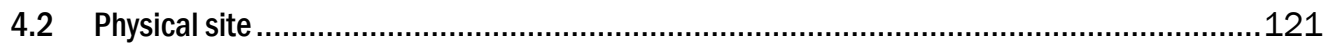

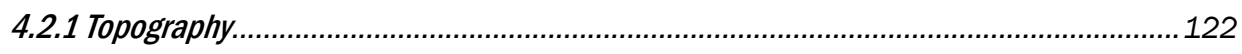

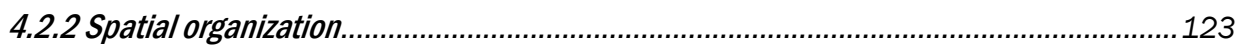

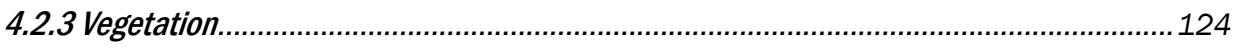

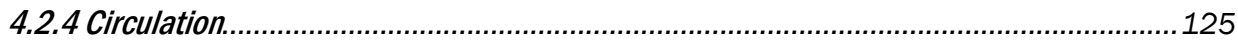

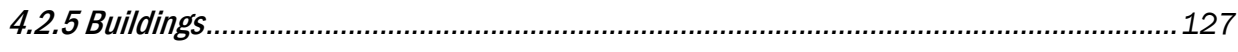

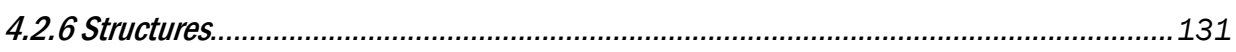

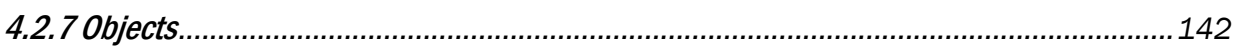

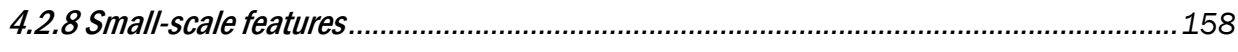

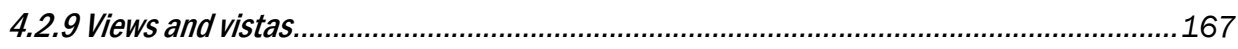

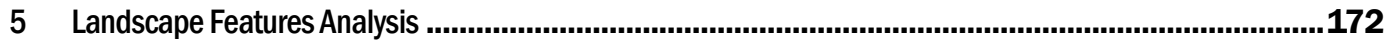

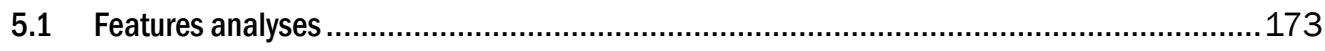

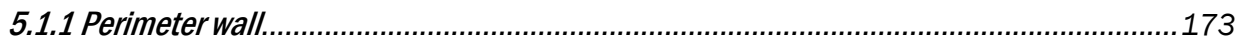

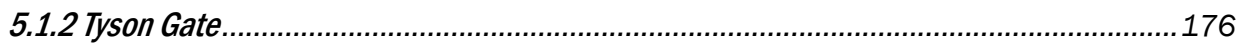

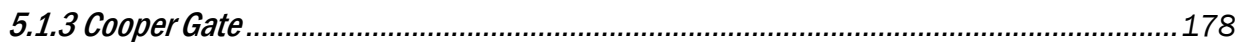

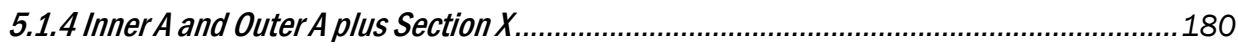

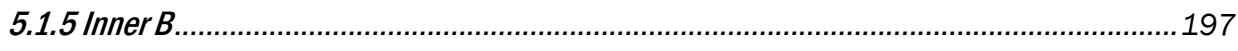

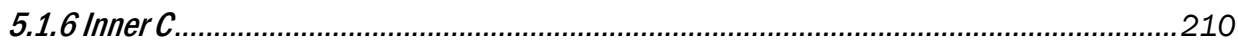

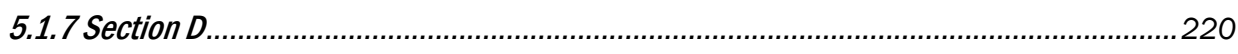

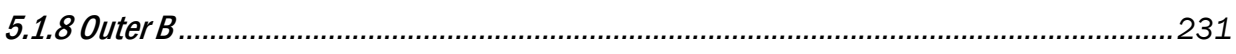

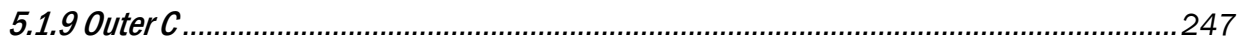

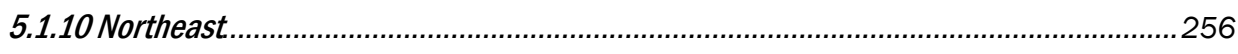

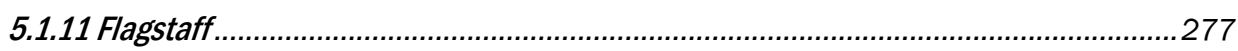

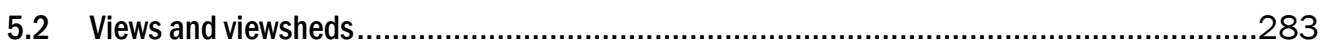

5.2.1 View northeast from Cooper Gate toward flagstaff...................................................2. 283

5.2.2 View southwest from the Tyson Gate ................................................................28

5.2.3 View southeast from Tyson Gate towards Union Soldier Monument..............................286

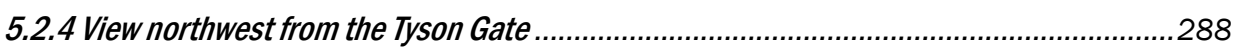

5.2.5 View northeast from circle drive towards flagstaff....................................................28

5.2.6 View southeast from flagstaff towards the Old Gray Cemetery......................................291

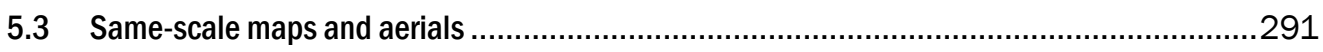

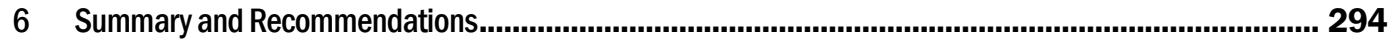

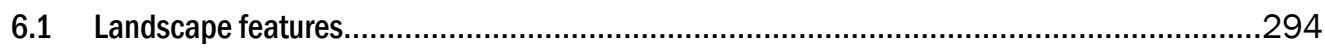

6.1.1 Character-defining landscape features..................................................................29

6.1.2 Character-defining buildings and structures.........................................................295

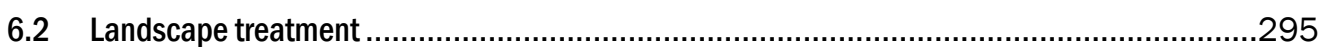

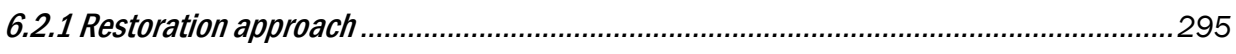

6.2.2 Reconstruction approach................................................................................296 


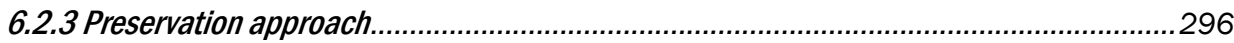

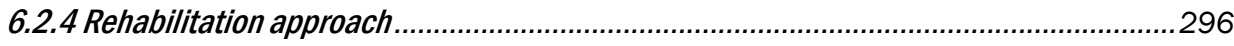

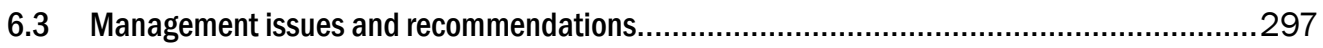

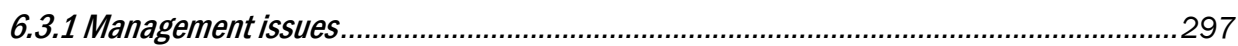

6.3.2 Historic landscape recommendations .....................................................................298

Bibliography ................................................................................................................................. 299

Acronyms and Abbreviations...................................................................................................... 311

Unit Conversion Factors ........................................................................................................................... 312

Report Documentation Page (SF289) ....................................................................................... 313 


\section{Figures and Tables}

\section{Figures}

Figure 1. Location of Knoxville National Cemetery, Knoxville, Tennessee (www.openstreetmap.org, accessed

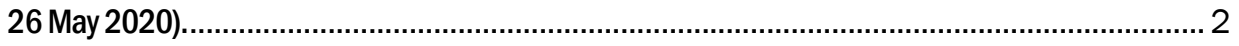

Figure 2. Site map of Knoxville National Cemetery (Google Earth, accessed 13 July 2020)................................ 3

Figure 3. Survey map of land conveyed to the Government for Knoxville National Cemetery, 1867 (NARA,

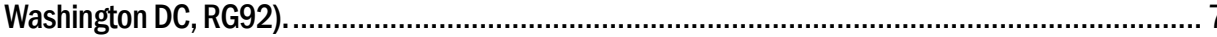

Figure 4. Map of collection area of Union Soldier remains for internment at Knoxville National Cemetery, c.1868 (NARA, Washington DC, RG92-CA) .................................................................. 8

Figure 5. Charles Hart, “Graves of the Highlanders,” Knoxville National Cemetery, 1864 (Library of

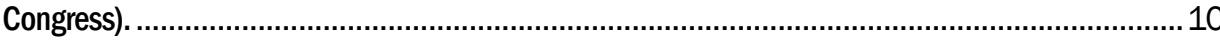

Figure 6. 1866 plan of Knoxville National Cemetery (NARA, Washington DC, RG92).....................................12

Figure 7. Sketch of entry over front and rear gates included in 1867 inspection report (NARA, Washington,

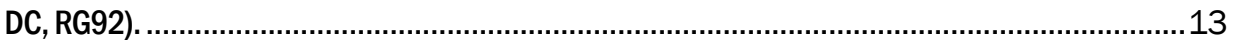

Figure 8. P.M. Radford, Map of Knoxville National Cemetery, 1869 (NARA, Washington DC, RG92)...................15

Figure 9. P.M Radford, View of Knoxville National Cemetery, 1869 (NARA, Washington DC)............................16

Figure 10. Detail of 1871 Birds-Eye View of Knoxville showing Knoxville National Cemetery with flagstaff, concentric rings, and a border of trees (Library of Congress).

Figure 11. Undated postcard showing one of two siege gun monuments located in the Knoxville National Cemetery (University of Tennessee, Knoxville, Library digital collections "Images of East Tennessee").

Figure 12. 1892 map of Knoxville National Cemetery showing location of siege gun monuments (circled), (VA NCA Archives, Washington, DC).

Figure 13. Detail of 1874 sketch plan showing front of the original lodge (NARA, Washington DC, RG92)...........21

Figure 14. Detail of 1874 sketch plan showing original lodge (NARA, Washington DC, RG92)...........................21

Figure 15. 1874 sketch plan showing original lodge to right, with privy, barn and shed to the rear (NARA, Washington DC, RG92)

Figure 16. Wall with iron fence and concrete fence post at north corner by the 1907 lodge, undated photo -

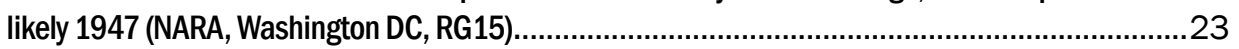

Figure 17. View of the original gate on Cooper Street, 1946 (NARA, Washington, DC, RG15). ......................... 24

Figure 18. Metal tablets flanking either side of entrance road, 1931 (NARA, Washington DC, RG15)................. 27

Figure 19. Plan of northwest Knoxville c.1879 showing closing of Jennings Street and parcel of land purchased by Gray Cemetery in 1879 (NARA, Washington, DC, RG92).

Figure 20. 1874 lodge in c.1910 photograph (NARA, Washington, DC, RG92-CA). .......................................30

Figure 21. Design for Superintendents Lodge, National Cemeteries, Office of the Quartermaster General, U.S. Army, 1871 (NARA, Washington, DC, RG92).

Figure 22. 1874 sketch plan showing 1874 lodge in right center (NARA, Washington DC, RG92). 32

Figure 23. Detail of 1886 Map of Knoxville, showing the Knoxville National Cemetery with the 1874 lodge and vegetation lining the walls (Library of Congress).

Figure 24. Plan of Cistern, Knoxville National Cemetery, 1874 (NARA, Washington DC, RG92)

Figure 25. C. M. Clarke, "Plan for changing Old Lodge into Summer kitchen, Tool House, etc."1874 (NARA, Washington, DC, RG92). 


\section{Figures}

Figure 26. Detail of 1874 sketch plan showing 1874 lodge, cistern, tool house with privies and summer kitchen, and new semi-circular driveway (NARA, Washington DC, RG92).

Figure 27. The 1879 rostrum in its original configuration, Knoxville National Cemetery, c.1932 (NARA, Washington DC, RG15).

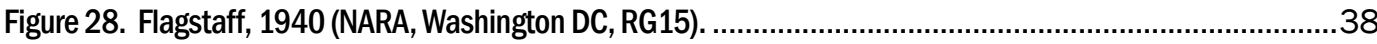

Figure 29. Original Tyson Street gate with rostrum to the right, 1909 (NARA, Washington, DC, RG92-CA)............ 41

Figure 30. Original gate on Tyson Street, 1904 (NARA, Washington DC, RG92-CA)....................................... 41

Figure 31. 1892 Map (revised 1909) of Knoxville National Cemetery, Office of Quartermaster General, U.S. Army (NARA, Washington DC, RG92).

Figure 32. Detail of 1892 map (revised c.1909) showing 1874 lodge with stable, privy, brick paved stable yard, gravel walks, the entrance gate on Cooper Street, and trees and shrubs, Office of Quartermaster General, U.S. Army (NARA, Washington DC, RG92)

Figure 33. Detail of 1892 map (revised c.1909) showing 1907 lodge, rostrum, and trees, Office of Quartermaster General, U.S. Army (NARA, Washington DC, RG92).

Figure 34. 1912 postcard showing spatial relationship between 1907 lodge and rostrum (University of Tennessee, Knoxville, Library digital collections “Images of East Tennessee").

Figure 35. Detail of 1892 map (revised c.1909) showing rostrum, main entrance gate on Tyson Street, and stone wall with iron fencing (NARA, Washington DC, RG92).

Figure 36. Original 1901 Union Soldier Monument (University of Tennessee, Knoxville, Library digital collections "Images of East Tennessee").

Figure 37. Lightning strike damage to the Union Soldier Monument, 1904 (VA NCA Archives, Washington, DC).

Figure 38. Rebuilt Union Soldier Monument, 1911 (University of Tennessee, Knoxville, Library digital collections "Images of East Tennessee").

Figure 39. 1907 Lodge shortly after construction (NARA Washington, DC, RG92-CA). .52

Figure 40. 1907 lodge along Tyson Street, 1931 (NARA, Washington DC, RG15).

Figure 41. 1898 stable building in back of the 1874 lodge, undated photograph (NARA, Washington, DC, RG92-CA)

Figure 42. 1887 Entrance Gates, undated photo - likely 1947 (NARA, Washington DC, RG15). .......................56

Figure 43. Aerial view of Knoxville National Cemetery, 1946 (HALS-TN-2, Library of Congress)..........................58

Figure 44. Planned tree removal sketch map, Section A, 1947 (NARA, Washington DC, RG92). ........................59

Figure 45. Planned tree removal sketch map, Section B, 1947 (NARA, Washington DC, RG92). .......................60

Figure 46. Aerial view of Knoxville National Cemetery, 1948 (HALS-TN-2, Library of Congress).......................... 61

Figure 47. Contour map of Knoxville National Cemetery, 1949 (VA NCA Archives, Washington, DC)....................62

Figure 48. Detail of sketch map showing location of rostrum, lodge, and utility building, 1947 (NARA, Washington DC, RG92).

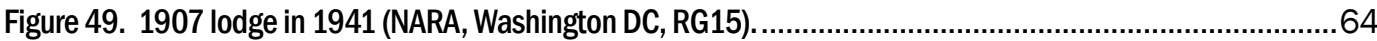

Figure 50. Utility Building No. 2, c.1940s (NARA Washington, DC, RG15). ...................................................65

Figure 51. Utility building, 1949 (NARA, Washington DC, RG15). .............................................................6

Figure 52. Addition to utility building, c.1950 (NARA Washington, DC, RG15). .............................................67

Figure 53. Rostrum after replacement of original pergola with hipped asphalt shingle roof, undated (NARA, Washington DC, RG15) 


\section{Figures}

Figure 54. New flagstaff at Knoxville National Cemetery, 1946 (NARA, Washington DC, RG15).

Figure 55. Main Entrance Gates in 1951, with metal tablets flanking the road to the flagstaff (VA NCA Archives, Washington, DC).

Figure 56. Circle drive with potholes and worn pavement, 1953 (VA NCA Archives, Washington, DC).

Figure 57. Sketch map by Superintendent John A. Boender showing location of plaques, 1958 (NARA, Washington DC, RG92).

Figure 58. 1963 Layout Plan of Knoxville National Cemetery showing lack of open space and new burial areas (VA NCA Archives, Washington, DC).

Figure 59. Planting plan for lodge area, 1966 (VA NCA Archives, Washington, DC).

Figure 60. Planting plan for south and southwest part of cemetery, 1966 (VA NCA Archives, Washington, DC).

Figure 61. 1978 map of Knoxville National Cemetery (VA NCA Archives, Washington, DC)

Figure 62. Aerial of Knoxville National Cemetery after removal of road and gate, 1995 (City of Knoxville, Tennessee).

Figure 63. 1985 Rededication Plaque located just inside the cemetery, 1989 (VA NCA Archives, Washington, DC).

Figure 64. View of Knoxville National Cemetery showing use of all available burial space, 1989 (VA NCA Archives, Washington, DC).

Figure 65. Road conditions in 1989 before resurfacing was done in 1990 (VA NCA Archives, Washington, DC).

Figure 66. 1907 lodge with original open front porch, 1961 (VA NCA Archives, Washington, DC).

Figure 67. Undated photo showing renovated front porch with aluminum frames and panels (VA NCA Archives, Washington, DC).

Figure 68. 1907 lodge with original open rear porch, 1961 (VA NCA Archives, Washington, DC).

Figure 69. 1989 view of the lodge, with slight visibility to changes to back porch (behind tree to right) showing low concrete block wall and corrugated fiberglass panels (VA NCA Archives, Washington, DC).

Figure 70. View of 1907 lodge after the 1990 fire (VA NCA Archives, Washington, DC)..................................85

Figure 71. Utility building before renovation (VA NCA Archives, Washington, DC) . ..........................................87

Figure 72. View of the utility building after renovation, 1989 (VA NCA Archives, Washington, DC). .....................87

Figure 73. Newspaper photo from Memorial Day 1954 showing rostrum (NARA, Washington DC, RG92)...........88

Figure 74. Rostrum after removal of asphalt roof, 1958 (NARA, Washington DC, RG15). .89

Figure 75. 1962 Entrance Gate with bronze plaques installed 2 July 1962, undated photo (NARA, Washington DC, RG15)

Figure 76. Reproduction of registration form for Knoxville National Cemetery nomination to NRHP, 1996 (NCA).

Figure 77. Reproduction of "A Clarification of Policy" for National Register Eligibility of National Cemeteries, 2011 (NPS)

Figure 78. Exaggerated topographic section of Knoxville National Cemetery, 2020 (ERDC-CERL).................. 122

Figure 79. Diagram of tree cover in Knoxville National Cemetery, 2020 (ERDC-CERL)..................................124

Figure 80. View to the northwest showing scattered spacing of shade trees (ERDC-CERL, 2019)................... 125

Figure 81. Circulation diagram showing the paved road and parking area in blue, 2020 (ERDC-CERL)............ 126 


\section{Figures}

Figure 82. Looking south along the circle drive showing the asphalt paving and concrete curbs (ERDC-CERL, 2019).

Figure 83. The location of buildings at Knoxville National Cemetery, 2020 (ERDC-CERL). ............................ 128

Figure 84. Southeast side of the restroom building (ERDC-CERL, 2019).................................................. 129

Figure 85. Southwest side of the restroom building (ERDC-CERL, 2019) ................................................. 129

Figure 86. View to the west of the maintenance building on the right and the restroom building on the left

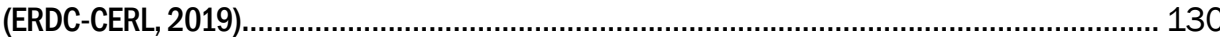

Figure 87. Oblique view of the east corner of the maintenance building (ERDC-CERL, 2019). ........................ 130

Figure 88. The location of structures at Knoxville National Cemetery, 2020 (ERDC-CERL). .............................131

Figure 89. Looking southeast at the Union Soldier Monument (ERDC-CERL, 2019). ................................... 132

Figure 90. Looking west at the Union Soldier Monument (ERDC-CERL, 2019). ........................................... 133

Figure 91. Looking northeast at the Union Soldier Monument (ERDC-CERL, 2019).................................... 134

Figure 92. Looking southwest at the Tyson Street wall (ERDC-CERL, 2019). .............................................. 135

Figure 93. Concrete pillar at the corner of Tyson and Bernard (ERDC-CERL, 2019)...................................... 136

Figure 94. Looking southeast at the Bernard Avenue wall (ERDC-CERL, 2019)........................................... 136

Figure 95. Looking northwest at the Cooper Street wall (ERDC-CERL, 2019). ..............................................137

Figure 96. Looking northwest at the concrete pillar between the two cemeteries (ERDC-CERL, 2019)............. 138

Figure 97. Looking south at the wall between the two cemeteries (ERDC-CERL, 2019). ................................. 139

Figure 98. Looking southwest at the wall between the two cemeteries (ERDC-CERL, 2019)......................... 139

Figure 99. Looking southwest at the main entrance gate (ERDC-CERL, 2019). ............................................ 140

Figure 100. Looking northeast at the Cooper Street where stone piers marked a former entrance to the

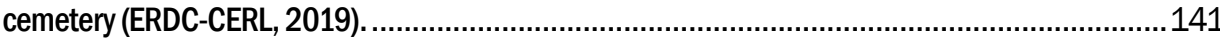

Figure 101. Looking north at the gravesite locator kiosk (ERDC-CERL, 2019). ........................................... 142

Figure 102. An example of a Civil War headstone featuring the original dimensions and layout of the markers (ERDC-CERL, 2019)

Figure 103. An example of a pre-1903 burial updated with the newer size but with the shield and name/unit incised into the stone (ERDC-CERL, 2019).

Figure 104. An example of a pre-1903 burial updated with the newer size but with the shield only incised into the stone in bas relief (ERDC-CERL, 2019).

Figure 105. Looking towards the flagpole at the Highlander portion of the cemetery in Section, 2019 A (ERDC-CERL, 2019)

Figure 106. Grave markers displaced by tree growth were laid flat to the ground near their original locations (ERDC-CERL, 2019) 146

Figure 107. Example of the Confederate grave marker at Knoxville National Cemetery (ERDC-CERL, 2019)...... 146

Figure 108. Section of Civil War unknown dead (ERDC-CERL, 2019)..........................................................147

Figure 109. An example of a post-1903 burial with the new size of headstone (ERDC-CERL, 2019). ............... 148

Figure 110. Nonstandard grave marker for Captain Walter Fitzgerald, who died in 1906 (ERDC-CERL, 2019)... 149

Figure 111. Grave marker for $1^{\text {st }}$ Lt. Belmont Earle, who died in 1918 (ERDC-CERL, 2019). .......................... 149

Figure 112. Nonstandard grave maker design for Lt Hosea Loftis, who died in 1908 (ERDC-CERL, 2019)........ 150

Figure 113. Burial plot for Superintendent Thomas Ridge, who died in 1918, and his family (ERDC-CERL, 2019). 


\section{Figures}

Figure 114. View looking northwest at the flagstaff (ERDC-CERL, 2019) . ..................................................151

Figure 115. POW flagpole and flag in Section B (ERDC-CERL, 2019) .................................................... 152

Figure 116. Ceremonial flagpoles on the south side of the flagstaff in Sections B and C (ERDC-CERL, 2019).... 152

Figure 117. The Hilltopper monument in Section A (ERDC-CERL, 2019). .................................................. 153

Figure 118. Granite marker with metal plaque for the First Marine Division in Knoxville National Cemetery

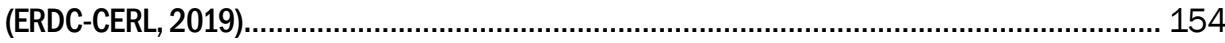

Figure 119. National Register of Historic Places (NHRP) monument (ERDC-CERL, 2019L)............................. 155

Figure 120. Bivouac of the Dead plaque (ERDC-CERL, 2019). ........................................................... 155

Figure 121. Gettysburg Address monument (ERDC-CERL, 2019)......................................................... 156

Figure 122. Memorial Area monument (ERDC-CERL, 2019). ..............................................................157

Figure 123. Looking southwest at the cemetery's rededication monument opposite the main entrance

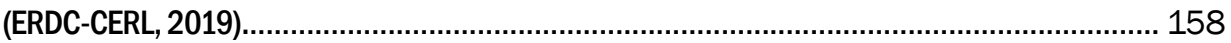

Figure 124. Knoxville National Cemetery plaque on the left pylon of the main entrance (ERDC-CERL, 2019).... 159

Figure 125. Veterans Administration plaque on the right pylon of the main entrance (ERDC-CERL, 2019)....... 160

Figure 126. Informational sign (ERDC-CERL, 2019). ........................................................................ 160

Figure 127. Sign that displays the history behind the formation of the national cemetery system (ERDC-

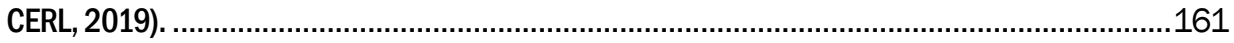

Figure 128. Sign outlining floral regulations (ERDC-CERL, 2019).........................................................161

Figure 129. Small sign dedicating a tree (ERDC-CERL, 2019) ............................................................... 162

Figure 130. Open hours sign on gate (ERDC-CERL, 2019). .................................................................. 162

Figure 131. Granite section markers for Section B (ERDC-CERL, 2019). ................................................... 163

Figure 132. Concrete water channel running through the eastern section of the cemetery (ERDC-CERL,

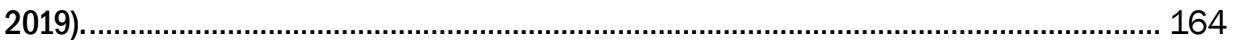

Figure 133. Concrete water channel running to southern corner of the cemetery (ERDC-CERL, 2019). ............. 164

Figure 134. Concrete water channel running to west corner of the cemetery (ERDC-CERL, 2019). .................. 165

Figure 135. Trash and flower vases receptacles at parking area in Section D (ERDC-CERL, 2019)................... 166

Figure 136. Trash receptacle near the flagstaff (ERDC-CERL, 2019) ........................................................ 166

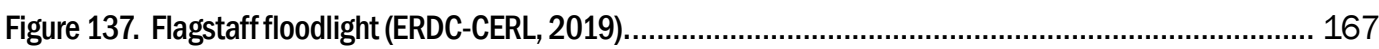

Figure 138. Viewshed from the main entrance into the cemetery (ERDC-CERL, 2019). ................................ 168

Figure 139. View southwest from the main entrance into the cemetery (ERDC-CERL, 2019)........................... 168

Figure 140. Viewshed from the flagstaff southeast into the Old Gray Cemetery (ERDC-CERL, 2020)............... 169

Figure 141. View from the flagstaff southeast into the Old Gray Cemetery (ERDC-CERL, 2019)........................170

Figure 142. Viewshed from the main entrance southeast to the Union Soldier Monument, (ERDC-CERL, 2020)

Figure 143. View from the main entrance southeast to the Union Soldier Monument (ERDC-CERL, 2019)......... 171

Figure 144. Knoxville National Cemetery divided into sections for landscape feature analysis, 2020 (ERDC-

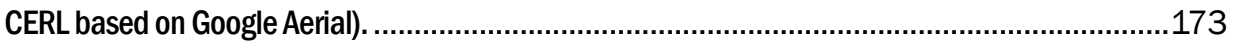

Figure 145. Looking northeast at a drawing of the wood fence along Cooper Street, 1869 (NARA, Washington DC, RG92).

Figure 146. Looking southwest at the stone wall with iron fence along Tyson Street, 1909 (NARA College Park, RG92-CA). 


\section{Figures}

Figure 147. Looking southwest at the stone wall with iron fence along Tyson Street (ERDC-CERL, 2019)...........175

Figure 148. A portion of a birds-eye drawing showing the concentric circles centered on the flagstaff with trees on the perimeter boundary of the cemetery, 1871 (Library of Congress).

Figure 149. A portion of a birds-eye drawing showing trees on the perimeter boundary of the cemetery, 1886 (Library of Congress).

Figure 150. Looking northeast at a drawing of the wood gate on Tyson Street, 1869 (NARA, Washington DC, RG92). 176

Figure 151. Looking southwest at the Tyson Gate, 1904 (NARA College Park, RG-92-CA)..............................177

Figure 152. Looking southwest at the Tyson Gate, 1951 (VA NCA Archives). .................................................177

Figure 153. Looking southwest at the Tyson Gate (ERDC-CERL, 2019).....................................................178

Figure 154. Looking northeast at a drawing of the wood gate on Cooper Street, 1867 (NARA, Washington

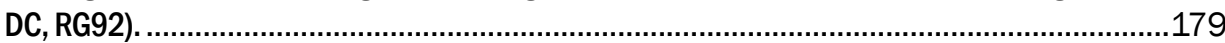

Figure 155. Looking southwest at the inside of the Cooper Gate, 1949 (VA NCA Archives)..............................179

Figure 156. Looking northeast at the outside of the Cooper Gate (ERDC-CERL, 2019)................................. 180

Figure 157. Looking west at the Highlanders graves and memorial [note no flagstaff is depicted], 1864 (Library of Congress).

Figure 158. Inner A, Outer A, and Section X as depicted on P.M. Radford's map, 1869 (NARA, Washington DC, RG92)

Figure 159. Inner A, Outer A, and Section X as depicted on a portion of the 1892 map (VA NCA Archives, Washington, DC).

Figure 160. Looking west at the Highlanders graves, 1895 (East Tennessee History Center McClurg Collection).

Figure 161. View to the south of the original Union Soldier Monument, 1906 (VA NCA Archives, Washington, DC). 184

Figure 162. Inner A, Outer A, and Section $X$ as depicted on a portion of the 1909 map shows the location of the Union Soldier Monument marked in black pen (NARA, Washington DC, RG92). 185

Figure 163. Postcard view of the reconstruction Union Soldier Monument, 1906 (University of Tennessee, Knoxville, Library digital collections "Images of East Tennessee").

Figure 164. View to the south of the Union Soldier Monument from the rostrum, c.1920s (University of Tennessee, Knoxville, Library digital collections “Images of East Tennessee”).

Figure 165. Inner A, Outer A, and Section X as depicted on a portion of the 1947 map with types of trees (NARA, Washington DC, RG15)

Figure 166. Aerial view of Section A and Section X showing extensive tree cover in Section A, 1948 (HALS-TN2 , Library of Congress).

Figure 167. View to the southeast of the Union Soldier Monument, 1945 (VA NCA Archives, Washington, DC). . 189

Figure 168. View to the northwest from the Union Soldier Monument towards the Tyson Gate, 1953 (VA NCA Archives, Washington, DC).

Figure 169. Inner A, Outer A, and Section X as depicted on a portion of the 1971 map (VA NCA Archives, Washington, DC).

Figure 170. View to the northeast along the circle drive towards the Union Soldier Monument, 1989 (VA NCA Archives, Washington, DC).

Figure 171. Inner A, Outer A, and Section X as depicted on a portion of the 2019 map (VA NCA Archives, Washington, DC). 


\section{Figures}

Figure 172. Looking west across Inner A at the Highlanders Memorial and graves with the flagstaff in the background (ERDC-CERL, 2019). .

Figure 173. Looking west at the back of the Highlanders Memorial (ERDC-CERL, 2019).

Figure 174. Looking east at the front of the Highlanders Memorial (ERDC-CERL, 2019). ............................. 193

Figure 175. Looking east across Inner A towards the Union Soldier Monument (ERDC-CERL, 2019). ............... 194

Figure 176. Looking southwest at the wall between the Knoxville National Cemetery and the Old Gray Cemetery where it intersects with the sidewalk along Tyson Street (ERDC-CERL, 2019).

Figure 177. Looking southeast at the Dogwood in the foreground and the Norway Spruce in the middle with the Union Soldier Monument in the background in Section X (ERDC-CERL, 2019). 195

Figure 178. Looking southeast across Inner A at two Crepe Myrtles at the location where the east-west drive once intersected with the circle drive (ERDC-CERL, 2019).

Figure 179. Looking southeast at the American Holly tree at the stone wall between the Knoxville National Cemetery and the Old Gray Cemetery in Outer A (ERDC-CERL, 2019).

Figure 180. Looking northwest at one of the Flowering Dogwoods in Inner A (ERDC-CERL, 2019).................. 196

Figure 181. Looking northwest at the Black Walnut tree in Inner A (ERDC-CERL, 2019).................................197

Figure 182. Inner B as depicted on P.M. Radford's drawing, 1869 (NARA, Washington DC, RG92). ................ 198

Figure 183. Inner B as depicted on P.M. Radford's map, 1869 (NARA, Washington DC, RG92). ..................... 198

Figure 184. Inner B as depicted on a portion of the 1892 map (VA NCA Archives, Washington, DC). ............... 199

Figure 185. Inner $B$ as depicted on a portion of the 1909 map (NARA, Washington DC, RG92)...................... 200

Figure 186. View to the northeast of the of the east-west drive from the circle drive with Inner $\mathrm{C}$ on the left and Inner B on the right, 1908 (NARA College Park RG92-CA).

Figure 187. Inner B as depicted on a portion of the 1947 map with types of trees (NARA, Washington DC, RG15).

Figure 188. Aerial view of Inner B showing extensive tree cover, 1948 (HALS-TN-2, Library of Congress)

202

Figure 189. View to the southeast along the circle drive with Inner B on the left with shrubs along road, 1953 (VA NCA Archives, Washington, DC).

Figure 190. View to the northeast along the circle drive with Inner B on the left with shrubs along road, 1953 (VA NCA Archives, Washington, DC). 203

Figure 191. Inner B as depicted on a portion of the 1971 map (VA NCA Archives, Washington, DC). 204

Figure 192. View to the northwest along the intersection of the circle drive and the north-south drive [Inner $B$ is on the left and Inner A is on the right], 1989 (VA NCA Archives, Washington, DC).

Figure 193. View to the northeast along the circle drive with Inner B on the left and Outer B on the right, 1989 (VA NCA Archives, Washington, DC).

Figure 194. Inner B as depicted on a portion of the 2019 map (VA NCA Archives, Washington, DC). 206

Figure 195. Looking northwest with Inner B on the left and Inner $A$ on the right and the east-west drive with the flagstaff in the background (ERDC-CERL, 2019).

Figure 196. Looking north across Inner B with a Sugar Maple (ERDC-CERL, 2019).

Figure 197. Looking north at a Sugar Maple in Inner B (ERDC-CERL, 2019). 208

Figure 198. Looking southeast along the circle drive with Inner B on the left and Outer B on the right (ERDCCERL, 2019).

Figure 199. Looking northeast from the circle drive at the former location of the east-west drive with Inner C on the left and Inner on the right (ERDC-CERL, 2019). 


\section{Figures}

Figure 200. Looking south from the flagstaff across Inner B (ERDC-CERL, 2019). .......................................210

Figure 201. Inner C as depicted on P.M. Radford's drawing, 1869 (NARA, Washington DC, RG92)..................211

Figure 202. Inner C as depicted on P.M. Radford's map, 1869 (NARA, Washington DC, RG92). .....................211

Figure 203. Inner $C$ as depicted on a portion of the 1892 map (VA NCA Archives, Washington, DC). ................212

Figure 204. Inner $\mathrm{C}$ as depicted on a portion of the 1909 (NARA, Washington DC, RG92).............................213

Figure 205. Inner $C$ as depicted on a portion of the 1947 map with types of trees (NARA, Washington DC,

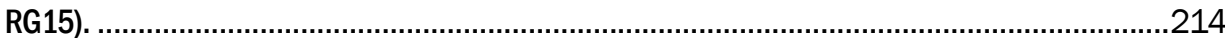

Figure 206. Aerial view of Inner C showing extensive tree cover, 1948 (HALS-TN-2, Library of Congress)............214

Figure 207. View to the southeast of the intersection of the north-south drive and the circle drive with Section D on the left and Inner C on the right, 1953 (VA NCA Archives, Washington, DC). Note the accent shrub at the intersection. ............................................................................................215

Figure 208. Inner C as depicted on a portion of the 1971 map (VA NCA Archives, Washington, DC)..................216

Figure 209. View to the south along the circle drive with Inner C shown in the center, 1989 (VA NCA Archives,

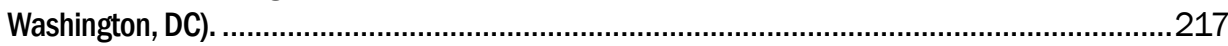

Figure 210. View to the southeast up the north-south drive with Section D on the left and Inner C on the right, 1989 (VA NCA Archives, Washington, DC).

Figure 211. Inner $\mathrm{C}$ as depicted on a portion of the 2019 map (VA NCA Archives, Washington, DC).................218

Figure 212. Looking north along the circle drive with Inner C on the right (ERDC-CERL, 2019). ......................219

Figure 213. Looking south along the circle drive with Inner C on the left (ERDC-CERL, 2019).........................219

Figure 214. View to the southeast up the north-south drive with Section D on the left and Inner C on the right (ERDC-CERL, 2019). 220

Figure 215. Section D as depicted on P.M. Radford's map, 1869 (NARA, Washington DC, RG92)..................221

Figure 216. Section D as depicted on a portion of the 1892 map (VA NCA Archives, Washington, DC)............. 222

Figure 217. Section D as depicted on a portion of the 1909 map (NARA, Washington DC, RG92).................. 223

Figure 218. Section D as depicted on a portion of the 1947 map with types of trees (NARA, Washington DC, RG15).

Figure 219. Aerial view of Section D showing extensive tree cover, 1948 (HALS-TN-2, Library of Congress)...... 225

Figure 220. View to the north of Section D from where the circle drive intersects with the north-south drive,

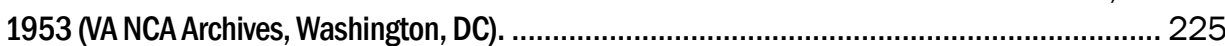

Figure 221. Section D as depicted on a portion of the 1971 map (VA NCA Archives, Washington, DC). ............. 226

Figure 222. View to the southwest towards Section D with a portion of Section Y in the foreground, 1989 (VA

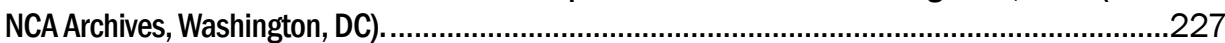

Figure 223. Section D as depicted on a portion of the 2019 map (VA NCA Archives, Washington, DC)............. 228

Figure 224. Looking east along the circle drive with Section D in the center (ERDC-CERL, 2019).................... 229

Figure 225. Looking west across Section D (ERDC-CERL, 2019). ........................................................... 229

Figure 226. Looking southwest from the Tyson Gate with Section A on the left and Section D on the right

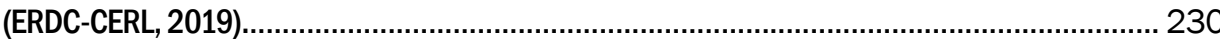

Figure 227. Looking south from the flagstaff across Section D (ERDC-CERL, 2019). .................................... 230

Figure 228. Outer B as depicted on P.M. Radford's drawing, 1869 (NARA, Washington DC, RG92).................231

Figure 229. Outer B as depicted on P.M. Radford's map, 1869 (NARA, Washington DC, RG92)..................... 232

Figure 230. Detail of a plan showing the stone superintendent's lodge and brick stables, 1874 (NARA, Washington DC, RG9). 


\section{Figures}

Figure 231. Outer B as depicted on a portion of the 1892 map (VA NCA Archives, Washington, DC). 234

Figure 232. View to the southeast of the stone superintendent's lodge, 1908 (NARA College Park RG92-CA). Note low ground cover around house foundation. 235

Figure 233. Postcard view of the siege gun monument in Outer B near the circle drive, c.1910 (University of Tennessee, Knoxville, Library digital collections “Images of East Tennessee”). Note the variety of evergreen and deciduous trees and shrubs.

Figure 234. Outer $B$ as depicted on a portion of the 1909 map shows the stone superintendent's lodge and brick stable (NARA, Washington DC, RG92). 236

Figure 235. View to the northeast of the brick stable, 1908 (NARA College Park RG92-CA). .237

Figure 236. Outer $B$ as depicted on a portion of the 1947 map with types of trees and the small restroom building marked as a rectangle (NARA, Washington DC, RG15).

Figure 237. Aerial view of Outer B showing little tree cover in the section close to the stone wall but there are a large group of shrubs in the southwest corner, 1948 (HALS-TN-2, Library of Congress)

Figure 238. View to the southwest of the Cooper Gate, 1946 (VA NCA Archives, Washington, DC). 239

Figure 239. Looking east at the small restroom building in Outer B, unknown date (VA NCA Archives, Washington, DC).

Figure 240. Outer B planting plan as depicted on a portion of the 1966 map (VA NCA Archives, Washington, DC). 240

Figure 241. Outer B as depicted on a portion of the 1971 map (VA NCA Archives, Washington, DC) 241

Figure 242. View to the east along the circle drive with Inner B on the left and Outer B on the right, 1989 (VA NCA Archives, Washington, DC).

Figure 243. Outer B as depicted on a portion of the 2019 map (VA NCA Archives, Washington, DC). .243

Figure 244. Looking southwest at the east edge of Outer B and the southwest stone wall on the left with the Old Gray Cemetery beyond (ERDC-CERL, 2019).

Figure 245. Looking south at the eastern portion of Outer B (ERDC-CERL, 2019). .244

Figure 246. Looking southwest at the Superintendent Thomas Ridge burial plot in Outer B (ERDC-CERL, 2019).

Figure 247. Looking south towards the southeast corner of Outer B (ERDC-CERL, 2019)..............................245

Figure 248. Looking northwest across Outer B (ERDC-CERL, 2019). Note very few trees are visible...................245

Figure 249. Looking southeast in Outer B at a Sugar Maple (ERDC-CERL, 2019). .246

Figure 250. Looking southeast at the two American Holly trees along the Cooper Street wall, as well as a remnant of Cooper Gate on right (ERDC-CERL, 2019).

Figure 251. Outer $C$ as depicted on P.M. Radford's drawing, 1869 (NARA, Washington DC, RG92)..................247

Figure 252. Outer C as depicted on P.M. Radford's map, 1869 (NARA, Washington DC, RG92).....................248

Figure 253. Front of the original wood lodge, 1874 (NARA, Washington DC, RG92). ......................................248

Figure 254. Outer $\mathrm{C}$ as depicted on a portion of the 1892 map (VA NCA Archives, Washington, DC)................249

Figure 255. Outer $C$ as depicted on a portion of the 1909 map (NARA, Washington DC, RG92). 250

Figure 256. Outer $C$ as depicted on a portion of the 1947 map with types of trees (NARA, Washington DC, RG15).

Figure 257. Aerial view of Outer C showing tree cover in Outer C, 1948 (HALS-TN-2, Library of Congress)...........251

Figure 258. Outer C planting plan as depicted on a portion of the 1966 map (VA NCA Archives, Washington, DC). 


\section{Figures}

Figure 259. Outer C as depicted on a portion of the 1971 map (VA NCA Archives, Washington, DC)................ 252

Figure 260. View to the southwest in Outer C along the stone wall, 1989 (VA NCA Archives, Washington, DC)... 253

Figure 261. View to the northwest across Outer C, 1989 (VA NCA Archives, Washington, DC). ....................... 253

Figure 262. Outer C as depicted on a portion of the 2019 map (VA NCA Archives, Washington, DC)................ 254

Figure 263. Looking southwest at the eastern edge of Outer C (ERDC-CERL, 2019).................................... 255

Figure 264. Looking west in Outer $\mathrm{C}$ at the Crepe Myrtle in Outer C, note pylons for the old Cooper Gate along

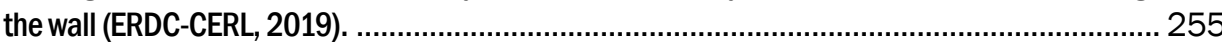

Figure 265. Looking northwest in Outer C at the Sugar Maple on the left and the American Elm on the right (ERDC-CERL, 2019) 256

Figure 266. The Northeast section as depicted on P.M. Radford's map, 1869 (NARA, Washington DC,

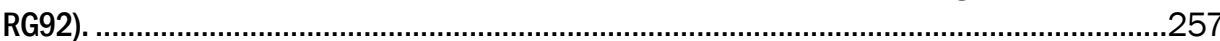

Figure 267. The Northeast section with the rostrum as depicted on a portion of the 1892 map (VA NCA Archives, Washington, DC). 258

Figure 268. The Northeast section as depicted on a portion of the 1909 map showing the location of the rostrum and the brick superintendent's lodge outside the circle drive (NARA, Washington DC, RG92).

Figure 269. View to the west of the brick superintendent's lodge, 1908 (NARA College Park RG92-CA). .......... 260

Figure 270. View to the northwest of the rostrum, 1908 (NARA College Park RG92-CA)................................ 260

Figure 271. View to the west of the Tyson Gate, trees, and rostrum, 1908 (NARA College Park RG92-CA).........261

Figure 272. The Northeast section as depicted on a portion of the 1947 map with types of trees (NARA,

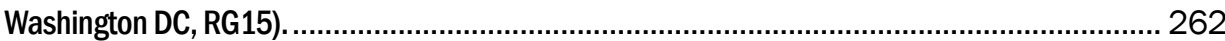

Figure 273. Restroom and utility building, 1949 (NARA, Washington DC, RG15)........................................ 263

Figure 274. View to the southwest of the brick superintendent's lodge showing the pedestrian gate, 1961 (VA

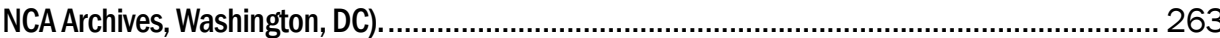

Figure 275. View to the northeast from the utility building to the rostrum, 1953 (VA NCA Archives, Washington, DC) 264

Figure 276. View to the northeast of the rostrum showing shrubs along foundation, 1953 (VA NCA Archives,

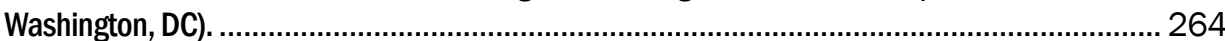

Figure 277. View to the north of the rostrum, circa 1950s (VA NCA Archives, Washington, DC)....................... 265

Figure 278. Aerial view of the Northeast section showing extensive cover surrounding the rostrum and brick superintendent's lodge, 1948 (HALS-TN-2, Library of Congress). ............................................. 265

Figure 279. View to the southwest in the Northwest area of the brick utility building, 1949 (VA NCA Archives, Washington, DC). Note the shrub in the foreground........................................................... 266

Figure 280. View to the southwest of the Tyson Gate, 1953 (VA NCA Archives, Washington, DC)..................... 266

Figure 281. Rostrum without a roof, circa 1958 (NARA, Washington DC, RG15). ...................................... 267

Figure 282. View to the south of the corner concrete pylon and brick superintendent's lodge, 1961 (VA NCA Archives, Washington, DC). ............................................................................................ 267

Figure 283. Planting plan for the brick superintendent's lodge as depicted on a portion of the 1966 map (VA NCA Archives, Washington, DC) 268

Figure 284. Northeast section as depicted on a portion of the 1971 map (VA NCA Archives, Washington, DC).. 269

Figure 285. View to the northwest of the restroom building showing creeping junipers and evergreen shrubs planted in front, 1989 (VA NCA Archives, Washington, DC). 


\section{Figures}

Figure 286. View to the northwest along the circle drive towards the Section Y with the Tyson Gate on the right, 1989 (VA NCA Archives, Washington, DC).

Figure 287. The Northwest area as depicted on a portion of the 2019 map (VA NCA Archives, Washington, DC).

Figure 288. Looking northeast at the southwest edge of the Northwest area with the restroom building and creeping juniper plantings (ERDC-CERL, 2019).

Figure 289. Looking northwest at the restroom building on the left and the utility building on the right in the Northwest area (ERDC-CERL, 2019).

Figure 290. Looking northwest at the fenced landscape waste area in the Northwest area (ERDC-CERL, 2019).

Figure 291. Looking northwest at the parking area in the Northwest area (ERDC-CERL, 2019). .273

Figure 292. Looking north at the Gettysburg Address monument in the Northwest area (ERDC-CERL, 2019)..... 274

Figure 293. Looking northeast at the Memorial Area in front and Section Y in the rear (ERDC-CERL, 2019). ......275

Figure 294. Looking northwest at the southeast edge of the Northwest area with Section Y in the foreground (ERDC-CERL, 2019)

Figure 295. Looking southwest at the former location of the brick superintendent's lodge [note former lodge pedestrian gate with light colored stone cap] (ERDC-CERL, 2019) 276

Figure 296. Looking south at the corner concrete pylon and Section CS-2 (ERDC-CERL, 2019). .....................276

Figure 297. The flagstaff at the center of the circle on the 1869 map (NARA, Washington DC, RG92)...............278

Figure 298. Looking northeast at a drawing of the wood fence along Cooper Street, 1869 (NARA, Washington DC, RG92).

Figure 299. Plan of the flagstaff on the 1892 cemetery plan (VA NCA Archives, Washington, DC). ................. 280

Figure 300. Aerial view of the flagstaff circle, 1948 (HALS-TN-2, Library of Congress)...................................281

Figure 301. Looking northeast over the flagstaff circle towards the Tyson Gate, 1953 (VA NCA Archives, Washington, DC).

Figure 302. Looking northwest at the flagstaff circle showing that there is no vegetation or curb (ERDCCERL, 2019)

Figure 303. View northeast from the Cooper Gate in 1869 (NARA, Washington DC, RG92) 284

Figure 304. View northeast toward former Cooper Gate and flagstaff (ERDC-CERL, 2019) 284

Figure 305. View southwest from the Tyson Gate in 1908 (NARA College Park, RG92-CA and ERDC-CERL)..... 285

Figure 306. View southwest from the Tyson Gate in 2019 (ERDC-CERL). 286

Figure 307. View southeast from the Tyson Gate towards the Union Soldier Monument in c.1910 (University of Tennessee, Knoxville, Library digital collections "Images of East Tennessee").

Figure 308. View southeast from the Tyson Gate towards the Union Soldier Monument in 2019 (ERDCCERL).

Figure 309. View northwest from the Tyson Gate towards the rostrum in c.1910 (University of Tennessee, Knoxville, Library digital collections "Images of East Tennessee"). 288

Figure 310. View northwest from the Tyson Gate towards the former site of the rostrum (ERDC-CERL, 2019). ... 289

Figure 311. View northeast from the circle drive towards the flagstaff with Section C on the left and Section B on the right in 1908 and 2019 (NARA College Park, RG92-CA and ERDC-CERL).

Figure 312. View northeast from the circle drive towards the flagstaff with Section C on the left and Section B on the right in 2019 (ERDC-CERL).

Figure 313. View southeast from the flagstaff towards the Old Gray Cemetery (ERDC-CERL, 2019). 


\section{Figures}

Figure 314. Sequence of maps for Knoxville National Cemetery 1869, 1892 [Left to Right, top row], 1906, 1949 [Left to Right, middle row], 1971, and 2019 [Left to Right, bottom row] (various sources).... 292

Figure 315. Sequence of aerial images from left to right, 1948, 1969, 1985, 1995, 2019 (HALS-TN-2, Library of Congress, city of Knoxville, and Google). 293

\section{Tables}

Table 1. Knoxville National Cemetery facilities transferred to the Veterans Administration in July 1973 (VA NCA Archives, Washington, DC).

Table 2. List of trees at Knoxville National Cemetery in May 2020 (ERDC-CERL). 


\section{Preface}

This study was conducted for the U.S. Department of Veterans Affairs National Cemetery Administration under Project 467132, "IAA with National Cemetery Admin - Cultural Landscape Survey for Knoxville National Cemetery." The technical monitor was Mr. W. Edward Hooker III (Historic Architect/Cultural Resources Manager, National Cemetery Administration).

The work was performed by the Land and Heritage Conservation Branch of the Installations Division, U.S. Army Engineer Research and Development Center - Construction Engineering Research Laboratory (ERDCCERL). At the time of publication, Ms. Ellen R. Hartman was Acting Chief of the Land and Heritage Conservation Branch; and Ms. Michelle J. Hanson was Chief of the Installations Division. The Acting Deputy Director of ERDC-CERL was Dr. George Calfas and the Acting Director was Dr. Kirankumar V. Topudurti.

COL Teresa A. Schlosser was Commander of ERDC, and Dr. David W. Pittman was the Director. 


\section{Introduction}

\subsection{Background}

The U.S. Congress codified the National Historic Preservation Act of 1966 (NHPA), which is the nation's most effective cultural resources legislation to date, to provide guidelines and requirements for preserving tangible elements of our nation's past. This preservation was done primarily through the creation of the National Register of Historic Places (NRHP). Contained within this piece of legislation are requirements for federal agencies to address their cultural resources, defined as any prehistoric or historic district, site, building, structure, or object (NHPA Sections 110 and 106). Section 110 requires federal agencies to inventory and evaluate their cultural resources. Section 106 requires the determination of the effects of federal undertakings on properties deemed eligible or potentially eligible for the NRHP.

The U.S. Department of Veterans Affairs (VA) National Cemetery Administration (NCA) administers 135 of the 149 National Cemeteries in the United States. The NCA was created in 1998 from the National Cemeteries System (NCS). The NCS had been created in 1973. At that time, 83 National Cemeteries were transferred from the Department of the Army to the VA, and those joined the 21 cemeteries located at hospitals and nursing homes that already were being administered by the VA. Knoxville National Cemetery was placed on the NRHP in 1996 as part of the "Civil War Era National Cemeteries" multiple-property submission under Criterion A. ${ }^{1}$

While the nomination of Knoxville National Cemetery to the NRHP includes some discussion of the important features, no landscape surveys have been completed to date. A landscape survey such as the work outlined in this report details the following: design and layout of the cemetery, any natural and cultural influences, circulation patterns, and vegetation. The nomination also did not include documentation of changes to the cemetery over time.

\footnotetext{
1 Therese T. Sammartino, “Knoxville National Cemetery," National Register of Historic Places Nomination Form, (Washington, DC: National Park Service, 1996).
} 
Knoxville National Cemetery is located at 939 Tyson Street, N.W. in Knoxville, Tennessee (Figure 1). Knoxville is a city of about 180,000 people in east Tennessee. It is the county seat of Knox County, and the state's third largest city. The town was first settled in 1786 , and it became a center of manufacturing and wholesaling. During the Civil War, the city was alternately occupied by Confederate and Union armies. Knoxville National Cemetery was begun in September 1863, shortly before the start of the Siege of Knoxville. At the time, the cemetery was located to the north of the city limits, but the town grew to encompass the cemetery. The roughly square 10 -acre cemetery was designed with the burial areas forming a large ring of concentric circles, divided into quarters by roads and paths. There is a flagpole in the center of the circle. The cemetery is bounded by three streets (Tyson Street to the northeast, Bernard Avenue to the northwest, and Cooper Street to the southwest), and the city's Old Gray Cemetery to the southeast. The only entrance to the cemetery is from Tyson Street (Figure 2). These street names are not the original ones, as Cooper Street was formerly Jacksboro Road, Tyson Street was Holston Street, and Bernard Avenue was Munson Street. To avoid confusion, the current names are used throughout this document, even when discussing time periods when the former names were in use.

Figure 1. Location of Knoxville National Cemetery, Knoxville, Tennessee (www.openstreetmap.org, accessed 26 May 2020).

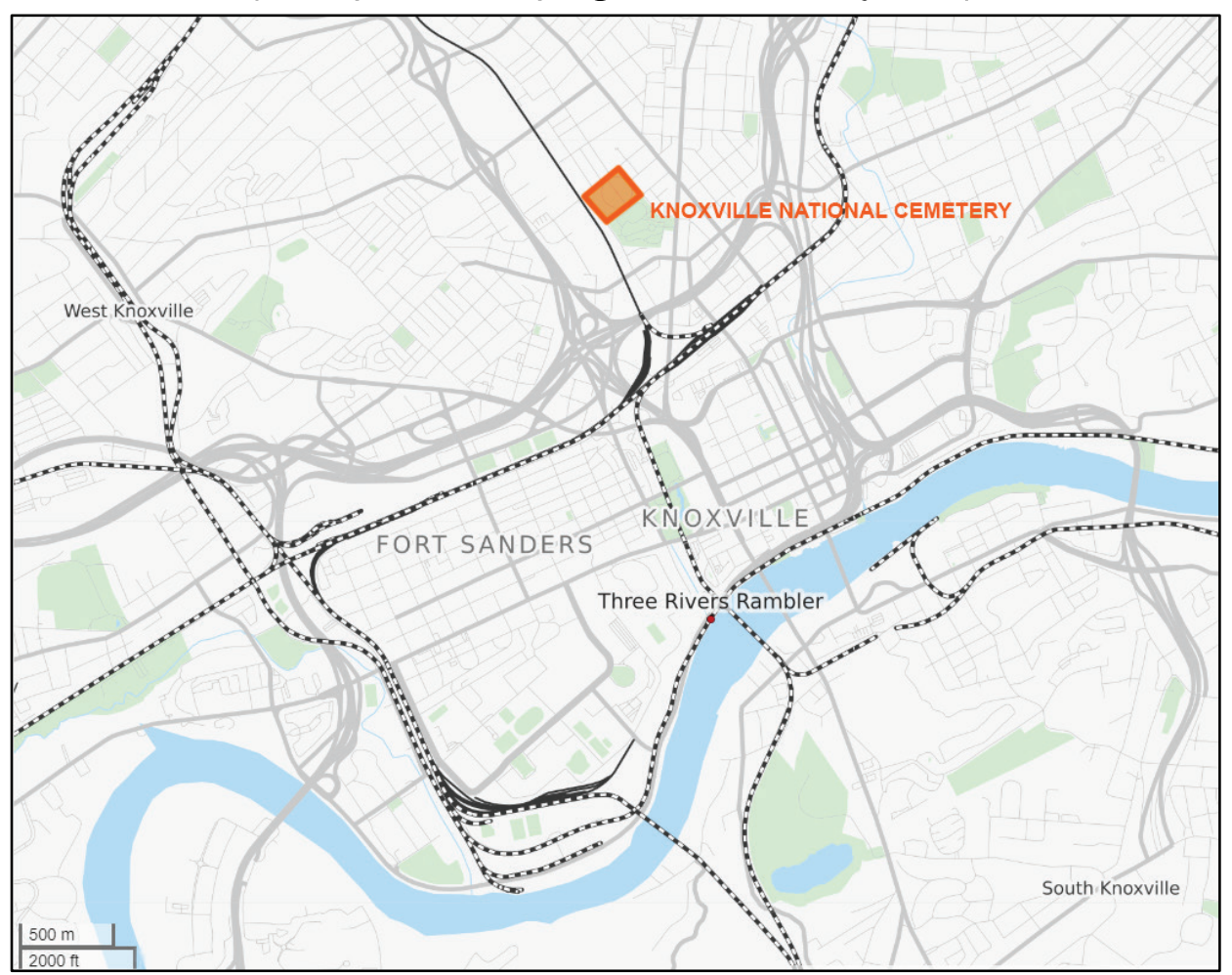


Figure 2. Site map of Knoxville National Cemetery (Google Earth, accessed 13 July 2020).

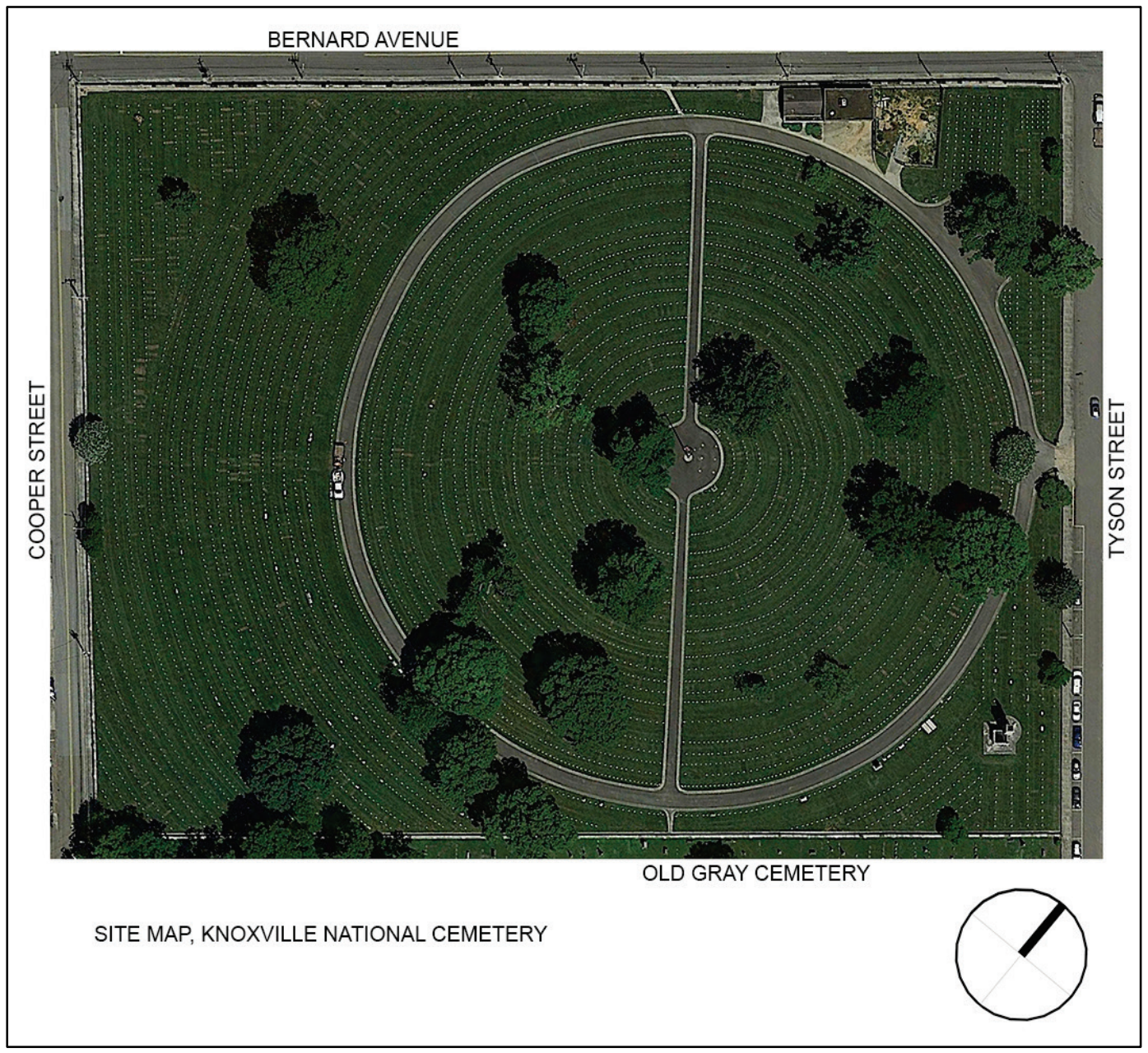

\subsection{Objectives}

The objective of this project was to develop a cultural landscape survey for Knoxville National Cemetery, Tennessee. The cultural landscape survey provides a historic landscape context, a landscape inventory, a list of characterdefining features, and a condition assessment of all features of the cultural landscape to assist the NCA in management of this historic resource.

\subsection{Approach}

This project was conducted by the U.S. Army Corps of Engineers, Engineering Research Development Center, Construction and Engineering Research Laboratory (ERDC-CERL), based in Champaign, IL. The research team included Susan Enscore, Doctor of Geography, as project manager and historian with 27 years of experience; Adam D. Smith, Master of Architecture, as research architect with 22 years of experience; and Megan 
Tooker, Master of Landscape Architecture, as landscape historian with 22 years of experience. All three researchers meet and exceed the Secretary of the Interior's Historic Preservation Professional Qualification Standards.

\subsection{Site visits}

\subsubsection{Knoxville National Cemetery}

ERDC-CERL personnel made one trip to Knoxville National Cemetery in October 2019 to inventory the landscape. During that week, members of the team inventoried and photographed the landscape features and conducted archival research.

\subsubsection{Archival repositories}

ERDC-CERL researchers conducted a review of books, archival repositories, and online resources related to Knoxville National Cemetery. The following places were contacted and/or searched:

- NRHP listings and nomination forms (online at https://www.nps.gov/Nr/publications/index.htm)

- Historic drawings, maps, photographs, and information provided by the VA NCA office in Washington, DC

- National Archives and Records Administration (NARA), College Park, Maryland

- Library of Congress, Washington, DC

- NARA, Washington, DC

- NARA, Atlanta, GA

- Knoxville History Project

- East Tennessee History Center

- University of Tennessee, Knoxville

- Knox County Public Library.

\subsection{Analysis}

After initial research was completed, the team analyzed the gathered information. Archival information and field information were integrated throughout the course of the project. The information available was contained in text documents, photographs, and historic maps. Using archival sources, the research team extracted relevant historical information. The material was then combined to tell the story in both text and images. 


\section{Landscape Development History}

Knoxville National Cemetery is still shaped by the original layout of the property. The cemetery is noted for its geometrical symmetry and a large Union Soldier Monument. The cemetery grounds and buildings were altered into the 1990s. Landscape development has been notable for the gradual loss of the original vegetation in the cemetery and the filling in of open space with gravesites, as well as the gradual reduction in the number of buildings on the site.

\subsection{Origins and original configuration, 1863-1873}

As one of the initial waves of National Cemeteries constructed from 1862 to 1869, Knoxville National Cemetery was created in 1863 to shelter the remains of Union soldiers killed in the Civil War. East Tennessee was a vital strategic area for both Union and Confederate forces early in the war. The Union Army leaders saw control of the region as a means to disrupt Confederate rail supply lines between Virginia and the Mississippi Valley (which ran through Knoxville), while the Confederate Army had established significant numbers of troops in the area even prior to secession in June $1861 .{ }^{2}$

The area around Knoxville had large pockets of pro-Union support, even as it served as headquarters for the District of East Tennessee of the Confederate Armies. After fortifying the most likely Union incursion point of Cumberland Gap on the border with Kentucky, the Confederate leaders set about eliminating the Union supporters in east Tennessee. The first part of 1862 saw the Department of East Tennessee build up its forces, and that summer the Confederate forces were able to protect the rail supply lines and solidify their control of the region. ${ }^{3}$

Union efforts to invade east Tennessee began in early 1863 with an incursion into Cumberland Gap and then moved south. The fighting reached Knoxville on 20 June with the arrival of Union forces in the city. After knocking out communication lines, the attackers were repulsed and retreated to the north. Due to Confederate troops being shifted away to assist other units, a brigade of Union Cavalry entered Knoxville unopposed on 2 September and occupied the city, with Infantry troops arriving on the 4th. General Ambrose Burnside was in command and headquartered in

2 Sammartino, “Knoxville National Cemetery," 1996.

3 Ibid. 
the city. Knoxville was fortified with the creation of Forts Sanders and Huntington Smith. 4

Confederate troops under command of General James Longstreet had surrounded the city on three sides (excepting the south at the Tennessee River) by 17 November 1863, and Union forces were ordered to stand and defend the city. The Siege of Knoxville lasted until 5 December, with skirmishes but only one major assault attempted by the Confederate Army, at Fort Sanders on the morning of 29 November. The 20-minute battle resulted in a Confederate defeat, with the Union Army suffering only five killed. Longstreet was called away to support units retreating from Missionary Ridge near Chattanooga, and victorious Union troops were advancing toward Knoxville. The siege continued without another assault, and the Confederate troops departed during the night of 4 December. ${ }^{5}$ Union troops remained in charge of Knoxville for the remainder of the war.

\subsubsection{Establishment of cemetery}

The cemetery had been established shortly before the siege, in the first week of September 1863. A tract of land directly north of the city's Gray Cemetery on the northern outskirts was selected for the purpose by General Burnside and laid out by Captain H.S. Chamberlain, Assistant Quartermaster General. ${ }^{6}$ Originally part of a grant from the State of North Carolina in the 1790s, the undeveloped land was appropriated by the United States from landowner John Damron (or Dameron). 7 Located north of the city limits, the cemetery property initially measured 7.856 acres. Approximately two additional acres were added to the cemetery's land in 1866 or early 1867 . The resulting nearly square, 9.83-acre parcel was court appraised in 1867 , and transferred to the U.S. Government in fee simple on 10 June of that year by John Damron, at the appraised cost of $\$ 5,000$

\footnotetext{
4 Orlando M. Poe, Occupation of East Tennessee and the Defense of Knoxville, reprint of the 1889 edition published by Ostler Printing Co. of Detroit, (Knoxville: East Tennessee Historical Society, 1963), 68; Sammartino, "Knoxville National Cemetery," 1996.

5 Sammartino, "Knoxville National Cemetery," 1996.

6 W.A. Wainwright, “Historical Report of the National Cemetery at Knoxville, East Tennessee," 25 January 1867, RG 92 Records of the Office of the Quartermaster General, Entry 576 General Correspondence and Reports Relating to National and Post Cemeteries (“Cemetery File"), 1865-1914, Box 38, National Archives and Records Administration, Washington, DC.

7 Sammartino, "Knoxville National Cemetery," 1996; “Knoxville, Tennessee, National Cemetery, (Second Class)," 1893, RG 15 Records of the Veterans Administration, Entry A1-25 Department of Memorial Affairs, National Cemetery Historical File, Box 24, National Archives and Records Administration, Washington, DC.
} 
(Figure 3). ${ }^{8}$ The cemetery had been in use for years at this point, having had the first interment by 7 September 1863 . Union soldiers that had been buried in the county cemetery were subsequently removed and interred at the new cemetery. 9

Figure 3. Survey map of land conveyed to the Government for Knoxville National Cemetery, 1867 (NARA, Washington DC, RG92).

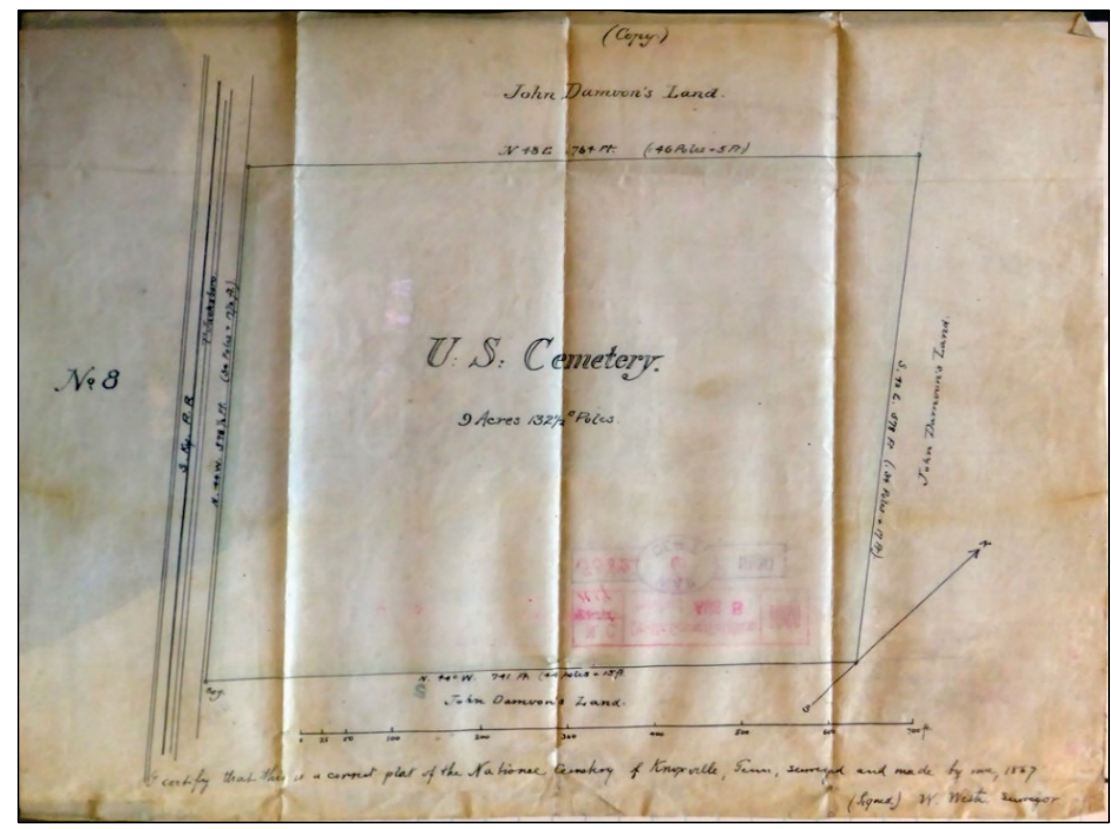

The many months of fighting in the area, combined with several battles, resulted in a large number of casualties. Concentrating the remains of Union soldiers from battlefields, camps, and hospitals in the area began after the war ended. ${ }^{10}$ The search and retrieval extended beyond the immediate area of Knoxville, including

in Tennessee from Tazewell, Claiborne County, 15 miles north; from Concord, Knox County, 20 miles west; from Christianburg, Montgomery

County, in Virginia, 200 miles east; from Asheville, Buncombe County, in North Carolina, 80 miles south, and from various places within those

\footnotetext{
8 John Damron, “Conveyance of Land," 10 June 1867, RG 15 Records of the Veterans Administration, Entry A1-25 Department of Memorial Affairs, National Cemetery Historical File, Box 24, National Archives and Records Administration, Washington, DC.

9 Robert P. McGinnis, "Historic Cemeteries of Old Knoxville, (Knoxville, TN: self-published, 2017), 84.

10 Virginia B. Price, "Historic American Landscapes Survey: Knoxville National Cemetery, Lodge," HALS No. TN-2-A, (Washington, DC: Department of the Interior, 2012), 5.
} 
limits; and from the cemetery at Cumberland Gap, in Claiborne County, Tennessee. ${ }^{11}$

The area from which the Union dead were disinterred for reburial at Knoxville National Cemetery was within the shaded red outlined area in Figure 4. Permission to begin the work of transferring remains to Knoxville was received in April 1866. At that time, there were already 1,700 graves at the cemetery. ${ }^{12}$ The work was supervised by Major W.A. Wainwright, Assistant Quartermaster, until later in 1867 when it was completed under Brevet Major E.B. Whitman. ${ }^{13}$

Figure 4. Map of collection area of Union Soldier remains for internment at Knoxville National Cemetery, c.1868 (NARA, Washington DC, RG92-CA).

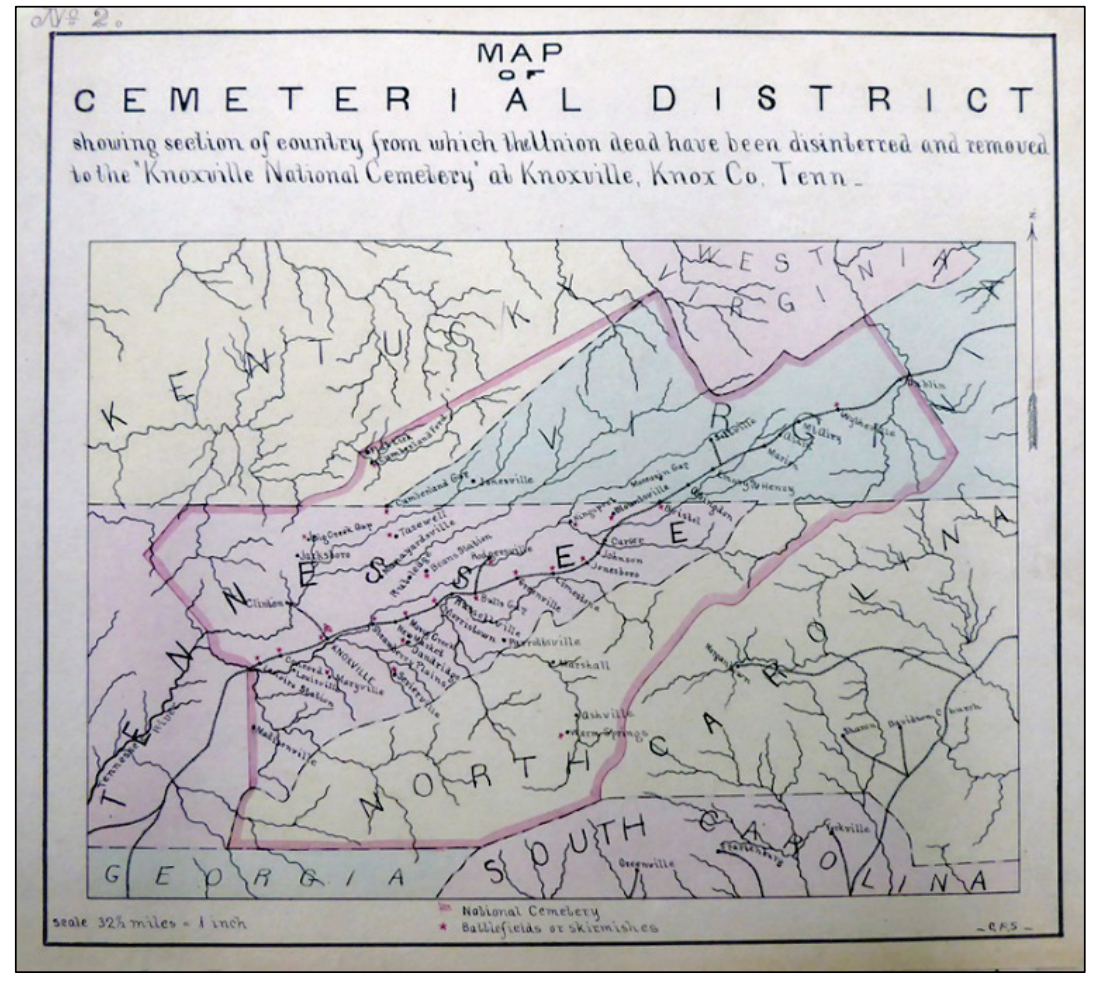

\footnotetext{
11 Sammartino, “Knoxville National Cemetery,” 1996.

12 Quartermaster General's Office, “Remarks of the Quartermaster General on Report of the soldiers Cemetery at Knoxville, Tenn.," April 1866, RG 92 Records of the Office of the Quartermaster General, Entry 576 General Correspondence and Reports Relating to National and Post Cemeteries ("Cemetery File”), 1865-1914, Box 38, National Archives and Records Administration, Washington, DC.

13 Brevet Lt. Colonel E.B. Whitman, “Report of E.B. Whitman, Superintendent National Cemeteries, Dept. of the Cumberland, Embracing Explorations of Battle fields, Cemeteries, and places where Union Dead were interred, Selection, Establishment, and Completion of National Cemeteries with Tables of Mortuary Statistics, Views and Plans," Louisville, KY: Mil. Div. of the Tennessee, 10 May 1869, RG 92 Records of the Office of the Quartermaster General, Entry 646A Report of E.B. Whitman 1868, Box 1, National Archives and Records Administration, Washington, DC.
} 
The site selection and initial design for the cemetery was created under Burnside's direction by Assistant Quartermaster Captain H.S. Chamberlain, with a formal design of concentric rings of burial sites surrounding a flag pole on the crest of a low hill. Known as the "wagon-wheel" design, its use at Knoxville was one of its earliest applications. ${ }^{14}$ Paths were laid out dividing the burial area to provide access to the gravesites. 15 The design of the cemetery was of such a military and formal nature that no changes were necessary when it officially became a National Cemetery a few years later. Brevet Major E.B. Whitman, responsible for mortuary records, described it in August 1866 as

the only burial ground of Union soldiers in this department originally laid out and conducted to the present time in a manner and on a system that render it suitable to be converted into a National Cemetery without material alteration or change, or removal of a single body. ${ }^{16}$

A somewhat stylized view of the cemetery from 1864 shows the central area sodded but without a flagstaff (Figure 5). Most graves are marked with the original wooden stakes; however, artistic license was taken with the markers for the $79^{\text {th }}$ New York Highlanders (the subject of the image) by showing them as unrealistically large and with the text on the outward side instead of the inward-facing side. Both deciduous and evergreen trees are depicted, showing the cemetery (if accurately rendered) was constructed around existing trees.

\footnotetext{
14 Jack Neely and Paul James, Knoxville's National Cemetery, (Knoxville, TN: Knoxville History Project, 2018), 17.

15 Price, “Historic American Landscapes Survey: Knoxville National Cemetery, Lodge," 2012, 5.

16 Edward Steere, "Early Growth of the National Cemetery System," Quartermaster Review, March-April 1953, https://www.amfound.com/article/early-growth-of-the-national-cemetery-system/.
} 
Figure 5. Charles Hart, “Graves of the Highlanders," Knoxville National Cemetery, 1864 (Library of Congress).

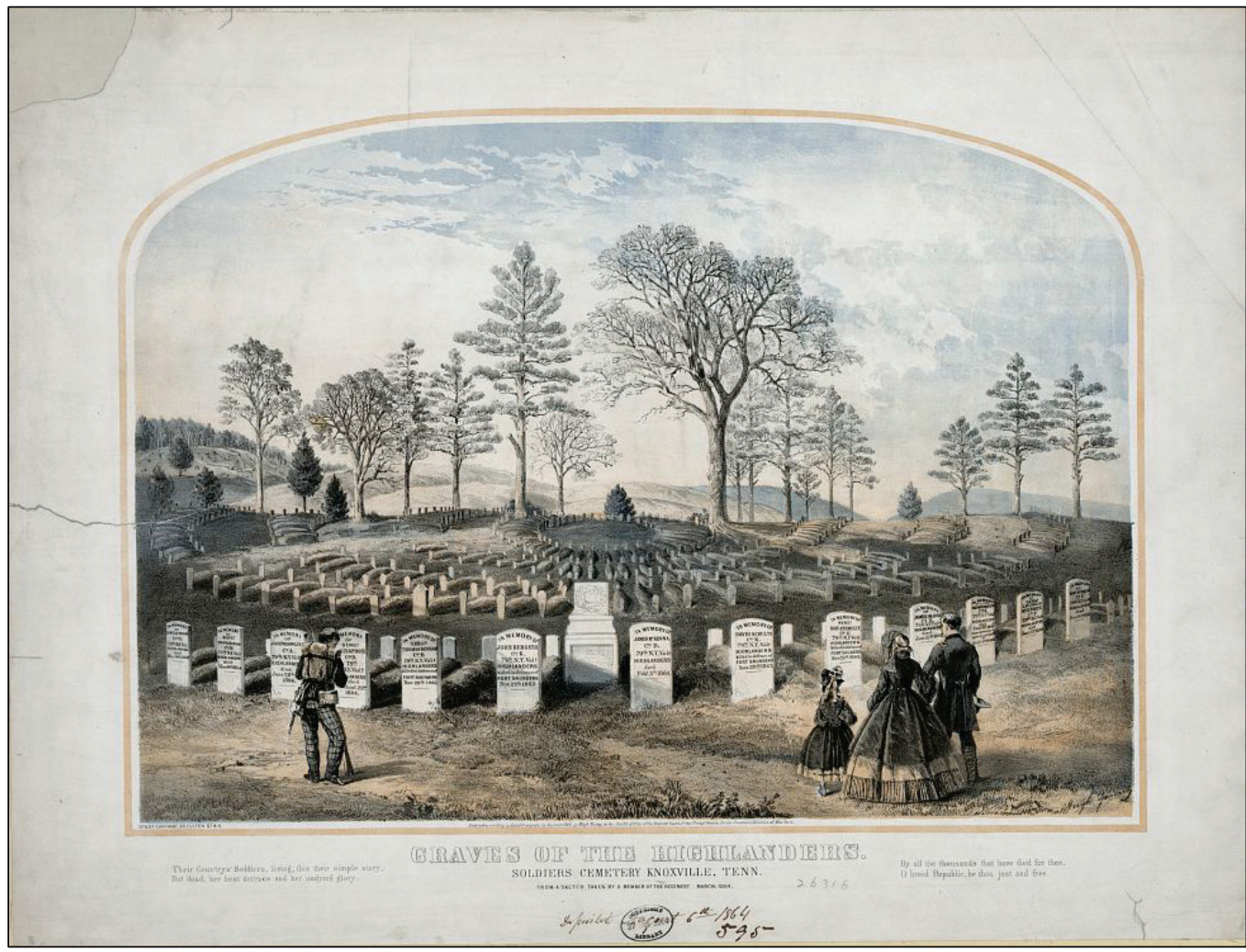

\subsubsection{Initial design of grounds}

An 1866 plan of the cemetery shows the layout with 10 concentric rings of burial spaces (Figure 6). ${ }^{17}$ The overall burial area was divided into four burial sections defined by two bisecting roads or paths. At this point, the outer circle of burial sites had not been completed. There were four entrances to the cemetery shown, at each end of the two roads. None of the entrances were indicated as being a main entrance. A note on the map indicated the cemetery contained 7.856 acres. ${ }^{18}$ The acreage had been expanded to the current 9.83 acres by adding "a strip of land lying between the old ground and the public road" shortly before the property was sold to

\footnotetext{
17 There are twelve cemeteries that have graves in some sort of circular or semi-circular pattern. The Glendale National Cemetery in Virginia has the same circle plan with a circle drive and two main axial drives as the Knoxville National Cemetery.

18 "Plan of the National Cemetery at Knoxville Tennessee, 1866," RG 92 Records of the Office of the Quartermaster General, Entry 576 General Correspondence and Reports Relating to National and Post Cemeteries (“Cemetery File”), 1865-1914, Box 38, National Archives and Records Administration, Washington, DC.
} 
the U.S. Government. ${ }^{19}$ This strip of land would provide spaces for both of the first two Superintendent's Lodges. A "plain panel fence" around the cemetery was in place before July $1865 .{ }^{20}$ Improvements to the property began early, with an inspector describing the cemetery as "one of great beauty," and that it "is being ornamented with shrubbery, flowers, etc. with an idea of improving it to such an extent as to meet with the praise of the Citizens.”21 There was already a flagstaff in place as an 1866 inspection report documented that a "fine National Flag" had been donated by the "Ladies of Knoxville" and raised on the existing flagstaff in front of roughly 1,000 people on the $4^{\text {th }}$ of July, $1866 .{ }^{22}$

\footnotetext{
19 Brevet Major E.B. Whitman, Superintendent National Cemeteries, Assistant Quartermaster, "Report on National Cemeteries No 10, Knoxville," 11 November 1867, RG 92 Records of the Office of the Quartermaster General, Entry 576 General Correspondence and Reports Relating to National and Post Cemeteries (“Cemetery File”), 1865-1914, Box 38, National Archives and Records Administration, Washington, DC.

20 W.A. Wainwright, "Report on Conditions of the Knoxville Soldiers Cemetery," 11 May 1866, RG 92 Records of the Office of the Quartermaster General, Entry 576 General Correspondence and Reports Relating to National and Post Cemeteries ("Cemetery File"), 1865-1914, Box 38, National Archives and Records Administration, Washington, DC.

21 "Report of Brevet Major W. A. Wainwright, Office of Assistant Quartermaster," 24 July 1866, RG 92 Records of the Office of the Quartermaster General, Entry 576 General Correspondence and Reports Relating to National and Post Cemeteries ("Cemetery File"), 1865-1914, Box 38, National Archives and Records Administration, Washington, DC.

22 Ibid.
} 
Figure 6. 1866 plan of Knoxville National Cemetery (NARA, Washington DC, RG92).

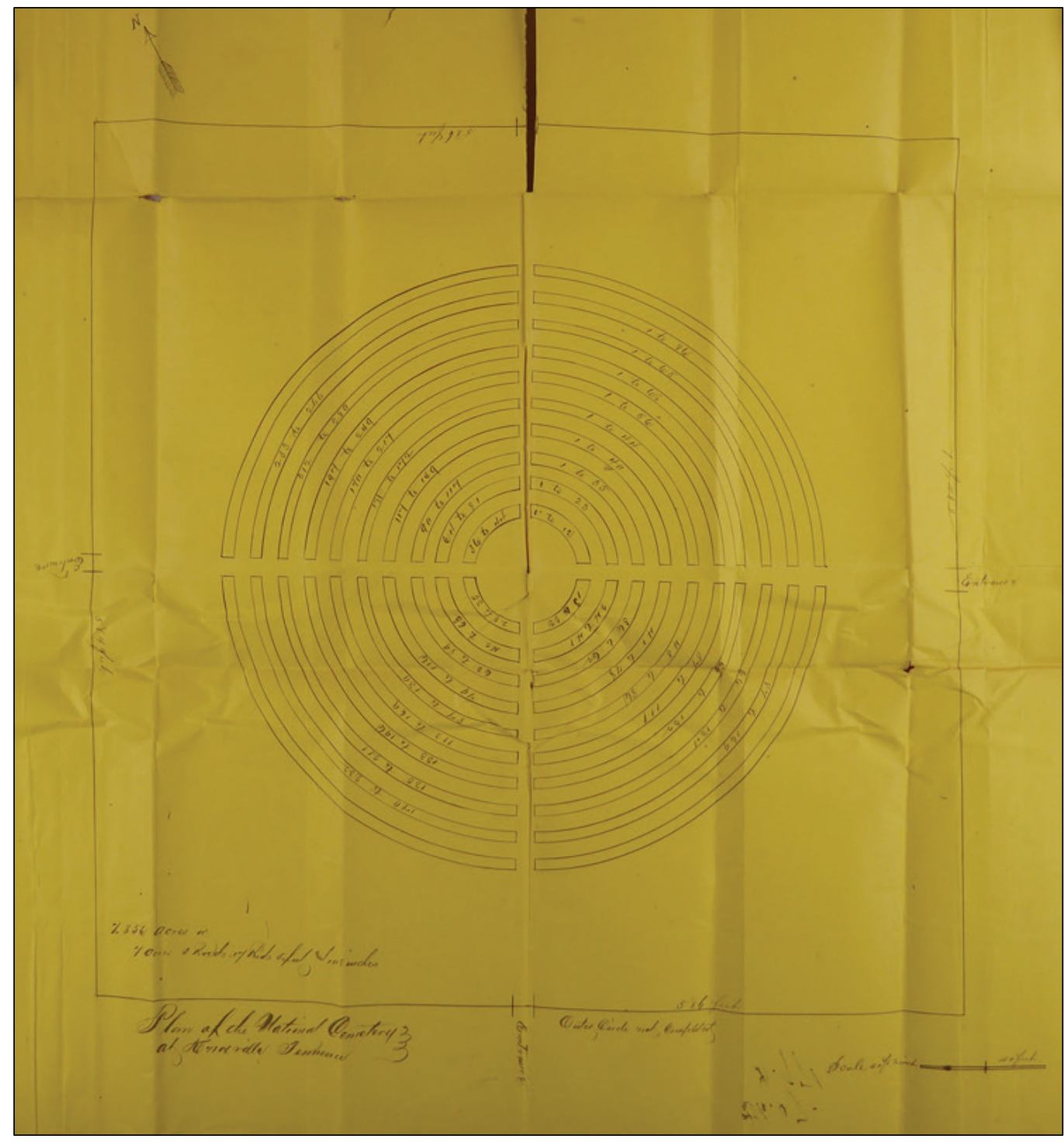

An inspection report from 1867 described the cemetery as having sodded graves, gravel drives and walks, and shrubbery. ${ }^{23}$ Another inspection later that same year provided detailed information on the layout and appearance of the cemetery: 24

a. The graves area arranged, at intervals of 2 feet, in 12 concentric belts, each belt 7 feet wide, with paths between the belts from 9 to 12 feet wide. Four

23 Wainwright, “Historical Report of the National Cemetery at Knoxville, East Tennessee," 25 January 1867.

24 Brevet Major C.W. Folsom, Assistant Quartermaster, “Inspection Report of Cemeteries at Knoxville Tennessee," 4 April 1867, RG 92 Records of the Office of the Quartermaster General, Entry 576 General Correspondence and Reports Relating to National and Post Cemeteries ("Cemetery File"), 18651914, Box 38, National Archives and Records Administration, Washington, DC. 
roads lead from the four gates to the centre, and a good carriage drive surrounds the outer belt of graves. The roads or paths are all wide enough for a carriage, and are well macadamized with slate rock. Soft or decayed slate has also been placed between the graves, to keep down the grass which was found too rank. The ground slopes gently from the northeast to the southwest; there is not much more ground, fit for similar use, on either the northwest or southeast sides, and but little on the rear of northeast side; but the ground on the front or southwest side is gently sloping and available.

b. The eight inner circles have headboards, painted white and lettered, of air quality. The four outer circles have, as yet, only numbered stakes, awaiting orders for a more permanent memorial. There are 53 marble headstones erected by friends; one group of 13 , with a central monument, by the $79^{\text {th }}$ N.Y. Vol's, "Highlanders."

c. There are a large number of small cedars planted among the graves, but none in the corner spaces of the Cemetery.

d. The graves are well sodded; and a well-shaped mound of good loam, 6 inches high, to each.

e. In the centre is a mound 5 feet high and 30 feet in diameter, with a rustic flagstaff, 60 feet high. There is no flag at present, the private one which the citizens had having been destroyed by the winds.

f. The Cemetery is surrounded with an open pine board fence, $4^{1 / 2}$ feet high; composed of four horizontal 5 -inch boards, one lower board, 10 inches wide, and a 5 -inch cap. The posts are cedar, 10 feet apart. The fence is sound, but the posts are loose and need straightening up. It is not painted, nor whitewashed. There are substantial plain gates in the centre of each of the four sides. Over the front and rear gate is a plain cross piece, slightly sagged (Figure 7).

g. There are no locks to the gates which are fastened only by a stick in staples.

Figure 7. Sketch of entry over front and rear gates included in 1867 inspection report (NARA, Washington, DC, RG92).

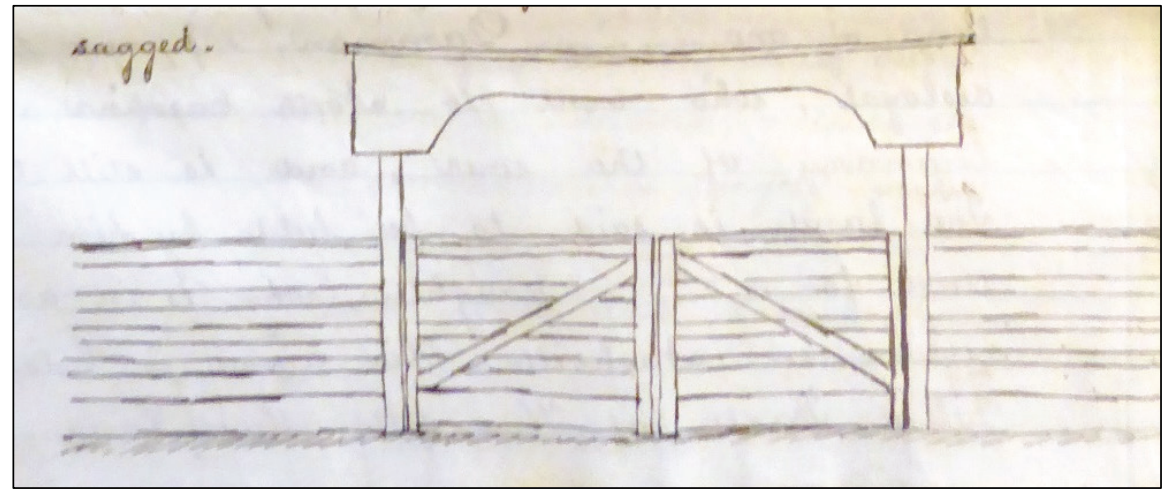


Brevet Major Folsom recommended that the fence be whitewashed, and that the gate arches be painted white, with "National Cemetery" being painted in black on the arches. The gate should be padlocked at night, that the flagstaff be replaced and painted white, and a flag procured. The grounds outside the burial circle should be improved with grass seed and the addition of trees other than pines or cedars be set out in those areas. These recommendations were approved several days later. ${ }^{25} \mathrm{~A}$ picket fence enclosing the land for the Superintendent's Lodge and garden areas, and approval for construction of a lodge were in place by November $1867 .{ }^{26}$

Several early images of the cemetery have survived and give a sense of the design and appearance. In 1869, the cemetery was sketched in both landscape view and plan by Mr. P.M. Radford of Nashville for Brevet Lt. Colonel E.B. Whitman of the Quartermaster Department, who was in charge of establishing National Cemeteries in the Military District of Tennessee (Figure 8). ${ }^{27}$ The 10 concentric rings shown in the 1866 plan have been increased to 13, with the outer ring labeled as being reserved for colored soldiers. There is a wide circular road around the burial area by this time, and two small burial sections have been marked out on the far side of the road, near the intersection of the axial road or pathway across the cemetery on the southwest side. The 1869 plan also shows the Superintendent's Lodge and Office to the southwest of the burial area, near the main entrance to the cemetery from Cooper Street. Well behind the lodge, a stable and attached shed were located in the far western corner of the cemetery. Four corner posts for the property are shown with the inscription "US."

25 Ibid.

26 Whitman, "Reports on National Cemeteries, No 10, Knoxville," 11 November 1867.

27 Whitman, “Report of E.B. Whitman,” 10 May 1869. 
Figure 8. P.M. Radford, Map of Knoxville National Cemetery, 1869 (NARA, Washington DC, RG92).

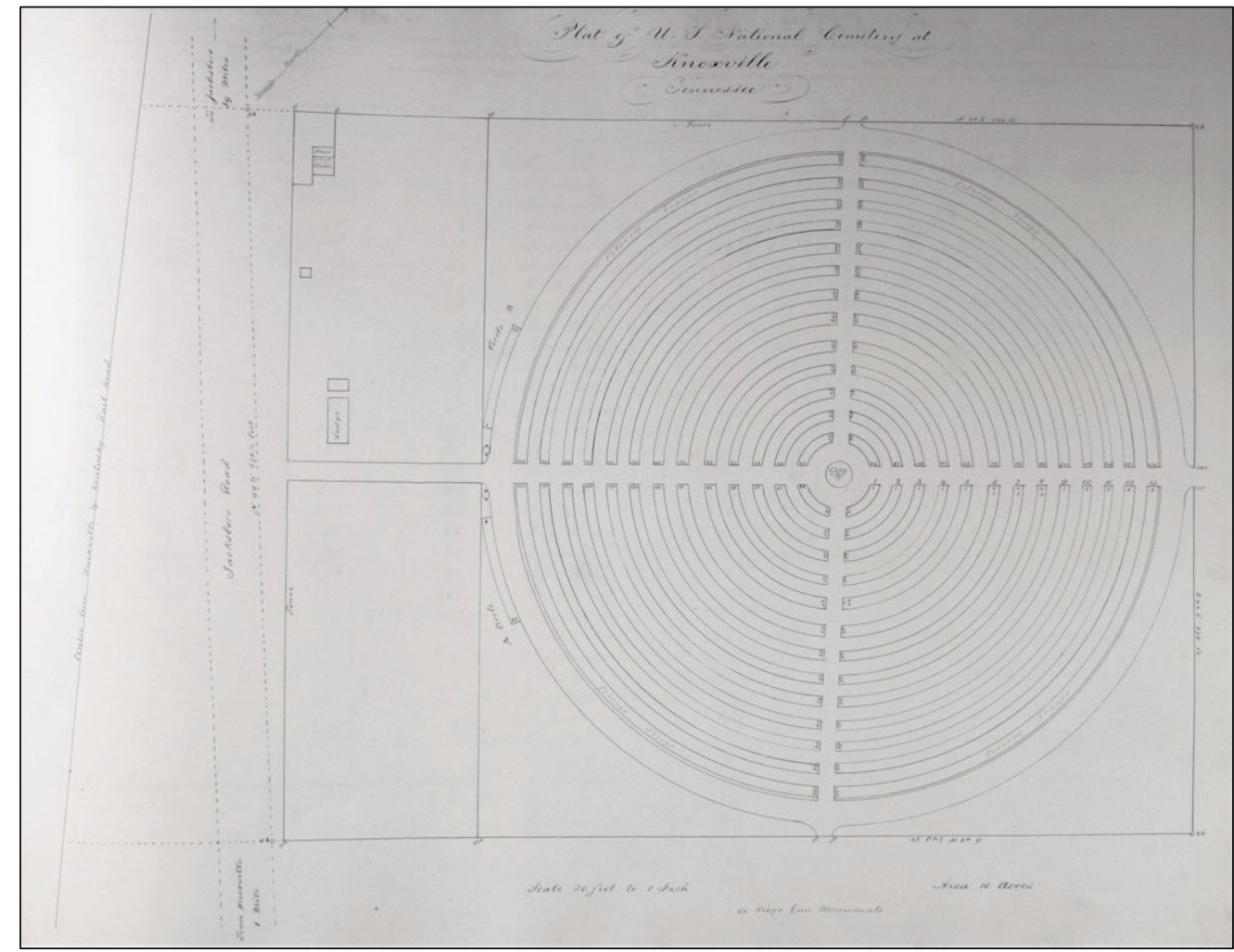

The accompanying view sketch of the cemetery shows the entire area surrounded by a wooden board fence with an entrance gate made of the same materials topped with a flat arch (Figure 9). The drive continues across the area reserved for the lodge and other buildings to another fence separating the working/residential area from the burial area. The gate into the burial area has a slightly oval arch. The drive then proceeds to the central flagpole (greatly exaggerated in height), and the far gate is shown simply as an arch. There are scattered trees in the burial area. The lodge is shown as adjacent to the drive, and near the main entrance, as stipulated in the 1867 Act, with a stable to the rear. ${ }^{28}$

\footnotetext{
28 Colonel E.B. Whitman, letter to Brevet Major General Thomas Swords, 5 August 1868, RG 92, Records of the Office of the Quartermaster General, Entry 576 General Correspondence and Reports Relating to National and Post Cemeteries ("Cemetery File"), 1865-1914, Box 22, National Archives and Records Administration, Washington, DC.
} 
Figure 9. P.M Radford, View of Knoxville National Cemetery, 1869 (NARA, Washington DC).

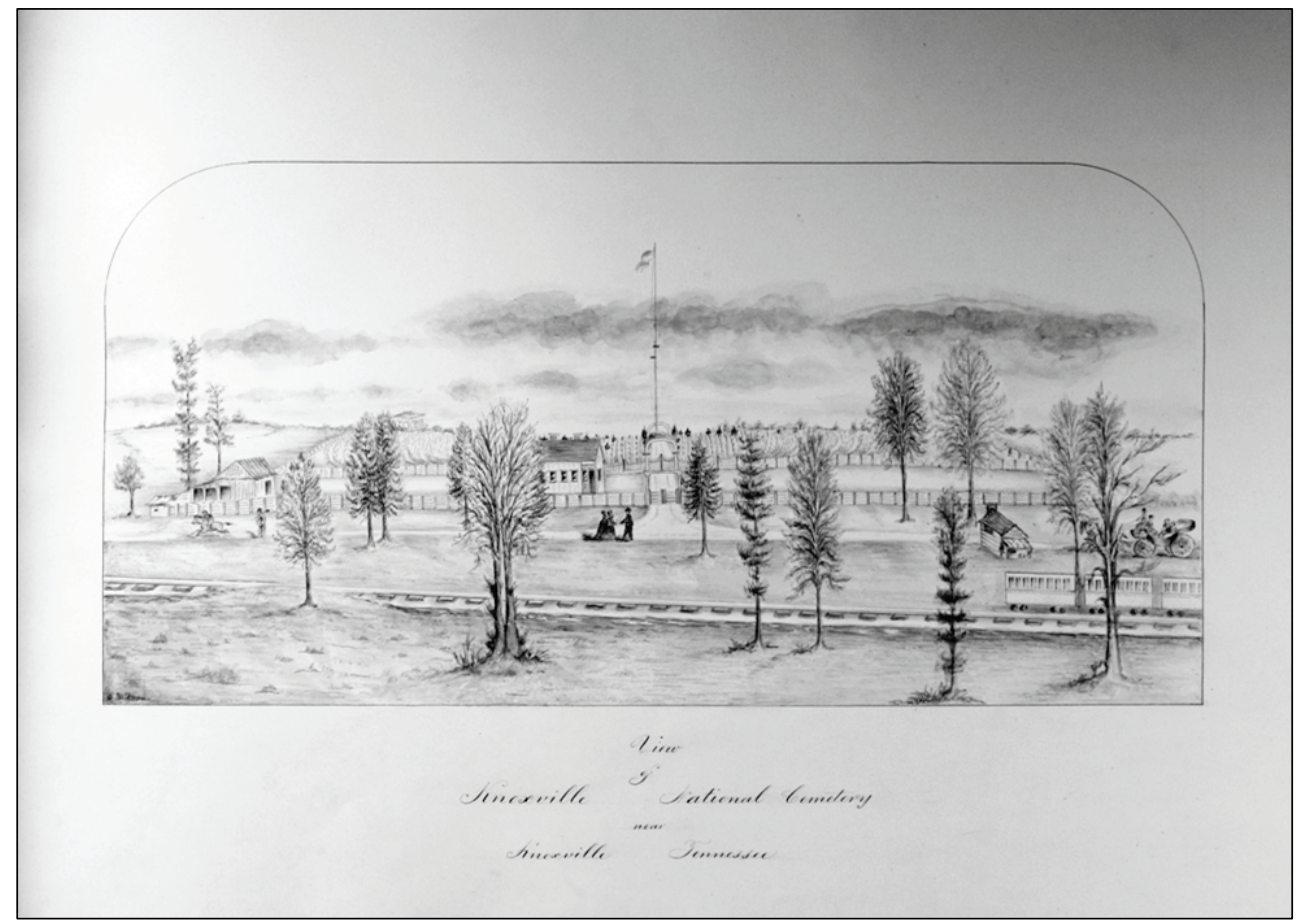

In his 1869 report, Whitman provides a brief verbal description of the Knoxville National Cemetery: "the National Cemetery at Knoxville Tenn contains eight acres in the Cemetery proper and two acres in the Keeper's garden lot ... two Siege Gun Monuments have been erected, and there is a fine FlagStaff. It is still enclosed with the original plank fence." 29 A bird's eye view drawing from 1871 shows the National Cemetery's concentric circles and central flagpole. The cemetery is shown as bounded by rows of trees (Figure 10). In October 1872, the Superintendent reported the fence was being protected by an Osage Orange hedge along the interior of the fence that "prevents parties from climbing the fence and breaking it down." 30 The same report indicates the paths in each burial section were being allowed to be covered in grass instead of gravel, and that trees and shrubs were growing well.

\footnotetext{
29 Whitman, “Report of E.B. Whitman,” 10 May 1869.

30 Thomas Ridge, "Monthly Report of the Condition of Knoxville National Cemetery at Knoxville, Tenn, for the Month of September 1872," 1 October 1872, RG 92 Records of the Office of the Quartermaster General, Entry 576 General Correspondence and Reports Relating to National and Post Cemeteries (“Cemetery File”), 1865-1914, Box 38, National Archives and Records Administration, Washington, DC.
} 
Figure 10. Detail of 1871 Birds-Eye View of Knoxville showing Knoxville National Cemetery with flagstaff, concentric rings, and a border of trees (Library of Congress).

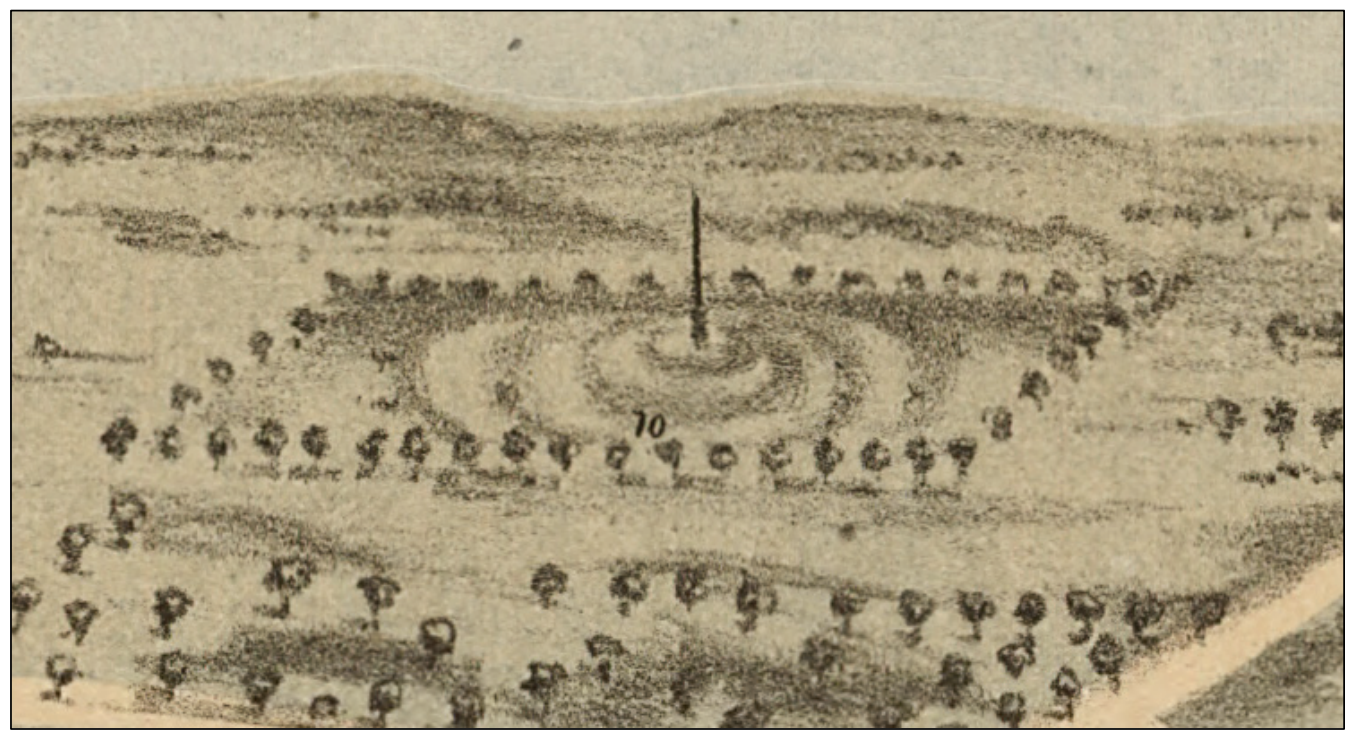

The two siege gun monuments were placed on the southwest and southeast quadrants of the burial area (Figure 11). They were located on the far side of the circle drive and can be seen on the 1892 map (Figure 12). The siege gun monuments were removed sometime after 1909.

Figure 11. Undated postcard showing one of two siege gun monuments located in the Knoxville National Cemetery (University of Tennessee, Knoxville, Library digital collections “Images of East Tennessee").

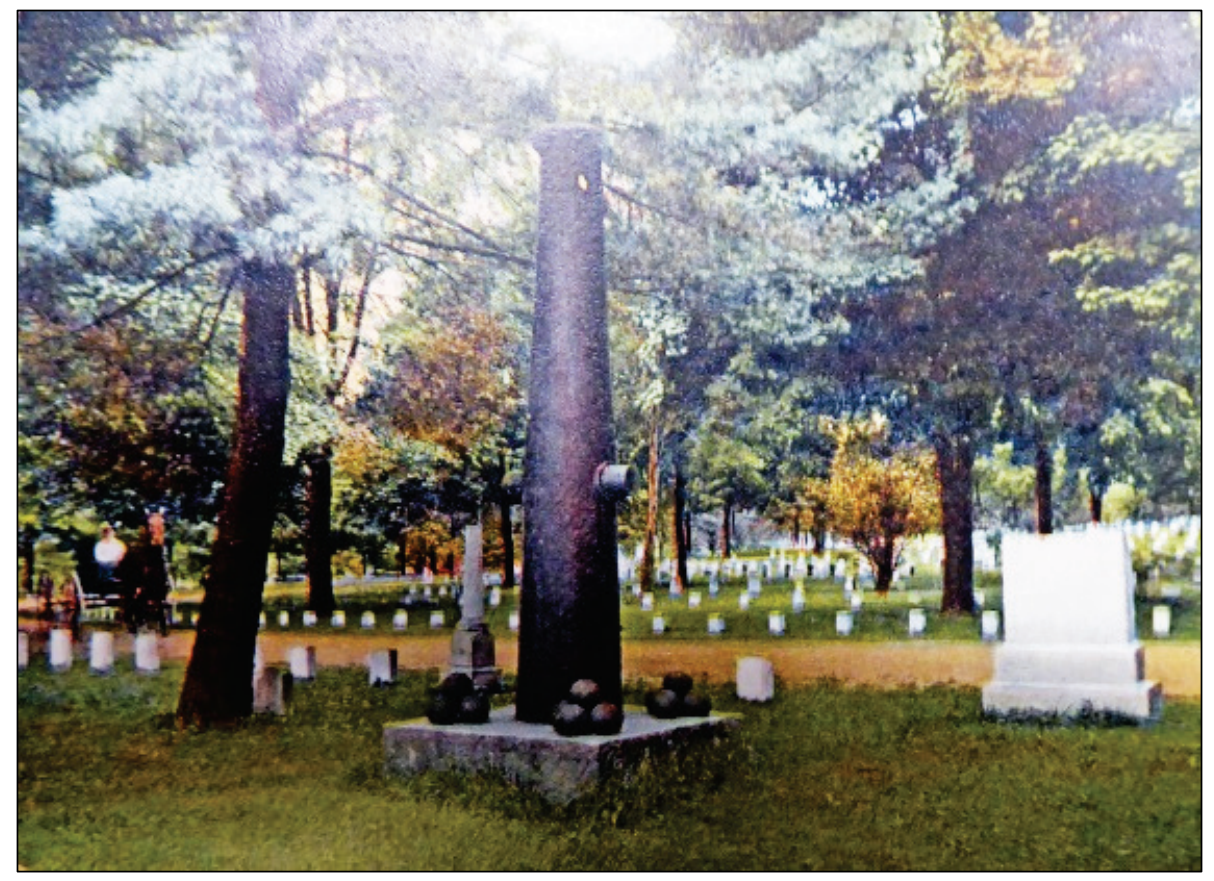


Figure 12. 1892 map of Knoxville National Cemetery showing location of siege gun monuments (circled), (VA NCA Archives, Washington, DC).

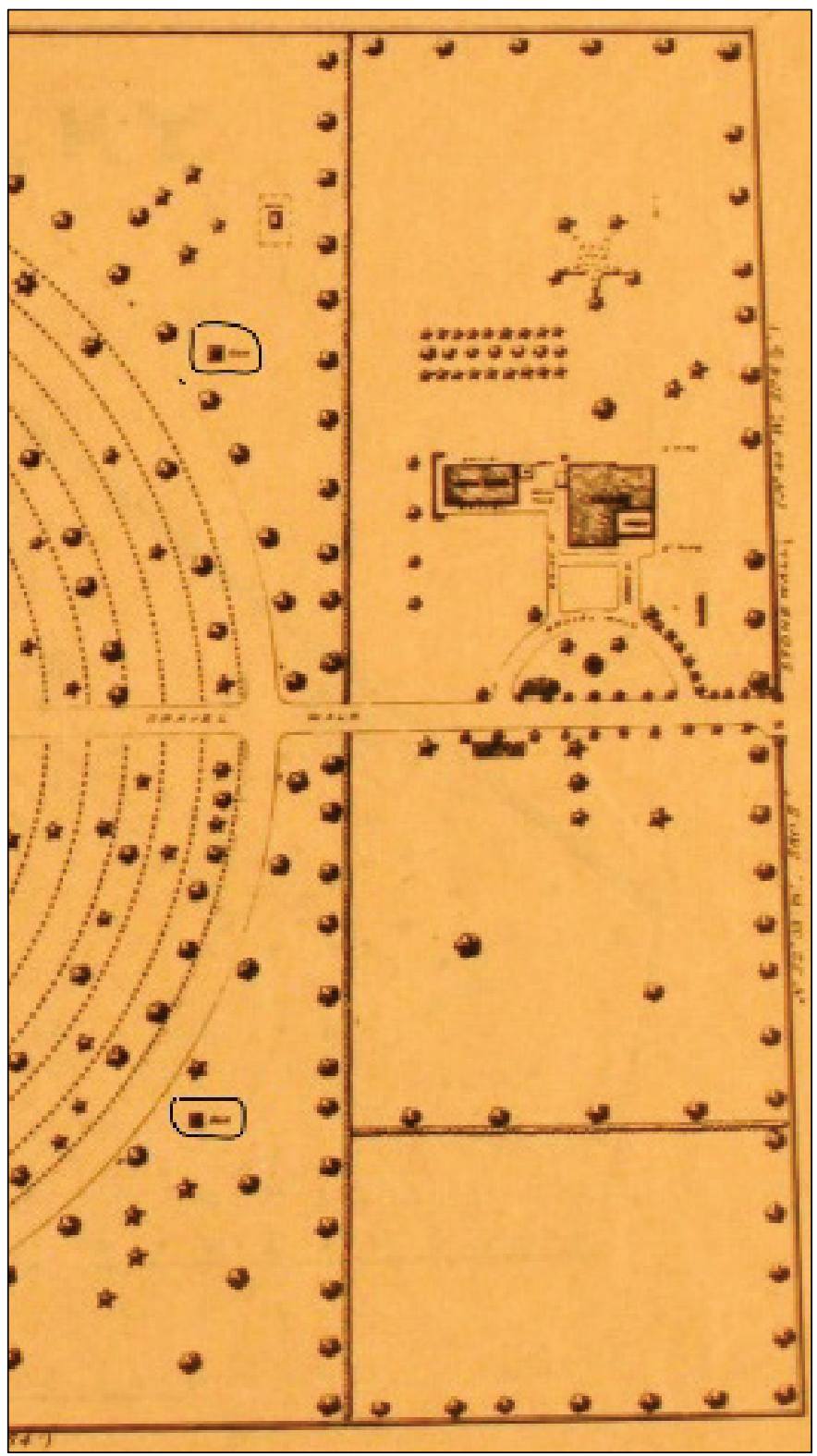

\subsubsection{Markers}

The original headboards at Knoxville National Cemetery were meant to be temporary and were in poor condition by July 1866. A contract to supply 2,00o head boards of the regulation pattern was advertised that month, with work expected to be completed by autumn. ${ }^{31}$ Funds appropriated in 1867 for construction of lodges also covered "land costs, fence 
construction, grave marking, and other actions" at National Cemeteries. ${ }^{2}$ The individual graves were identified with numbered wooden stakes. According to Brevet Lt. Colonel E.B. Whitman, by May 1969 all the National Cemeteries in the Department of the Cumberland had graves "marked with small head stakes, neatly painted and bearing a number to correspond with the number upon the Record." 33 By January 1868, there were 3,128 interments in the cemetery, with wooden headboards "well painted and lettered," and 32 marble head stones "erected by friends of the deceased." 34 Replacement of the wooden markers with permanent Vermont marble makers began in 1876.35 The cemetery contains the burial of one Confederate soldier, Captain George M. Coleman of the 9th Kentucky Regiment, who is buried in Section D, Grave $2538 .{ }^{6}$ No information was found relating to his burial.

\subsubsection{Buildings and structures}

The 1867 "Act to Establish and Protect National Cemeteries" included requirements that each cemetery be enclosed by a stone wall or iron fence and have a lodge for a cemetery manager or Superintendent. 37 The person had to be an enlisted veteran and live on site to provide both protection for the cemetery and information to visitors. $3^{8}$ The cemetery's first Superintendent was Thomas Ridge, in the position since at least July 1866 as foreman of cemetery workers, then as Superintendent by April 1867.39 In the spring of 1867 , his family and he were living in a "small cabin in the eastern corner, at the rear side of the grounds, not separated by any fence from

\footnotetext{
32 Michael R. Harrison, “National Cemeteries, Superintendent's Lodges," Historic American Buildings Survey No. DC-46, (Washington, DC: National Park Service, 2013), 46, 17.

33 Whitman, "Report of E.B. Whitman," 10 May 1869.

34 Major General Thomas Swords, Assistant Quartermaster General, Department of the Cumberland, United States Army, "Consolidated Monthly Report of Progress on the National Cemeteries in the Department of the Cumberland for the Month of January 1968," January 1868, RG 15 Records of the Veterans Administration, Entry A1-25 Department of Memorial Affairs, National Cemetery Historical File, Box 24, National Archives and Records Administration, Washington, DC.

35 Gjore J. Mollenhoff, Historic Preservation Officer, Letter to Herbert L. Harper, Tennessee Historical Commission, 13 January 1986, Folder: “Knoxville National Cemetery - General," National Cemetery Administration Archives, Washington, DC.

36 U.S. Department of the Interior, "Knoxville National Cemetery, Knoxville, Tennessee," https://www.nps.gov/nr/travel/national cemeteries/Tennessee/Knoxville National Cemetery.html\#: :text=0ne\%20Confederate\%20soldier\%2C\%20Captain\%20George, in\%20Section\%20D\%2C\%20Grave\%202538.\&text=Knoxville\%20National\%20Cemetery\%20is\%20located,daily\%20from\%20sunrise $\% 20$ to $\% 20$ sunset.

37 Public Law 37 was passed by the U.S. Congress on 22 February 1867.

38 The practice of appointing Civil War veterans was suspended in 1910. Harrison, "Superintendent's Lodges," 2013, 6, 17.

39 W.A. Wainwright, "Report on Conditions of the Knoxville Soldiers Cemetery," 11 May 1866.
} 
the rest of the Cemetery" (this is likely in the area now occupied by the Union Soldier Monument). $4^{\circ}$ The Superintendent's Lodge was planned to be placed in the "front" of the cemetery on the strip of land beside Cooper Street, and the strip of land was enclosed with a fence.

Designed by the Quartermaster Department, the initial standard lodges were wood-framed buildings clad in battened board siding, with gable roofs. Covered porches were located at one or both ends, and a central chimney served both fireplaces. ${ }^{41}$ There were two linear rooms, an office and a living room. The two-bedroom lodge was constructed in 1867 and 1868. A three-room version was constructed beginning in 1868 . In addition to the third room, other changes were the addition of a second chimney, a veranda on one side of the office that provided doors into the living room and into the office, and a rear door directly into the kitchen. The three-room lodge was constructed between 1868 and 1870, by which time nearly every other National Cemetery had a lodge. ${ }^{2}$

The first lodge at Knoxville was completed in January 1868 and was the three-room version, measuring $38^{\prime}$ long x $16^{\prime}$ wide (Figure 13 - Figure 15). 43 A sketch plan of the lodge and surrounding area shows the singlestory building with a walk from the main drive through the cemetery. The building consisted of steps up to the "Piazza" or porch with the double entrances, a living room, and a kitchen, and containing two chimneys (Figure 14). Attached at the rear were a shed and a summer kitchen, with no connecting doors into the lodge. These may have been added after the original construction, as they were not part of the standard plan. A large flower bed was placed beside the lodge. The stable at the rear corner of the property consisted of a barn with a shed attached to the rear (Figure 15). A threeperson privy building was located roughly halfway between the lodge and the stable and was likely available to visitors.

\footnotetext{
40 Folsom, “Inspection Report of Cemeteries at Knoxville Tennessee," 4 April 1867.

41 Harrison, “National Cemeteries, Superintendent's Lodges,” 2013, 18-19.

42 Ibid.

43 Swords, "Consolidated Monthly Report of Progress on the National Cemeteries in the Department of the Cumberland for the Month of January 1968," January 1868.
} 
Figure 13. Detail of 1874 sketch plan showing front of the original lodge (NARA, Washington DC, RG92).

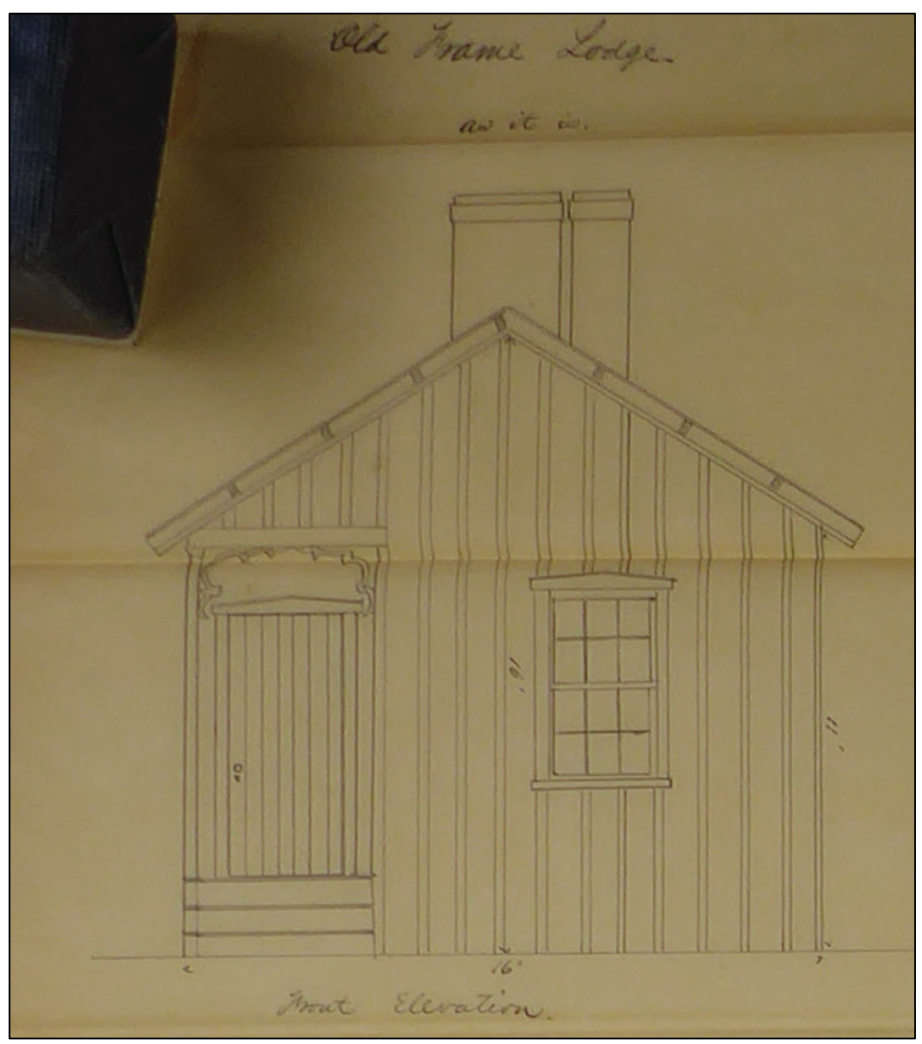

Figure 14. Detail of 1874 sketch plan showing original lodge (NARA, Washington DC, RG92).

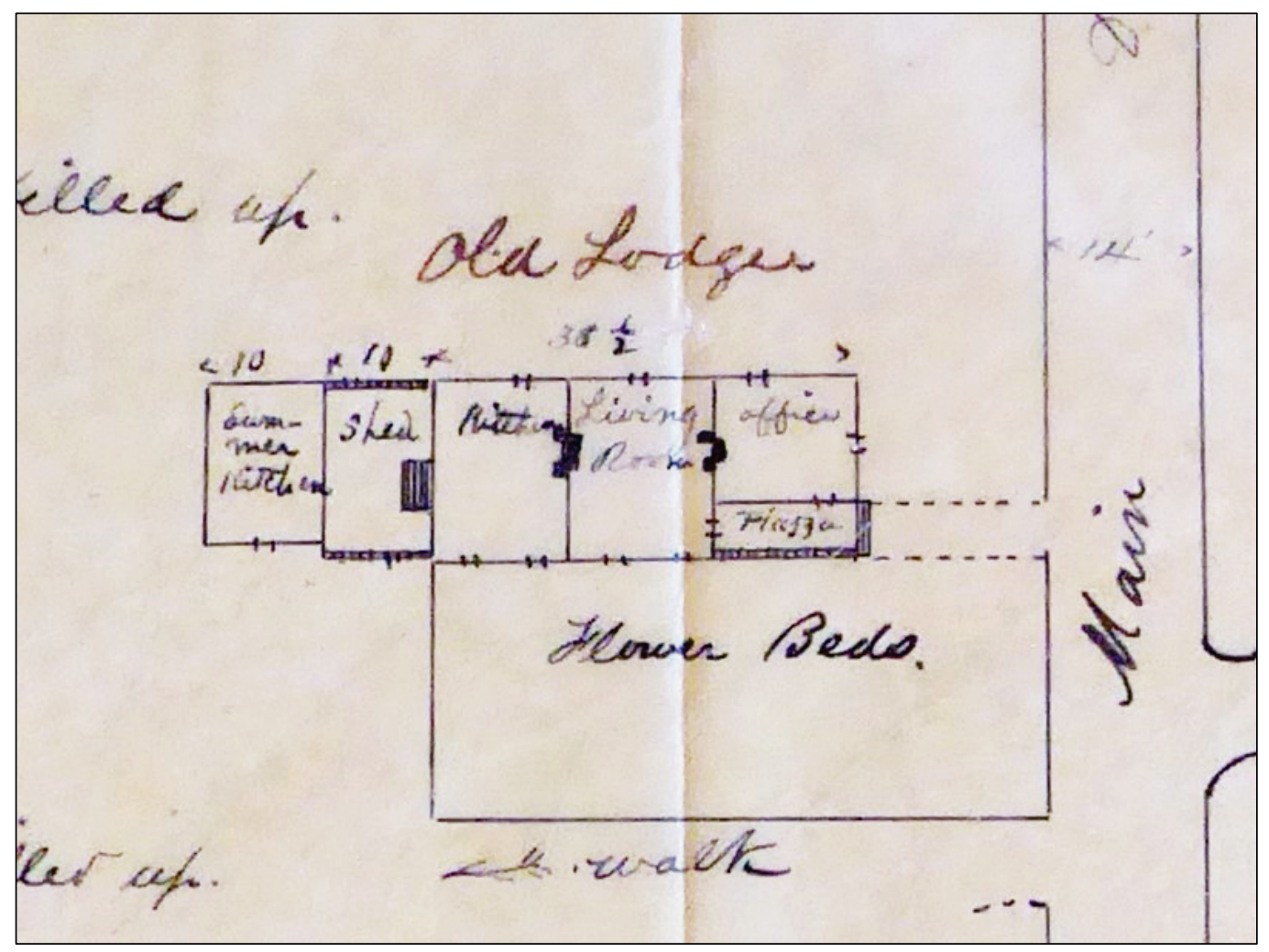


Figure 15. 1874 sketch plan showing original lodge to right, with privy, barn and shed to the rear (NARA, Washington DC, RG92).

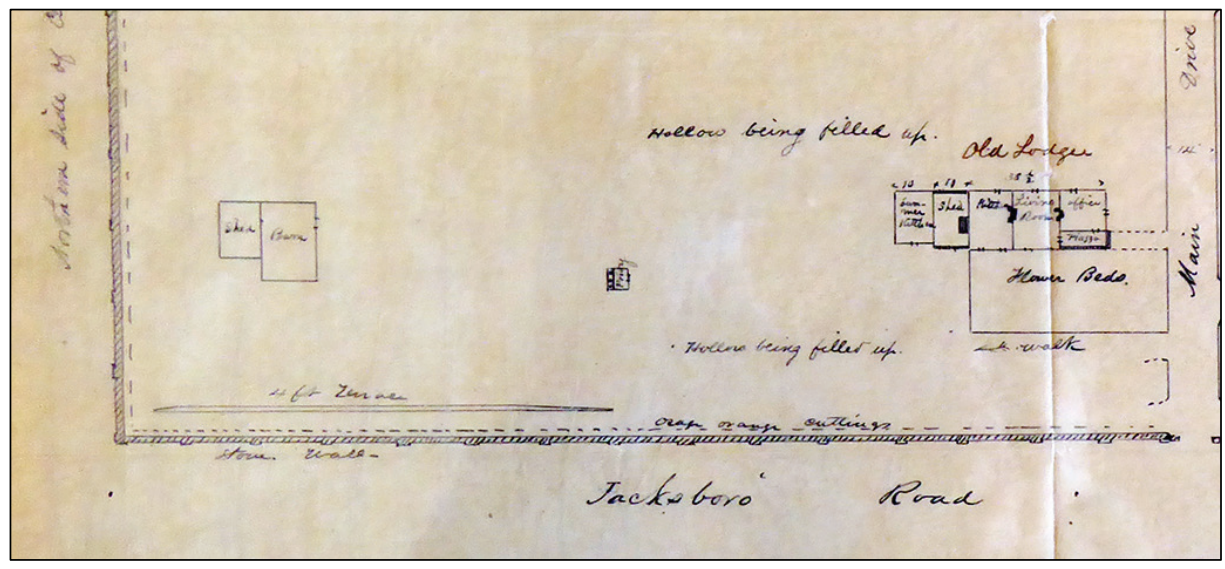

Problems were apparent very quickly, with an 1869 inspection stating "the lodge is very badly built. The plank was not seasoned, and the shingles were most inferior. The shrinkage has been very great, and every rain storm beats through the doors and casements of the windows, covering the floors with water. The roof leaks badly. The plastering was done in midwinter. The mortar contains very little lime, and is constantly falling off." 44

\subsubsection{Walls, roads, and gates}

An 1867 inspection report lists the perimeter of the cemetery as $2,630^{\prime} .45$ National Cemeteries were required to be enclosed by a wall made of permanent materials and to have a coping on the top of that wall.46 By 1871, plans were in effect to replace the wooden perimeter fence with a permanent one. In the spring of that year, construction specifications and requests for bids were released by the Quartermaster Department for walls of brick or stone and iron railings at several National Cemeteries, including Knoxville. 47

\footnotetext{
44 Sammartino, “Knoxville National Cemetery,” 1996.

45 Whitman, “Reports on National Cemeteries, No 10, Knoxville," 11 November 1867.

46 Bingham to Quartermaster General, Letter 19 November 1881, Record Group 92 Records of the Office of the Quartermaster General, Entry 576 General Correspondence and Reports Relating to National and Post Cemeteries ("Cemetery File"), 1865-1914, Box 22. Washington, DC.

47 A.R. Eddy, Chief Quartermaster, Department of the South, “Proposals," 10 April 1871, RG 92 Records of the Office of the Quartermaster General, Entry 576 General Correspondence and Reports Relating to National and Post Cemeteries (“Cemetery File”), 1865-1914, Box 38, National Archives and Records Administration, Washington, DC; Montgomery C. Meigs, Quartermaster General, letter to Major A.R. Eddy, Chief Quartermaster, Department of the South, 20 June 1871, RG 92 Records of the Office of the Quartermaster General, Entry 576 General Correspondence and Reports Relating to National and Post Cemeteries (“Cemetery File”), 1865-1914, Box 38, National Archives and Records Administration, Washington, DC.
} 
The enclosing wall at Knoxville National Cemetery was constructed between November 1872 and May $1873.4^{8}$ Constructed of rubble stone and laid in mortar, the wall was $4^{\prime}, 8^{\prime \prime}$ high and topped with a $4^{\prime \prime}$ hard compact limestone slab coping. 49 Due to the topography of the land, the top of the wall in the southwest portion of the cemetery was nearly level with the ground. As surface water flowed downward to this spot, a drainage issue required excavating a slope toward the wall and installation of a gutter. $5^{5}$ Each corner of the wall had a concrete fence post. The square posts had a circular cap with a round finial and "U.S." painted on every side (Figure 16). 51

Figure 16. Wall with iron fence and concrete fence post at north corner by the 1907 lodge, undated photo - likely 1947 (NARA, Washington DC, RG15).

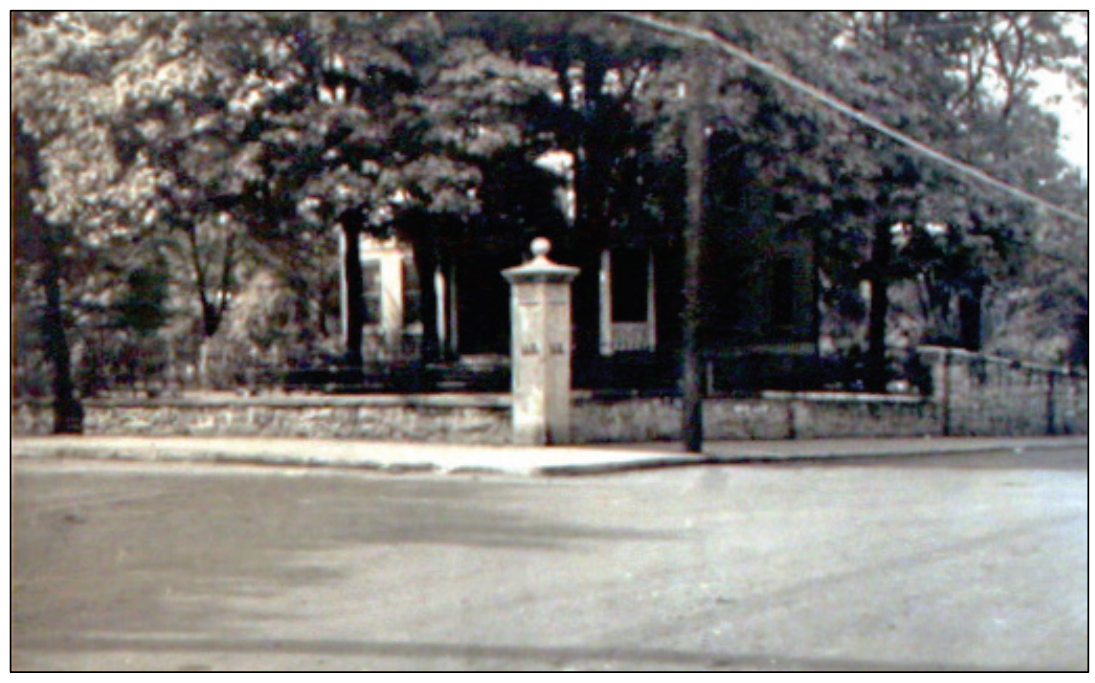

The original permanent main gate to the cemetery was constructed in 1873 and opened onto Cooper Street. The double iron gates served as the carriage entrance and were flanked on the south side by a single iron

\footnotetext{
48 "Veteran to Fill Final Grave in Old Cemetery," The Knoxville Journal, 20 April 1973; RG 15 Records of the Veterans Administration, Entry A1-25 Department of Memorial Affairs, National Cemetery Historical File, Box 24, National Archives and Records Administration, Washington, DC; Sammartino, "Knoxville National Cemetery," 1996.

49 “Inspection Report, Knoxville Cemetery," 28 August 1874, RG 92 Records of the Office of the Quartermaster General, Entry 649 Reports of Inspection-National Cemeteries, 1874-1883, Box 1, National Archives and Records Administration, Washington, DC.

50 Ibid.

51 "Enclosing Walls and Fences," Real Property Form, U.S. National Cemetery, Knoxville, Tenn., 1967, RG 15 Records of the Veterans Administration, Entry A1-25 Department of Memorial Affairs, National Cemetery Historical File, Box 24, National Archives and Records Administration, Washington, DC; “Inspection Report, Knoxville Cemetery," 28 August 1874.
} 
pedestrian gate. $5^{2}$ The gates were supported by three stone gate posts (Figure 17). The double gate had "U.S. National Cemetery" lettering on metal plates near the top of the gate. There was also a single small iron gate "on the southwest corner," and "a small iron gate in the Southeast angle." 53 The former might have provided access for carts or other transport for supplies related to the lodge grounds, and the latter may have been used by pedestrians. The Tyson Street entrance did not exist at this point.

Figure 17. View of the original gate on Cooper Street, 1946 (NARA, Washington, DC, RG15).

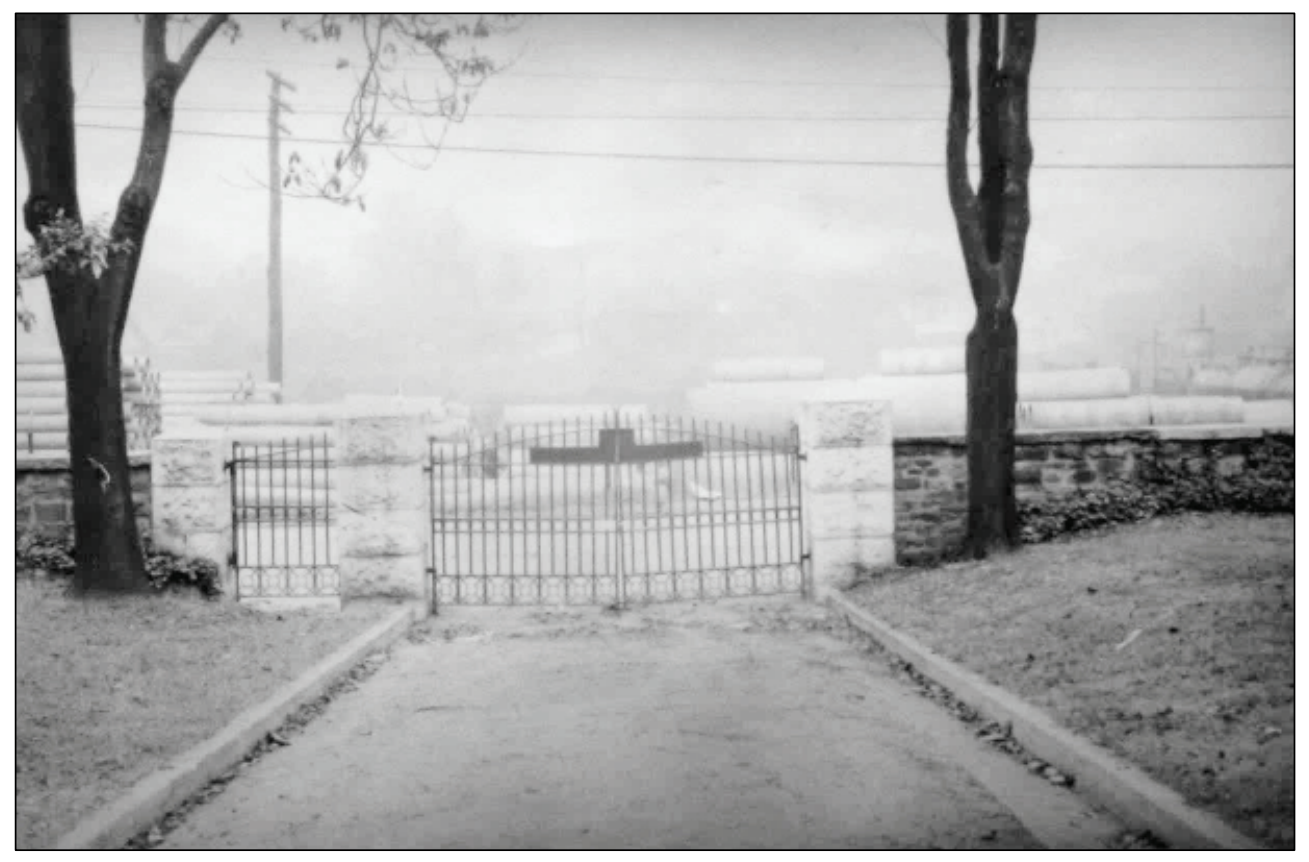

\subsection{Establishing permanence, 1874-1890}

Facilities at the cemetery were increased during this era, including a new lodge and a rostrum. The burial areas were expanded outside the circle drive, and the main entrance was shifted, along with new main gates.

\subsubsection{Cemetery design and grounds}

By June 1875, there were 3,135 interments at the cemetery. This total included 29 commissioned officers, 2,750 soldiers - white (770 unknown),

\footnotetext{
52 “Entrance Gates," Real Property Form, U.S. National Cemetery, Knoxville, Tenn., 1962, RG 15 Records of the Veterans Administration, Entry A1-25 Department of Memorial Affairs, National Cemetery Historical File, Box 24, National Archives and Records Administration, Washington, DC.

53 “Inspection Report, Knoxville Cemetery," 28 August 1874; W.H. Davis, Inspector General, letter to Inspector General, Headquarters, U.S. Army, 16 April 1878, RG 92 Records of the Office of the Quartermaster General, Entry 649 Reports of Inspection-National Cemeteries, 1874-1883, Box 1, National Archives and Records Administration, Washington, DC.
} 
333 soldiers - colored (259 unknown), 20 civilians (18 employees and two children), and three Confederate soldiers (one unknown) [an 1881 report listed one known and one unknown Confederate soldiers, and an 1889 report listed no Confederate interments and 15 civilians]. 54 In 1873, War Department General Orders No. 6 was published, concerning regulations for the guidance of National Cemetery Superintendents in performing their duties. Several referring to vegetation - the graves should be covered with sod and close cut, and the walks and drives should be allowed to be covered in closely cut grass. Bermuda or other "strong-rooted creeping grasses" were recommended for the walks and drives. 55 These directives were implemented at the Knoxville National Cemetery over the next several years. An 1877 inspection report described the burial area and graves, with "the circular lines on which interments are made are from 15 to 18 feet apart, 6 or 7 feet of this space is occupied by the graves, the remainder is a graveled walk. Little by little the Superintendent has been removing this gravel in over to facilitate the grassing over of these walks." 56 The interior drives had slight depressions along their edges to serve as gutters. A project was proposed to tamp down and grade the tops of the graves to make a flat surface for the use of a horse drawn mower, and the work was completed the following year. 57 Dimensions of the interior drives were provided in an 1889 report as $16^{\prime}$ wide (circle drive) and 12' wide (axial drives). By this point, the circular burial area was likely full, as the same

\footnotetext{
54 Thomas Ridge, Superintendent, "Classified Statement of Interments in the Knoxville, Tenn. National Cemetery, June 30, 1875," RG 92 Records of the Office of the Quartermaster General, Entry 576 General Correspondence and Reports Relating to National and Post Cemeteries ("Cemetery File"), 18651914, Box 38, National Archives and Records Administration, Washington, DC; Major C.H. Carlton, "Report of an Inspection of the National Cemetery at Knoxville Tennessee," 23 November 1881, RG 92 Records of the Office of the Quartermaster General, Entry 576 General Correspondence and Reports Relating to National and Post Cemeteries ("Cemetery File"), 1865-1914, Box 38, National Archives and Records Administration, Washington, DC; Superintendent, Knoxville National Cemetery, "Questionnaire on Status and History of Cemetery," to Quartermaster General, U.S. Army, 8 January 1889, RG 92 Records of the Office of the Quartermaster General, Entry 576 General Correspondence and Reports Relating to National and Post Cemeteries (“Cemetery File"), 1865-1914, Box 38, National Archives and Records Administration, Washington, DC.

55 E.D. Townsend, Adjutant General, War Department, “General Orders No. 6," 18 June 1873, RG 92 Records of the Office of the Quartermaster General, Entry 576 General Correspondence and Reports Relating to National and Post Cemeteries ("Cemetery File"), 1865-1914, Box 38, National Archives and Records Administration, Washington, DC.

56 Captain S.M. Robbins, "Report on National Cemetery Knoxville Tennessee," 20 June 1877, RG 92 Records of the Office of the Quartermaster General, Entry 576 General Correspondence and Reports Relating to National and Post Cemeteries ("Cemetery File"), 1865-1914, Box 38, National Archives and Records Administration, Washington, DC.

57 James Gall, Jr., Quartermaster Department, letter to Colonel Rockwell, U.S. Army, 15 February 1878, RG 92 Records of the Office of the Quartermaster General, Entry 576 General Correspondence and Reports Relating to National and Post Cemeteries (“Cemetery File”), 1865-1914, Box 38, National Archives and Records Administration, Washington, DC.
} 
report indicated there were " 83 graves along the driveway on the west and opposite side from the circle." 58

There were many trees in the burial areas, "fine young cedars" growing in such profusion as to hide from view the foliage of the "many maples, elms, sassafras catalpa, silver maples planted among them." 59 The cedars were subsequently thinned out, with 116 of 225 being cut down. The thick growth of deciduous trees in the burial sections were transplanted to the outer edge of the circle drive and used to fill in spots along the four axial drives, resulting in tree-lined transportation corridors. The Superintendent had "lifted and brought from the neighboring forests a fine family of native evergreens. All except the laurel are yet too small to place in the Sections ... Four points were selected near the angles of the wall for groups of evergreens, and sites for the several varieties marked with stakes." 60 Most of the trees planted in the burial sections were arranged on lines radiating from the flagstaff, but it was planned to break up this arrangement when thinning and transplanting. A small area near the 1874 lodge was used for a tree nursery, and in 1877 had "20 young white pines, and 15 Balsam Firs" for transplanting. ${ }^{61}$ An inspection report from 1878 listed "some 150 evergreens of Pines, Cedars, Firs, etc. ... of deciduous trees, there are some 300 , more or less, being maples, silver poplars, sassafras, elms, Catawba, sourwood, with Peach and Apple in the N.W. part of the ground west of the crop hedge." ${ }^{2}$ The inspector felt there were sufficient trees in the cemetery.

A March 1877 inspection report provided some information on the appearance and condition of signage at the cemetery, stating that "sign posts and frames are rough and somewhat unsightly, the rain has penetrated into and disfigured the printed notices. New and more ornamental posts should be provided and frames made water proof." 63

There was a War Department program in the early 1880 s to provide National Cemeteries with iron tablets inscribed with lines from the Theodore

\footnotetext{
58 Superintendent, Knoxville National Cemetery, "Questionnaire on Status and History of Cemetery," 8 January 1889.

59 Robbins, “Report on National Cemetery Knoxville Tennessee," 20 June 1877.

60 Ibid.

$61 \mathrm{lbid}$.

62 Davis, letter to Inspector General, 16 April 1878.

63 H.B. Larson, Quartermaster Department, letter to the Quartermaster General, 30 March 1877, RG 92 Records of the Office of the Quartermaster General, Entry 576 General Correspondence and Reports Relating to National and Post Cemeteries ("Cemetery File"), 1865-1914, Box 38, National Archives and Records Administration, Washington, DC.
} 
O'Hara poem, "Bivouac of the Dead." Several of these tablets would be placed around the cemetery, and when viewed in sequence, they would relate the entire poem. At Knoxville, these tablets were installed along the main driveway around the grounds (Figure 18). 64

Figure 18. Metal tablets flanking either side of entrance road, 1931 (NARA, Washington DC, RG15).

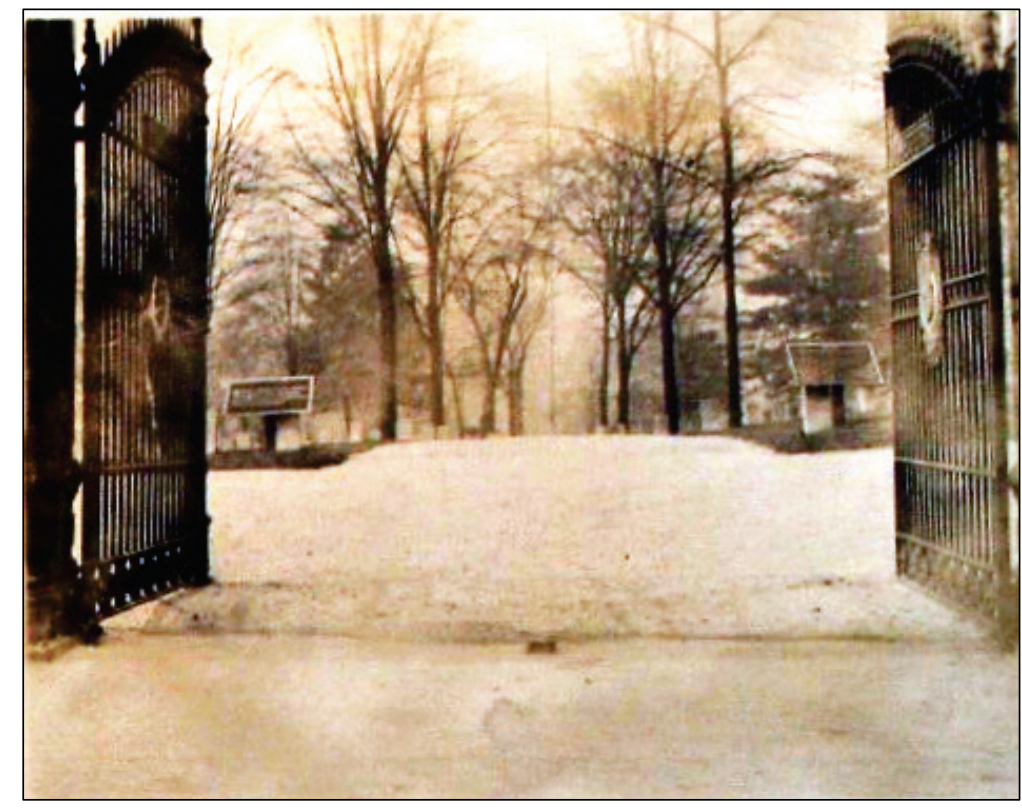

The cemetery was plagued with drainage problems documented in an 1876 inspection report. Cobbled stone gutters had just been installed along the "west front of the cemetery, between the newly planted hedge and the foot of the slope, and running north and south from the entrance" to carry away water. ${ }^{65}$ Drainage outlets in the enclosing wall were enlarged and additional ones added. The northeast corner of the cemetery was receiving large amounts of runoff from outside the cemetery, and the accumulation of water was undermining the wall at that point. It was recommended to fill the low point and build a drainage ditch to eliminate the problem. There was also a poorly drained area on the north side at the intersection

\footnotetext{
64 National Cemetery Administration, “Bivouac of the Dead," (Washington, DC: National Cemetery Administration, last updated 2015), https://www.cem.va.gov/history/bivouac.asp.

65 James Gall, Jr., Civil Engineer, Quartermaster Department, letter to the Quartermaster General, Quartermaster Department, 16 February 1876, RG 92 Records of the Office of the Quartermaster General, Entry 576 General Correspondence and Reports Relating to National and Post Cemeteries ("Cemetery File”), 1865-1914, Box 38, National Archives and Records Administration, Washington, DC.
} 
of the circle drive and the "cross road" that was recommended to be fixed with the installation of $125^{\prime}$ of pipe. ${ }^{66}$

In 1879 , a parcel of privately owned land between the National Cemetery and Gray Cemetery was purchased by the latter. ${ }^{67}$ This had the effect of leaving Jennings Street as the border between the two sites. A circa 1879 map shows the private parcel but also shows Jennings Street no longer an open road (Figure 19). By late 1881, Gray Cemetery had expanded to meet the National Cemetery, encompassing Jennings Street. ${ }^{68}$ The two cemeteries were now separated only by the National Cemetery's enclosing wall. 69

Figure 19. Plan of northwest Knoxville c.1879 showing closing of Jennings Street and parcel of land purchased by Gray Cemetery in 1879 (NARA, Washington, DC, RG92).

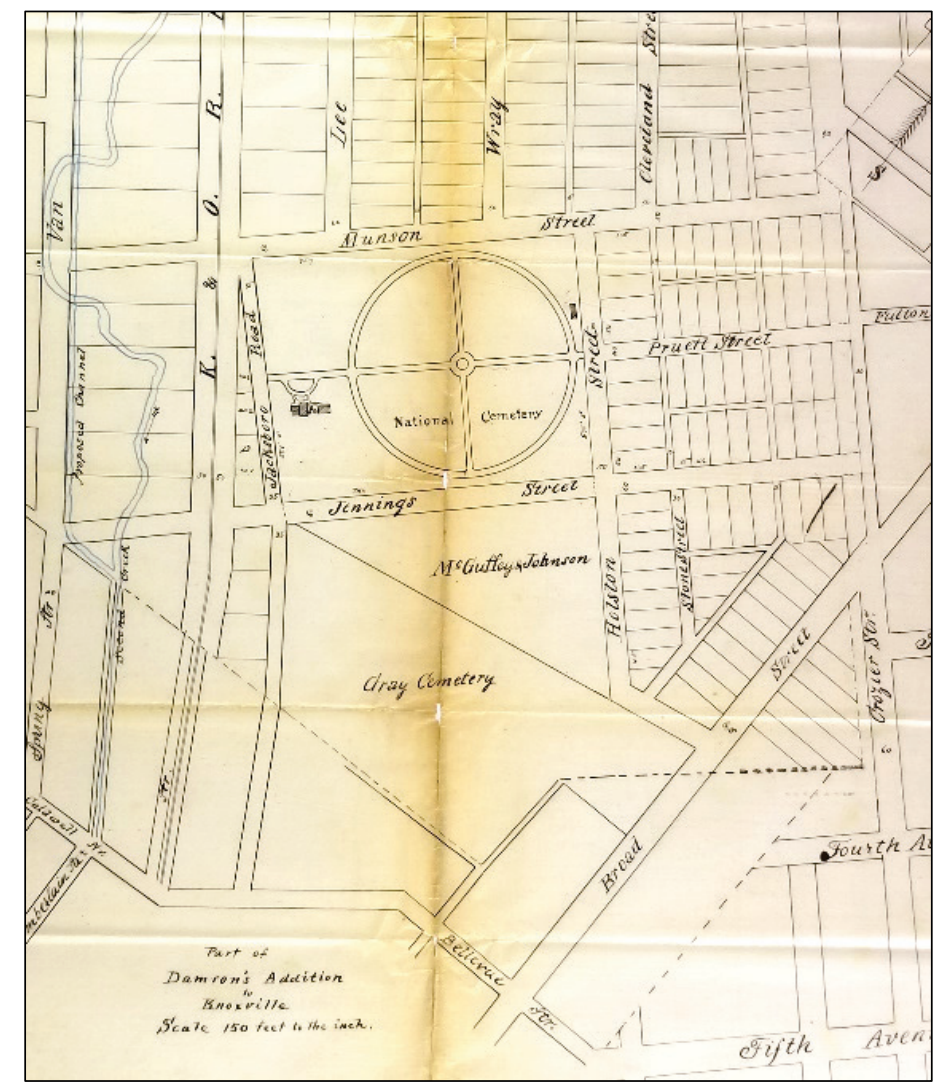

66 Ibid.

67 Ann K. Bennett, Knoxville-Knox County Metro Planning Commission, "National Register of Historic Places Registration Form - Old Gray Cemetery, Knoxville, Tennessee," 14 December 1996, https://npgallery.nps.gov/GetAsset/57260983-9faf-412e-b78c-7e27f69210ec.

68 C.M. Clarke, Civil Engineer, Quartermaster Department to Major B.C. Card, Quartermaster, U.S. Army, 27 June 1881, NARA RG 92 Records of the Office of the Quartermaster General, Entry 576 General Correspondence and Reports Relating to National and Post Cemeteries (“Cemetery File"), 1865-1914, Box 38, National Archives and Records Administration, Washington, DC.

69 Clarke, letter to Major B.C. Card, Quartermaster, 27 June 1881. 


\subsubsection{Markers}

By 1873 , the deteriorating wooden headboards at many National Cemeteries focused attention on the question of replacing them with permanent headstones. On 3 March 1873, Congress appropriated \$1,000,ooo for erecting permanent headstones at all National Cemeteries.70 The government-issued headstones were of two kinds. For known soldiers, the white marble slab was 4 " thick, $10^{\prime \prime}$ wide, and $3^{\prime}$ long (with $12^{\prime \prime}$ to be above the ground when set). The polished stone was slightly curved on top and was inscribed with the number of the grave, rank and name of the soldier, and his home state. There was a sunken shield on the headstone where the inscription appeared in bas relief. Known as the "Civil War" type, this headstone design was used for Union Army dead. ${ }^{11}$ Unknown Soldiers received a marble block 6" square and 30" long, with only the flat top and upper 4 " finished. The number of the grave was cut into the flat top. ${ }^{72}$ At Knoxville National Cemetery, the first permanent markers arrived on 5 April 1876. Produced in Rutland, Vermont, a total of 3,100 markers were arranged for and were installed that spring under the supervision of Captain R. M. Robbins, U.S. Army Corps of Engineers. 73

The 1889 report provided information on the monuments in the burial areas, "Supt. Ridge has put a monument on his lot which is located about $130^{\prime}$ from west wall and about $30^{\prime}$ from south wall. It is said to have cost $\$ 350.00$. There are 45 small monuments and headstones scattered over the grounds erected by friends and comrades which cost about $\$ 450.00 . " 74$ Correspondence in 1891 concerning unmarked graves related the presence

\footnotetext{
70 U.S. Secretary of War, "Annual Report of the Secretary of War," 43rd Congress, 1st Session, Ex. Doc. No. 1, Part 6, (Washington, DC: Government Printing Office, 1873); National Cemetery Association, "History of Government Furnished Headstones and Markers," Washington, DC: Department of Veterans Affairs National Cemetery Administration, last updated 2015). https://www.cem.va.gov/history/hmhist.asp.

71 National Cemetery Association, "History of Government Furnished Headstones and Markers," 2015.

72 U.S. Secretary of War, "Annual Report of the Secretary of War," 1873, 200; National Cemetery Association, “History of Government Furnished Headstones and Markers," 2015.

73 “Soldiers' Tomb-Stones," Knoxville Daily Tribune, 6 April 1876, in Folder: "Knoxville," VA NCA Archives, Washington, DC.

74 Superintendent, Knoxville National Cemetery, "Questionnaire on Status and History of Cemetery," 8 January 1889.
} 
of one Confederate soldier, Frank Blair of the $11^{\text {th }}$ Virginia Cavalry in grave number 1925. He may have been a prisoner of war. 75

\subsubsection{Buildings and structures}

The permanent era of Knoxville National Cemetery began with plans for a second lodge to replace the temporary wooden one on site. The contract for construction of a stone lodge was awarded to Bearden and Patterson in July 1873. Construction was begun in the autumn of 1873 and completed in March 1874 at a cost of $\$ 7,000$ (Figure 20). 76

Figure 20. 1874 lodge in c.1910 photograph (NARA, Washington, DC, RG92-CA).

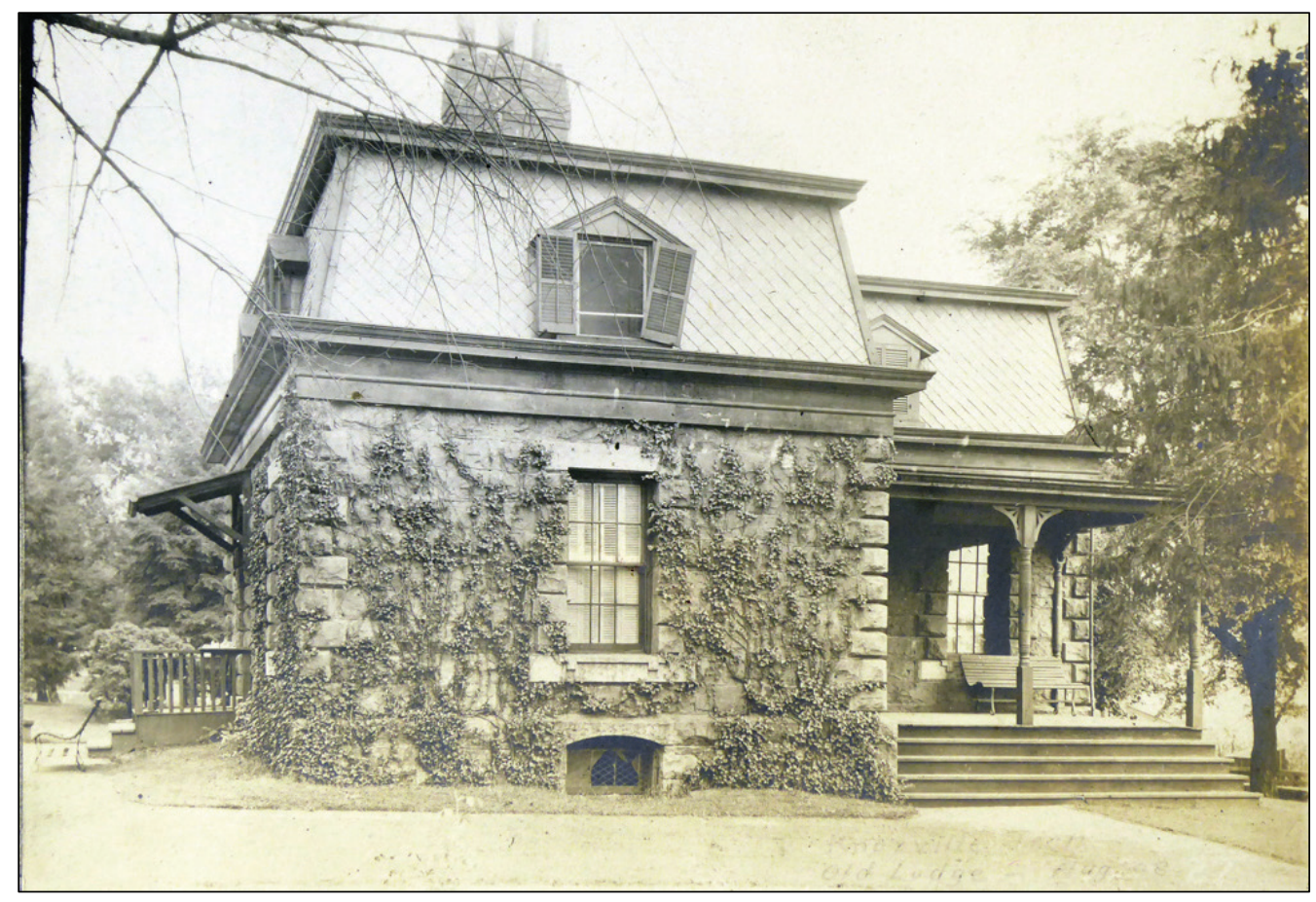

The building was constructed to what became known as the "Meigs plan" after Quartermaster General Montgomery C. Meigs, who acquired it from architect Edward Clark in 1869. As Quartermaster General, Meigs made final decisions on designs for all National Cemeteries at that time. ${ }^{77}$ The

\footnotetext{
75 Thomas Ridge, Superintendent, Knoxville National Cemetery, Letter to Major J.W. Scully, Quartermaster Department, 7 December 1891, RG 92 Records of the Office of the Quartermaster General, Entry 576 General Correspondence and Reports Relating to National and Post Cemeteries ("Cemetery File"), 1865-1914, Box 38, National Archives and Records Administration, Washington, DC.

76 Office of the Quartermaster General, letter to Mr. Bearden and Mr. Patterson, 7 July 1873, RG 92 Records of the Office of the Quartermaster General, Entry 576 General Correspondence and Reports Relating to National and Post Cemeteries ("Cemetery File"), 1865-1914, Box 38, National Archives and Records Administration, Washington, DC;

77 Harrison, “Superintendent's Lodges," 2013, 43.
} 
final design for the standardized Meigs plan lodges included an L-shape, $1^{1 / 2}$ stories, brick or stone walls, and a distinctive slate and tin mansard roof (Figure 21). ${ }^{78}$ This roof style was most notably associated with the Second Empire architectural style that became popular after the Civil War. This lodge type was constructed in over 50 cemeteries by 1881 . The L-plan provided a more private office area, separated from living quarters with a separate entrance. There were six rooms (three bedrooms) with both front and rear porches, and a cellar.79

Figure 21. Design for Superintendents Lodge, National Cemeteries, Office of the Quartermaster General, U.S. Army, 1871 (NARA, Washington, DC, RG92).

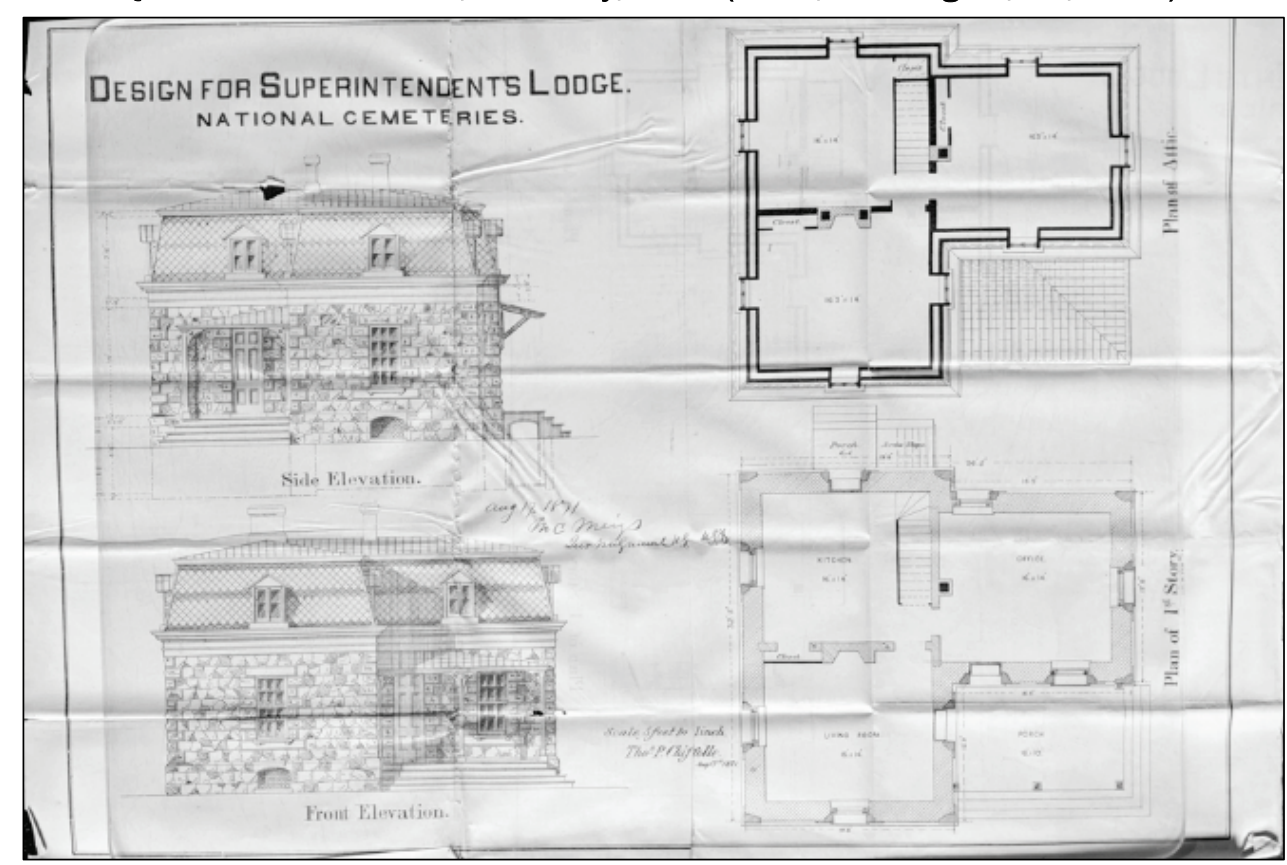

The stone lodge at Knoxville was located across the main cemetery entrance avenue from the original lodge (Figure 22). As seen in the 1874 sketch map, a new semi-circular drive from the main avenue provided access to the lodge. A flower bed was planted between the entrance gate and the semi-circular drive. The open space to the south of the lodge was intended for lawn and shrubbery but was used for a while as a kitchen garden. By 1876, a hedge had been planted around the lodge grounds, and the kitchen garden was in the process of being converted to lawn. That same year, the kitchen garden across the main avenue (created for the old wooden lodge) was reduced in size by two-thirds, and the excess area

78 Harrison, “Superintendent's Lodges," 2013, 2, 11.

79 Ibid, 10, 32. 
converted to lawn. ${ }^{80} \mathrm{~A}$ hedge was planted in 1878 between the kitchen garden and lawn. ${ }^{81}$ An 1886 bird's eye view shows the new lodge but not the other buildings (Figure 23).

Figure 22. 1874 sketch plan showing 1874 lodge in right center (NARA, Washington DC, RG92).

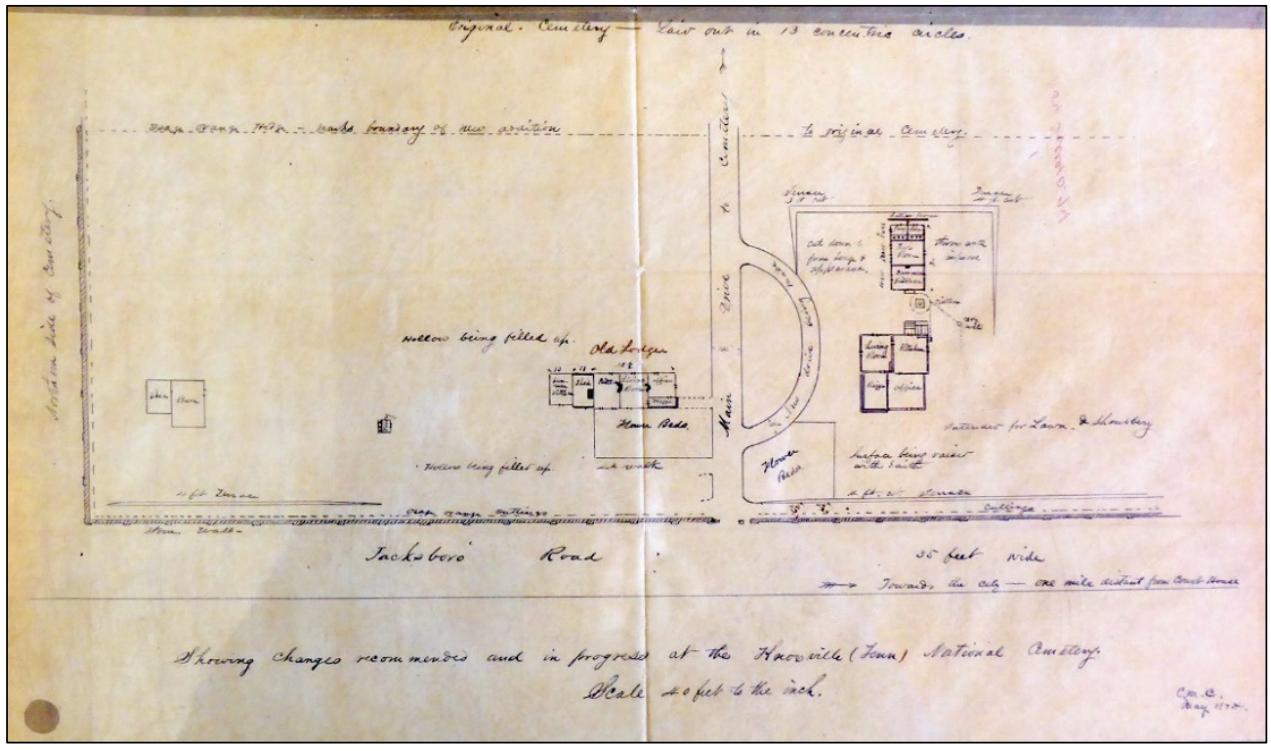

Figure 23. Detail of 1886 Map of Knoxville, showing the Knoxville National Cemetery with the 1874 lodge and vegetation lining the walls (Library of Congress).

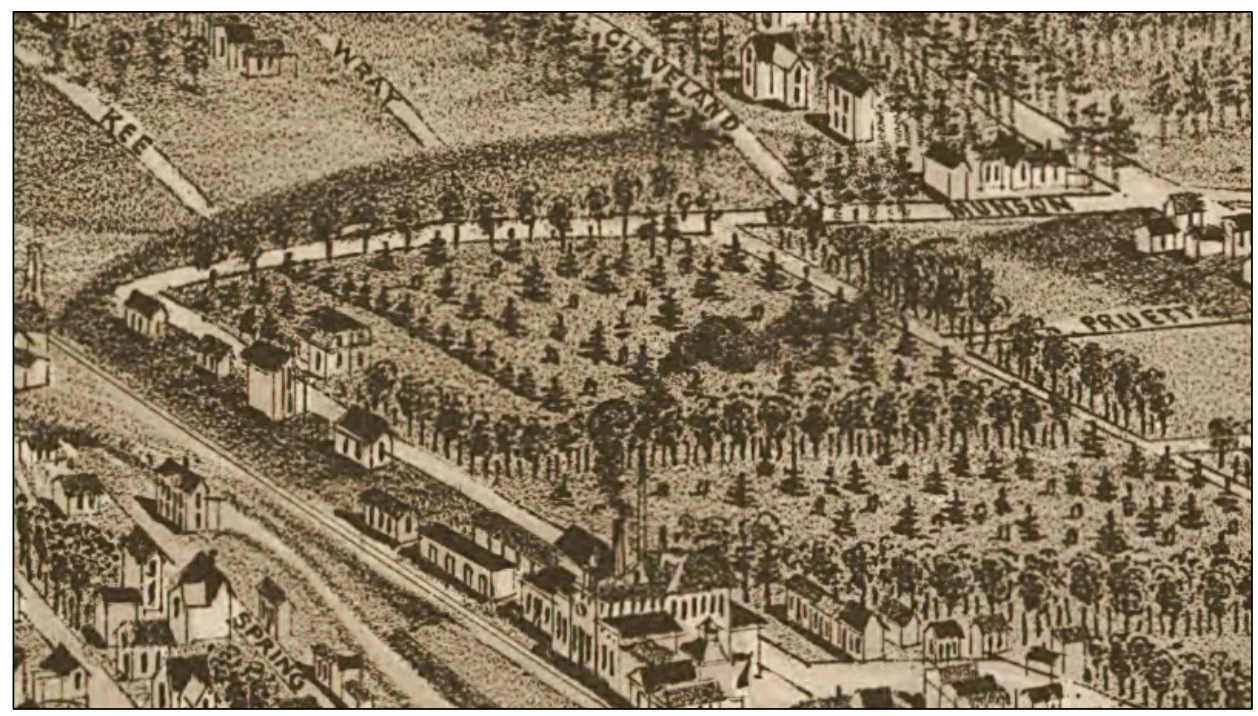

80 Gall, letter to the Quartermaster General, 16 February 1876.

81 Montgomery C. Meigs, Quartermaster General, letter to Lieutenant George S. Heys, 8 August 1878, RG 92 Records of the Office of the Quartermaster General, Entry 576 General Correspondence and Reports Relating to National and Post Cemeteries (“Cemetery File”), 1865-1914, Box 38, National Archives and Records Administration, Washington, DC. 
To the east of the lodge, a cistern and well were located also in 1874 . The Quartermaster Department had a standardized plan for the cistern (Figure 24). The brick structure had a supply pipe leading to the lodge. The cistern had a raised lattice cover placed over it in $1878 .{ }^{82}$

Figure 24. Plan of Cistern, Knoxville National Cemetery, 1874 (NARA, Washington DC, RG92).

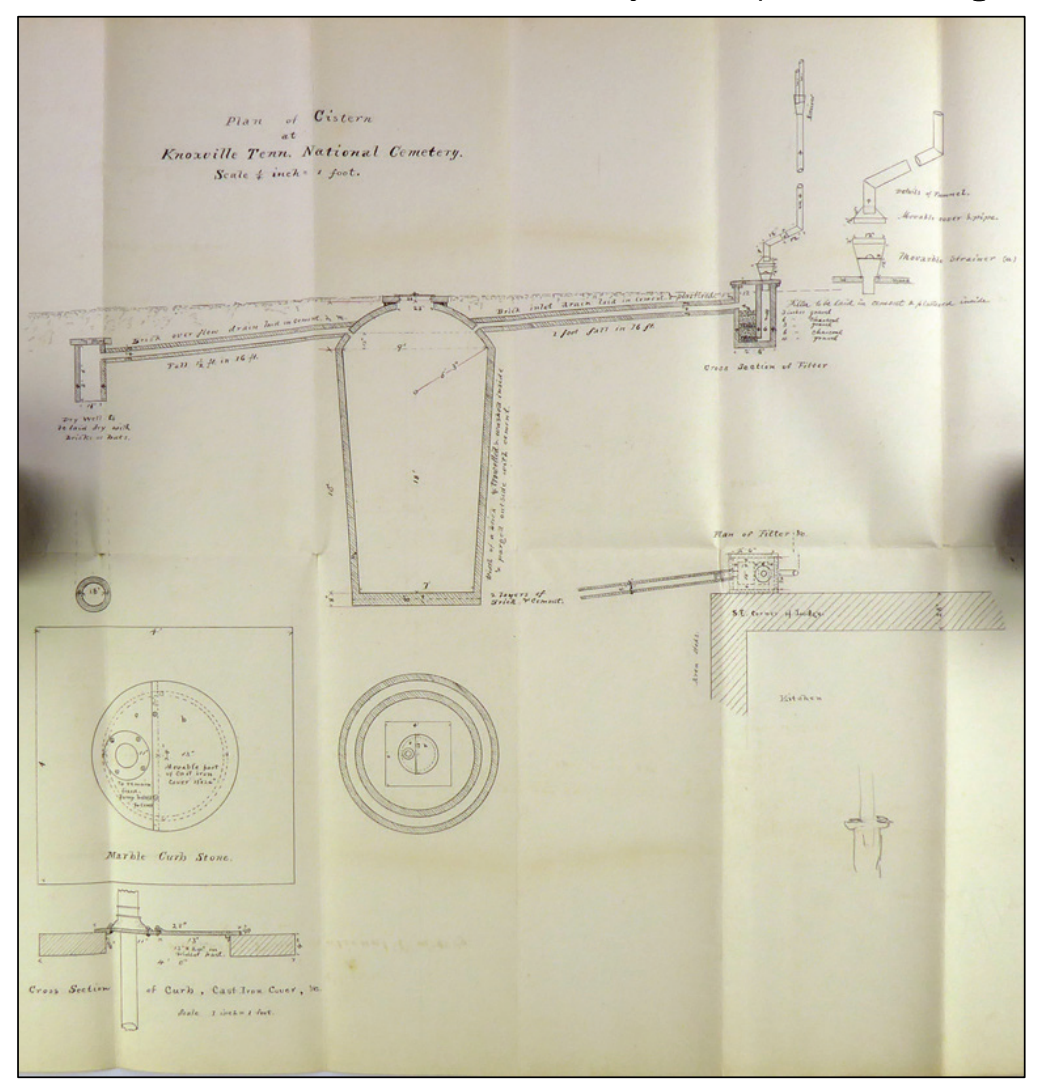

About $2 \mathrm{O}^{\prime}$ to the rear of the lodge was an outbuilding also constructed in 1874 (Figure 25). The materials for this building came from the old wooden lodge, which was demolished 2 months after the new one was completed. ${ }^{83}$ The rebuilt structure was shortened to fit the site, and slightly lower, in order to reuse vertical siding that had suffered decay to the bottom parts. The outbuilding served as a summer kitchen, tool room, and two privies that had a lattice screen directly across from the entrances (Figure 25). The privies were intended for use by the public:

\footnotetext{
82 James Gall, Jr., "Report on Inspection of the Chattanooga and Knoxville National Cemeteries," 11 June 1878, RG 92 Records of the Office of the Quartermaster General, Entry 576 General Correspondence and Reports Relating to National and Post Cemeteries ("Cemetery File"), 1865-1914, Box 38, National Archives and Records Administration, Washington, DC.

83 Price, “Historic American Landscapes Survey: Knoxville National Cemetery, Lodge,” 2012, 1.
} 
Two screened closets are intended to relive the embarrassment on public days, such as during the Exercises of Decoration Day, when many Ladies and Gentlemen and children are collected in the cemetery. The Cemeteries are also likely intended to be open to the Public on all days and often many visit the Cemetery here on Sundays, it being so near the city. 84

By the mid-1880s, the building's appearance was becoming unpleasant to inspectors and recommendations began to be made for its replacement, preferably with one of brick or stone. ${ }^{85}$

Figure 25. C. M. Clarke, “Plan for changing Old Lodge into Summer kitchen, Tool House, etc."1874 (NARA, Washington, DC, RG92).

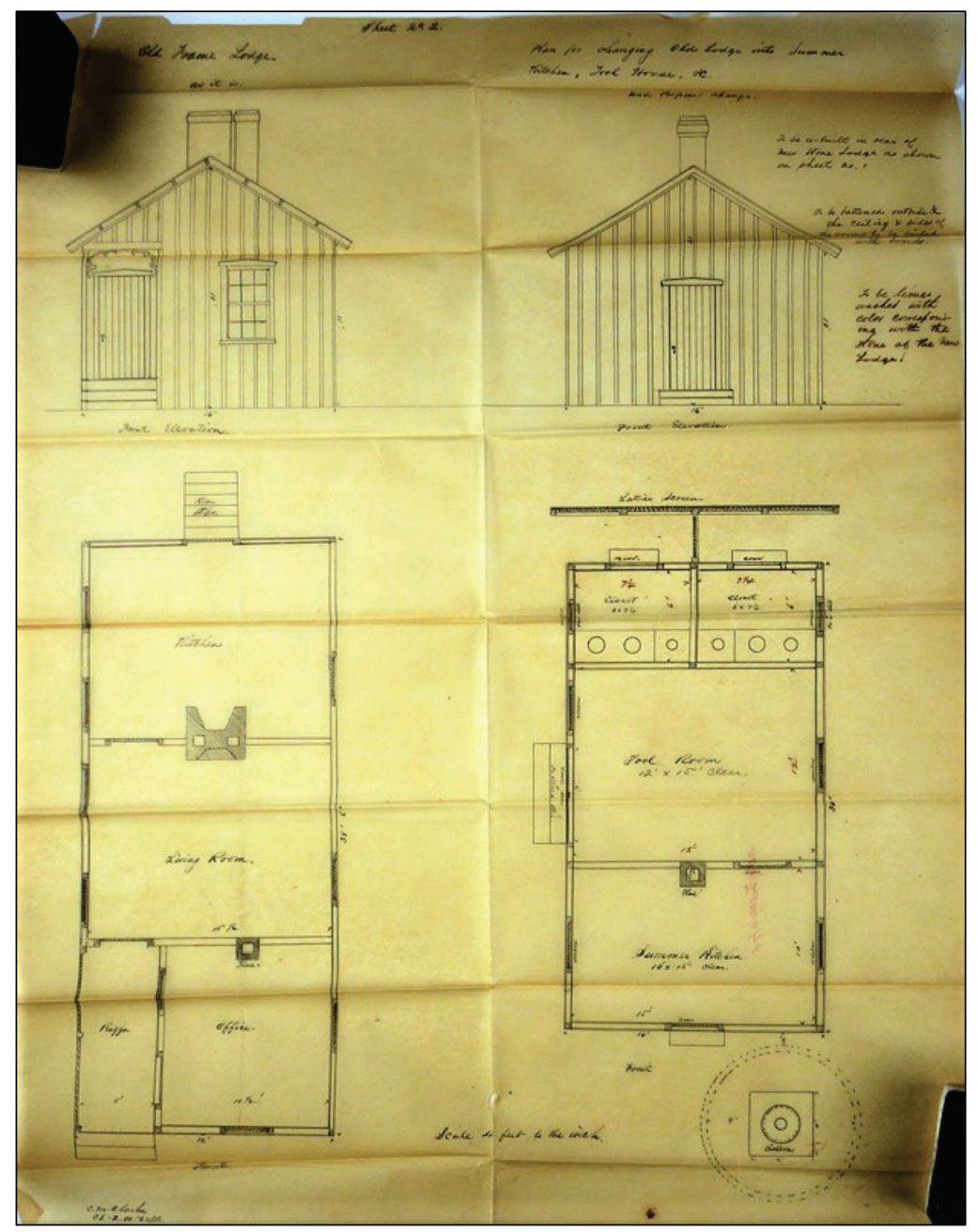

84 Robbins, “Report on National Cemetery Knoxville Tennessee," 20 June 1877.

85 W.H. Owen, Quartermaster Corps, Letter to Lt. Colonel R.N. Batchelder, Deputy Quartermaster General, 7 May 1886, RG 92 Records of the Office of the Quartermaster General, Entry 576 General Correspondence and Reports Relating to National and Post Cemeteries ("Cemetery File”), 1865-1914, Box 38, National Archives and Records Administration, Washington, DC. 
The land for the lodge and outbuilding had been graded, and a terrace existed at the far side of the lodge grounds, beyond the outbuilding (Figure 26). ${ }^{86}$

Figure 26. Detail of 1874 sketch plan showing 1874 lodge, cistern, tool house with privies and summer kitchen, and new semi-circular driveway (NARA, Washington DC, RG92).

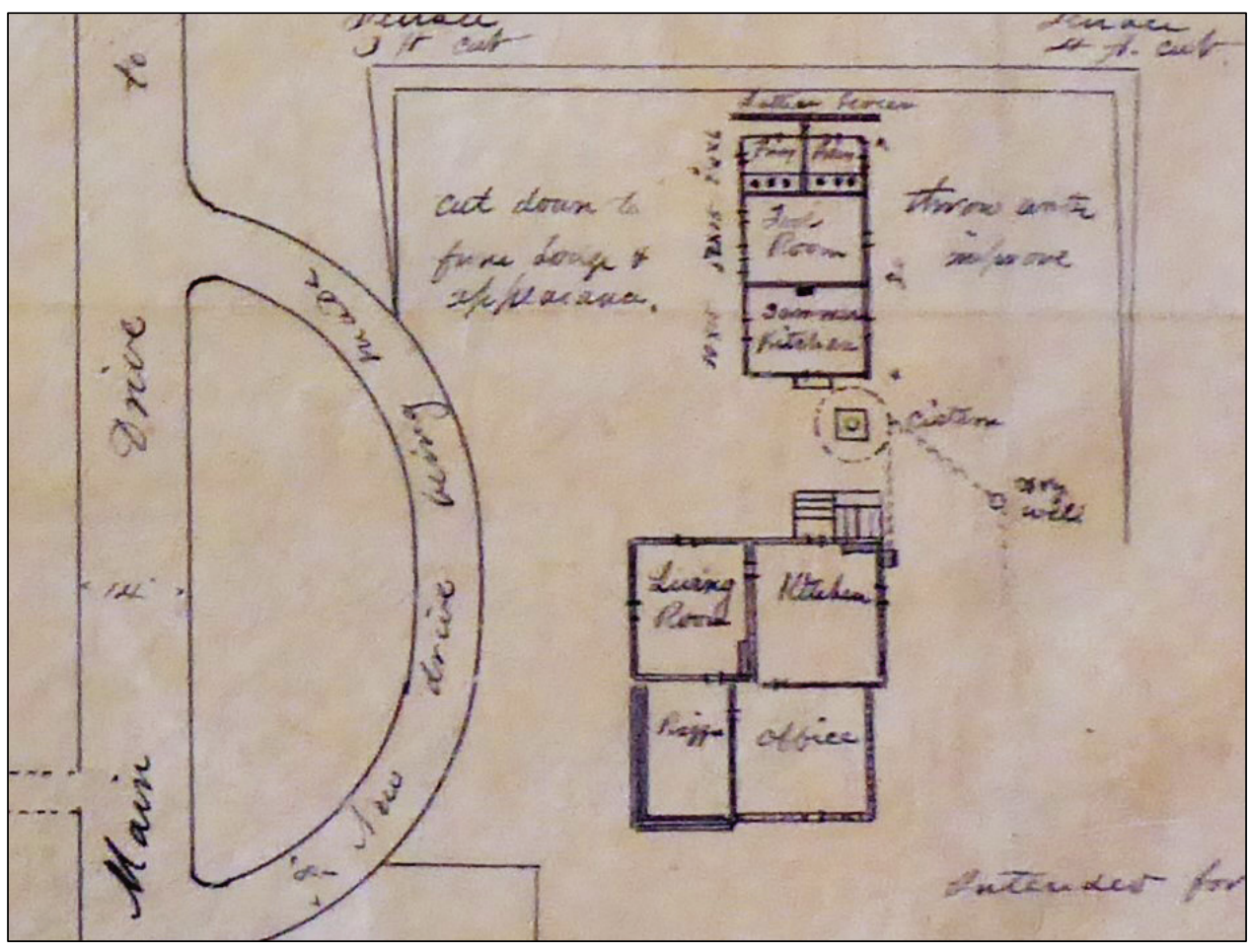

Like its predecessor, this lodge also had some physical issues, such as the upper windows leaking. A storm in 1884 blew off part of the roof framing, and the repaired roof leaked around the chimney for some time. The 1874 lodge at Knoxville National Cemetery remained in use by the Superintendent until a new one was constructed in $1907 .{ }^{87}$

As National Cemeteries took on a more public memorial and ceremonial role in the decades after the Civil War, facilities were created to support those roles. With the enormous popularity of Decoration Day observances in the National Cemeteries (what later became Memorial Day), a space was needed to focus the ceremonial activities. This need led to the frequent construction of temporary speakers' stands to accommodate orators, choirs, and brass bands. At Knoxville National Cemetery in 1873,

\footnotetext{
86 C. M. Clarke, Civil Engineer, Quartermaster Department, letter to the Quartermaster General, Quartermaster Department, 13 May 1874, RG 92 Records of the Office of the Quartermaster General, Entry 576 General Correspondence and Reports Relating to National and Post Cemeteries ("Cemetery File"), 1865-1914, Box 38, National Archives and Records Administration, Washington, DC.

87 Price, “Historic American Landscapes Survey: Knoxville National Cemetery, Lodge,” 2012, 5.
} 
temporary speakers' and musicians' stands built on the Superintendent's initiative were completed the day before the ceremonies. ${ }^{88}$ It is not known where these facilities were placed or if they were continued to be used over the next several years.

The Quartermaster General began a program in 1873 of constructing permanent rostrums or stands for speakers. ${ }^{89}$ This effort got off to a slow start due to lack of appropriations. A plan for the rostrum at Knoxville was created in 1874, but funds were not available until $1879 .{ }^{\circ}$ By that time a standardized plan for rostrums had been completed by the Quartermaster Department, based on Quartermaster General Montgomery C. Meigs design for a rostrum at Arlington National Cemetery. The plan was for a rectangular structure of red brick with $5^{\prime}$ walls supporting a flat podium created by filling in the area between the walls with earth and covering the surface with grass. Twelve brick columns along the edge of the podium and down the center supported a wooden trellis meant to be covered with vines for shade. Two sets of stone steps led up to the podium from the short sides, and raised horizontal iron handrails provided a safety feature. 91

A standard rectangular rostrum was constructed in the cemetery in the spring of 1879, along with rostrums at Chalmette (LA), Antietam, Chattanooga, Vicksburg (MS), Jefferson Barracks (MO) and Gettysburg (PA). The contracts required completion by 25 May, in time for Decoration Day. The Knoxville National Cemetery Rostrum was built by John W. Adams and completed at a cost of $\$ 1,452$ (Figure 27). ${ }^{22}$ The rostrum was described in an 1889 report:

The rostrum is located close to wall about $6 \mathrm{o}^{\prime}$ north of entrance from Holston St. and is a brick building $37^{\prime}$ by $22^{\prime}$. The walls are $4^{\prime} 6 "$ above the general level of the ground. The floor is grassed and level with the

\footnotetext{
88 Michael R. Harrison (historian), “National Cemeteries, Rostrums," Historic American Buildings Survey (HABS) No. DC-47, (Washington, DC National Park Service, 2013), 18; Historic American Landscapes Survey, "Lodges and Rostrums Data Recorded by HALS," 2013 Excel Spreadsheet, in the collection of the National Cemetery Administration, U.S. Department of Veterans Affairs, Washington, DC.

89 Harrison, “National Cemeteries, Rostrums," 2013, 28; Historic American Landscapes Survey, “Lodges and Rostrums Data Recorded by HALS," 2013.

90 Office of National Cemeteries, letter to Quartermaster General, Quartermaster Department, 4 February 1875, RG 92 Records of the Office of the Quartermaster General, Entry 225 Consolidated Correspondence File, 1794-1915, Box 1058, National Archives and Records Administration, Washington, DC.

91 Harrison, "National Cemeteries, Rostrums," 2013, 21-22.

92 Ibid, 28; Historic American Landscapes Survey, “Lodges and Rostrums Data Recorded by HALS," 2013.
} 
slope of the walls. Twelve brick columns $18^{\prime \prime}$ by $18^{\prime \prime} 13^{\prime}$ high support a heavy wooden frame of stringers and joists. There are eight stone steps with iron railings at the North and South ends. The top of walls and columns are coped with stone. 93 Figure 27. The 1879 rostrum in its original configuration, Knoxville National Cemetery,
c.1932 (NARA, Washington DC, RG15).

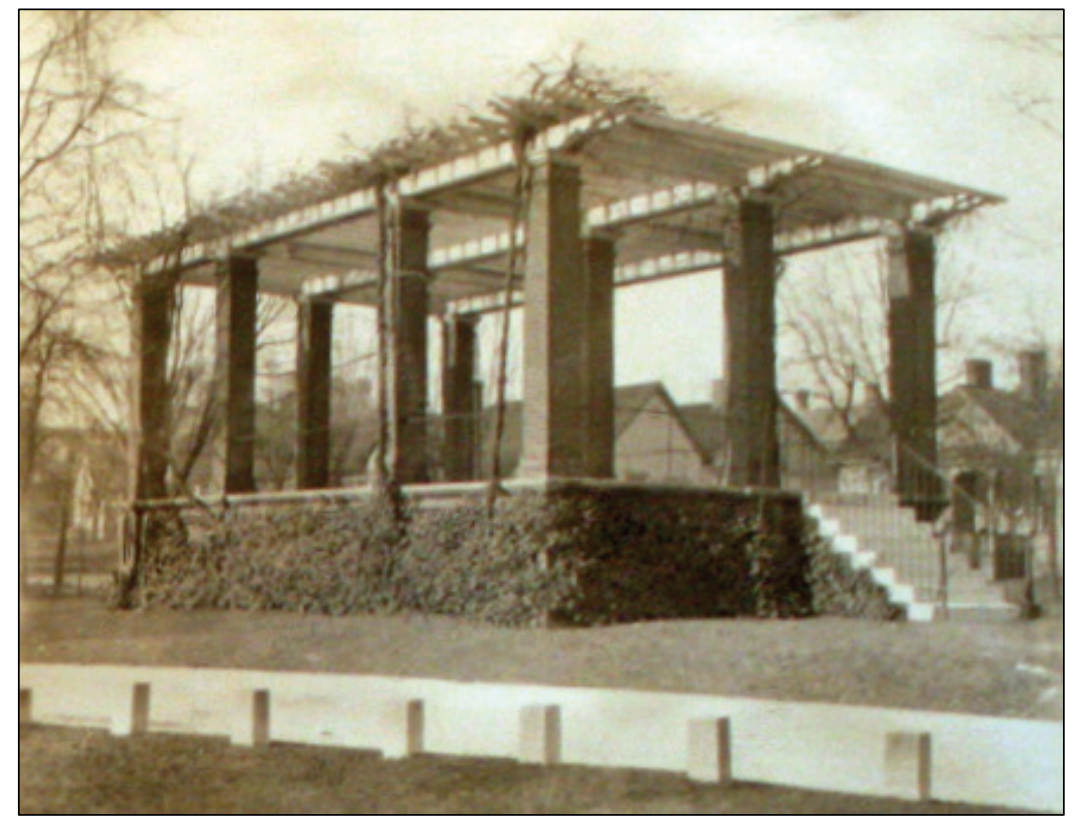

The original flagstaff was decaying and fell down on 14 July 1875 . It was replaced in November 1875.94 A 60' flagstaff in a concrete foundation was erected at a cost of $\$ 385$. It occupied the same spot as the original flagstaff, in the center of the concentric burial area on a central mound. The mound was rebuilt when the new flagstaff was installed and covered with bluegrass. This flagstaff remained until it was replaced in 1940 and again in 1946 (Figure 28). 95

\footnotetext{
93 Superintendent, Knoxville National Cemetery, "Questionnaire on Status and History of Cemetery," 8 January 1889.

94 "Monthly Report of Superintendent of the National Cemetery at Knoxville, Tenn," November 1873 June 1876, RG 92 Records of the Office of the Quartermaster General, Entry 643 Records Relating to Functions: Cemeterial, 1828-1929, Box 1, National Archives and Records Administration, Washington, DC.

95 Gall, letter to the Quartermaster General, 16 February 1876; “Flagstaff," Real Property Form, U.S. National Cemetery, Knoxville, Tenn., 1945, RG 15 Records of the Veterans Administration, Entry A1-25 Department of Memorial Affairs, National Cemetery Historical File, Box 24, National Archives and Records Administration, Washington, DC; "The Knoxville Cemeteries," Knoxville Daily Tribune, 14 August 1881, in Folder: “Knoxville," VA NCA Archives, Washington, DC.
} 
Figure 28. Flagstaff, 1940 (NARA, Washington DC, RG15).

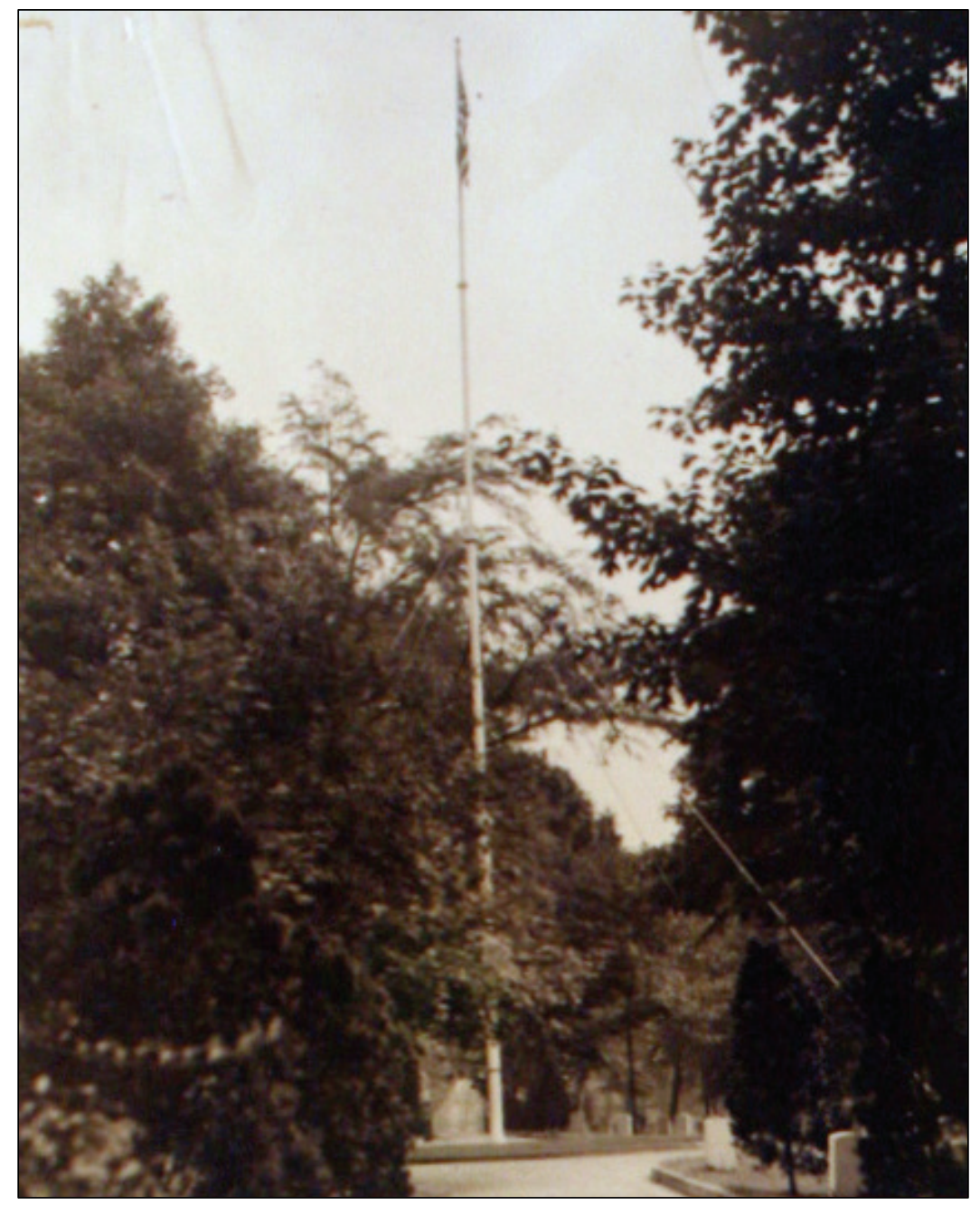

\subsubsection{Walls, roads, and gates}

An inspection report from 1877 indicated the stone walls had visible cracks on the outside, while the inside was not visible due to the Osage Orange hedge growing alongside the wall. Water was percolating into the foundation of the east and north walls, and it was suggested that dirt be placed at the outside of the foundation to provide a slope away from the walls. ${ }^{6}$ Just a year later, an inspection report indicated a breach in the northeast wall at the "rear end" of the cemetery (meaning directly across from the main entrance at Tyson Street), but recommended it stay open temporarily to expedite bringing in soil needed for use on the grounds. ${ }^{97}$ In 1881, an inspector recommended the opening "be continued as an entrance and a pair

\footnotetext{
96 Robbins, Quartermaster Department, letter to the Quartermaster General, 20 June 1877.

97 Gall, “Report on Inspection of the Chattanooga and Knoxville National Cemeteries," 11 June 1878.
} 
of iron gates placed in it." 98 The entire wall was repointed that same year. ${ }^{99}$ In 1890 , the perimeter wall was described as a "stone wall $4^{\prime} 6$ " high from top of foundation to top of coping, and 18" thick. Coping is $3^{\prime \prime}$ thick and $2 \mathrm{O}^{\prime \prime}$ wide. Osage Orange hedge along the inside of wall." 100

Letters from 1880 indicate an existing gate on the south side of the $\mathrm{Na}-$ tional Cemetery. ${ }^{101}$ An inspection report from November 1881 mentions a "small entrance gate" in the south wall near where it meets the east wall with a graveled path leading to the circular drive. ${ }^{102}$ This is likely the aforementioned small iron gate on the "southeast angle" of the cemetery. The gate no longer exists and was likely removed when Gray Cemetery finished its expansion.

The Knoxville Cemetery was also responsible for the sidewalks on the outside of the enclosing wall, and in 1876 these walks were paved with broken stone and covered with a dressing of "debris" from a neighboring slate quarry; the same surface was used on the interior cemetery roads. ${ }^{103}$

The idea of moving the main entrance to the opposite side of the cemetery was raised in the spring of 1877 . Across Cooper Street and opposite the main entrance, piles of refuse stone had narrowed the road to the point where it was difficult for carriages to turn into the cemetery. Additionally, the kitchen garden presented an unflattering appearance just inside the wall (the garden was gone by 1886), and the grounds around the lodge had too much litter. ${ }^{104}$ Nothing came of this recommendation for a decade,

\footnotetext{
98 Carlton, "Report of an Inspection of the National Cemetery at Knoxville Tennessee," 23 November 1881.

99 C.M. Clarke, Civil Engineer, Quartermaster Department, letter to Major B.C. Card, Quartermaster, U.S. Army, 25 June 1881, RG 92 Records of the Office of the Quartermaster General, Entry 576 General Correspondence and Reports Relating to National and Post Cemeteries ("Cemetery File"), 1865-1914, Box 38, National Archives and Records Administration, Washington, DC.

100 Superintendent, Knoxville National Cemetery, "Questionnaire on Status and History of Cemetery," 8 January 1889.

101 Letter from Captain Russell Williams, Office of the Acting Quartermaster, Atlanta, GA to the Quartermaster General, Quartermaster Department, Washington, DC, 28 February 1880, RG 92 Records of the Office of the Quartermaster General, Entry 576 General Correspondence and Reports Relating to National and Post Cemeteries ("Cemetery File"), 1865-1914, Box 38, National Archives and Records Administration, Washington, DC.

102 Carlton, "Report of an Inspection of the National Cemetery at Knoxville Tennessee," 23 November 1881.

103 Gall, letter to the Quartermaster General, 16 February 1876.

104 Larson, letter to the Quartermaster General, 30 March 1877; W.H. Owen, Civil Engineer, Quartermaster Department, Manuscript notes, 9 February 1887, RG 92 Records of the Office of the Quartermaster General, Entry 576 General Correspondence and Reports Relating to National and Post Cemeteries (“Cemetery File”), 1865-1914, Box 38, National Archives and Records Administration, Washington, DC.
} 
although an inspection report in 1881 reiterated that the opening in the northeast wall "should be the main entrance to the Cemetery for the present main entrance (west side) is from a narrow road and not far from the railroad tracks." 105 Another inspection report from the same year suggested the change, as the northeast side was on high ground, and moving the main entrance would permit "a fine drive being made to that point" leaving the city along Broad Street, the "best drive out of the city in the direction of the Cemetery." 106

The decision was made to build a new approach road on Tyson Street, and a right of way was granted by the city of Knoxville in September 1886 running from Broad Street to Bernard Avenue. The U.S. Government had appropriated $\$ 6,000$ for this new roadway a few months earlier. ${ }^{107}$ Construction was soon underway. By February 1887 the grading was nearly complete, and the road was ready to be macadamized with completion expected by the middle of March. ${ }^{108}$ The street had masonry curbing, guttering and drains, and new culverts and manholes. ${ }^{109}$ The street was not the property of the United States, as determined by the Judge Advocate General of the United States in 1892 and again in 1906. ${ }^{110}$

As part of this work, the opening in the northeast wall was made permanent as the new main entrance to the cemetery. Three stone gateposts (two large and one smaller) anchor a double wrought-iron center gate, with a pedestrian gate north of the center gate (Figure 29 and Figure 30). Metal bars on each half of the center gate meet to make a nameplate reading "U.S. National Cemetery." The gateway was constructed at a cost of $\$ 375$ and in place by February 1887.111

\footnotetext{
105 Carlton, "Report of an Inspection of the National Cemetery at Knoxville Tennessee," 23 November 1881.

106 Clarke, letter to Major B.C. Card, Quartermaster, 25 June 1881.

107 “Knoxville Tenn. Nat. Cemetery \& Road," undated, RG 15 Records of the Veterans Administration, Entry A1-25 Department of Memorial Affairs, National Cemetery Historical File, Box 24, National Archives and Records Administration, Washington, DC.

108 Owen, Manuscript notes, 9 February 1887.

109 “Letter to Major Scully," 6 January 1890, RG 92 Records of the Office of the Quartermaster General, Entry 576 General Correspondence and Reports Relating to National and Post Cemeteries ("Cemetery File”), 1865-1914, Box 38, National Archives and Records Administration, Washington, DC.

110 L.S. Doolittle, Superintendent, Knoxville National Cemetery, Letter to Quartermaster General, U.S. Army, 27 April 1909, RG 92 Records of the Office of the Quartermaster General, Entry 576 General Correspondence and Reports Relating to National and Post Cemeteries ("Cemetery File"), 1865-1914, Box 38, National Archives and Records Administration, Washington, DC.

111 Owen, Manuscript notes, 9 February 1887.
} 
Figure 29. Original Tyson Street gate with rostrum to the right, 1909 (NARA, Washington, DC, RG92-CA).

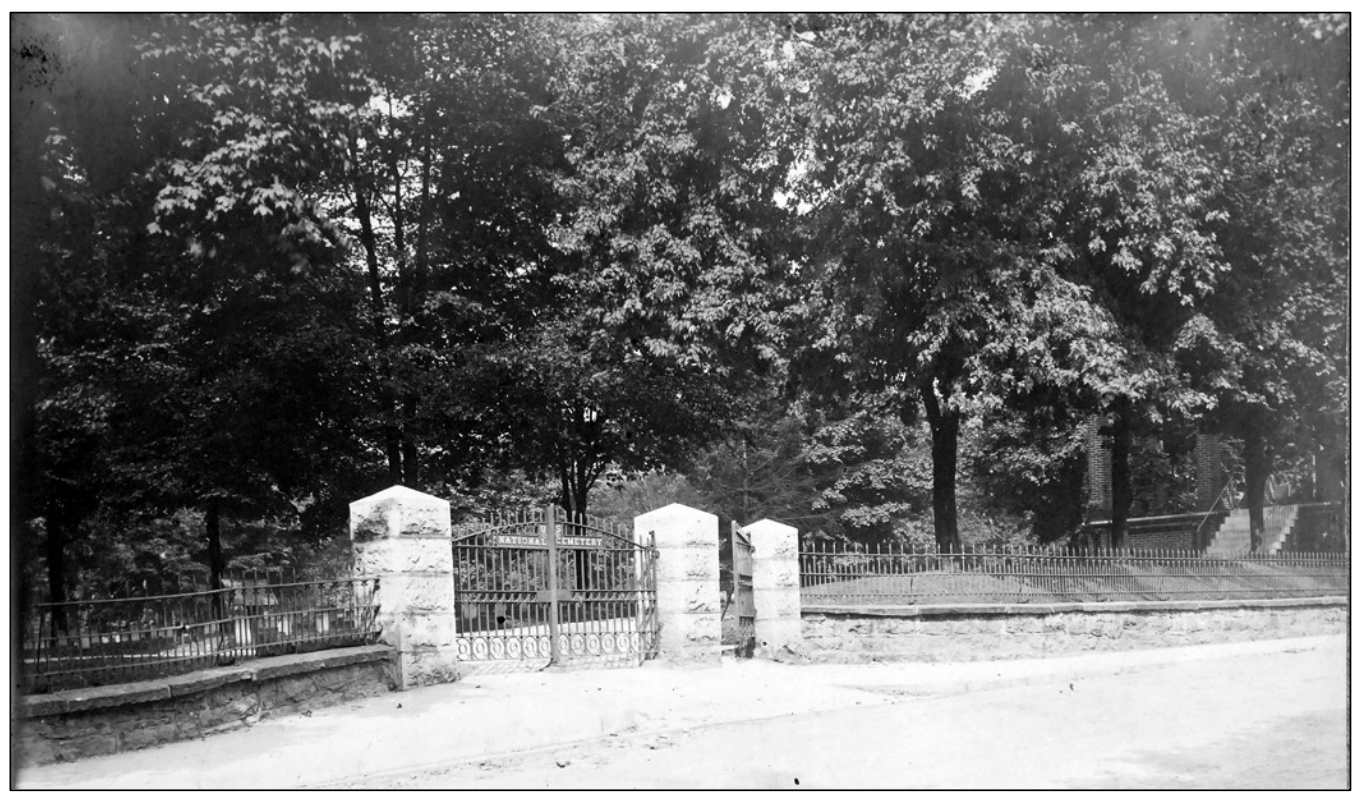

Figure 30. Original gate on Tyson Street, 1904 (NARA, Washington DC, RG92-CA).

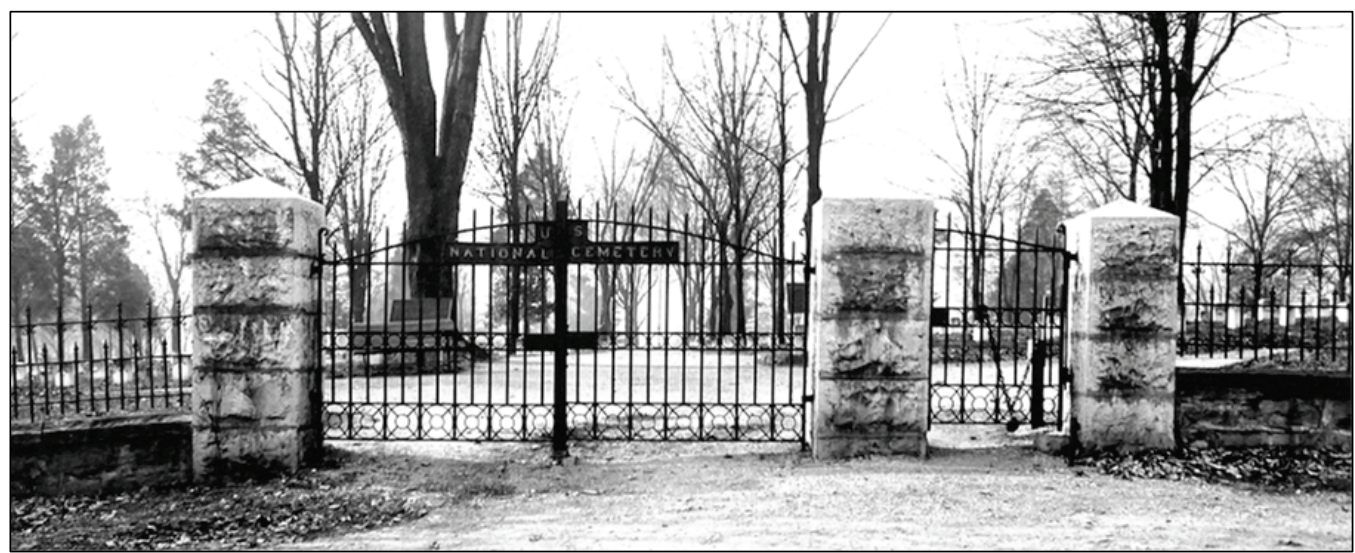

In remaking Tyson Street, the road was re-graded to a lower level, resulting in the top of the stone wall along the cemetery border being anywhere from $7^{\prime}$ to $11^{\prime}$ above the road, particularly along the section between the new gate and Bernard Avenue. The project engineer recommended the wall be rebuilt to a total height of $2^{\prime}$ including coping "and surmounted by a W.I. [wrought-iron] fence about 4 ' high, so as to give a good view of the Cemetery from the street." ${ }_{112}$

\footnotetext{
112 "Letter to Major Kirk for a more exact estimate," 17 December 1888, RG 92 Records of the Office of the Quartermaster General, Entry 576 General Correspondence and Reports Relating to National and Post Cemeteries (“Cemetery File”), 1865-1914, Box 38, National Archives and Records Administration, Washington, DC.
} 
A contract for approach road repairs was awarded to J.A. and W.C. Doyle of Knoxville in April 1889 and included work on the wall. ${ }^{113}$ According to a January 1890 report, "the Cemetery wall on the east side, including gate posts and gates, was taken down and re-built," and a sidewalk was constructed alongside it. ${ }^{114}$ The existing coping and wall stones were reused wherever possible, with the new rubble stone wall laid in mortar of sand and cement. ${ }^{115}$ The ground inside the wall was terraced and sodded, with a drainage pipe laid at the junction of the ground and the wall. As had been suggested, the new wall was topped with a wrought-iron picket fence manufactured by the Van Dorn Iron Works of Akron, Ohio. ${ }^{116}$ Specifications for the fence stated that it be of wrought iron with "a rail 1-3/4" x 3/4", and 3/4" square pickets malleable iron spear heads ... making connections with stone gate Posts, and stone wall at ends." 117 The fence was installed in the spring of $1890 .{ }^{118}$ The U.S. Government also paid for raising the retaining wall along the east side of Gray Cemetery and topping it with a wroughtiron fence manufactured by the Champion Iron Works of Kenton, Ohio. ${ }^{119}$

\subsection{Maturation of cemetery grounds, 1891-1934}

By the end of the $19^{\text {th }}$ Century, the cemetery was firmly established. Changes, however, were only a few years away. The first part of the $20^{\text {th }}$ Century would see a new lodge, a significant new monument, and a

\footnotetext{
113 "Brief to Major E.B. Kirk," 23 March 1888, RG 92 Records of the Office of the Quartermaster General, Entry 576 General Correspondence and Reports Relating to National and Post Cemeteries ("Cemetery File”), 1865-1914, Box 38, National Archives and Records Administration, Washington, DC.

114 “Letter to Major Scully," 6 January 1890.

115 "Specifications for changes and additions to repairs of Cemetery road," 11 January 1889, RG 92 Records of the Office of the Quartermaster General, Entry 576 General Correspondence and Reports Relating to National and Post Cemeteries ("Cemetery File"), 1865-1914, Box 38, National Archives and Records Administration, Washington, DC.

116 "Brief to Major E.B. Kirk," 29 December 1888, RG 92 Records of the Office of the Quartermaster General, Entry 576 General Correspondence and Reports Relating to National and Post Cemeteries ("Cemetery File"), 1865-1914, Box 38, National Archives and Records Administration, Washington, DC; “Letter to Major Scully," 6 January 1890.

117 "Specifications for changes and additions to repairs of Cemetery road," 11 January 1889.

118 M. Nicholson, Engineer in Charge, Letter to Major J.W. Scully, Quartermaster Department, 5 March 1890, RG 92 Records of the Office of the Quartermaster General, Entry 576 General Correspondence and Reports Relating to National and Post Cemeteries (“Cemetery File”), 1865-1914, Box 38, National Archives and Records Administration, Washington, DC.

119 M. Nicholson, Civil Engineer, Letter to Major J.W. Scully, Quartermaster Department, 24 December 1889, RG 92 Records of the Office of the Quartermaster General, Entry 576 General Correspondence and Reports Relating to National and Post Cemeteries (“Cemetery File"), 1865-1914, Box 38, National Archives and Records Administration, Washington, DC.
} 
continued reorientation of the cemetery's improvements to the new entrance and the north corner of the grounds off Tyson Street.

\subsubsection{Cemetery design and grounds}

An 1892 map of the cemetery (revised with 1909 information) provided a detailed look at the layout of the burial sections, the roads and walks, buildings and structures, and the type and density of vegetation (Figure $31) .{ }^{120}$ The original layout of circular burial sites with gravel walks intersecting at a flagstaff and a circular gravel drive had not changed in many years. Deciduous trees lined the inside of the perimeter walls and also formed a line demarcating the separation between the burial area and the residential areas. A mixture of deciduous and evergreen trees was generously scattered over the burial area.

Figure 31. 1892 Map (revised 1909) of Knoxville National Cemetery, Office of Quartermaster General, U.S. Army (NARA, Washington DC, RG92).

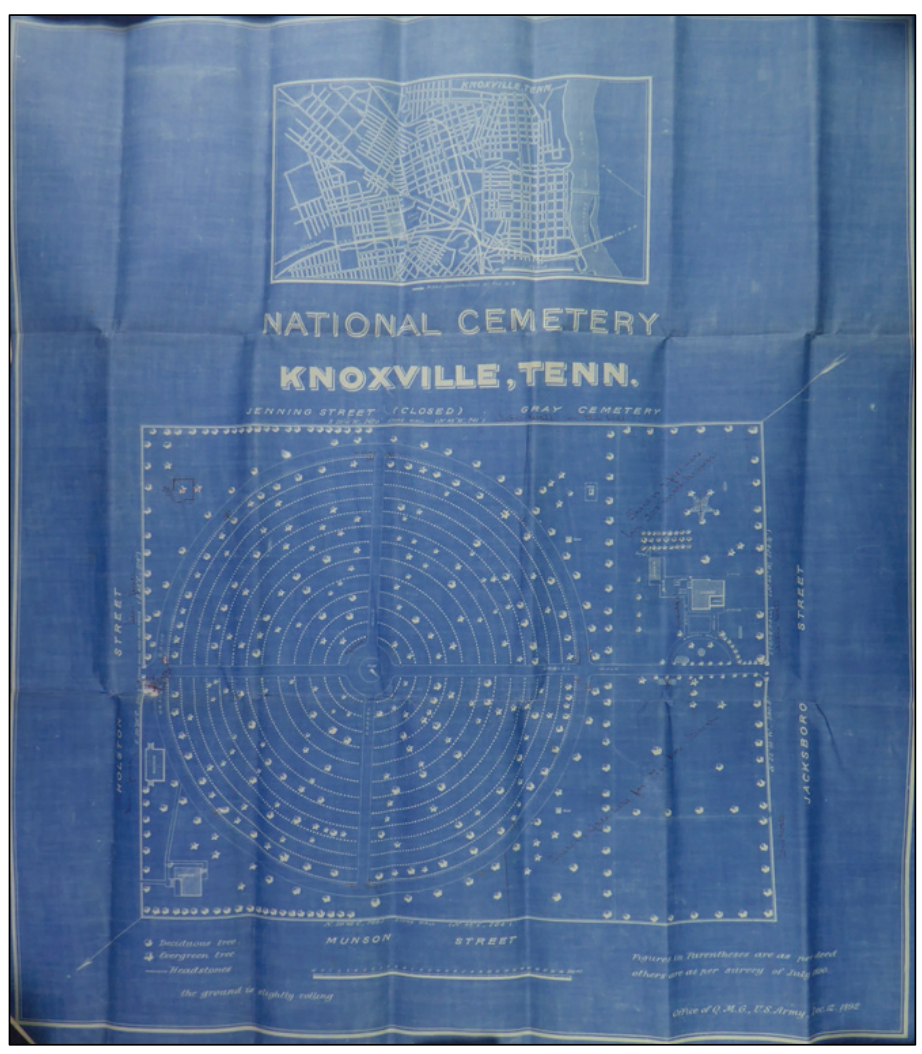

120 Although the map is dated 1892, buildings not constructed until 1907 are depicted. A request for information on the status of the cemetery was sent to Superintendents in 1909 and they were instructed to update the maps and return them with their other data. It is likely this map was revised after the information was received, but the date on the map was not changed. 
In the south corner of the map is the residential area with the 1873 Meigs Plan stone lodge (Figure 32). The major change shown in this section of the map was the new 1898 brick stable building that replaced the wooden outbuilding. The semi-circular gravel walk from the main entrance drive enclosed trees and shrubs, with small trees or shrubs lining the southwest side of the walk. A brick walk led to the lodge's front entry, while a second brick walk led to the brick paved stable yard. A decorative star created from evergreen trees and shrubs or flowers was located south of the lodge. Three rows of trees had been planted south of the stable before 1892; however, the middle row and parts of the other two rows had been removed by 1909. This could be the remnant of the tree nursery started in the $1870 \mathrm{~s}$.

Figure 32. Detail of 1892 map (revised c.1909) showing 1874 lodge with stable, privy, brick paved stable yard, gravel walks, the entrance gate on Cooper Street, and trees and shrubs, Office of Quartermaster General, U.S. Army (NARA, Washington DC, RG92).

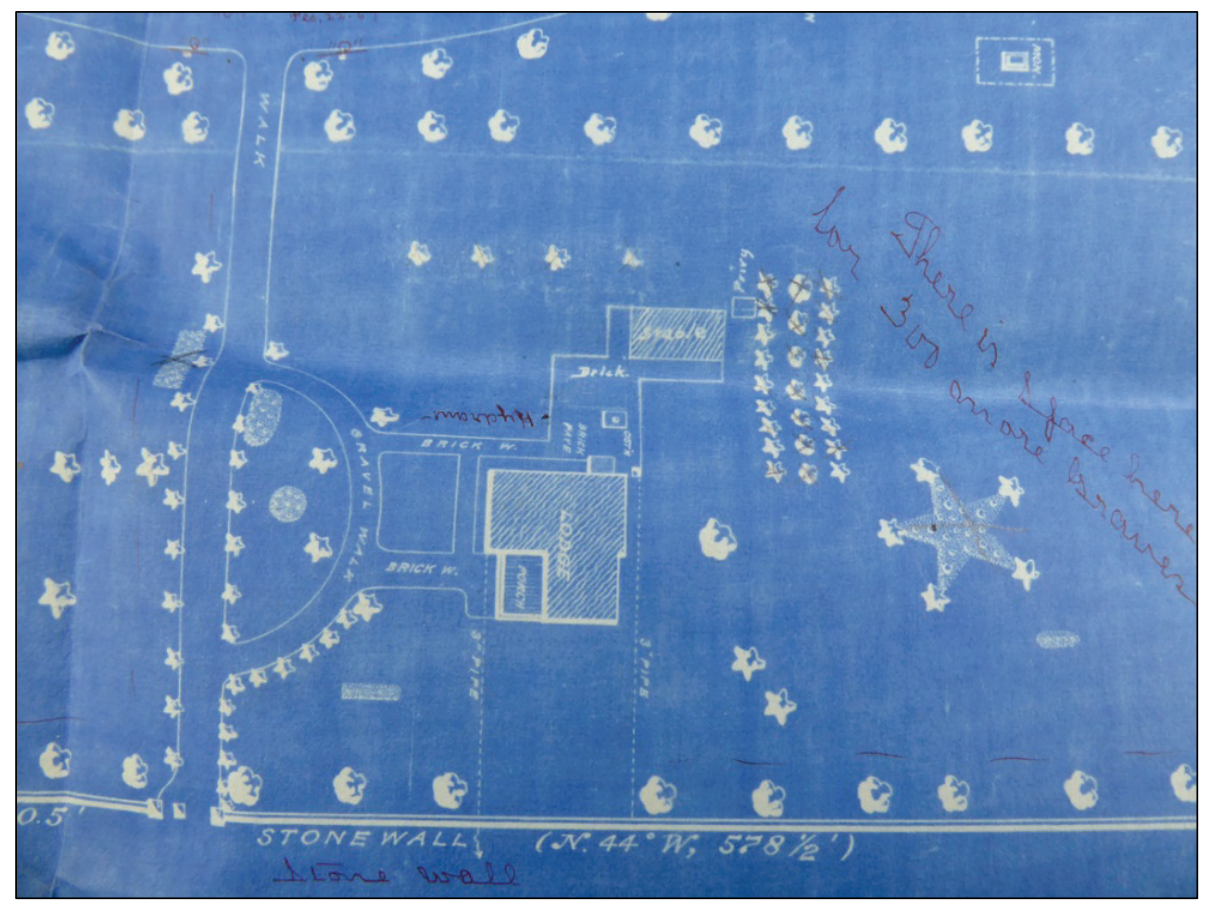

The other built-up area was shown in the north corner of the map (Figure 33). The 1907 lodge was shown with walkways to the street and to the circle drive. The lodge yard had deciduous and evergreen trees, but no shrubs were shown in this part of the cemetery. The rostrum was located between the Tyson Street wall and the circle drive. A 1912 postcard showed the location of both the lodge and the rostrum along the drive (Figure 34). The 1892/1909 map showed the location of the rostrum relative to the new main entrance from Tyson Street and indicated the iron fence along the perimeter wall and the gateposts (Figure 35 ). 
Figure 33. Detail of 1892 map (revised c.1909) showing 1907 lodge, rostrum, and trees, Office of Quartermaster General, U.S. Army (NARA, Washington DC, RG92).

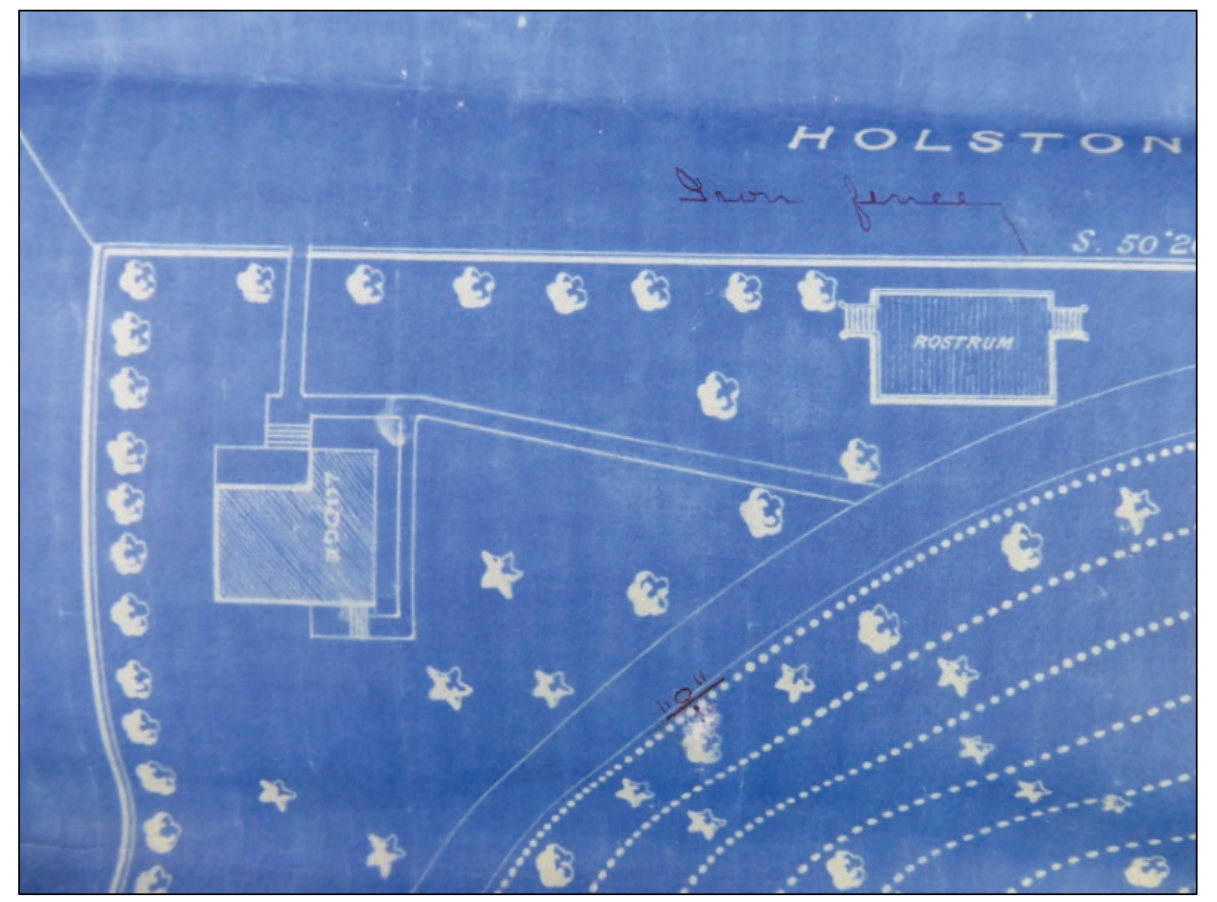

Figure 34. 1912 postcard showing spatial relationship between 1907 lodge and rostrum (University of Tennessee, Knoxville, Library digital collections "Images of East Tennessee").

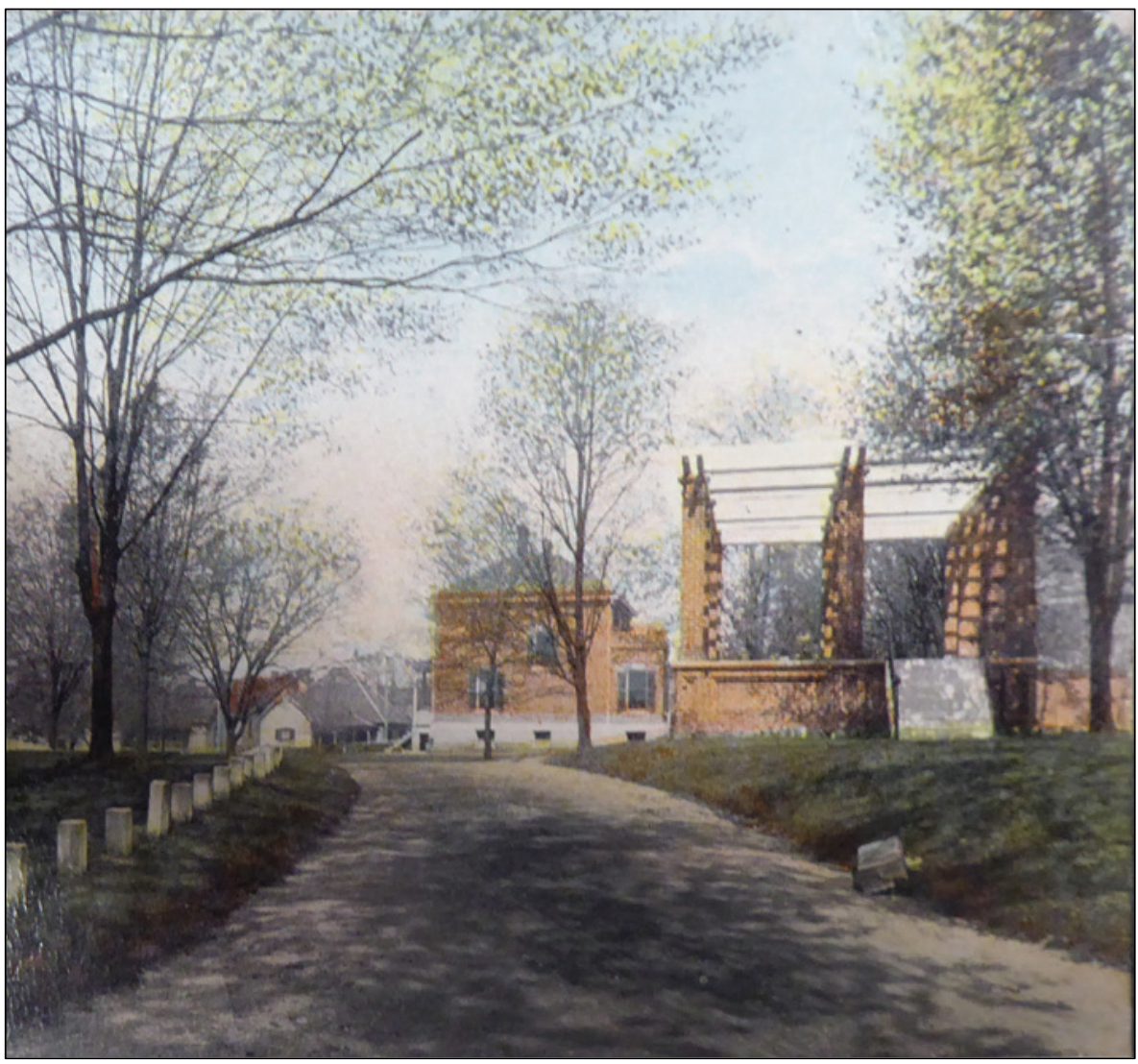


Figure 35. Detail of 1892 map (revised c.1909) showing rostrum, main entrance gate on Tyson Street, and stone wall with iron fencing (NARA, Washington DC, RG92).

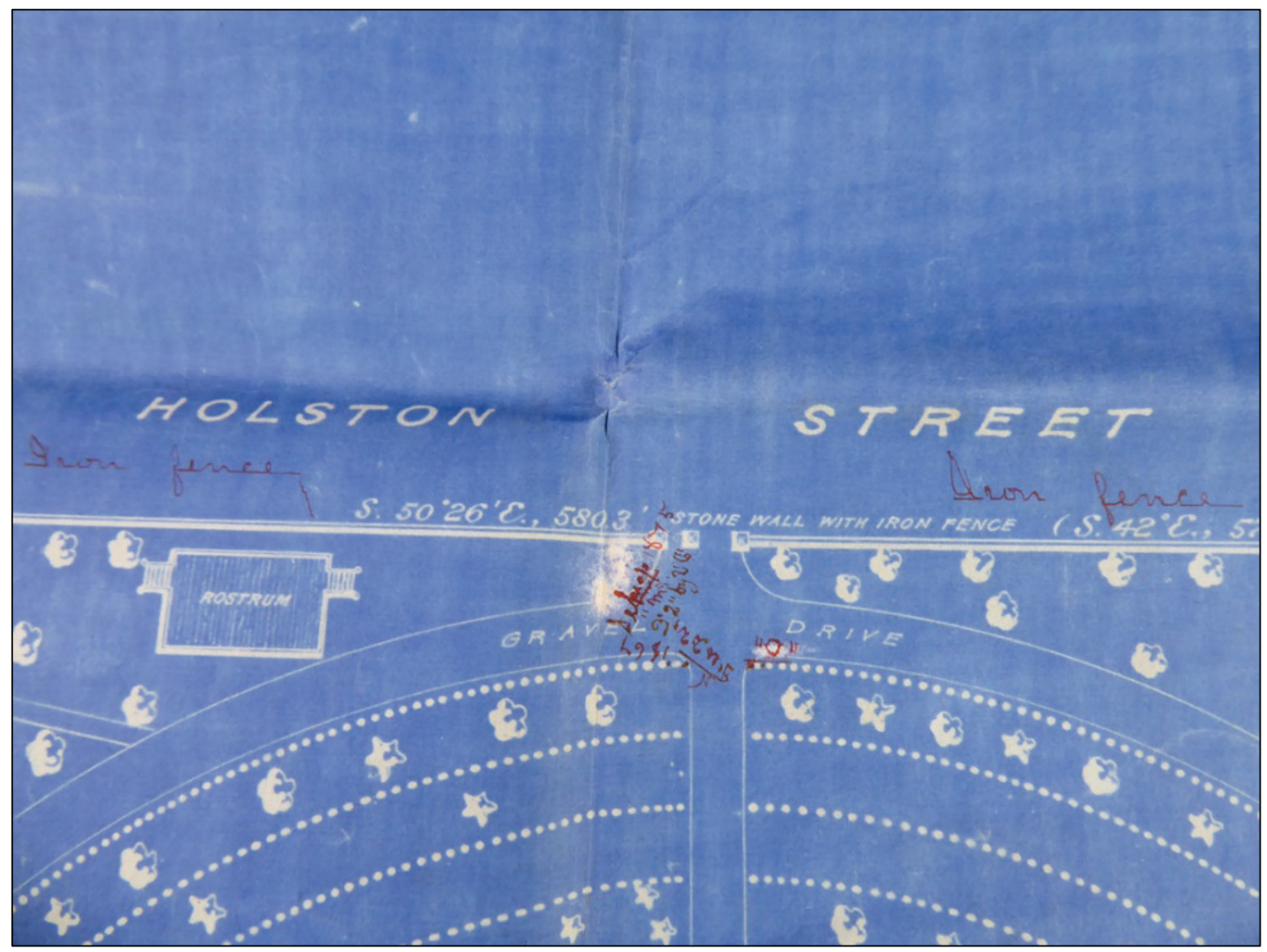

\subsubsection{Markers and memorials}

The headstones of each of the four burial sections were oriented to form circles across the sections. These circles converged at the central area containing the flagstaff. The cemetery contained small monuments erected by family and friends of the deceased. By the end of 1893, there were 3,188 internments, 2,141 known and 1,047 unknown. ${ }^{121}$ By the end of 1909, that number had grown to 2,356 known and 1,067 unknown, with room for approximately 1,000 more. ${ }^{122}$

In 1903, the standard size of headstones was modified from that established in 1873. The width of the stone was increased to 12", and the aboveground height was changed to 24 " from a total 39 " tall marker. The

\footnotetext{
121 “Knoxville, Tennessee, National Cemetery, (Second Class)," 1894, RG 15 Records of the Veterans Administration, Entry A1-25 Department of Memorial Affairs, National Cemetery Historical File, Box 24, National Archives and Records Administration, Washington, DC.

122 War Department, “Questionnaire for Superintendents," 1 March 1909, RG 92 Records of the Office of the Quartermaster General, Entry 576 General Correspondence and Reports Relating to National and Post Cemeteries (“Cemetery File"), 1865-1914, Box 38, National Archives and Records Administration, Washington, DC.
} 
modified stones had a thickness of 4". Unknown dead who had previously received 6" square blocks received the standard headstone but inscribed with the word "Unknown." 123

Members of the Department of Tennessee, Grand Army of the Republic (G.A.R.) decided in early 1896 to erect a monument honoring the Union soldiers of Tennessee and selected the Knoxville National Cemetery as an appropriate location. A committee was formed and permission for the statue's erection was requested from the U.S. Army Quartermaster General on 7 February 1896. ${ }^{124}$ The site requested was "a plot of ground 50 feet square in the northeast corner" of the cemetery, and that this site was "the spot most suitable for this Monument and least likely to interefere [sic] at any time with the use of the cemetery for burial purposes." 125 The history of the $60^{\prime}$ tall monument's design and construction is provided in the National Register of Historic Places (NHRP) nomination for Knoxville National Cemetery as:

In the spring of 1896, the group forwarded, for the approval of the United States Quartermaster General, the chief supervising agency for all G.A.R. construction, a design for the monument. The structure was to be a fifty-foot Tennessee marble shaft, embellished with unidentified bronze figures on the comers, and a single statue at the summit. A design was agreed upon and, on May 8, 1896, approved by the United States Quartermaster's Office. Approval was conditioned by the proviso "that no part of the expense attending the work be made a charge against the United States." In the summer, the memorial committee signed a contract with William B. McMullen, president of the Tennessee Producers Marble Company and the Southern Monument Company, for material and construction, and with Colonel William A. Gage for engineering consultation. The design showed that flanking entrances were to lead, as if from drawbridges, into a small sanctuary dressed entirely with marble. In its west wall was to be an "art glass" window. The east wall would be hung with tablets detailing regimental histories. Close by the entrances would appear the national emblem and state hatchment, as well as an epitaph and dedication. The monument was a miniature medieval fortress complete with its unique inner room, stained glass window and mosaic star. David H. Geddes, chief carver and foreman at the Southern Monument

\footnotetext{
123 National Cemetery Association, “History of Government Furnished Headstones and Markers," 2015. 124 William J. Ramage, letter to The Quartermaster General, U.S.A., 7 February 1896, RG 15 Records of the Veterans Administration, Entry A1-25 Department of Memorial Affairs, National Cemetery Historical File, Box 24, National Archives and Records Administration, Washington, DC. 125 Ibid.
} 
Company, and his assistants apparently had admirably sculpted the crenelated bastions, turrets, corbelled table, decorative frieze, round-arch openings, and rusticated wall surfaces. But, looking high over Holston Street to the central turret, one found...a ferocious bronze eagle with wings widely spread (Figure 36). The monument cost $\$ 11,300$ and was nearly paid for by soldier residents of the state. Of the estimated 7,00o donations, most came as one dollar offerings from dutiful pensioners. The monument was formally turned over to the Government and accepted by the Secretary of War on October 24, 1901.

On August 22, 1904, a powerful bolt of lightning struck the monument. Only the steps and part of the foundation remained, and these were scarred (Figure 37). The stones and eagle, its wings "closely cropped at its body as evenly as if the work had been done by an instrument," were flung to the ground and into the street. Lightning had apparently been attracted to a steel rod that anchored the eagle to the shaft; consequently, the sculpture had sustained a direct hit. Through the state department, the committee sponsored G.A.R. General Orders No 2, calling for immediate reconstruction. United States Representative Henry R. Gibson introduced before the House a bill calling for $\$ 10,000$ to secure the repairs. The bill passed on April 25, 1905, but the appropriation was for a maximum of $\$ 5$,000 or "so much thereof might be necessary to repair the monument." In November 1905, the committee retained Baumann Brothers, Incorporated, of Knoxville as the consulting architect. Reconstruction began the next May, following acceptance of a $\$ 4,300$ bid submitted by the Fenton Construction Company. The Baumann design must have closely duplicated the original plan. The bronze eagle was replaced with an eight-foot-tall soldier, taking his post on top of the castle's main turret (Figure 38). The coat of arms was left off, for fear it would draw more lightning. The project was completed on October 15, 1906. ${ }^{126}$ 
Figure 36. Original 1901 Union Soldier Monument (University of Tennessee, Knoxville, Library digital collections "Images of East Tennessee").

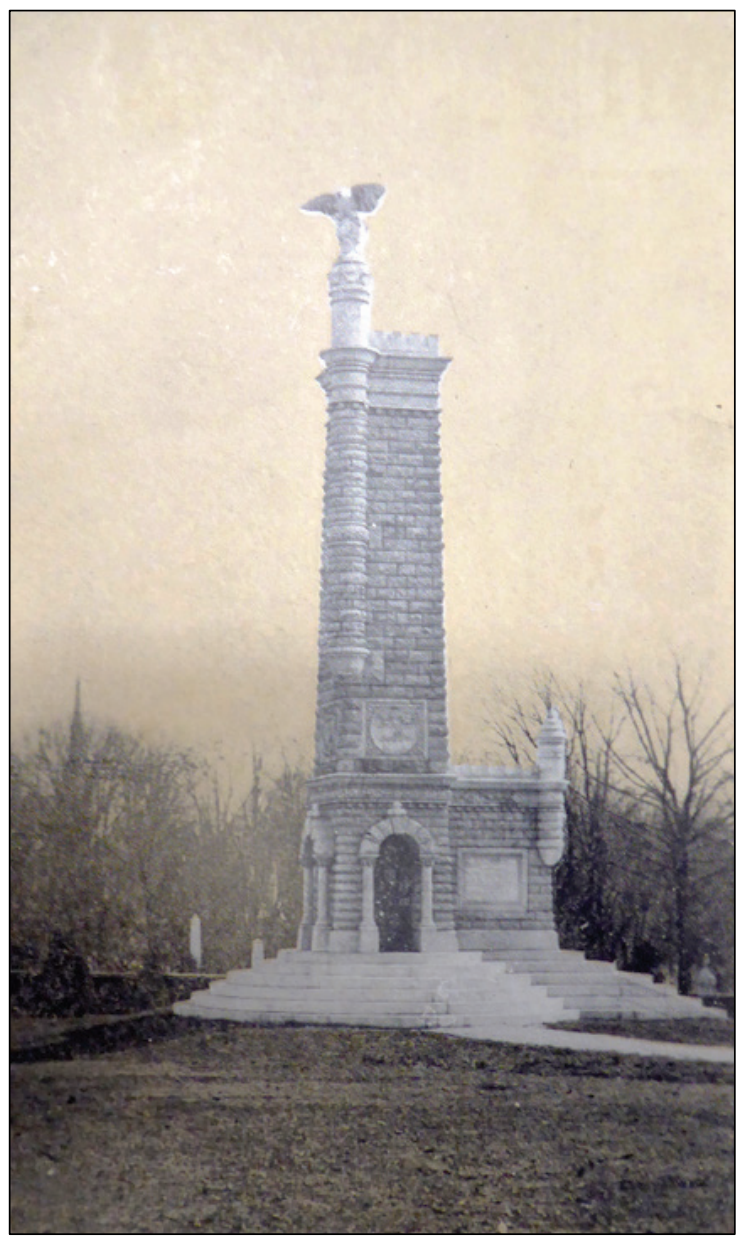

Figure 37. Lightning strike damage to the Union Soldier Monument, 1904 (VA NCA Archives, Washington, DC).

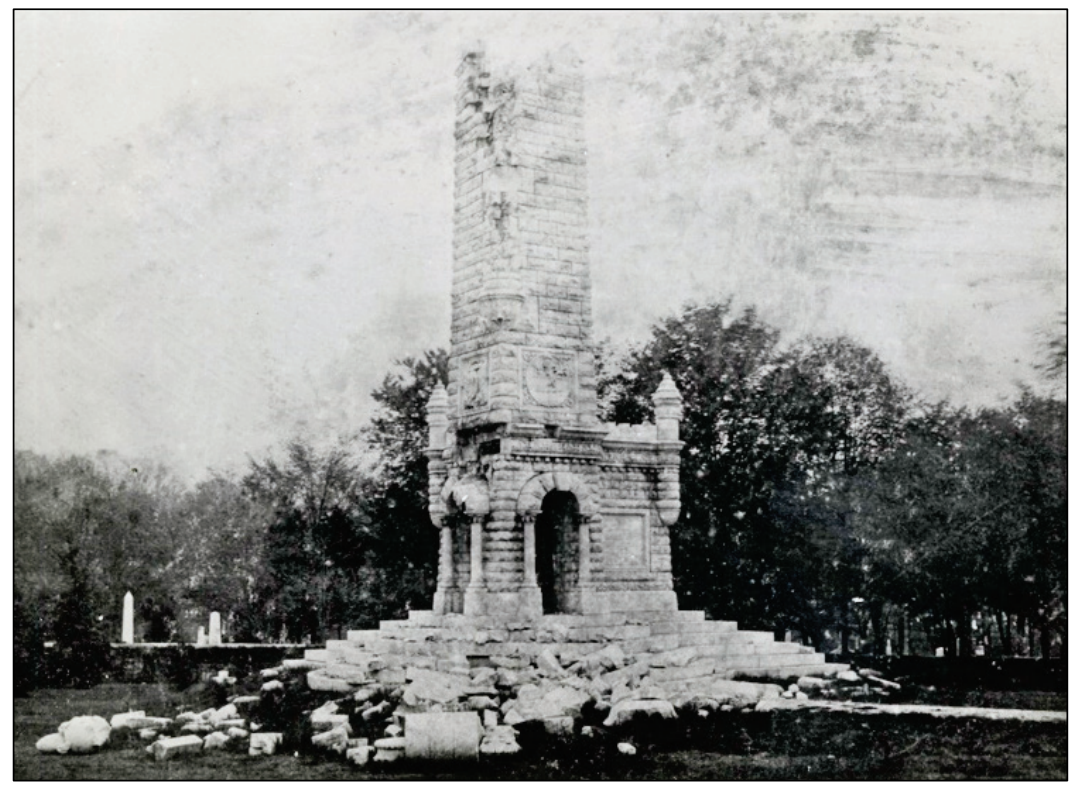


Figure 38. Rebuilt Union Soldier Monument, 1911 (University of Tennessee, Knoxville, Library digital collections "Images of East Tennessee").

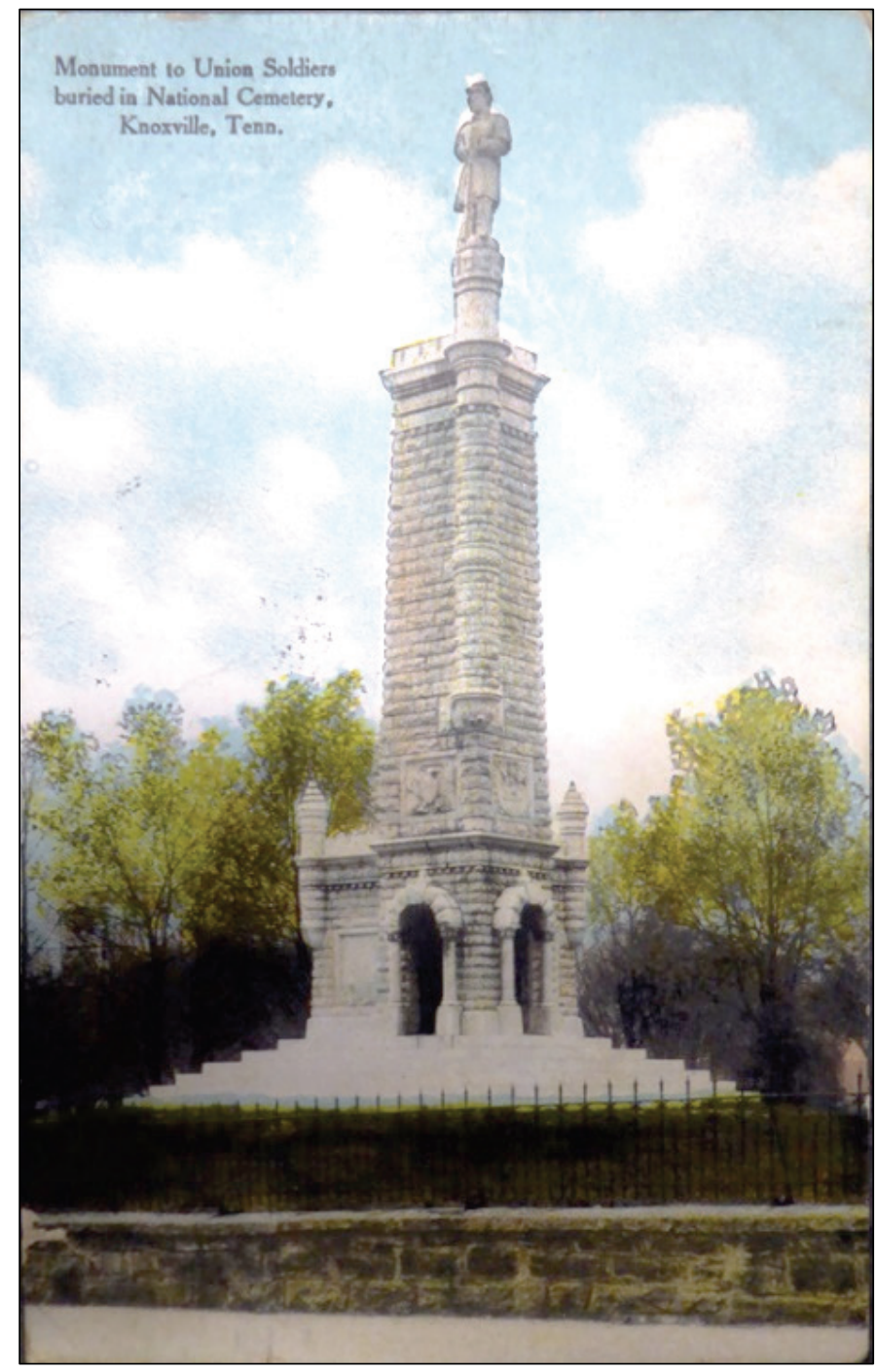

Tablets in National Cemeteries containing President Lincoln's Gettysburg address were in place by $1909 .{ }^{127}$ This text was chosen because it had previously been featured as a permanent element in national cemetery landscapes as early as 1895, when legislation authorized a monument to the speech at the Soldiers National Cemetery. The original Gettysburg Address cast-iron tablets were produced in 1909 by the U.S. Army Rock Island Arsenal in Illinois and placed in all National Cemeteries. ${ }^{128}$

\footnotetext{
127 VA National Cemetery Administration, "New Gettysburg Address Tables for National Cemeteries to Honor Abraham Lincoln Bicentennial." https://www.cem.va.gov/history/LincBic.asp, 2015.

128 VA National Cemetery Division, "150th Anniversary National Cemeteries of the Civil War 2012 planner," 2011, National Cemetery Administration Archives, Washington, DC; VA National Cemetery Division, “New Gettysburg Address Tablets for National Cemeteries," 2015.
} 


\subsubsection{Buildings and structures}

The 1874 stone lodge was in use into the $20^{\text {th }}$ century, largely unchanged. A report from 1894 described the lodge as "of stone, one and one-half stories in height, with mansard roof. It contains six rooms and three cellar compartments, and is located at the center of the south end."129 There was a 4,600-gallon cistern located near the lodge. ${ }^{130}$ After a new lodge was constructed in 1907, the Assistant Superintendent moved into the 1874 lodge. It was in use at least until 1909; it had been demolished sometime after that year and before $1935 \cdot{ }^{131}$

The Quartermaster General began a process of replacing some of the Meigs Plan lodges in 1905, and new plans were drawn up over the next several years. One of the plans to emerge was a four-square, and between 1906 and 1910, eight lodges of this design were constructed. The earliest were frame, two-story, with front and rear porches on each story, and were built at Barrancas, Florida, and Florence, South Carolina, in 1906. Over the next 3 years, two-story brick, center-hall plan four-square lodges were constructed in six cemeteries, including Knoxville. The others were located at Andrew Johnson, Greeneville, Tennessee; San Antonio, Texas; Gettysburg, Pennsylvania; Little Rock, Arkansas; and Camp Butler, Illinois. ${ }^{132}$

The 1907 four-square lodge at Knoxville was constructed of brick on a stone and concrete foundation, with two stories and a basement, and a hipped slate roof with two eyebrow dormers (Figure 39). The central hall plan provided four rooms on each floor ( $1^{\text {st }}-$ parlor, dining room, pantry and kitchen, and Superintendent's office; $2^{\text {nd }}$ - four bedrooms and bath), with polished wood floors and natural wood finish. The basement held three rooms. Dimensions were $34^{\prime}$ x $30^{\prime}$, with $2,240 \mathrm{sq} f \mathrm{ft}$ above the basement. There were two interior chimneys for the fireplaces and a coal-fired hot air furnace. The brick lodge had electric, water, sewer, and gas connections. There were porches on the front and rear, with the front porch on the north side of the front facade, with a projecting room on the south side for the

\footnotetext{
129 “Knoxville, Tennessee, National Cemetery, (Second Class)," 1894.

130 Ibid.

131 War Department, "Questionnaire for Superintendents," 1 Mar 1909.

132 Harrison, “Superintendent's Lodges," 2013, 42-43, 62, 71.
} 
office. ${ }^{133}$ In her Historic American Landscapes Survey documentation of the lodge, Price provides more detail about the building, "the windows were wood, and appear to be double-hung sash glazed with six-over-two lights on the second floor, and two over- two lights on the first floor. The sills look to be made of stone." 134 The lodge was constructed at a cost of $\$ 7,000.135$ The lodge was located at the north corner of the cemetery, on a previously empty area near the wall on Bernard Avenue, with the front door facing Tyson Street. This location placed the lodge near the rostrum and the main entrance. There was a pedestrian gate from the street leading to the lodge via a walk that turned at the lodge steps and continued around to the rear. The lodge sat on a grass lawn, with no foundation plantings. It is not known when the fencing along Bernard Avenue was installed to match that along Tyson Street, but it was likely done when the lodge was built.

Figure 39. 1907 Lodge shortly after construction (NARA Washington, DC, RG92-CA).

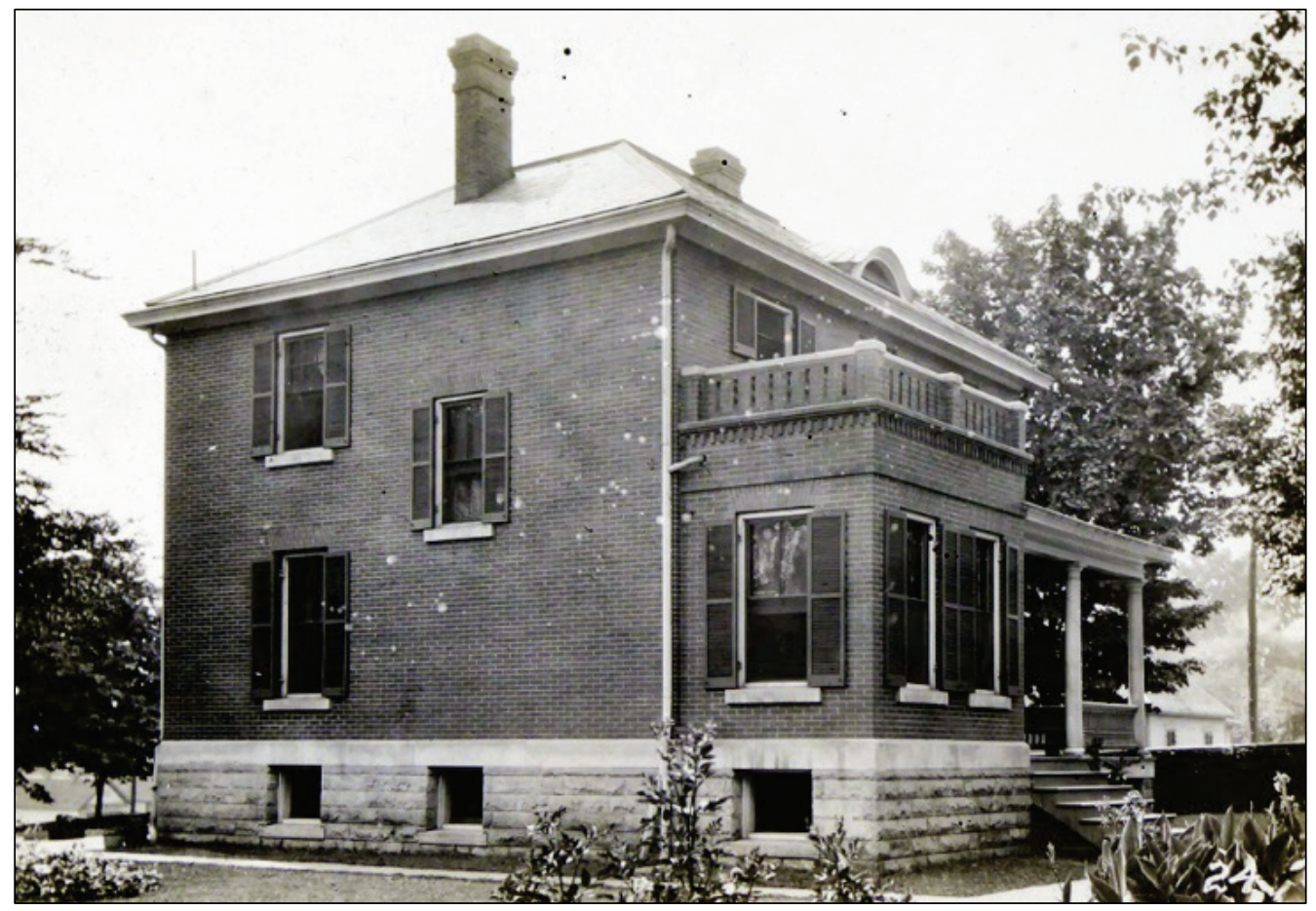

The existing maintenance record for the lodge begins in 1931 and indicates minor repairs made to the building in the early 1930 (Figure 40). During

\footnotetext{
133 Ibid, 42-43; Sammartino, "Knoxville National Cemetery," 1996; Price, "Historic American Landscapes Survey: Knoxville National Cemetery, Lodge," 2012, 1; “Lodge," Real Property Form, U.S. National Cemetery, Knoxville, Tenn., 1934, RG 15 Records of the Veterans Administration, Entry A1-25 Department of Memorial Affairs, National Cemetery Historical File, Box 24, National Archives and Records Administration, Washington, DC.

134 Price, “Historic American Landscapes Survey: Knoxville National Cemetery, Lodge," 2012, 4.

135 Harrison, “Superintendent's Lodges," 2013, 43.
} 
these years, the lodge received a new kitchen sink and new window screens in 1931, and the rear steps were replaced with new concrete ones that same year. Light fixtures and switches were installed in 1932, and the exterior woodwork, gutters, downspouts, and porch floors were painted in $1933 .{ }^{136}$

Figure 40. 1907 lodge along Tyson Street, 1931 (NARA, Washington DC, RG15).

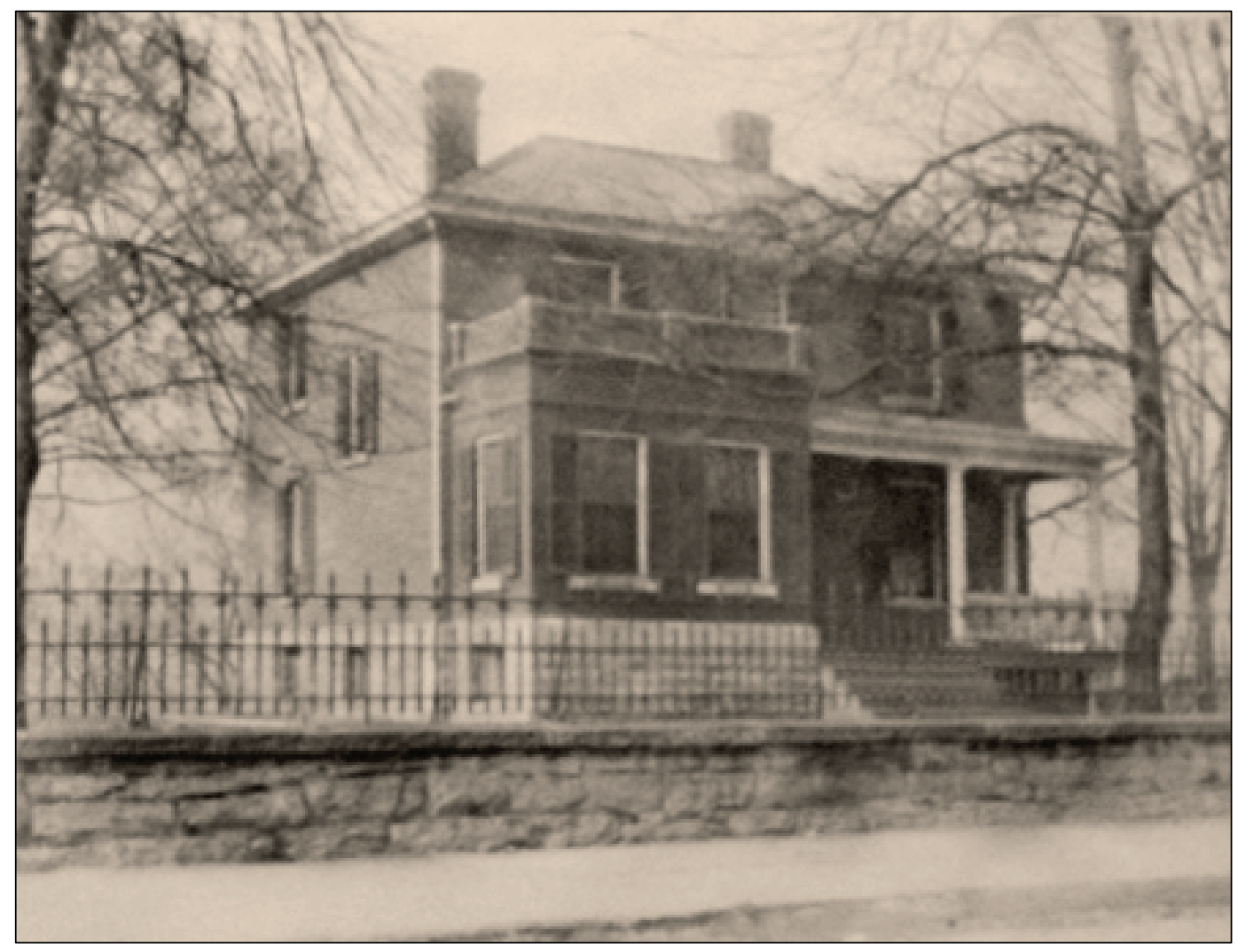

In 1894 , the frame outbuilding at the lodge was still in place, containing a tool room, fuel room, and two privies. ${ }^{137}$ In 1898 , the building was removed and a brick building containing a tool room, work shop, and stable "for horse when one is used" was constructed (Figure 41). ${ }^{138}$ This building eventually contained public toilets, but it is not known if they were original to the building. The tool room/stable was constructed in the same area as the old frame outbuilding but oriented with the broader elevation facing the lodge. Measuring roughly $18^{\prime}$ x $30^{\prime}$ the three-room structure had a

\footnotetext{
136 “Lodge," 1934.

137 “Knoxville, Tennessee, National Cemetery, (Second Class)," 1894.

138 War Department, “Questionnaire for Superintendents," 1 Mar 1909.
} 
brick and concrete foundation with concrete floors, brick walls, and an asphalt shingle roof. ${ }^{139}$ The rostrum did not change over this period. ${ }^{140}$

Figure 41. 1898 stable building in back of the 1874 lodge, undated photograph (NARA, Washington, DC, RG92-CA).

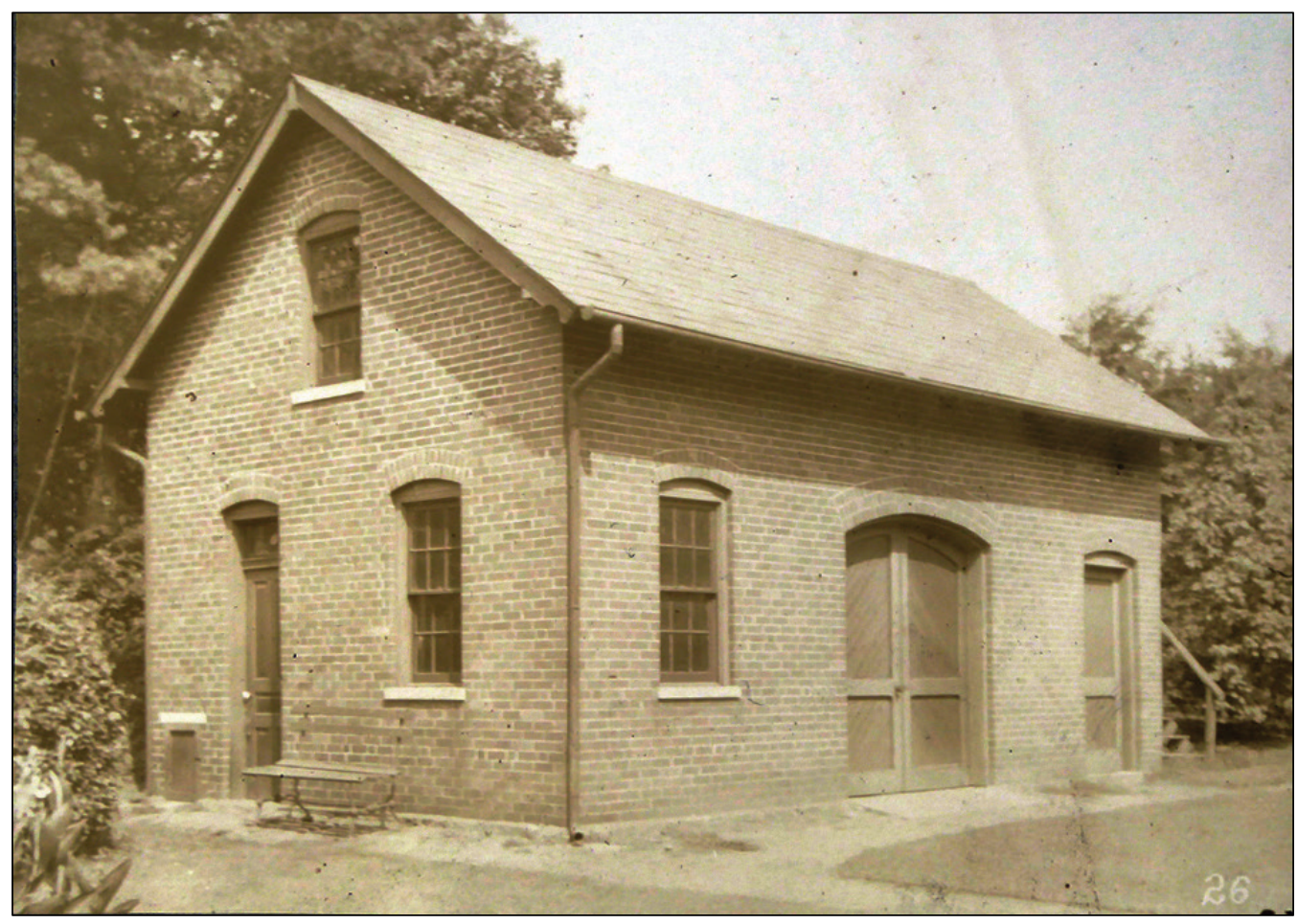

\subsubsection{Walls, roads, and gates}

An 1894 report on the cemetery described it as being "enclosed by a stone wall, on the north side of which is an iron fence," and that there were double iron gates at the entrances. ${ }^{141}$ When the new lodge was constructed in 1907, a pedestrian iron gate was installed on Tyson Street. The gate led to a sidewalk that ran to the front porch of the brick lodge. In a 1909 questionnaire for Superintendents, a question about the condition of the walls elicited this response, "One half of the enclosing wall is in good condition." ${ }^{142}$ No further clarification was provided. The same survey listed three entrances to the cemetery - main entrance on Tyson Street, secondary entrance on Cooper Street, and the pedestrian gate leading to the

\footnotetext{
139 "Tool Room and Public Toilets," Real Property Form, U.S. National Cemetery, Knoxville, Tenn., undated, RG 15 Records of the Veterans Administration, Entry A1-25 Department of Memorial Affairs, National Cemetery Historical File, Box 24, National Archives and Records Administration, Washington, DC; Price, “Historic American Landscapes Survey: Knoxville National Cemetery, Lodge," 2012, 5.

140 “Knoxville, Tennessee, National Cemetery, (Second Class)," 1894.

141 Ibid.

142 War Department, “Questionnaire for Superintendents,” 1 Mar 1909.
} 
lodge. The sidewalk next to the wall on Tyson Street had been paved with concrete by this time. ${ }^{143}$

A 1894 status report for the cemetery mentions the graveled circle drive running around the circular burial sections and ending in entrances on either side, and that the Government had built a "macadamized roadway 1,325 feet in length" beginning at the intersection of Broad and Tyson Streets to the intersection of Tyson Street and Bernard Avenue at the north corner of the cemetery. The Government was given a $55^{\prime}$ wide right of way. ${ }^{144}$ The right of way included 1.52 acres along the roadway. ${ }^{145}$ A revocable license was given to the Fountain Head Railroad Company in 1890 to construct a line across the lower part of Tyson Street. ${ }^{146}$

At some point after 1909 and before 1931, a new gate was installed at the main entrance. The rather grand structure had an arched double iron gate ranging from $11^{\prime}, 10^{\prime \prime}$ to $5^{\prime}, 6^{\prime \prime}$ tall flanked by two metal gateposts. The posts were highly decorated with insignia, coats of arms, and painted images, and were topped with large decorative urns (Figure 42). There were two additional gateposts further out made of concrete, with metal pedestrian gates linking each set of gateposts. The iron vehicular gates were arched and had "U.S. National Cemetery" lettering on metal plates above two coats of arms. The pedestrian gates each had a smaller coat of arms. ${ }^{147}$

\footnotetext{
143 Ibid.

144 “Knoxville, Tennessee, National Cemetery, (Second Class)," 1894; J.A.M. Campbell, Road Commissioner, "Right of Way for Holston Road," 1886, RG 15 Records of the Veterans Administration, Entry A125 Department of Memorial Affairs, National Cemetery Historical File, Box 24, National Archives and Records Administration, Washington, DC.

145 "Historical Summary," 11 January 1936, Folder: Audit No. 462, National Cemetery Administration Archives, Washington, DC.

146 Ibid.

147 “Entrance Gates," 1962; Superintendent, Knoxville National Cemetery, "Questionnaire on Status and History of Cemetery," 8 January 1889; Owen, Manuscript notes, 9 February 1887.
} 
Figure 42. 1887 Entrance Gates, undated photo - likely 1947 (NARA, Washington DC, RG15).

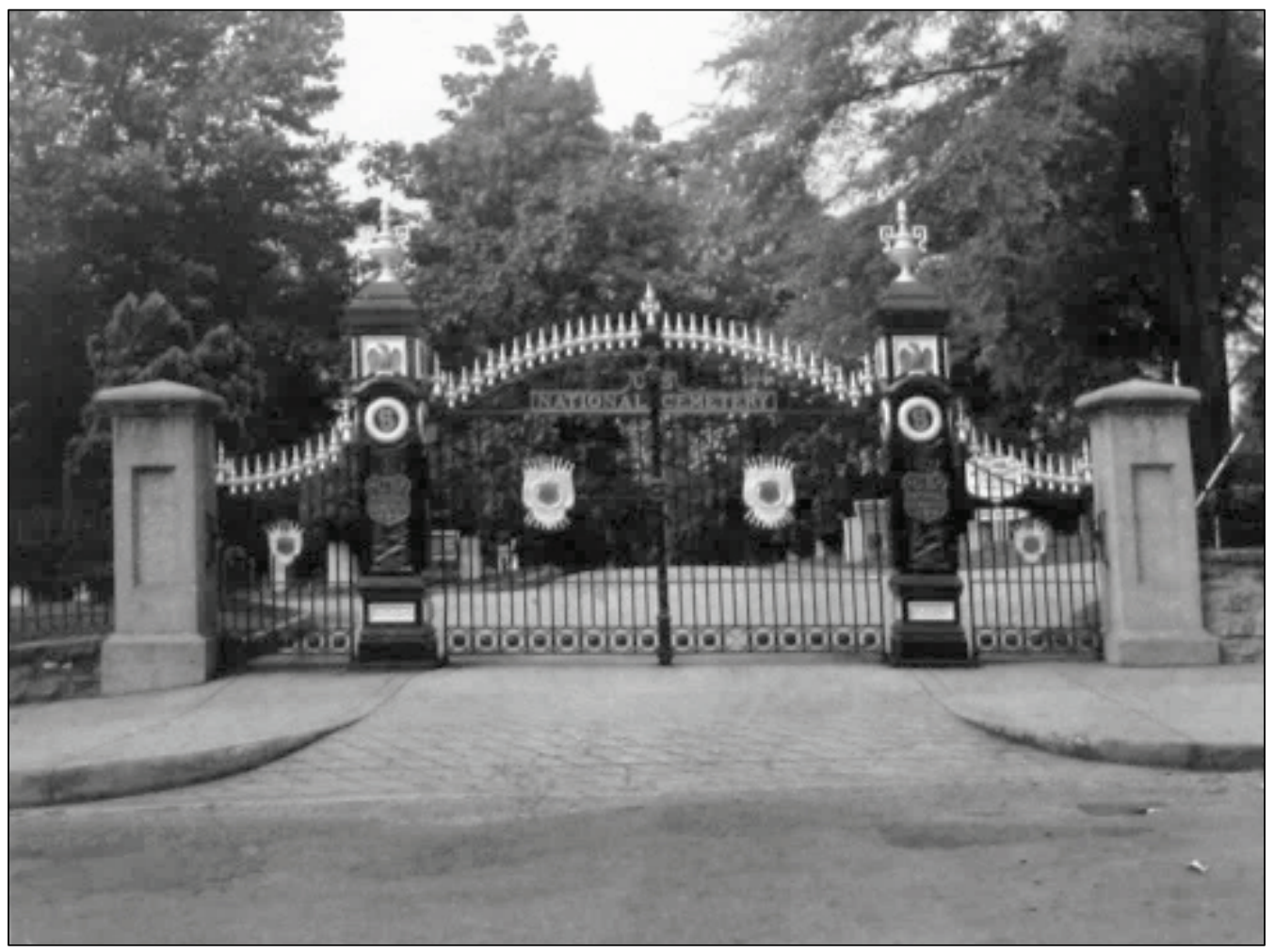

\subsection{Modernization period, 1935-1956}

The Knoxville National Cemetery was officially designated by the War Department through General Orders, No. 7 in $1936 .{ }^{148}$ As a result, jurisdiction of the cemetery was vested in the Commanding General, $4^{\text {th }}$ Corps Area, U.S. Army. ${ }^{149}$ In the aftermath of the Second World War, the cemetery entered its busiest phase as a number of that war's dead were buried there. By 1948, there was an average of 100 interments a year, with a peak of 16 in 1 week that year. ${ }^{150}$

\subsubsection{Cemetery design and grounds}

In November 1944, an inspection was made of the cemetery's landscape conditions after a storm. It was determined that the number of trees "exceeds the number necessary to provide adequate shade and a pleasing

\footnotetext{
148 "South Atlantic Division Historical File Summary," undated, Folder: Audit No. 462, National Cemetery Administration Archives, Washington, DC.

149 "Historical Summary," 11 January 1936.

150 "Many Graves Are Added to U.S. Cemetery," Knoxville News-Sentinel, 1948, in Folder: "Knoxville," National Cemetery Administration, U.S. Department of Veterans Affairs, Washington, DC.
} 
contrast of sunny and shaded areas," and it was recommended that densely shaded areas should have some trees removed to create more open areas. ${ }^{151}$ The report mentioned foundation plantings at the lodge and at the lodge pedestrian gate, but not what kind of plants. Flowering shrubs were located between the headstones, but the inspector recommended removing them to mass planting beds to keep from breaking up the "landscape viewpoint" among the headstones. ${ }^{152}$ Possibly as a result of this inspection, an account from August 1945 listed a cost of $\$ 2,775$ for "seeding and topsoil, for transplanting and pruning 15 trees, for purchase and transplanting of 125 shrubs and for the removal of 3 dead or diseased trees." 153

An inventory report from 1947 describes some of the cemetery's built environment components. The cemetery had $2,935^{\prime}$ of gravel road, with $5,750^{\prime}$ of curbs and gutters. There were $260^{\prime}$ of concrete walks and a number of lawn hydrants. ${ }^{154}$ All the roads in the cemetery were resurfaced with asphalt in early 1948 , and 2 years later $286^{\prime}$ of $8^{\prime \prime}$ drain tile was installed in association with road repairs. Drainage remained a problem, and the road surface was raised in two places in 1951, with drainage installed. A compost pit and screened wall were recommended in 1946, along with underground storage for gasoline. 155 These were later constructed on either side of the utility building at unknown dates. The iron tablets in the cemetery were painted and relettered in 1958, and eight iron settees around the grounds were repainted that year. ${ }^{156}$

Infrequently, major changes were made to the cemetery's trees. In 1947, two local commercial tree experts recommended that a number of trees be

\footnotetext{
151 “Knoxville National Cemetery Inspection," November 1944, RG 15 Records of the Veterans Administration, Entry A1-25 Department of Memorial Affairs, National Cemetery Historical File, Box 24, National Archives and Records Administration, Washington, DC.

152 Ibid.

153 “Knoxville, Tennessee, Project 311, Landscape," 2 August 1945, RG 15 Records of the Veterans Administration, Entry A1-25 Department of Memorial Affairs, National Cemetery Historical File, Box 24, National Archives and Records Administration, Washington, DC.

154 “National Cemetery," 1 August 1947, RG 15 Records of the Veterans Administration, Entry A1-25 Department of Memorial Affairs, National Cemetery Historical File, Box 24, National Archives and Records Administration, Washington, DC.

155 Lt. Col. D.K. Donelson, Maj. M.J. Gill, and Chas. J. Dorman, Management \& Inspection Branch, Memorial Division, Quartermaster Corps, "Report of Official Travel," 10 October 1946, RG 15 Records of the Veterans Administration, Entry A1-25 Department of Memorial Affairs, National Cemetery Historical File, Box 24, National Archives and Records Administration, Washington, DC.

156 “Flagstaff (cont'd)," Real Property Form, U.S. National Cemetery, Knoxville, Tenn., 1958, RG 15 Records of the Veterans Administration, Entry A1-25 Department of Memorial Affairs, National Cemetery Historical File, Box 24, National Archives and Records Administration, Washington, DC.
} 
removed due to being badly decayed or "crowding out more desirable trees which should be retained." 157 The existing trees at the time can be seen in a 1946 aerial (Figure 43). They selected "three Maples in Section B, two Maples, one Elm and one Sycamore in Section C, four Maples and one Magnolia in Section D, also, twenty six Catalpas along north, west and east walls of cemetery." ${ }^{158}$ Superintendent Keel requested permission to carry out this work, writing that "the thinning will be necessary to secure a satisfactory sod throughout the cemetery." 159 He created a sketch map showing the marked trees with red for the decaying ones and heavy black for the ones needing to be thinned (key on first map quarter) (Figure 44 and Figure 45). As the request involved the loss of a large number of trees, it was forwarded to the Office of the Quartermaster General for concurrence. 160 The archival record does not indicate if the work was carried out, but the loss of trees in the cemetery over time suggests the trees were removed.

\footnotetext{
157 J.L. Wolf, letter to Superintendent, Knoxville National Cemetery, 12 February 1947, RG 15 Records of the Veterans Administration, Entry A1-25 Department of Memorial Affairs, National Cemetery Historical File, Box 24, National Archives and Records Administration, Washington, DC.

158 lbid.

159 Owen H. Keel, Superintendent, letter to Commanding General, Seventh Army, 14 February 1947, RG 15 Records of the Veterans Administration, Entry A1-25 Department of Memorial Affairs, National Cemetery Historical File, Box 24, National Archives and Records Administration, Washington, DC.

160 Matthew H. Jones, Quartermaster, Seventh Army, letter to Quartermaster General, Washington, DC, 17 February 1947, RG 15 Records of the Veterans Administration, Entry A1-25 Department of Memorial Affairs, National Cemetery Historical File, Box 24, National Archives and Records Administration, Washington, DC.
} 
Figure 43. Aerial view of Knoxville National Cemetery, 1946 (HALS-TN-2, Library of Congress).

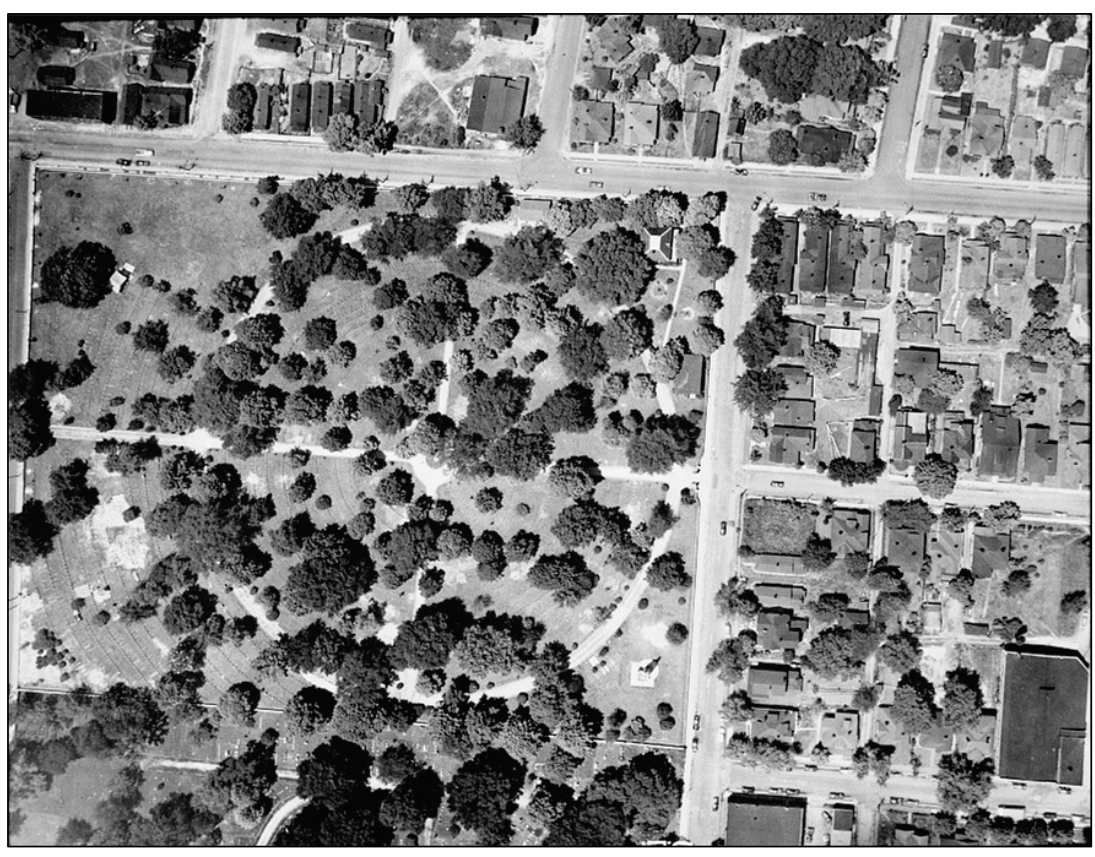


Figure 44. Planned tree removal sketch map, Section A, 1947 (NARA, Washington DC, RG92).

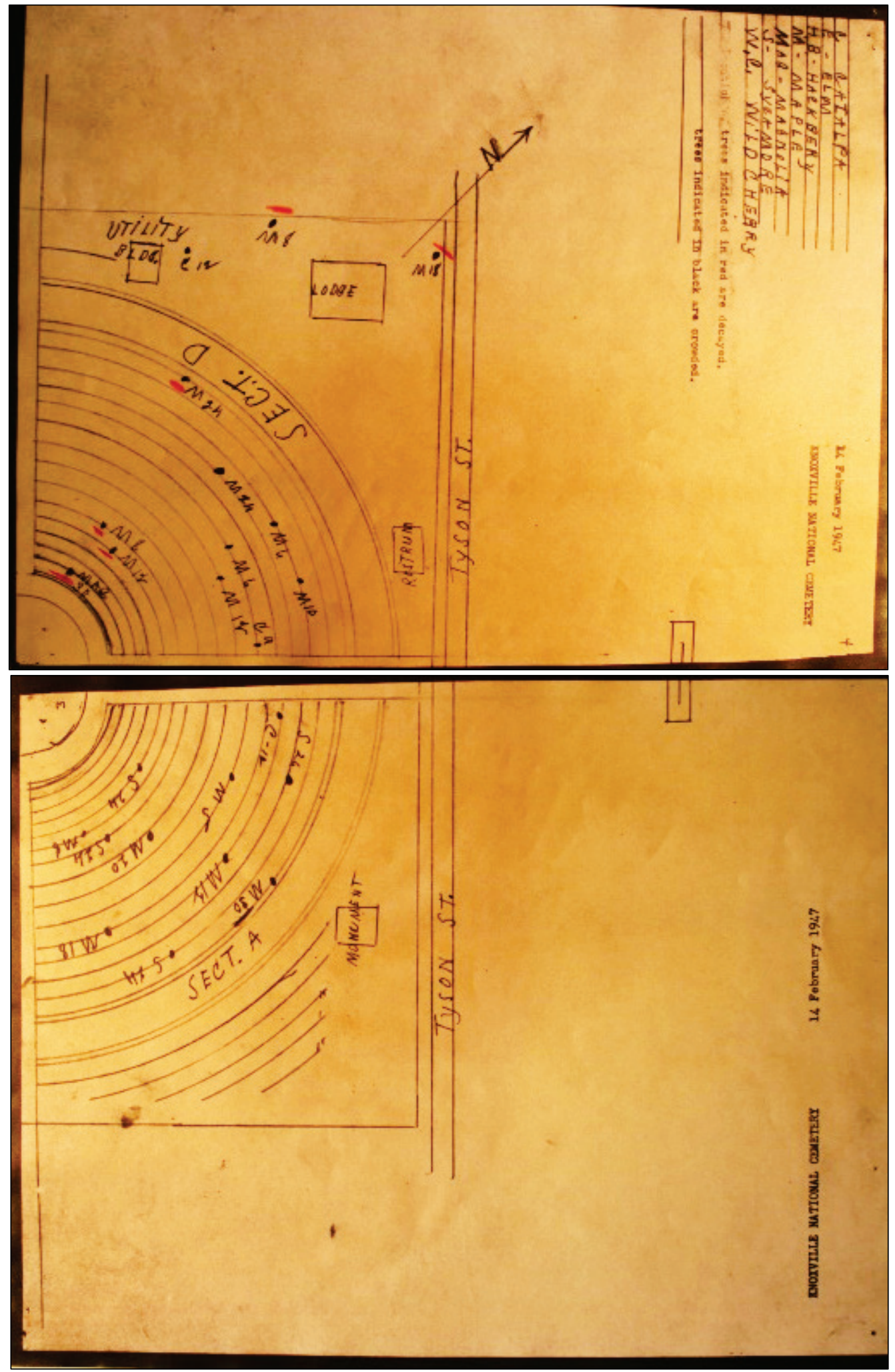


Figure 45. Planned tree removal sketch map, Section B, 1947 (NARA, Washington DC, RG92).

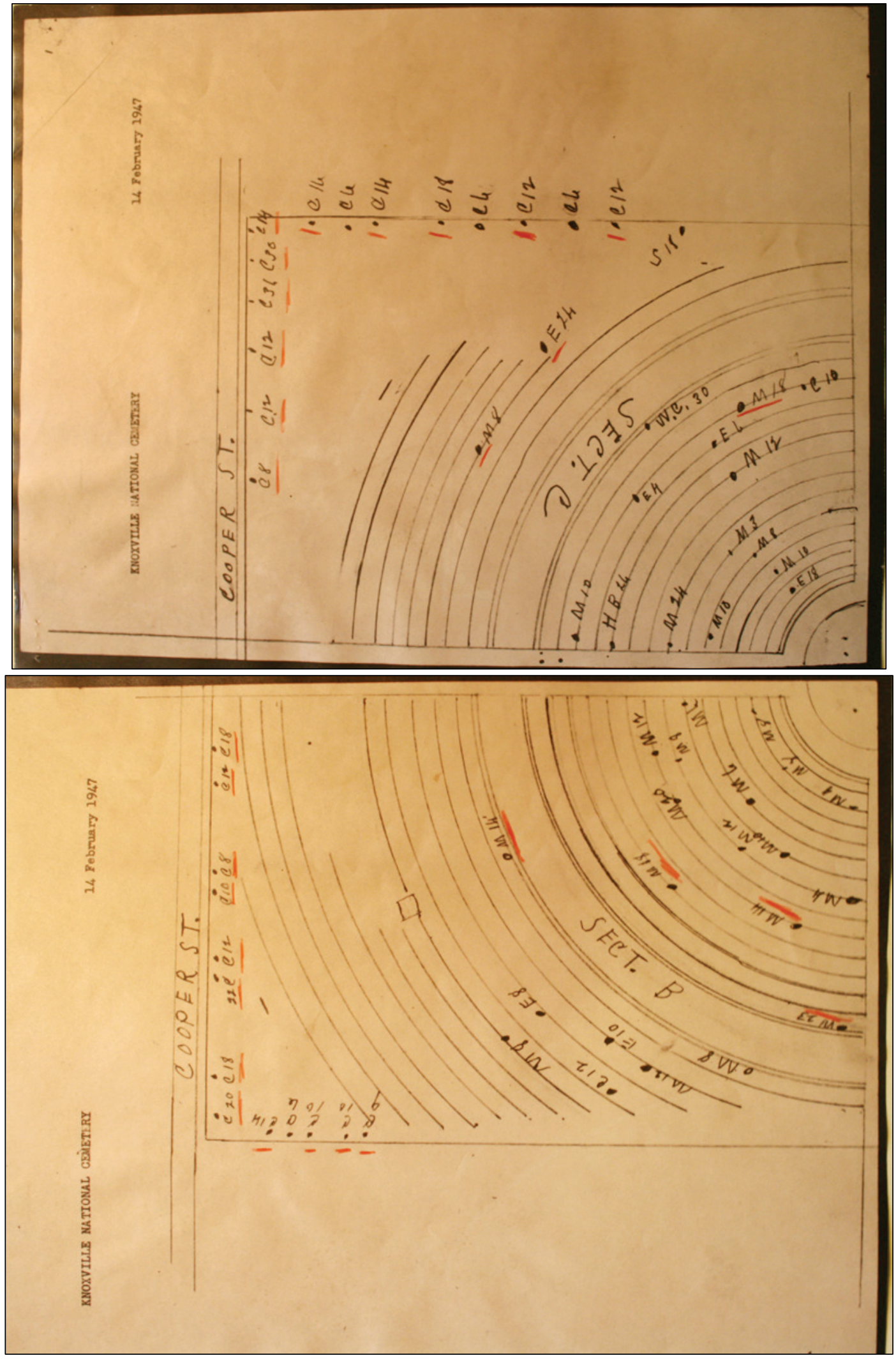


An aerial map from 1948 and a contour map from 1949 provides a snapshot of the cemetery, showing a complete lack of buildings in any area other than the north corner (Figure 46 and Figure 47). The only entrances to the cemetery are the Cooper Street gate, the main entrance from Tyson Street, and the pedestrian gate to the lodge on Tyson Street. The layout of the burial area is unchanged with the circle drive and two axial roads that meet at the flagpole. Vegetative cover is evenly spread throughout with a mixture of evergreens, deciduous trees, and shrubs, with the exception of a "clump of shrubs" at the south corner. There were catch basins in the corner of the walls in the south and west, and a culvert in the west section of the circle drive. There were also two concrete drains, one each on the Bernard Avenue wall and one on the common wall with Gray Cemetery.

Figure 46. Aerial view of Knoxville National Cemetery, 1948 (HALS-TN-2, Library of Congress).

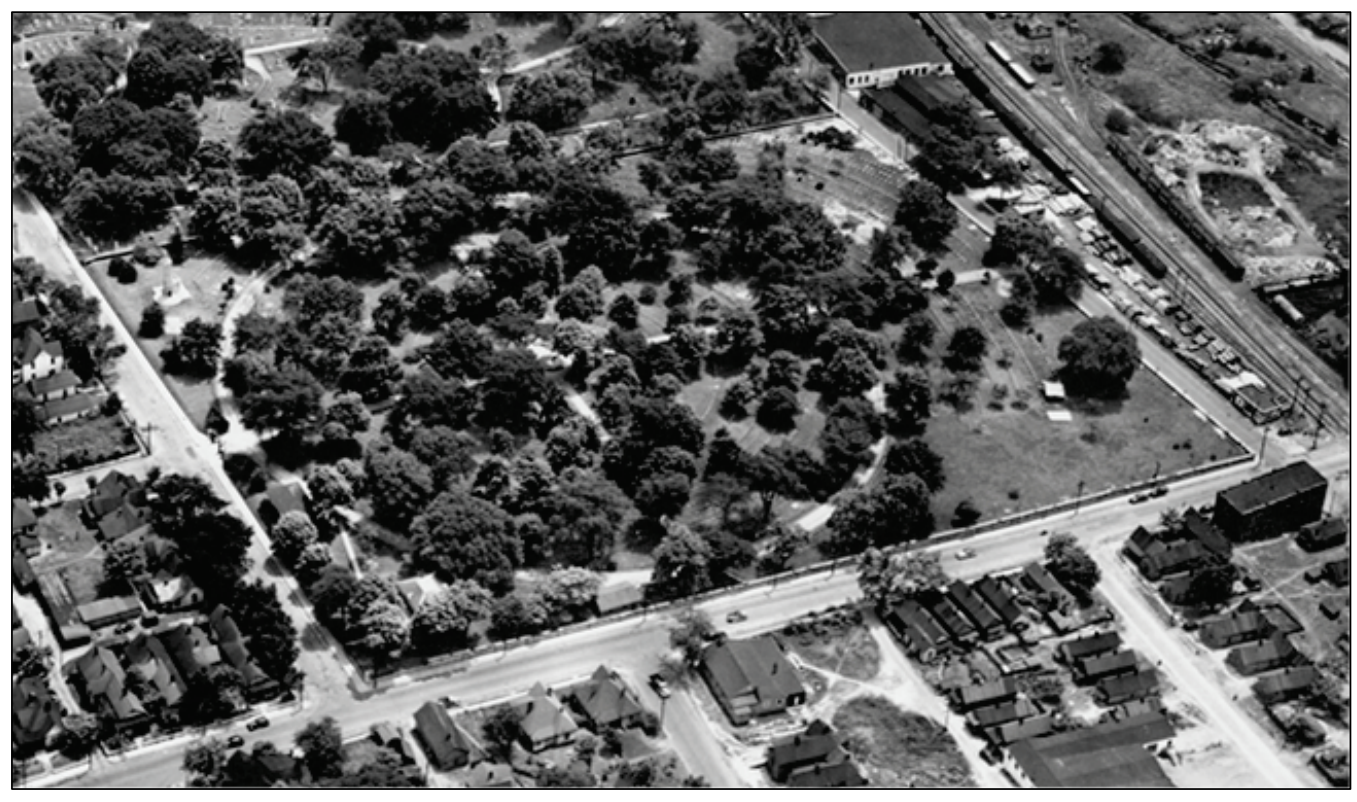


Figure 47. Contour map of Knoxville National Cemetery, 1949 (VA NCA Archives, Washington, DC).

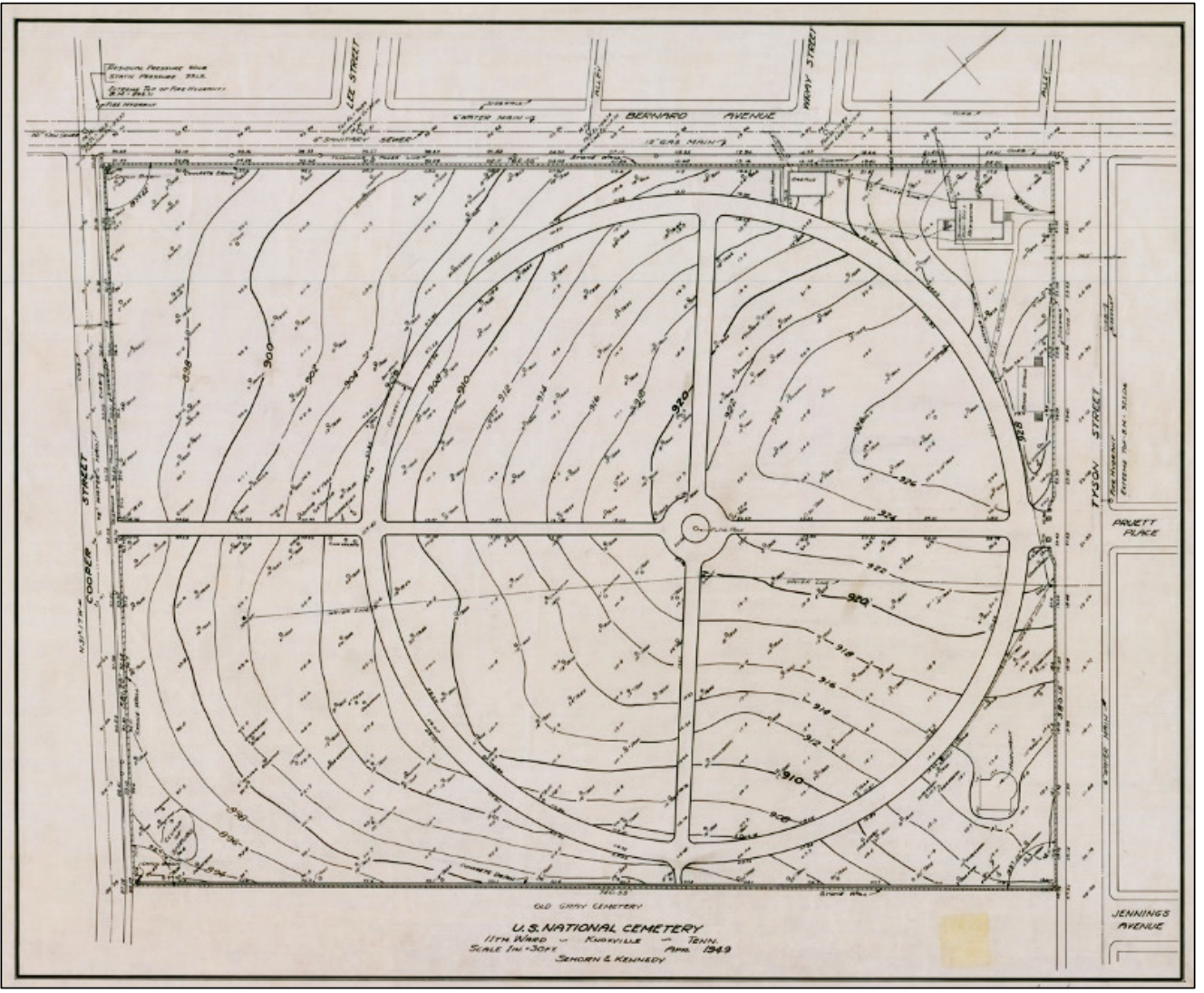

\subsubsection{Markers}

Headstones were redesigned after World War I, and they were used for all graves except those of Civil War and Spanish-American War veterans. Referred to as the "General" type of headstone, the white marble stone was $42^{\prime \prime}$ long, 13 " wide, and 4" thick, with a slightly rounded top. The inscription contained a soldier's name, rank, regiment, division, date of death, and home state. For the first time, there was a choice of two religious emblems-a Latin Cross for the Christian faith or the Star of David for the Jewish faith. ${ }^{161}$

A major difficulty with the markers at Knoxville National Cemetery came to light in a 1946 inspection report. The headstones had absorbed soot and acids from the railroads and industries in the adjacent areas, particularly a nearby gas manufacturing plant. The markers were exhibiting a "permanent dead gray cast," the marble was decomposing, and it could not be 
cleaned. ${ }^{162}$ Polished granite in the cemetery did not seem to be affected, so it was recommended that the markers be replaced with granite ones for all new interments and for replacement markers.

Documents from 1965 indicate the old Civil War markers were in the process of being replaced. At that time, there were 6,100 interments in 5,959 graves including Union soldiers, veterans from other wars, some family members of veterans, civilian cemetery employees, and "at least two veterans were Confederates, one an officer (captain?) and one a sergeant." ${ }^{163}$

\subsubsection{Buildings and structures}

Between 1935 and 1956, two new buildings were added to the cemetery grounds, the lodge was repaired and slightly renovated, two new flagstaffs were installed, and roads were repaired. A 1947 sketch map shows the locations of the rostrum, lodge, and utility building (without addition) in the north corner (Figure 48). All traces of buildings other than the 1907 lodge, the utility building, and the rostrum were gone by 1949 .

Figure 48. Detail of sketch map showing location of rostrum, lodge, and utility building, 1947 (NARA, Washington DC, RG92).

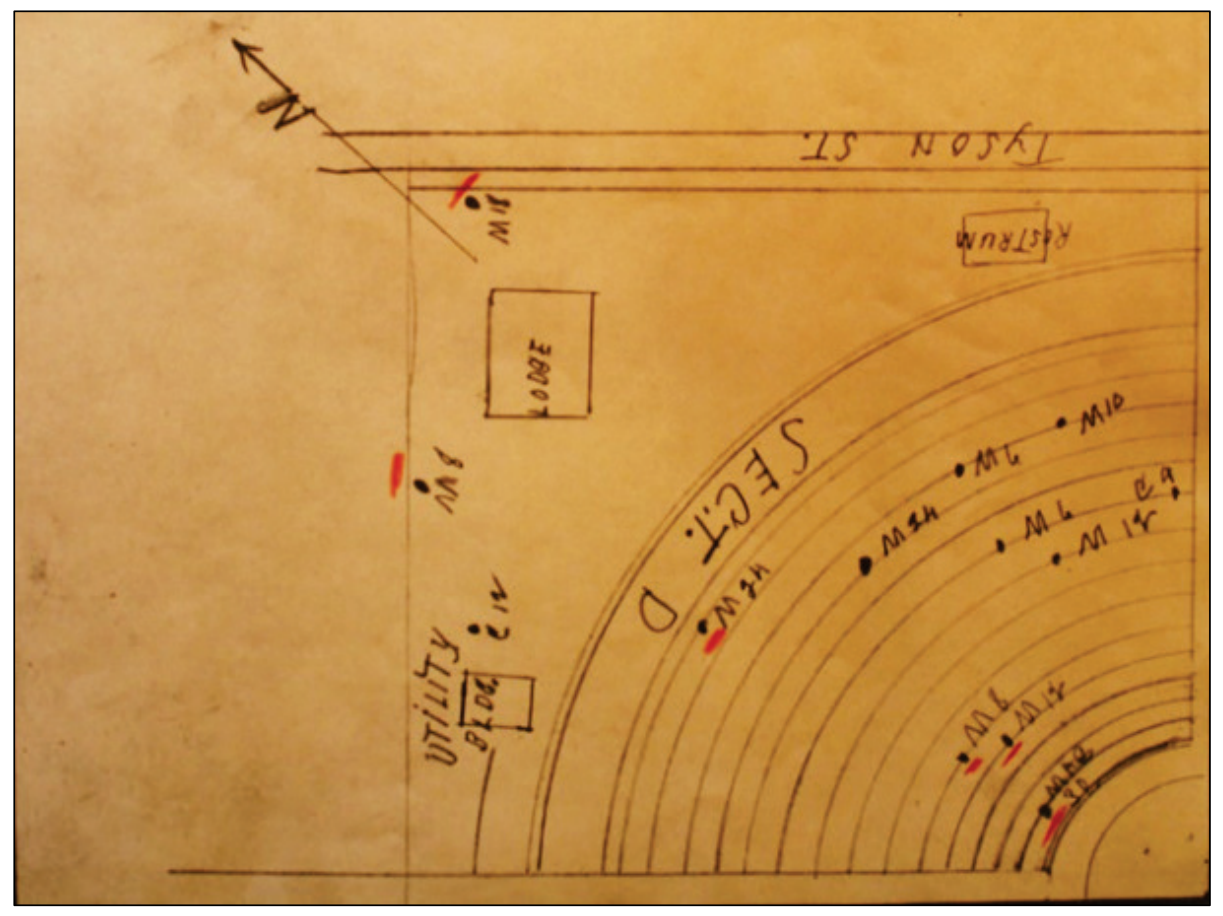

\footnotetext{
162 Donelson, Gill, and Dorman, “Report of Official Travel,” 10 October 1946.

163 University of TN Knoxville, Special Collections Library, Harold S. Fink Papers, 1959-1970, Box 2, Folder: Folder IX, MS-779, Knoxville National Cemetery, Old Gray Cemetery, 1966.
} 
A series of upgrades and repairs were made to the lodge. The chimney, fireplace and partition between the parlor and dining room was removed, and repairs were made to the roof, ceilings, walls and floors in 1939. A steam heating plant was installed in 1942, and the front porch received a new roof in 1946. The main roof, gutters, and rear porch were repaired in 1946 and the bathroom was renovated a year later. A gas furnace replaced the old one in 1950, and a gas hot water heater was added. The cornice and front porch steps were replaced in 1951, and flood lights were installed on the rear porch in 1956. There were shrubs planted along the foundations by 1941 , and new concrete walks were constructed around the lodge in 1944 (Figure 49). ${ }^{164}$

Figure 49. 1907 lodge in 1941 (NARA, Washington DC, RG15).

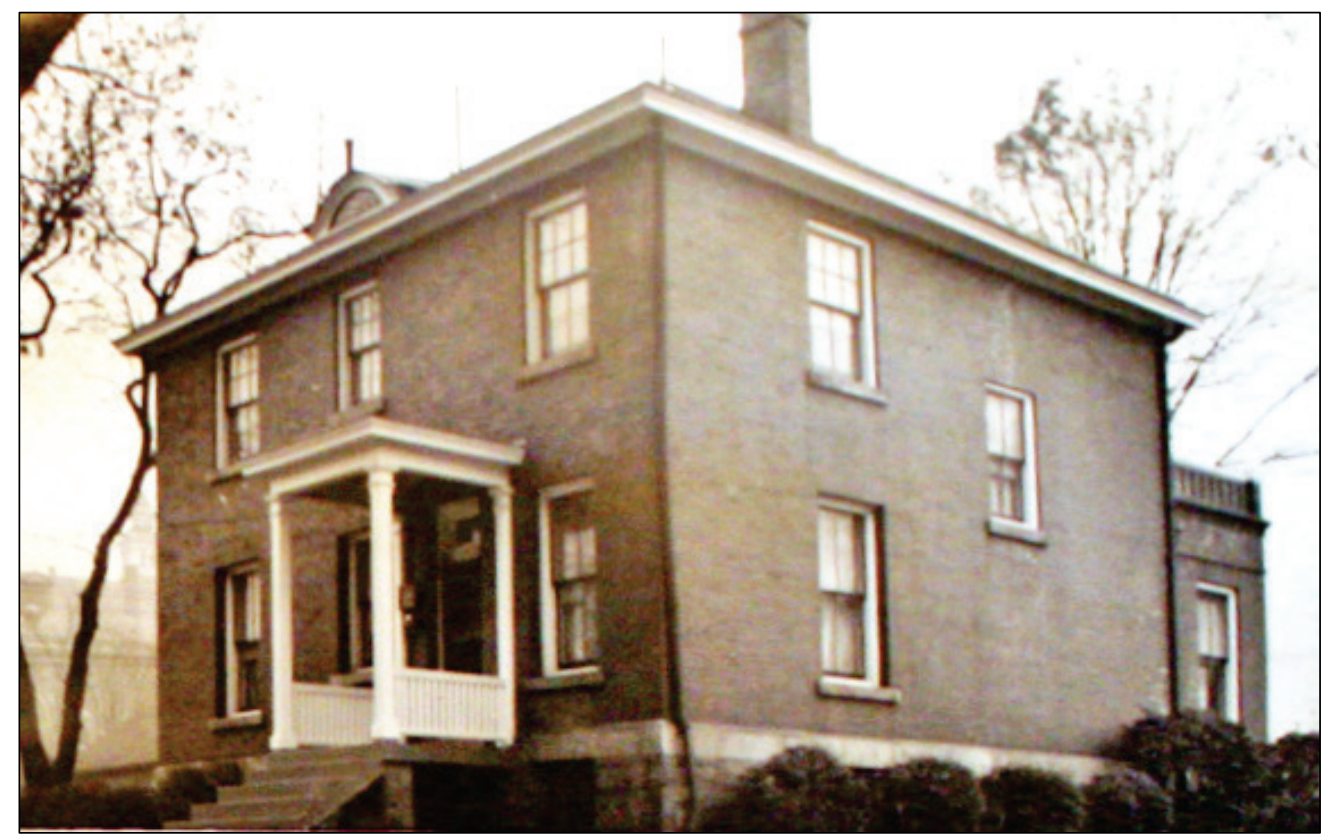

A small utility building with restrooms, measuring $17^{\prime}, 6^{\prime \prime} \mathrm{x} 12^{\prime}$ was constructed in 1935 at an estimated cost of $\$ 550$ (Figure 50). 165 The building was placed on the site of the 1898 stable. It is not known why this site was vacant, as no documentation was found describing the removal of the stable.

\footnotetext{
164 “Superintendent's Lodge (Cont'd)," Real Property Form, U.S. National Cemetery, Knoxville, Tenn., 1957, RG 15 Records of the Veterans Administration, Entry A1-25 Department of Memorial Affairs, National Cemetery Historical File, Box 24, National Archives and Records Administration, Washington, DC. 165 “Utility Building No. 2," Real Property Form, U.S. National Cemetery, Knoxville, Tenn., undated, RG 15 Records of the Veterans Administration, Entry A1-25 Department of Memorial Affairs, National Cemetery Historical File, Box 24, National Archives and Records Administration, Washington, DC
} 
Figure 50. Utility Building No. 2, c.1940s (NARA Washington, DC, RG15).

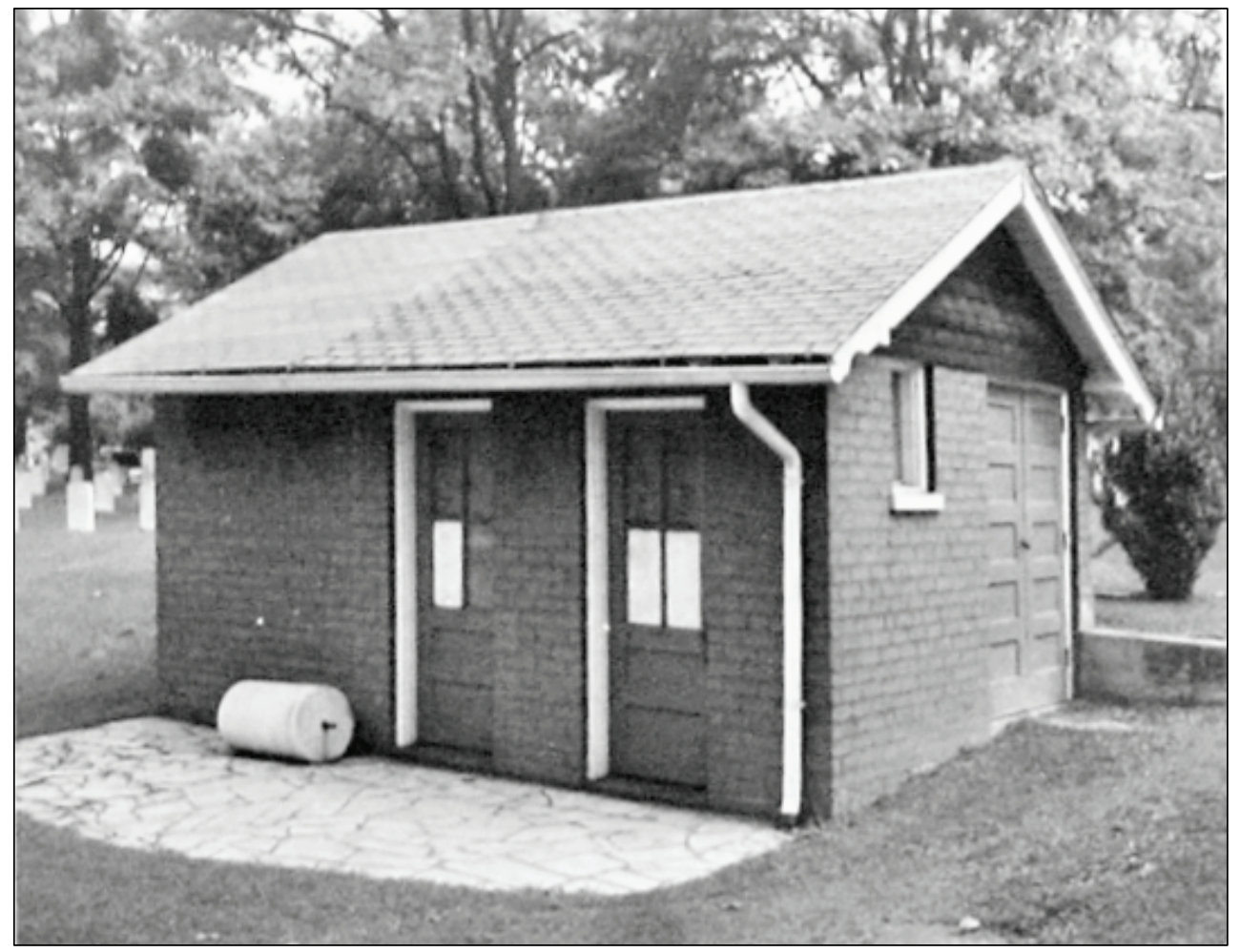

With the information available, it is possible that something catastrophic happened to the stable in the early 1930 - a tree fall, or windstorm perhaps - that damaged the building beyond repair. Apparently the 1935 building reused parts of the stable materials, as historic photos indicate the rakeboard is the same on both buildings, and the brickwork on one corner of the comfort station matches the brickwork on the same corner of the stable. Additionally, the privy for the 1874 lodge was behind and a little to the side of the stable, and the same relationship occurs with the restroom building and the privy. A 1935 aerial photograph shows a building similar in size and shape to the restroom building is in this location.

The brick building had dirt, wood floors, and a roof with asphalt shingles (Figure 50). After the construction of a larger utility building the following year (see below), this building became known as Utility Building No. 2. Just 11 years later, the building (referred to as the tool storage and auxiliary comfort station building) was criticized for taking up potential burial space and not being up to National Cemetery design standards. The building was removed by 1948.166 
A new utility building was constructed a year after the smaller and rougher brick building. The construction of two service buildings within a year of each other may be explained by the erection of the first building in 1935 as materials were at hand. There may have been appropriation requests for a service building/public toilet that had not come through, so the first building met a need at hand. It could be that funding for the larger and more permanent utility building arrived soon after. Available records did not provide reasons for the two service buildings constructed at nearly the same time.

The 1936 utility building was constructed directly to the southwest of the 1907 lodge, continuing the concentration of new buildings in the north corner of the cemetery. Built of brick, on a concrete foundation and with an asbestos shingle roof, the building had no basement. Inside, there were two toilet rooms and two storage bays. The utility building measured $2 \mathrm{O}^{\prime} \mathrm{x}$ $31^{\prime}$, contained $610 \mathrm{sq} \mathrm{ft}$, and was constructed at a cost of approximately $\$ 1,466$ (Figure 51). ${ }^{167}$

Figure 51. Utility building, 1949 (NARA, Washington DC, RG15).

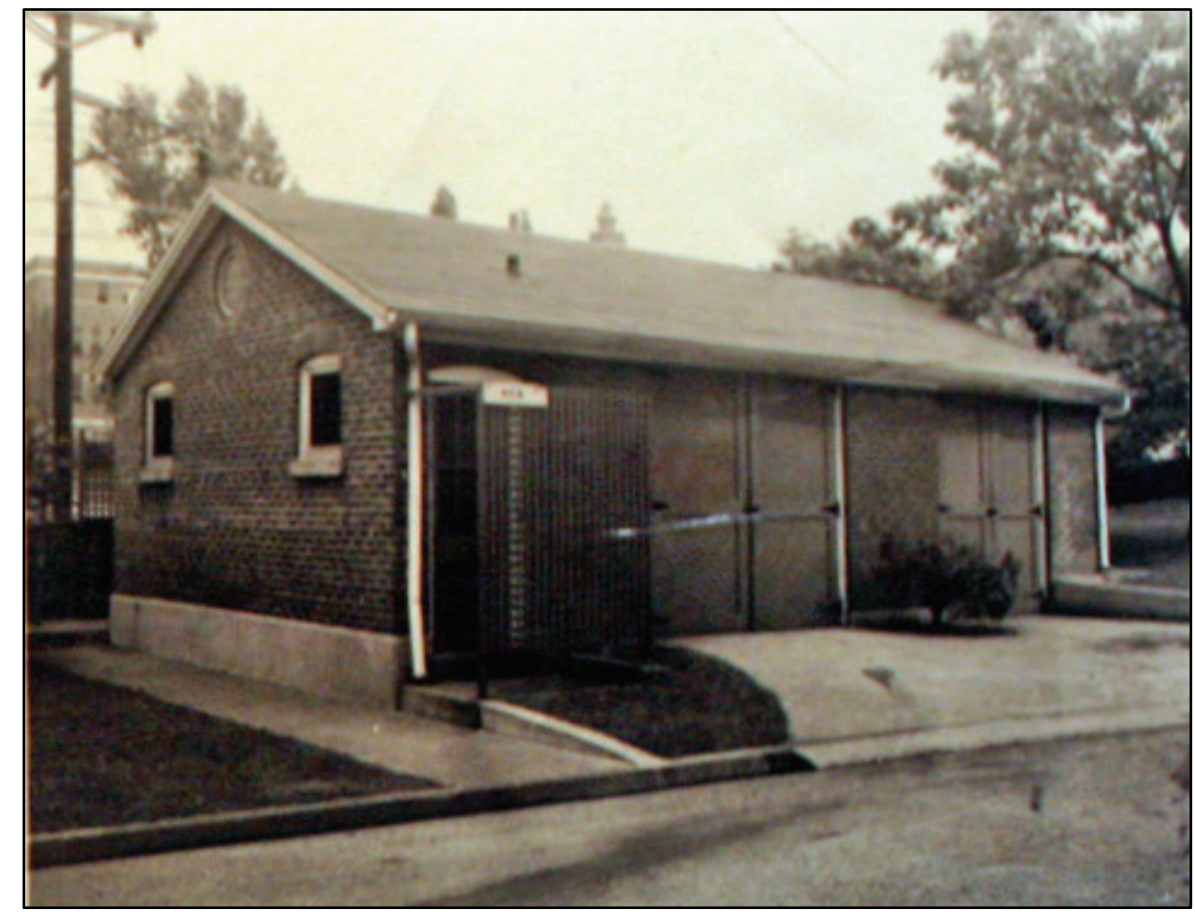

167 “Utility Building," Real Property Form, U.S. National Cemetery, Knoxville, Tenn., 1963, RG 15 Records of the Veterans Administration, Entry A1-25 Department of Memorial Affairs, National Cemetery Historical File, Box 24, National Archives and Records Administration, Washington, DC; Sammartino, "Knoxville National Cemetery," 1996. 
A 1946 inspection report indicated that the utility building did not have a garage space that was necessary for a newly acquired truck and that an area for separate paint and oil storage was needed. A recommendation was made to construct a garage addition to the utility building with an equipment room and space for oil and paint storage. ${ }^{168}$

The addition was constructed on the northeast side of the utility building and completed in September 1949 at a total cost of $\$ 12,865.88$ (including concrete apron and retaining wall) (Figure 52). Built on a concrete foundation, the garage had brick walls, a built-up flat roof, and measured $25^{\prime} \mathrm{x}$ $37^{\prime}, 4^{\prime \prime} .{ }^{169}$ Flood lights were installed on the corner of the utility building in 1956 , the same year that shower facilities were installed and the restroom fixtures were repaired. Interior cabinets were built, and heaters were installed in the restrooms and garage in 1961. ${ }^{170}$

Figure 52. Addition to utility building, c.1950 (NARA Washington, DC, RG15).

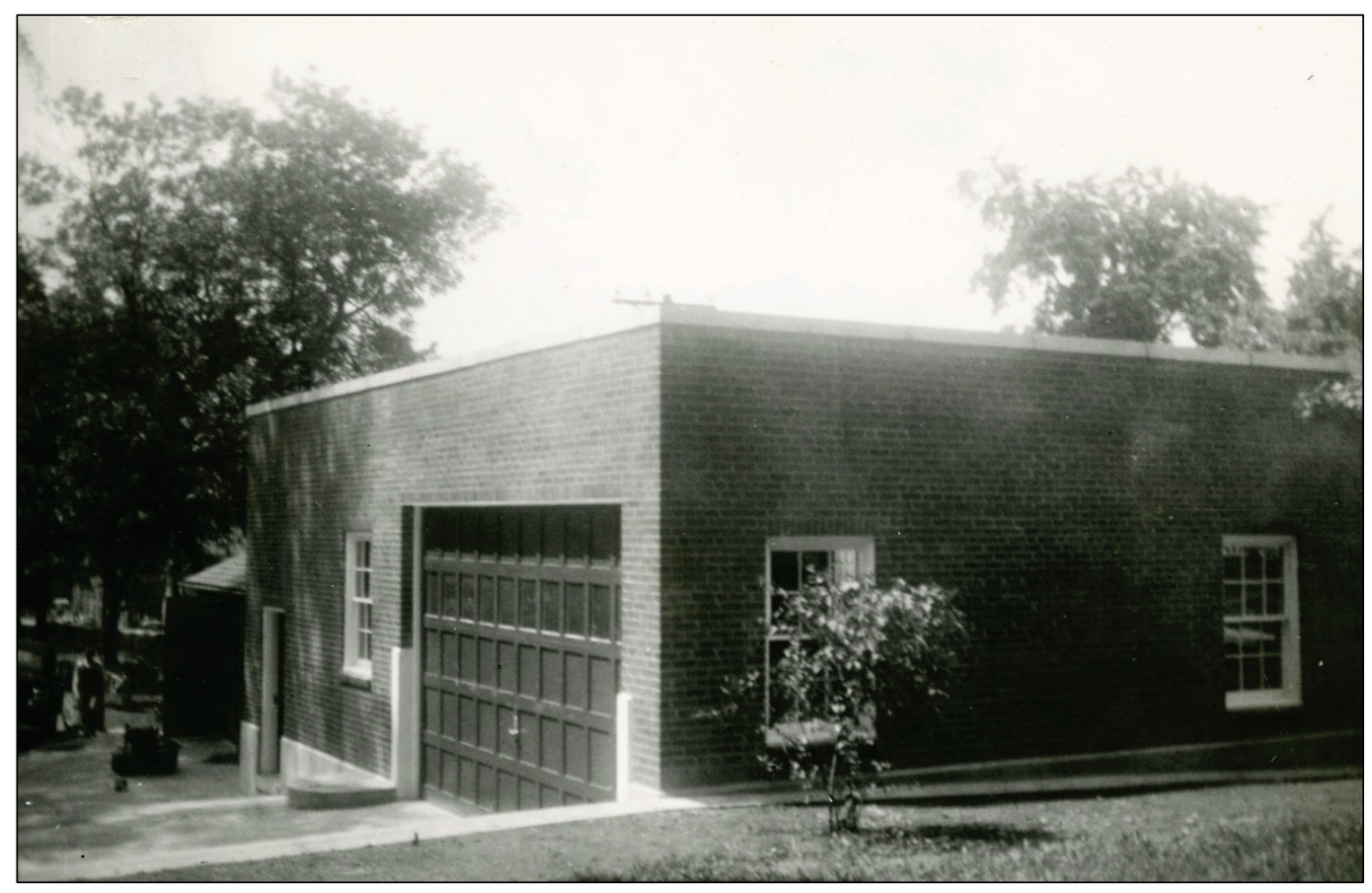

The rectangular rostrum underwent a major change sometime prior to 1932 when the pergola was removed and replaced with a wooden hipped

\footnotetext{
168 Donelson, Gill, and Dorman, “Report of Official Travel,” 10 October 1946.

169 Sammartino, “Knoxville National Cemetery," 1996; “Utility Building," 1963.

170 “Addition to Util. BIdg. on NE side," Real Property Form, U.S. National Cemetery, Knoxville, Tenn., 1961, RG 15 Records of the Veterans Administration, Entry A1-25 Department of Memorial Affairs, National Cemetery Historical File, Box 24, National Archives and Records Administration, Washington, DC; "Utility Building," 1963.
} 
roof with asphalt shingles (Figure 53). ${ }^{171}$ A cemetery inventory from 1947 gives the rostrum's dimensions as $21^{\prime}, 10^{\prime \prime} \times 37^{\prime} .{ }^{172}$ That same inventory lists a gravel podium floor. Dissatisfaction with the rostrum was recorded in a 1946 inspection report that stated it "presents unsightly appearance and it is inappropriately located for public gatherings." 173

Figure 53. Rostrum after replacement of original pergola with hipped asphalt shingle roof, undated (NARA, Washington DC, RG15).

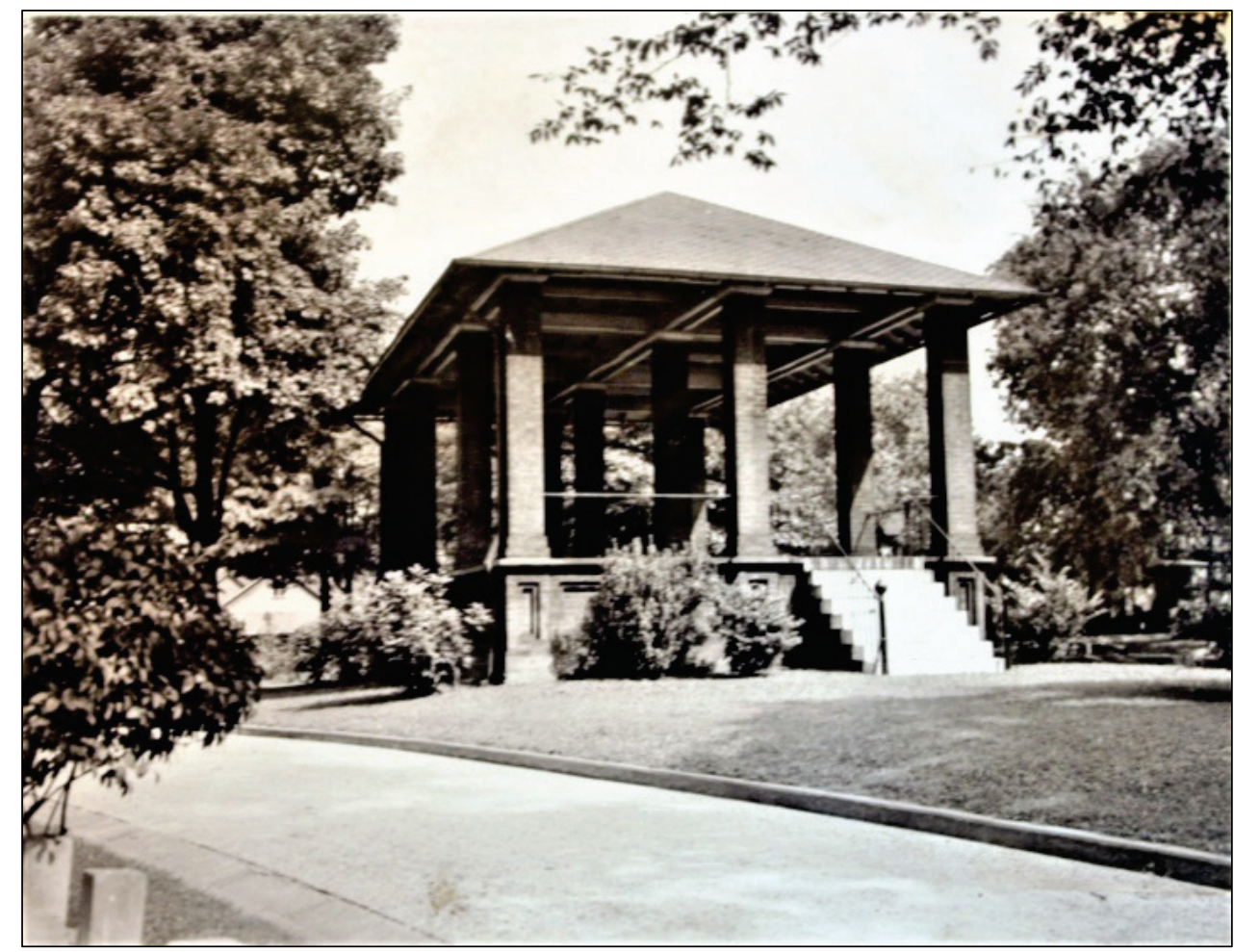

Flagstaff

A new flagstaff was erected on 27 April 1940 at the center of the circular burial area. It was replaced on 14 October 1946, at a cost of $\$ 1,340$. The 1940 flagstaff was in bad condition and out of alignment. The earlier flagstaff was stored in the rear of the utility building when the replacement flagstaff was erected. A 1947 inventory describes the flagstaff as a standard

\footnotetext{
171 “Rostrum," Real Property Form, U.S. National Cemetery, Knoxville, Tenn., 1932, RG 15 Records of the Veterans Administration, Entry A1-25 Department of Memorial Affairs, National Cemetery Historical File, Box 24, National Archives and Records Administration, Washington, DC.; Sammartino, "Knoxville National Cemetery," 1996.

172 “National Cemetery," 1 August 1947.

173 Donelson, Gill, and Dorman, “Report of Official Travel,” 10 October 1946.
} 
model $71^{\prime}$ in height (Figure 54). It remained in place until at least 1958, but it is unknown if it is the current flagstaff. ${ }^{174}$

Figure 54. New flagstaff at Knoxville National Cemetery, 1946 (NARA, Washington DC, RG15).

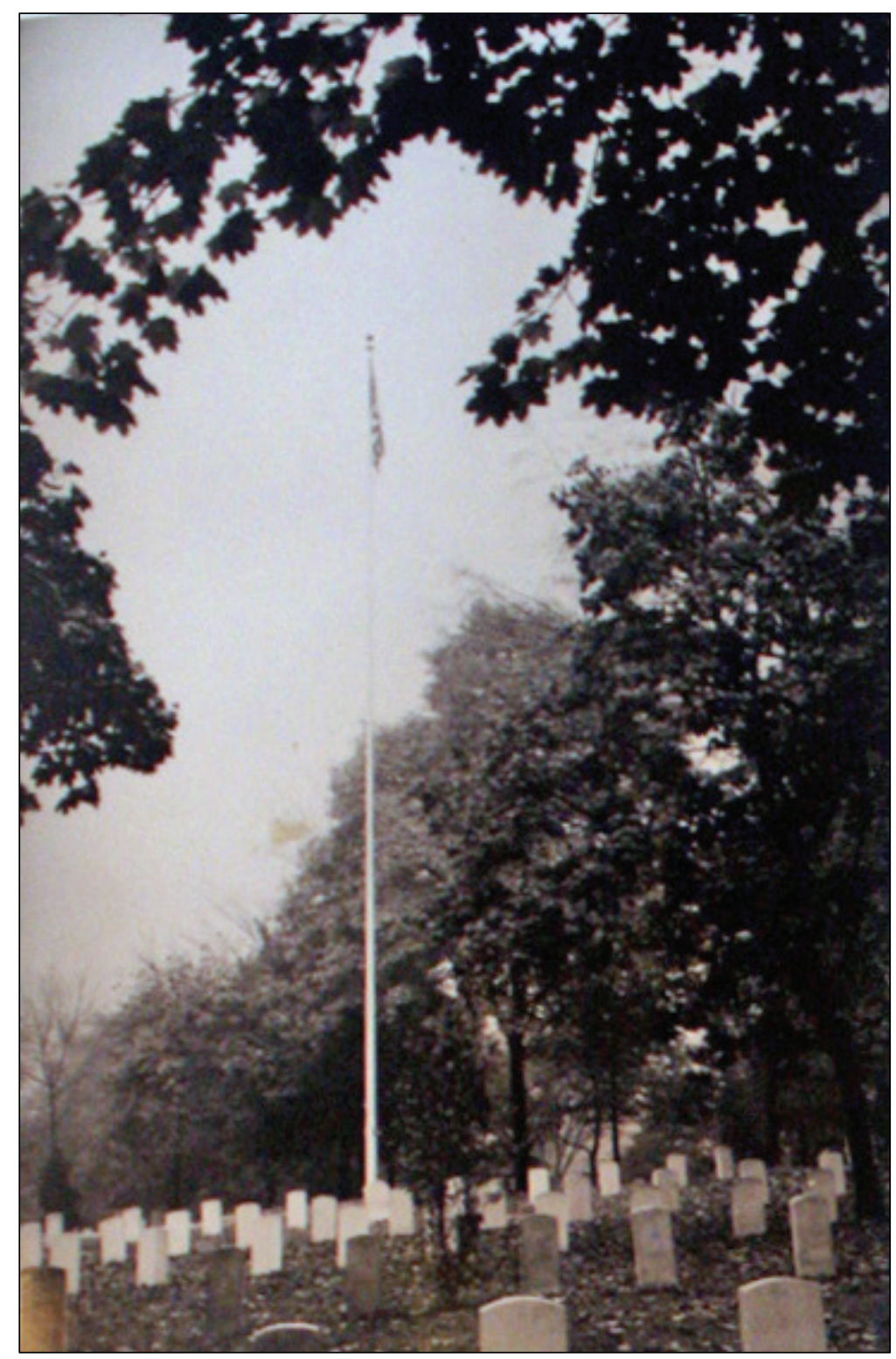

\subsubsection{Walls, roads, and gates}

The 1947 inventory listed 2,050' of stone wall measuring 5' in height, and $625^{\prime}$ of $2^{\prime}$ high stone wall topped with a $3^{\prime}$ high wrought-iron fence. ${ }^{175}$ The inventory for gates listed a wrought-iron main entrance gate with two

174 “Flagstaff," 1957; “National Cemetery," 1 August 1947.

175 “National Cemetery,” 1 August 1947. 
metal posts. The gate measured $12^{\prime}$ wide by $10^{\prime}$ high, with the pedestrian gates at $4^{\prime}$ wide by $6^{\prime}$ high (Figure 55 ). The service gate, also of wrought iron and with masonry piers, was $12^{\prime}$ wide by $6^{\prime}$ high and had a pedestrian gate measuring $3^{\prime}, 6^{\prime \prime}$ wide by $4^{\prime}, 6^{\prime \prime}$ high. ${ }^{176}$ Minor repairs were done to the entrance gates in 1948.177

Figure 55. Main Entrance Gates in 1951, with metal tablets flanking the road to the flagstaff (VA NCA Archives, Washington, DC).

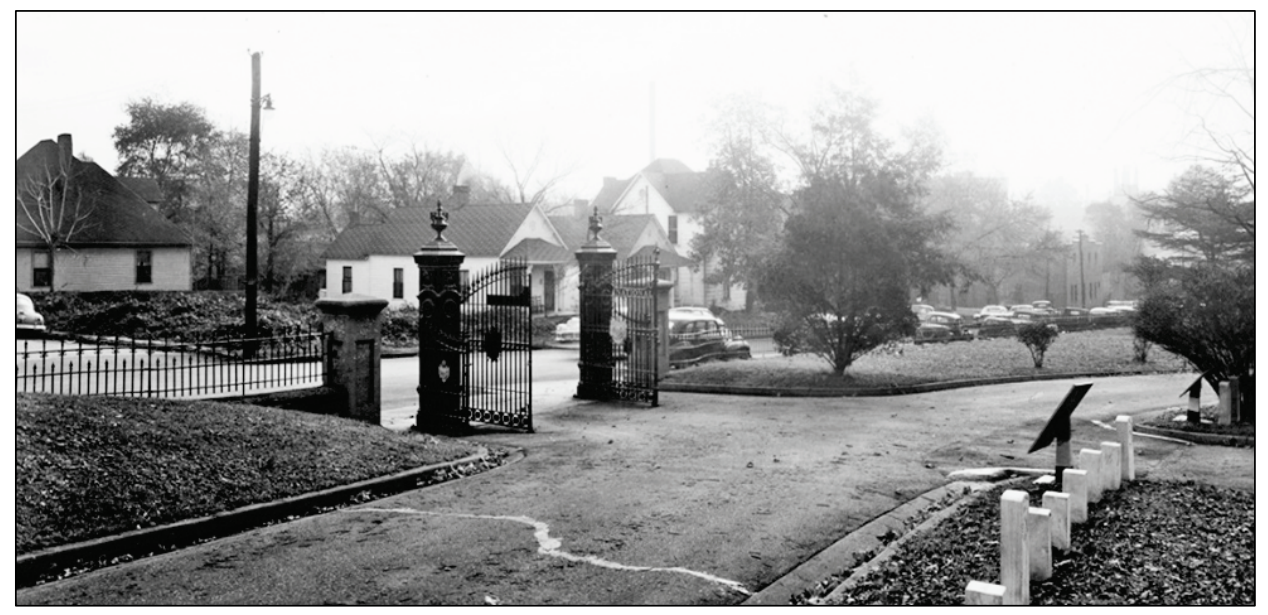

The roads within the cemetery were showing quite a bit of wear by 1951 (Figure 56). Repairs would not be immediately forthcoming.

Figure 56. Circle drive with potholes and worn pavement, 1953 (VA NCA Archives, Washington, DC).

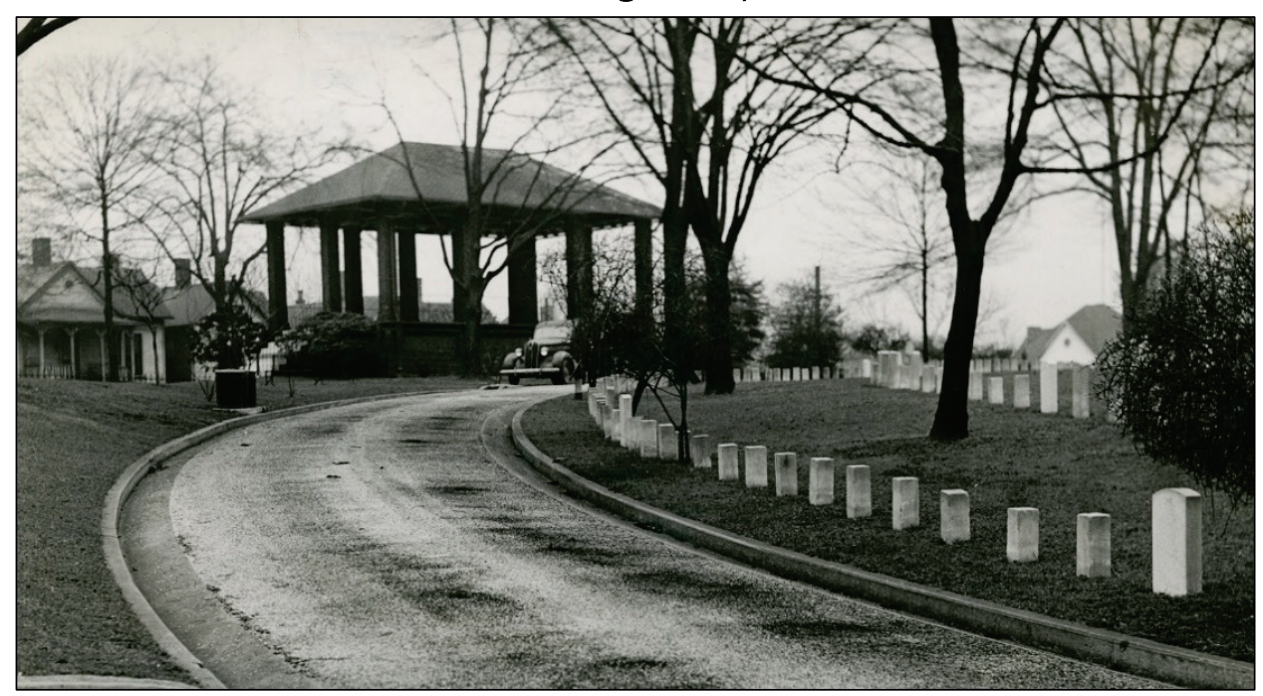

176 Ibid.

177 “Entrance Gates,” 1962. 


\subsection{Mid-century to present day, 1957-2020}

This period of the cemetery's history encompassed several major changes including the demolition of the lodge, the removal of one of the axial roads, the renovation of the utility building, the removal of the Cooper Street gate, and the complete replacement of the Tyson Street entrance gate.

A series of questionnaires and data sheets completed by the cemetery Superintendent in 1958-59 provide a snapshot of the physical condition of the cemetery (covered below), as well as information on its operations. The 9.83acre cemetery contained 5,377 internments in 5,267 gravesites, with 299 gravesites reserved and only 1,081 gravesites available for use, as the cemetery was fully developed by that time. ${ }^{178}$ Memorial Day 1958 saw the arrival of 1,800 visitors, by far the busiest day of the year as the annual visitor total was listed at 5,700. In addition to the public holiday, special services were held twice a year; the American Legion Post No 2, Knoxville held memorial services after the public activities on Memorial Day, and the John Lilly Unit of the Marine Corps Auxiliary had memorial services the day before Memorial Day. Various Scout troops made annual special pilgrimages. ${ }^{179}$

The administration of the cemetery changed on 1 September 1973, when 82 of the 84 National Cemeteries under the jurisdiction of the Secretary of the Army were transferred to the Veterans Administration, including Knoxville National Cemetery. ${ }^{180}$ When the Veterans Administration took over Knoxville National Cemetery, a transfer of real property form was produced, listing the cemetery assets at that time (Table 1).

Table 1. Knoxville National Cemetery facilities transferred to the Veterans Administration in July 1973 (VA NCA Archives, Washington, DC).

\begin{tabular}{|l|c|c|l|}
\hline Facility & $\begin{array}{c}\text { Unit of } \\
\text { Measure }\end{array}$ & Total Quantity & Cost (\$) \\
\hline FE Maintenance Shop & SF & 1,533 & 11,100 \\
\hline Flagpole & & 1 & 1,000 \\
\hline Family Housing & SF & 3,344 & 17,200 \\
\hline
\end{tabular}

\footnotetext{
178 “National Cemetery Data," Knoxville National Cemetery, 5 October 1959, RG 15 Records of the Veterans Administration, Entry A1-25 Department of Memorial Affairs, National Cemetery Historical File, Box 24, National Archives and Records Administration, Washington, DC.

179 “Questionnaire for Superintendents, Knoxville National Cemetery," 18 November 1958, RG 15 Records of the Veterans Administration, Entry A1-25 Department of Memorial Affairs, National Cemetery Historical File, Box 24, National Archives and Records Administration, Washington, DC.

180 National Cemetery Association, “History of Government Furnished Headstones and Markers," 2015.
} 


\begin{tabular}{|l|c|c|c|}
\hline Electrical Distribution System & LF & 400 & 300 \\
\hline Sanitary Sewer & LF & 275 & 500 \\
\hline Water Pipe Line Potable & LF & 915 & 300 \\
\hline Roads Paved & SY & 5,107 & 9,700 \\
\hline Vehicle parking Area & SY & 178 & 1,900 \\
\hline Sidewalk & SY & 95 & 400 \\
\hline Storm Sewer & LF & 386 & 1,000 \\
\hline Gutter & LF & 1,507 & 700 \\
\hline Fence or Walls & LF & 2,610 & 14,000 \\
\hline Gates & LF & 33 & 3,200 \\
\hline Land Purchase & AC & 10 & 5,000 \\
\hline \multicolumn{2}{|r|}{ SF = square feet; LF $=$ linear feet, SY = square yards, and AC = acres } \\
\hline
\end{tabular}

\subsubsection{Cemetery design and grounds}

A 1953 cemetery status report mentions a complete lack of section markers and relays a need to acquire them. ${ }^{181}$ The cemetery's tablets were inventoried in 1958. There were a total of 11 plaques in the cemetery, located on both sides of the circle drive. Figure 57 shows the location of the plaques at that time. Of the 11 plaques, numbers $1,3,4,5,6,7$, and 8 each held two lines from the "Bivouac of the Dead" poem. Plaques number 2 and 9 contained the text to the 1867 Act of Congress establishing National Cemeteries, Section 3. Plaque number 11 contained text from General Orders No. 80 providing the rules for visitors. The rules included a ban on picnic parties and refreshment sales, entrance only between sunrise and sunset, and driving inside the cemetery at no more than walking speed. ${ }^{182}$ Somewhat at variance with the others was Plaque number 10 that invited visitors to "enter the office of the Superintendent's Lodge where a register is kept and where information concerning this cemetery will be cheerfully given."183 A $12^{\text {th }}$ plaque was made of bronze and contained Lincoln's Gettysburg Address. This plaque was located on the front porch of the Superintendent's Lodge, near the door to the office. ${ }^{184}$

\footnotetext{
181 Owen H. Keel, “Questionnaire-National Cemeteries,” 28 May 1953, RG 15 Records of the Veterans Administration, Entry A1-25 Department of Memorial Affairs, National Cemetery Historical File, Box 24, National Archives and Records Administration, Washington, DC.

182 “Questionnaire for Superintendents, Knoxville National Cemetery," 18 November 1958.

183 Ibid.

184 Ibid.
} 
Figure 57. Sketch map by Superintendent John A. Boender showing location of plaques, 1958 (NARA, Washington DC, RG92).

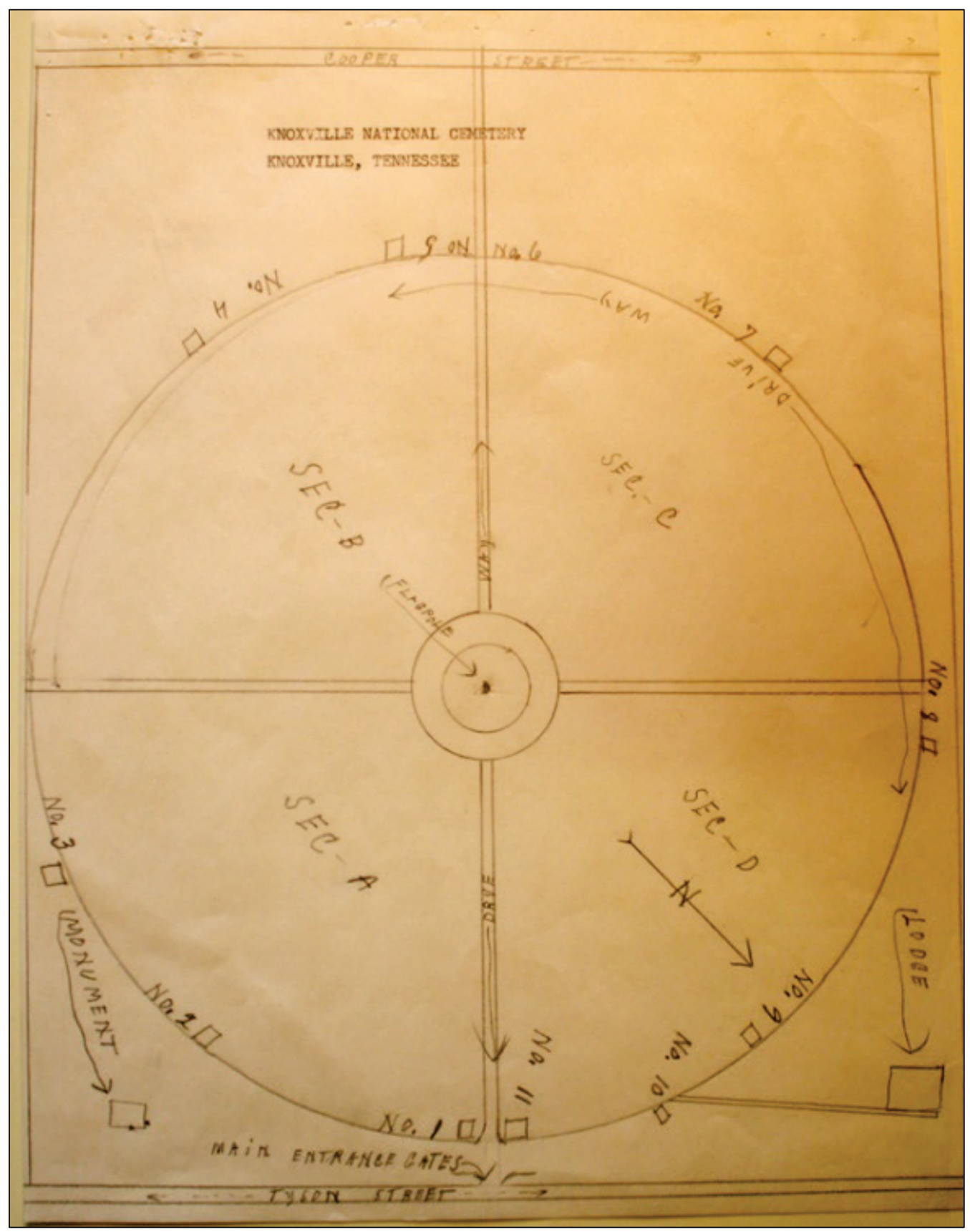

A 1963 layout plan of the cemetery shows the use of nearly all available land for burials (Figure 58). Except for along some of the margins, the concentric layout of the burial area was continued on the exterior of the circle drive. The area previously occupied by the rostrum has been entirely filled in only 3 years after the structure was removed, with a designated "memorial section" within these new burials. A concrete walk led from the pedestrian gate on Tyson Street to the lodge entry and wrapped around to 
the rear. There was a concrete walk leading from the lodge to the parking area east of the lodge. The interior roads were surfaced with asphalt. A drinking fountain was located just off the central flagstaff circle.

Figure 58. 1963 Layout Plan of Knoxville National Cemetery showing lack of open space and new burial areas (VA NCA Archives, Washington, DC).

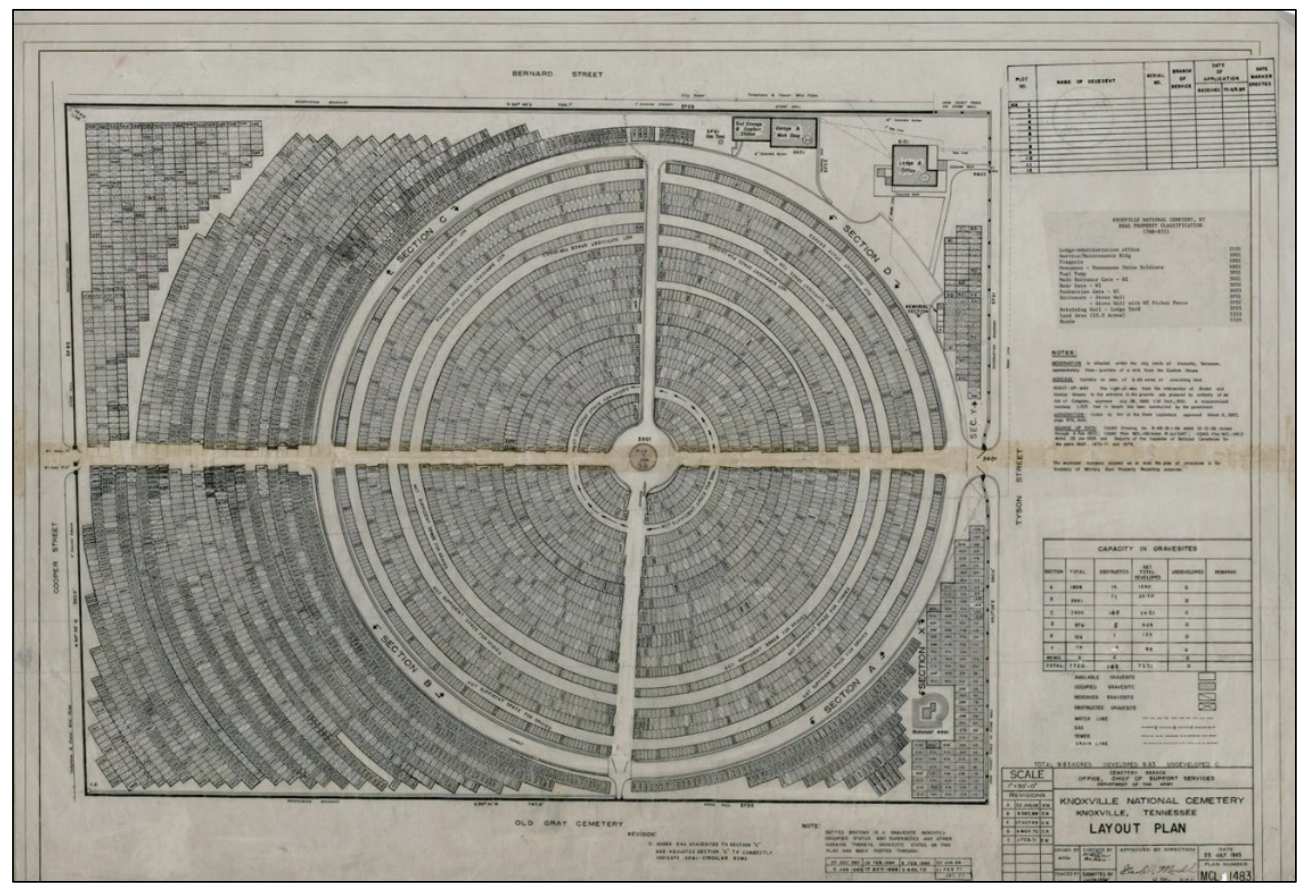

Grounds maintenance was a continuous effort. Between 1957 and 1970, in addition to interments, the most common actions were setting, raising and/or realigning, and replacing headstones, refilling and reseeding or resodding graves. More infrequently, headstones were cleaned, and dead or dying trees were removed. ${ }^{185}$

A planting plan for the cemetery from 1966 highlights the area around the lodge and the south and west areas of the cemetery, along Cooper Street. There were two Redflowering Dogwood trees in the lawn area between the lodge and the parking lot and two Magnolia trees flanking the walk to the pedestrian gate (Figure 59). A bed of Creeping Juniper was placed in the corner of the walk across from the front steps. There were foundation plantings around the east corner of the lodge including Chinese Holly, American Holly, Compact Juniper, and Common Laurelcherry. On the other side of the front steps and continuing along the side of the lodge

\footnotetext{
185 “Grounds," Real Property Form, U.S. National Cemetery, Knoxville, Tenn., 1957-1970, RG 15 Records of the Veterans Administration, Entry A1-25 Department of Memorial Affairs, National Cemetery Historical File, Box 24, National Archives and Records Administration, Washington, DC.
} 
were Japanese Holly, American Holly, Holly Osmanthus, and Anglojap Yew. A new basket-weave fence enclosed the back yard, with a gate at the building's west corner leading to the rear steps. ${ }^{186}$

Figure 59. Planting plan for lodge area, 1966 (VA NCA Archives, Washington, DC).

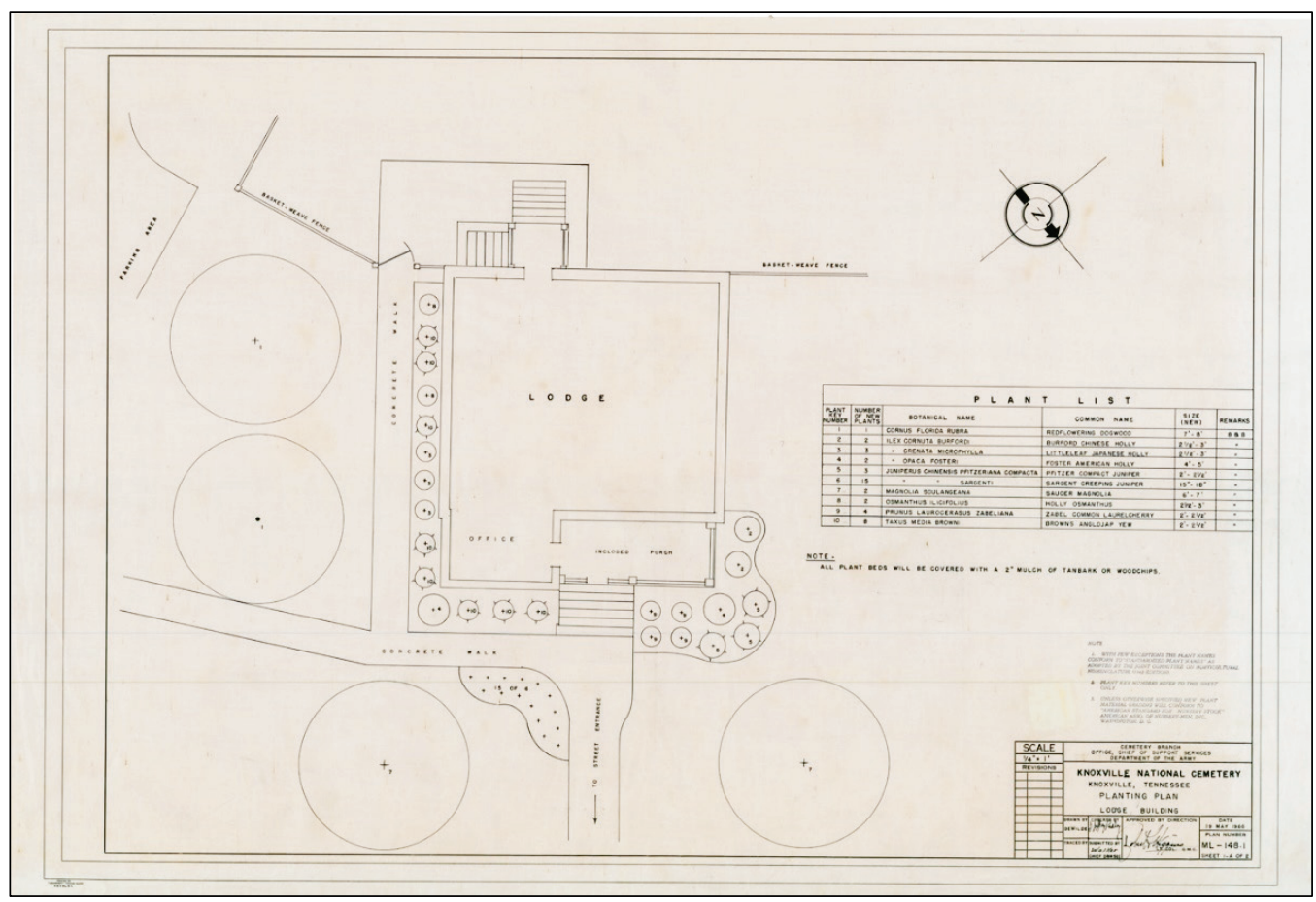

For the area in the south and southwest part of the cemetery, the planting plan primarily involved filling in along the walls to create a line of vegetation (Figure 60). There were only 16 existing trees along the walls, mostly Sugar Maples and American Elms. The infill material was about one-third coniferous evergreens (Cedars and White Pines), and two-thirds deciduous (Eastern Redbud, Purple Crabapple, American Holly, Japanese Flowering Crabapple, Shadelow Serviceberry, Southern Magnolia, European White Birch, and Katsuratree). The existing trees in the burial areas beyond the walls, the primary types were Red Maples, Silver Maples, Sugar Maples, Silktree Albizzia, American Elm and Smoothleaf Elm. These areas were not impacted by the 1966 planting plan. ${ }^{187}$

\footnotetext{
186 Cemetery Branch, Office, Chief of Support Services, Department of the Army, "Knoxville National Cemetery, Knoxville, Tennessee, Planting Plan," 19 May 1966, Plan Number ML-148.1, Sheet 1 of 2, U.S. Department of Veterans Affairs, National Cemetery Administration Archives.

187 Cemetery Branch, Office, Chief of Support Services, Department of the Army, "Knoxville National Cemetery, Knoxville, Tennessee, Planting Plan," 19 May 1966, Plan Number ML-148.1, Sheet 2 of 2, U.S. Department of Veterans Affairs, National Cemetery Administration Archives.
} 
Figure 60. Planting plan for south and southwest part of cemetery, 1966 (VA NCA Archives, Washington, DC).

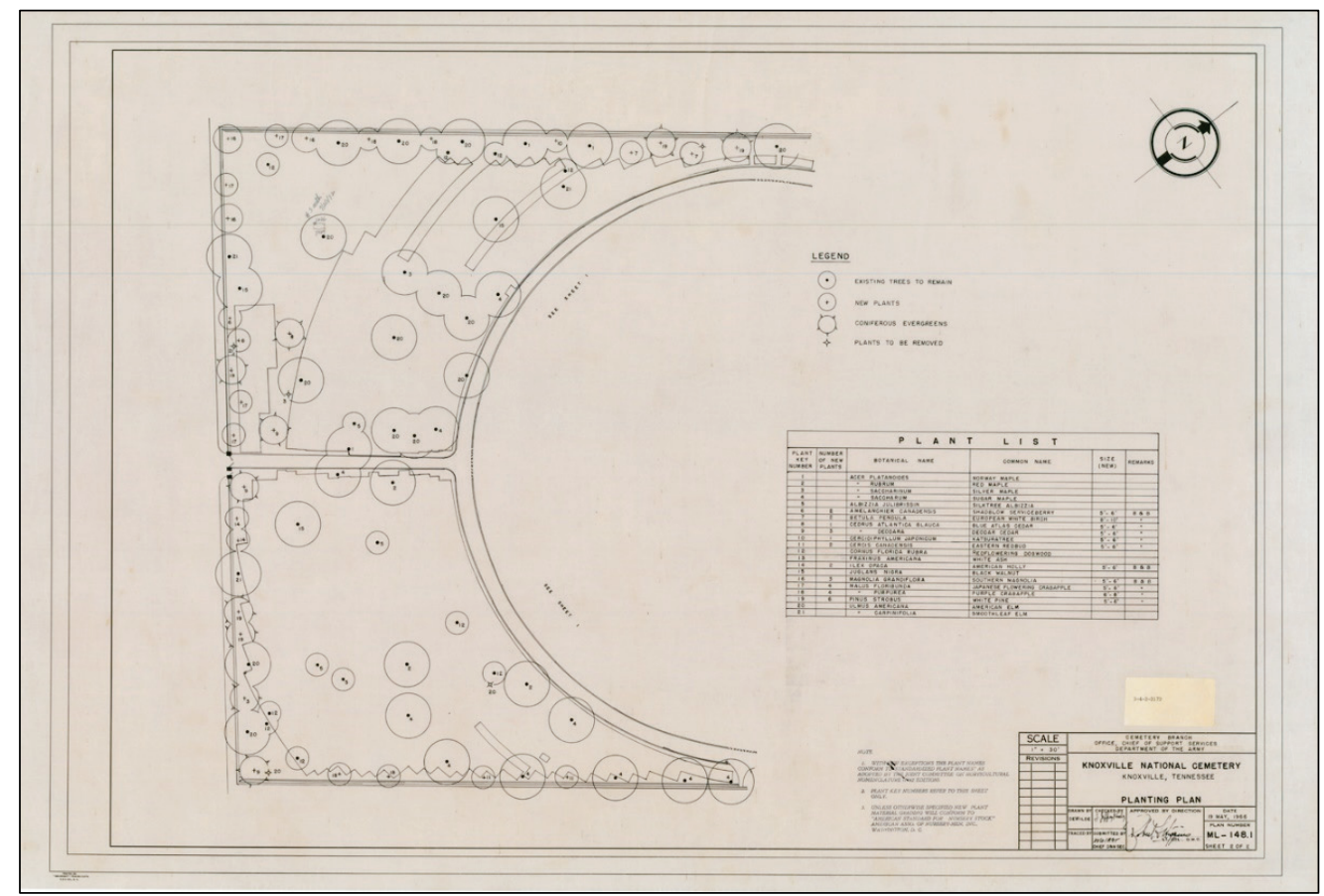

The last available gravesite was used for interment in April 1973. ${ }^{188}$ The cemetery was closed for burials on May 1, 1973. Although the cemetery was closed, the property remained open to the public. A map on a visitor handout from 1978 showed the original symmetry of the burial area remained intact, with the concentric rings, the circle drive, and the two axial roads intersecting at the central flagstaff (Figure 61). The rostrum area was now Burial Section Y, and the Memorial Section had expanded to the north. The only buildings remaining on the site were the utility building/Garage and the lodge. ${ }^{189}$ At about the same time, the cemetery had a total of 7,500 interments utilizing 7,189 gravesites, with 274 gravesites reserved. 190

\footnotetext{
188 “Veteran to Fill Final Grave in Old Cemetery,” 20 April 1973.

189 Veterans Administration, "Knoxville National Cemetery," 1977, Folder: "Knoxville National Cemetery General," National Cemetery Administration Archives, Washington, DC.

190 “National Cemetery Data: Knoxville N/C," 1978, Folder: “Knoxville National Cemetery - General," National Cemetery Administration Archives, Washington, DC.
} 
Figure 61. 1978 map of Knoxville National Cemetery (VA NCA Archives, Washington, DC).

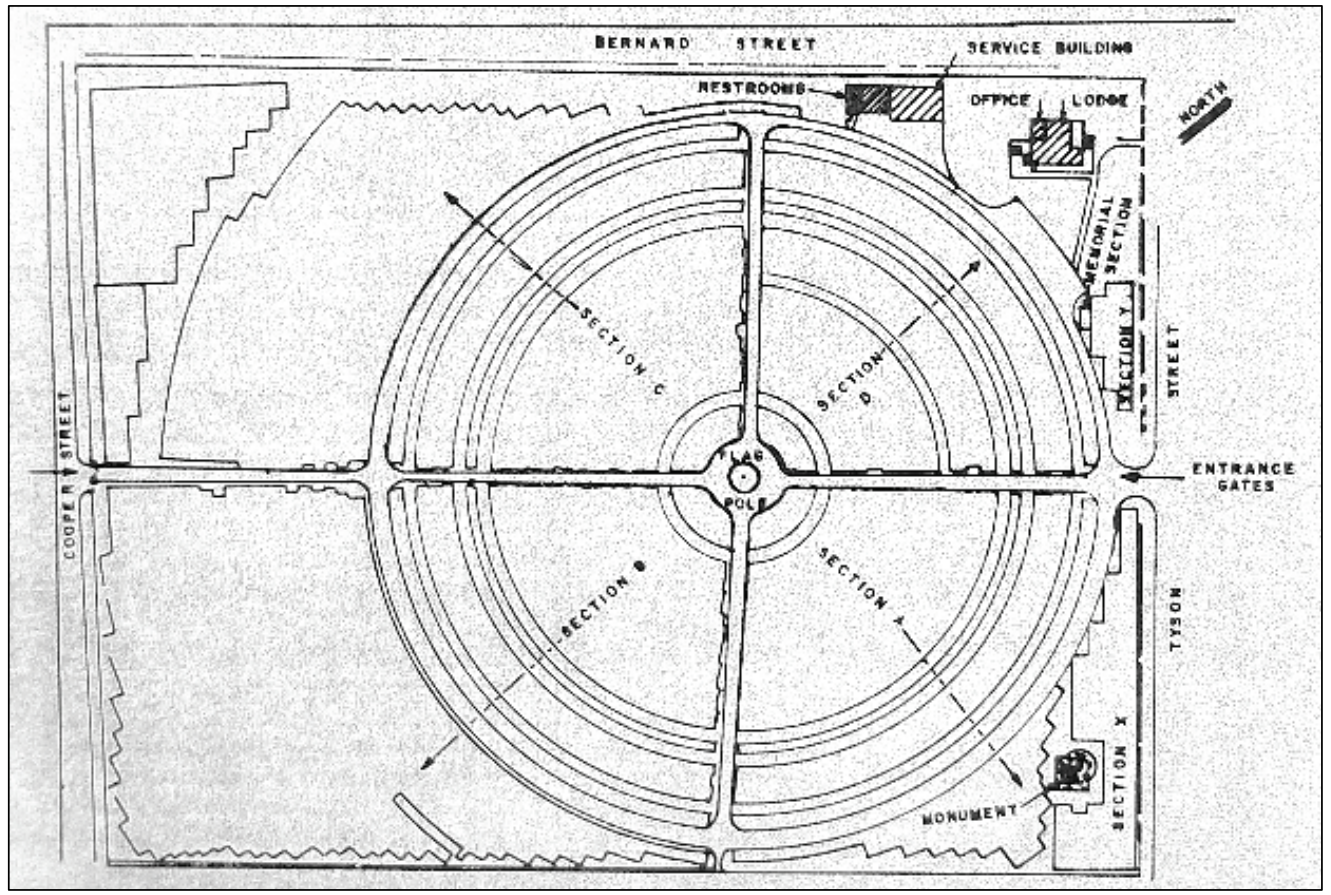

A $\$ 59,950$ project to develop new gravesites was begun in late 1984 and completed on 6 June 1986 by Gaiter Construction. ${ }^{191}$ The new burial sites were infilled in existing burial areas and in newly cleared areas and matched the existing gravesites in terms of sizes and upright headstones. ${ }^{192}$ As part of this project, the axial interior road between the main entrance on Tyson Street and secondary entrance on Cooper Street was removed (Figure 62). The road removal began in early March 1986, and all asphalt paving, concrete curbs, and gutters were taken out. As a result, there was no longer a formal view to the flagstaff in the center of the cemetery from either side. The newly available area was graded, seeded, and utilized for burial spaces. 193

191 "VA Construction Project Management Information Report," 12 June 1986, Folder: "Knoxville National Cemetery Project No. 788-855-002-FY86," National Cemetery Administration Archives, Washington, DC.

192 Rob R. Beller, "Trip Report Response - Knoxville and Mountain Home National Cemeteries," 21 November 1986, Folder: "Knoxville National Cemetery Project No. 788-855-002-FY86," National Cemetery Administration Archives, Washington, DC.

193 Idem, “Develop New Gravesites, Project No. 788-855-001," 17 September 1984, Folder: “Knoxville National Cemetery - General," National Cemetery Administration Archives, Washington, DC. 
Figure 62. Aerial of Knoxville National Cemetery after removal of road and gate, 1995 (City of Knoxville, Tennessee).

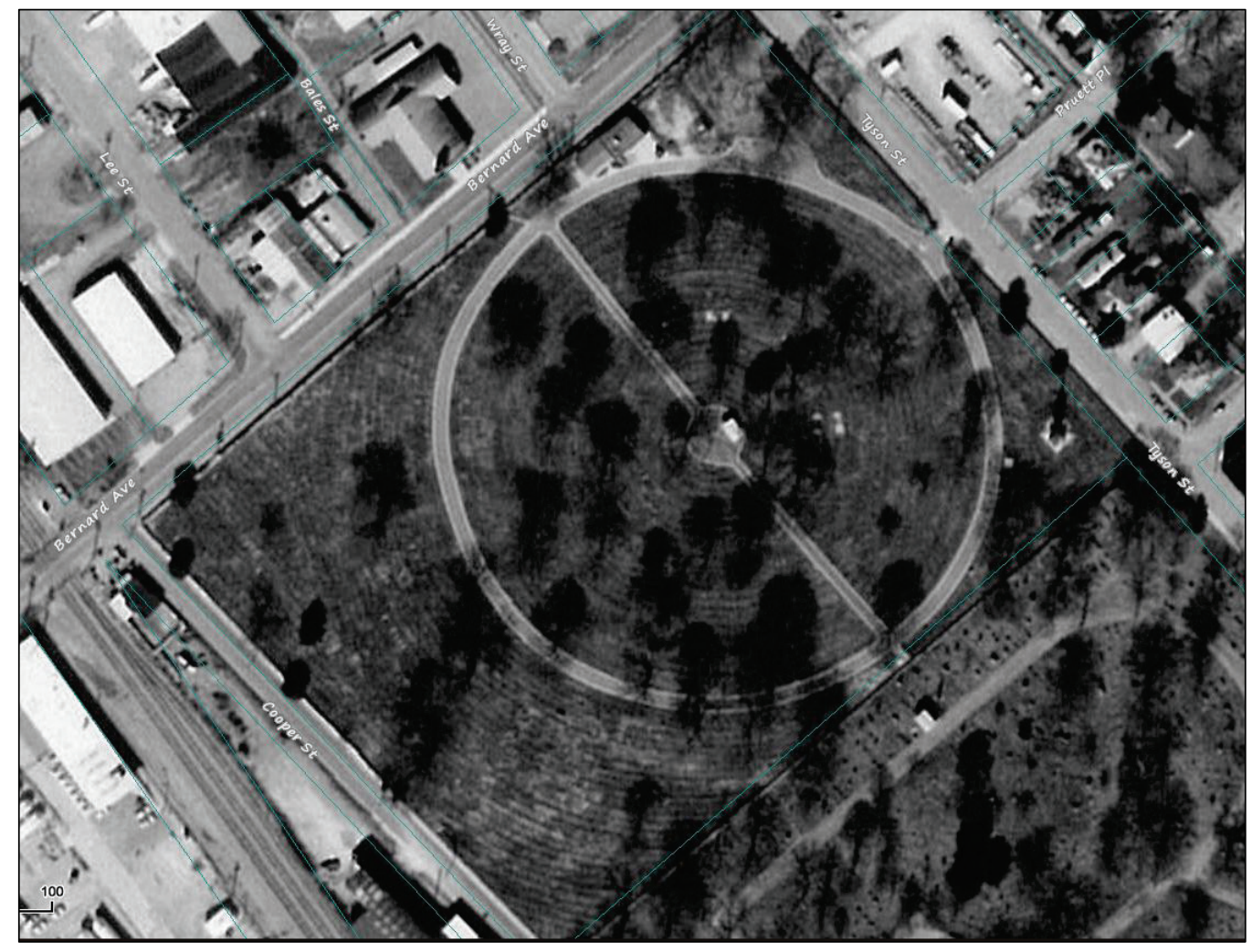

The locating of scattered available gravesites, including pathways, and plans to develop new gravesites resulted in the cemetery being reopened on 29 July $1985 .{ }^{194}$ To honor the occasion, a new plaque was installed to commemorate the rededication of the cemetery (Figure 63). It was placed at the entrance, straight across the circle drive from the gates, therefore becoming the first plaque seen by visitors.

194 Idem, to Director, Office of Planning, Veterans Administration, 3 January 1986, Folder: “Knoxville National Cemetery - General," National Cemetery Administration Archives, Washington, DC. 
Figure 63. 1985 Rededication Plaque located just inside the cemetery, 1989 (VA NCA Archives, Washington, DC).

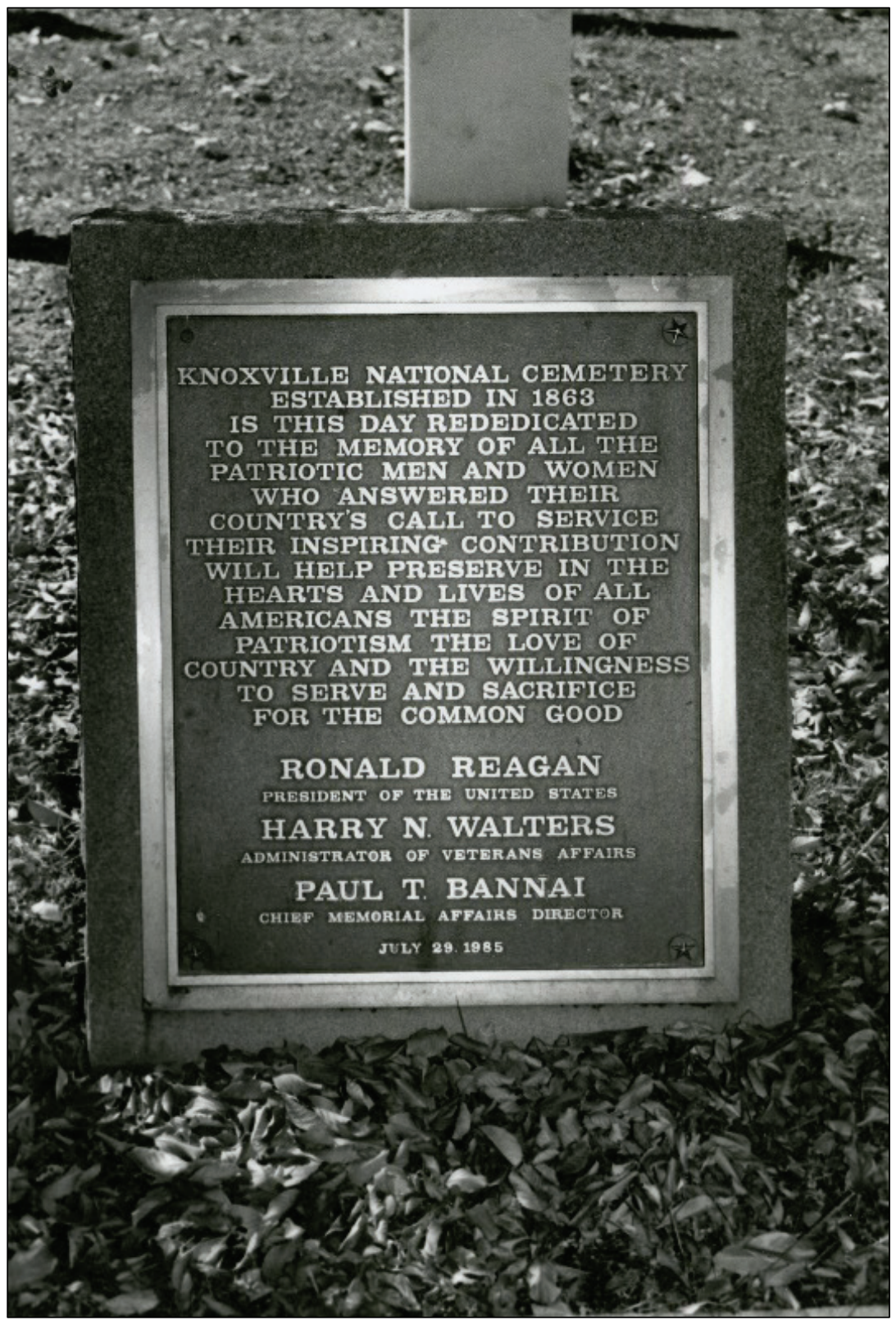

The cemetery then officially closed again in 1990 when the additional burial space had run out (Figure 64). Burials continued for veterans with reserved gravesites and for eligible spouses and children in existing gravesites. "As of May 31, 1996, there were 125 gravesites available (121 reserved) for the interment of casketed remains and 108 sites available for the interment of cremated remains." 195 
Figure 64. View of Knoxville National Cemetery showing use of all available burial space, 1989 (VA NCA Archives, Washington, DC).

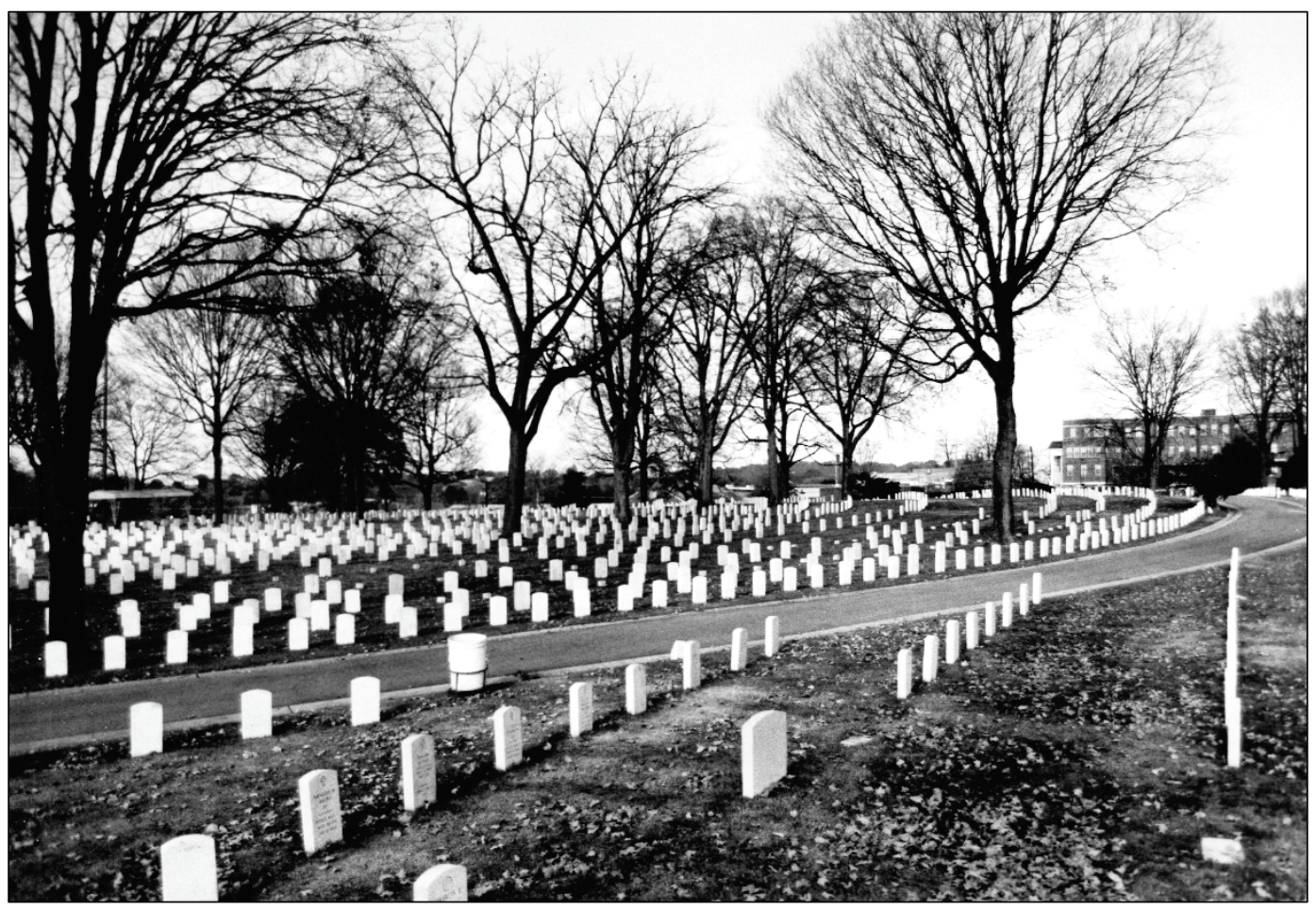

\subsubsection{Markers}

Small-scale changes during this period included inscriptions on the headstones. On 31 October 1983, the VA authorized "Lebanon" or "Grenada" to be labeled as the war service for those killed during those conflicts. In December 1988, the Director of Monument Services, Veterans Administration, authorized designations of "MIA" and "POW" to be inscribed on headstones at the government's expense for those soldiers listed as missing in action (MIA) or prisoner of war (POW). And then a year later in December 1989, the Director of the National Cemetery System, Veterans Administration, authorized "Panama" and "Persian Gulf" as an inscription for personnel killed during those military actions. ${ }^{196}$ In the early 1990 s, headstone modifications included authorization of "Persian Gulf" and "Somalia" to be inscribed on headstones for the soldiers killed during those military conflicts. ${ }^{197}$

In 2009, the VA NCA initiated a project to fabricate and install replica Gettysburg Address tablets to replace the ones that in 1909 had originally commemorated the centennial of President Lincoln's birth at all National

196 National Cemetery Association, “History of Government Furnished Headstones and Markers," 2015. 197 Ibid. 
Cemeteries. Because some of the original tablets had been removed from cemeteries and omitted from the creation of new cemeteries, not all National Cemeteries still featured the tablets. This lack of uniformity justified the re-creation and installation of the replicas. ${ }^{198}$ The Gettysburg Address tablet at Knoxville National Cemetery was placed at the head of the Memorial Section just off the circle drive. Other markers and informational signs were placed in the same area, approaching the utility building/office.

There was a project to repair the Union Soldier Monument, with permission to proceed granted on 11 April 1989. The work included masonry tuckpointing with specifications for Portland cement, masonry cement, hydrated lime, and fine aggregate (sand). Surface repair of cracked or blemished marble with a patching compound, and roof repair/replacement with installation of unbonded elastomeric sheet roofing, stone ballast, flashing and counterflashing, and sealing the roofing membrane. ${ }^{199}$

Road conditions had deteriorated again by the late 1980 os (Figure 65). A project to resurface roads in the cemetery was conducted in 1990. The work involved removal or repair of existing asphalt pavement and laying of asphalt concrete pavement. ${ }^{200}$ This project also included new curbs and gutters, replacement of three yard hydrants, new drainage structures, and a new sidewalk in front of the renovated utility building/office with a new handicap ramp. ${ }^{201}$

\footnotetext{
198 VA National Cemetery Division, “150th Anniversary," 2011; VA National Cemetery Division, "New Gettysburg Address Tablets for National Cemeteries," 2015.

199 Roger R. Rapp, Director, Field Operations, Veterans Administration, letter to Director, VA Medical Center, Mountain Home, TN, 12 April 1989, Folder: “Knoxville National Cemetery Project No. 788-855-002FY86," National Cemetery Administration Archives, Washington, DC.

200 Memorandum, Field Operations, National Cemetery Administration, 19 April 1990, Folder: "Knoxville," National Cemetery Administration Archives, Washington, DC.

201 Vaughn \& Melton, Engineers-Architects, “Preliminary Engineering Report: Resurface Roads, Knoxville National Cemetery, Knoxville, Tennessee," 19 April 1989, in Folder: “Knoxville National Cemetery, FY89 Minor Resurface Roads," VA NCA Archives, Washington, DC.
} 
Figure 65. Road conditions in 1989 before resurfacing was done in 1990 (VA NCA Archives, Washington, DC).

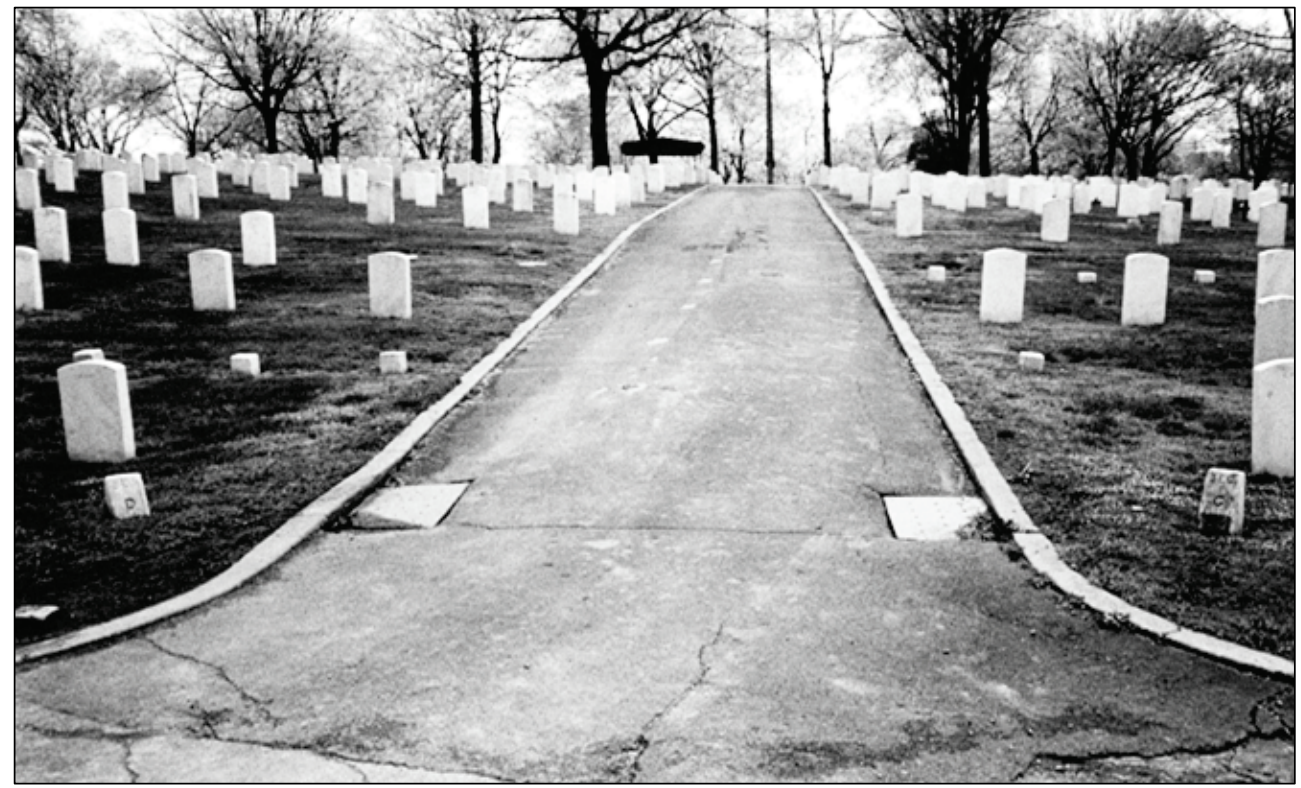

\subsubsection{Buildings and structures}

It was reported in 1959 that the 1907 lodge had seven rooms as living quarters, along with an office. The building utilities included city water and sewer service. ${ }^{202}$ Work on the lodge between 1960 and 1965 included replacement of the front porch floor, roof repairs, installation of storm windows and doors, replacement of flooring on the main floor, and a new furnace. Additionally, the front porch pillars were replaced with aluminum posts and screens, and the back yard was fenced. ${ }^{203}$

The historic character of the lodge had been altered by the "enclosure of the front entry porch with aluminum frames and glass or aluminum panels; partial enclosure of the rear porch with corrugated fiberglass panels and low concrete block walls to replace wood handrails; and low block walls that screen the steps to the basement entrance (Figure 66 - Figure 69)." 204 The lodge ceased to be used as living quarters and administrative office in 1984, with operations supervised from the Mountain Home National Cemetery. Plans were made that year to demolish the structure, and work was begun in 1986 but not completed due to regulatory requirements

\footnotetext{
202 “National Cemetery Data," 5 October 1959.

203 “Superintendent's Lodge (Cont'd)," 1968.

204 “Knoxville National Cemetery Lodge Technical Assessment,"17 February 1988, Folder: “Knoxville National Cemetery Project No. 788-855-002-FY86," National Cemetery Administration Archives, Washington, DC.
} 
remaining to be met. A 1988 assessment found that the heating and air conditioning systems, the plumbing system, and most of the electrical system had been removed, and the interior was in disrepair. It was decided to complete the demolition, as restoring the building to a usable state was prohibitively expensive, and the land was needed for additional burials. ${ }^{205}$ A fire in 1990 caused extensive damage, and the lodge was demolished on 28 September 1993 (Figure 70). The area previously occupied by the lodge was cleared, graded, seeded, and repurposed as burial spaces.

Figure 66. 1907 lodge with original open front porch, 1961 (VA NCA Archives, Washington,

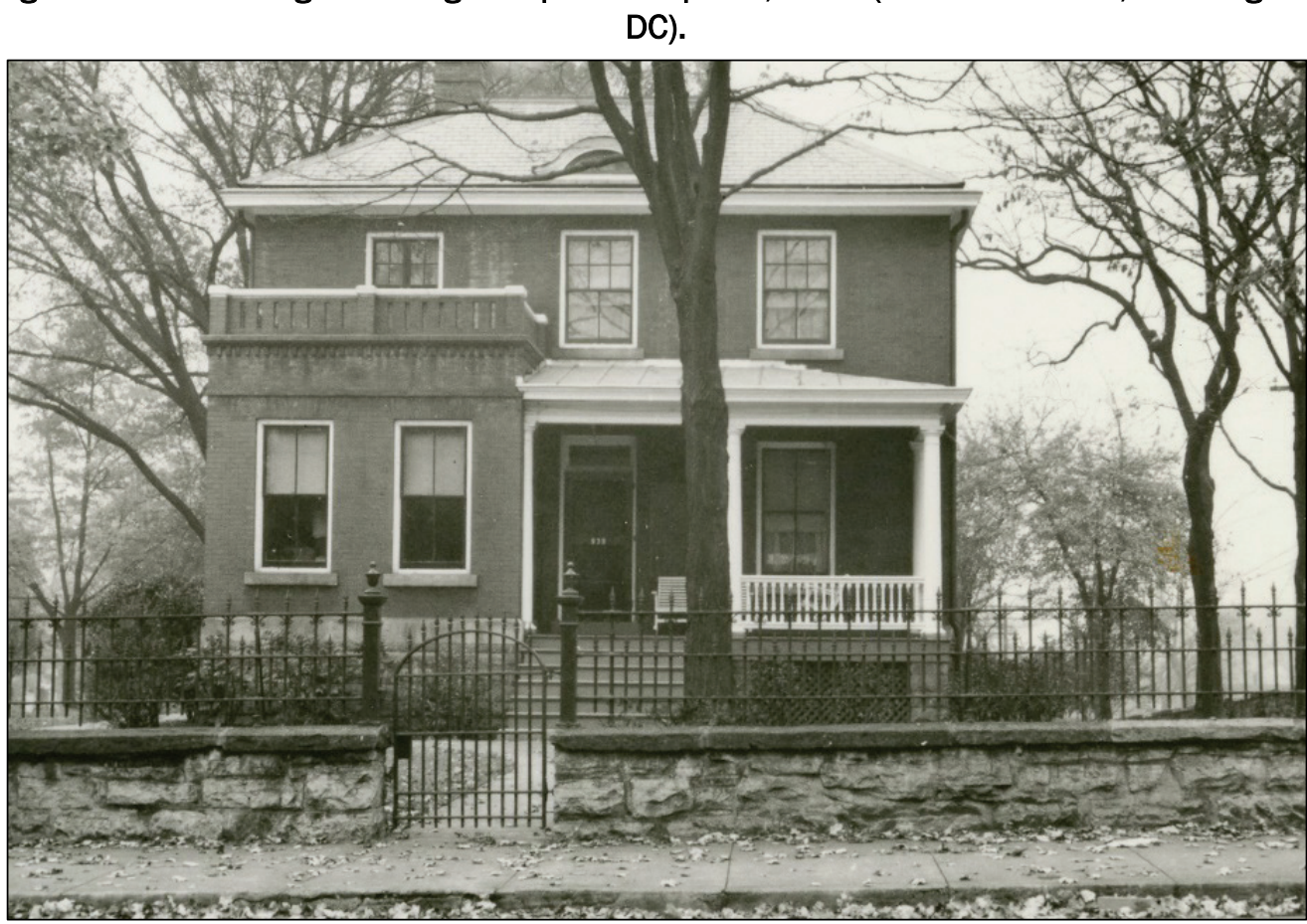

205 “Knoxville National Cemetery Lodge Technical Assessment,"17 February 1988; Sammartino, "Knoxville National Cemetery,” 1996; Wilfred L. Ebel, “Trip Report,” 16 June 1988, Folder: “Knoxville National Cemetery - General," National Cemetery Administration Archives, Washington, DC. 
Figure 67. Undated photo showing renovated front porch with aluminum frames and panels (VA NCA Archives, Washington, DC).

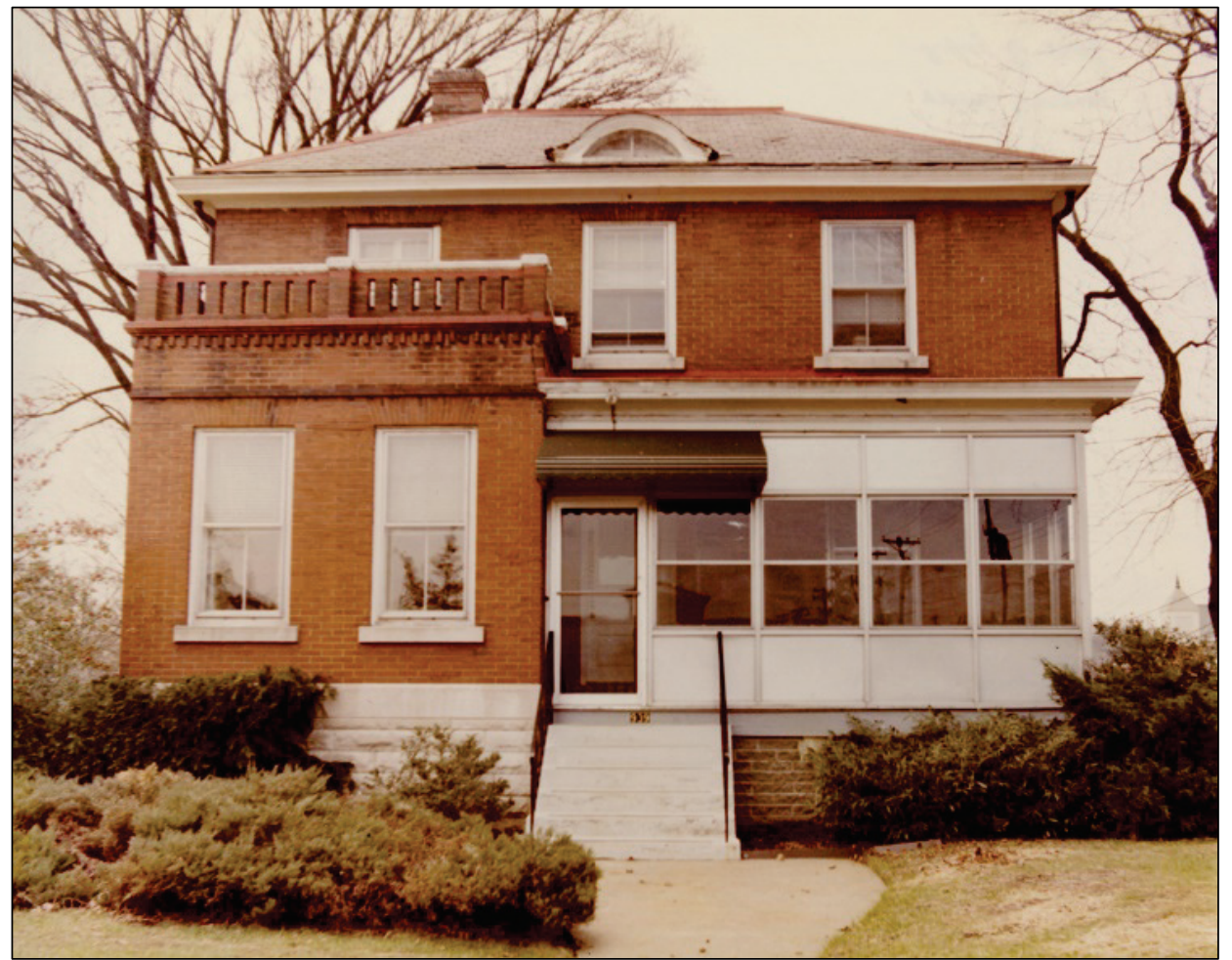

Figure 68. 1907 lodge with original open rear porch, 1961 (VA NCA Archives, Washington, DC).

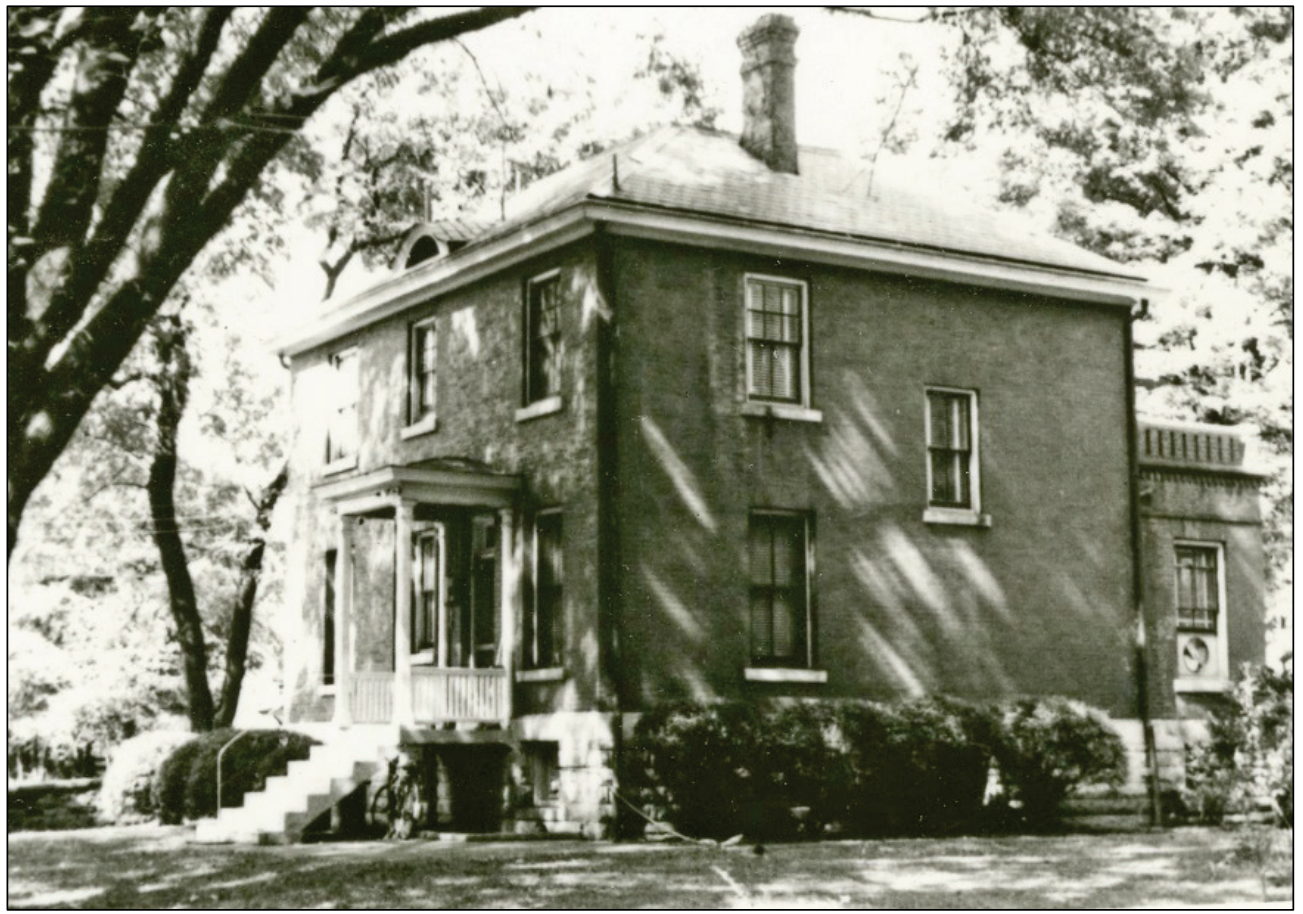


Figure 69. 1989 view of the lodge, with slight visibility to changes to back porch (behind tree to right) showing low concrete block wall and corrugated fiberglass panels (VA NCA Archives, Washington, DC).

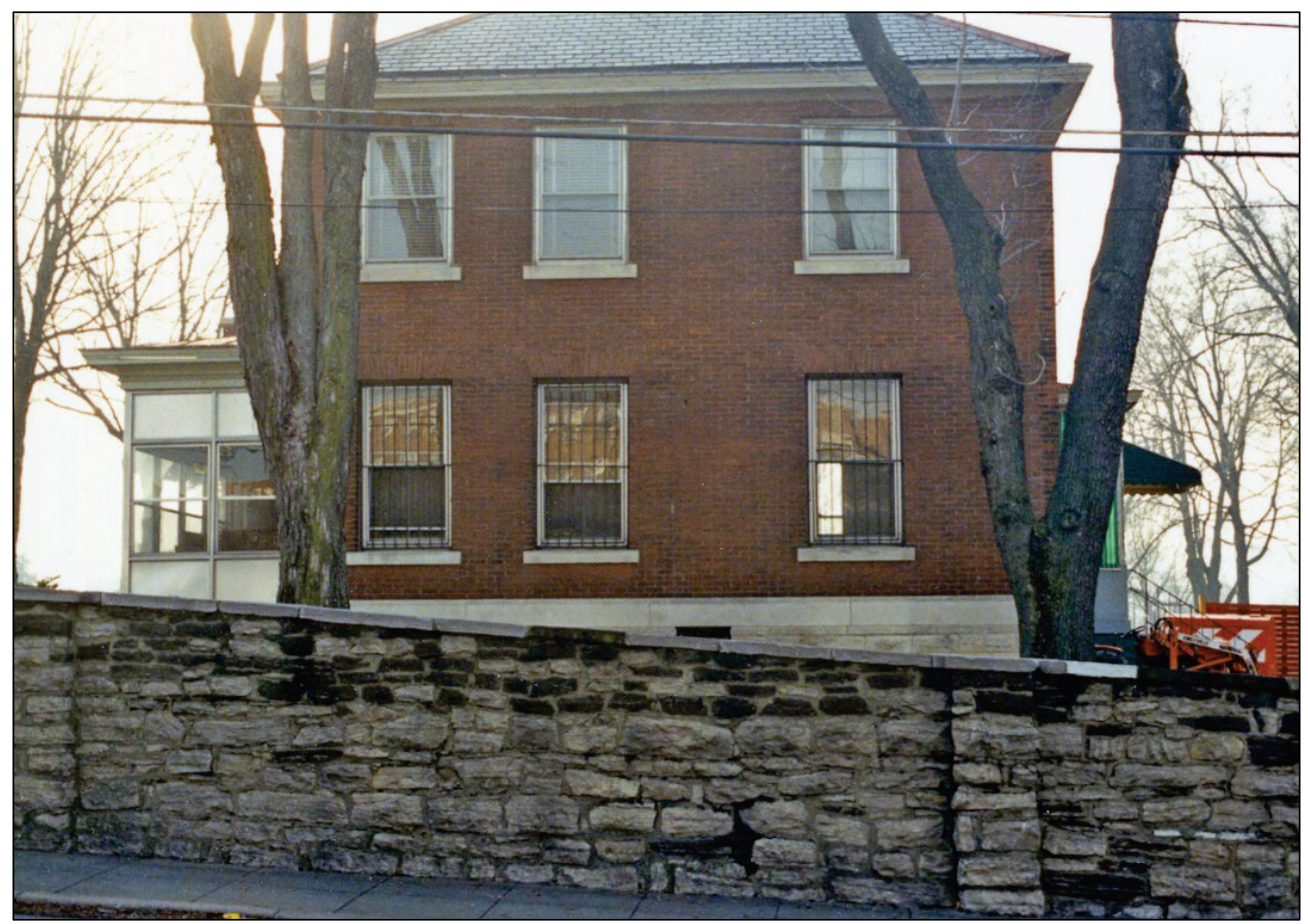

Figure 70. View of 1907 lodge after the 1990 fire (VA NCA Archives, Washington, DC).

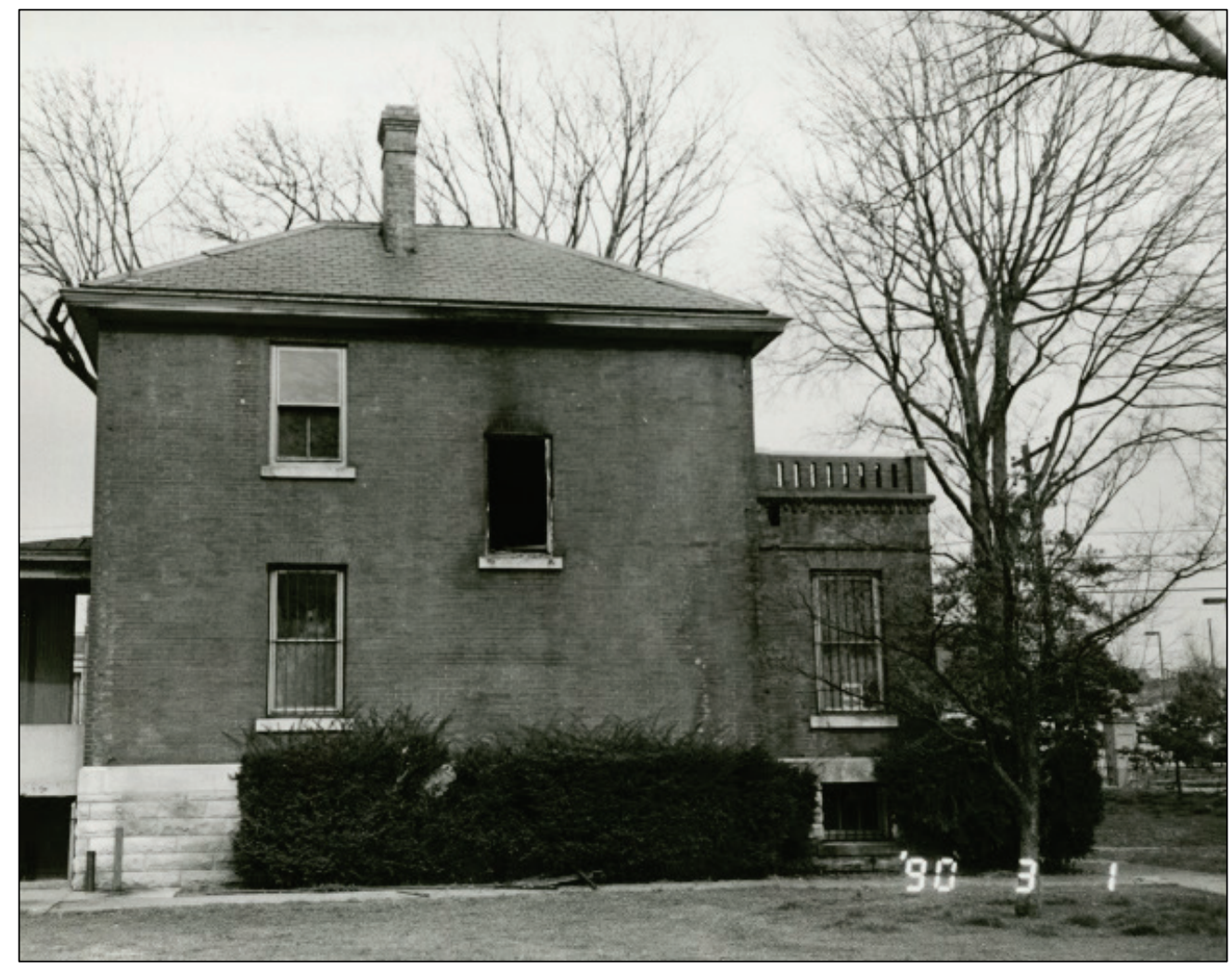


With the 1984 decision to demolish the lodge, the Cemetery Office needed to be relocated. The only option was the utility building, which was itself in dire need of repair (Figure 71). Formal plans to repair and refurbish the utility building began in late 1984/early 1985 with initial focus on the exterior. The project was planned to add a concrete ramp with a safety railing, remove and re-pour the concrete aprons, tuckpoint and waterproof all masonry, replace windows, downspouts, and trim, and add a new woodframed porch. Wood windows were to be repaired or replaced with aluminum frame windows with insulating glass and screens. ${ }^{206}$ Interior and exterior doors were replaced, and new attic insulation was installed. A new wooden garage door was provided. ${ }^{207}$ Security bars were placed over the windows, a security alarm was installed, and two planting areas were developed at the office entrance. ${ }^{208}$ Gas and water utility lines from the lodge were moved to the service building, including removal of the lines from the burial area. Interior work included creating an administrative office, creating a lunchroom, renovating the restrooms and making them handicapped accessible (one became an employee restroom), and installing new carpeting (office), vinyl (lunchroom) and ceramic tile (restrooms) floors. A new heating and ventilating system was installed. ${ }^{209}$ The work was completed in February 1987 at a cost of $\$ 97,300$ (Figure 72). ${ }^{210}$ The exterior lattice was removed at some point after 1995 .

\footnotetext{
206 "Application for General Operating Expense Construction and Repair Project and Minor Construction Project: Knoxville National Cemetery," 9 January 1985, Folder: "Knoxville National Cemetery Project No. 788-855-002-FY86," National Cemetery Administration Archives, Washington, DC; Sammartino, "Knoxville National Cemetery," 1996.

207 Veterans Administration, “Design Requirements for Renovate Maintenance Building at Knoxville National Cemetery," 5 November 1984, Folder: “Knoxville National Cemetery Project No. 788-855-002FY86," National Cemetery Administration Archives, Washington, DC.

208 Margaret B. Jensen, Technical Service Division, “Trip Report - Knoxville National Cemetery,” 26 February 1988, Folder: “Knoxville National Cemetery Project No. 788-855-002-FY86," National Cemetery Administration Archives, Washington, DC.

209 Veterans Administration, “Design Requirements for Renovate Maintenance Building at Knoxville National Cemetery," 5 November 1984.

210 Jensen, “Trip Report - Knoxville National Cemetery,” 26 February 1988.
} 
Figure 71. Utility building before renovation (VA NCA Archives, Washington, DC).

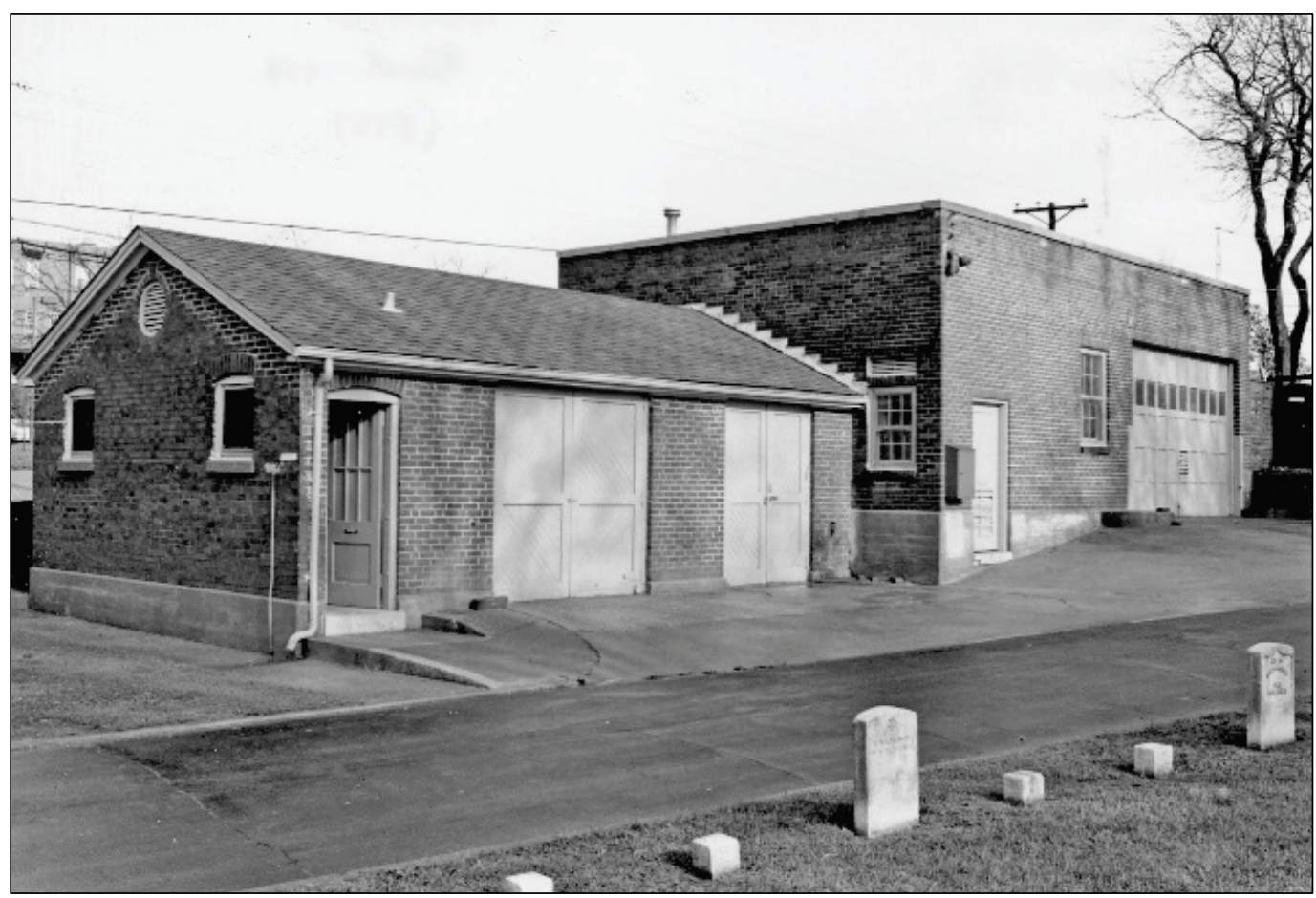

Figure 72. View of the utility building after renovation, 1989 (VA NCA Archives, Washington, DC).

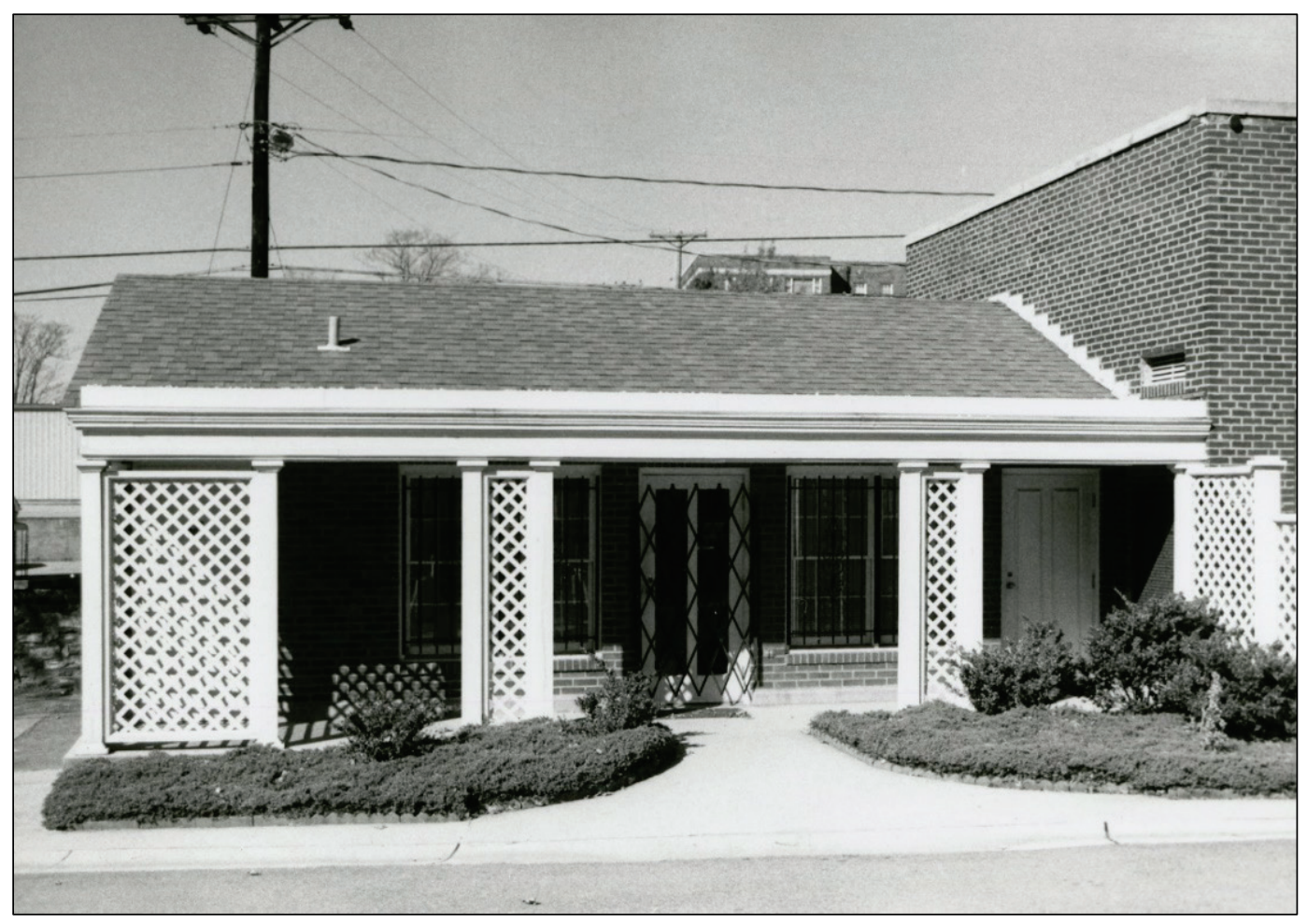


The rostrum's asphalt roof was replaced in 1953, at a cost of $\$ 396$. The podium floor had been changed from gravel to concrete sometime before 1960. ${ }^{211}$ The rostrum continued to be used for Memorial Day services (Figure 73). Further major changes occurred in 1958, when the entire roof was removed by the Locke Plumbing \& Heating Company at a cost of $\$ 315$. The brick columns were reduced to just several feet and capped (Figure 74). This open rostrum remained until 30 September 1960, when the entire structure was removed. ${ }^{212}$

Figure 73. Newspaper photo from Memorial Day 1954 showing rostrum (NARA, Washington DC, RG92).

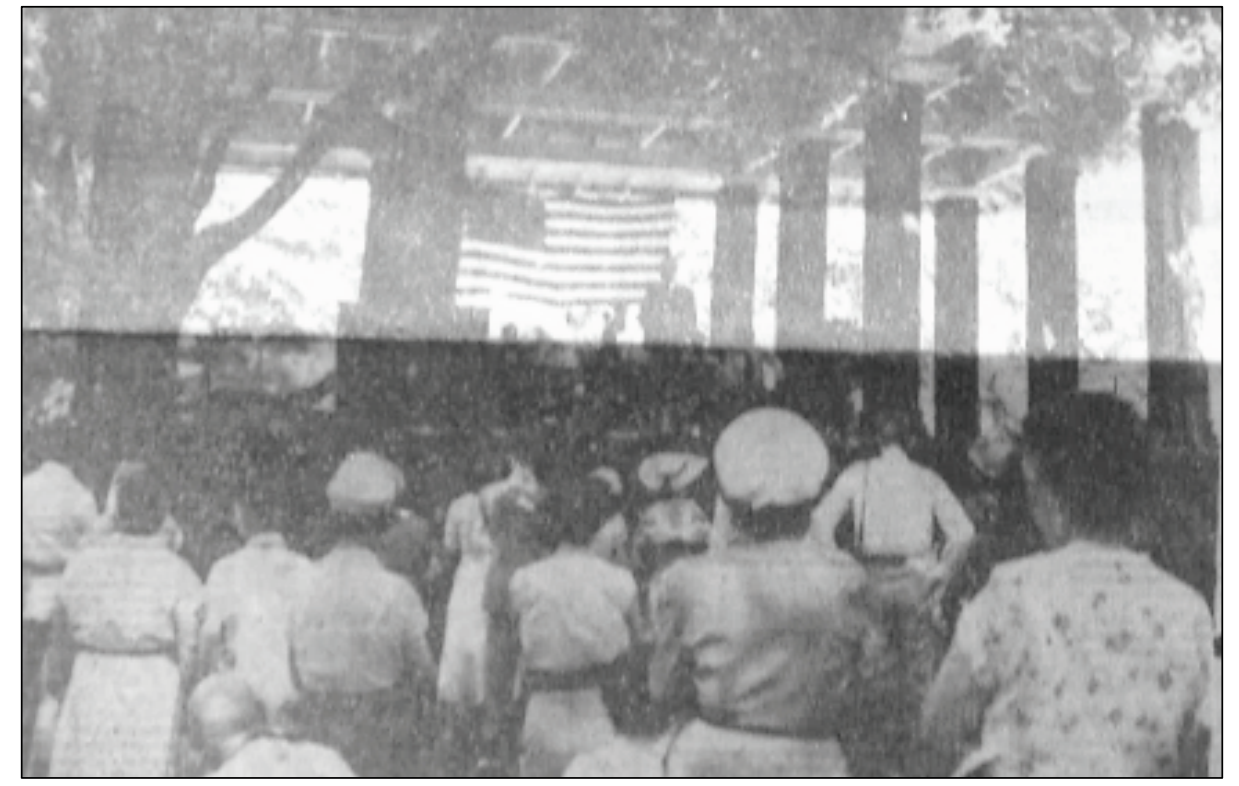

211 “Rostrum," 1960.

212 Ibid; Sammartino, “Knoxville National Cemetery,” 1996. 
Figure 74. Rostrum after removal of asphalt roof, 1958 (NARA, Washington DC, RG15).

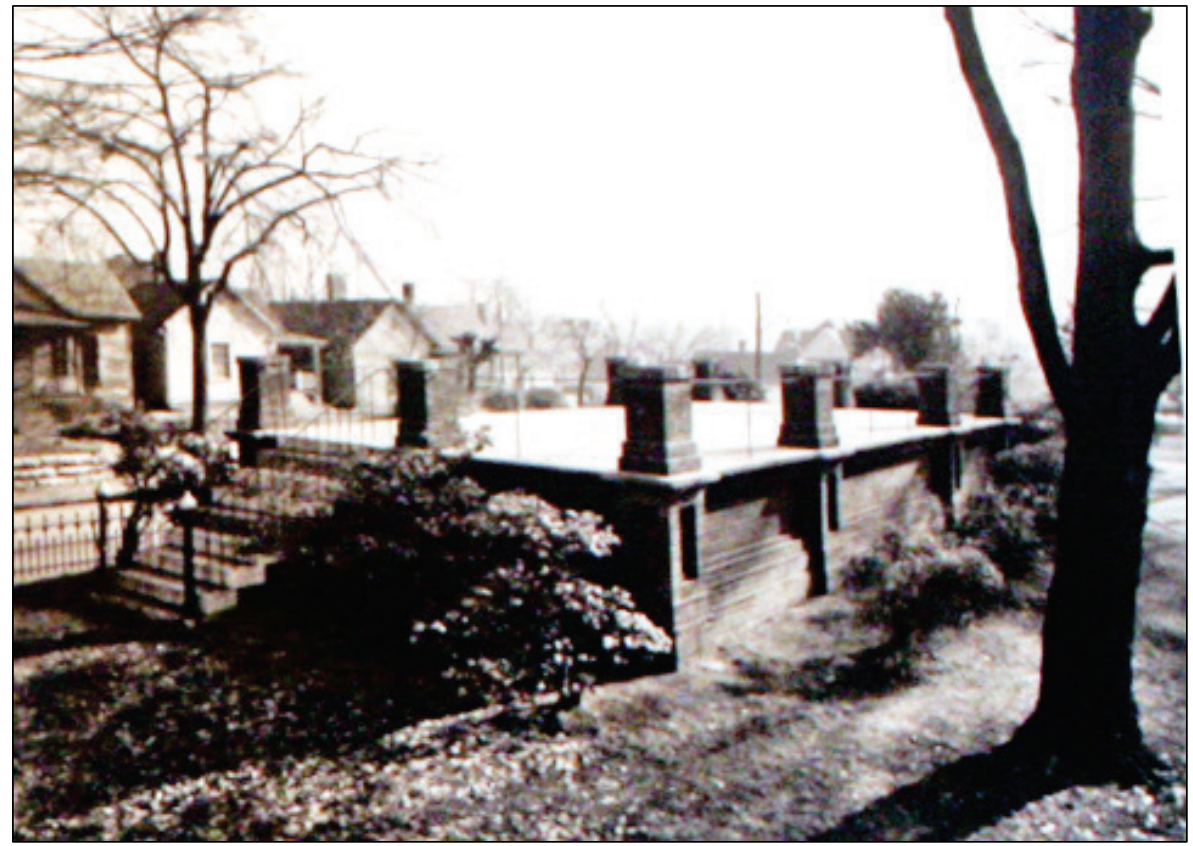

\subsubsection{Walls, roads, and gates}

The exterior walls were cleaned in 1953, then cleaned and tuckpointed in 1967. ${ }^{213}$ A major renovation project occurred just in the last few years, with complete repointing, replacement of some coping on the southeast wall, installation of drainage ditches parallel to the northwest and southeast walls, and corner inlets at the bottom of the cemetery improved. ${ }^{214}$

The main entrance was altered in the first half of 1962 when the old main entrance gate was replaced. The new gate had two concrete posts with pyramidal caps. The double metal gates were rectangular in shape, not arched as were the original gates. The pedestrian gates on either side were not replicated in the new gate. Bronze plaques were installed on the main gate posts with the downslope plaque reading "United States of America" and the upslope plaque reading "Knoxville National Cemetery" (Figure 75). ${ }^{215}$ At some point before 1989, the "United States of America" plaque was removed, the "Knoxville National Cemetery" plaque was moved to the now empty spot, and a "Veterans Administration 1930" plaque was put in its old

\footnotetext{
213 “Enclosing Walls and Fences," 1967.

214 William E. Hooker, III, E-mail correspondence with Susan Enscore, ERDC-CERL, 25 June 2020.

215 “Entrance Gates," 1962.
} 
spot. When the new gate was installed, the approach from Tyson Street was widened and made of concrete. New concrete curbs were also installed. ${ }^{216}$

Figure 75. 1962 Entrance Gate with bronze plaques installed 2 July 1962, undated photo (NARA, Washington DC, RG15).

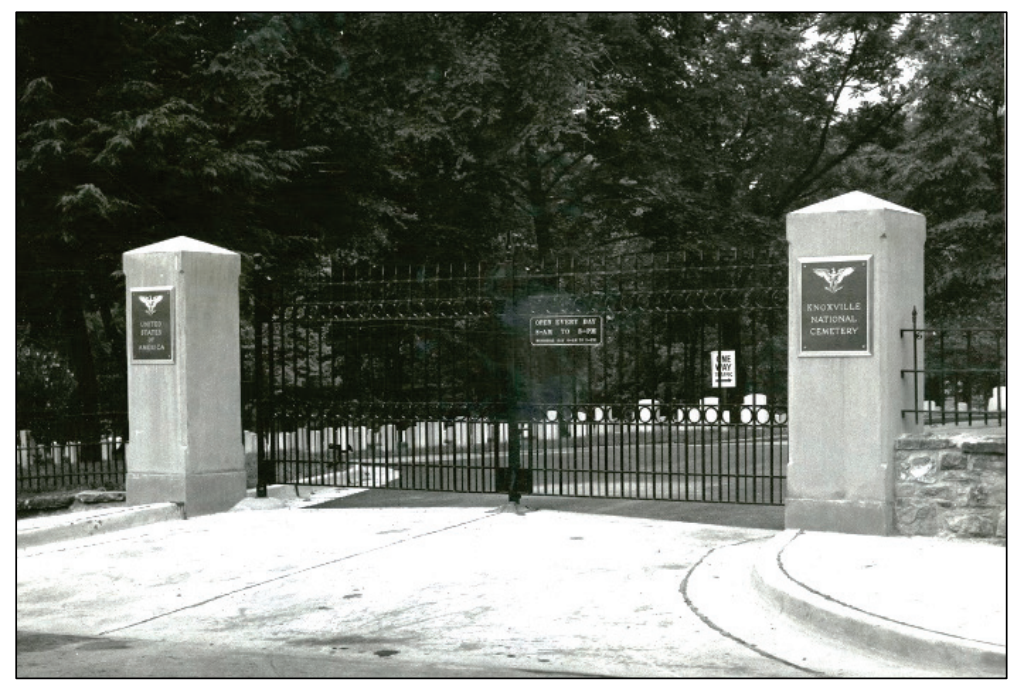

Repairs to drives were carried out in 1957 and 1958, with portions of concrete curbs replaced. ${ }^{217}$ Five sections of broken gutters and curbs were repaired in 1960, a parking lot was constructed in 1962, and a driveway was resurfaced in 1967.218 The burial space expansion project in 1984-1986 resulted in the removal of the cemetery's original entrance on Cooper Street, as the gate and gateposts were removed, and the open space enclosed by continuation of the stone wall across the area. ${ }^{219}$ The pedestrian gates on Cooper Street and Tyson Street, used for lodge/office access, were also removed at this time and infilled with matching stone wall. Removal of the pedestrian gate on Tyson Street required the purchase and installation of custom iron fencing to match the existing fence. ${ }^{220}$ These was the last significant changes to the walls, roads, and gates at Knoxville National Cemetery.

\footnotetext{
216 Ibid.

217 “Roads," Real Property Form, U.S. National Cemetery, Knoxville, Tenn., 1957, RG 15 Records of the Veterans Administration, Entry A1-25 Department of Memorial Affairs, National Cemetery Historical File, Box 24, National Archives and Records Administration, Washington, DC.; "Roads (Cont'd)," Real Property Form, U.S. National Cemetery, Knoxville, Tenn., 1967, RG 15 Records of the Veterans Administration, Entry A1-25 Department of Memorial Affairs, National Cemetery Historical File, Box 24, National Archives and Records Administration, Washington, DC.

218 “Roads (Cont'd)," 1967.

219 Curtis L. Cannon, "Report of Contact," 26 February 1986, Folder: “Knoxville National Cemetery - General," National Cemetery Administration Archives, Washington, DC.

220 "EMIS Construction Program - Estimate Worksheet Project VG21P-1772," 13 March 1985, in Folder: “Develop New Gravesites Project," VA NCA Archives, Washington, DC.
} 
As of June 2020, there are over 9,00o burials at Knoxville National Cemetery. Among them are two Medal of Honor recipients. Troy A. McGill, Sergeant, U.S. Army, Troop G, 5th Cavalry Regiment, 1st Cavalry Division was awarded the honor "for conspicuous gallantry and intrepidity above and beyond the call of duty in action with the enemy at Los Negros Islands, Admiralty Group, on March 4, 1944 ... he is buried in Section B, Grave 6294." ${ }^{221}$ Timothy Spillane, Private, Company C, 16th Pennsylvania Cavalry, when "at Hatcher's Run, Virginia, on February 7, 1865, his gallantry and good conduct in action as well as his bravery in a charge and reluctance to leave the field after being twice wounded, earned him the Medal of Honor. He is buried in Section A, Grave 3 319." 222

One of the most elaborate monuments in the cemetery marks the resting place of Thomas Ridge and his wife. Mr. Ridge was the first Superintendent at the cemetery and with the exception of 4 years in the late 1880 s, served in the role until 1904. Mr. Ridge died in September 1918, and was buried at the cemetery he had helped create. His obituary noted that "through his management of the ground dedicated for the resting place of the nation's dead were transformed from rugged trenches to one of ornament and beauty he having planted every tree and shrub that marks the resting place of his dead compatriots.”223

\footnotetext{
221 Sammartino, “Knoxville National Cemetery,” 1996.

222 Ibid.

223 Neely and James, Knoxville's National Cemetery, 2018, 62; J.B. Bellinger, Major and Quartermaster, U.S. Army, "Orders," 24 May 1904, RG 92 Records of the Office of the Quartermaster General, Entry 601, Records Relating to Functions: Cemeterial, 1828-1929, National Archives and Records Administration, Washington, DC; "Ridge," The Knoxville Journal and Tribune, 6 September 1918, 7, in the East Tennessee History Center McClurg Collection, Knoxville, Tennessee; undated newspaper clipping in the East Tennessee History Center McClurg Collection, Knoxville, Tennessee.
} 


\section{National Register Evaluation}

\subsection{6 nomination}

The 1996 nomination is part of a multiple-property theme of Civil War Era National Cemeteries. The VA nominated 14 National Cemeteries to the NRHP, including Knoxville. Knoxville National Cemetery was significant for its association with the Civil War and ongoing association with veterans from multiple wars. The nomination was accepted 1 August 1996.

The period of significance in the 1996 nomination is from 1867 to 1905 and 1936, and the only significant dates are 1867 and 1936 . The cemetery is nominated under Criterion $\mathrm{C}$. The contributing resources include one building (Service building [today's restroom and maintenance buildings]), the site, two structures (gate and perimeter wall), and two objects (flagpole and monument). There are no noncontributing resources. The headstones are not included on either list. Figure 76 reproduces the cemetery's 23page NRHP nomination form from 1996 (not including photos). 
Figure 76. Reproduction of registration form for Knoxville National Cemetery nomination to NRHP, 1996 (NCA).

NPS Form 10-900
(Oct. 1990)
United States Department of the Interior
National Park Service
National Register of Historic Places
Registration Form

United States Department of the Interio National Park Service

\section{Registration Form}

This form is for use in nominating or requesting determinations for individual properties and districts. See instnuctions in How to Complete the National Register of Histork Places Registrition Form (National Register Bulletin 16A). Complete each item by marking " $x$ " in the appropriate box or by entering the information requeated. If ary item does not apply to the property being documented, enter "N/A" for "not applicable." For functions, architectural classification, materials, and areas of significance, enter only categories and subcategories from the instructions. Place additional entries and narrative items on contlnuation sheets (NPS Form 10-9003). Use a typewriter, word processor, or computer, to complete all items.

\section{Name of Property}

historic name Knoxville National Cemetery

other names/site number

\begin{tabular}{|c|c|c|c|c|c|c|c|c|c|}
\hline \multicolumn{2}{|c|}{ street \& number } & \multicolumn{4}{|l|}{239 Tyson Street, $\mathrm{NW}$} & $\square$ & \multicolumn{2}{|c|}{ not for publication } & N/A \\
\hline \multicolumn{2}{|c|}{ city or town } & oxville & & & & & 国 & vicinity & \\
\hline state & Tennesse & code & TN & county & Knox & code & 093 & zip code & 37917 \\
\hline
\end{tabular}

\section{State/Federal Agency Certification}

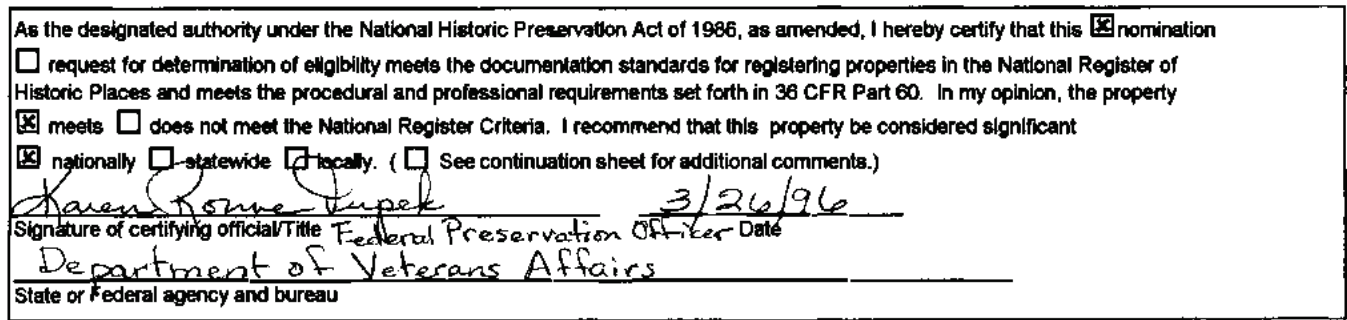

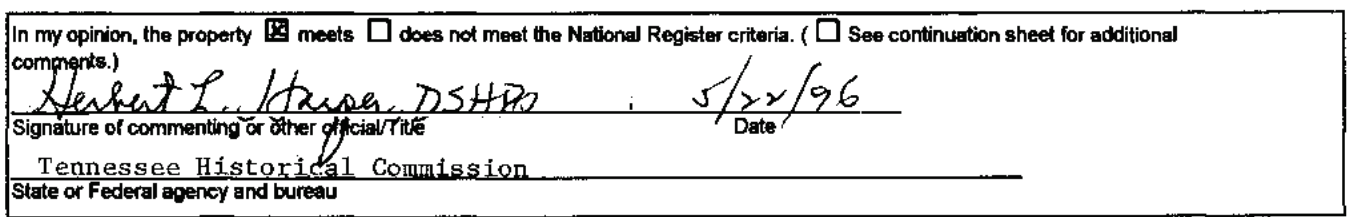

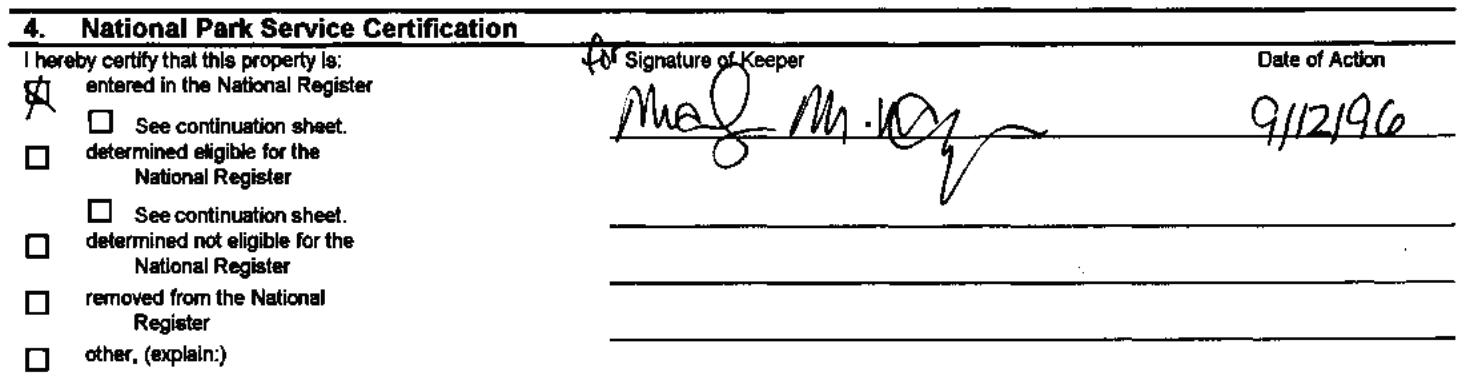


Knoxville National Cemetery Name of Property
Knox County, Tennessee

County and State

\section{Classification}

Ownership of Property

(Check as many boxes as apply)

$\square$ private

$\square$ public-local

$\square$ public-State

国 public-Federal
Category of Property

(Check only one box)

$\square$ building(s)

$\square$ district

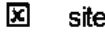

$\square$ structure

$\square$ object

Name of related multiple property listing

(Enter "N/A" if property is not part of a multiple property listing.)

Civil War Era National Cemeteries

\section{Function or Use}

Historic Functions

(Enter categories from instructions)

Funerary: Cemetery

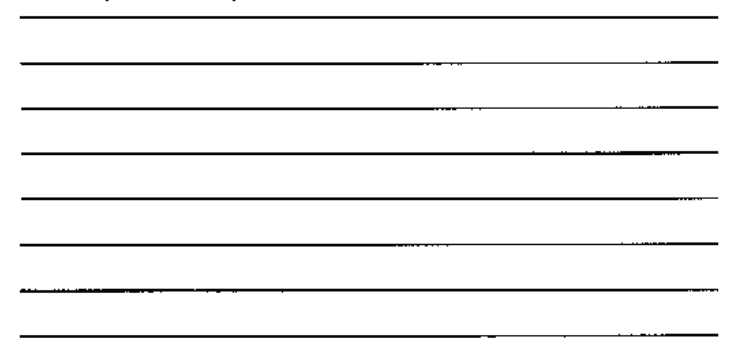

7. Description

Architectural Classification

(Enter categories from instructions)

$\mathrm{N} / \mathrm{A}$

Narrative Description

(Describe the historic and current condition of the property on one or more continuation sheets.)

Number of Resources within Property

(Do not include previously listed resources in the count.)

Contributing Noncontributing

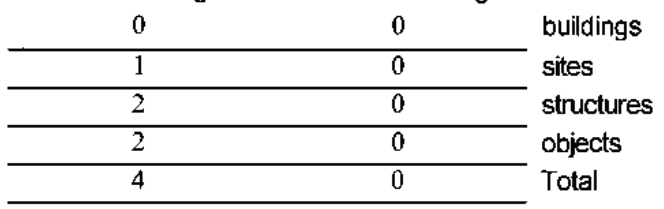

Number of contributing resources previously listed in the National Register

0

\section{Current Functions}

(Enter categories from instructions)

Funerary: Cemetery

\section{Materials}

(Enter categories from instructions)

foundation Concrete

walls Brick

roof Asbestos

other Metal: Iron; Stone: Marble, Stone 
Knoxville National Cemetery

Name of Property

Knox County, Tennessee

County and State

8. Statement of Significance

Applicable National Register Criteria

(Mark " $x$ " in one or more boxes for the criteria qualifying the property for National Register listing.)

$\otimes$ A Property is associated with events that have made a significant contribution to the broad patterns of our history.

B Property is associated with the lives of persons significant in our past.

ㄷ Property embodies the distinctive characteristics of a type, period, or method of construction or represents the work of a master, or possesses high artistic values, or represents a significant and distinguishable entity whose components lack individual distinction.

D Property has yielded, or is likely to yield, information important in prehistory or history.

\section{Criteria Considerations}

(Mark " $x$ " in all boxes that apply.)

Property is:

A owned by a religious institution or used for religious purposes.

B removed from its original location.

Significant Person

(Complete if Criterion B is marked above)

C a birthplace or grave.

因 D a cemetery.

E a reconstructed building, object or structure.

F a commemorative property.

$\square$ G less than 50 years of age or achieved significance within the past 50 years.

Areas of Significance

(Enter categories from instructions)

Military

Period of Significance

1867-1905, 1936

\section{Significant Dates}

1867

1936

N/A

\section{Cultural Affiliation}

N/A

Architect/Builder

N/A

Narrative Statement of Significance

(Explain the significance of the property on one or more continuation sheets.)

9. Major Bibliographical References

Bibliography

(Cite the books, articles, and other sources used in preparing this form on one or more continuation sheets.)

Previous documentation on file (NPS):

ㅁ preliminary determination of individual listing (36 CFR 67) has been requested

$\square$ previously listed in the National Register

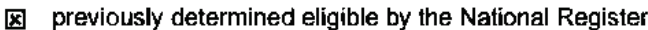

ㅁ designated a National Historic Landmark

$\square$ recorded by Historic American Buildings Survey \#

口 recorded by Historic American Engineering Record

Primary location of additional data:

$\square$ State Historic Preservation Office

$\square$ Other State agency

ख Federal agency

ㄴ Local government

$\square$ University

$\square$ Other

Name of repository

Department of Veterans Affairs 
Knoxville National Cemeter

Knox County, Tennessee

Name of Property

County and State

10. Geographical Data

Acreage of Property $\quad 9.8$

UTM References

(Place additional UTM references on a continuation sheet)

\begin{tabular}{|c|c|c|}
\hline 17 & 236020 & 3985000 \\
\hline Zone & Easting & Northing \\
\hline
\end{tabular}

3

4

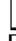

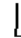

Easting

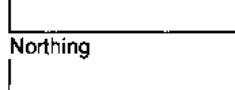

Northing

Verbal Boundary Description

(Describe the boundaries of the property on a continuation sheet.)

Boundary Justification

(Explain why the boundaries were selected on a continuation sheet.)

\section{Form Prepared By}

name/title Therese T. Sammartino, Staff Assistant, National Cemetery System

organization Department of Veterans Affairs date July 8,1996

street \& number 810 Vermont Avenue, N.W telephone

(202) 565-4895

city or town Washington, D.C. state zip code 20420

\section{Additional Documentation}

Submit the following items with the completed form:

\section{Continuation Sheets}

Maps

A USGS map (7.5 or 15 minute series) indicating the property's location.

A sketch map for historic districts and properties having large acreage or numerous resources.

\section{Photographs}

Representative black and white photographs of the property.

Additional items

(Check with the SHPO or FPO for any additional items)

\section{Property Owner}

(Complete this item at the request of the SHPO or FPO.)

name Department of Veterans Affairs

street \& number 810 Vermont Avenue, N.W. telephone

city or town Washington, D.C. state zip code $\quad 20420$

Paperwork Reduction Act Statement: This information is being collected for applications to the National Register of Historic Places to nominate properties for listing or determine eligibility for listing, to list properties, and to amend existing listings. Response to this request is required to obtain a benefit in accordance with the National Historic Preservation Act, as amended (16 U.S.C. 470 et seq.)

Estimated Burden Statement: Public reporting burden for this form is estimated to average 18.1 hours per response including the time for reviewing instructions, gathering and maintaining data, and completing and reviewing the form. Direct comments regarding this burden estimate or any aspect of this form to the Chief, Administrative Services Division, National Park Service, P.O. Box 37127, Washington, DC 20013-7127; and the Office of Management and Budget, Papenwork Reductions Project (1024-0018), Washington, DC 20503. 
Knoxville National Cemetery

Name of Property $\quad$ County and State

Knox County, Tennessee

10. Geographical Data

Acreage of Property $\quad 9.8$

UTM References

(Place additional UTM references on a continuation sheet)

$1 \mid 17$

2

$\frac{236020}{\text { Easting }}$

3985000 Northing

Verbal Boundary Description

(Describe the boundaries of the property on a continuation sheet.)

Boundary Justification

(Explain why the boundaries were selected on a continuation sheet.)

\section{Form Prepared By}

name/title Therese T. Sammartino, Staff Assistant, National Cemetery System

organization Department of Veterans Affairs date July 8,1996

street \& number 810 Vermont Avenue, N.W. telephone (202) 565-4895

city or town Washington, D.C. state zip code $\quad 20420$

Additional Documentation

Submit the following items with the completed form:

\section{Continuation Sheets}

Maps

A USGS map ( 7.5 or 15 minute series) indicating the property's location.

A sketch map for historic districts and properties having large acreage or numerous resources.

\section{Photographs}

Representative black and white photographs of the property.

Additional items

(Check with the SHPO or FPO for any additional items)

\section{Property Owner}

(Complete this item at the request of the SHPO or FPO.)

name Department of Veterans Affairs

street \& number 810 Vermont Avenue, N.W telephone

city or town Washington, D.C. state zip code 20420

Paperwork Reduction Act Statement: This information is being collected for applications to the National Register of Historic Places to nominate properties for listing or determine eligibility for listing, to list properties, and to amend existing listings. Response to this request is required to obtain a benefit in accordance with the National Historic Preservation Act, as amended (16 U.S.C. 470 et seq.)

Estimated Burden Statement: Public reporting burden for this form is estimated to average 18.1 hours per response including the time for reviewing instructions, gathering and maintaining data, and completing and reviewing the form. Direct comments regarding this burden estimate or any aspect of this form to the Chief, Administrative Services Division, National Park Service, P.0. Box 37127, Washington, DC 20013-7127; and the Office of Management and Budget, Paperwork Reductions Project (1024-0018), Washington, DC 20503 


\author{
NPS Form 10-900-a \\ (8-86) \\ United States Department of the Interior \\ National Park Service
National Register of Historic Places Continuation Sheet

OMB No. 10024-0018

Civil War Era National Cemeteries

Knoxville National Cemetery

Knox County, Tennessee

\section{NARRATIVE DESCRIPTION}

The Knoxville National Cemetery is located at 939 Tyson Street, N.W., within the city limits of Knoxville, Tennessee, in Knox County. The site is nearly square in shape, and the burial sections are arranged in the shape of a large circle, separated by conveniently arranged walks. Each section forms a quarter of the large circle, while the headstones at the graves form circles, all converging toward the intersection of two walks, where the flagpole is located. The grounds are enclosed by a stone wall, constructed in 1875 , on the north side of which is an iron fence. The main entrance is situated at the center of the south side and is protected by a double iron gate. There are two additional entries to the cemetery that are no longer used. The Cooper Street entry in the rear of the cemetery is now closed by a stone wall, and a pedestrian entry near the northern corner of the cemetery is now closed by wrought-iron fencing. A service building containing an administrative office and public restroom, is located to the northwest of the main entrance.

The cemetery was established in September 1863. Graves were originally marked with painted and lettered headboards and by numbered stakes. These were later replaced with upright marble markers.. The cemetery was closed on May 1, 1973, but reopened on July 29, 1985, when part of the road system was removed to create additional grave space. The road that was removed extended from the cemetery entry to the former entry gate at Cooper Street. The cemetery remained open for five additional years and was officially closed in 1990 . Interments of casketed remains in occupied graves and reserved graves, as well as interments of cremated remains, continue. As of May 31, 1996, there were 8, 012 graves used for the interment of 8,503 casketed remains and 154 sites used for the interment of 209 cremated remains. As of May 31, 1996, there were 125 gravesites available (121 reserved) for the interment of casketed remains and 108 sites available for the interment of cremated remains.

The original superintendent's lodge was constructed some time prior to 1868 . According to the Report of Inspector of the National Cemeteries of the United States for 1869, "The lodge is very badly built. The plank was not seasoned, and the shingles were most inferior. The shrinkage has been very great, and every rain storm beats through the doors and casements of the windows, covering the floors with water. The roof leaks badly. The plastering was done in mid-winter. The mortar contains very little lime, and is constantly falling off." The same report for the years 1870 and 1871 states that the lodge is a small wooden cottage in poor condition. National Cemetery System records show that a two-story brick, stone, and concrete lodge with office building was constructed in 1907. The roof was slate. Cemetery superintendents or directors resided in the lodge until 1984. That same year, a decision was made to demolish the lodge. Compliance with Section 106 of the National Historic Preservation Act was begun. Subsequently, in 1990, a fire caused extensive damage to the structure. It was later demolished on September 28, 1993. 
NPS Form 10-900-a

(8-86)

OMB No. $10024-0018$

United States Department of the Interior

National Park Service

National Register of Historic Places Continuation Sheet

Civil War Era National Cemeteries

Section number

Page

Knoxville National Cemetery

Knox County, Tennessee

\section{NARRATIVE DESCRIPTION (Continued)}

The brick service building was constructed in 1936. It originally contained two storage bays and two toilets. A brick addition and garage were constructed in 1949. The roof of the building is covered with asbestos shingles, and the garage area has a built-up flat roof. The interior and exterior of the original service building were renovated in 1987 to accommodate the administration office, since the lodge was going to be demolished, and to provide handicapped accessible restroom facilities. One of the public toilets was converted to an employee restroom. The total area of the building and garage is 1,578 square feet. There is also an enclosed fuel storage area adjacent to the service building.

A brick and concrete rectangular rostrum, 22 feet by 37 feet, with an asphalt shingle roof, was constructed in 1885 . It was located near the northeast corner of the cemetery and was removed on September 30, 1960.

A monument, sixty feet in height, prominently displayed in the northeast corner of the national cemetery, was erected by members of the Department of Tennessee, Grand Army of the Republic (G.A.R.). Department Commander H. C. Whittaker first publicly outlined the plan on March 23, 1893, during the tenth annual G.A.R. encampment at Harriman. A memorial committee was chaired by William Rule, influential editor of the Knoxville Daily Journal, who later wrote that plans for the memorial were first presented at the Athens encampment in 1892. There was little hope that the state would sanction funding for a Union monument; this sadly was a burden each veteran and his friends would have to bear. After a promising beginning in 1893, the funding campaign became dismally inactive. Three years later, only $\$ 1,300$ had been collected. In the spring of 1896 , the group forwarded, for the approval of the United States Quartermaster General, the chief supervising agency for all G.A.R. construction, a design for the monument. The structure was to be a fifty-foot Tennessee marble shaft, embellished with unidentified bronze figures on the corners, and a single statue at the summit. A design was agreed upon and, on May 8, 1896, approved by the United States Quartermaster's Office. Approval was conditioned by the proviso "that no part of the expense attending the work be made a charge against the United States." In the summer, the memorial committee signed a contract with William B. McMullen, president of the Tennessee Producers Marble Company and the Southern Monument Company, for material and construction, and with Colonel William A. Gage for engineering consultation. The design showed that flanking entrances were to lead, as if from drawbridges, into a small sanctuary dressed entirely with marble. In its west wall was to be an "art glass" window. The east wall would be hung with tablets detailing regimental histories. Close by the entrances would appear the national emblem and state hatchment, as well as an epitaph and dedication. The monument was a miniature medieval fortress complete with its unique inner room, stained glass window and mosaic star. David H. Geddes, chief carver and foreman at the Southern Monument Company, and his assistants apparently had admirably sculpted the crenelated 
NPS Form 10-900-a

OMB No. $10024-0018$

(8-86)

United States Department of the Interior

National Park Service

National Register of Historic Places
Continuation Sheet

Civil War Era National Cemeteries

Section number

Page

Knoxville National Cemetery

Knox County, Tennessee

\section{NARRATIVE DESCRIPTION (Continued)}

bastions, turrets, corbelled table, decorative frieze, round-arch openings, and rusticated wall surfaces. But, looking high over Holston Street to the central turret, one found not only a sentry peering steadfastly toward the southern horizon, but a ferocious bronze eagle with wings widely spread. The monument cost $\$ 11,300$ and was nearly paid for by soldier residents of the state. Of the estimated 7,000 donations, most came as one dollar offerings from dutiful pensioners. The monument was formally turned over to the Government and accepted by the Secretary of War on October 24, 1901.

On August 22, 1904, a powerful bolt of lightning struck the monument. Only the steps and part of the foundation remained, and these were scarred. The stones and eagle, its wings "closely cropped at its body as evenly as if the work had been done by an instrument," were flung to the ground and into the street. Lightning had apparently been attracted to a steel rod that anchored the eagle to the shaft; consequently, the sculpture had sustained a direct hit. Through the state department, the committee sponsored G.A.R. General Orders No 2, calling for immediate reconstruction. United States Representative Henry R. Gibson introduced before the House a bill calling for $\$ 10,000$ to secure the repairs. The bill passed on April 25,1905 , but the appropriation was for a maximum of $\$ 5,000$ or "so much thereof might be necessary to repair the monument." In November 1905, the committee retained Baumann Brothers, Incorporated, of Knoxville as the consulting architect. Reconstruction began the next May, following acceptance of a $\$ 4,300$ bid submitted by the Fenton Construction Company. The Baumann design must have closely duplicated the original plan. The bronze eagle was replaced with an eight-foot-tall soldier, taking his post on top of the castle's main turret. The coat of arms was left off, for fear it would draw more lightning. The project was completed on October 15, 1906. A fanciful local legend identified the soldier figure with General John T. Wilder, who was the only ranking general on the memorial committee. Union General Wilder first came to Tennessee in 1863, when he marched his Indiana brigade through what is now Rockwood to join the Union Army at Chattanooga. He took part in the Battle of Chickamauga and, on that battlefield, there is an imposing monument to him and his brigade. While camping in what is now Rockwood, General Wilder, a mineralogist and engineer, noticed signs of both coal and iron ore in close proximity. After the war, he came back to Knoxville, established the Roane Iron Company, and operated it for several years. During the McKinley Administration, he was appointed Federal pension agent and maintained an office in the old post office. Every three months, he issued pension checks to hundreds of Union veterans. 
NPS Form 10-900-a

OMB No. 10024-0018

(8-86)

United States Department of the Interior

National Park Service

National Register of Historic Places

Continuation Sheet

Civil War Era National Cemeteries

Section number

Page

Knoxville National Cemetery

Knox County, Tennessee

\title{
NARRATIVE DESCRIPTION (Continued)
}

The monument is inscribed as follows:

Northeast Opening

1861

1865

IN MEMORIAM
UNION SOLDIERS
OF
TENNESSEE
OCTOBER 15,1896

REST ON, EMBALMED AND SAINTED DEAD,

DEAR AS THE BLOOD YE GAVE;

NO IMPIOUS FOOTSTEP HERE SHALL TREAD

THE HERBAGE OF YOUR GRAVE;

NOR SHALL YOUR GLORY BE FORGOT

WHILE FAME HER RECORD KEEPS, OR HONOR POINTS THE HALLOWED SPOT

WHERE VALOR PROUDLY SLEEPS.

TENNESSEE FURNISHED FOR THE UNION ARMY 31092 MEN.

CASUALTIES 6776.

Northwest Wall

\author{
1896 \\ 1901 \\ TO THE TENNESSEE MEN \\ WHO LAID DOWN THEIR LIVES A VOLUNTARY \\ SACRIFICE ON \\ FREEDOM'S ALTAR; \\ WHO ENDURED WITH FORTITUDE A TEMPORARY BANISH- \\ MENT FROM THEIR MOUNTAIN HOMES WHO FOLLOWED \\ THE FLAG THEY LOVED; \\ ON SCORGES OF BATTLE-FIELDS AND WHO FELL \\ VALIANTLY FOR \\ NATIONAL UNITY \\ THIS MONUMENT \\ IS LOVINGLY ERECTED BY THEIR SURVIVING \\ COMRADES AND FRIENDS.
}




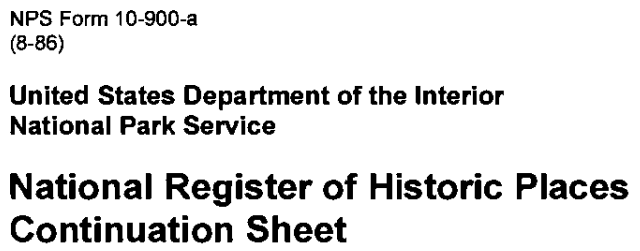

National Register of Historic Places Continuation Sheet

Page
OMB No. $10024-0018$

Civil War Era National Cemeteries

Knoxville National Cemetery

Knox County, Tennessee

\section{NARRATIVE DESCRIPTION (Continued)}

When looking through the wrought-iron gate on the northeast side of the monument, you can see the following inscribed on a slab forming a part of the interior wall:

Monument Committee

WILLIAM RULE

W.R. CARTER

W.J. RAMAGE

R.R. SAMUEL

H.C. WHITAKER

W.E.F. MILBURN

A.J. GAHAGAN

E.H. MATHEWS

FRANK WEISE

J.W. CARTER

G.W. PETERS

J. T. WILDER

D.M. COLDWELL

Farther inside the monument, inscribed on another wall, is the following:
CHAIRMAN

SECRETARY

TREASURE

DIED SEPT. 29. 1898.

\section{ORGANIZATION OF TENNESSEE UNION TROOPS CAVALRY.}




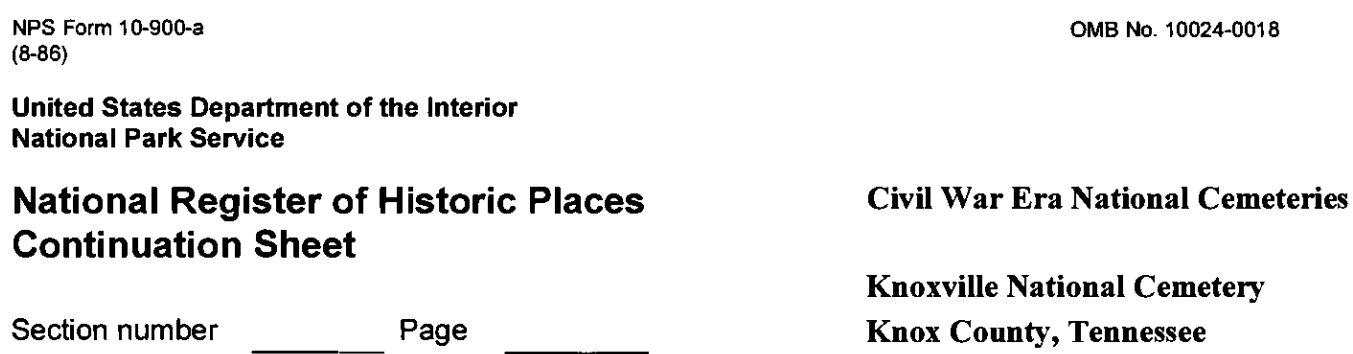

\section{NARRATIVE DESCRIPTION (Continued)}

1ST. CAMP GARBER, KY., MAR., 1862.

2D. CUMBERLAND GAP, TENN., AUG. AND SEPT., 1862.

3D. CUMBERLAND GAP, TENN., AUG. AND SEPT. 1862.

4TH. CUMBERLAND GAP, TENN., AUG. AND SEPT., 1862.

5TH. NASHVILLE, TENN., JULY, 1862.

7TH. HUNTINGDON, TENN., NOV. 1862.

8TH. CAMP NELSON, KY., JUNE, 1863.

9TH. CAMP NELSON, KY., JUNE 1863.

10TH. NASHVILLE, TENN., OCT. 1863.

11TH. CAMP NELSON, KY., OCT., 1863

12TH. NASHVILLE, TENN., OCT., 1863.

13TH. STRAWBERRY PLAINS, TENN., SEPT., 1863.

14TH UNION CITY, TENN., DEC., 1863.

On the southeast elevation of the monument is a stained-glass window. Inside the monument to the left of this window, the following is inscribed:

INFANTRY

1ST. CAMP DICK ROBINSON, KY., AUG. 1861

2D. CAMP PICKETT ROBINSON, KY., SEPT. 1861

3D. FLAT LICK, KY., FEB. 1862

4TH LOUISVILLE, KY., MAR. 1863

5TH BARBOURVILLE, KY., MAR. 1862

6TH BARBOURVILLE, KY., MAR. 1862

7TH NEVER ORGANIZED MEN TRANSFERRED TO OTHER REGIMENTS

8TH LEXINGTON, KY., SEPT. 1862

9TH NEVER ORGANIZED MEN TRANSFERRED TO OTHER REGIMENTS

10TH NASHVILLE, TENN., MAY 1862

As you enter the cemetery, there is a dedicatory plaque that was placed there when the cemetery was reopened on July 29, 1985. It is inscribed as follows: 
United States Department of the Interior National Park Service

National Register of Historic Places

Civil War Era National Cemeteries Continuation Sheet

Section number

Page

Knoxville National Cemetery

Knox County, Tennessee

\title{
NARRATIVE DESCRIPTION (Continued)
}

\author{
KNOXVILLE NATIONAL CEMETERY \\ ESTABLISHED IN 1863 \\ IS THIS DAY REDEDICATED \\ TO THE MEMORY OF ALL THE \\ PATRIOTIC MEN AND WOMEN \\ WHO ANSWERED THEIR \\ COUNTRY'S CALL TO SERVICE \\ THEIR INSPIRING CONTRIBUTION \\ WILL HELP PRESERVE IN THE \\ HEARTS AND LIVES OF ALL \\ AMERICANS THE SPIRIT OF \\ PATRIOTISM THE LOVE OF \\ COUNTRY AND THE WILLINGNESS \\ TO SERVE AND SACRIFICE \\ FOR THE COMMON GOOD \\ RONALD REAGAN \\ PRESIDENT OF THE UNITED STATES \\ HARRY N. WALTERS \\ ADMINISTRATOR OF VETERANS AFFAIRS \\ PAUL T. BANNAI \\ CHIEF MEMORIAL AFFAIRS DIRECTOR \\ JULY 29,1985
}

There are two known Medal of Honor recipients buried in the Knoxville National Cemetery:

Troy A. McGill, Sergeant, U.S. Army, Troop G, 5th Cavalry Regiment, 1st Cavalry Division World War II - For conspicuous gallantry and intrepidity above and beyond the call of duty in action with the enemy at Los Negros Islands, Admiralty Group, on March 4, 1944. In the early morning hours Sergeant McGill, with a squad of eight men, occupied a revetment that bore the brunt of a furious attack by approximately 200 drink-crazed enemy troops. Although covered by crossfire from machine guns on the right and left flanks he could receive no support from the remainder of our troops stationed at his rear. All members of the squad were killed or wounded except Sergeant McGill and another man, whom he ordered to return to the next revetment. Courageously resolved to hold his position at all costs, he fired his weapon until it ceased to function. Then, with the enemy only five yards away, he charged from his foxhole in the face of certain death and clubbed the enemy with his 
NPS Form 10-900-a

OMB No. $10024-0018$

(8-86)

United States Department of the Interior

National Park Service

National Register of Historic Places Continuation Sheet

Civil War Era National Cemeteries

Knoxville National Cemetery

Section number

Page

Knox County, Tennessee

\section{NARRATIVE DESCRIPTION (Continued)}

rifle in hand-to-hand combat until he was killed. At dawn, 105 enemy dead were found around his position. Sergeant McGill's intrepid stand was an inspiration to his comrades and a decisive factor in the defeat of a fanatical enemy. He is buried in Section B, Grave 6294 .

Timothy Spillane, Private, Company C, 16th Pennsylvania Cavalry, Civil War - At Hatcher's Run, Virginia, on February 7, 1865, his gallantry and good conduct in action as well as his bravery in a charge and reluctance to leave the field after being twice wounded, earned him the Medal of Honor. He is buried in Section A, Grave 3319.

The numbers shown for contributing resources within the property reflect the following:

Buildings: Service building

Sites: Cemetery

Structures: Gate, perimeter wall

Objects: Flagpole, monument

\section{NARRATIVE STATEMENT OF SIGNIFICANCE}

The Knoxville National Cemetery is significant under Criterion A, and is an important component of the multiple property submission of Civil War Era National Cemeteries. It is significant under Criterion A because of its association with the Civil War.

To Abraham Lincoln, there was no question that East Tennessee and its people were his main source of strength in the South and, immediately after the disaster that befell his army at Bull Run, he ordered an all-out advance into East Tennessee from the Cincinnati base. There were both military and political reasons for his strategy. Union occupation of the territory would sever the vital railroad line connecting Virginia with the Mississippi Valley, and the area was ablaze with Unionists eager to join his legions. East Tennessee was even more important to the Confederate States. Even before Tennessee had broken from the Union, companies of rebel troops were recruited in Knoxville and nearby counties, mustered into service with state militia, and stationed at strategic points. 
NPS Form 10-900-a

(8-86)

OMB No. $10024-0018$

United States Department of the Interior

National Park Service

National Register of Historic Places

Continuation Sheet

Section number ___ Page

Knoxville National Cemetery

Knox County, Tennessee

\section{NARRATIVE STATEMENT OF SIGNIFICANCE (Continued)}

By the summer of 1861, the Confederate States of America had assumed all the characteristics of an independent nation. In early June, the city of Knoxville was still controlled by the Military League troops. Their primary function was to protect the manufacturing facilities and the railroads that were daily transporting soldiers from the Southwestern states through East Tennessee into Virginia. The continuous transit of troops was witnessed by people loyal to the Union with feelings of dissatisfaction, which sometimes grew into animated wrath. At Strawberry Plains, Tennessee, a regiment of southern troops being transported by train, fired on a mass meeting of Unionists as they passed, and the fire was returned. No lives were lost, but feelings of hatred were naturally intensified. To prevent further occurrences, President Jefferson Davis established the District of East Tennessee of the Confederate Armies, and Brigadier General Felix K. Zollicoffer was named first commander. He established his headquarters in Knoxville and chose General William R. Caswell as his aide and Major B.F. Fogg as his adjutant. Zollicoffer found himself surrounded by multiple pockets of resistance as the mountaineers gathered all available weapons and met in secret rendezvous to plan their own private revolution. They brazenly exercised their freedom at the ballot box in August by electing Union candidates overwhelmingly in the congressional districts around Knoxville.

The Confederate govemment was well aware that any Federal move into East Tennessee would have to come through southeastern Kentucky, following the route of the forbidding, ancient Wilderness Trail that passed through Cumberland Gap, a narrow and easily defended pass located sixty miles north of Knoxville. Charged with the defense of the Gap and the entire Western Territory was General Albert Sidney Johnston, a man President Davis considered the ablest soldier in the entire Confederacy. On his journey from Richmond to East Tennessee, he stopped in Knoxville to confer with General Zollicoffer. The two quickly agreed that the natural defense of East Tennessee began at Cumberland Gap, and Johnston ordered that it be occupied immediately. Opposing the Confederates forty miles north of the Gap at Camp Andrew Johnson, near Barbourville, Kentucky, was an unlikely group of refugees from East Tennessee, calling themselves the First and Second Tennessee volunteers, organized and commanded by Samuel P. Carter. President Davis ordered Zollicoffer to shift his troops from Knoxville to Cumberland Gap and seize Camp Johnson as well as Camp Robinson that was commanded by Lieutenant William Nelson. Zollicoffer took three regiments and established Camp Buckner at Cumberland Ford. He captured the salt works at Manchester, took the salt and wagons and sent them on to Knoxville. He left General William Churchwell in command at Cumberland Gap and went back to East Tennessee. Operating out of Knoxville, the Confederates then began a more potent campaign to wipe out resistance. Vigilance committees were dispersed all around East Tennessee with the authority to arrest persons on suspicion of hostility. Jefferson Davis and his War Department, for some time, had doubts about the military abilities of Zollicoffer. Consequently, they assigned Major General George B. Crittenden to take over the District 
NPS Form 10-900-a

(8-86)

OMB No. 10024-0018

United States Department of the Interior

National Park Service

National Register of Historic Places

Continuation Sheet

Section number

Page

Knoxville National Cemetery

Knox County, Tennessee

\section{NARRATIVE STATEMENT OF SIGNIFICANCE (Continued)}

of East Tennessee. Zollicoffer was later killed at the Battle of Mill Springs in Kentucky. At Knoxville, the news of his death caused great consternation. He was the most popular Confederate leader in Tennessee and was the first Tennessee general killed in the Civil War.

The spring of 1862 witnessed a falling-off of acts of violence in East Tennessee. At Knoxville on March 8, 1862, Major General Edmund Kirby Smith succeeded General George B. Crittenden as Confederate commander of the District of East Tennessee, which was soon reorganized as the Department of East Tennessee, with headquarters at Knoxville. His first task was to muster sufficient forces for adequate defense of East Tennessee. By June 1862, his forces had swelled to 18,000. Confederates in East Tennessee were threatened by encirclement of Federal forces occupying Kentucky, western and central Tennessee, and northern Mississippi and Alabama. General Braxton Bragg assumed command in the West. A Confederate invasion of Kentucky took place and failed to turn the tide of the war in favor of the South. Bragg's and Smith's combined operations had produced some positive results for the South. East Tennessee and the valuable rail lines that ran through Knoxville were secured for the South for months to come.

In January 1863, General Ambrose Burnside was the new Federal Commander of the Army of the Ohio. In June, to pave the way for the invasion of East Tennessee, Burnside sent Colonel William P. Sanders to lead a cavalry raid on Confederate lines south of Cumberland Gap to tear up bridges and communications. The night of June 19, Colonel Sanders ran into the Confederate pickets outside Knoxville. On the 20th, he was moving toward the center of Knoxville on the Tazewell Road. War had come to Knoxville. The Confederates in Knoxville knew that a Union raid on the city was a certainty. The call went out for Knoxville citizens to help defend their city and brace the garrison. By nightfall, two hundred citizens and convalescent soldiers reported for duty, and the batteries were manned. Colonel Sanders and his raiders arrived in Knoxville after dark. The skirmish, mainly an artillery duel, lasted little more than an hour. Two Confederate officers and an enlisted man lost their lives. Their primary mission was to destroy communication lines. Sanders was later promoted to Brigadier General. On November 18, General Sanders and his aide, Major R.E. Lawder, were watching as the gray line swarmed up the hill against the Federal position on Kingston Pike in front of Fort Loudon. They saw Captain Winthrop, a lone Confederate horseman, charging directly into a murderous fire of rifles. They turned and began to retreat for cover behind the hill. Sanders was hit and Lawder caught the general in his arms and quickly collected a few men, who carried their bleeding commander to the Anderson House where they found an old ladder and used it as a stretcher to move Sanders to a room at the Lamar House, where he was examined by Dr. J.C. Hatchitt. A Minie ball had entered his left side and tore the spleen. Sanders, 28 years old, died the next morning, November 19. It was decided that, for the sake of the morale among the soldiers, General Sanders's 
United States Department of the Interior National Park Service

National Register of Historic Places Continuation Sheet
Civil War Era National Cemeteries

Knoxville National Cemetery Knox County, Tennessee

\section{NARRATIVE STATEMENT OF SIGNIFICANCE (Continued)}

death would be concealed for the time being. The funeral with graveside service would be held at night, as silently as possible. He was buried in the graveyard next to the Second Presbyterian Church, and his remains were later moved to the Chattanooga National Cemetery, Chattanooga, Tennessee. He is buried in Section C, Grave 1601. Sanders was the only Southern-born Union general officer killed in the Civil War and was a cousin of Jefferson Davis. By command of General Burnside, Fort Loudon was renamed Fort Sanders in his honor.

Union commander General Burnside established his Knoxville headquarters in the home of John H. Crozier, which stood on the northeast corner of Gay Street and Clinch Avenue (site of the present-day Farragut Building). By early September, he had occupied Knoxville and closed the short interior lines of communication from Virginia to Tennessee.

General James Longstreet was Lee's most trusted corps commander. He urged President Davis and General Robert E. Lee to send him and his First Corps by rail from Virginia through Knoxville to join Bragg.

General Longstreet's mission was to destroy Burnside quickly at Knoxville and return to the assistance of Bragg who, for the moment, had Grant trapped in Chattanooga. Burnside, on the other hand, had to delay Longstreet in order to increase Grant's chances of defeating Bragg and breaking out of the trap.

From Campbell's Station on November 16,1863, General Burnside had sent instructions to Captain Orlando Poe, chief engineer of the Army of the Ohio, at Knoxville, to prepare lines of defense for the town, employing the engineering battalion of the 23rd Corps and such civilians as he could impress into service.

The siege of Knoxville effectively began on November 17, 1863, when the Confederates surrounded Knoxville except where it was bounded on the south by the Tennessee River. The Union troops, ordered by Bumside to retreat no farther, to stand or die in Knoxville, now began to number the days of the siege. The third day, November 19, was memorable, for in the early morning hours the 79th New York Highlanders inside the earthwork fort erected their flag staff, and for the first time the Stars and Stripes flew over the red clay ramparts. For these three days, the Confederate force had ringed the town but had not made a serious demonstration at any point. On November 20 , offensive lines began to appear as Longstreet ordered the construction of entrenchments. To strengthen their "diggings," the Union troops reinforced their lines with every material on hand. 
United States Department of the Interior National Park Service

\section{National Register of Historic Places Continuation Sheet}

Civil War Era National Cemeteries

\author{
Knoxville National Cemetery
}

Knox County, Tennessee

\section{NARRATIVE STATEMENT OF SIGNIFICANCE (Continued)}

Fort Sanders was the most heavily fortified emplacement. The west front of this fort was in the vicinity of 17th Street between Clinch and Laurel Avenues, with the northwest bastion near the present site of Fort Sanders Manor, an apartment building at the intersection of 17th and Laurel. Both sides knew that, although this fort was constructed according to classical engineering principles, with a profile of moat, embankment, and parapet, its northwest bastion, a prominent salient in the main Union line of defense, had been built upon a hill that fell off sharply to the northwest. Beneath the brow of this hill a large attacking force could approach within 100 yards without being exposed to view or to fire either from the fort or from the adjacent rifle pit.

By the night of November 20, the physical divisions of offensive and defensive lines were clearly drawn. On Saturday, November 21, the fifth day of the siege of Knoxville, there was no significant change in the positions of the lines. Longstreet's philosophy of attack was to move into enemy territory, select a defensive position, and entice the enemy into attacking from a disadvantageous angle. But Burnside, whose mission was defensive, had no intention of leaving his fortifications and attacking in open ground.

Sunday, the 22nd, there was less firing than usual, but several Union men were hit by Rebel snipers as the guard was changed in daylight hours at Fort Sanders. On the 23rd, Longstreet received word from Bragg that a large force was advancing from Kingston against the Confederates at Knoxville. Longstreet immediately withdrew most of Wheeler's cavalry from the line and sent them toward Kingston to block the progress of the unknown force pressing from the rear. Bragg, sensing an attack upon his own position at Missionary Ridge, decided to recall Longstreet from Knoxville. He dispatched Brigadier General Danville Leadbetter, his chief engineering officer, to Longstreet to personally urge either an immediate Confederate assault or a hasty withdrawal. The night of the $23 \mathrm{rd}$, the Union picket lines between First and Second creeks were driven in, and it appeared that a general engagement would result. Burnside ordered his troops to set fire to the long line of buildings north of the railroad between the two armies. Flames lighted up the wintry sky and the whole town was illuminated by the blazing buildings.

Tuesday, November 24, there was very little picket firing. Most of the day, the Confederates were occupied in establishing their rifle guns on Cherokee Heights south of the river, from which they could enfilade the western side of Fort Sanders. The attack was ordered to commence at sunrise of the 25th. Before orders could be issued to the subordinate officers, Longstreet learned that the brigades of Generals Bushrod Johnson and Archibald Gracie, about 2,600 men, were on their way to reinforce him and would arrive the night of the 25 th from Loudon. The attack was postponed once again. General Leadbetter arrived at Longstreet's headquarters after dark on the 25th with orders from Bragg to attack 


\section{National Register of Historic Places Continuation Sheet}

Section number
Civil War Era National Cemeteries

Knoxville National Cemetery

Knox County, Tennessee

\section{NARRATIVE STATEMENT OF SIGNIFICANCE (Continued)}

and crush Burnside quickly. Longstreet suggested that with more reinforcements expected that evening and in the next few days, Union troops could be starved into surrender without the needless expense of Confederate lives in an assault that may not be successful. He added that if an assault must be made, it should be directed against the northwest bastion of Fort Sanders. Leadbetter agreed but requested that the final decision be delayed until he could make a thorough reconnaissance of the Federal lines and concluded that an attack upon Mabry's Hill was impossible. On Saturday, November 28, the siege of Knoxville went into its twelfth day and General Leadbetter delivered General Bragg's order to attack immediately. Longstreet ordered General McLaws to strike at Fort Sanders as soon as it became visible in the morning sun of the 28th, but it was extremely cold and foggy. Once more, Longstreet canceled the attack order. The attack was then to begin in the darkness of the 28th just before sunrise, preceded by only a few rounds of artillery fire to encourage the infantry, and the assault would be made by the infantry alone. As the Rebel sharpshooters advanced into position about eleven o'clock that evening, Burnside's entire command was alerted to the point of attack. During the cold night of November 28, the Union soldiers ate and slept fully armed. Just before dawn on November 29, the Confederate troops moved forward. The bloody fight lasted only twenty minutes. The confederates felt that without ladders they were not given a fair chance, and they wanted another crack at the fort. General Jenkins pleaded with Longstreet and finally obtained permission to renew the assault. While plans were being made, a courier suddenly arrived with a telegram which President Jefferson Davis sent to Major General Robert Ransom to relay to Longstreet. General Grant had driven Bragg's army from Missionary Ridge and Longstreet was ordered to join Bragg near Ringgold or Dalton, Georgia. As soon as it became evident to General Burnside that the assault was over, he ordered General Potter to arrange a thirty-minute truce with Colonel Sorrel of Longstreet's staff in order to care for the wounded and bury the dead. The attacking Confederate troops sustained 813 casualties-- 129 killed, 458 wounded, and 226 missing. Union losses in the fort were reported as 5 killed and 8 wounded. At 7 p.m. on November 29, a single cannon's roar marked the end of the truce. The victorious Union Army was once again besieged in Knoxville. The "defeated" Confederate army was still in a position to starve the Union army into surrender or to capture it by another assault. At midnight on December 4, 1863, as the men in Fort Sanders were standing to arms, something of an unusual nature was observed going on in the Confederate camps.

They made wild speculations. Some thought the Confederates were preparing for one final assault, others that they were retreating. At daylight, Captain Ames, Company B of the 36th Massachusetts, discovered that the Confederates were indeed gone. The siege of Knoxville was over. 
NPS Form 10-900-a
$(8-86)$

OMB No. 10024-0018

United States Department of the Interior

National Park Service

National Register of Historic Places Continuation Sheet

Civil War Era National Cemeteries

Knoxville National Cemetery

Section number

Page

Knox County, Tennessee

\section{NARRATIVE STATEMENT OF SIGNIFICANCE (Continued)}

The Knoxville National Cemetery was established in September 1863. Bodies were removed in Tennessee from Tazewell, Claiborne County, 15 miles north; from Concord, Knox County, 20 miles west; from Christianburg, Montgomery County, in Virginia, 200 miles east; from Asheville, Buncombe County, in North Carolina, 80 miles south, and from various places within those limits; and from the cemetery at Cumberland Gap, in Claiborne County, Tennessee.

The Knoxville National Cemetery consists of 9.8 acres. The property was formerly owned by John Damron, who on June 10,1867, in accordance with an appraisement made by a decree of the Court, conveyed the same to the United States, in fee simple, for the sum of $\$ 5,000$.

\section{MAJOR BIBLIOGRAPHICAL REFERENCES}

National Cemetery System Microfilm Records

Department of Veterans Affairs Historic Preservation Office

Report of Inspector of the National Cemeteries of the United States for 1869

Report of the Inspector of the National Cemeteries for the years 1870 and 1871

Seymour, Digby Gordon. Divided Loyalties. University of Tennessee Press, 1963. East Tennessee Historical Society, 1982.

Moffatt, Frederick C. A Tale of Two Monuments: Civil War Sculpture in Knoxville East Tennessee Historical Society.

\section{GEOGRAPHICAL DATA - VERBAL BOUNDARY DESCRIPTION}

The boundaries are indicated on the accompanying base map. 
NPS Form 10-900-a

(8-86)

OMB No. 10024-0018

United States Department of the Interior

National Park Service

National Register of Historic Places

Continuation Sheet

Civil War Era National Cemeteries

Section number

Page

Knoxville National Cemetery

Knox County, Tennessee

\section{BOUNDARY JUSTIFICATION}

The National Cemetery System has used the existing boundaries of the cemetery. 


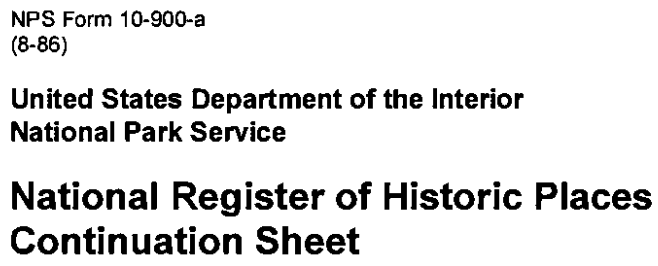

Knoxville National Cemetery Knox County, Tennessee
OMB No. $10024-0018$

Civil War Era National Cemeteries

KNOXVILLE NATIONAL CEMETERY

City of Knoxville, Tennessee

Armando A. Sammartino, photographer

Dates of Photographs: November 12 and 13, 1995

All negatives are stored with Technical Support Service (401B), National Cemetery System, Department of Veterans Affairs, 810 Vermont Avenue, N.W., Washington, D.C. 20420

VIEW OF: Entrance gate, view looking southwest

NEG. NO. 49949-1

PHOTO 1 of 17

VIEW OF: Flagpole, view looking west NEG. NO. 49949-11

PHOTO 2 of 17

VIEW OF: Service building (office portion), southeast elevation NEG. NO. 49949-15

PHOTO 3 of 17

VIEW OF: Service building, southeast elevation NEG. NO. 49949-14

PHOTO 4 of 17

VIEW OF: Service building, southwest elevation

NEG. NO. 49949-16

PHOTO 5 of 17

VIEW OF: Service building, northwest elevation

NEG. NO. 49949-21

PHOTO 6 of 17
VIEW OF: Monument, northeast elevation

NEG. NO. 49949-6

PHOTO 7 of 17

VIEW OF: Monument, northwest elevation NEG. NO. 49949-4

PHOTO 8 of 17

VIEW OF: Monument, southeast elevation

NEG. NO. 49949-8

PHOTO 9 of 17

VIEW OF: Monument, southwest elevation NEG. NO. 49949-9

PHOTO 10 of 17

VIEW OF: Stained-glass window on southeast elevation of monument

NEG. NO. 49949-10

PHOTO 11 of 17

VIEW OF: Rededication plaque at cemetery entrance

NEG. NO. 49949-3

PHOTO 12 of 17 
NPS Form 10-900-a

(8-86)

OMB No. 10024-0018

United States Department of the Interior

National Park Service

National Register of Historic Places Continuation Sheet

Section number

Page

Knoxville National Cemetery

Knox County, Tennessee

VIEW OF: Cemetery, view looking northwest

VIEW OF: Cemetery, view looking southwest showing portion of perimeter wall

NEG. NO. 49949-23

NEG. NO. 49949-18

PHOTO 13 of 17

PHOTO 16 of 17

VIEW OF: Cemetery, view looking west

VIEW OF: Cemetery, view looking east,

NEG. NO. 49949-22

PHOTO 14 of 17

showing several private monuments

NEG. NO. 49949-12

PHOTO 17 of 17

VIEW OF: Cemetery, view looking west

showing portion of perimeter wall

NEG. NO. 49949-17

PHOTO 15 of 17 

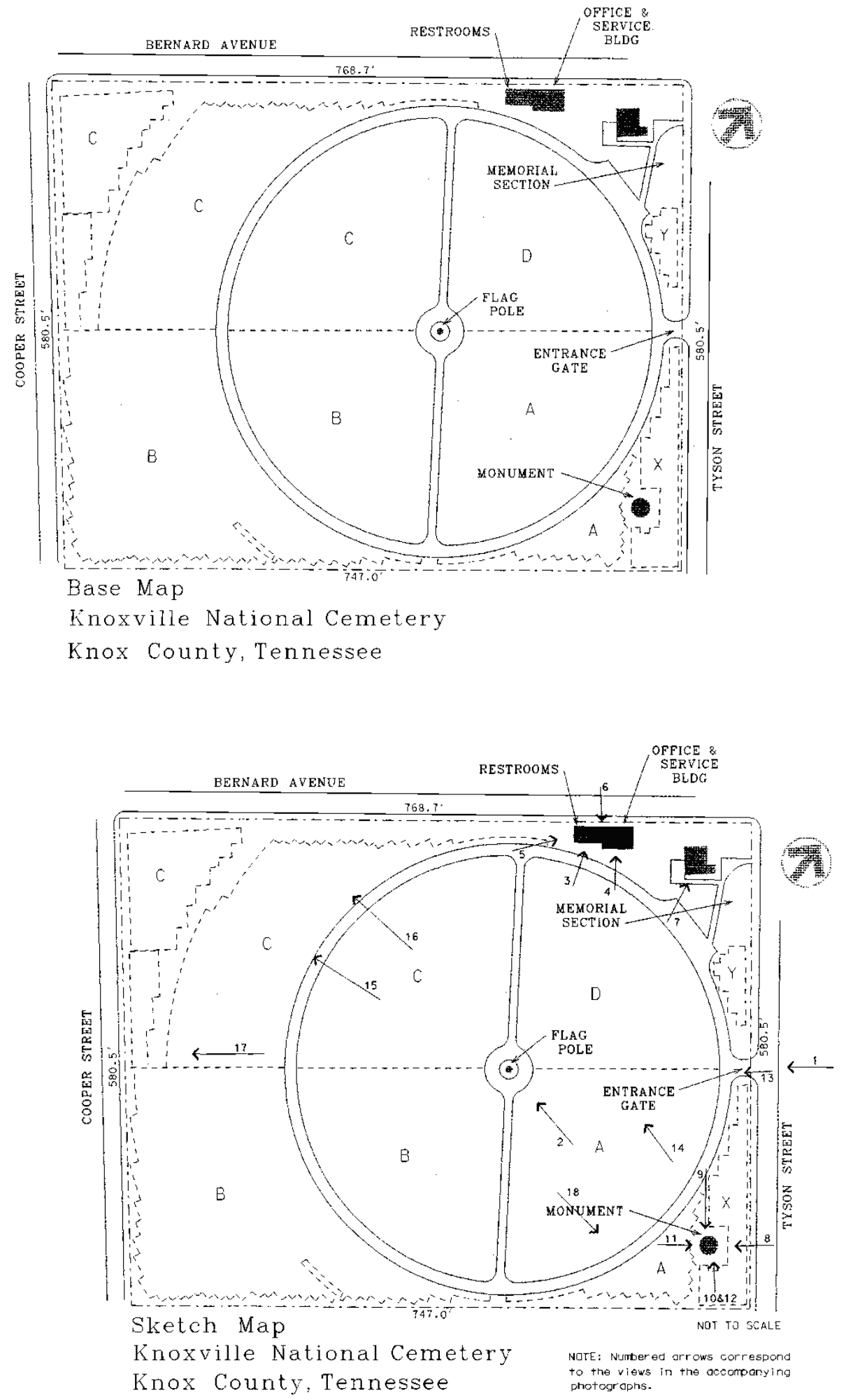


\subsection{National Register Eligibility of National Cemeteries - A Clarification Policy (9/8/2011)}

In 2011, the NRHP staff clarified certain aspects of nominating National Cemeteries to the NRHP and their component parts and character-defining features. The key parts of this clarification policy are that "The period of significance for a National Cemetery is the period of time beginning with the date of the earliest burials and extending to the present." It also clarified that "...component resources contribute to the cemetery's significance regardless of their age, function, or administrative role." In addition, "Certain smaller-scale features, such as grave markers, street signs, water fountains, curbs and culverts, and plantings are considered integral to the overall contributing site and its identity as a National Cemetery; these should be described collectively as significant or character-defining features of the site in Section 7 of the National Register form but do not need to be classified and counted separately." 224 Figure 77 reproduces the NRHP's four-page clarification policy.

\footnotetext{
224 National Park Service, National Register of Historic Places, "National Register Eligibility of National Cemeteries-a Clarification of Policy," (Washington, DC: NRHP, 08 September 2011). Accessed online: https://www.cem.va.gov/CEM/pdf/Final_Eligibility of VA cemeteries A Clarification_of Policy rev.pdf.
} 
Figure 77. Reproduction of "A Clarification of Policy" for National Register Eligibility of National Cemeteries, 2011 (NPS).

\begin{abstract}
National Register Eligibility of National Cemeteries - A Clarification of Policy - A Clarification of Policy $(9 / 8 / 2011)$
\end{abstract}

$\underline{\text { Summary }}$

All national cemeteries are considered exceptionally significant as a result of their Congressional designation as nationally significant places of burial and commemoration. This means they meet the special requirements set forth in the National Register Criterion Considerations for cemeteries, graves, commemorative properties, and resources less-than-50 years of age. It also means that for the purpose of documenting a national cemetery as a National Register district, facilities and sections developed within the past fifty years are considered significant and are eligible for National Register listing as contributing resources. While most national cemeteries fall under the jurisdiction of the U.S. Department of Veterans Affairs, several others are managed by either the National Park Service or the U.S. Department of Defense.

\title{
Background
}

National cemeteries continue to expand, and many include land held for future development. For this reason, questions typically arise about the selection of boundaries and the contributing/noncontributing status of parcels of land within a cemetery's boundaries. Based on prior agency to agency consultations, the Keeper of the National Register in June 1981 sent a letter to the Federal Preservation officer of the Veterans Administration (after 1989 known as the Department of Veterans Affairs) clarifying a policy that applied to the National Register eligibility and the unique set of issues associated with the eligibility of national cemeteries-properties considered ever-changing and recognized for their continuing exceptional importance.

The following statement of policy was consequently set forth on page 36 of the National Register Bulletin, How to Apply the National Register Criteria for Evaluation:

National Cemeteries administered by the Veterans Administration are eligible because they have been designated by Congress as primary memorials to the military history of the United States. Those areas within a designated national cemetery that have been used or prepared for the reception of the remains of veterans and their dependents, as well as any landscaped areas that immediately surround the graves may qualify. Because these cemeteries draw their significance from the presence of the remains of military personnel who have served the country throughout its history, the age of the cemetery is not 
a factor in judging eligibility, although integrity must be present. A national cemetery or portion of a national cemetery that has only been set aside for use in the future is not eligible.

This statement clarified that, for evaluating National Register eligibility, the age of a national cemetery was not a determining factor and that sections of the cemetery prepared for use or already in use were differentiated from unimproved land that was not ready to receive burials. Recent efforts to nominate national cemeteries have raised additional questions and are addressed in this clarification of policy.

\section{Classification}

Because they contain a combination of resource types and cover substantial acreage, national cemeteries are considered historic districts for the purposes of National Register listings and determinations of eligibility. Generally national cemeteries are significant under criterion A for their association with significant events related to the nation's military history and the role of the Department of Veterans Affairs. Those having artistic or architectural significance as designed landscapes or for the design of memorials, monuments, or historic buildings, may also be documented under Criterion $\mathrm{C}$.

Regardless of the date of acquisition or construction, the overall acreage within the boundaries of the cemetery that has been developed for cemetery purposes is considered one contributing site for National Register purposes. This site includes commemorative sections of the cemetery containing existing graves and memorials, sections having the infrastructure necessary to receive new interments and memorials (for example, streets, utilities, pre-placed crypts, columbaria, and memorial walkways), and areas of the cemetery developed for administrative and maintenance purposes (offices, restrooms, garages, and maintenance yards). Unimproved acreage within the cemetery boundaries that is being held for future use is considered noncontributing; although it does not need to be counted as a separate noncontributing site, its location and approximate size should be described in Section 7 of the National Register nomination and indicated on the sketch map for the district. As additional sections are developed in the future, the National Register documentation can be updated with continuation sheets describing the newly developed section and revising the description of the acreage considered contributing. In cases where new land is acquired after National Register listing, the more involved process for expanding boundaries set forth in 36 CFR Part 60.14(a) will need to be followed to update the nomination. 
Buildings, structures, or objects that are substantial in size or scale or have special importance are to be classified according to the definitions provided on page 15 of the National Register Bulletin, How to Complete the National Register Registration Form. Certain smaller-scale features, such as grave markers, street signs, water fountains, curbs and culverts, and plantings are considered integral to the overall contributing site and its identity as a national cemetery; these should be described collectively as significant or character-defining features of the site in Section 7 of the National Register form but do not need to be classified and counted separately.

\section{Period of Significance}

The period of significance for a national cemetery is the period of time beginning with the date of the earliest burials and extending to the present. A closing date of "present" allows the recognition of the highly significant values these places have had in the recent past (for example, honoring those killed in recent wars). This policy means that recently developed areas are to be included within the boundaries of the historic district and recently constructed resources are to be recognized as contributing resources. Land acquired for future development but not yet developed can be included in the National Register boundaries but will not be considered contributing.

The period of significance for a national cemetery may include development that occurred before its designation as a national cemetery, and resources in place at the time of nomination may be considered contributing. It is anticipated that most cemeteries will represent multiple layers of expansion with new sections being acquired and developed for use periodically as available grave sites are depleted.

Several other possible closing dates were considered. It was suggested that "1973," the date when the majority of military cemeteries was transferred from the U.S. Army to what is now the National Cemetery Administration, be used as an end date for all national cemeteries. While "1973" is a date of great importance in the administration of the nation's programs to provide burial benefits to veterans and their families, it is not a date that applies to the continuing evolution of these places as national cemeteries or to the ongoing program of cemetery administration. That year may mark the beginning of a new stage in the history of national cemetery management, but it doesn't qualify as the endpoint of historically significant activities.

The suitability of using the date fifty years before the present as the closing date was also considered. While this approach is often taken in National Register nominations, it often results in an arbitrary end date and, in the case of properties having continuing significance, warrants frequent revision. For 
national cemeteries, which by their designation are deemed in perpetuity exceptionally important, such a date has little meaning and precludes recognition of the highly significant values these places engender as they receive more burials and continue to honor those who have served the nation. A question was also raised about inactive cemeteries and the suitability of ending the period of significance for such a cemetery with the date it was officially closed to new burials. While such a date may be meaningful from a historical perspective, it does not take into consideration the ongoing role and exceptional importance of national cemeteries as public places of commemoration and honor even if new burials can no longer be accommodated. After closely examining this issue, the National Register has determined that the "present" is the end date most consistent with the Congressional intent of the federal laws establishing the national cemeteries and with the National Register policies for evaluating properties of continuing exceptional importance.

\section{Boundaries}

The boundaries of an eligible historic district for a national cemetery can be based on the current land holdings of the federal agency responsible for managing the cemetery. National Register boundaries should encompass all portions of the land that are used for burial, commemorative, and administrative purposes, including recently improved areas and new construction. To avoid having to expand the boundaries at a later date, the district can also include any noncontributing acreage currently being held for the future expansion of the cemetery.

\section{Contributing and Noncontributing Resources}

National Register documentation standards require that resources that are substantial in size or scale or importance be classified as contributing or noncontributing. The National Register program recognizes that the contributing resources for a given cemetery may differ in age, function, design qualities, and the way each relates to the mission of the national cemetery program or the operation of the national cemetery. Differences may also exist between those resources that are integral to the nationally significant values and commemorative functions of the national cemetery-including memorials, areas prepared for burials, designed landscape features, and administration buildings-and those that relate to the day-to-day operations of the cemeteryincluding comfort stations, maintenance facilities, and service roads. For National Register purposes, component resources contribute to the cemetery's significance regardless of their age, function, or administrative role. In addition, some resources may reflect additional historical values important at the local, state, or national levels of significance due to their age or history prior to a cemetery's designation. 


\section{Current Conditions}

The existing conditions of the Knoxville National Cemetery were surveyed in November 2019 by Adam Smith, an architectural historian and by Megan Tooker, a landscape architect.

\subsection{Ownership and oversight}

The cemetery is a federal property that is owned and maintained by the U.S. Department of Veterans Affairs National Cemetery Administration. The cemetery is managed as a satellite of the Nashville National Cemetery located in Nashville, Tennessee. The Southeast District of the National Cemetery Administration, with its office located at Atlanta, Georgia, is responsible for projects undertaken at Knoxville National Cemetery, since Tennessee is one of the states within that district.

\subsection{Physical site}

Knoxville National Cemetery is located in Knox County in Knoxville, Tennessee. Knoxville is a city of about 187,000 people in eastern Tennessee. It is the county seat of Knox County. The town was founded in 1786 but was relatively isolated until the coming of the railroad in the 1850 os. After the Civil War, the city grew rapidly as a manufacturing and wholesaling center, but it declined significantly during and after the Great Depression. The Knoxville National Cemetery was established in 1863. At the time, the location of the cemetery north of downtown was on the outskirts of town, but as the town grew, residential and industrial neighborhoods surrounded the almost 10-acre cemetery. The cemetery is bounded by Bernard Avenue on the northwest, Tyson Street to the northeast, the Old Gray Cemetery (Gray Cemetery at some point became Old Gray Cemetery) to the southeast, and Cooper Street on the southwest.

Knoxville is in the Ridge and Valley ecoregion, specifically Southern Limestone/Dolomite Valleys and Low Rolling Hills of Tennessee, and that ecoregion is composed of a mix of "white oak forests, bottomland oak forests, and sycamore-ash-elm riparian forests are the common forest types, and grassland barrens intermixed with cedar-pine glades also occur here." ${ }^{225}$ Climatologically, the area is subtropical and has hot, humid summers and mild winters. In general, the area receives regular rain events, 
with peak rainfall in early spring to midsummer. ${ }^{226}$ The region has a mix of medium and finely textured soils that vary in depth. ${ }^{227}$ Storm water in the cemetery is managed on site with concrete channels that direct flow into the municipal storm water system.

\subsubsection{Topography}

The region's general surface land form are valleys and long hills with elevations of $800^{\prime}$ at the riverfront to $1000^{\prime}$ on various hilltops. ${ }^{228}$ The site of Knoxville National Cemetery on average is $900^{\prime}$, with the highest point occurring at the Main Gate with an elevation of $918^{\prime}$, the flagstaff at $915^{\prime}$, and the lowest spot on Cooper Street at 892' (Figure 78). Overall, the site slopes downward from northeast to southwest. 229

Figure 78. Exaggerated topographic section of Knoxville National Cemetery, 2020 (ERDCCERL).

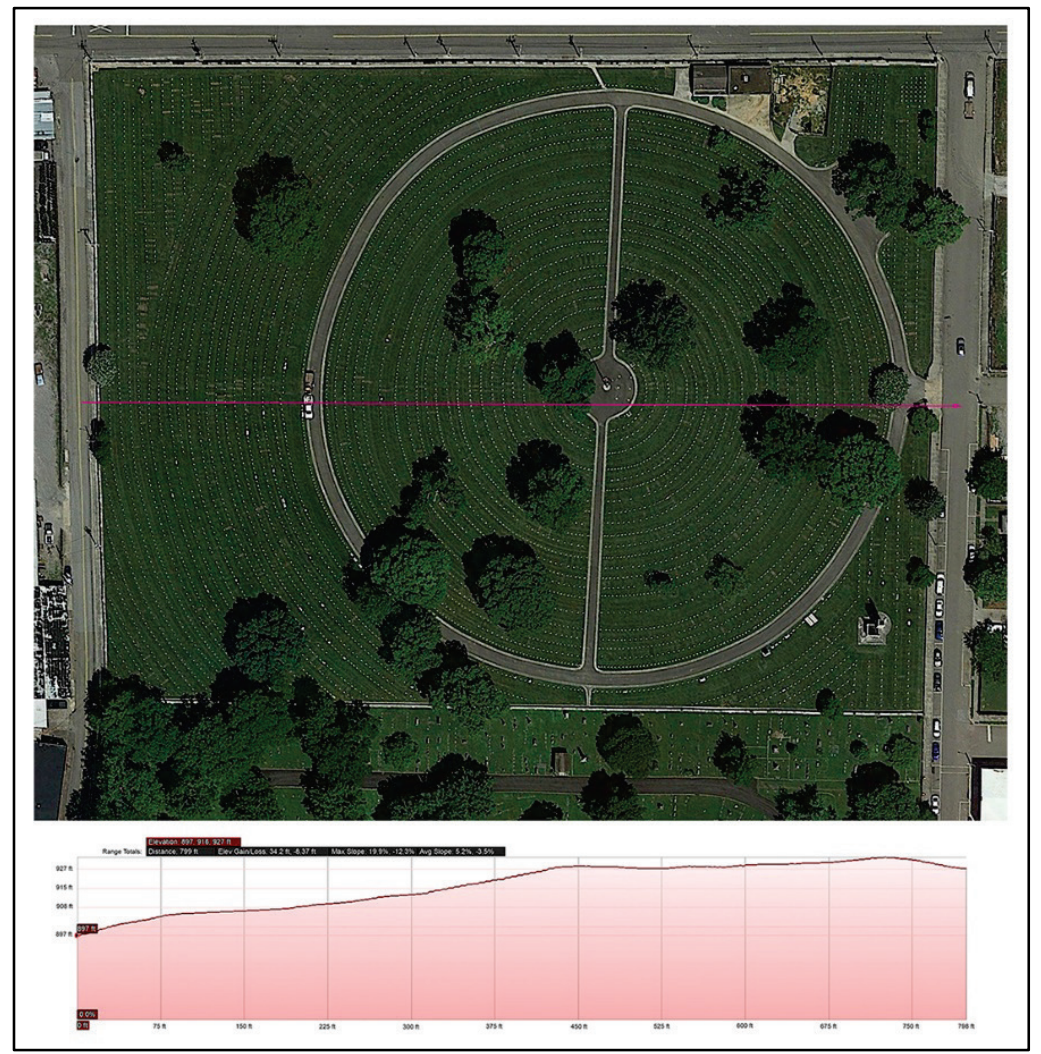

\footnotetext{
226 Tennessee Planting Zones. Accessed online: https://gilmour.com/tennessee-planting-zones.

227 U.S. Department of Agriculture, "Soil Survey of Knox County." Accessed online: https://www.nrcs.usda.gov/Internet/FSE_MANUSCRIPTS/tennessee/knoxTN2006/Knox_TN.pdf. 228 "Knoxville," Accessed online: https://en-us.topographic-map.com/maps/nsr/Knoxville/. 229 "Elevation Finder," Accessed online: https://www.freemaptools.com/elevation-finder.htm.
} 


\subsubsection{Spatial organization}

Knoxville National Cemetery adheres to a standard, shared, spatial organization that reflects military culture. The military has a unique culture with its own system of beliefs, practices, and cultural values associated with hierarchy, uniformity, order, utility, discipline, and patriotism. Those values are symbolized within a military landscape such as a national cemetery. ${ }^{230}$ The National Cemeteries that were designed and constructed to inter the Civil War dead used spatial organization and physical object placements to visually emphasize the values upheld in military culture. Knoxville National Cemetery was designed with those principles, and it features a distinct hierarchy of functional spaces, ordered and uniformly constructed objects and headstones, and manicured vegetation.

Currently, the cemetery is bounded by a stone wall or stone with wroughtiron wall that varies in height due to changes in topography but is around $4^{\prime}$ tall. The cemetery is organized around a circle drive, with the main entrance on the northeast side. A flagstaff is at the center of the circle, and a drive divides the circle into northeast/southwest halves. The center drive encircles the flagstaff. There are eight burial sections, and interestingly, these sections extend across the circle drive.

In the late 1870s, the defining visual expression of the National Cemeterydesigned landscape was the regularly spaced and uniform headstones. At Knoxville, the uniform headstones are arrayed in distinct geometric patterns that delineate burial sections. Throughout the cemetery, the circular design of the headstones emphasizes the hierarchy of the site with the flagstaff at the center.

The most dominant structure on the site is the Union Soldier Monument in the eastern corner of the cemetery. All support buildings are clustered together on the northwest side of the cemetery. The grouping includes a maintenance and restroom building, with a metal fenced open storage area directly on the northeast of it.

\footnotetext{
230 Suzanne Keith Loechl, Susan I. Enscore, Megan Weaver Tooker, and Samuel A. Batzli, Guidelines for Identifying and Evaluating Historic Military Landscapes, ERDC/CERL TR-09-6 (Champaign, IL: ERDC/CERL, 2009), 3.
} 


\subsubsection{Vegetation}

The vegetation within the cemetery includes tall deciduous and evergreen trees, a few small ornamental trees, and very few shrubs. The tree species are typical of the climate zone and include maples, dogwoods, black walnuts, and hollies. Deciduous and evergreen trees are lightly scattered throughout the site with smaller flowering trees near the current and former entrances (Figure 79). Throughout the cemetery, trees have been removed and not replaced, which has altered the original planting plan (Figure 80).

Table 2 lists of trees within Knoxville National Cemetery in November 2019. The only remaining shrubs in the cemetery are two beds of Creeping Juniper (Juniperus horizontalis) planted in front of the restroom building.

Figure 79. Diagram of tree cover in Knoxville National Cemetery, 2020 (ERDC-CERL).

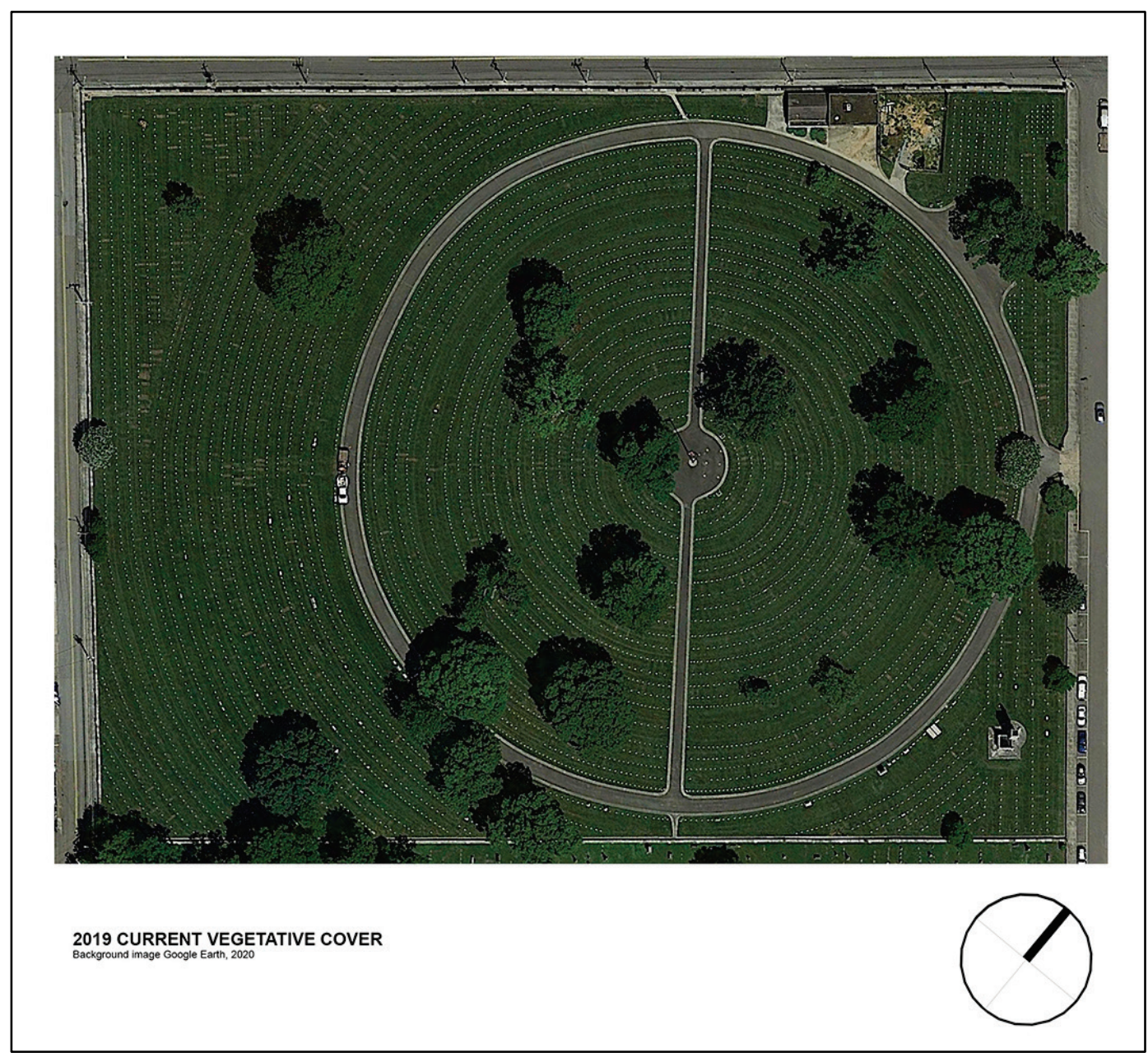


Figure 80. View to the northwest showing scattered spacing of shade trees (ERDC-CERL, 2019).

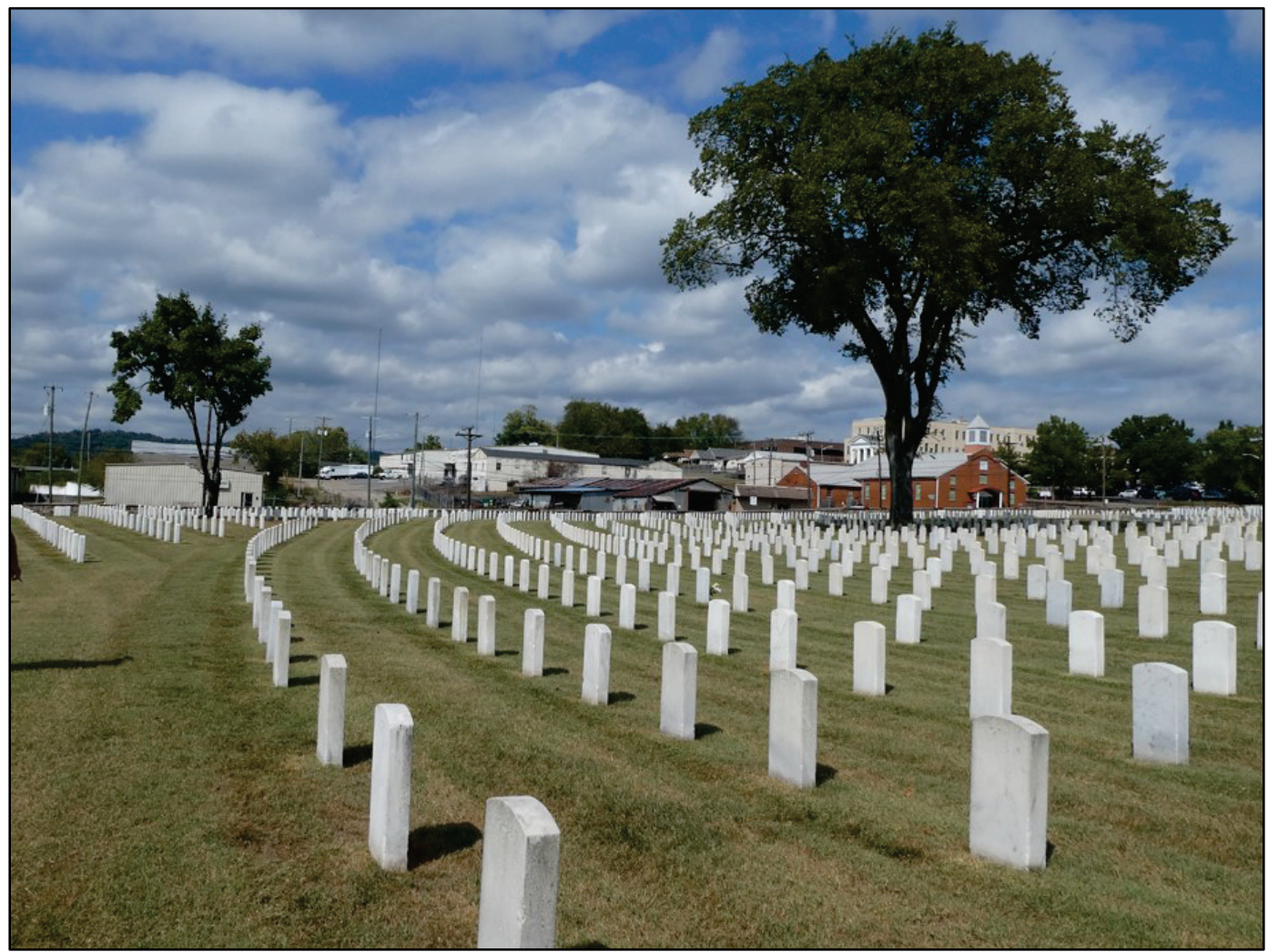

Table 2. List of trees at Knoxville National Cemetery in May 2020 (ERDC-CERL).

\begin{tabular}{|l|l|}
\hline Common Name & Scientific Name \\
\hline Sugar Maple & Acer saccharum \\
\hline Red Maple & Acer rubrum \\
\hline Flowering Dogwood & Cornus florida \\
\hline American Holly & Ilex opaca \\
\hline Black Walnut & Juglans nigra \\
\hline Common Crape Myrtle & Lagerstroemia indica \\
\hline Norway Spruce & Picea abies \\
\hline White Poplar & Populus alba \\
\hline
\end{tabular}

\subsubsection{Circulation}

The entrance road, circle drive, and cross drive are paved, and curbs discourage visitors from driving or parking on the grass (Figure 81). In the northern corner of the cemetery is a small visitor parking area with informational signs. Since there is only a small, designated parking area, vehicles park on the sides of the roads. Pedestrians walk through around the headstones to 
navigate through the cemetery. There are no sidewalks inside the cemetery; there are sidewalks along the streets outside the perimeter fence.

Figure 81. Circulation diagram showing the paved road and parking area in blue, 2020 (ERDC-CERL).

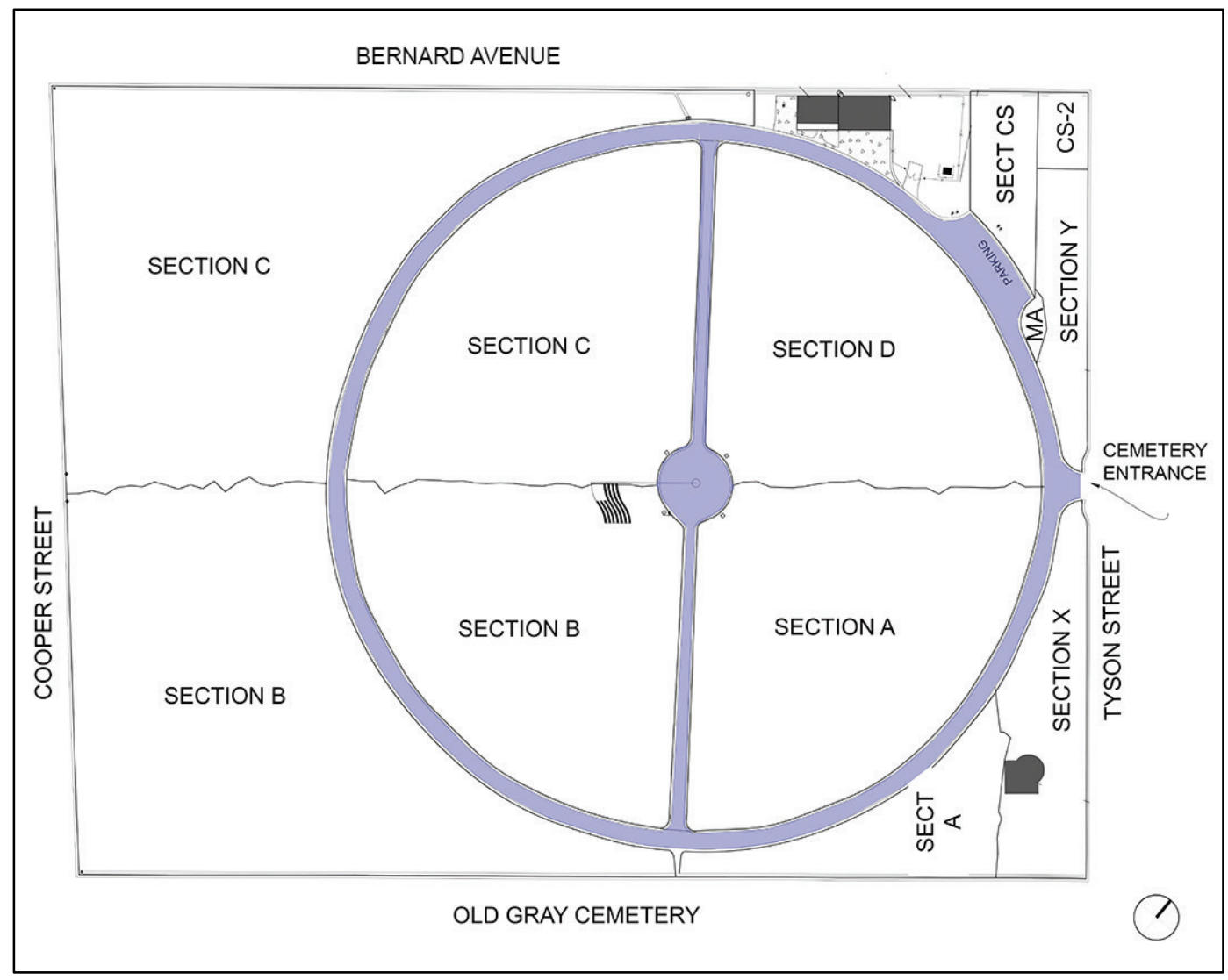

\subsubsection{Road paving materials}

The roads through the cemetery are paved with asphalt and have concrete water gutters running on both sides. (Figure 82). 
Figure 82. Looking south along the circle drive showing the asphalt paving and concrete curbs (ERDC-CERL, 2019).

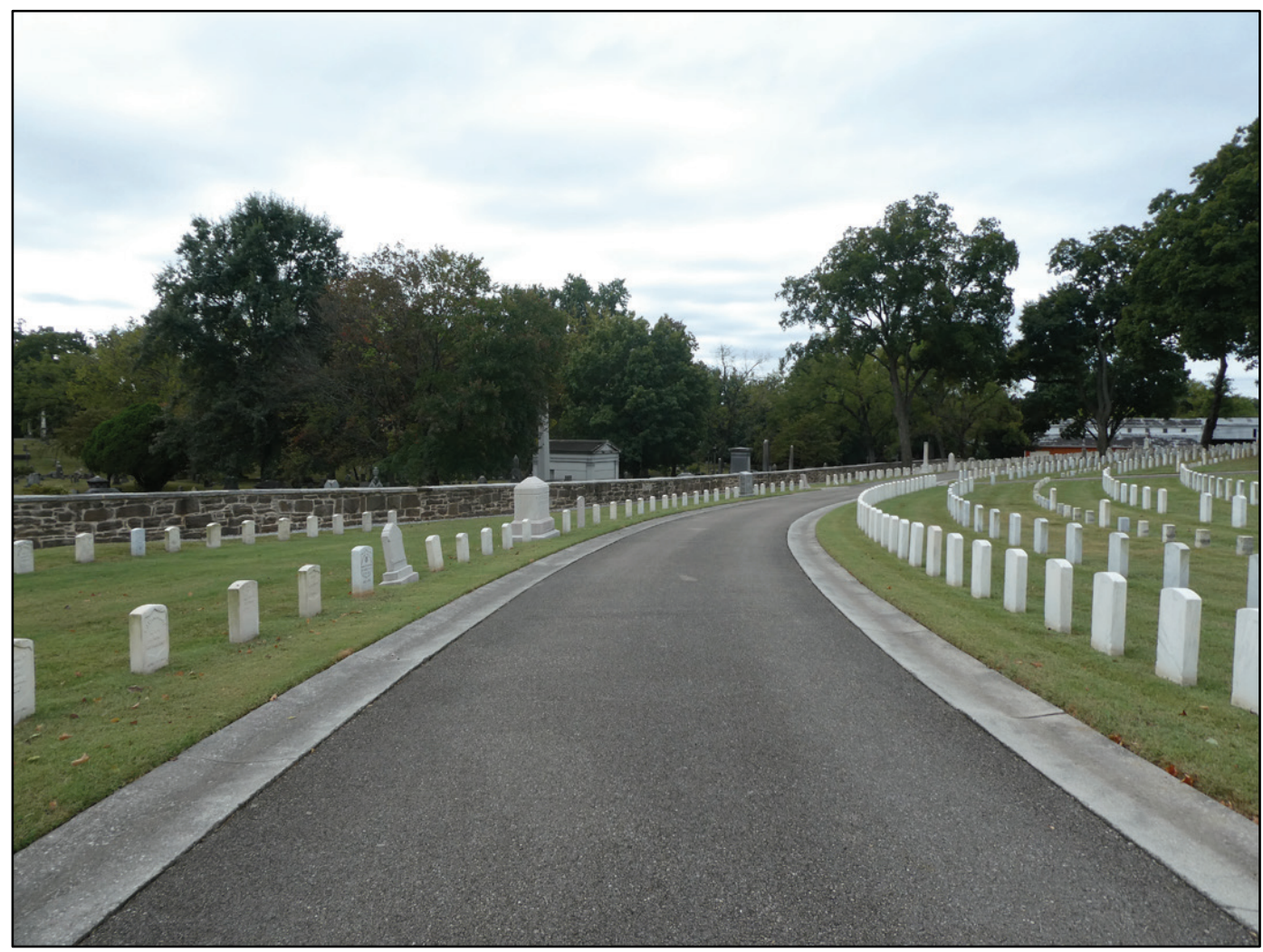

\subsubsection{Sidewalk paving materials}

There are no sidewalks at the Knoxville National Cemetery.

\subsubsection{Buildings}

According to National Register Bulletin \#15, buildings are structures created to "shelter any form of human activity." ${ }^{231}$ At Knoxville National Cemetery, the buildings are the maintenance building with attached restrooms. They are located on the northwest side of the cemetery (Figure 83).

231 NPS (National Park Service), National Register Bulletin \#15: How to Apply the National Register Criteria for Evaluation (Washington, DC: U.S. Department of the Interior, National Park Service, 1997), 4. 
Figure 83. The location of buildings at Knoxville National Cemetery, 2020 (ERDC-CERL).

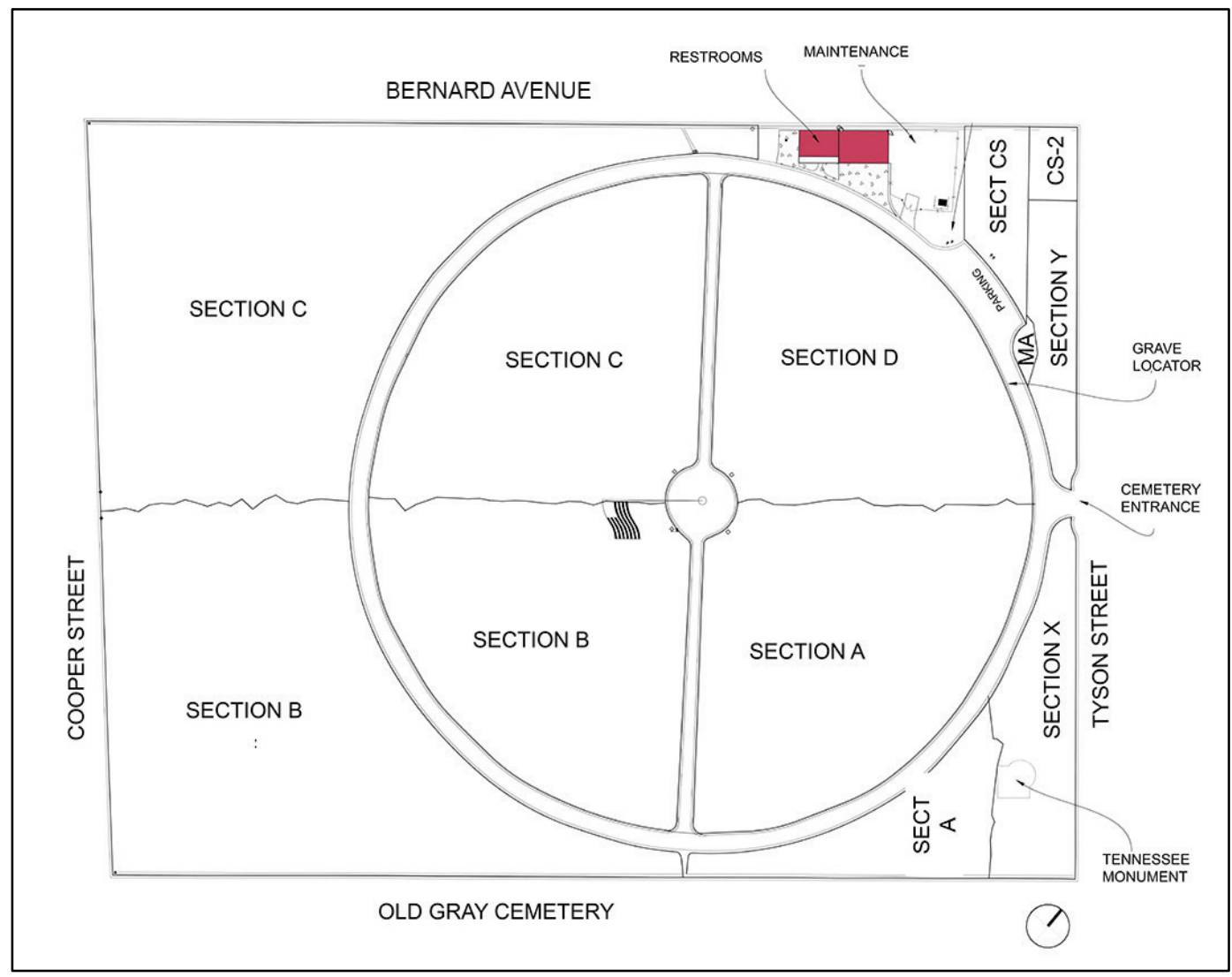

\subsubsection{Restroom building (originally a utility building)}

The restroom building is a one-story, rectangular in shape, clad in red brick, and was constructed in 1936 . The building has a gable roof. It is 20' wide by $31^{\prime}$ deep and is attached on its northeast side to the maintenance building. The building has three doors and two sets of double-hung windows on the southeast side; it is attached to the maintenance building on its northeast side; it has two six-over-six double-hung windows and one door on the northwest side; and it has two small six pane windows on the southwest side. The building has a shallow porch (Figures 84 and 85 ). 
Figure 84. Southeast side of the restroom building (ERDC-CERL, 2019).

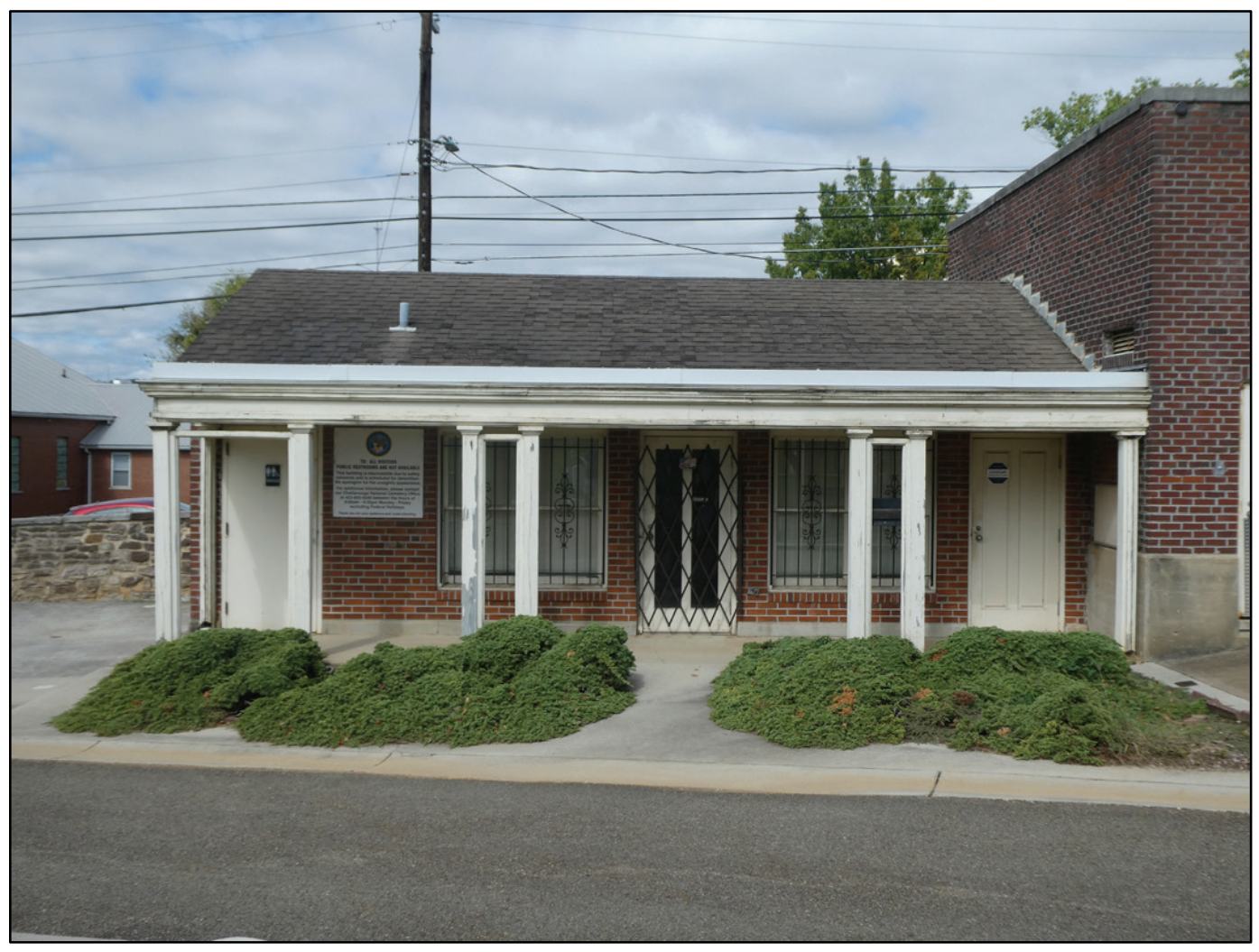

Figure 85. Southwest side of the restroom building (ERDC-CERL, 2019).

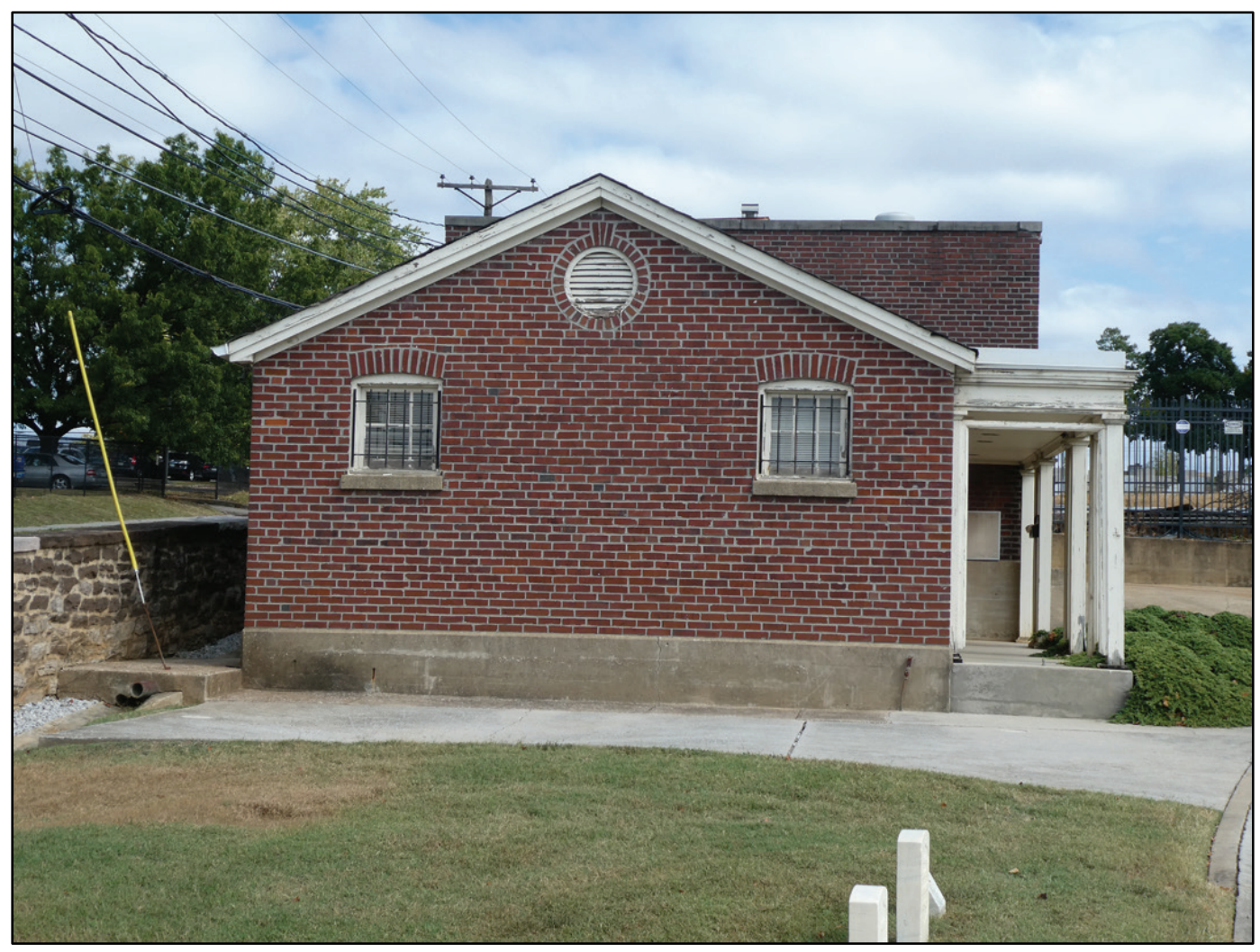




\subsubsection{Maintenance building}

The maintenance building was constructed in 1949. It is a one-story rectangular building clad in brick, and it has a flat roof. It is $25^{\prime}$ wide by $37^{\prime}$, 4 " deep, and is attached on its southwest side to the restroom building. The southeast side has a metal entrance door, a boarded-up window, and a large metal garage door; the northeast side has two six-over-six wood windows; the northwest side has two boarded-up windows; and the southwest side is attached to the restroom building (Figures 86 and 87).

Figure 86. View to the west of the maintenance building on the right and the restroom building on the left (ERDC-CERL, 2019).

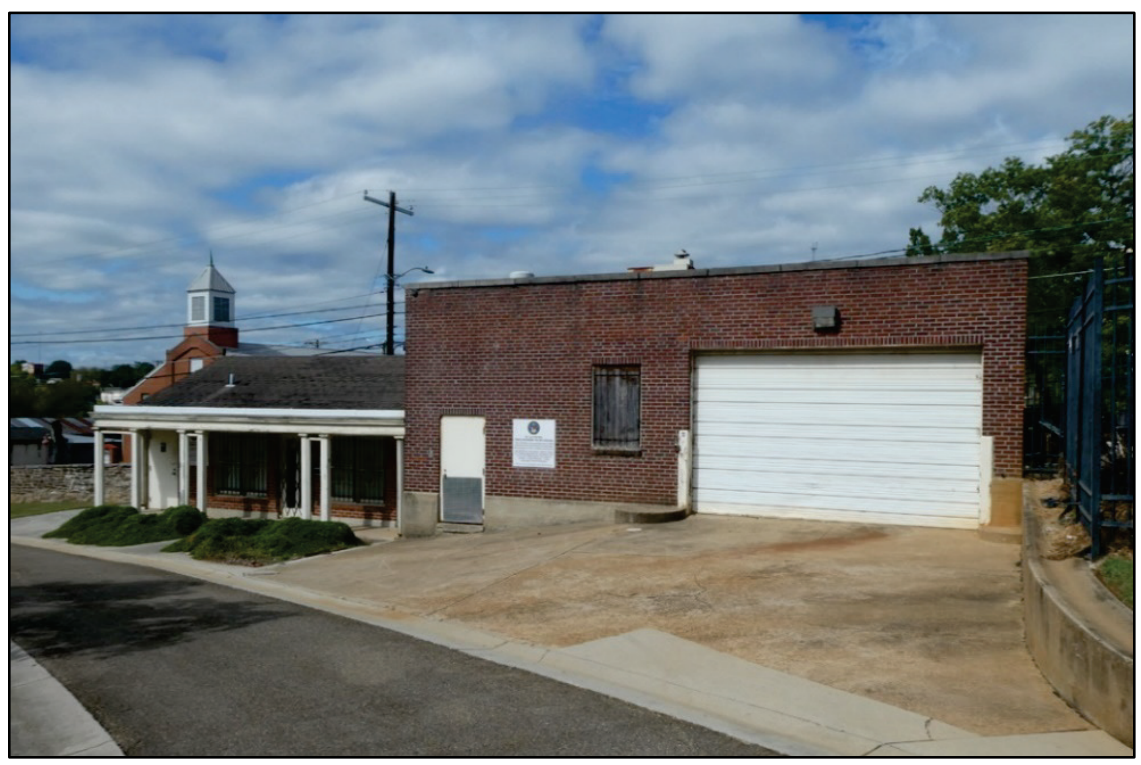

Figure 87. Oblique view of the east corner of the maintenance building (ERDC-CERL, 2019).

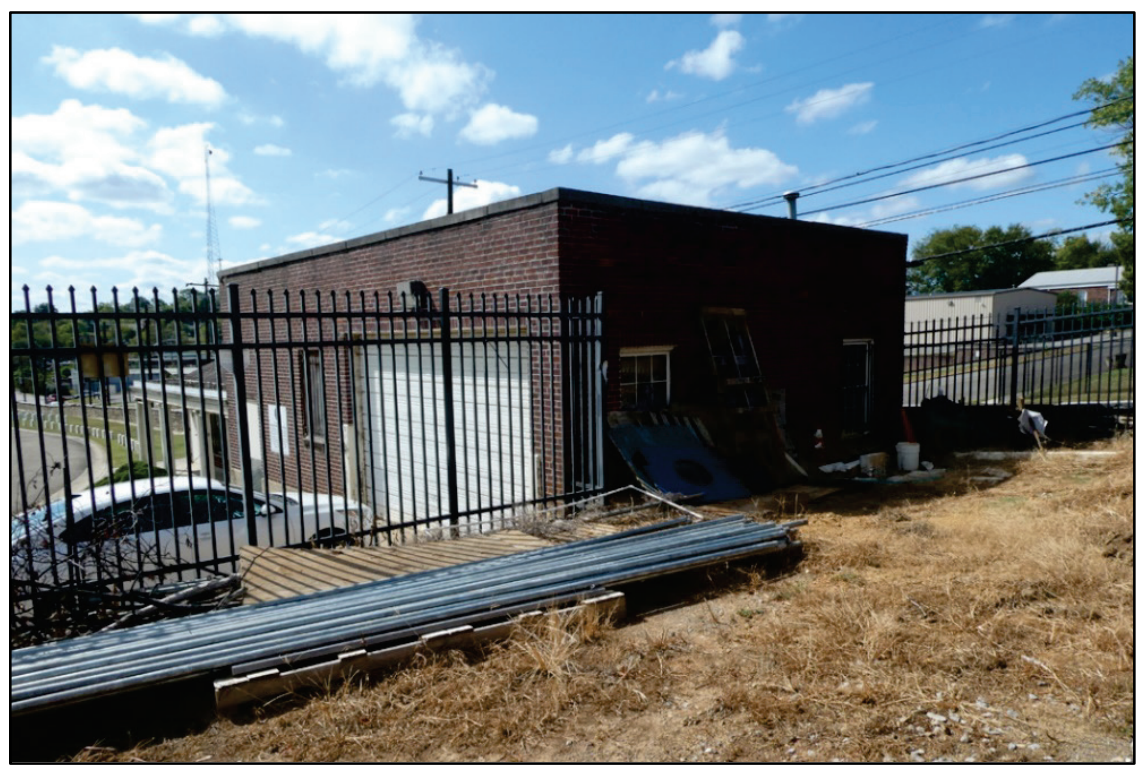




\subsubsection{Structures}

According to National Register Bulletin \#15, structures are used "for purposes other than to create human shelter." ${ }^{232}$ There are three significant structures at the Knoxville National Cemetery-the Union Soldier Monument, the perimeter wall, and the main entrance (Figure 88). There is also a minor structure that protects the grave site information.

Figure 88. The location of structures at Knoxville National Cemetery, 2020 (ERDC-CERL).

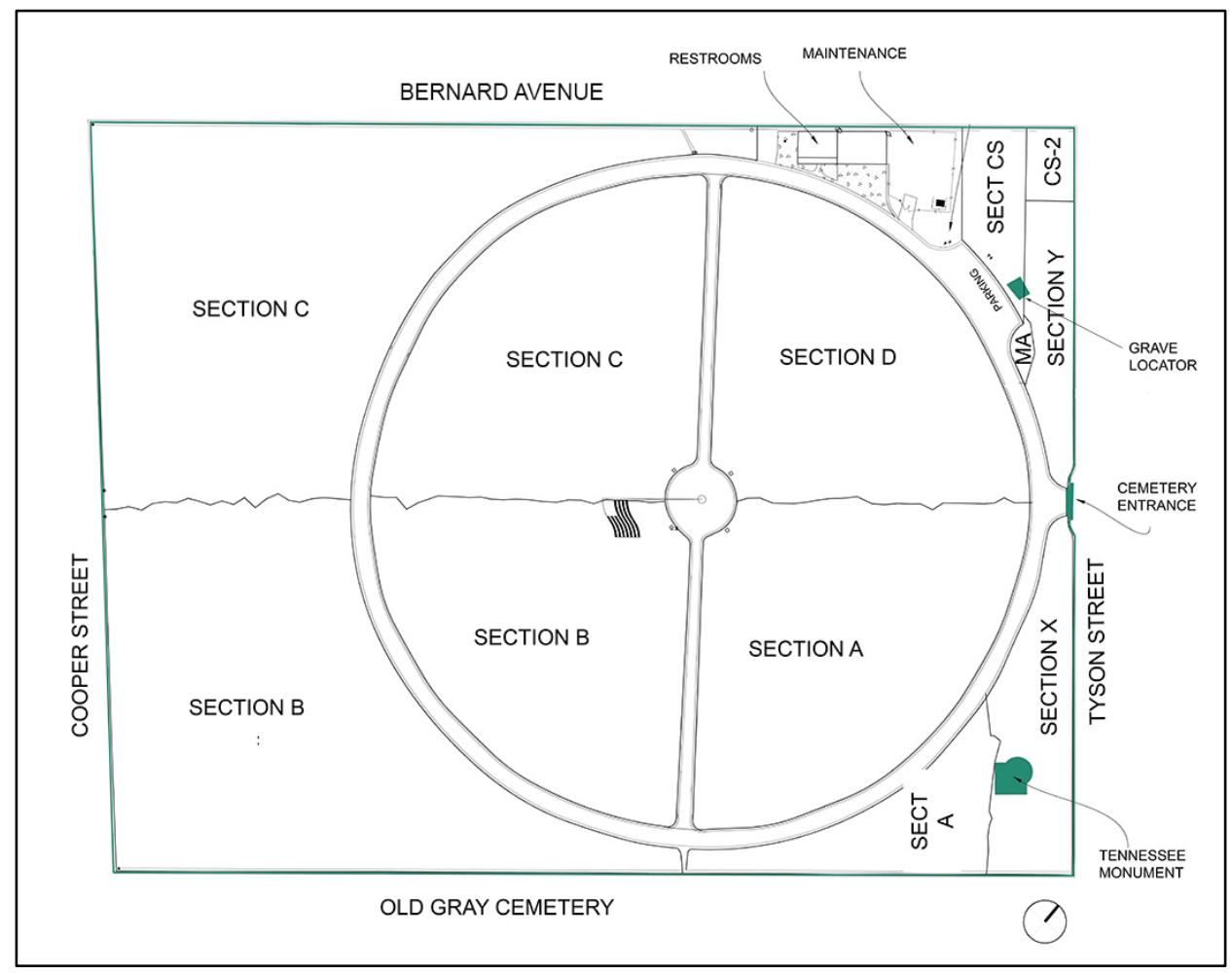

\subsubsection{Union Soldier Monument}

Located at the east corner of the cemetery is the Union Soldier Monument, also referred to as the Tennessee Monument. The monument was originally dedicated in 1901 but was destroyed by lightning in 1904. It was rebuilt in 1906. The monument, which stands 60' tall, is a castle-like structure consisting of a crenulated stone tower attached to a memorial chamber. The chamber interior is accessed through ornate iron gates on two sides of the tower. The chamber features a stained-glass window on the southeast facade. On the top of the tower is a statue of a soldier at parade rest (Figures 89-91). 
Figure 89. Looking southeast at the Union Soldier Monument (ERDC-CERL, 2019).

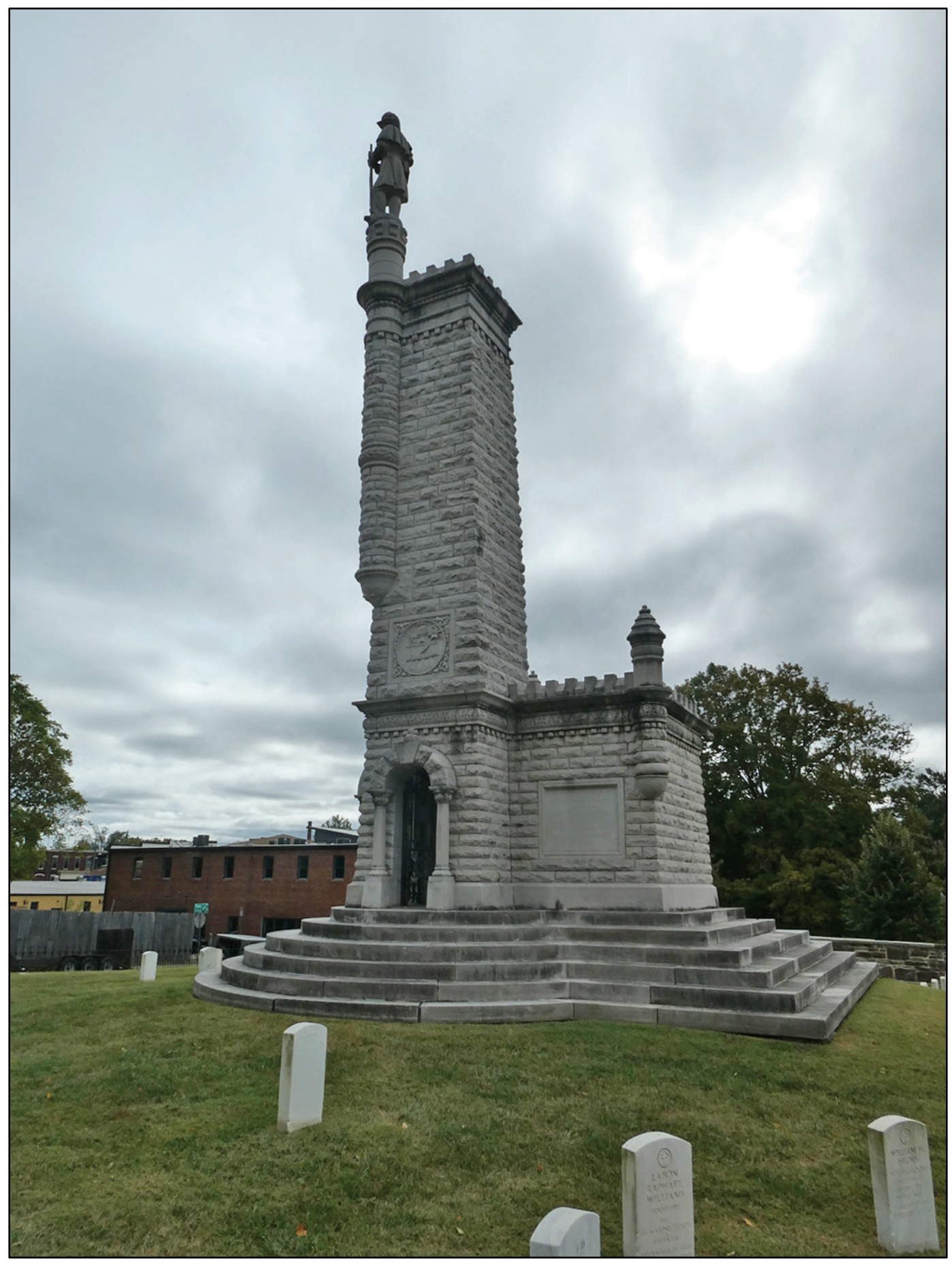


Figure 90. Looking west at the Union Soldier Monument (ERDC-CERL, 2019).

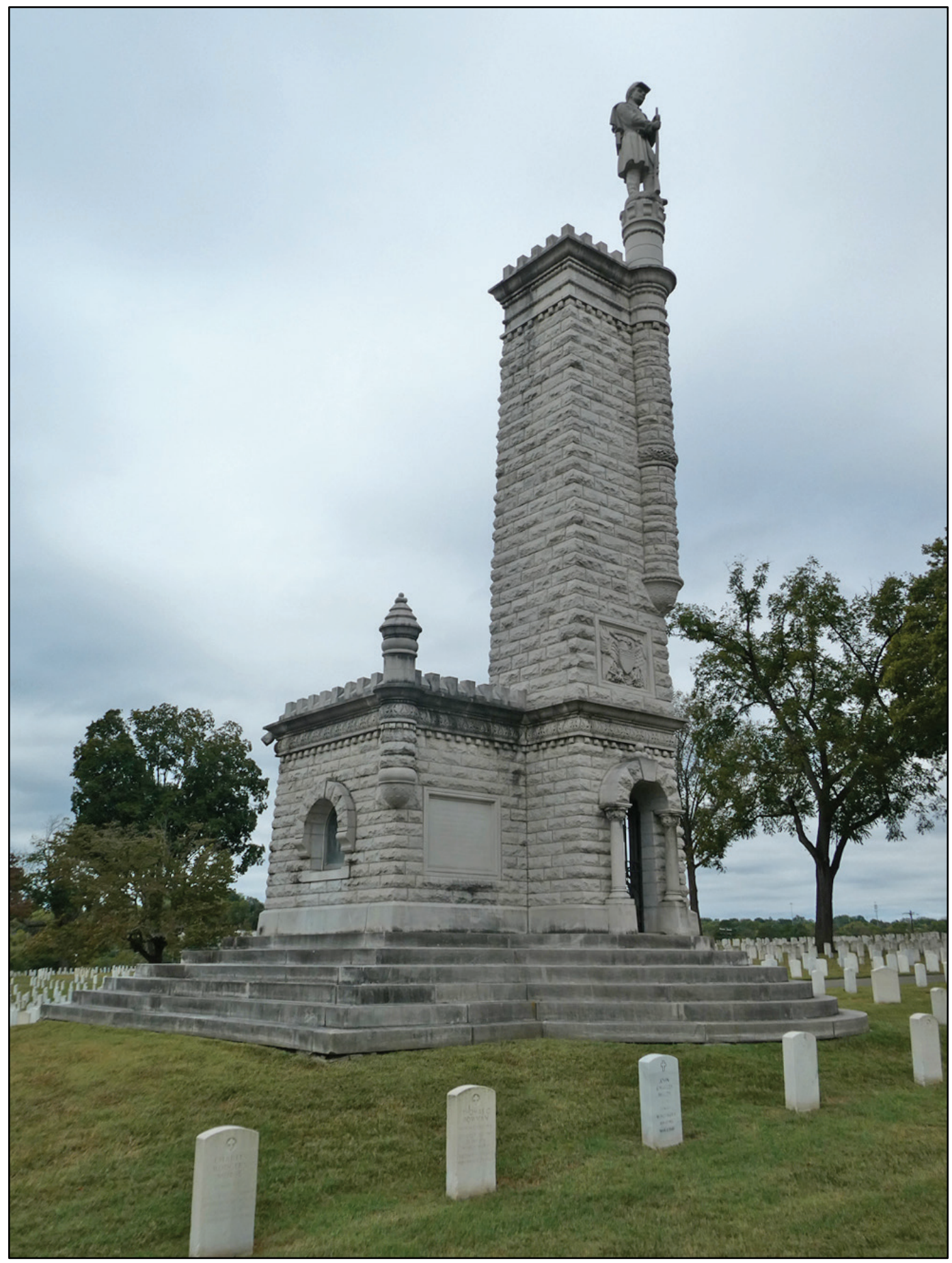


Figure 91. Looking northeast at the Union Soldier Monument (ERDC-CERL, 2019).

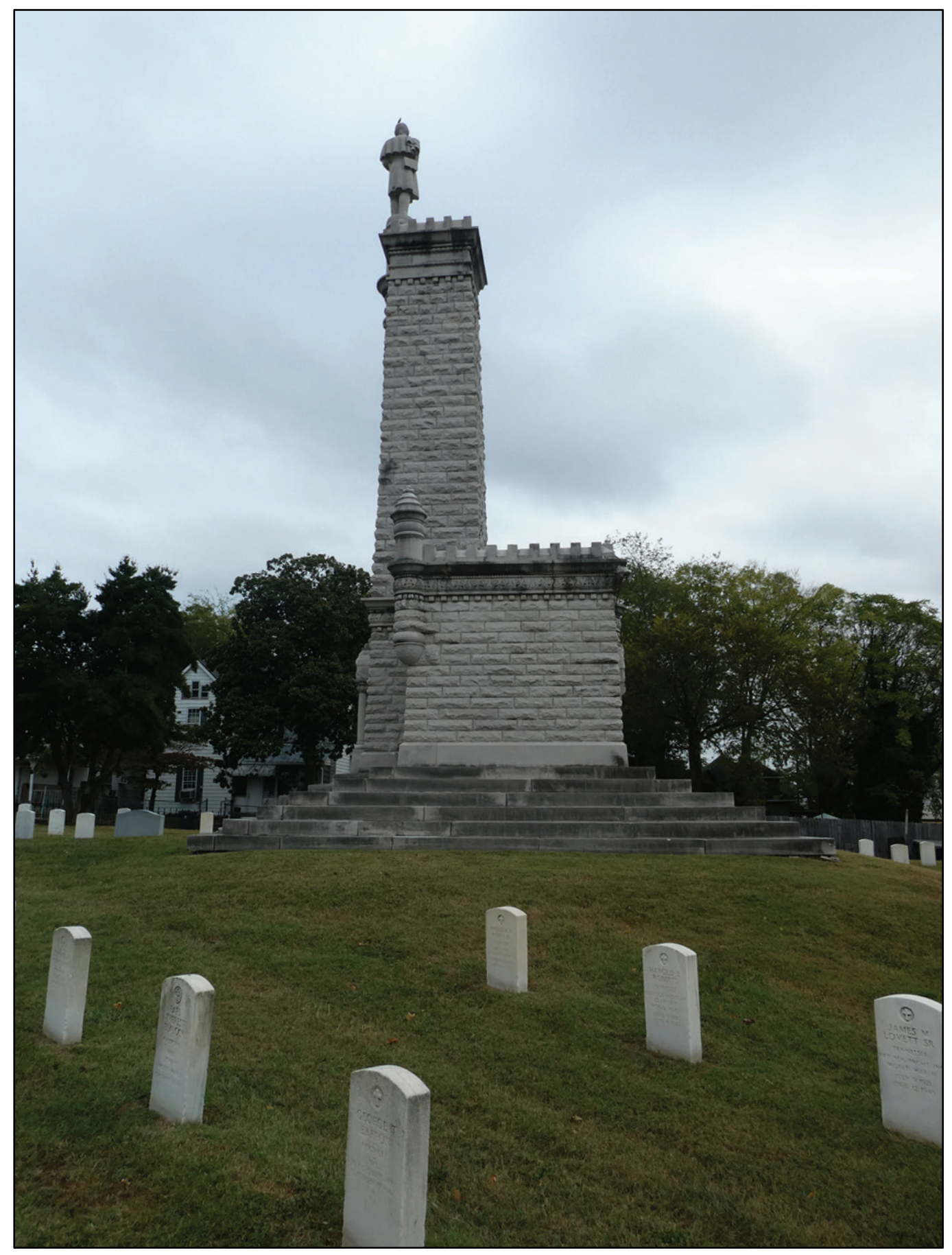

\subsubsection{Perimeter wall}

The perimeter wall is squared-rubble stone. The wall varies in height according to the topography and from the inside of the cemetery to the outside. Generally, on the inside, the wall height is from $2^{\prime}$ to $4^{\prime}$ high, while on the outside it ranges from $4^{\prime}$ to $6^{\prime}$. The Tyson Street wall is topped by stone 
coping and a metal decorative fence (Figure 92). There is a high-aggregate cast concrete pillar at the corner of Tyson Street and Bernard Avenue (Figure 93). The Bernard Avenue wall has a short section of stone wall, topped by stone coping and a metal decorative fence, but for most of its length, it is just capped by stone with larger stone portions every 12' (Figure 94). There is another high-aggregate cast concrete pillar at the corner of Bernard Avenue and Cooper Street. The Cooper Street wall is similar to the one on Bernard Avenue (Figure 95). There is a high-aggregate cast concrete pillar at the south corner that divides the National Cemetery wall from the Old Gray Cemetery wall (Figure 96). The wall that divides the two cemeteries is similar to both the Bernard Avenue and Cooper Street walls (Figure 97). There is no concrete pillar at the east end at the point between the wall of the two cemeteries (Figure 98).

Figure 92. Looking southwest at the Tyson Street wall (ERDC-CERL, 2019).

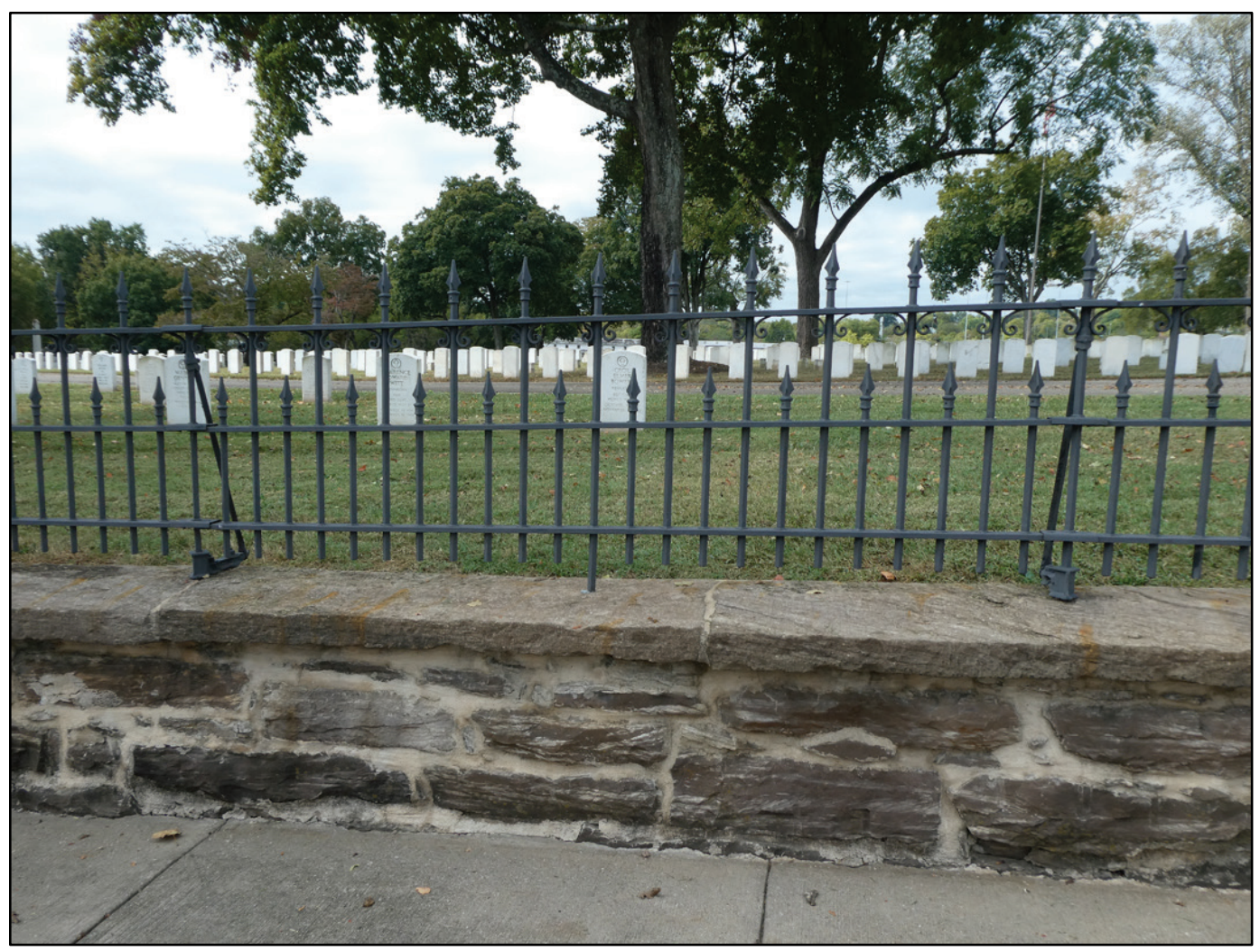


Figure 93. Concrete pillar at the corner of Tyson and Bernard (ERDC-CERL, 2019).

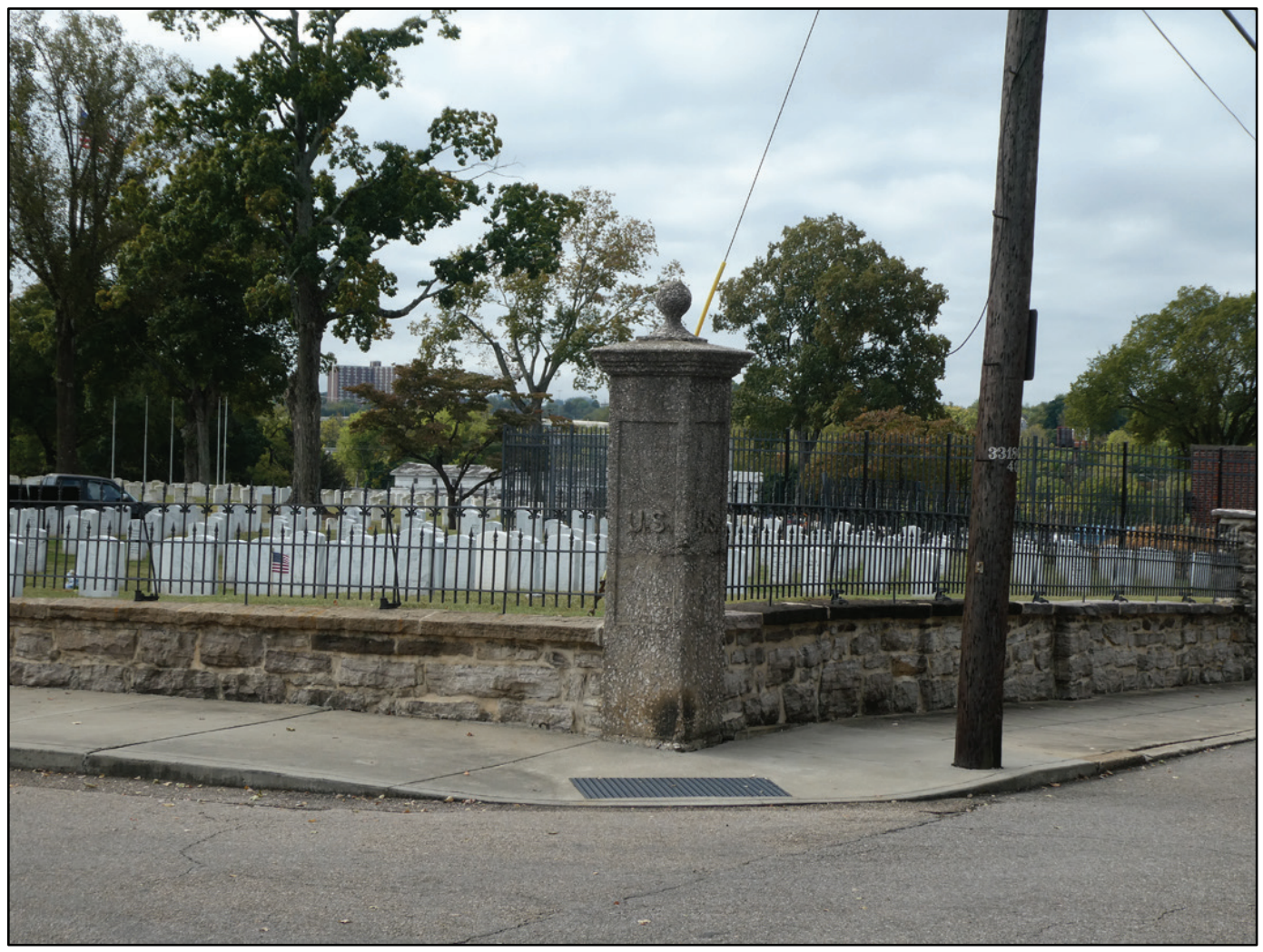

Figure 94. Looking southeast at the Bernard Avenue wall (ERDC-CERL, 2019).

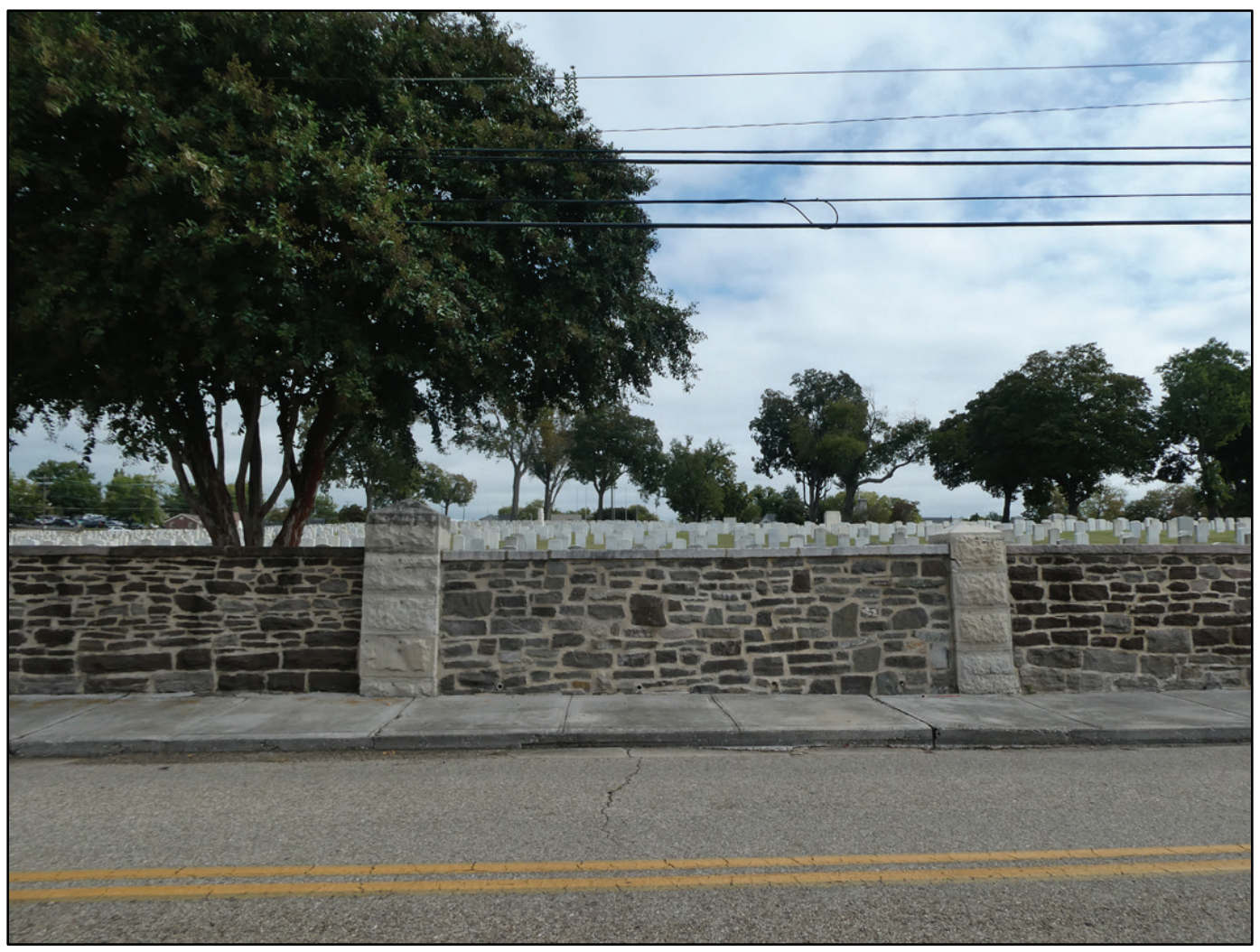


Figure 95. Looking northwest at the Cooper Street wall (ERDC-CERL, 2019).

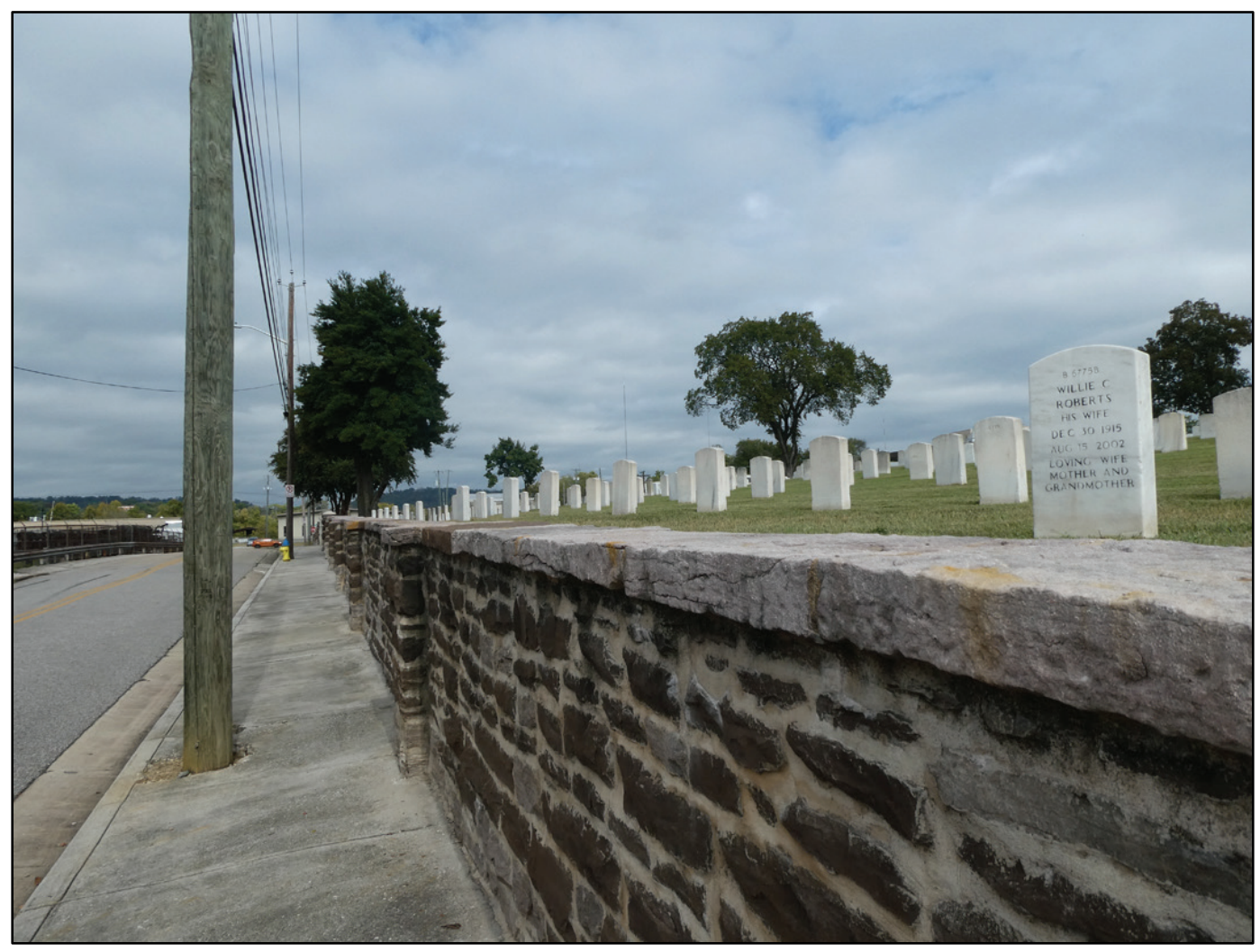


Figure 96. Looking northwest at the concrete pillar between the two cemeteries (ERDC-CERL, 2019).

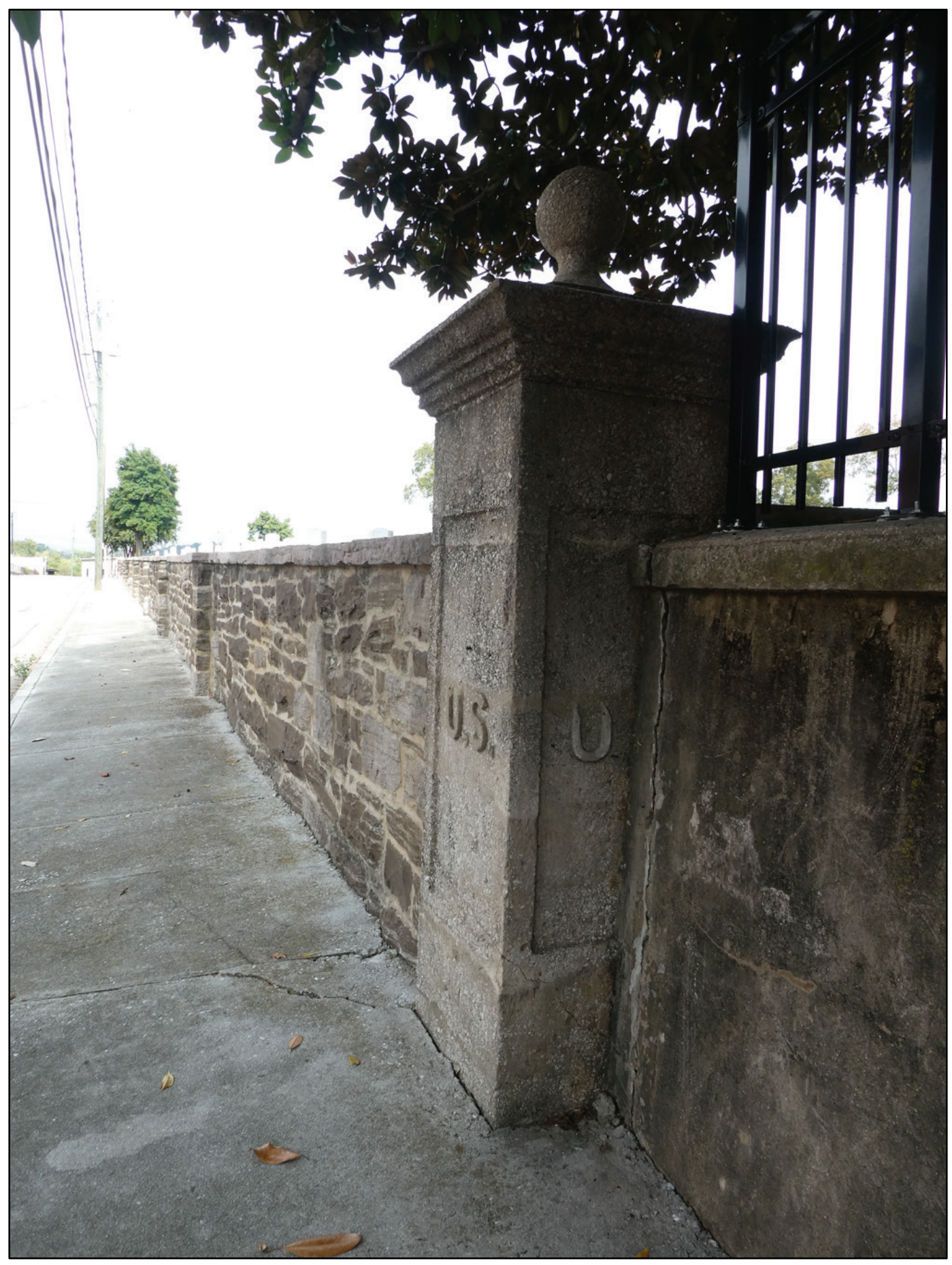


Figure 97. Looking south at the wall between the two cemeteries (ERDC-CERL, 2019).

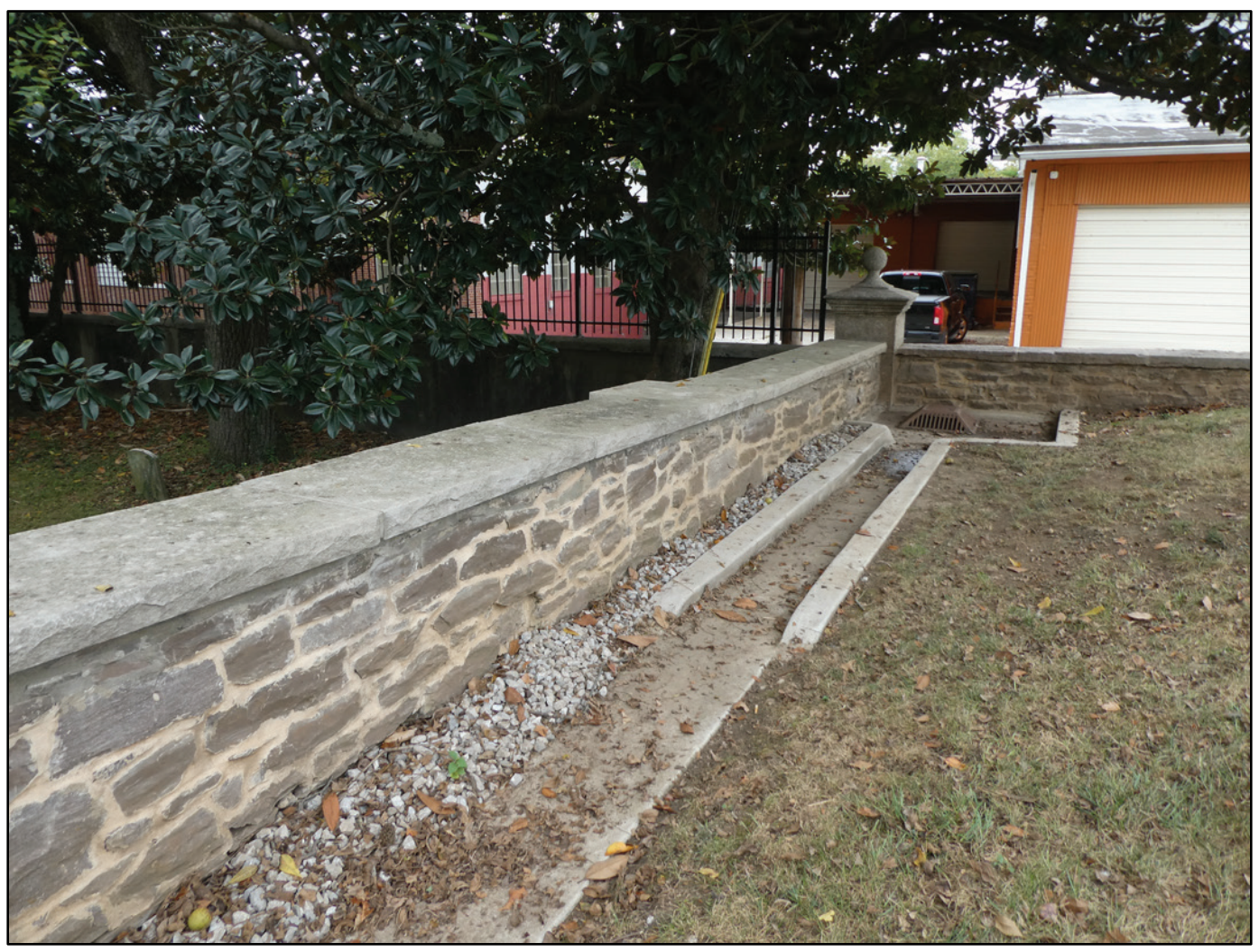

Figure 98. Looking southwest at the wall between the two cemeteries (ERDC-CERL, 2019).

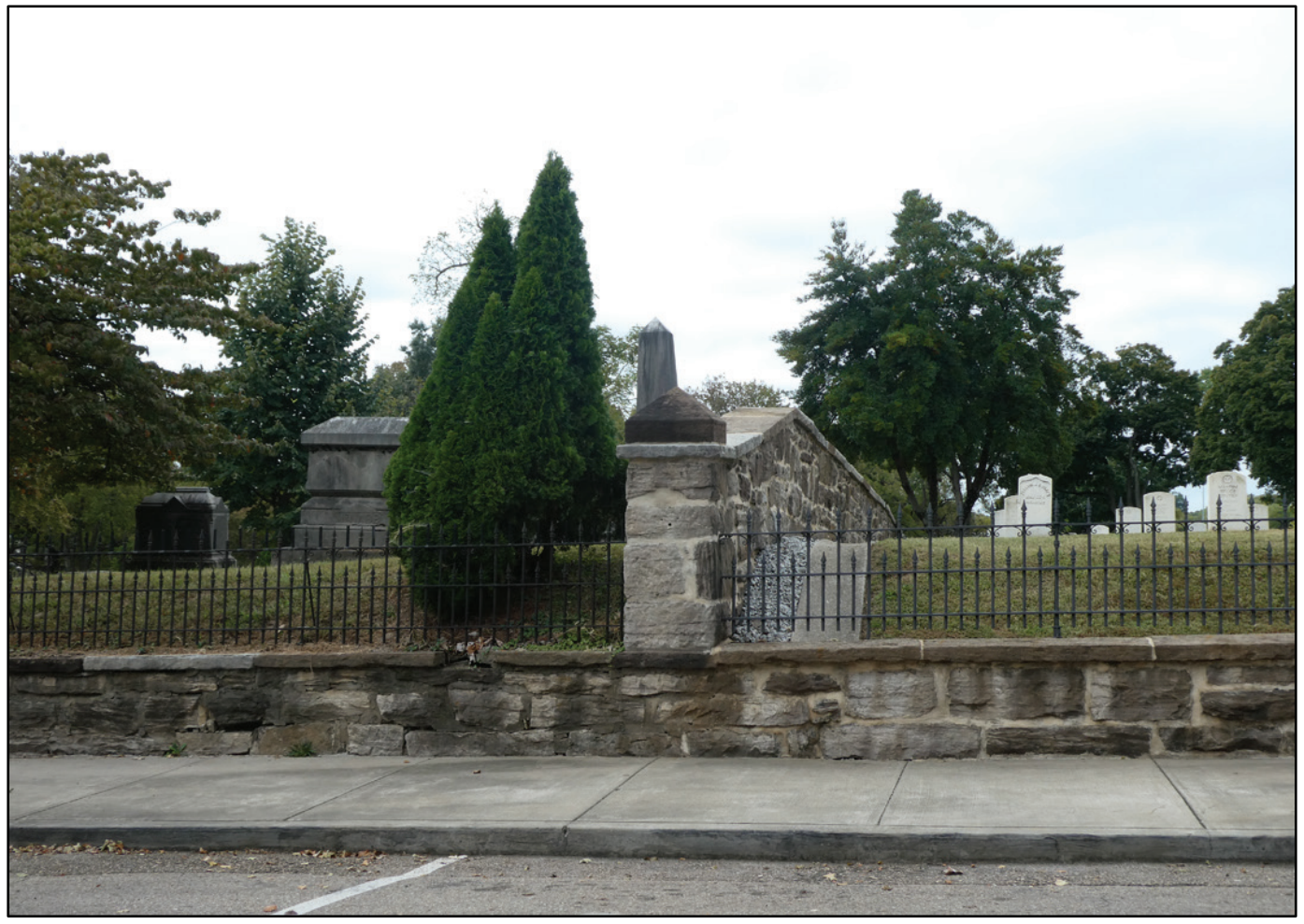




\subsubsection{Entrance gate}

The main entrance gate is on the northeast side of the property. It is composed of a wide vehicular gate defined by two concrete piers that support ornamented wrought-iron gates. (Figure 99).

Figure 99. Looking southwest at the main entrance gate (ERDC-CERL, 2019).

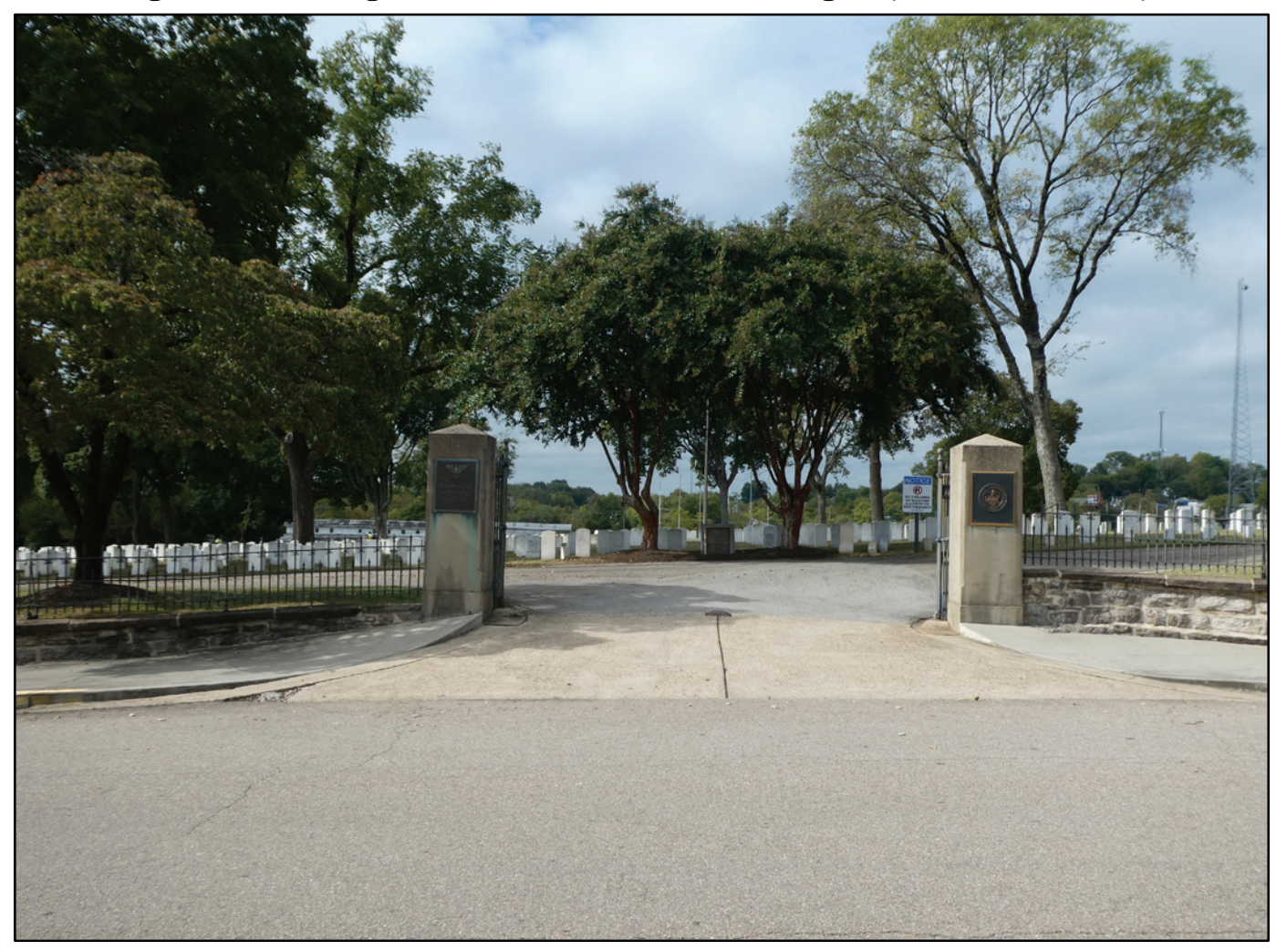

The Cooper Street stone wall once also had an entrance gate; the stone piers remain part of the wall (Figure 100). 
Figure 100. Looking northeast at the Cooper Street where stone piers marked a former entrance to the cemetery (ERDC-CERL, 2019).

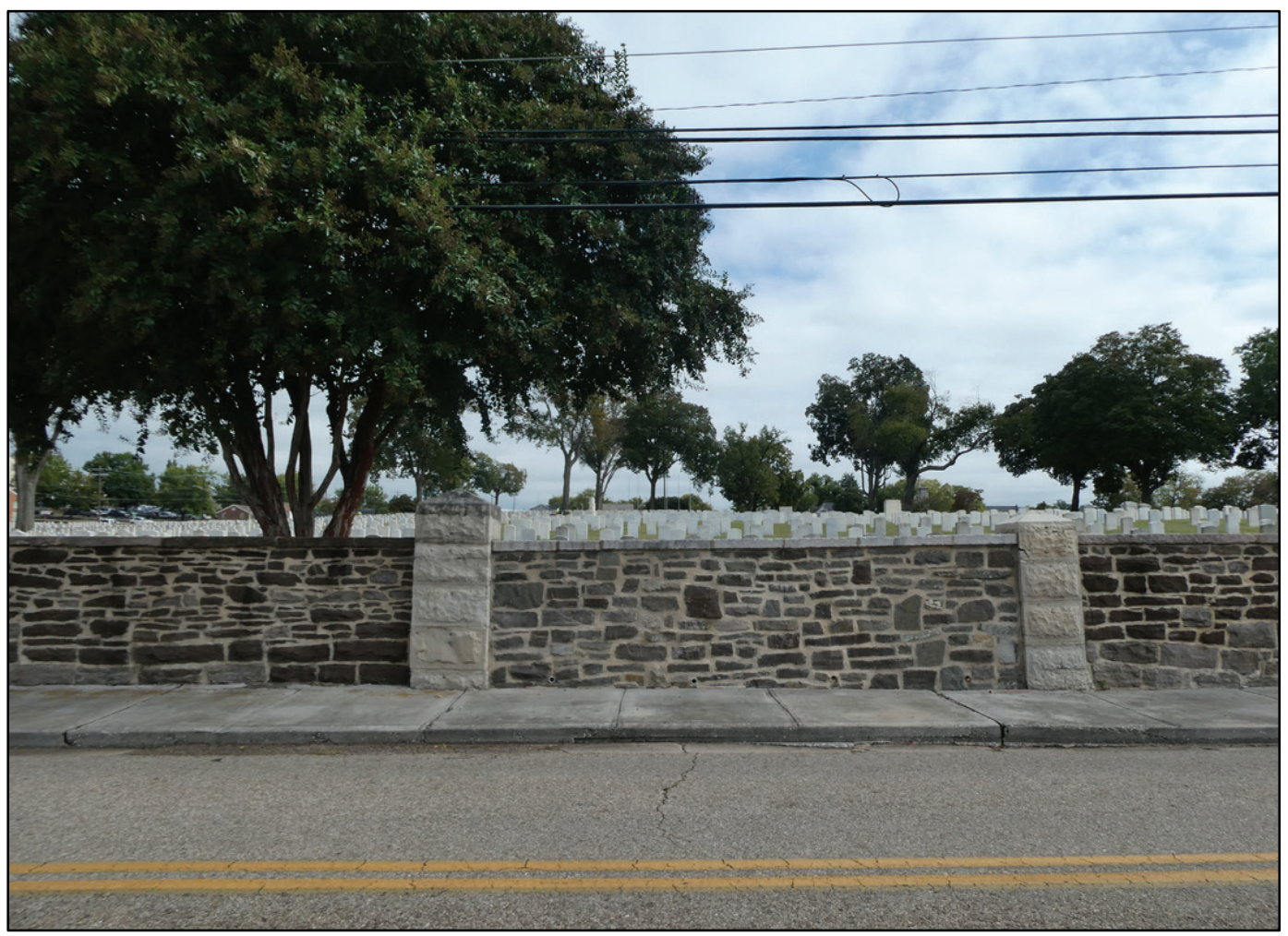

\subsubsection{Committal shelter}

The Knoxville National Cemetery does not have a committal shelter.

\subsubsection{Grave information shelter}

A gravesite locator shelter is located adjacent to the parking area and waste receptacles in the north corner of the cemetery. It was constructed in the 2010s (Figure 101). 
Figure 101. Looking north at the gravesite locator kiosk (ERDC-CERL, 2019).

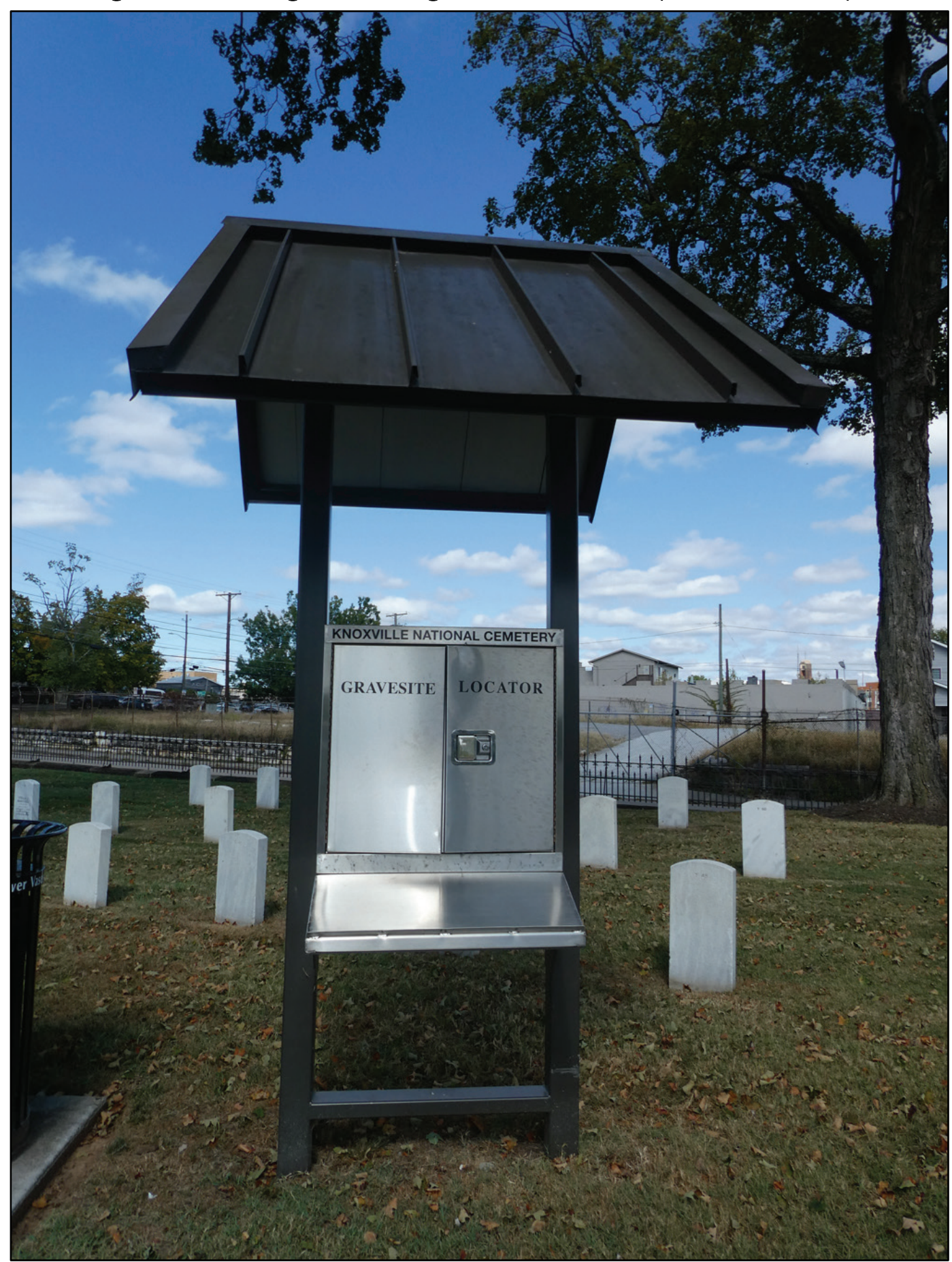

\subsubsection{Objects}

The National Register defines an "object" as an element distinct from buildings and structures and "those constructions that are primarily artistic in nature or are relatively small in scale and simply 
constructed." 233 There are three predominate objects at Knoxville National Cemetery-the headstones, the flagstaff, and the monuments that are placed throughout the cemetery.

\subsubsection{Headstones}

The headstones at Knoxville National Cemetery are grouped into eight sections. In most sections, the headstones now face towards the flagstaff in a circular pattern. ${ }^{234}$ The original configuration of headstones had four sections. The circular pattern was followed on the outside of the circle drive, although as the burials reach the edges of the cemetery they are in a linear pattern.

The War Department adopted the Civil War-type headstone in 1873. The headstone consisted of white marble slab that measured $12^{\prime \prime}$ high, $10^{\prime \prime}$ wide, and 4 " thick, with a rounded top. A shield was cut into the face, and it contained the grave number, soldier rank, soldier name, and home state's name in bas relief (Figure 102). This type of headstone was used to mark the graves of soldiers killed during all conflicts through the Spanish-American War. In 1903, the headstone's size was increased to 39" high and 12" wide, but still 4" thick (Figures 103 and 104). The Highlander portion of the cemetery in Section A has a memorial and 12 specially designed markers for those interred (Figure 105). At Knoxville National Cemetery, headstones that have been displaced by tree growth have been re-laid to be flat to the ground (Figure 106). There is one Confederate marker in the cemetery near the maintenance building. This marker has a peaked top that delineates them from the Union grave markers (Figure 107).

\footnotetext{
233 NPS, National Register Bulletin \#15, 1997, 5.

234 There is some evidence that the headstones within the circle drive once faced outwards to the drive. The date for this change could not be determined due to the lack of archival material.
} 
Figure 102. An example of a Civil War headstone featuring the original dimensions and layout of the markers (ERDC-CERL, 2019).

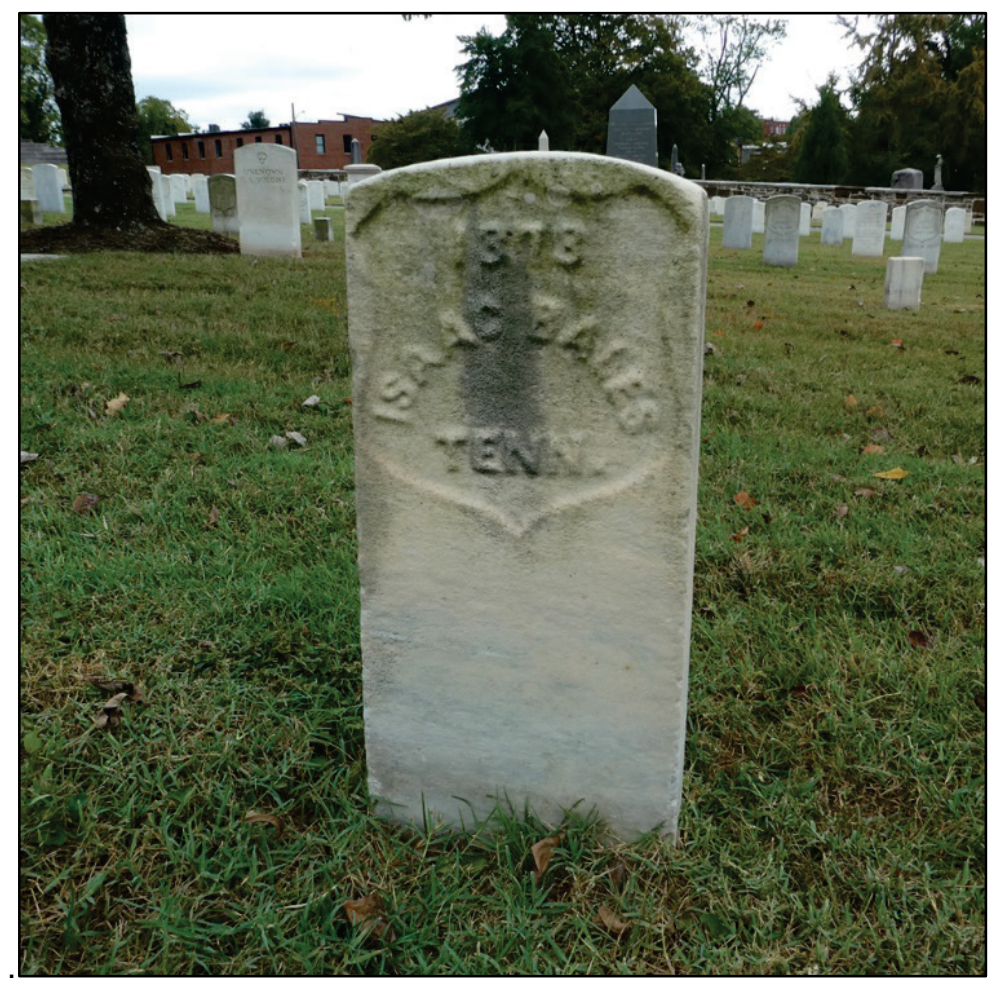

Figure 103. An example of a pre-1903 burial updated with the newer size but with the shield and name/unit incised into the stone (ERDC-CERL, 2019).

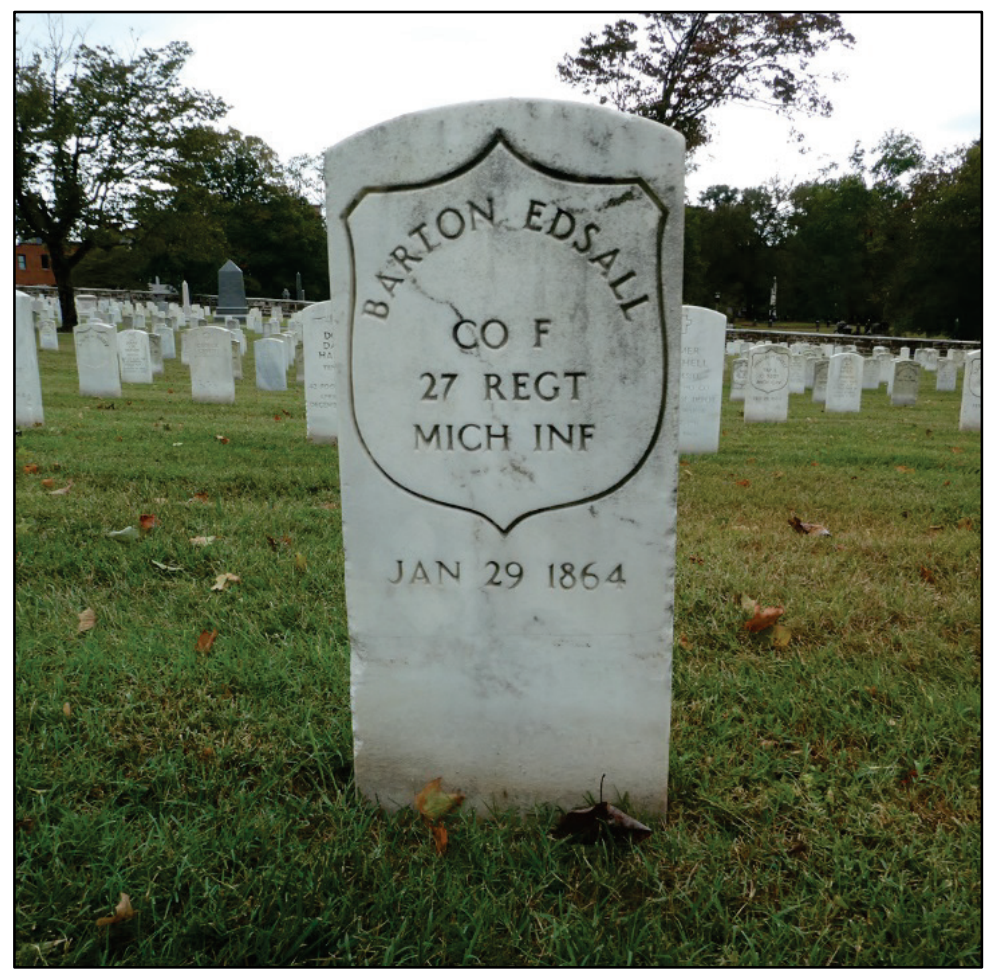


Figure 104. An example of a pre-1903 burial updated with the newer size but with the shield only incised into the stone in bas relief (ERDC-CERL, 2019).

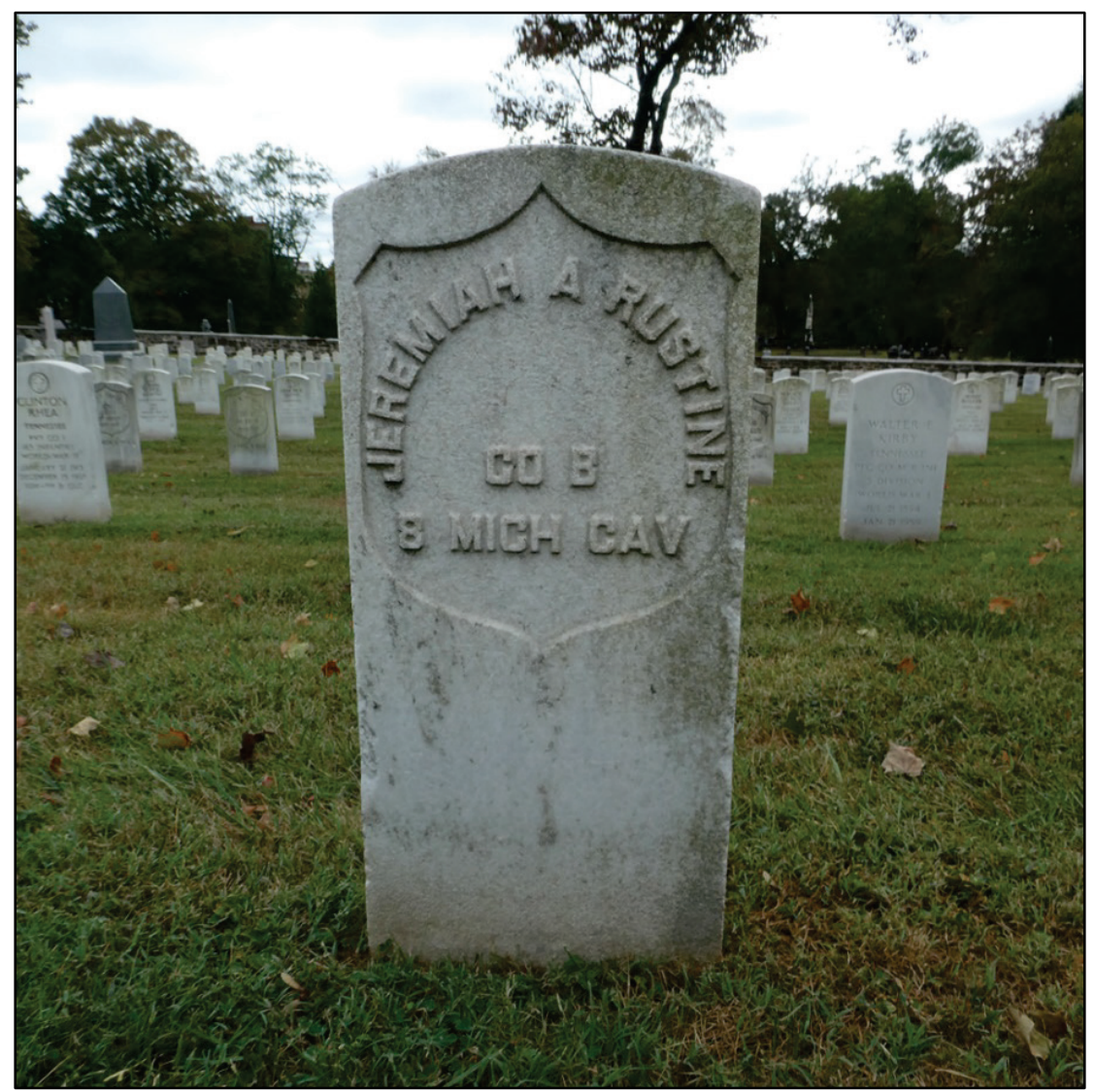

Figure 105. Looking towards the flagpole at the Highlander portion of the cemetery in Section, 2019 A (ERDC-CERL, 2019).

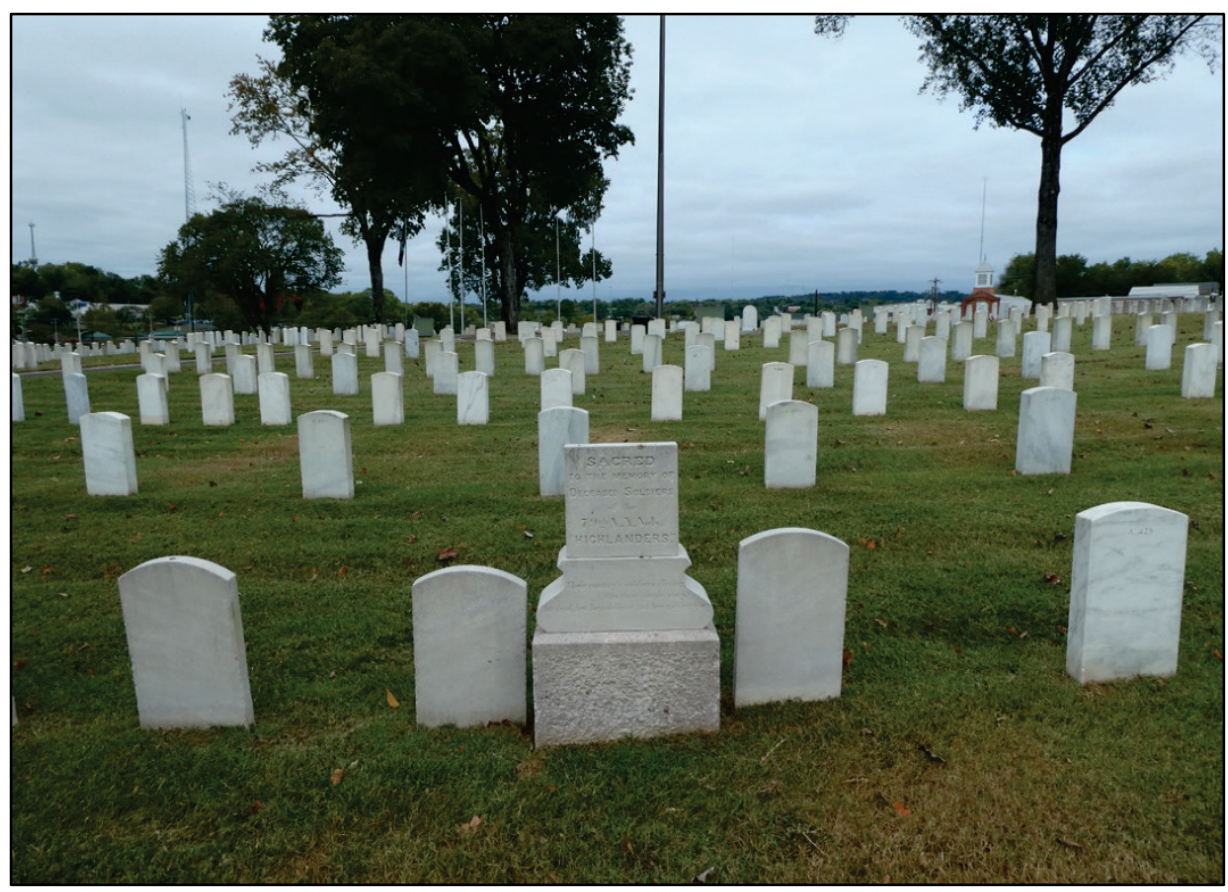


Figure 106. Grave markers displaced by tree growth were laid flat to the ground near their original locations (ERDC-CERL, 2019).

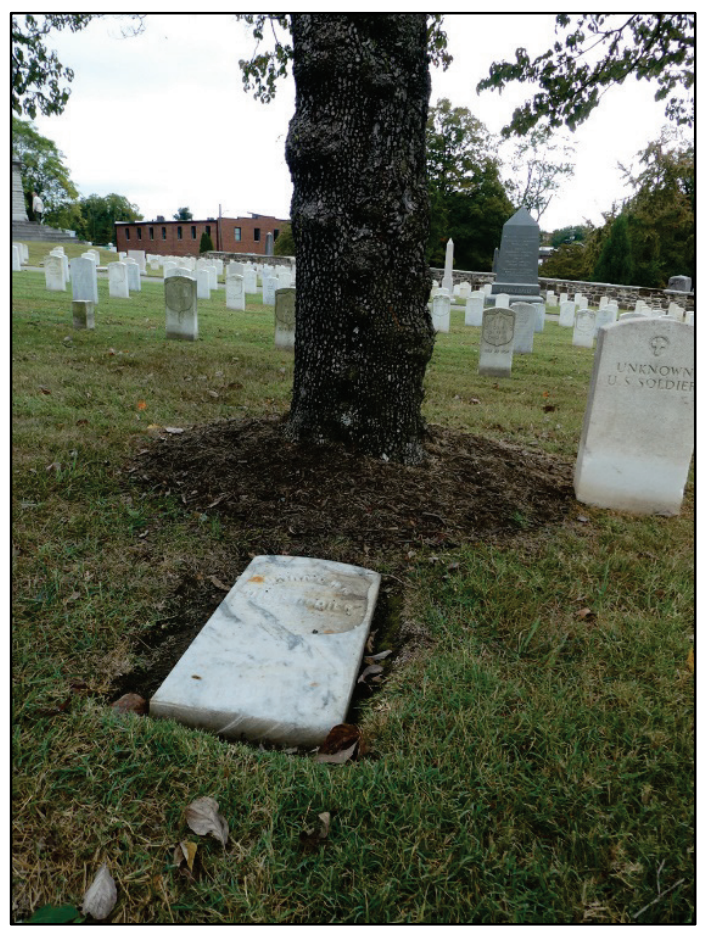

Figure 107. Example of the Confederate grave marker at Knoxville National Cemetery (ERDCCERL, 2019).

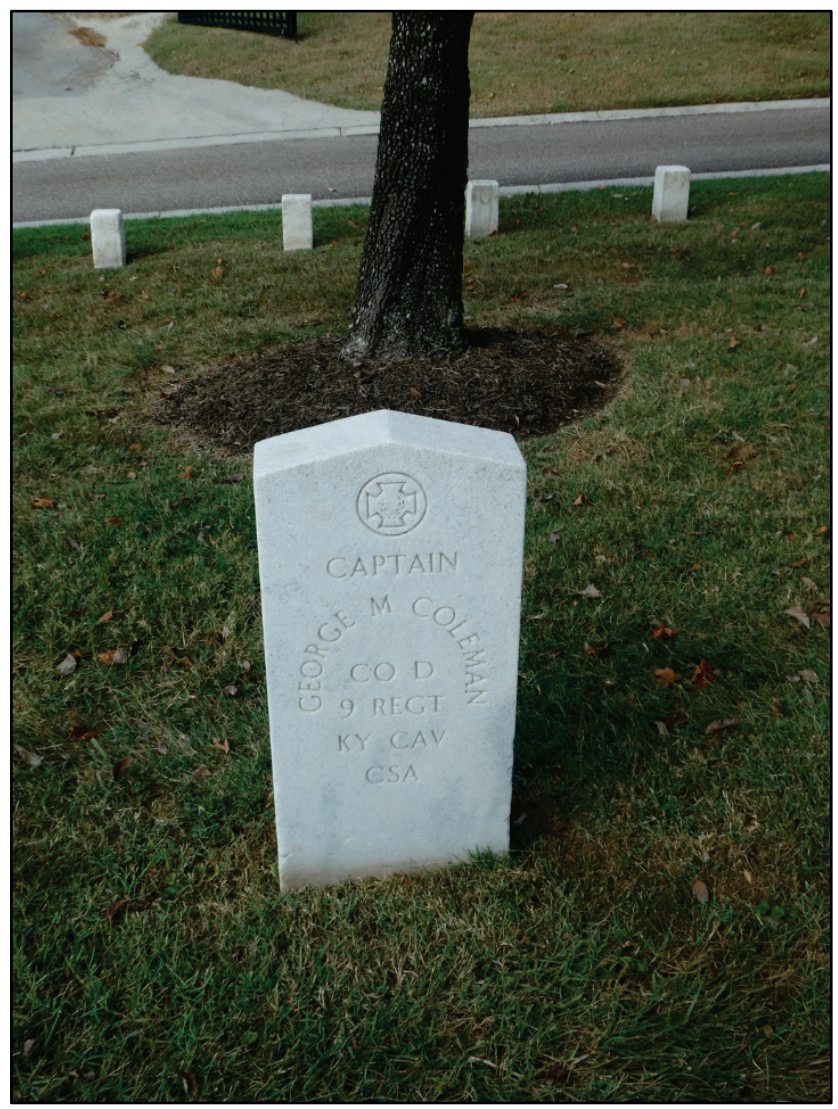


For the Union Civil War unknown dead, headstone design is a marble block 6" square and 30" high (Figure 108). The top and upper 4" were dressed, and the grave number was inscribed into the block's top. The unknown headstones at Knoxville have been raised. The War Department discontinued use of the unknown type of headstone in 1903.

Figure 108. Section of Civil War unknown dead (ERDC-CERL, 2019).

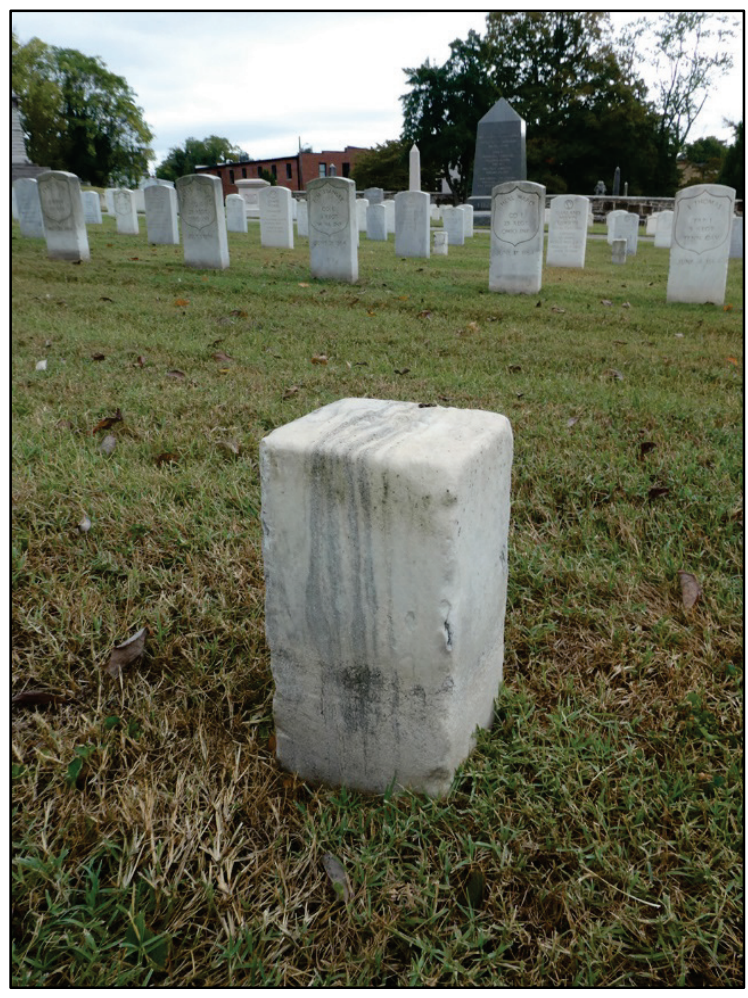

The War Department started using the general type of headstone after World War I. The headstone consisted of white marble that was $42^{\prime \prime}$ high, 13 " wide, and 4" thick, and it had a rounded top (Figure 109). The general type is now used for all headstones at Knoxville National Cemetery. New stones are intermingled with old stones. 
Figure 109. An example of a post-1903 burial with the new size of headstone (ERDC-CERL, 2019).

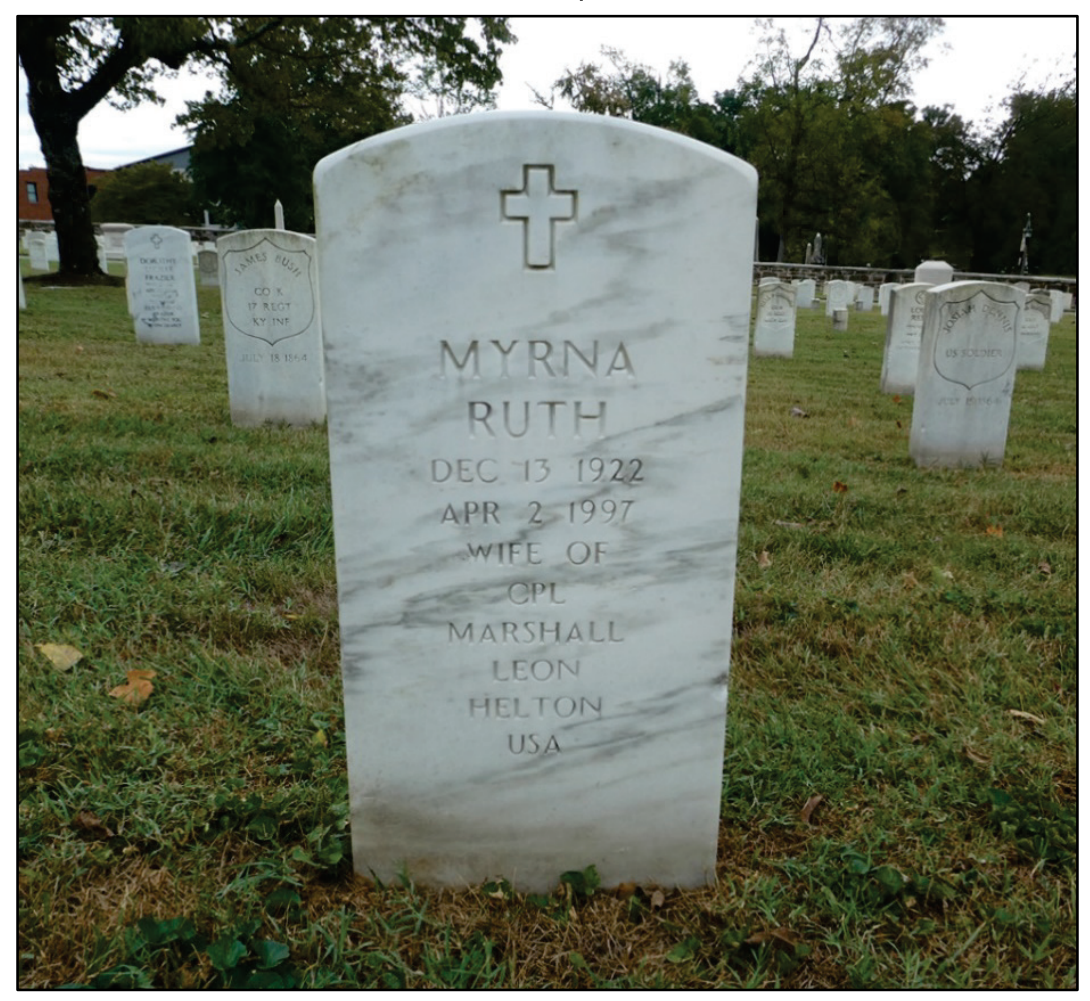

The cemetery has a number of privately furnished headstones of various designs (Figures 110 to 112). The use of nongovernment-furnished headstones was stopped after the general type of headstone was introduced after World War I. The most notable is the Thomas Ridge family plot in Section B of one of the former Superintendents of the cemetery (Figure 113). 
Figure 110. Nonstandard grave marker for Captain Walter Fitzgerald, who died in 1906 (ERDC-CERL, 2019).

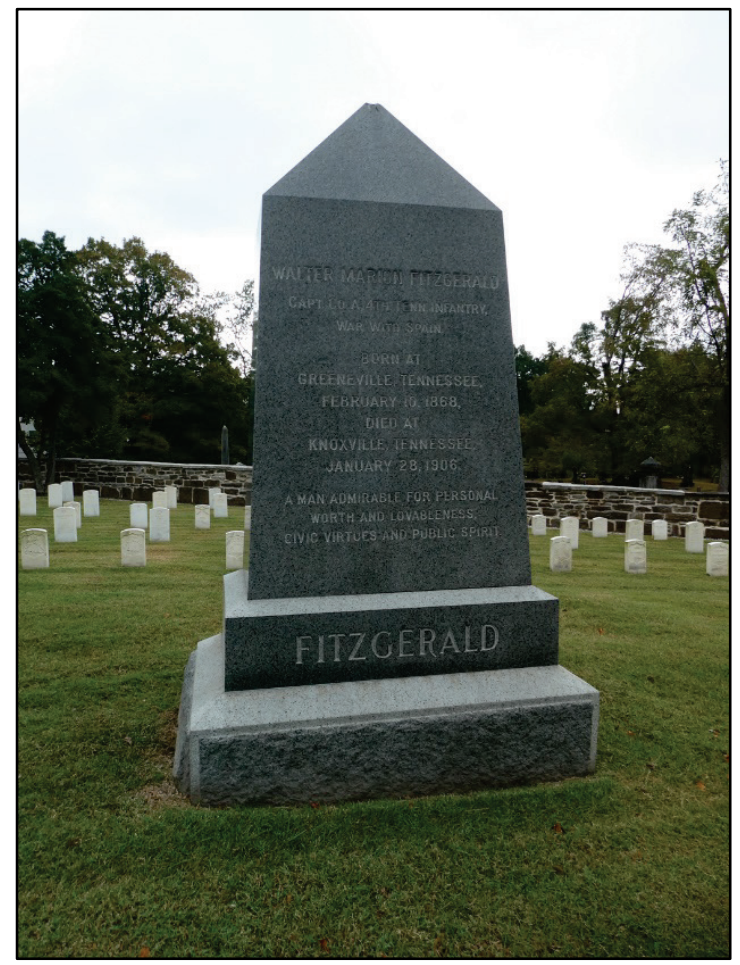

Figure 111. Grave marker for $1^{\text {st }}$ Lt. Belmont Earle, who died in 1918 (ERDC-CERL, 2019).

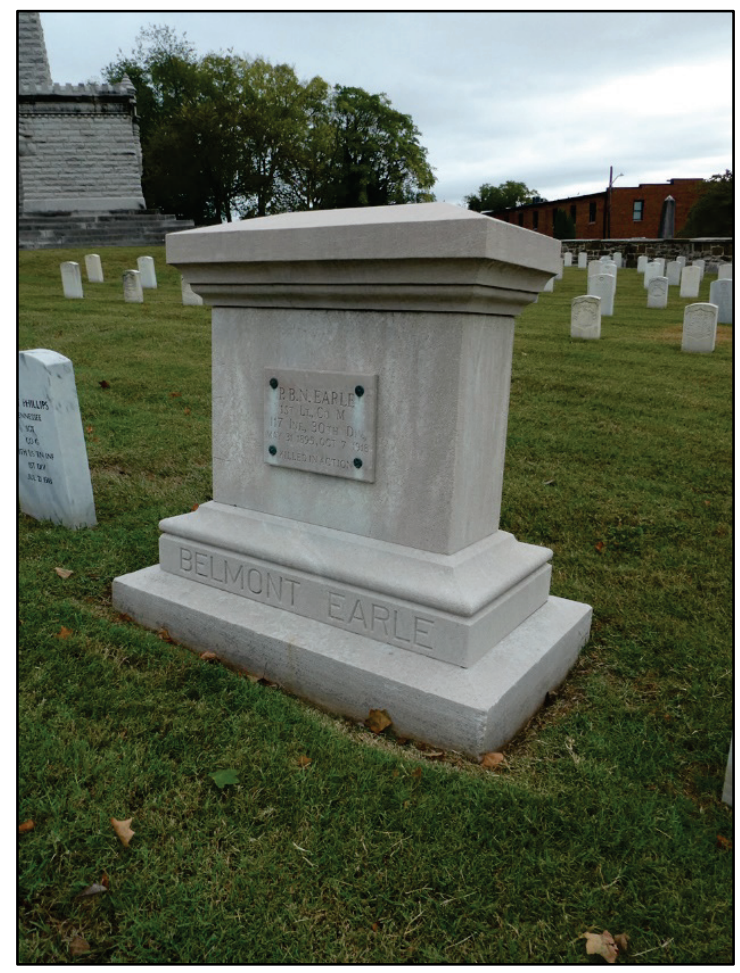


Figure 112. Nonstandard grave maker design for Lt Hosea Loftis, who died in 1908 (ERDCCERL, 2019).

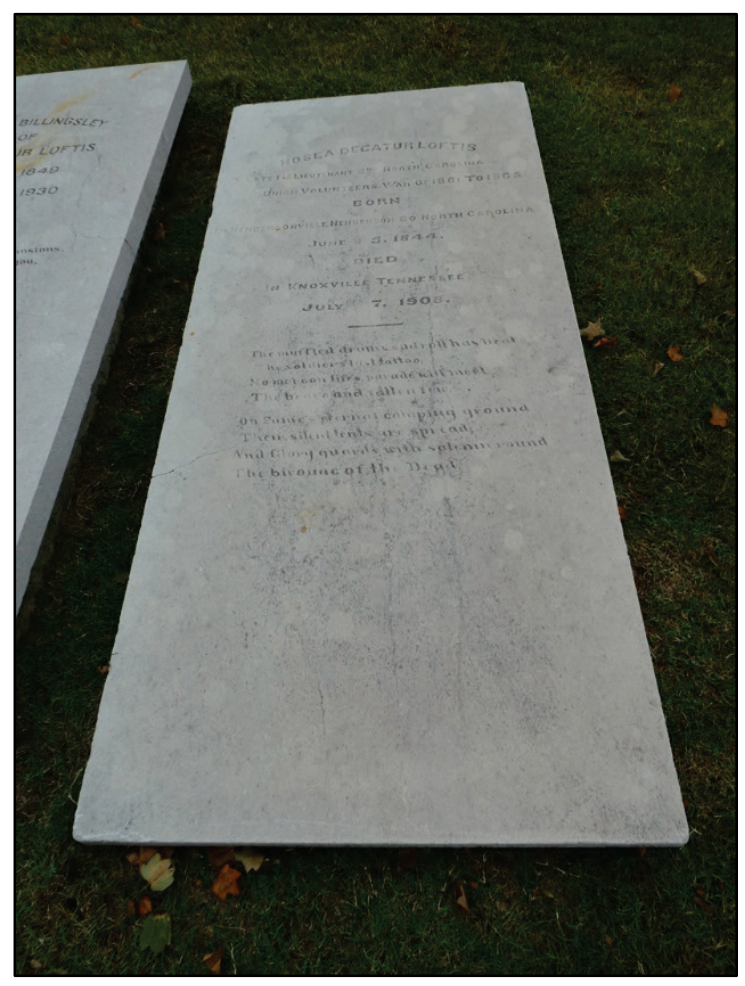

Figure 113. Burial plot for Superintendent Thomas Ridge, who died in 1918, and his family (ERDC-CERL, 2019).

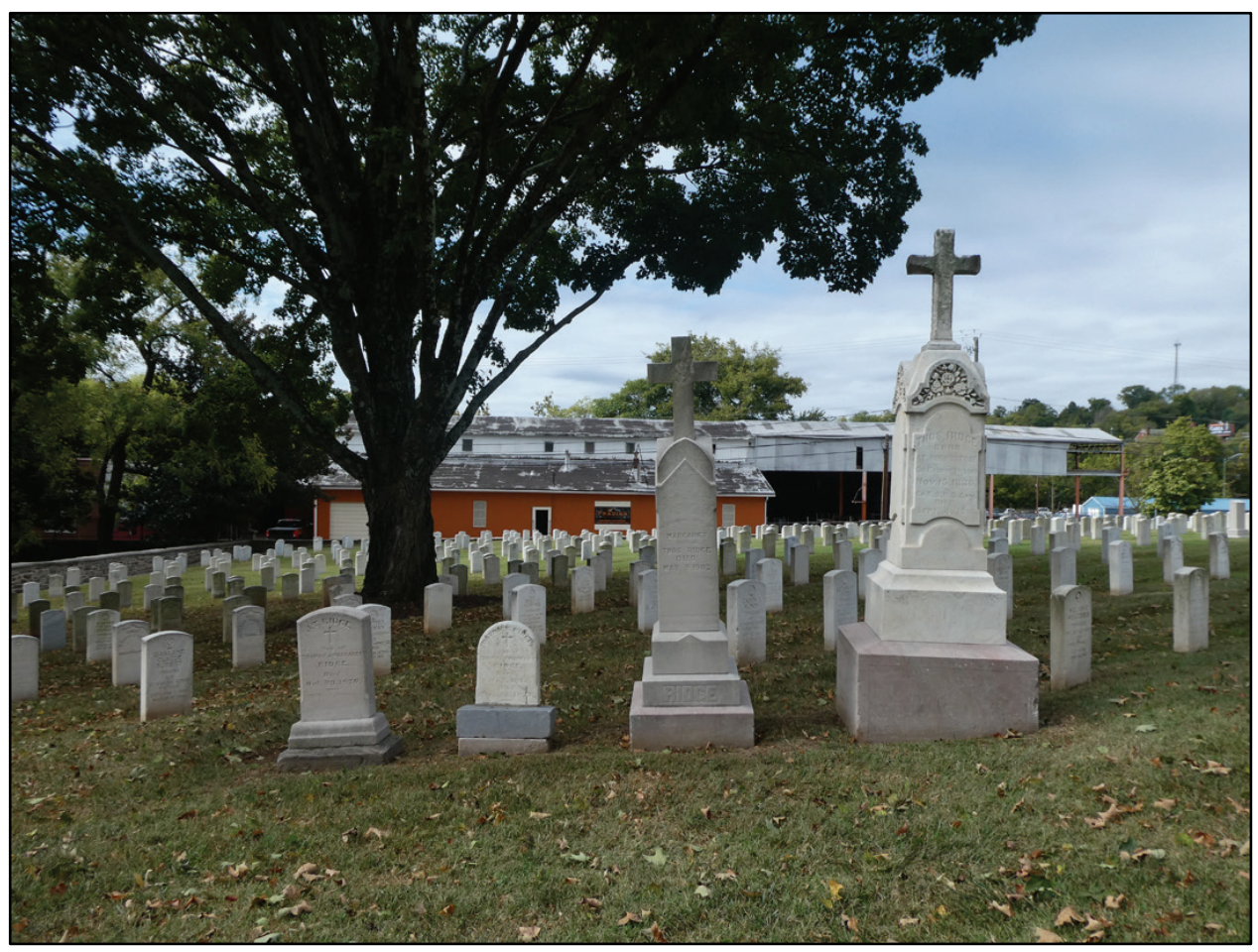




\subsubsection{Flagstaffs}

There are two flagstaffs in the Knoxville National Cemetery. They are located in the center of the cemetery. The cross road encircles the main flagstaff. The tallest flagstaff, that flies the American flag, is located at the center (Figure 114). The second flagstaff is located to the south of main flagstaff and flies the POW flag (Figure 115). On the south side of the flagstaff area are a series of small flagpoles for ceremonial occasions (Figure 116).

Figure 114. View looking northwest at the flagstaff (ERDC-CERL, 2019).

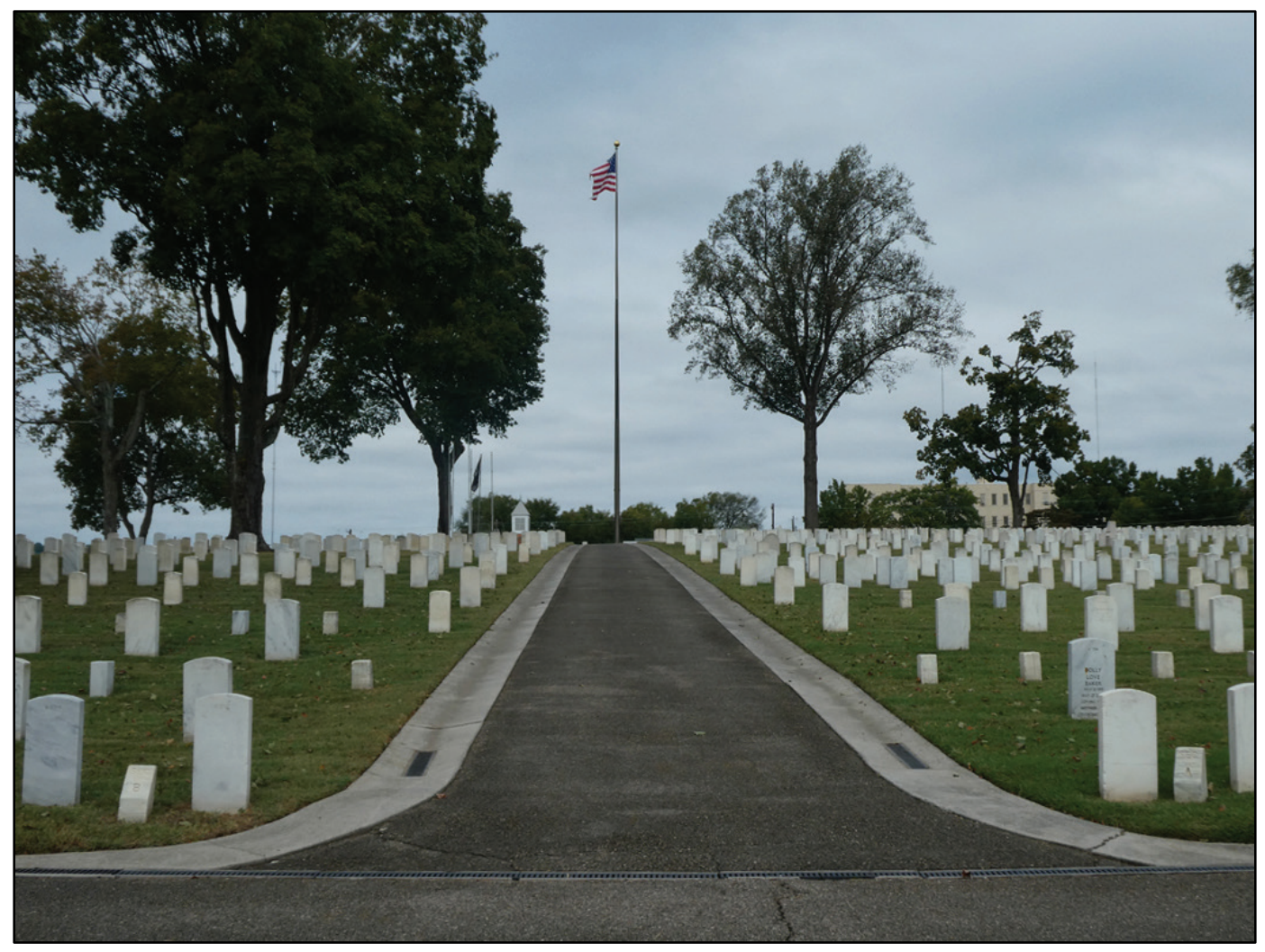


Figure 115. POW flagpole and flag in Section B (ERDC-CERL, 2019).

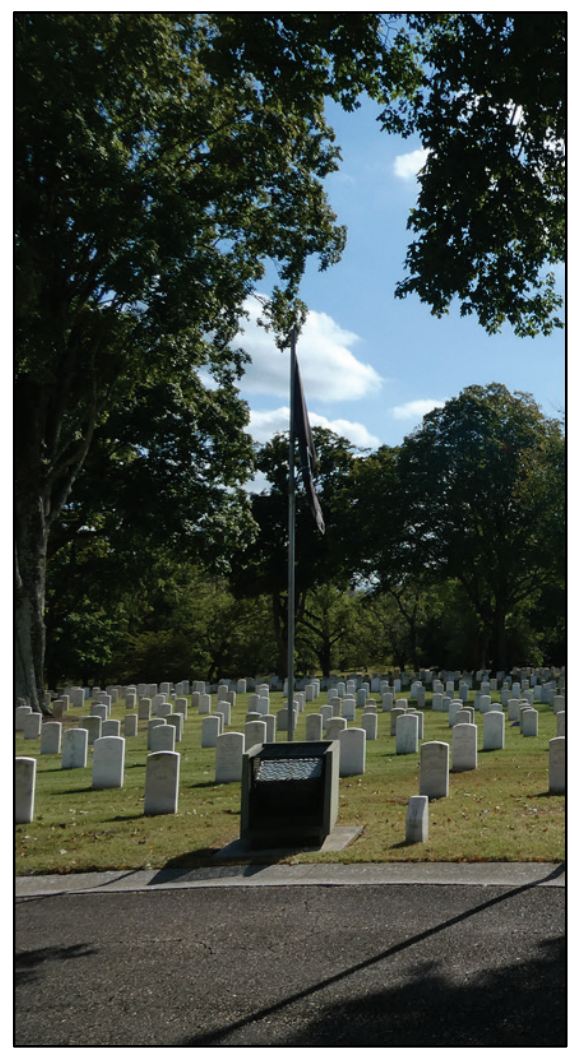

Figure 116. Ceremonial flagpoles on the south side of the flagstaff in Sections B and C (ERDC-CERL, 2019).

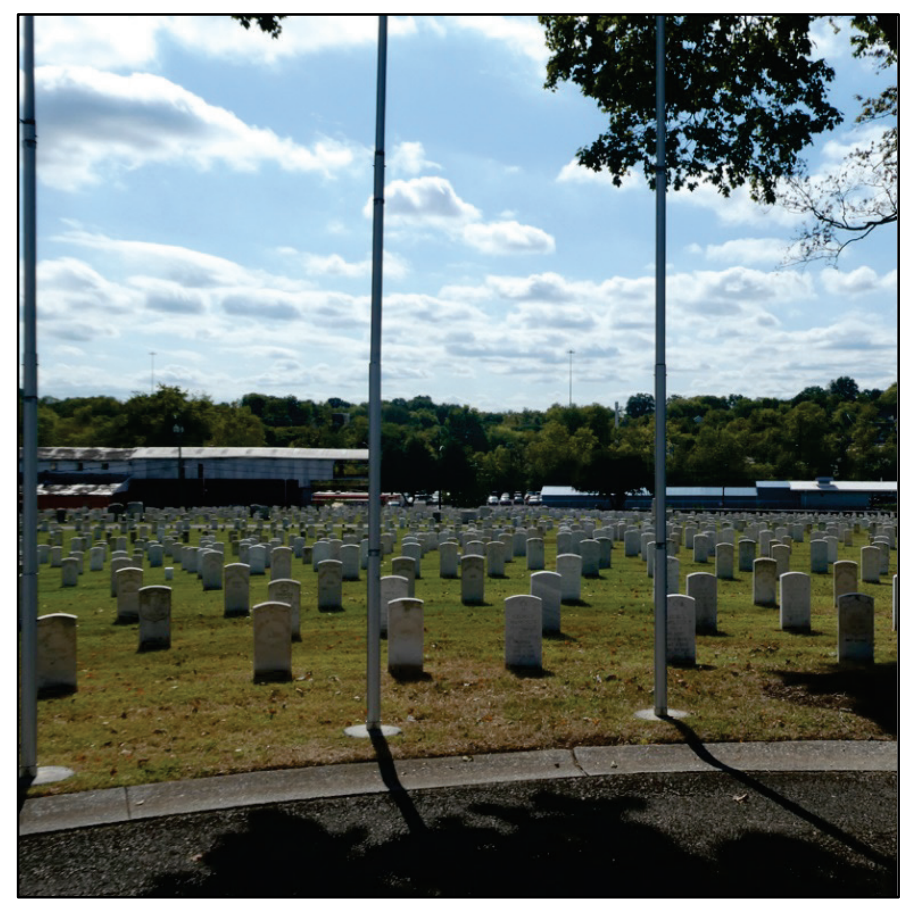




\subsubsection{Monuments}

There are several monuments in the cemetery. The oldest one is in Section A for the Hilltoppers (Figure 117). It is surrounded on either side by the graves of the Hilltoppers.

Figure 117. The Hilltopper monument in Section A (ERDC-CERL, 2019).

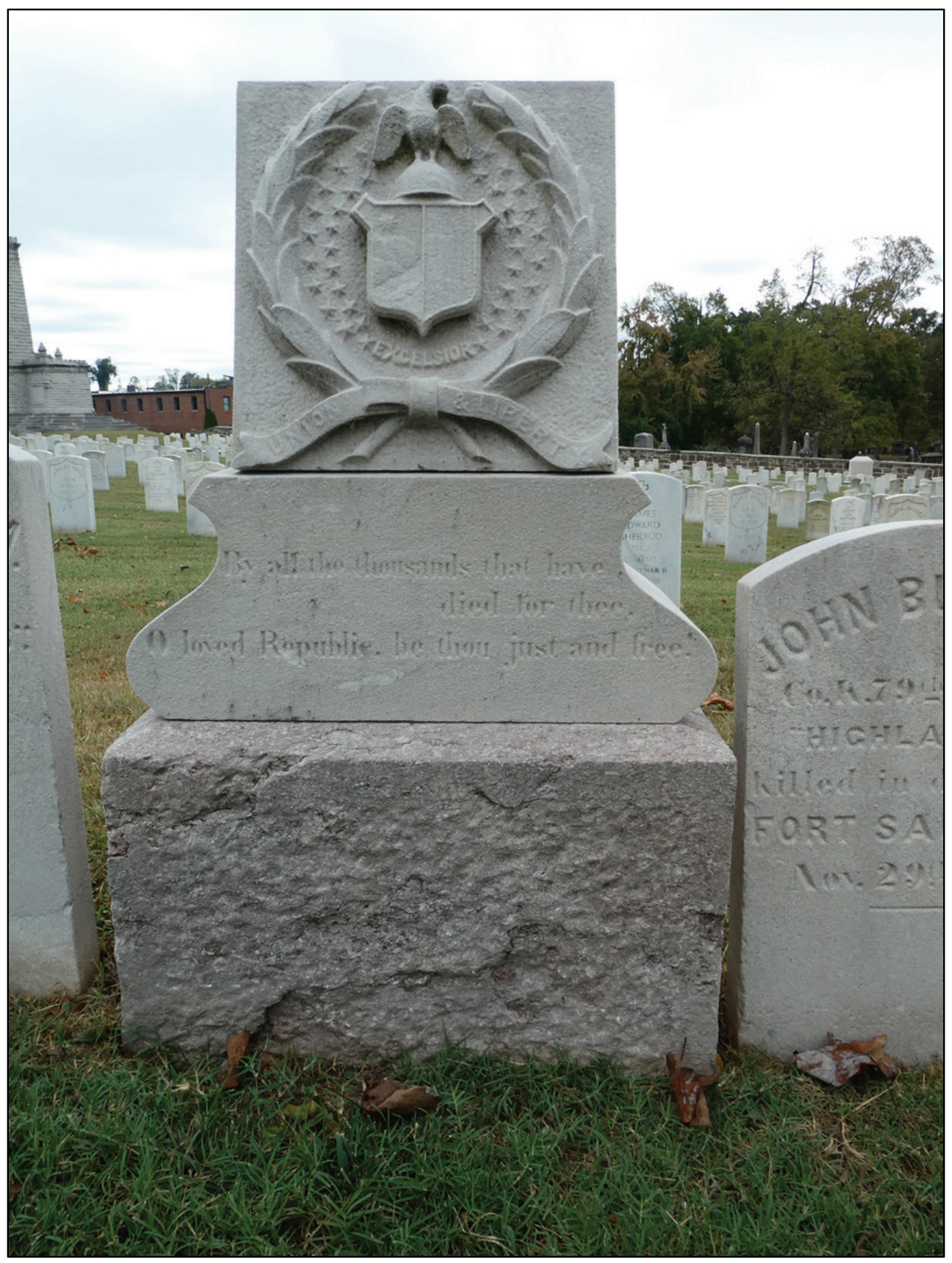


Most of the monuments and memorials are located in Section $\mathrm{D}$ by the small parking area. There is a bronze tablet on a granite stone memorializing the First Marine Division (Figure 118), a monument for the NRHP plaque (Figure 119), a metal plaque with a inscribed with a passage from the poem by Theodore O'Hara, The Bivouac of the Dead (Figure 120), the Gettysburg Address memorial (Figure 121), and a marker for the Memorial Area (Figure 122).

Figure 118. Granite marker with metal plaque for the First Marine Division in Knoxville National Cemetery (ERDC-CERL, 2019).

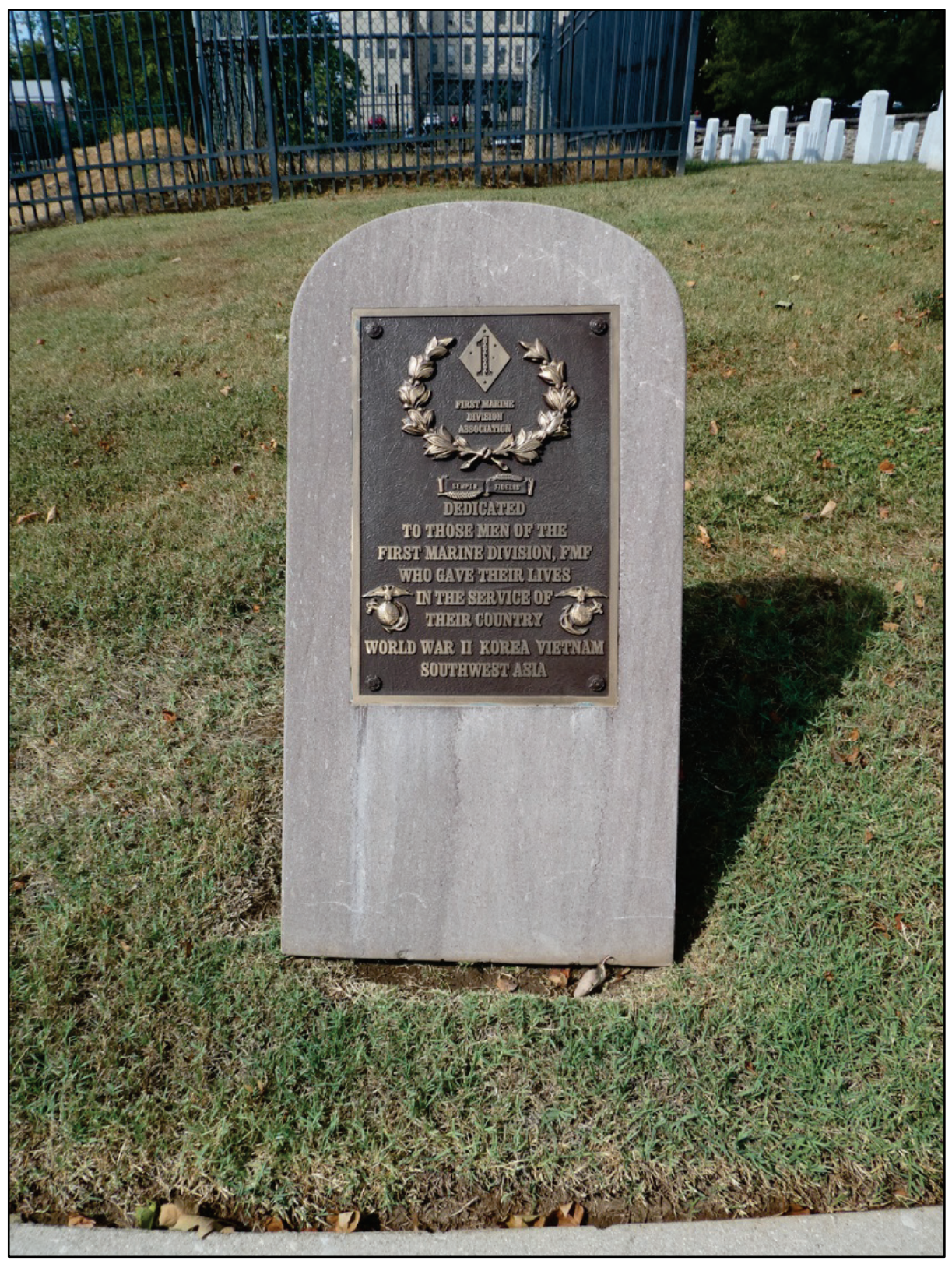


Figure 119. National Register of Historic Places (NHRP) monument (ERDC-CERL, 2019L).

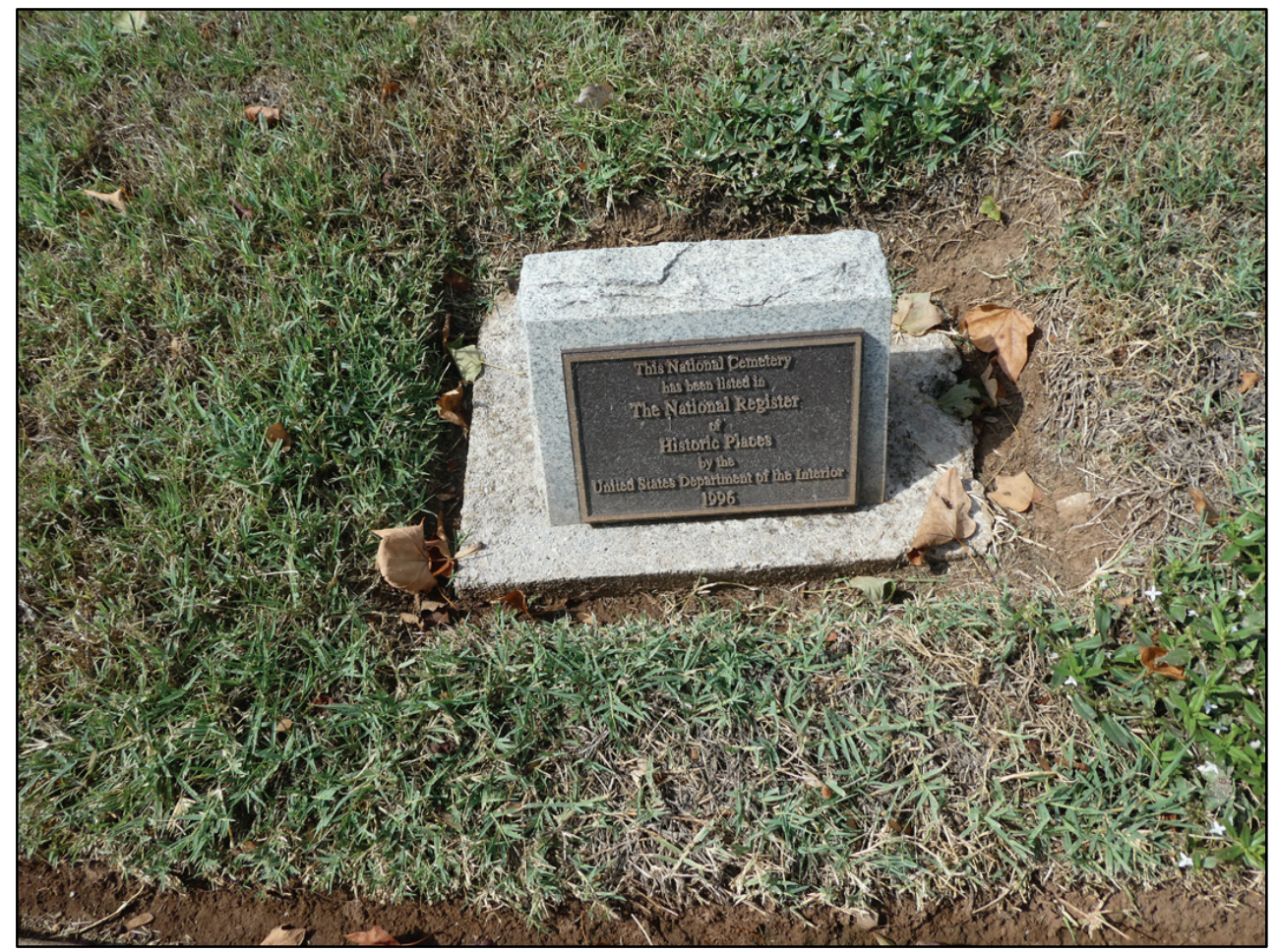

Figure 120. Bivouac of the Dead plaque (ERDC-CERL, 2019).

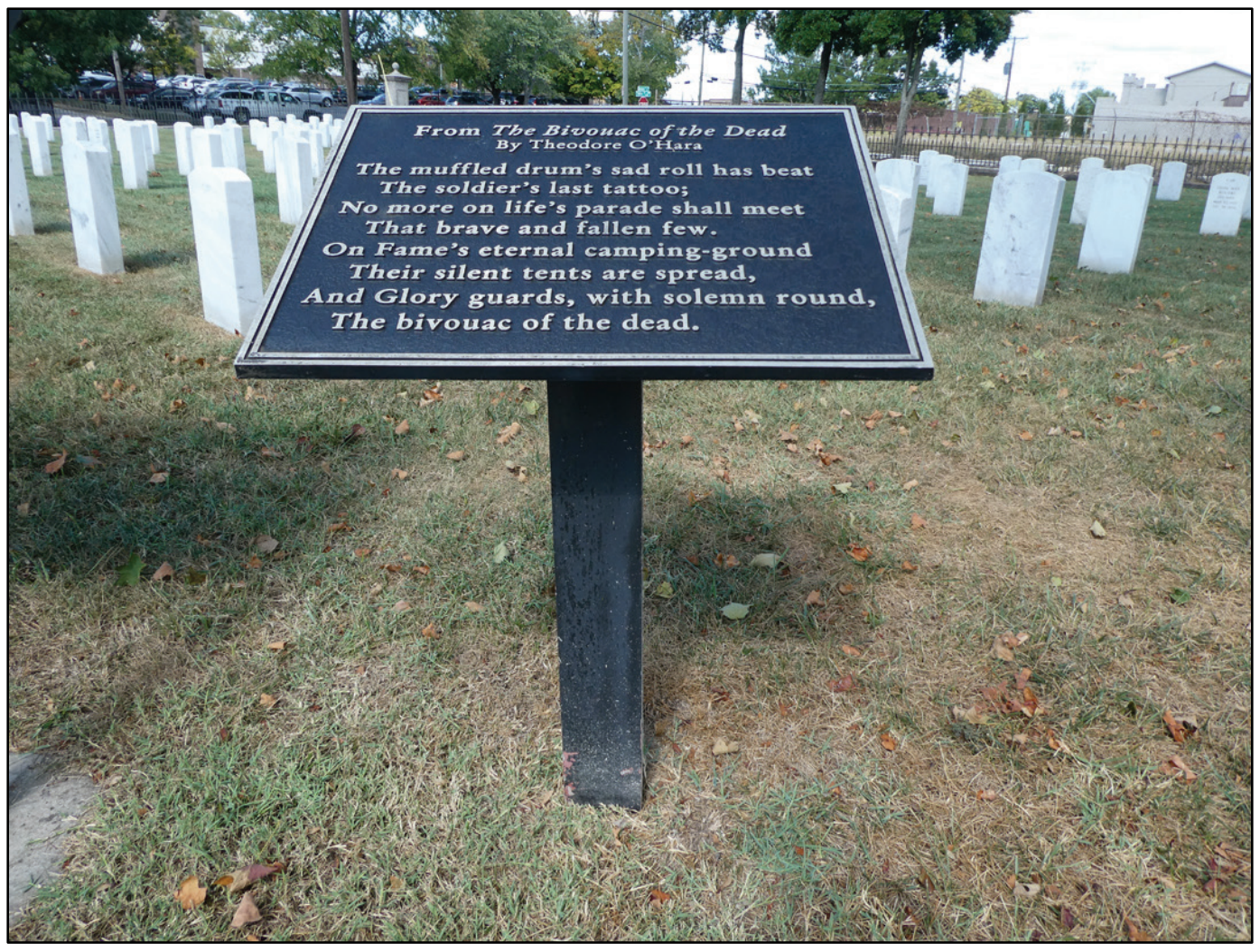


Figure 121. Gettysburg Address monument (ERDC-CERL, 2019).

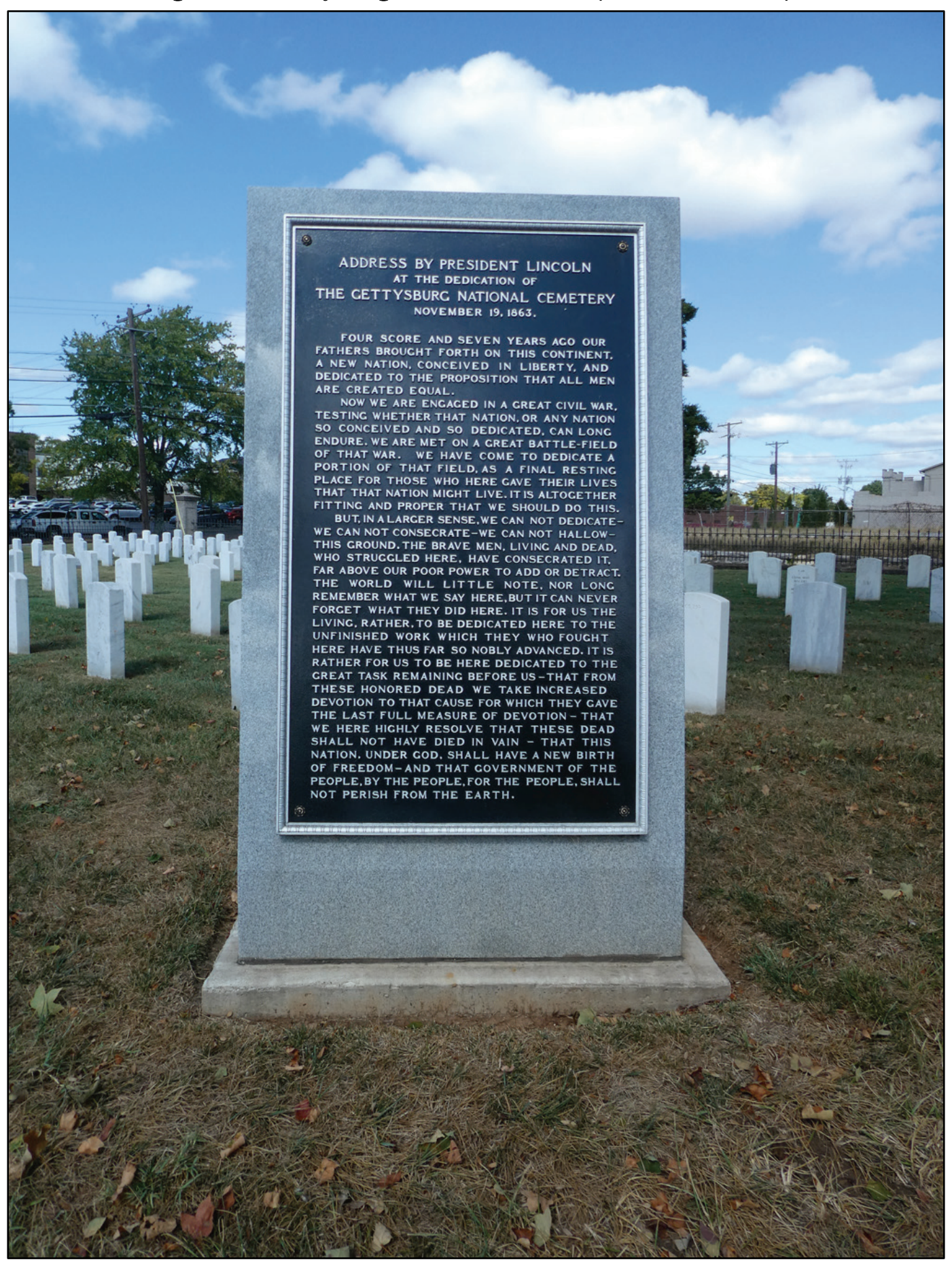


Figure 122. Memorial Area monument (ERDC-CERL, 2019).

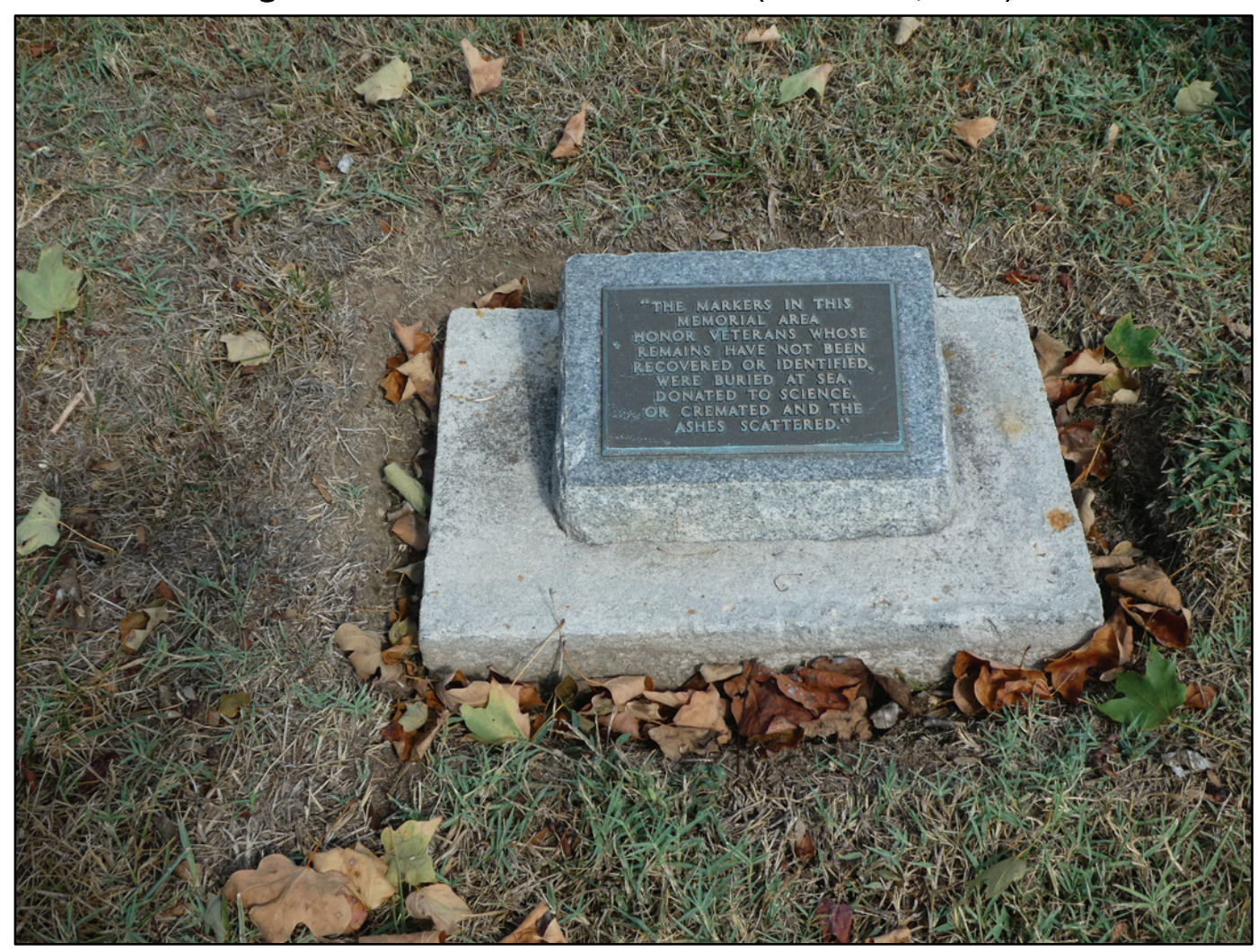

In between Section A and Section D facing the main entrance is the Knoxville National Cemetery rededication monument (Figure 123). 
Figure 123. Looking southwest at the cemetery's rededication monument opposite the main entrance (ERDC-CERL, 2019).

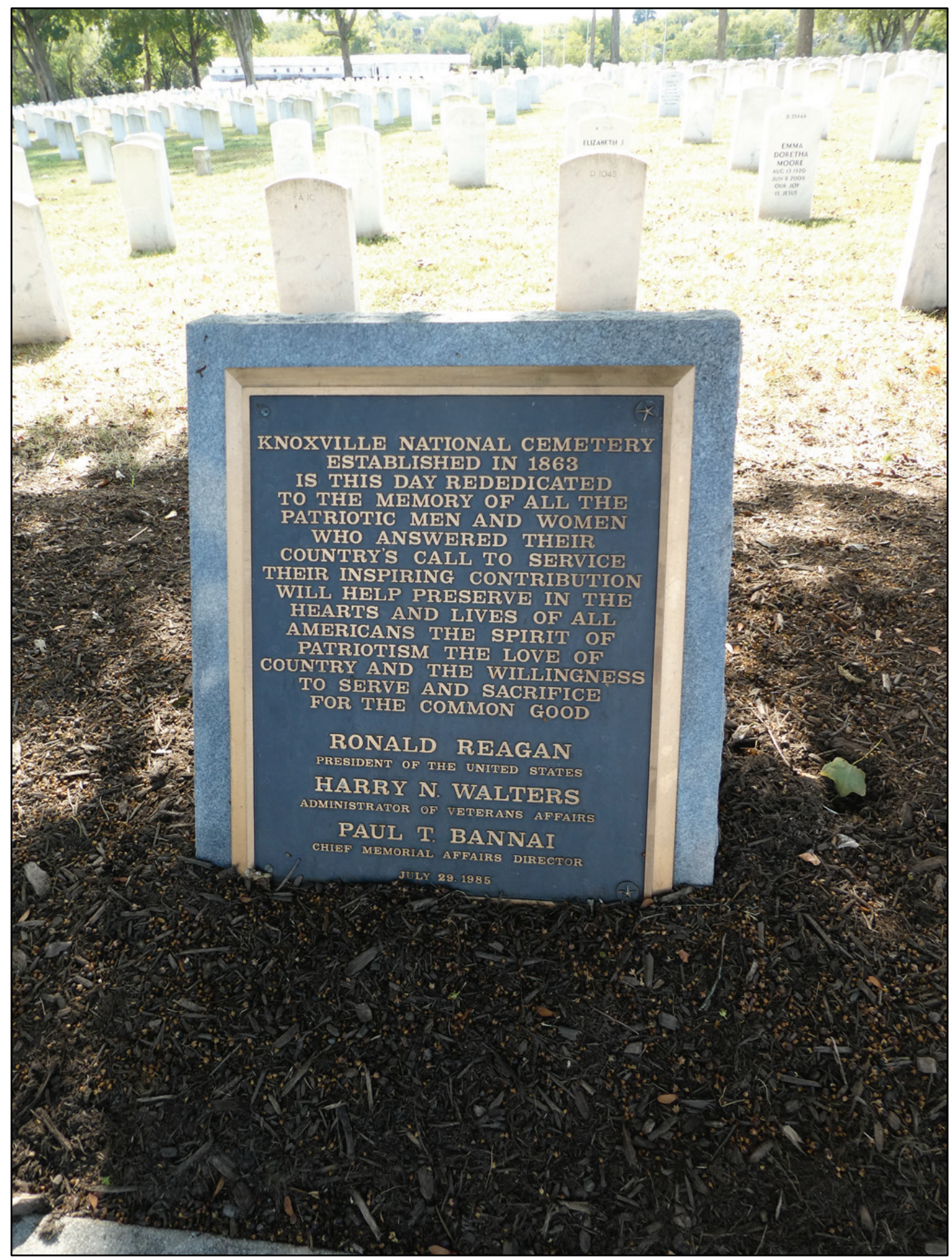

\subsubsection{Small-scale features}

Small-scale features are elements in the landscape that are intentionally placed and serve a prosaic purpose. Small-scale features are integral to how people use and navigate a site. 


\subsubsection{Benches}

There are no benches at Knoxville National Cemetery.

\subsubsection{Signage}

There are several signs and plaques throughout the cemetery. In general, they are arrayed near the entrance and at the small parking area in Section D. The signs are constructed in a variety of styles in both wood and metal. Figures 124-130 show the different types of signs in Knoxville National Cemetery.

Figure 124. Knoxville National Cemetery plaque on the left pylon of the main entrance (ERDC-CERL, 2019).

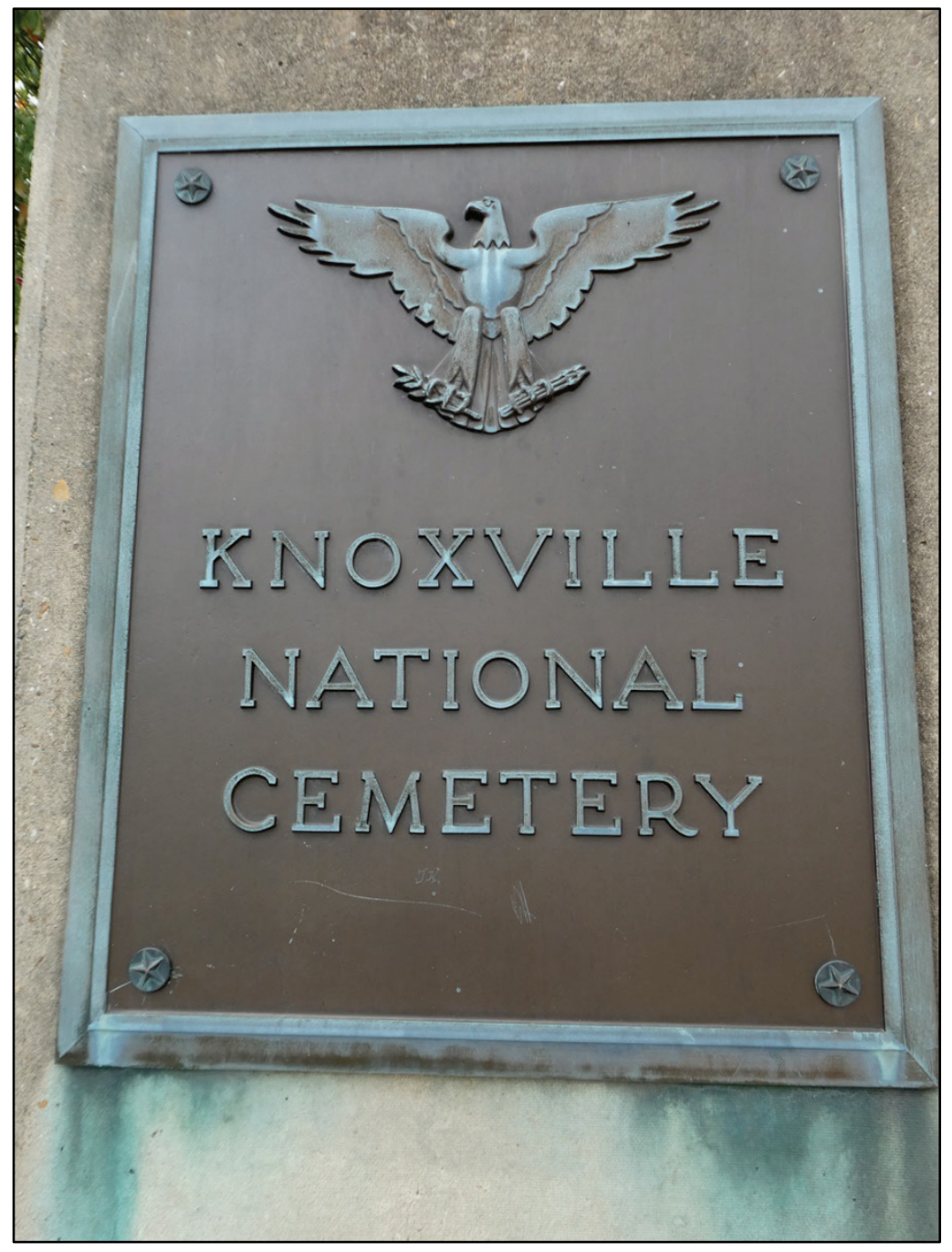


Figure 125. Veterans Administration plaque on the right pylon of the main entrance (ERDCCERL, 2019).

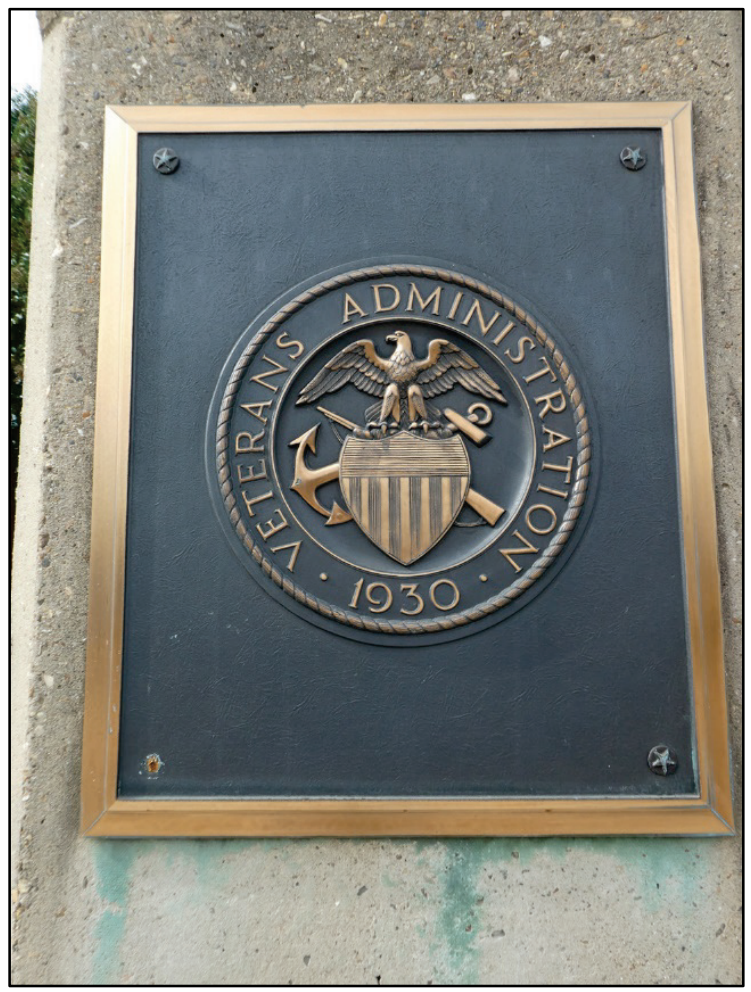

Figure 126. Informational sign (ERDC-CERL, 2019).

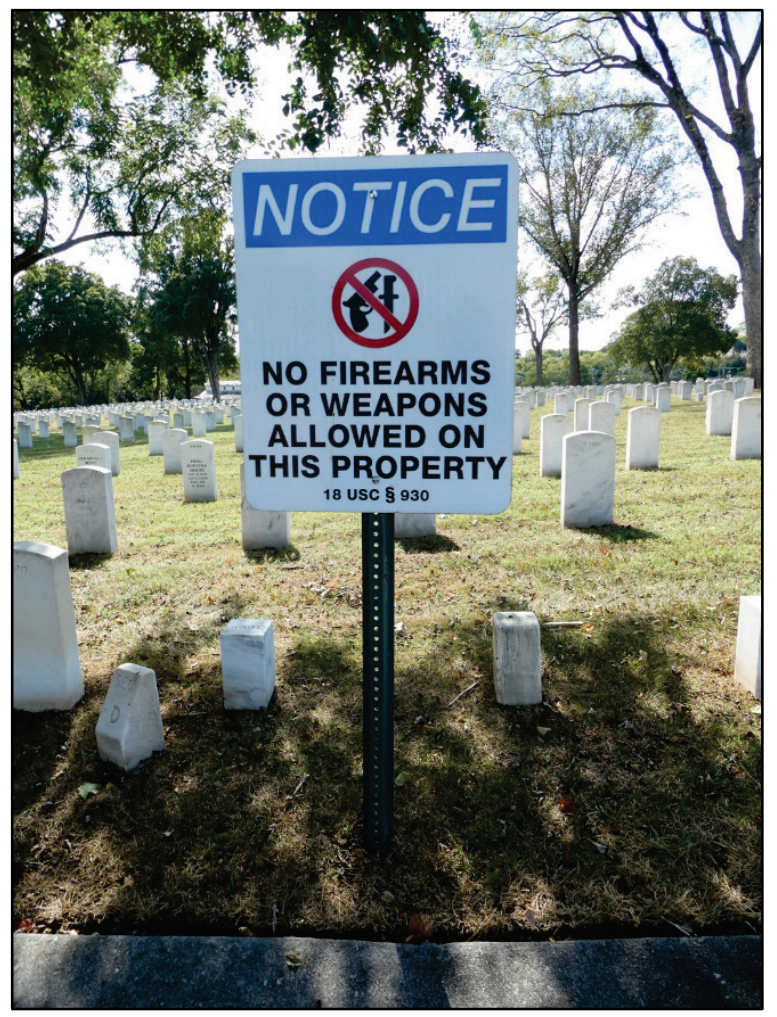


Figure 127. Sign that displays the history behind the formation of the national cemetery system (ERDC-CERL, 2019).

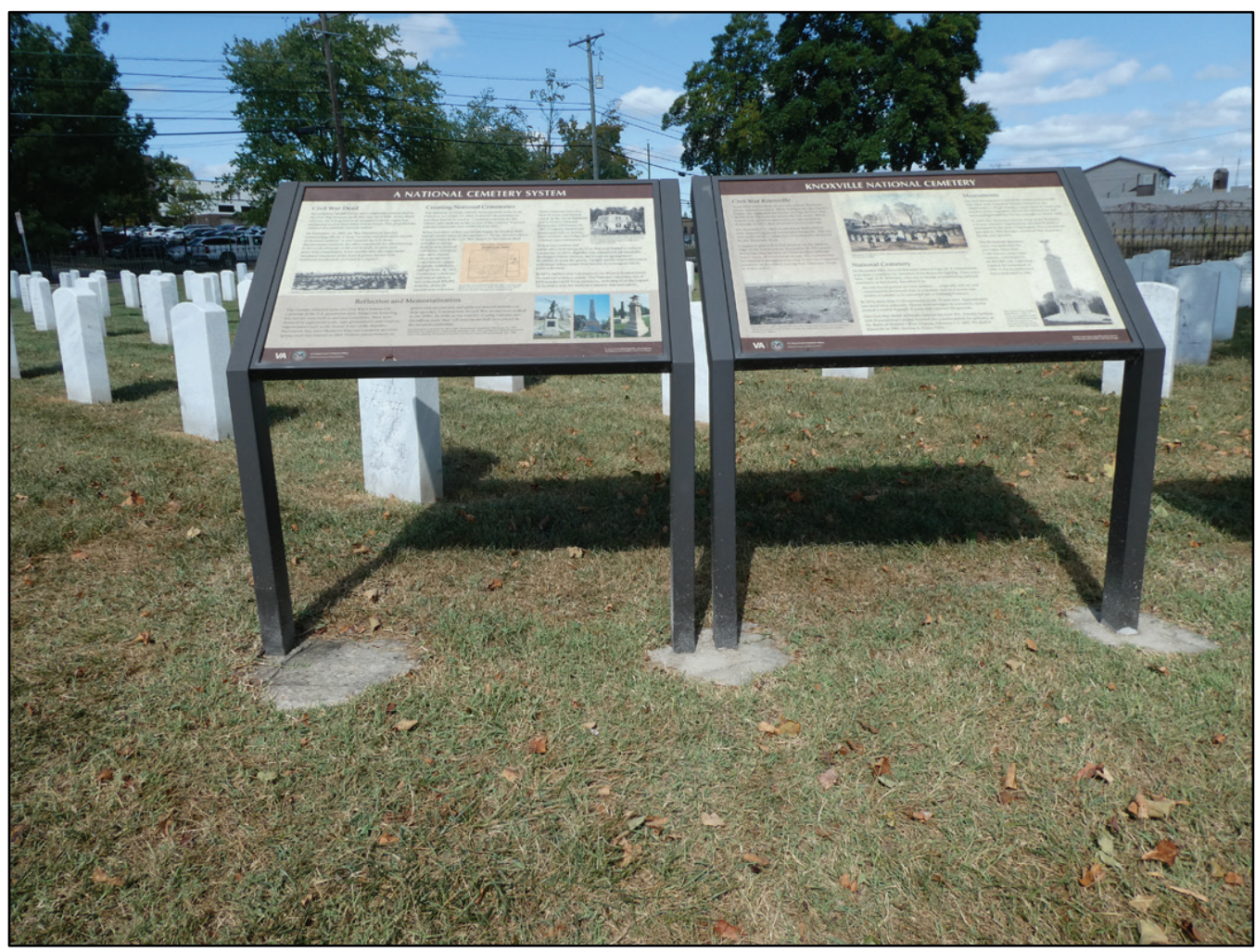

Figure 128. Sign outlining floral regulations (ERDC-CERL, 2019).

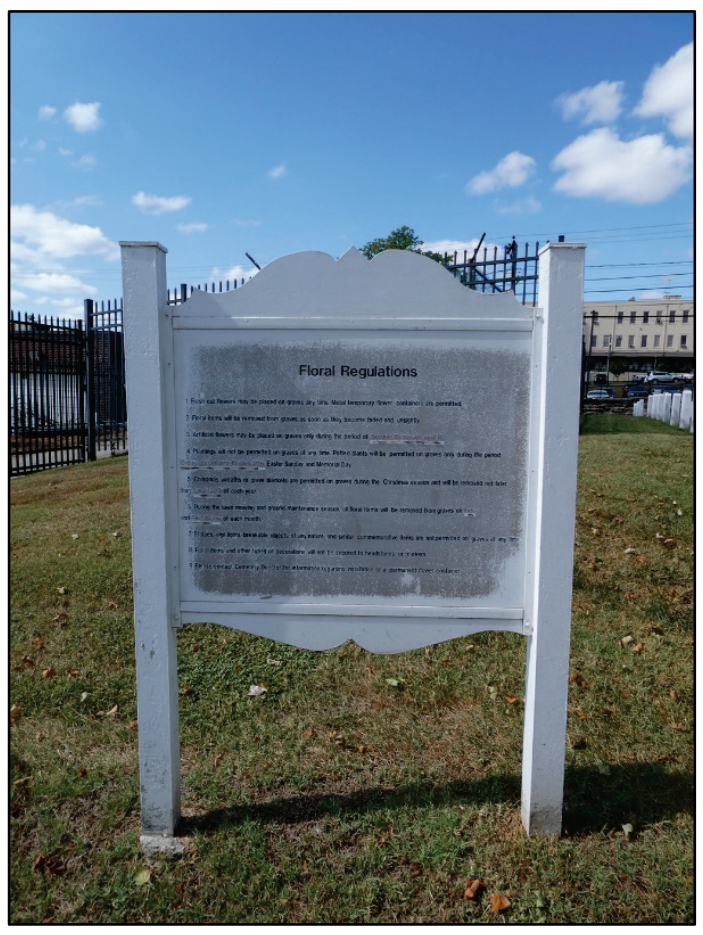


Figure 129. Small sign dedicating a tree (ERDC-CERL, 2019).

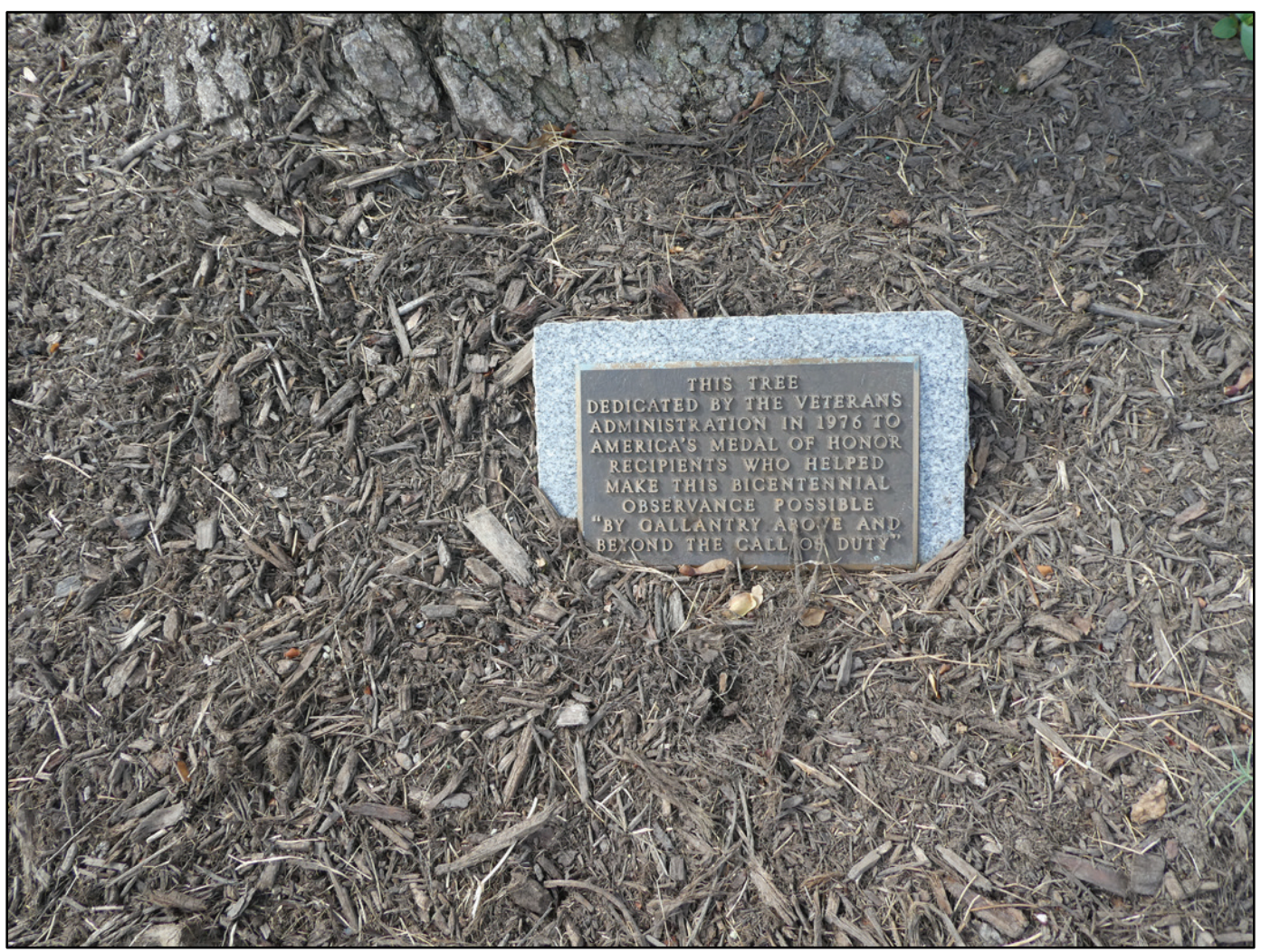

Figure 130. Open hours sign on gate (ERDC-CERL, 2019).

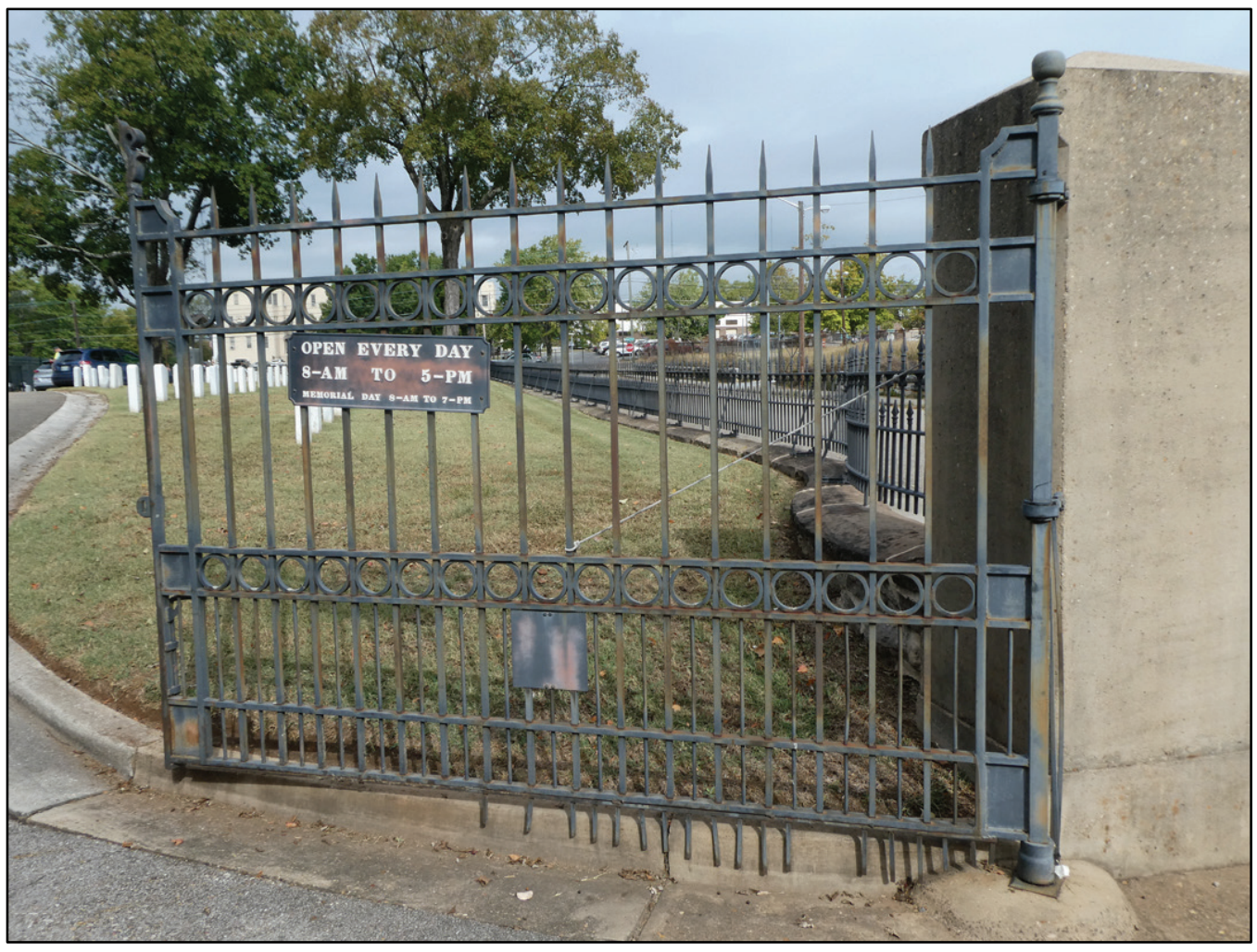




\subsubsection{Section markers}

The section markers, marking the burial sections, are marble cubes with an angled face where the section label is engraved into the stone (Figure 131).

Figure 131. Granite section markers for Section B (ERDC-CERL, 2019).

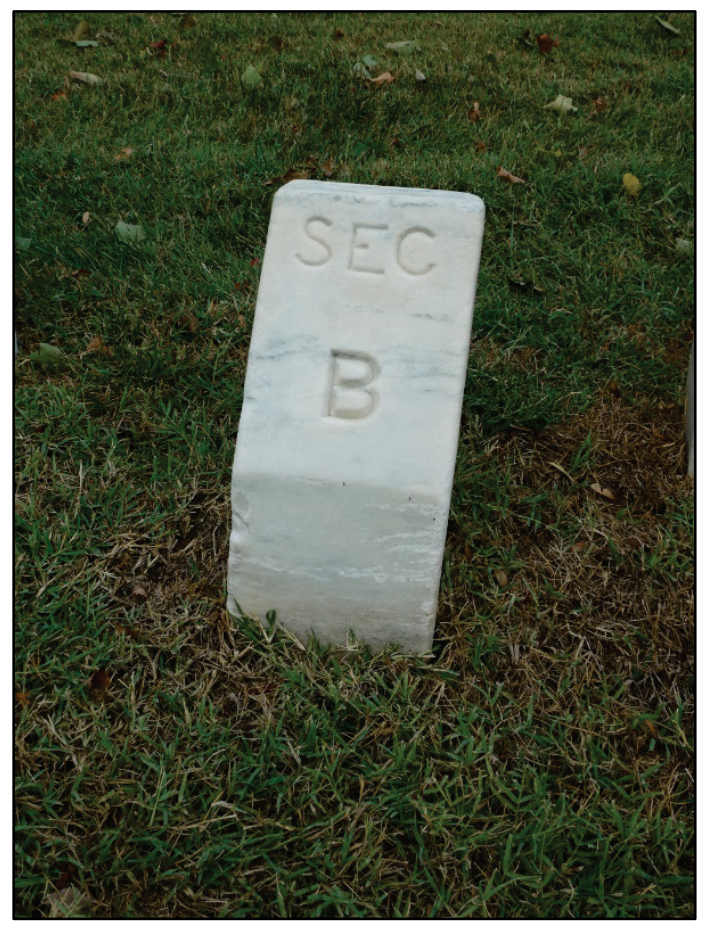

\subsubsection{Water related infrastructure-irrigation and drainage}

On the northwest side of the cemetery where the cross road meets the circle drive, there is a small rainfall drainage area (Figure 132). In addition, along the Old Gray Cemetery wall and the Barnard Avenue wall, there are concrete water channels leading to storm drains in the west and south corners of the cemetery (Figures 133 and 134). There are no other water drainage, supply, or irrigation features in the cemetery. 
Figure 132. Concrete water channel running through the eastern section of the cemetery (ERDC-CERL, 2019).

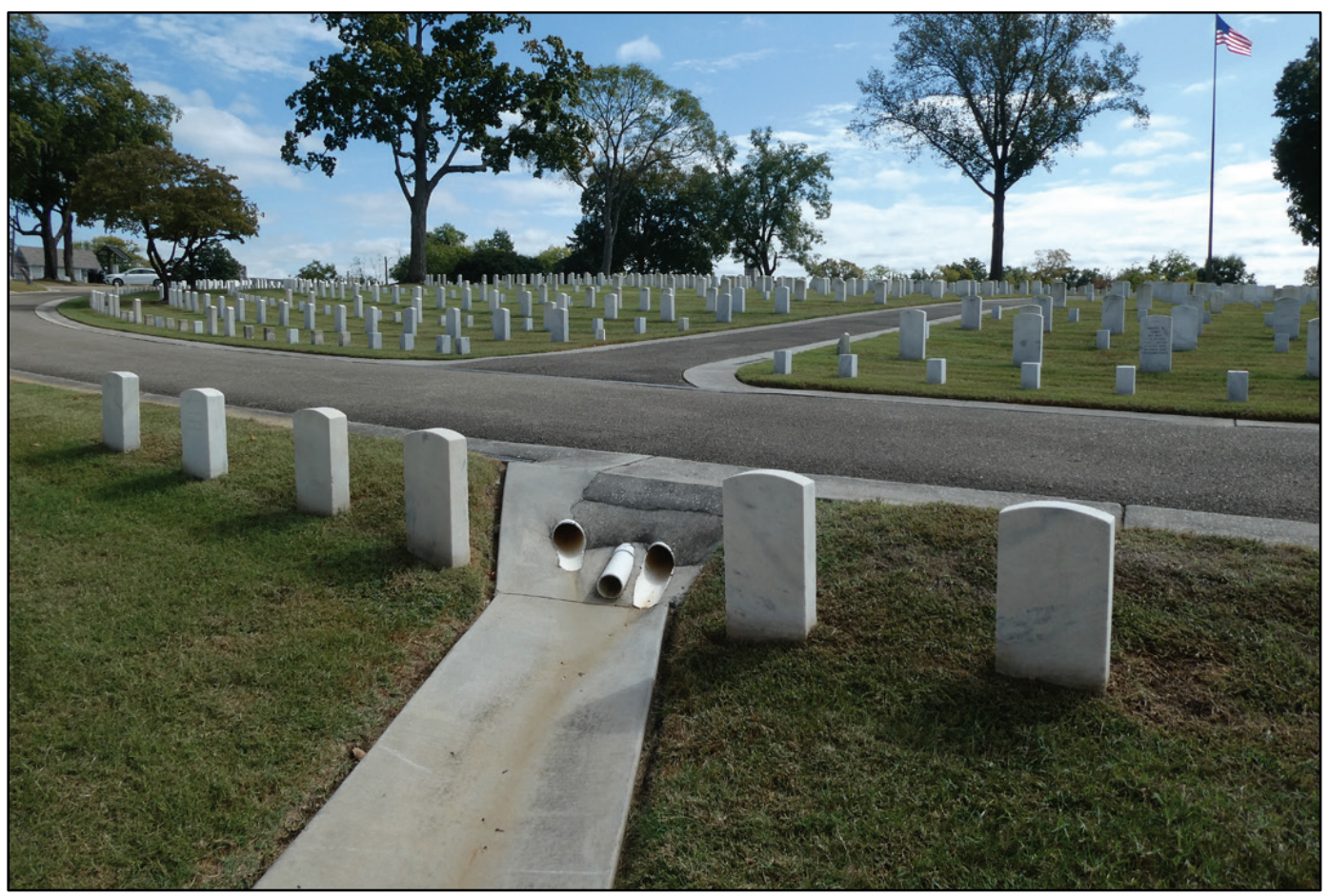

Figure 133. Concrete water channel running to southern corner of the cemetery (ERDC-CERL, 2019).

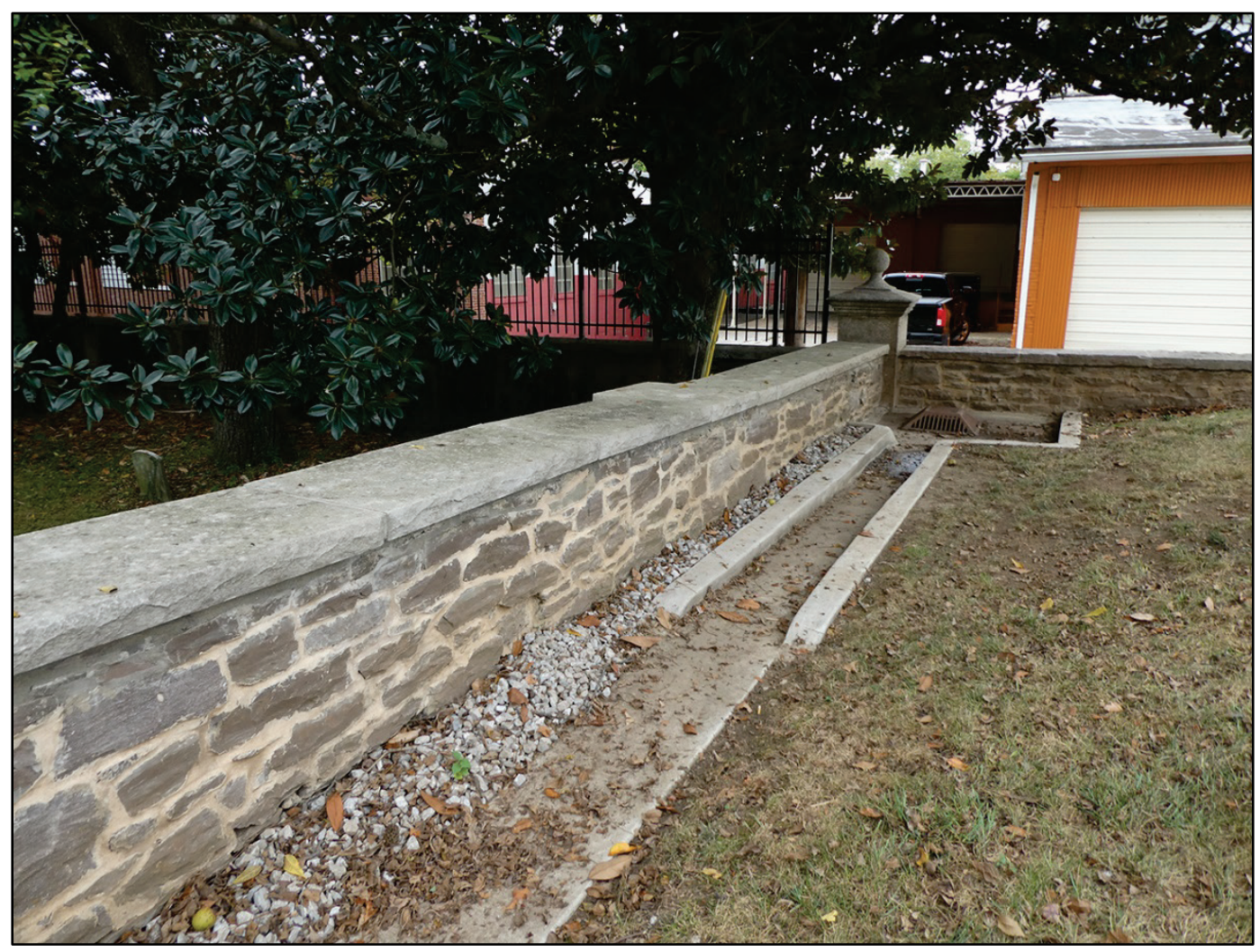


Figure 134. Concrete water channel running to west corner of the cemetery (ERDC-CERL, 2019).

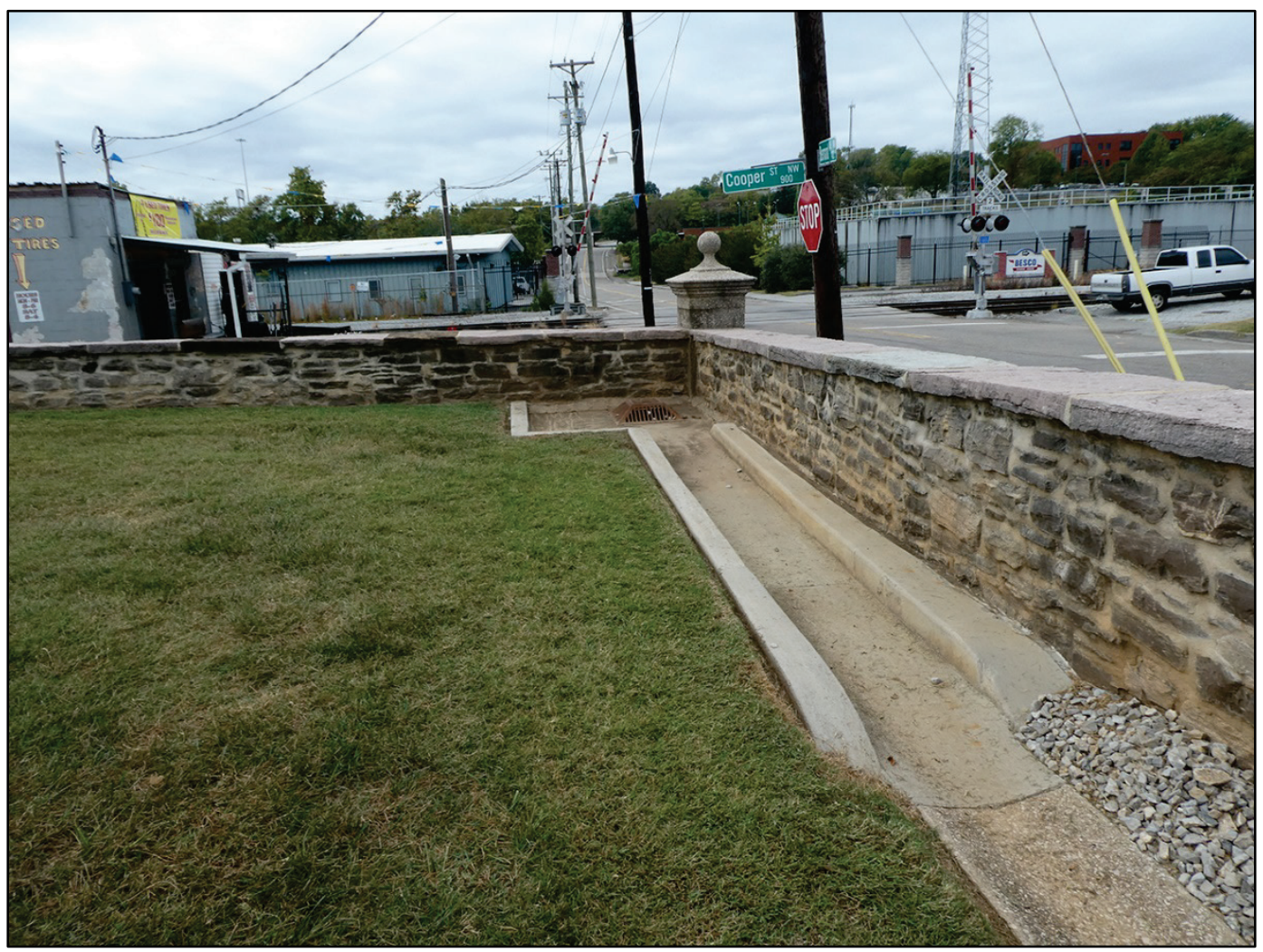

\subsubsection{Trash receptacles}

There is one trash receptacle and one flower vase receptacle located at the small parking area in Section D adjacent to the gravesite locator kiosk (Figure 135). There is also one trash receptacle near the flagstaff (Figure 136). 
Figure 135. Trash and flower vases receptacles at parking area in Section D (ERDC-CERL, 2019).

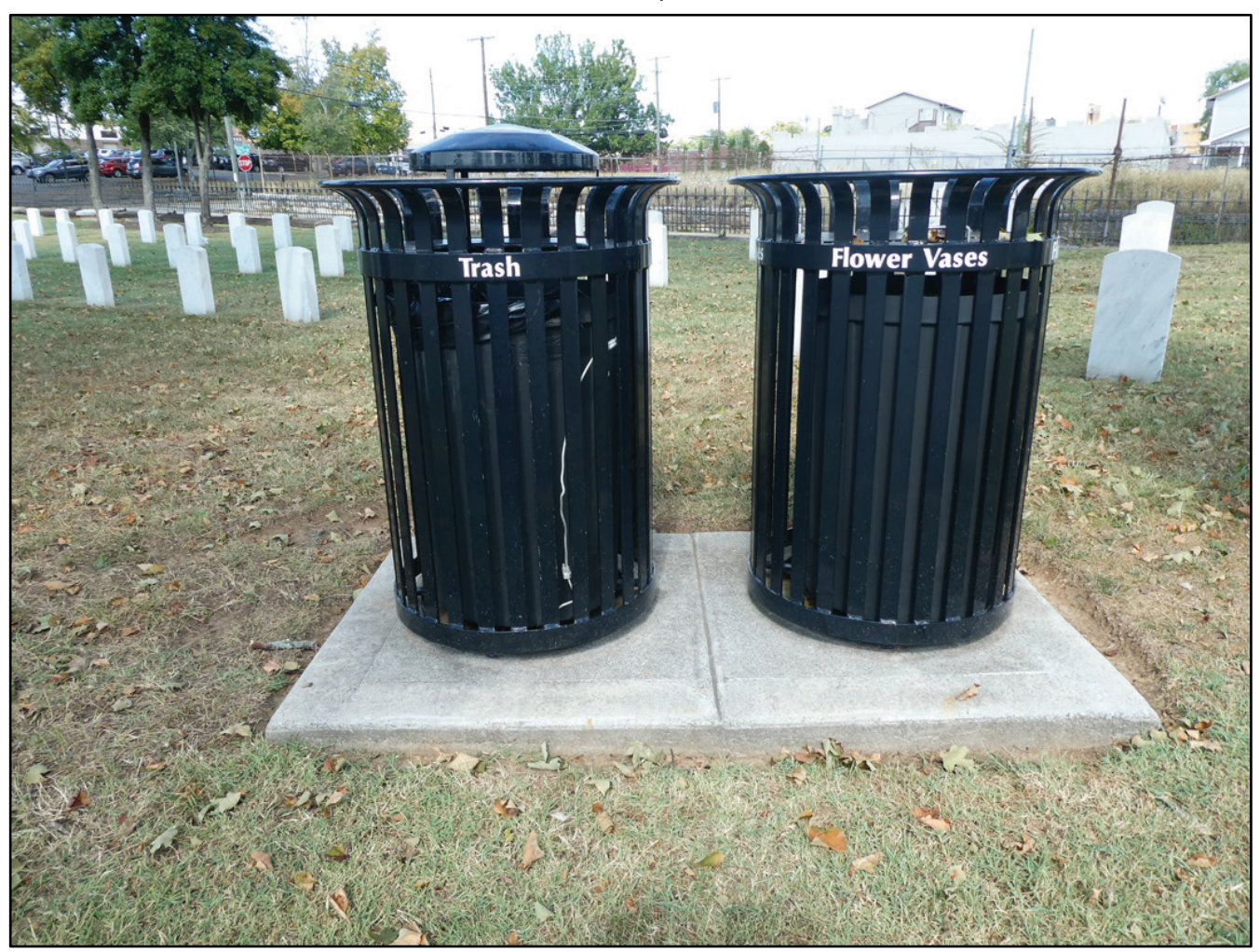

Figure 136. Trash receptacle near the flagstaff (ERDC-CERL, 2019).

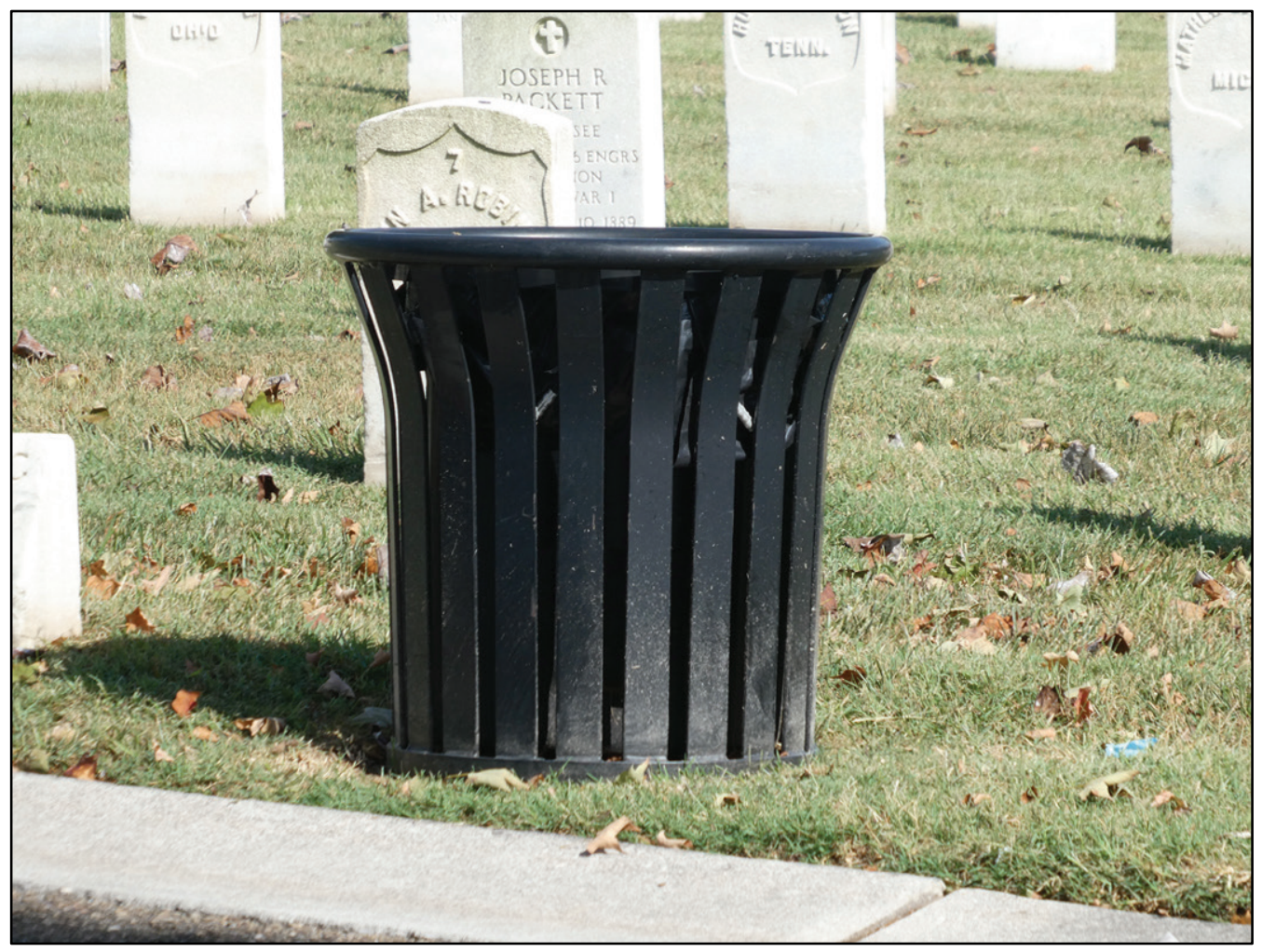




\subsubsection{Lighting}

There is one type of light fixture in the Knoxville National Cemetery. The four fixtures illuminate the flagstaff (Figure 137).

Figure 137. Flagstaff floodlight (ERDC-CERL, 2019).

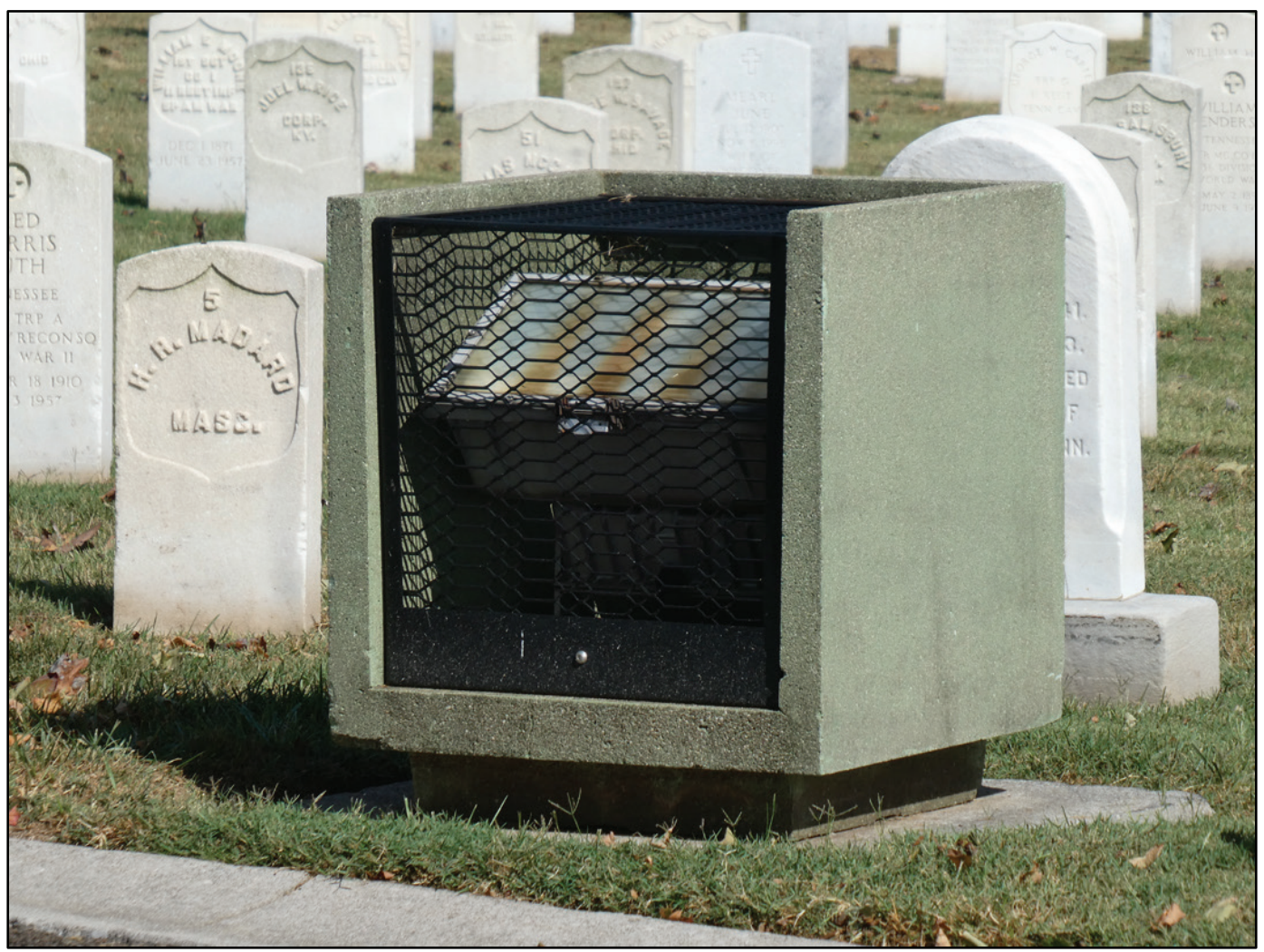

\subsubsection{Miscellaneous}

There are no miscellaneous small-scale features at the Knoxville National Cemetery.

\subsubsection{Views and vistas}

Because Knoxville National Cemetery encompasses a small site, most of the cemetery can be seen from any one point; however, there are three significant viewpoints-one from the main entrance into the cemetery (Figures 138 and 139), one from the flagstaff mound looking southeast into Old Gray Cemetery (Figures 140 and 141), and the last one from the main entrance looking southeast towards the Union Soldier Monument (Figures 142 and 143). 
Figure 138. Viewshed from the main entrance into the cemetery (ERDC-CERL, 2019).

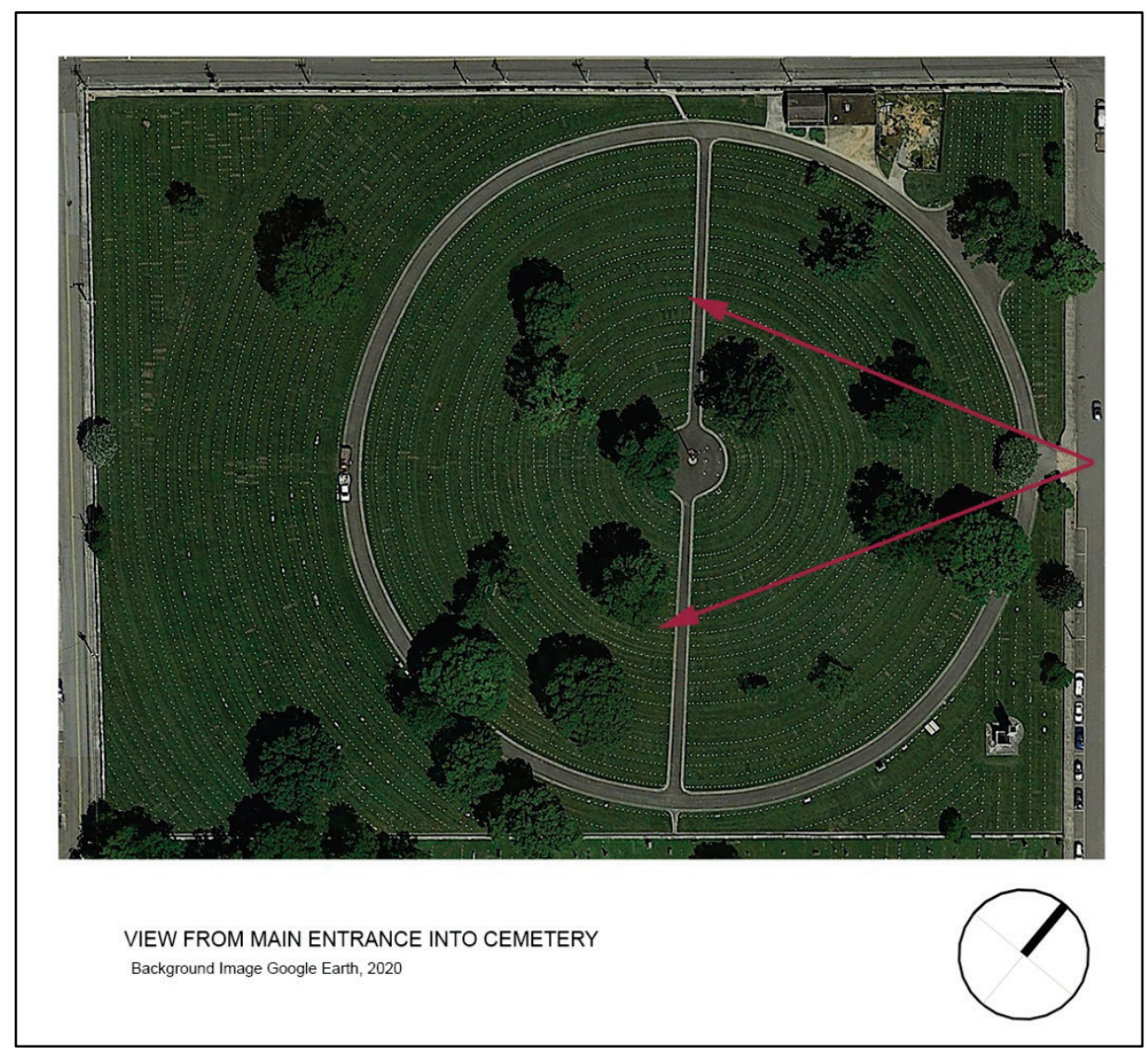

Figure 139. View southwest from the main entrance into the cemetery (ERDC-CERL, 2019).

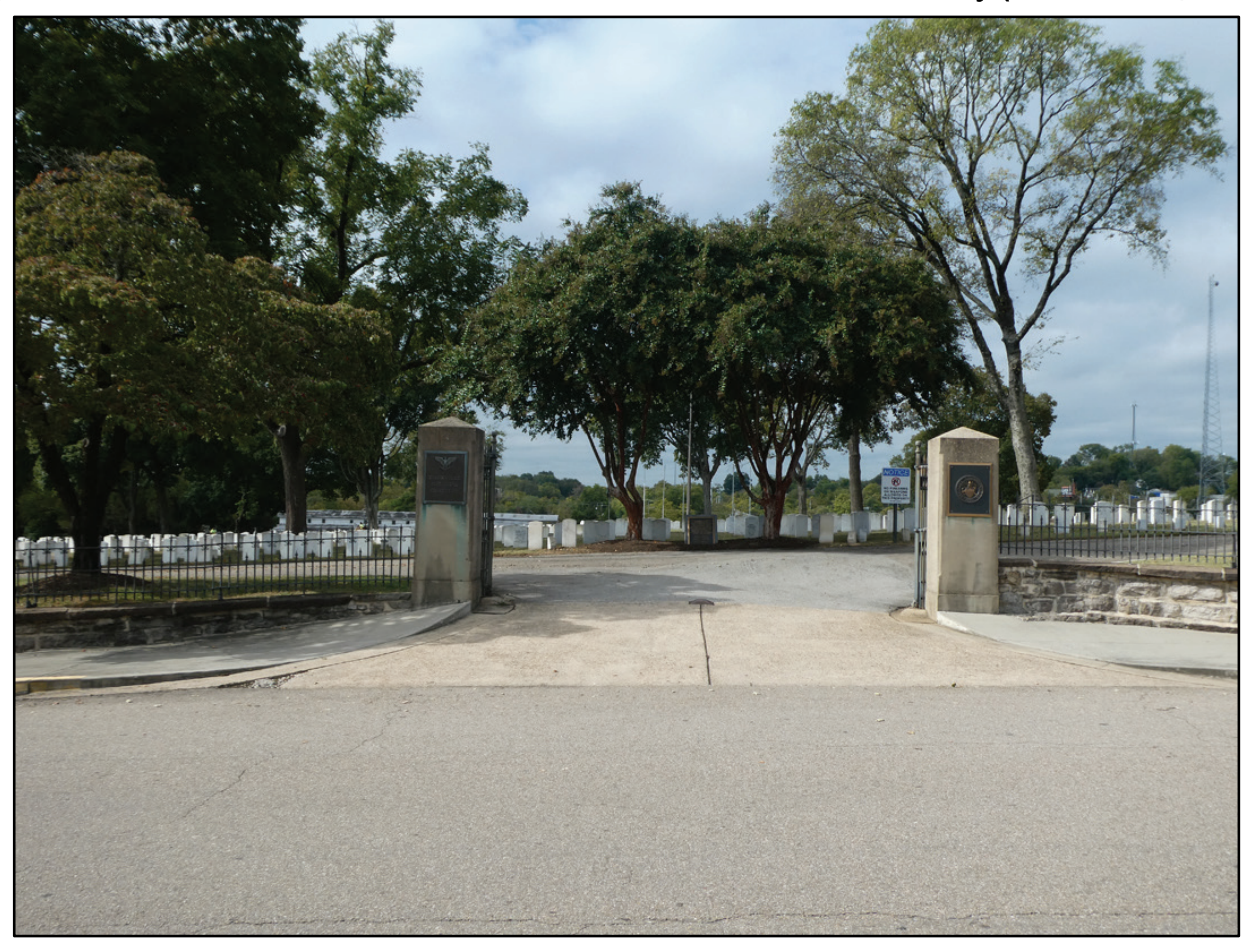


Figure 140. Viewshed from the flagstaff southeast into the Old Gray Cemetery (ERDC-CERL, 2020).

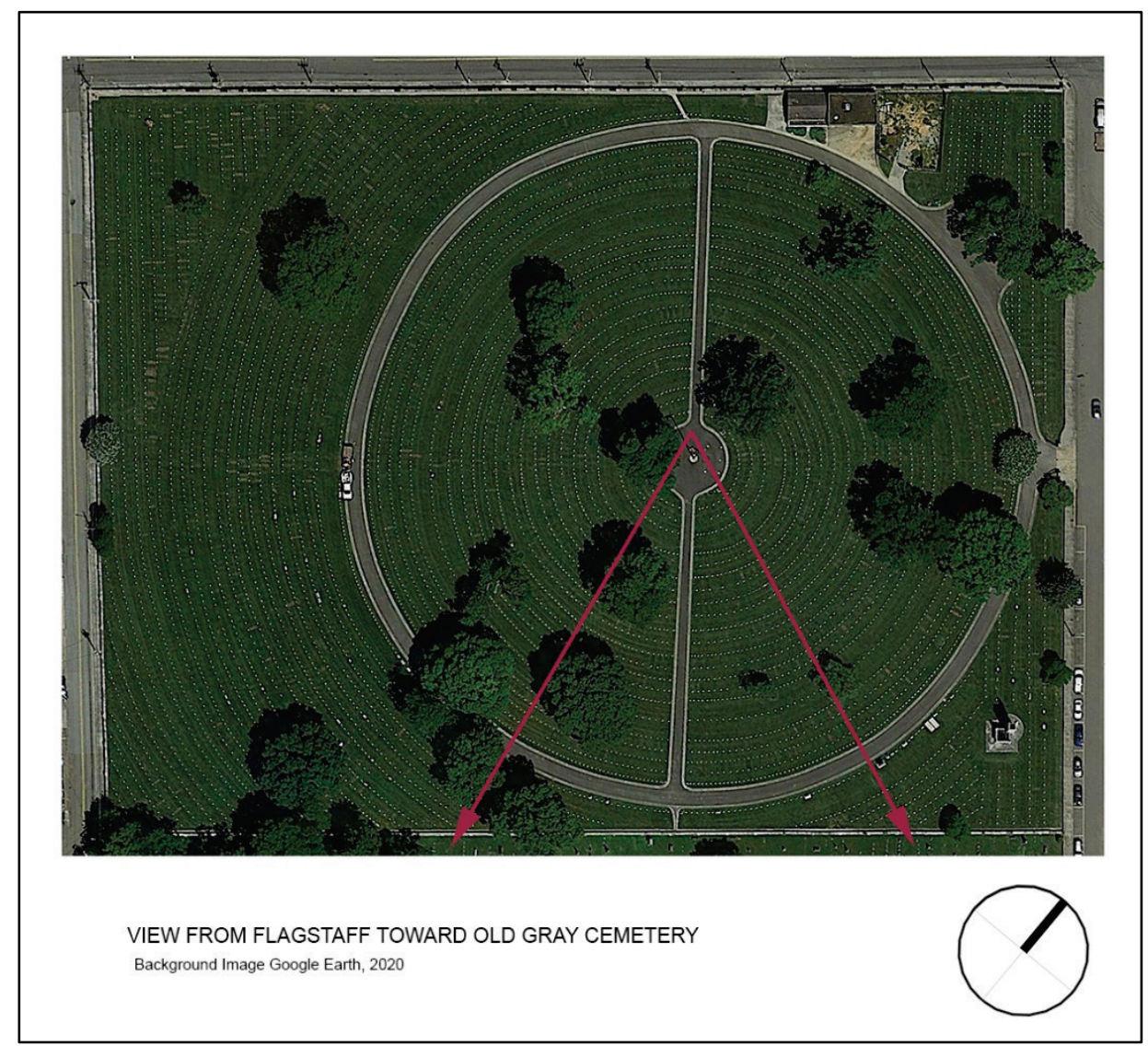


Figure 141. View from the flagstaff southeast into the Old Gray Cemetery (ERDC-CERL, 2019).

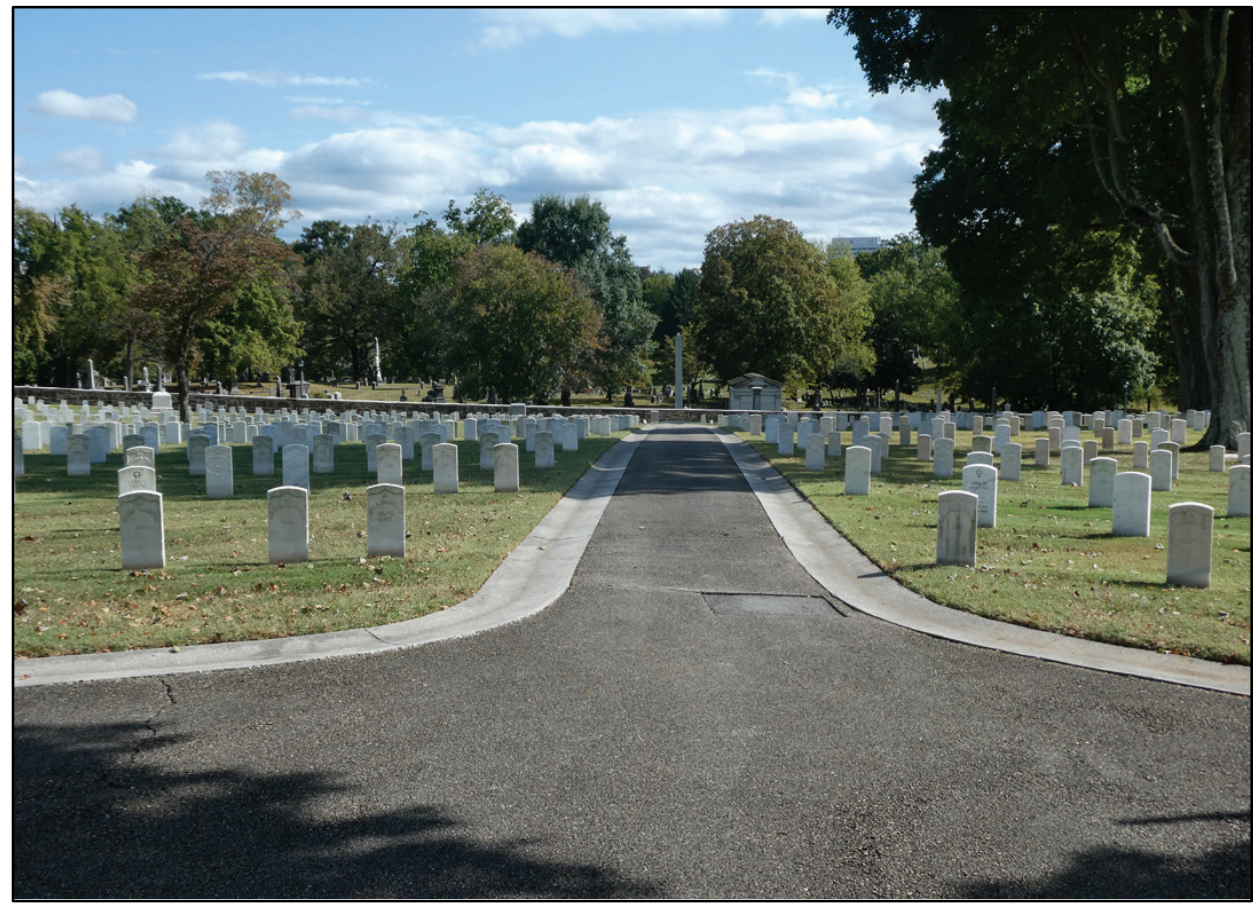

Figure 142. Viewshed from the main entrance southeast to the Union Soldier Monument, (ERDC-CERL, 2020).

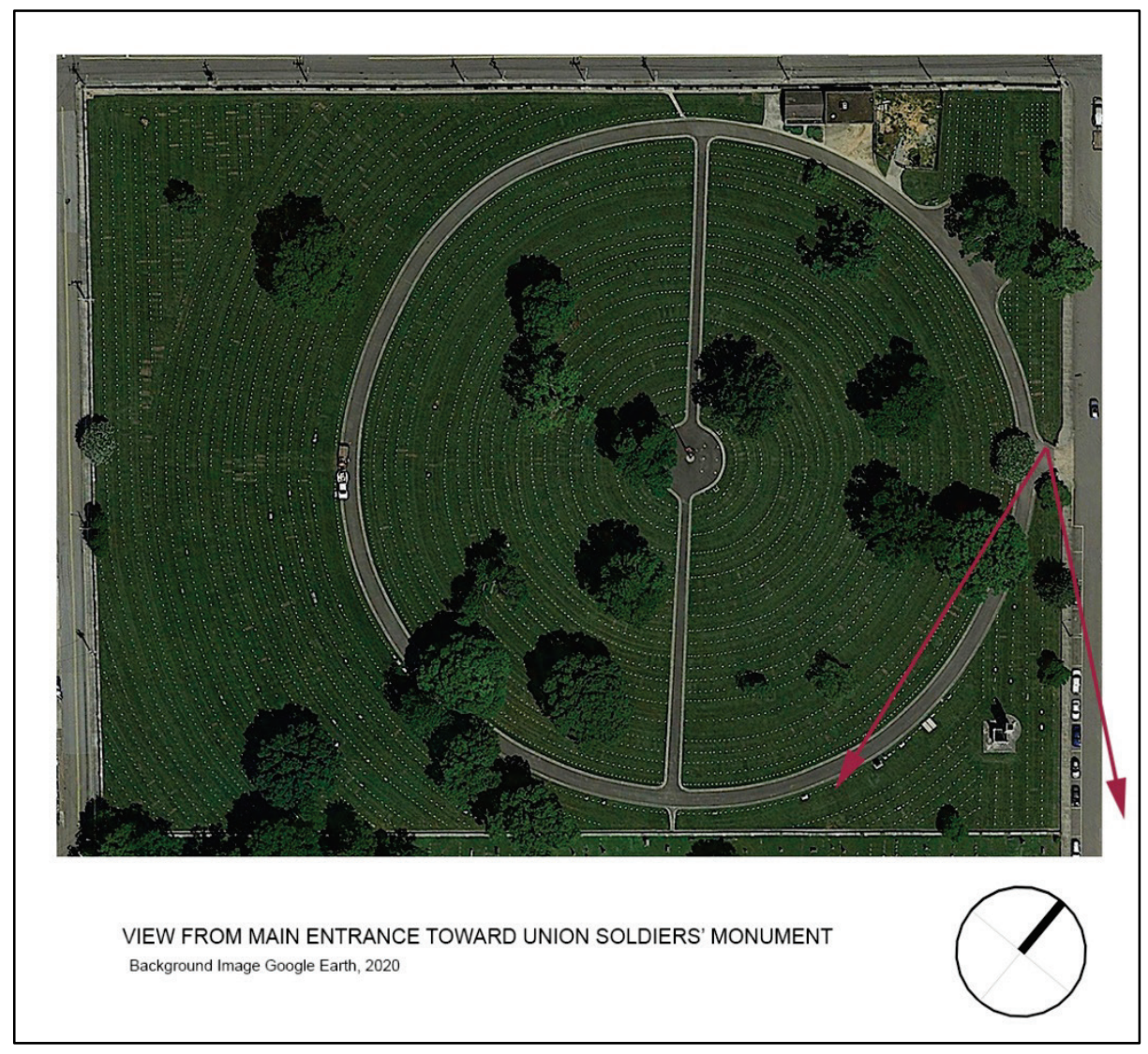


Figure 143. View from the main entrance southeast to the Union Soldier Monument (ERDCCERL, 2019).

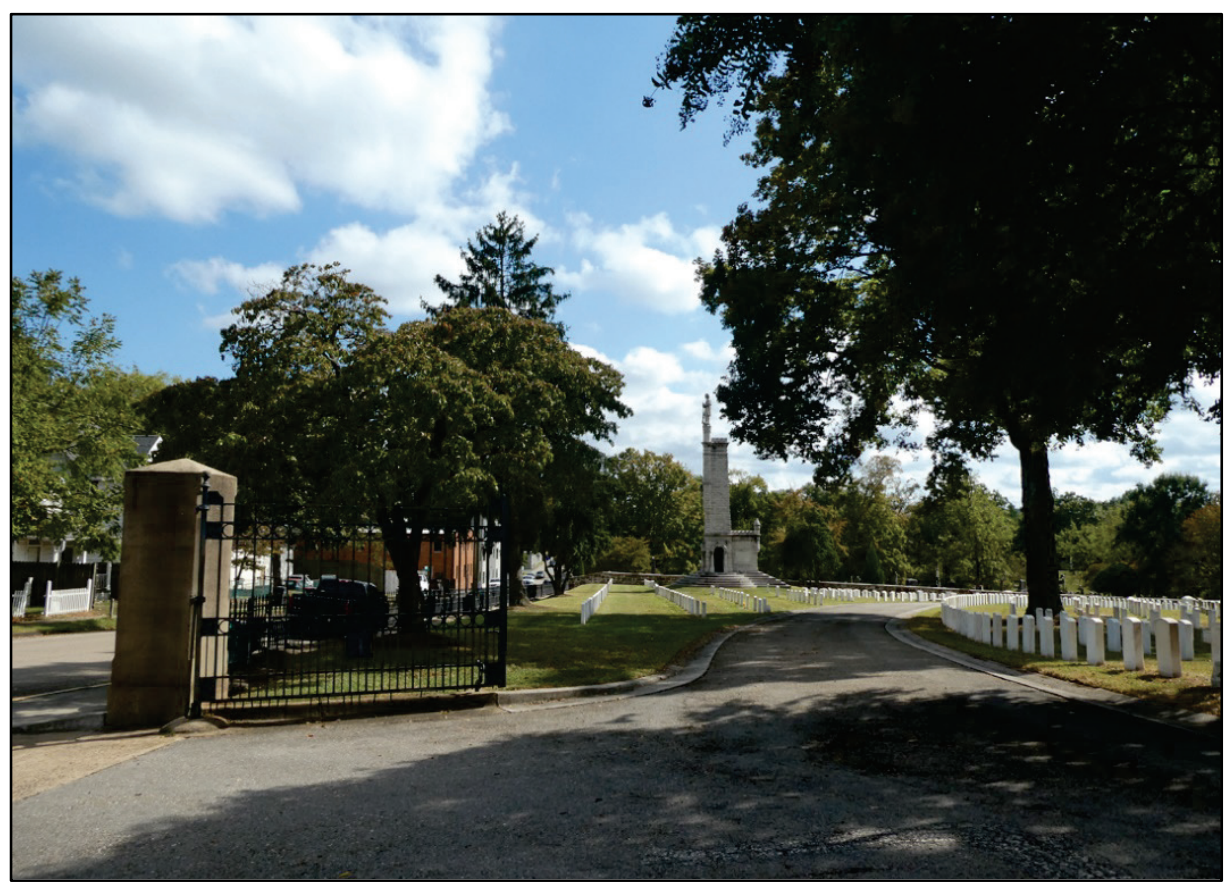




\section{Landscape Features Analysis}

As stated in the 2011 clarification policy from NRHP, all features within the boundary of a National Cemetery are considered to be contributing resources to the history of the site. ${ }^{235}$ That type of all-encompassing consideration is different from most NRHP-eligible properties. For most properties, there are almost always some resources that do not contribute to the significance of the property, whether that property is a site, building, structure, object, or district.

The inventory and analysis for this work documents the physical changes to Knoxville National Cemetery over time-from its inception through 2019. The resources used for the analysis are historic plans of the cemetery (1869, 1892, 1909, 1947, 1949, 1966, 1971, and 2019), historic aerials, historic photographs, and the field survey the authors conducted during November 2019. As of spring 2020, there were more than 9,000 burials recorded at Knoxville National Cemetery.

For purposes of analyzing the landscape of Knoxville National Cemetery, the site has been divided into seven sections-Inner A, Outer A plus Section X; Inner B; Inner C; D; Outer B; Outer C; and Northeast (Sections, Y, $\mathrm{CS}$, and CS-2). The site is divided into those sections naturally by the circle drive and the original east-west and north-south grass drives (Figure 144). Each section's analysis is given below in sections 5.1.4 - 5.1.10. The site's perimeter wall is discussed in section 5.1.1, the entrance gates in sections 5.1.2 - 5.1.3 and the flagstaff is discussed individually in section 5.1.11.

\footnotetext{
235 NPS, National Register of Historic Places, "National Register Eligibility of National Cemeteries-a Clarification of Policy,"
} 
Figure 144. Knoxville National Cemetery divided into sections for landscape feature analysis, 2020 (ERDC-CERL based on Google Aerial).

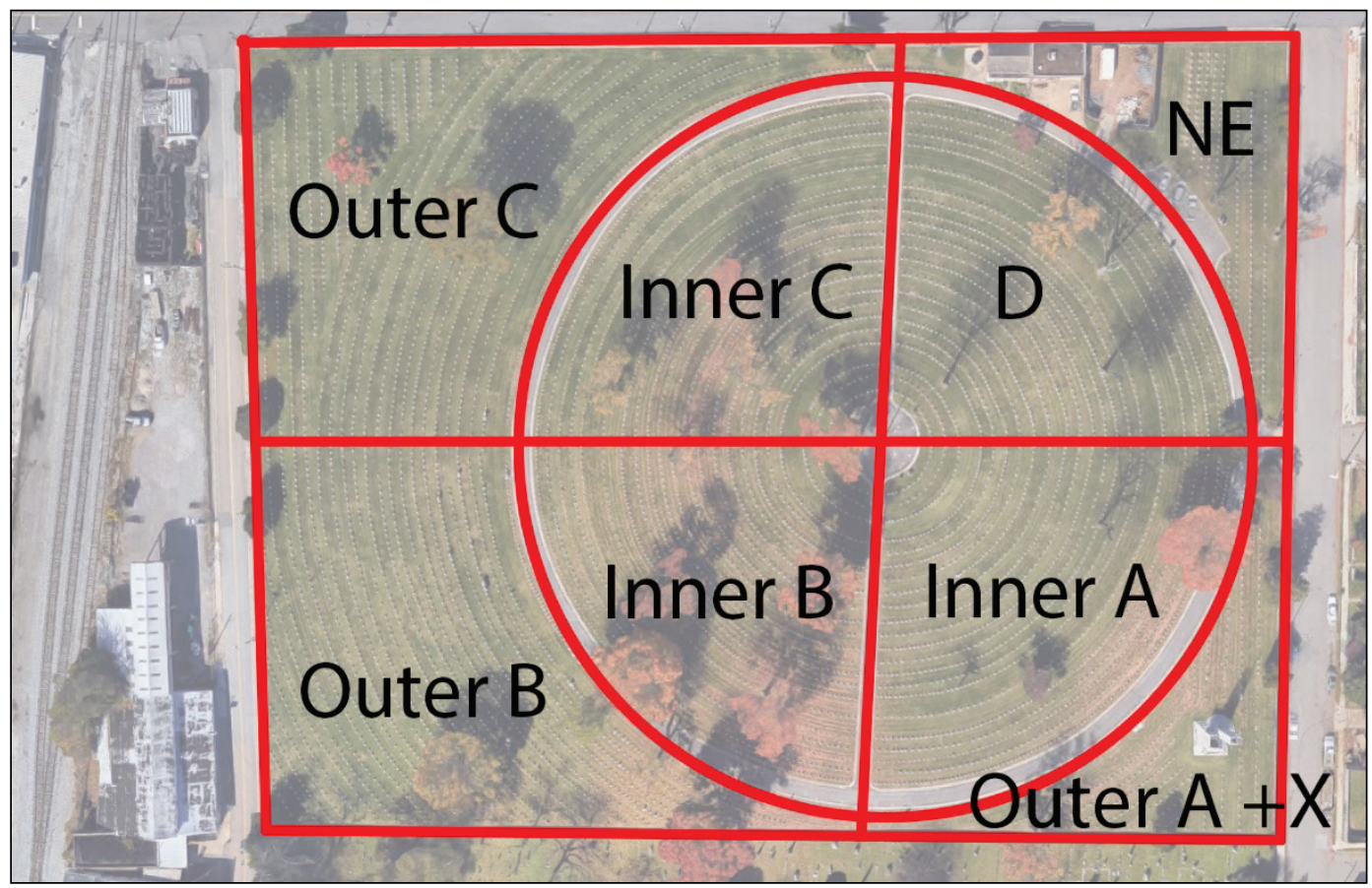

\subsection{Features analyses}

\subsubsection{Perimeter wall}

According to the original Act of Congress establishing the National Cemeteries, Knoxville National Cemetery was bounded by a perimeter fence. The original fence was built from wooden posts and boards (Figure 145). It had wood gates at the intersection of each drive with the wood fence, but the wood fence was replaced with a stone wall between November 1872 and May 1873. The portion of the stone wall along Tyson Street and a portion along Bernard Avenue have an iron fence on top of the stone portion (Figures 146 and 147). Since the construction of the original stone wall, the wall has been repaired and/or replaced several times. The placement of the current wall reflects the location of the original wall, the location of the Tyson Gate on the northeast, and the former Cooper Gate within the current wall.

Two birds-eyes lithographs show that the wall was lined with trees on the inside of the wall (Figures 148 and 149). 
Figure 145. Looking northeast at a drawing of the wood fence along Cooper Street, 1869 (NARA, Washington DC, RG92).

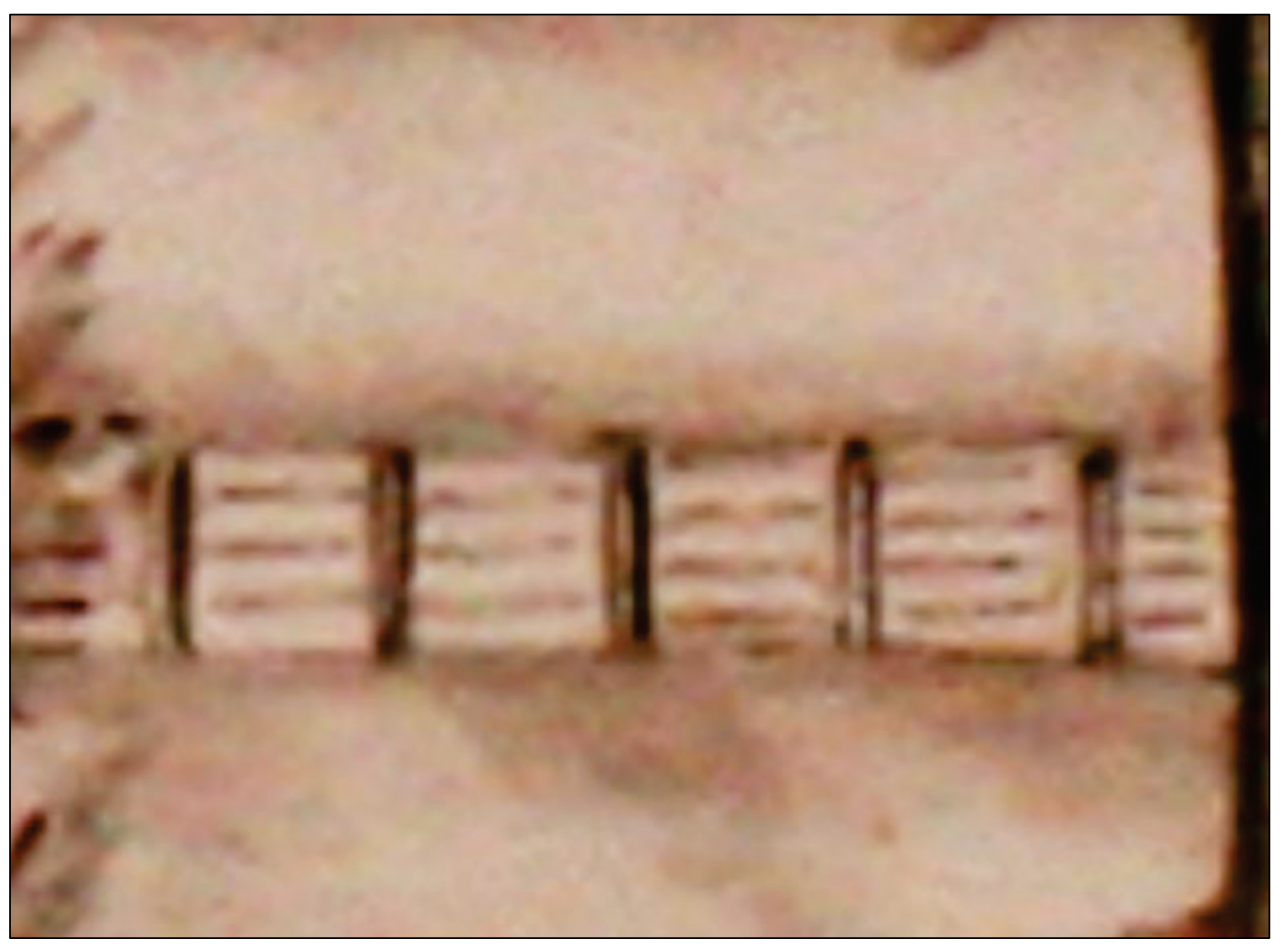

Figure 146. Looking southwest at the stone wall with iron fence along Tyson Street, 1909 (NARA College Park, RG92-CA).

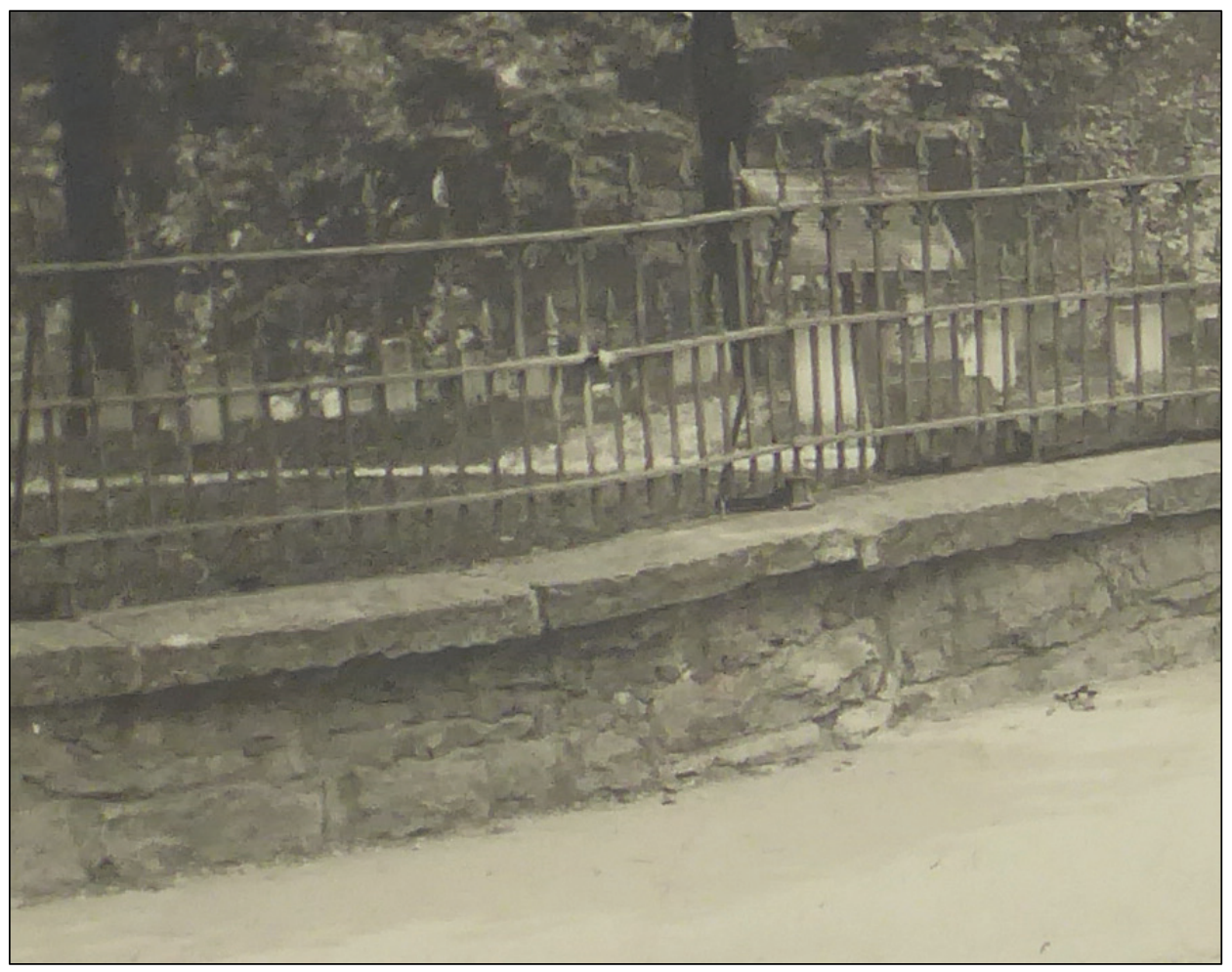


Figure 147. Looking southwest at the stone wall with iron fence along Tyson Street (ERDCCERL, 2019).

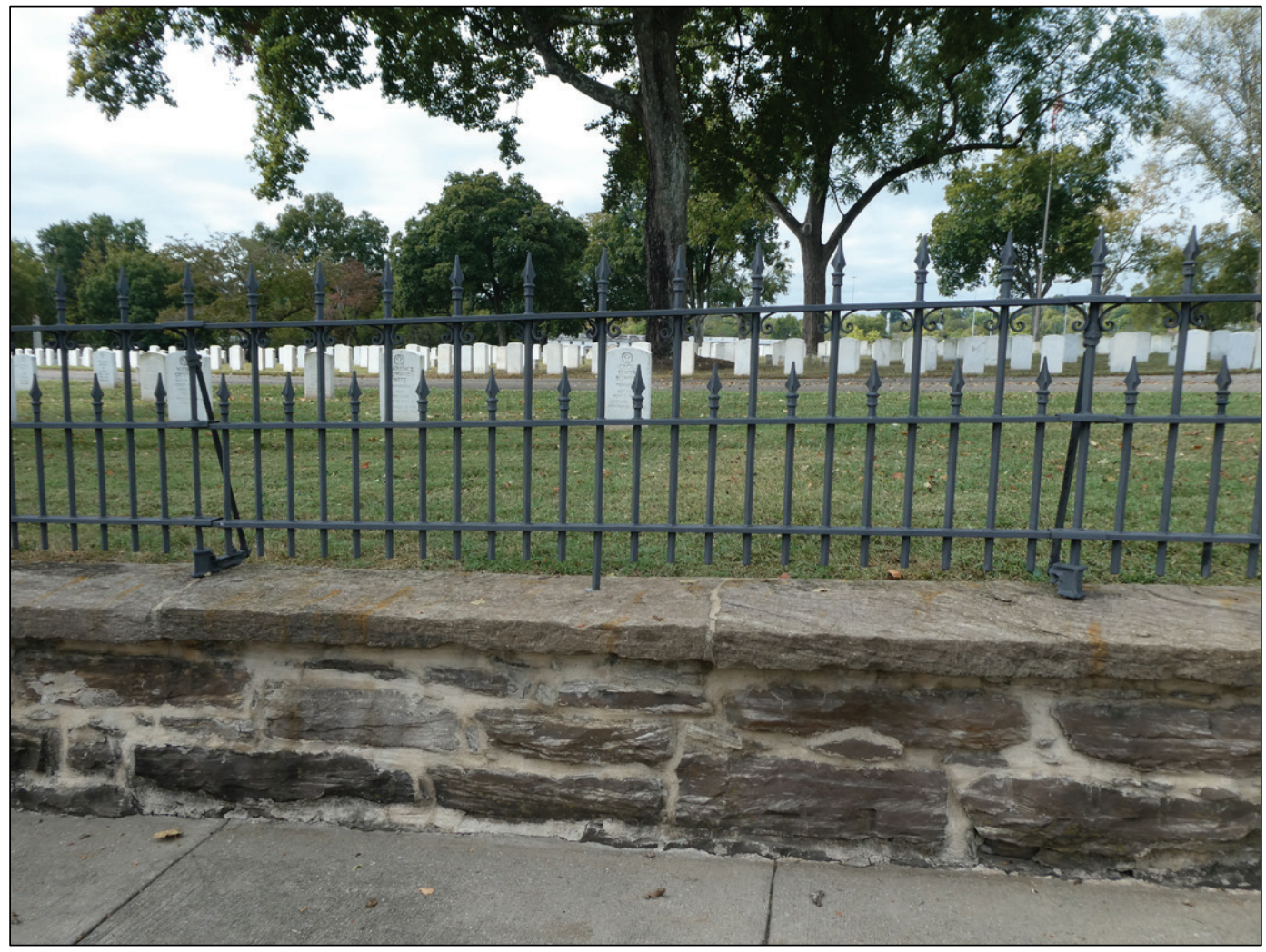

Figure 148. A portion of a birds-eye drawing showing the concentric circles centered on the flagstaff with trees on the perimeter boundary of the cemetery, 1871 (Library of Congress).

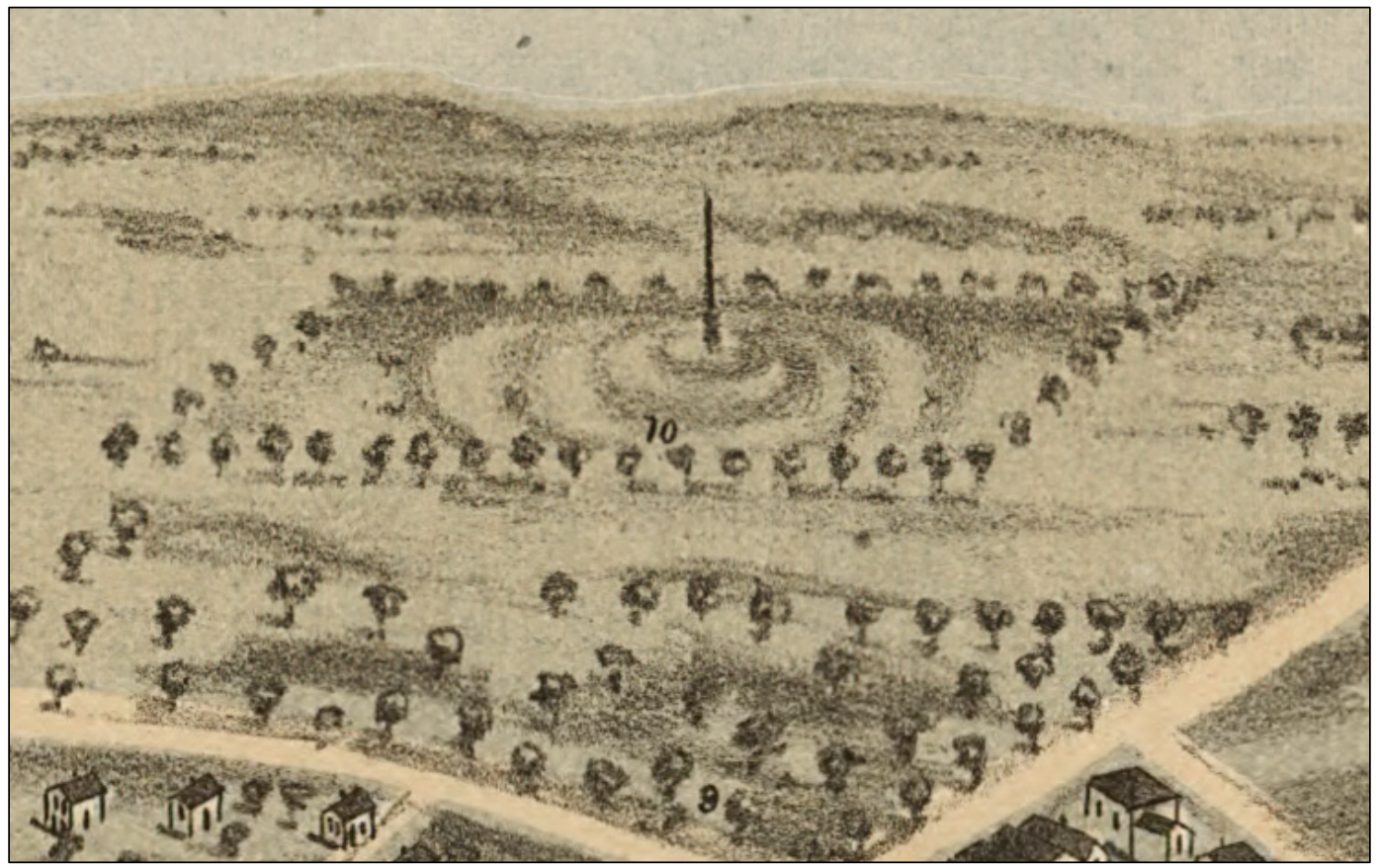


Figure 149. A portion of a birds-eye drawing showing trees on the perimeter boundary of the cemetery, 1886 (Library of Congress).

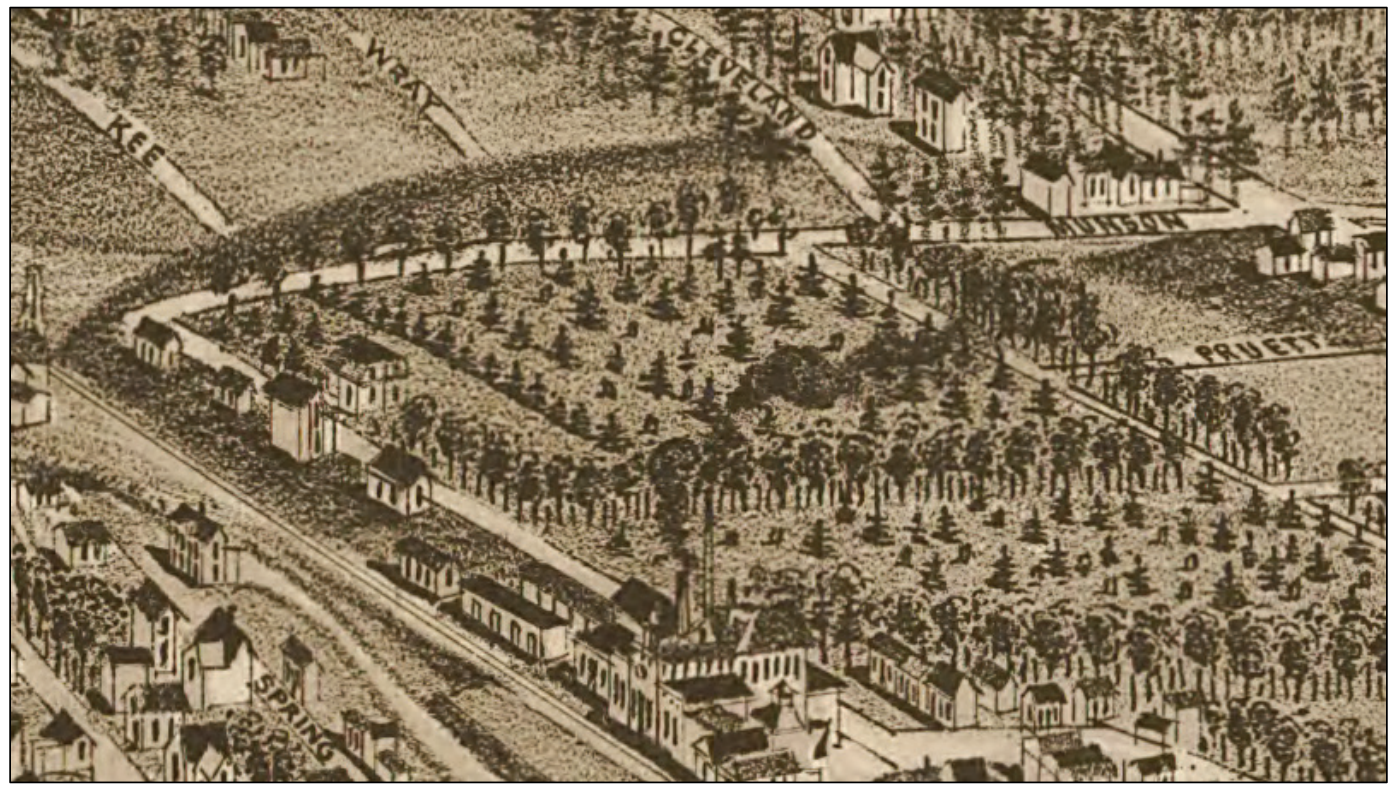

\subsubsection{Tyson Gate}

The entranceway to the cemetery from Tyson Street (originally called Holston Street) is original, although this was considered the rear gate until approximately 1907 when the brick superintendent's lodge was constructed. The gate itself has gone through some major changes throughout the years from its original wooden gate to a three-stone pier gate to a cast-iron gate to the current concrete pier gate (Figures 150-153).

Figure 150. Looking northeast at a drawing of the wood gate on Tyson Street, 1869 (NARA, Washington DC, RG92).

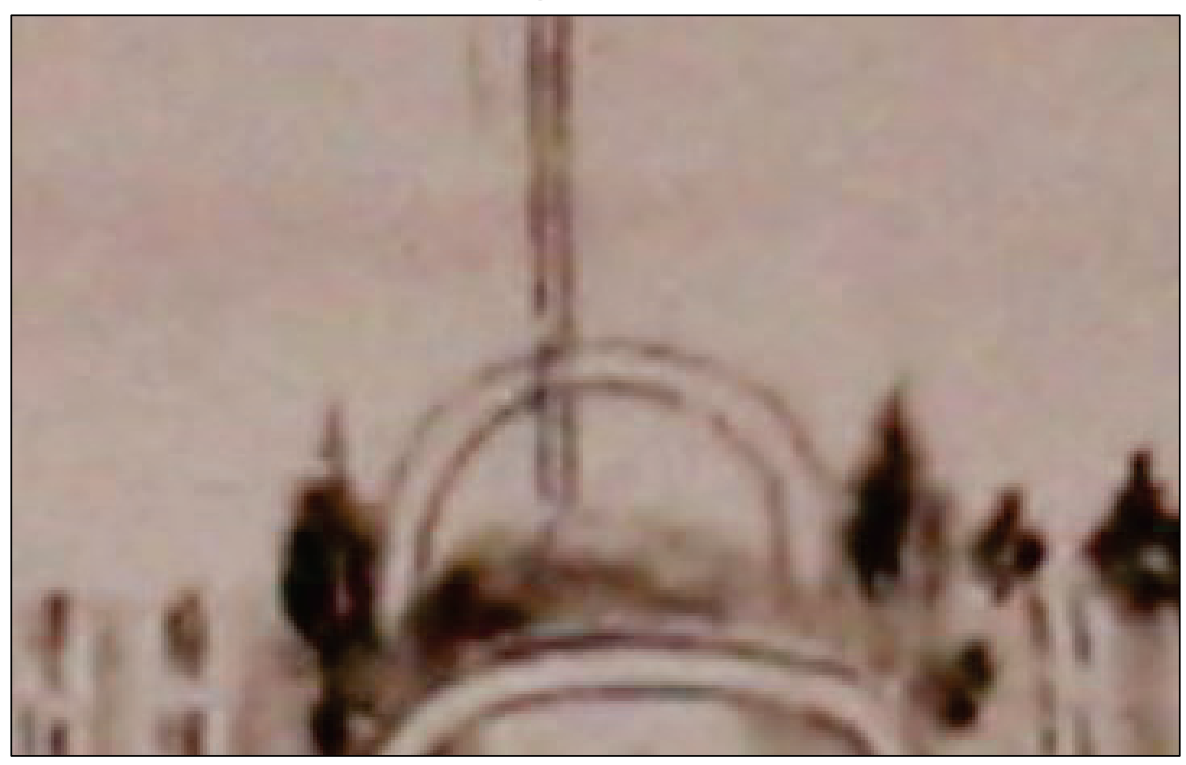


Figure 151. Looking southwest at the Tyson Gate, 1904 (NARA College Park, RG-92-CA).

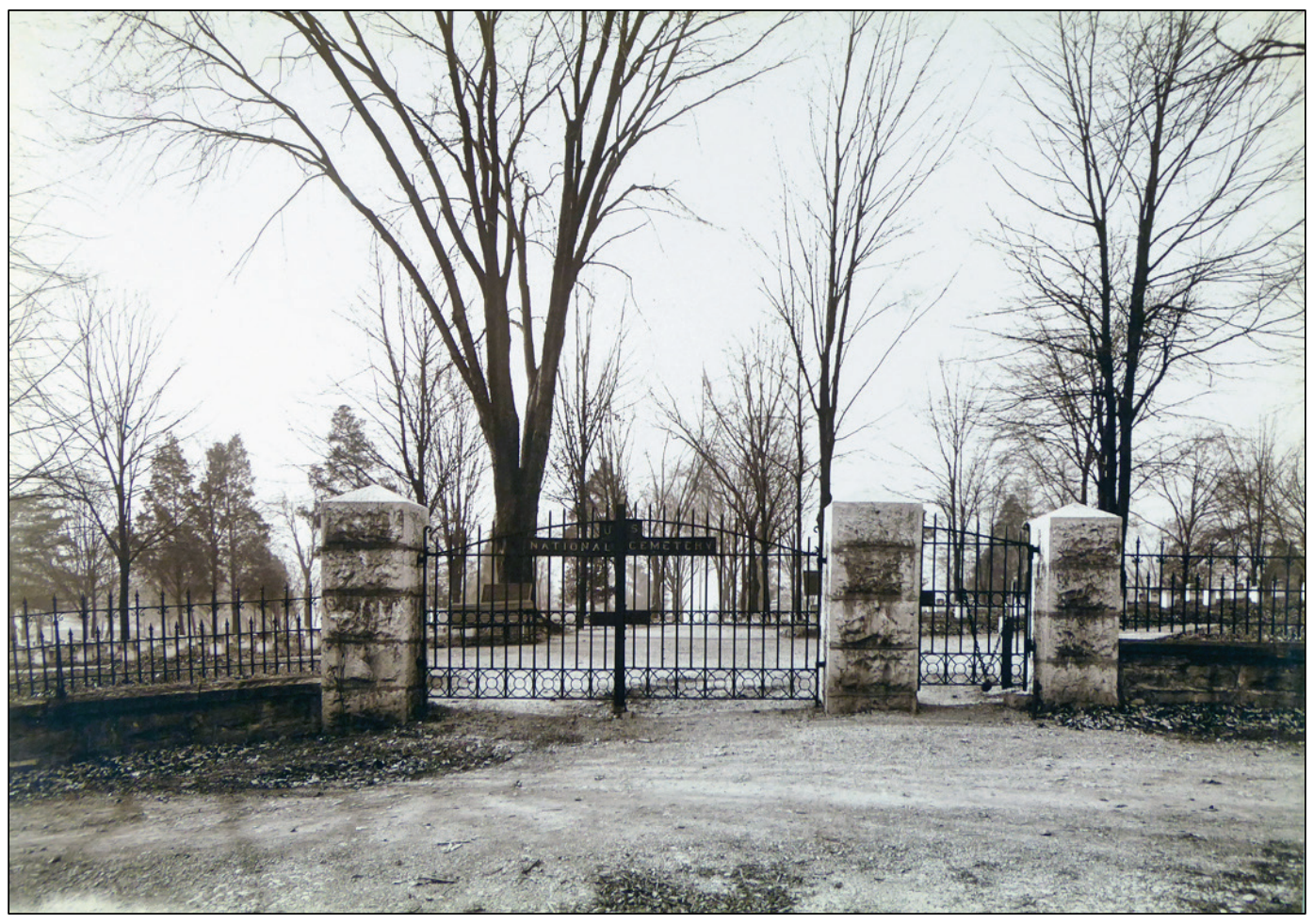

Figure 152. Looking southwest at the Tyson Gate, 1951 (VA NCA Archives).

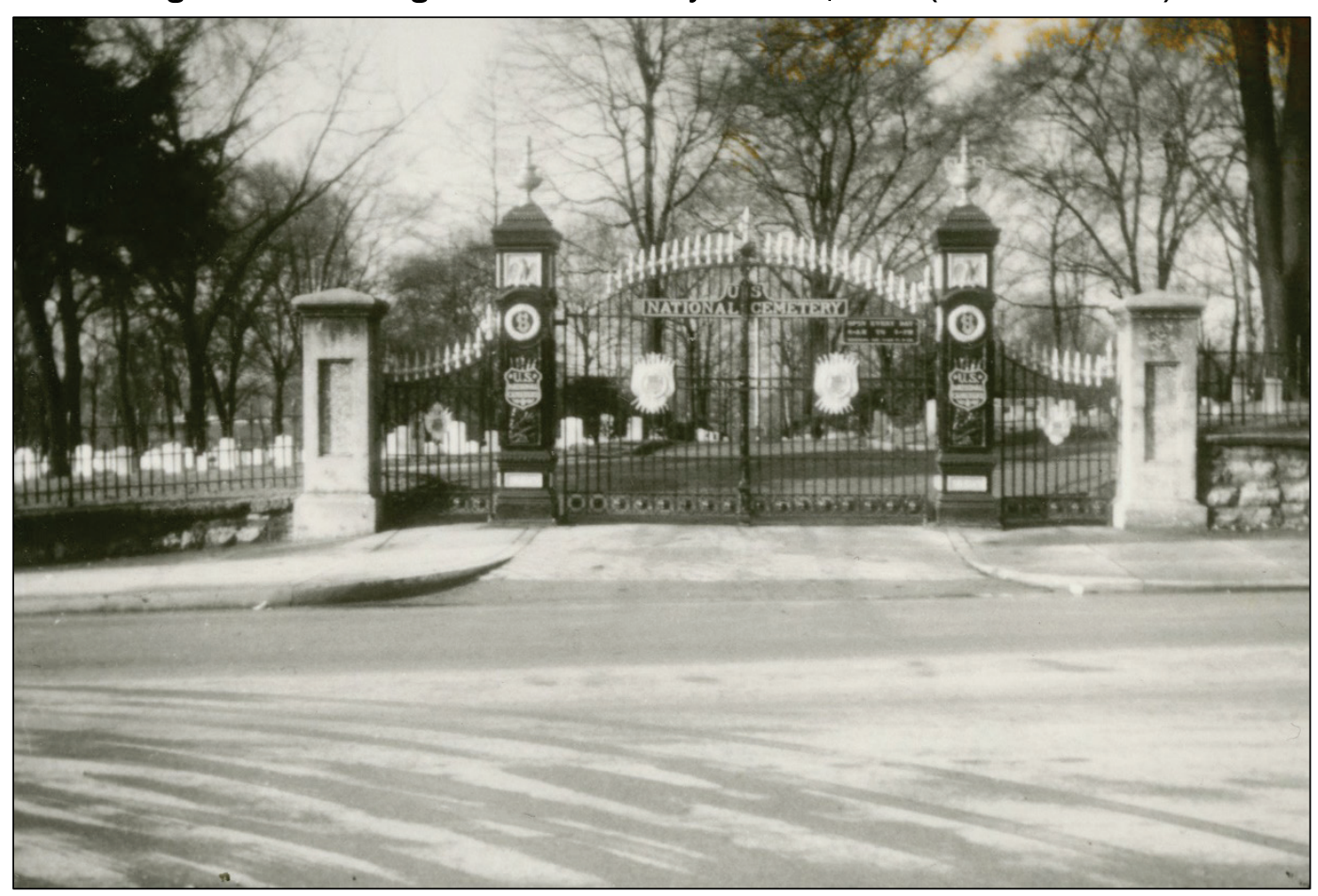


Figure 153. Looking southwest at the Tyson Gate (ERDC-CERL, 2019).

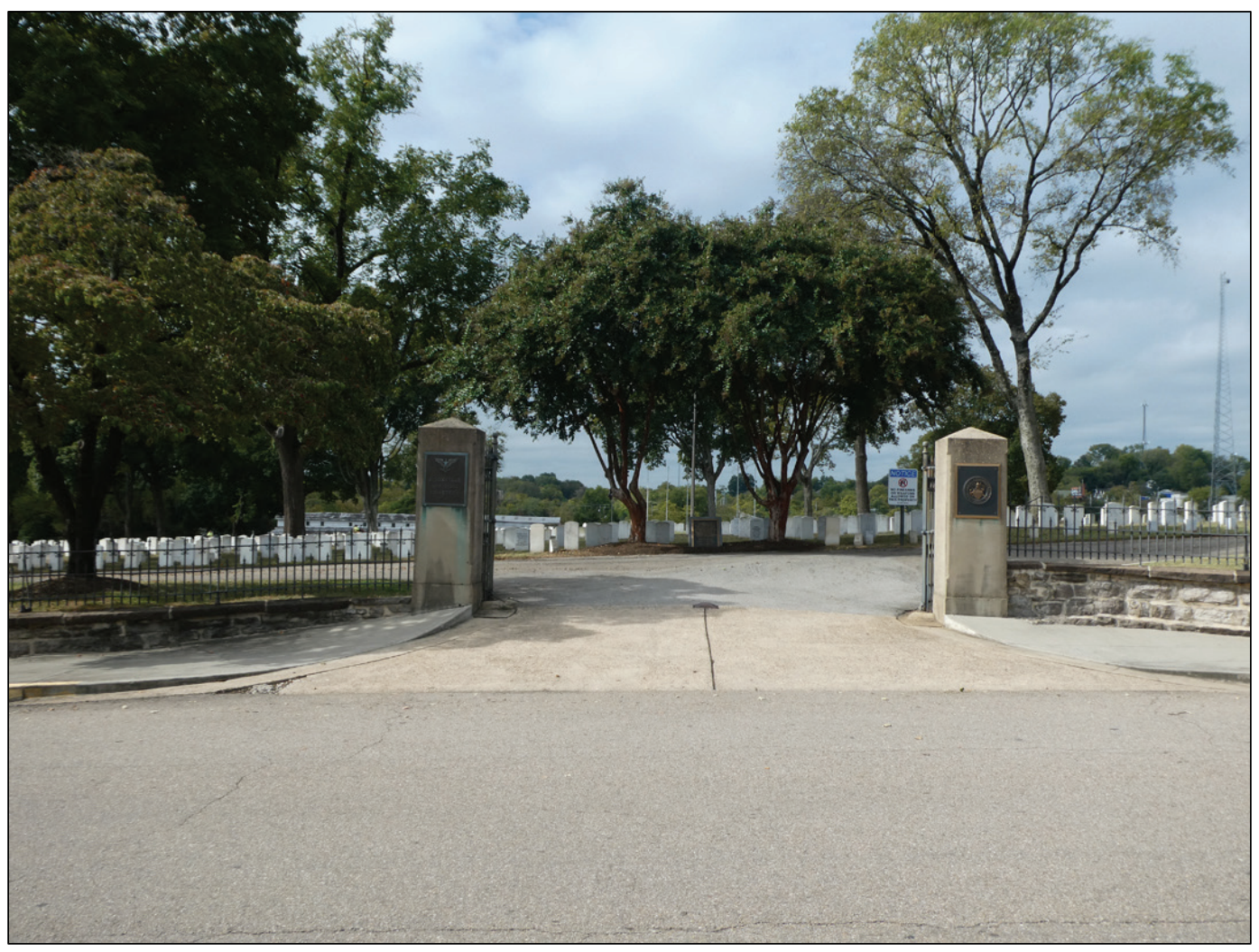

\subsubsection{Cooper Gate}

The former entranceway to the cemetery from Cooper Street (originally called Jacksboro Street) is original but is now filled in with stone. This was considered the main gate until approximately 1907 when the brick superintendent's lodge was constructed in the northern corner of the cemetery facing Tyson Street. The Cooper Gate prior to being filled in went through some major changes throughout the years from its original wooden gate to a three-stone pier gate to the now filled in wall (Figures 154-156). 
Figure 154. Looking northeast at a drawing of the wood gate on Cooper Street, 1867 (NARA, Washington DC, RG92).

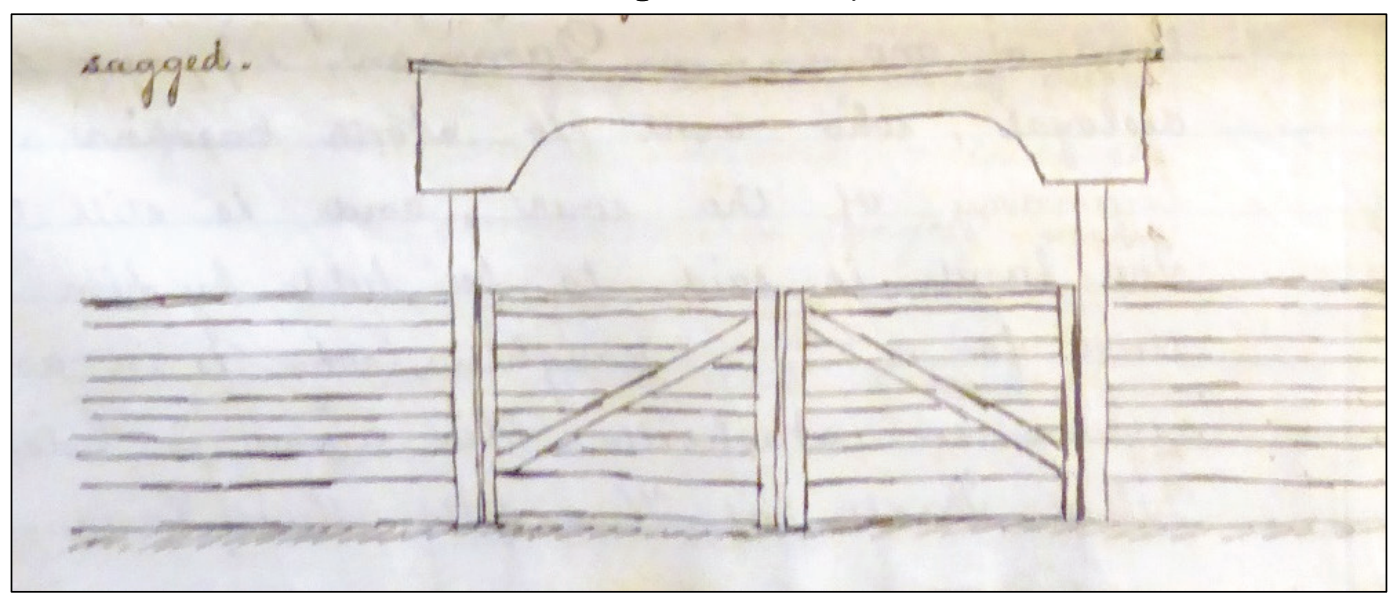

Figure 155. Looking southwest at the inside of the Cooper Gate, 1949 (VA NCA Archives).

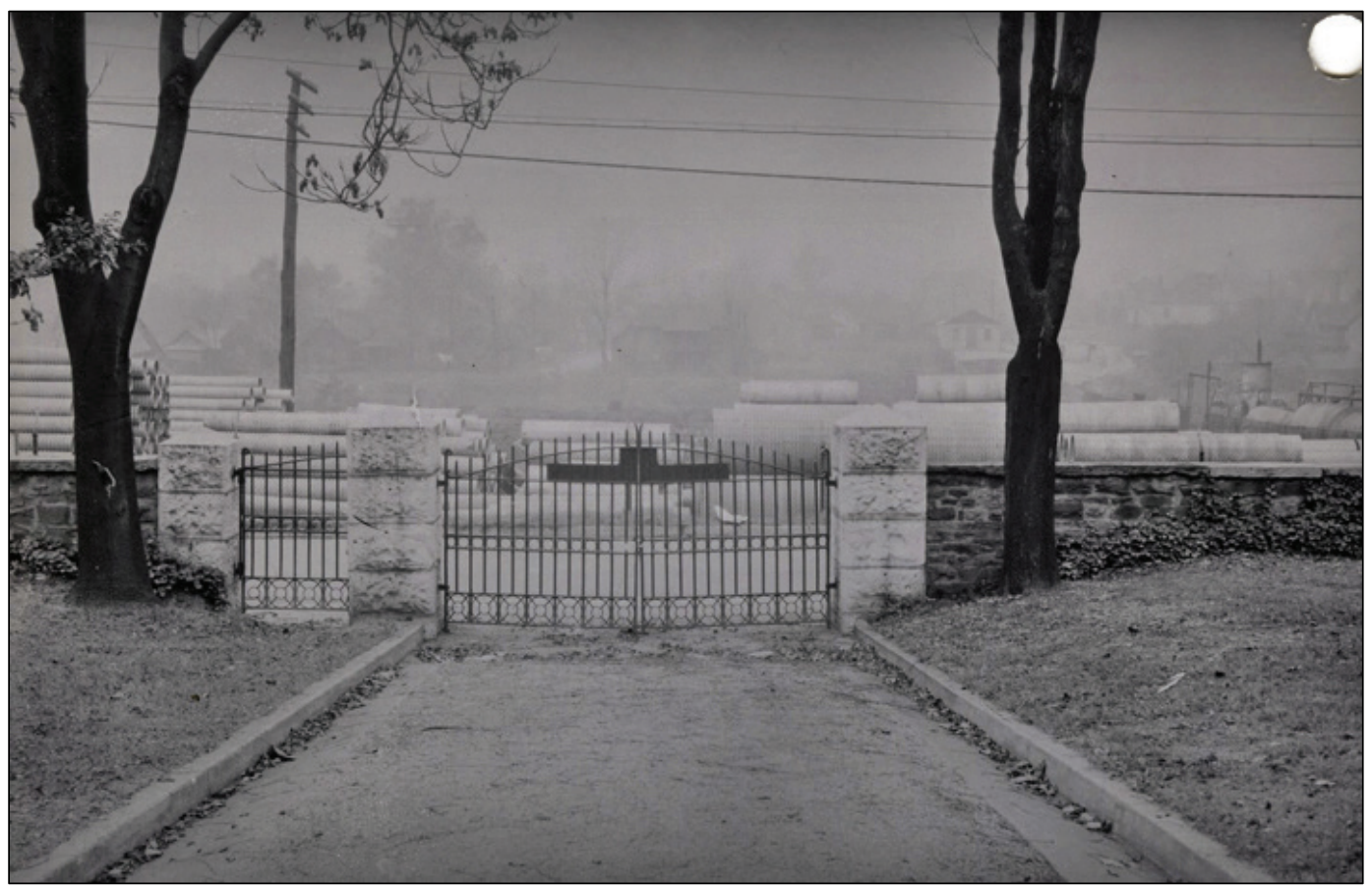


Figure 156. Looking northeast at the outside of the Cooper Gate (ERDC-CERL, 2019).

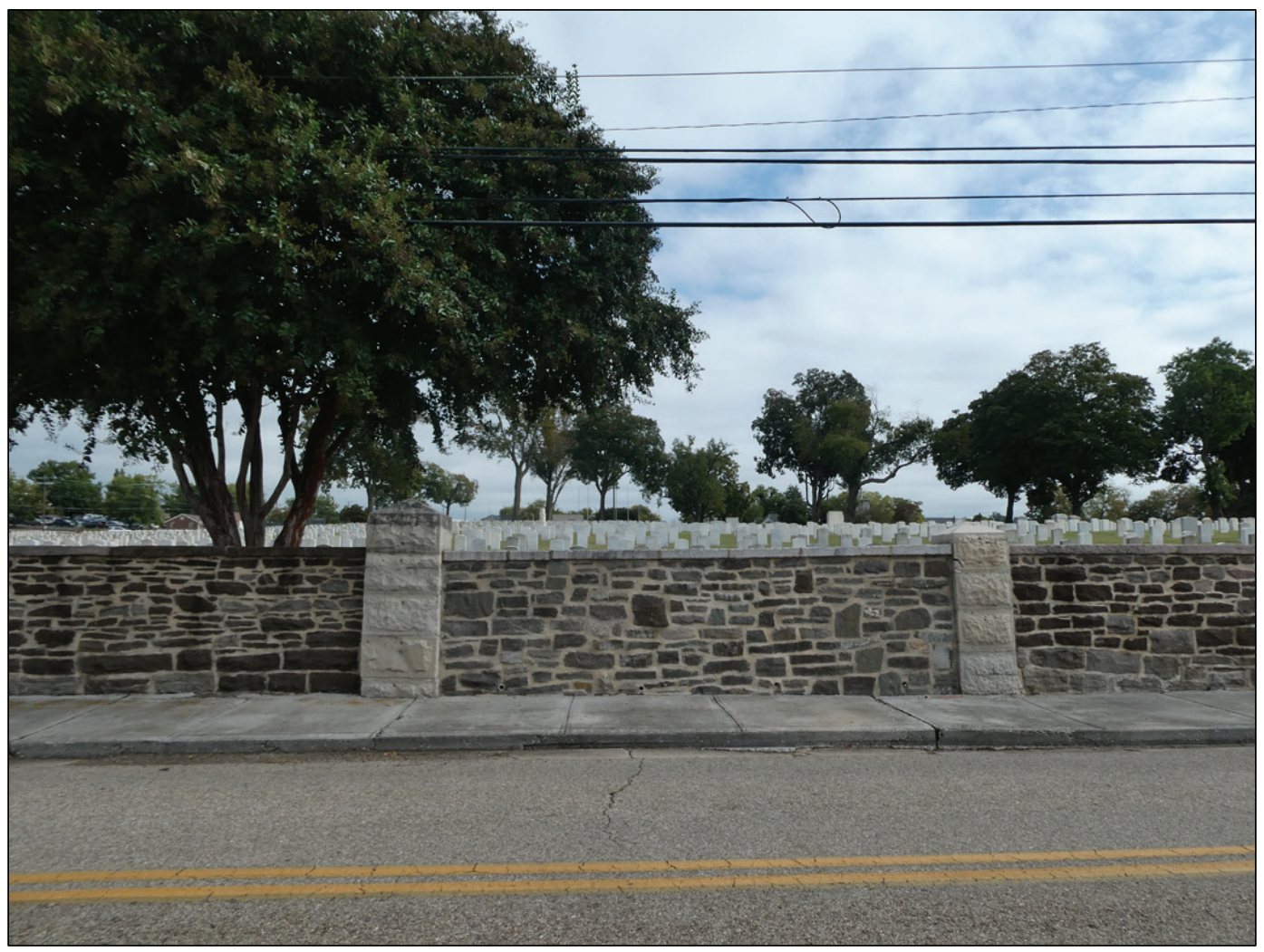

\subsubsection{Inner A and Outer A plus Section X}

The Inner A section of the cemetery is an original burial area of the cemetery and has a significant burial feature with the 13 graves of the Highlanders and the Highlanders Memorial (Figure 157). The ground slopes down from the circle drive, which is at 918' elevation to the flagpole, which is at $915^{\prime}$. Most of the 1,486 burials are located within the circle drive with a small number buried outside the circle drive in Outer A and Section X. 
Figure 157. Looking west at the Highlanders graves and memorial [note no flagstaff is depicted], 1864 (Library of Congress).

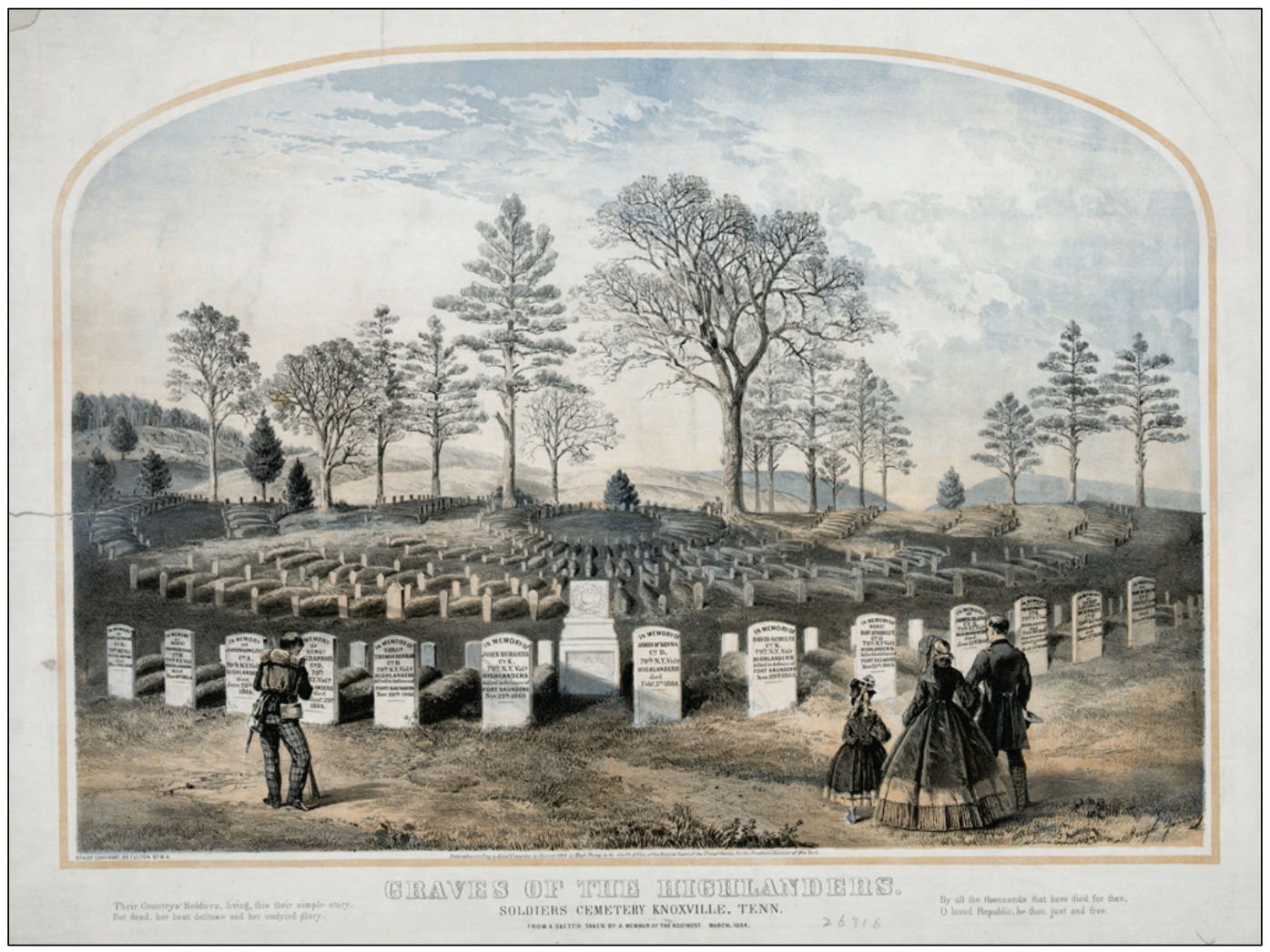

\subsubsection{1869 map}

The 1869 map drawn by P.M. Radford shows 13 concentric rows of radiating out from the center within the circle drive with the graves of Black soldiers on the outermost row (Figure 158). No graves are shown on the outside of the circle drive in the Outer A or Section $\mathrm{X}$ areas. This map does not show any landscaping. The Highlanders graves and memorial are not depicted on this map. 
Figure 158. Inner A, Outer A, and Section X as depicted on P.M. Radford's map, 1869 (NARA, Washington DC, RG92).

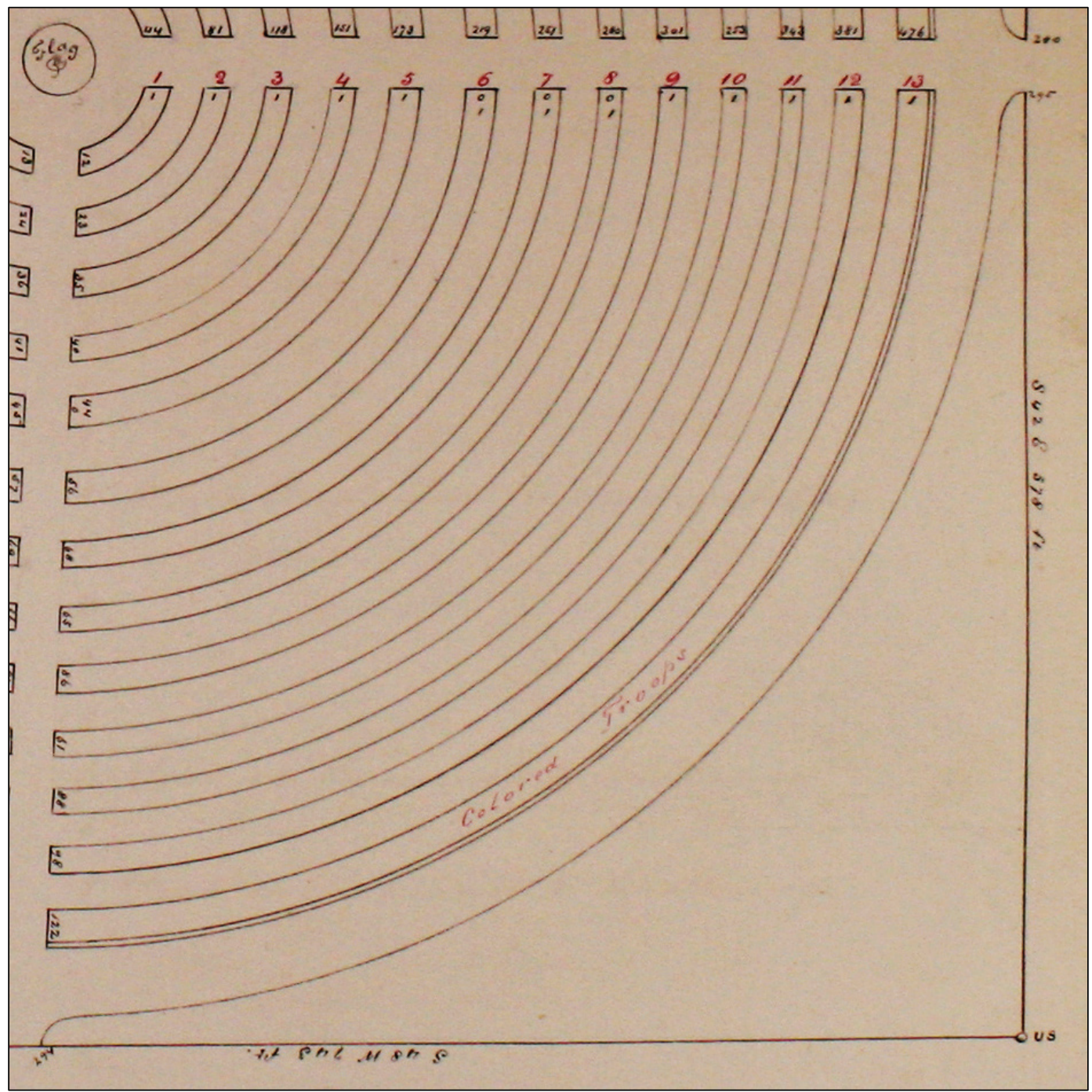

\subsubsection{1892 map}

The map from 1892 still has 13 concentric rows of graves radiating out from the center (Figure 159). The Highlanders graves and memorial and the graves of Black soldiers are not shown on this map, but a photo from 1895 shows them and that Inner A had a significant number of trees (Figure 160). No graves are shown on the outside of the circle drive in Outer A and Section X. There are deciduous trees and evergreen shrubs spread throughout the section with the stone wall lined with deciduous trees. The Union Soldier Monument was dedicated in 1901, but it was planned during this period (Figure 161). 
Figure 159. Inner A, Outer A, and Section X as depicted on a portion of the 1892 map (VA NCA Archives, Washington, DC).

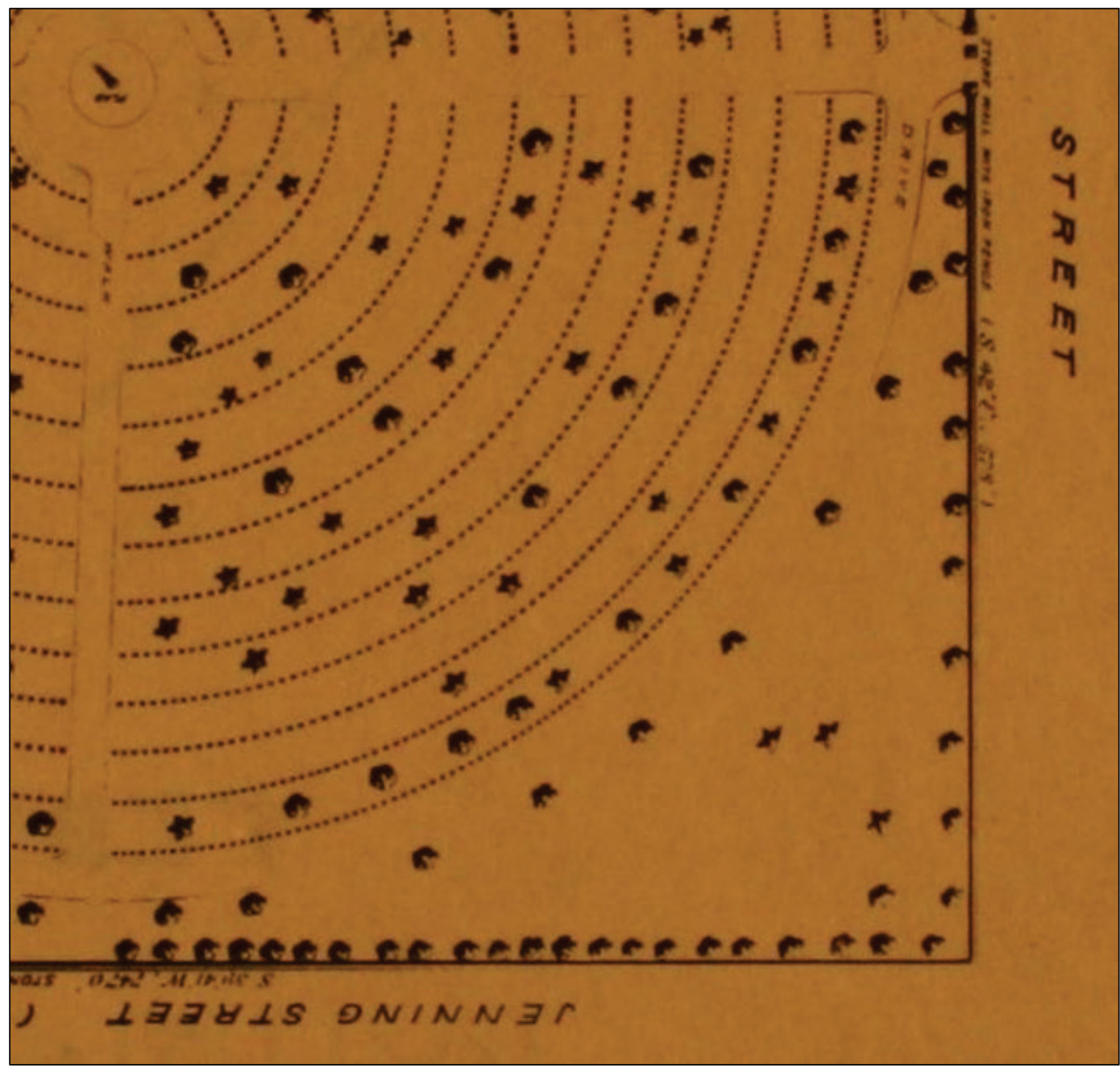

Figure 160. Looking west at the Highlanders graves, 1895 (East Tennessee History Center McClurg Collection).

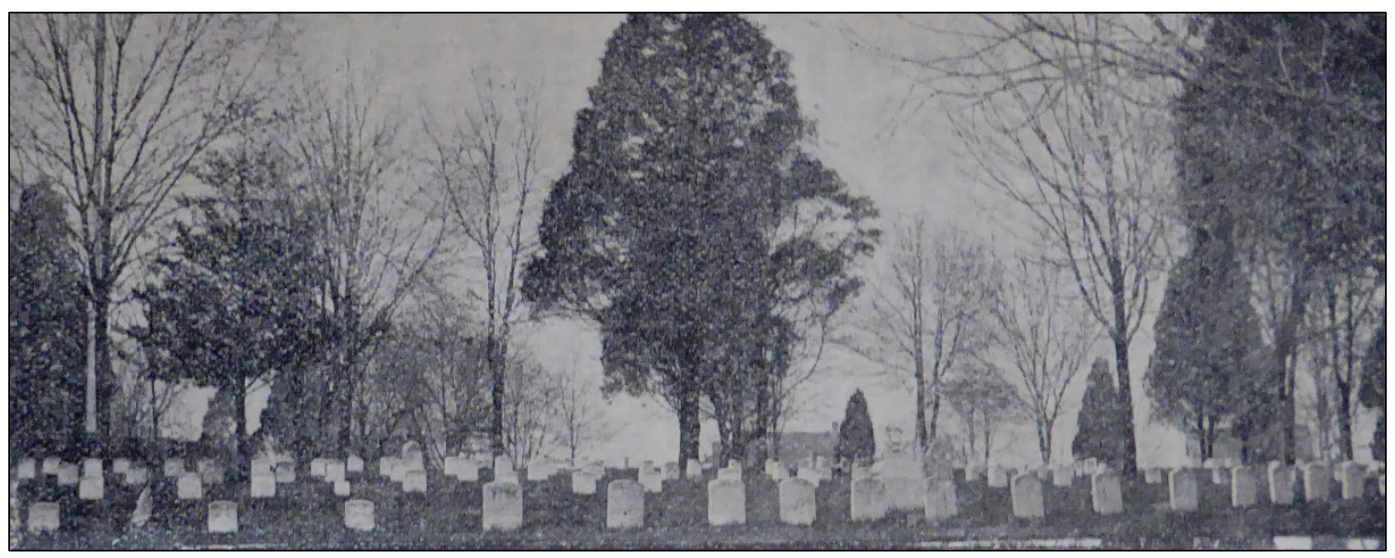


Figure 161. View to the south of the original Union Soldier Monument, 1906 (VA NCA Archives, Washington, DC).

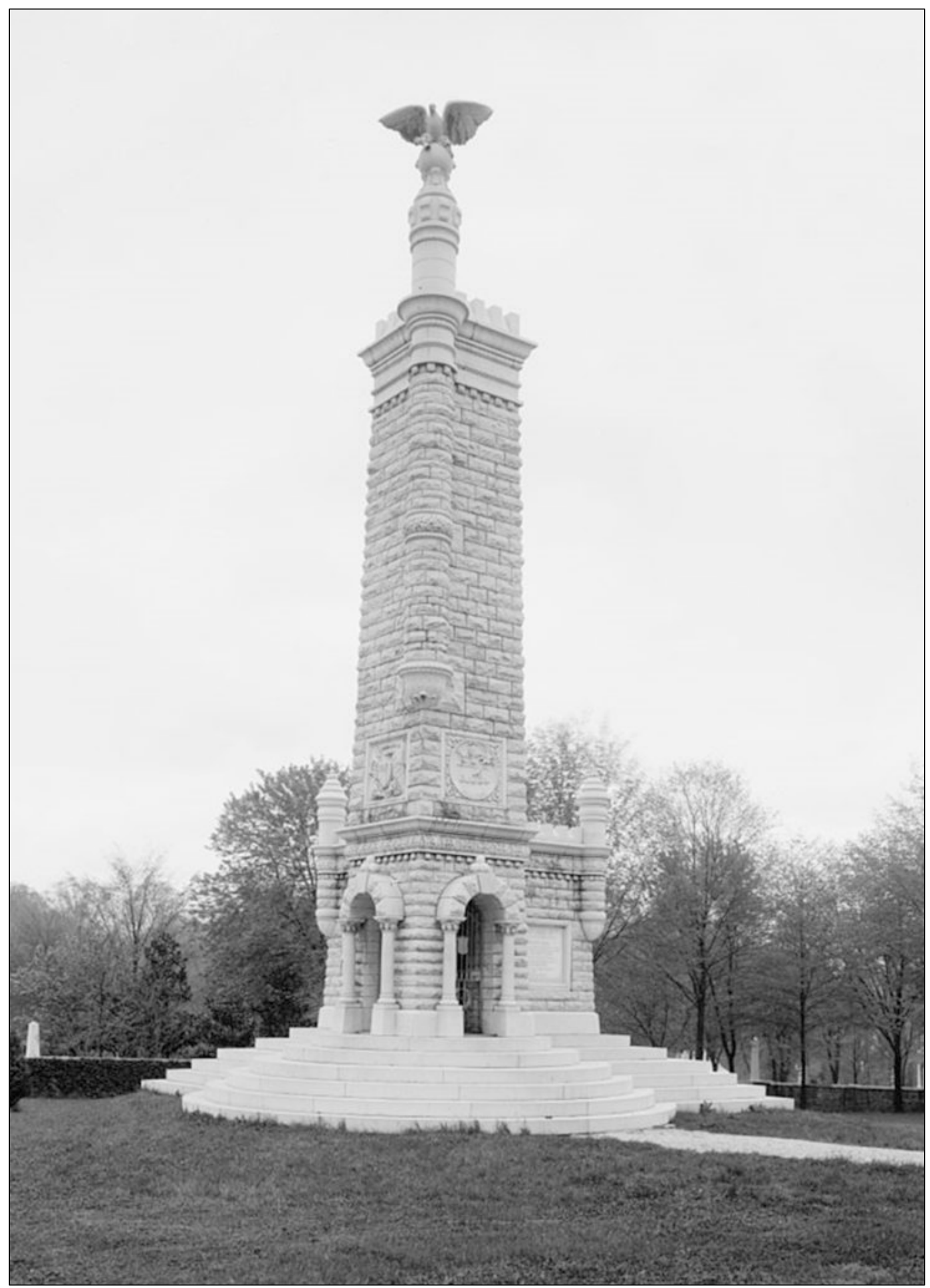




\subsubsection{1909 map}

The map from 1909 is an update of the 1892 map. The only difference between the two maps is the location of the Union Soldier Monument is marked on the map in the Section $X$ area (Figure 162). The Union Soldier Monument was heavily damaged by a lightning strike in 1904 and was rebuilt with a soldier statue on top instead of an eagle (Figure 163). The view in from the Tyson Gate to the Union Soldier Monument became a popular view (Figure 164).

Figure 162. Inner $A$, Outer $A$, and Section $X$ as depicted on a portion of the 1909 map shows the location of the Union Soldier Monument marked in black pen (NARA, Washington DC, RG92).

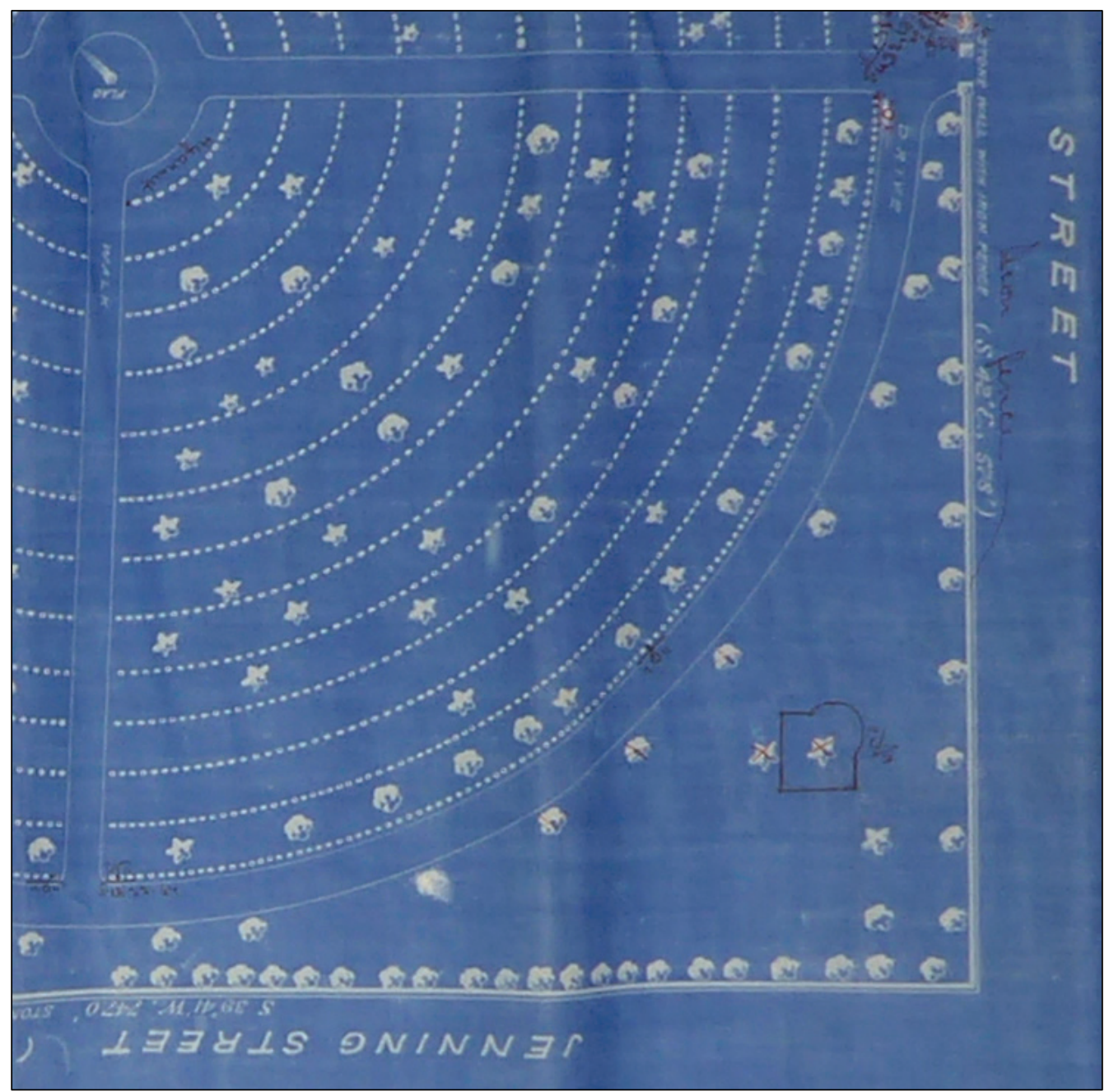


Figure 163. Postcard view of the reconstruction Union Soldier Monument, 1906 (University of Tennessee, Knoxville, Library digital collections "Images of East Tennessee").

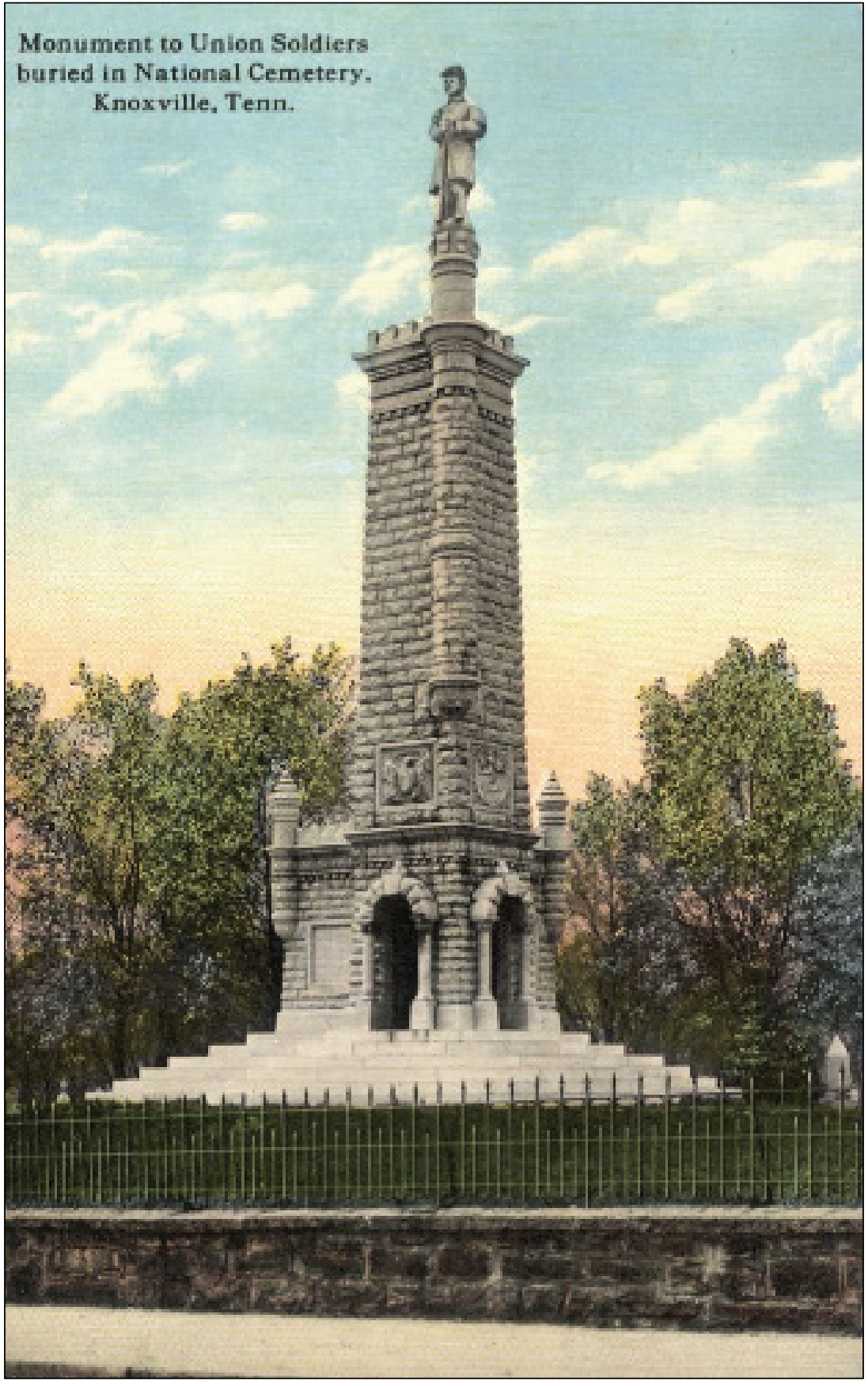


Figure 164. View to the south of the Union Soldier Monument from the rostrum, c.1920s (University of Tennessee, Knoxville, Library digital collections “Images of East Tennessee”).

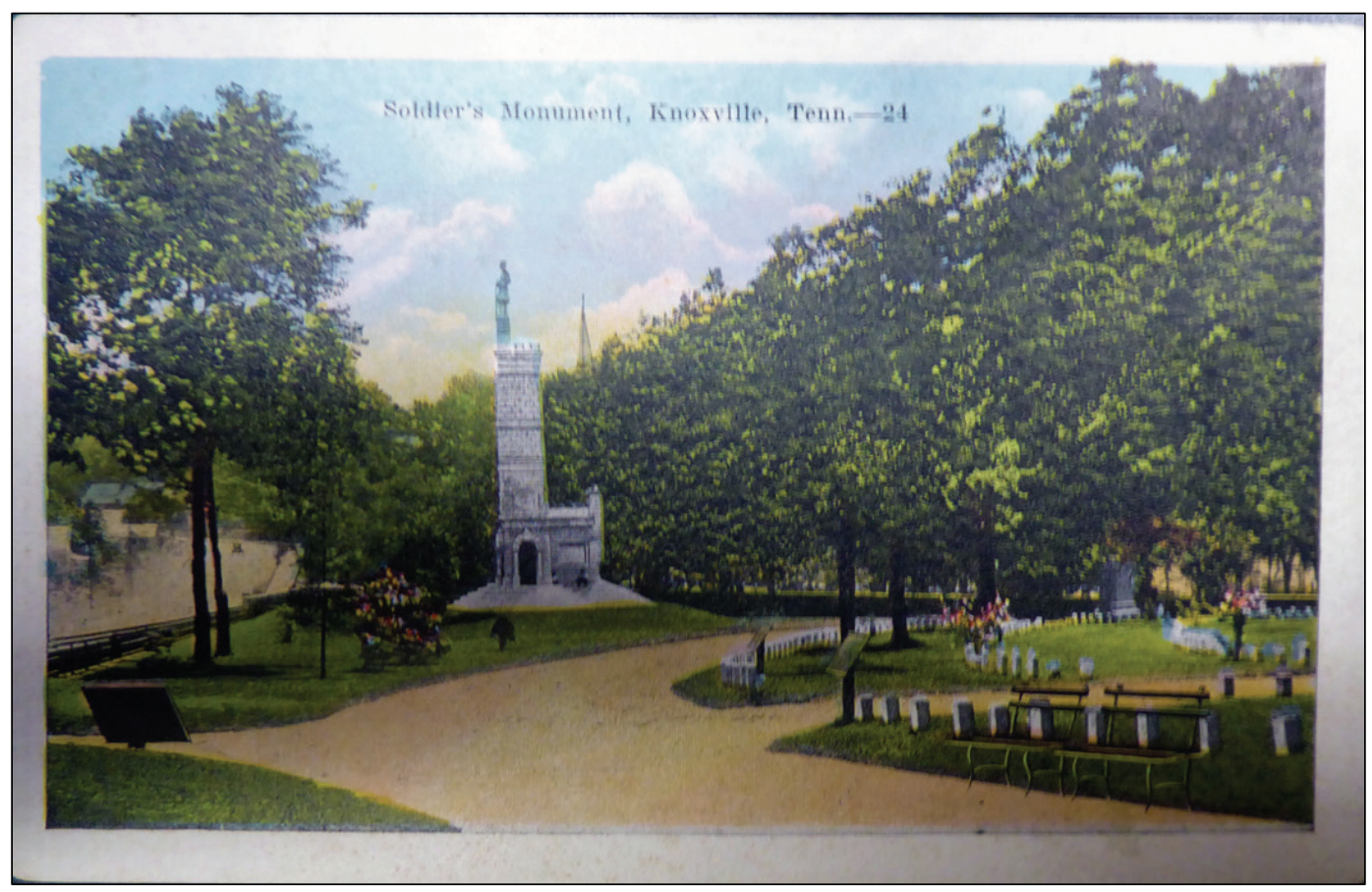

\subsubsection{1947 map}

The map from 1947 is the first map that has the species of trees indicated on it. The map also shows that there are graves on the outside of the circle drive plus the location of the Union Soldier Monument Outer A and Section X. The map still has 13 concentric rows of graves radiating out from the center. The Highlanders graves and memorial and the graves of Black soldiers are not shown on this map. No landscaping is shown along the stone wall. There were six Maples, four Sycamores, and one Catalpa (Figure 165). The 1947 map only has trees shown and listed, but an aerial from 1948 shows that Section A and Section X had quite a number of shrubs, especially along the circle drive and perimeter stone wall (Figure 166). The view to the southeast of the Union Soldier Monument (Figure 167) and the view to the northwest of the rostrum remained popular views (Figure 168). 
Figure 165. Inner A, Outer A, and Section $X$ as depicted on a portion of the 1947 map with types of trees (NARA, Washington DC, RG15).

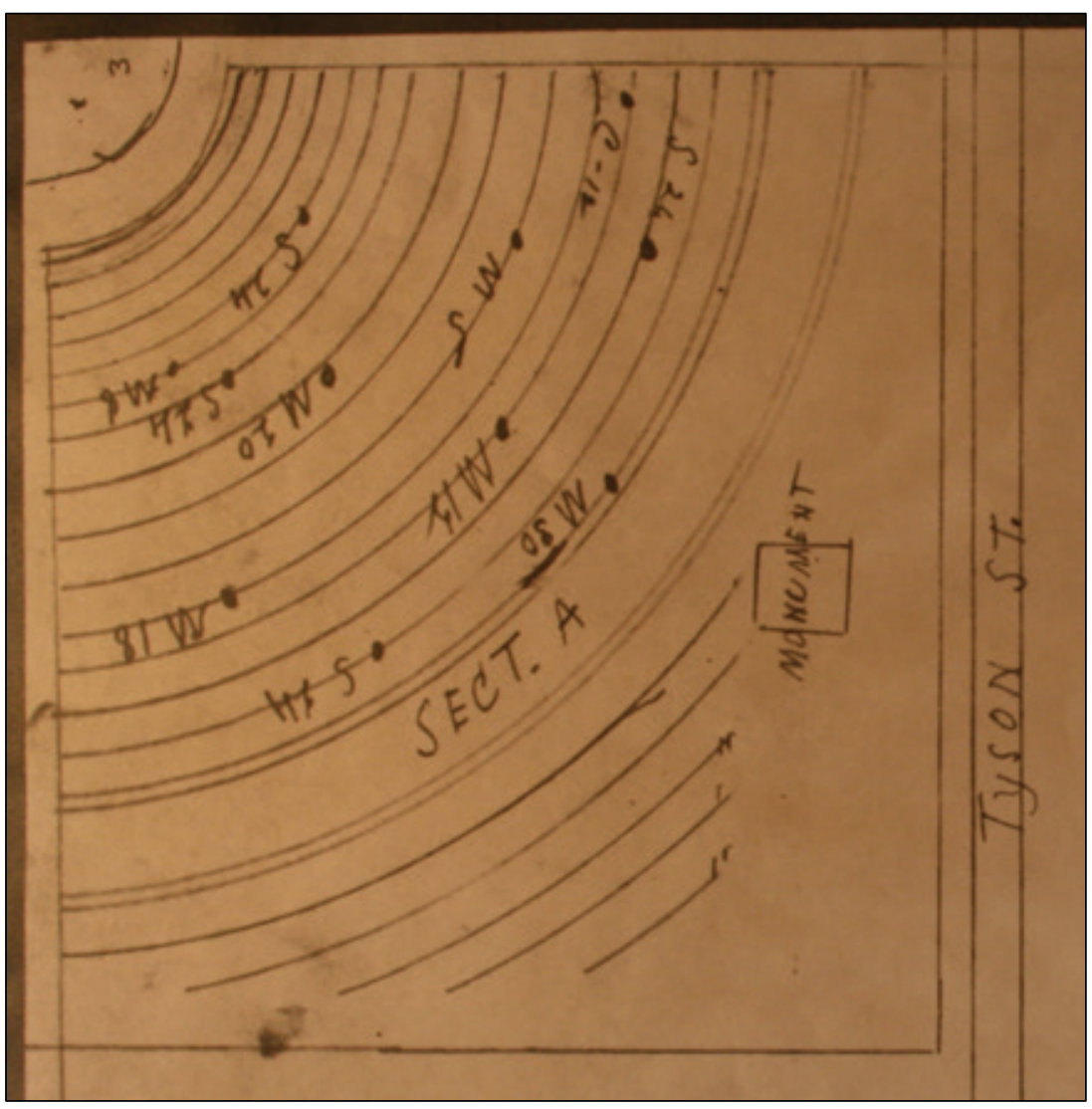

Figure 166. Aerial view of Section A and Section X showing extensive tree cover in Section A, 1948 (HALS-TN-2, Library of Congress).

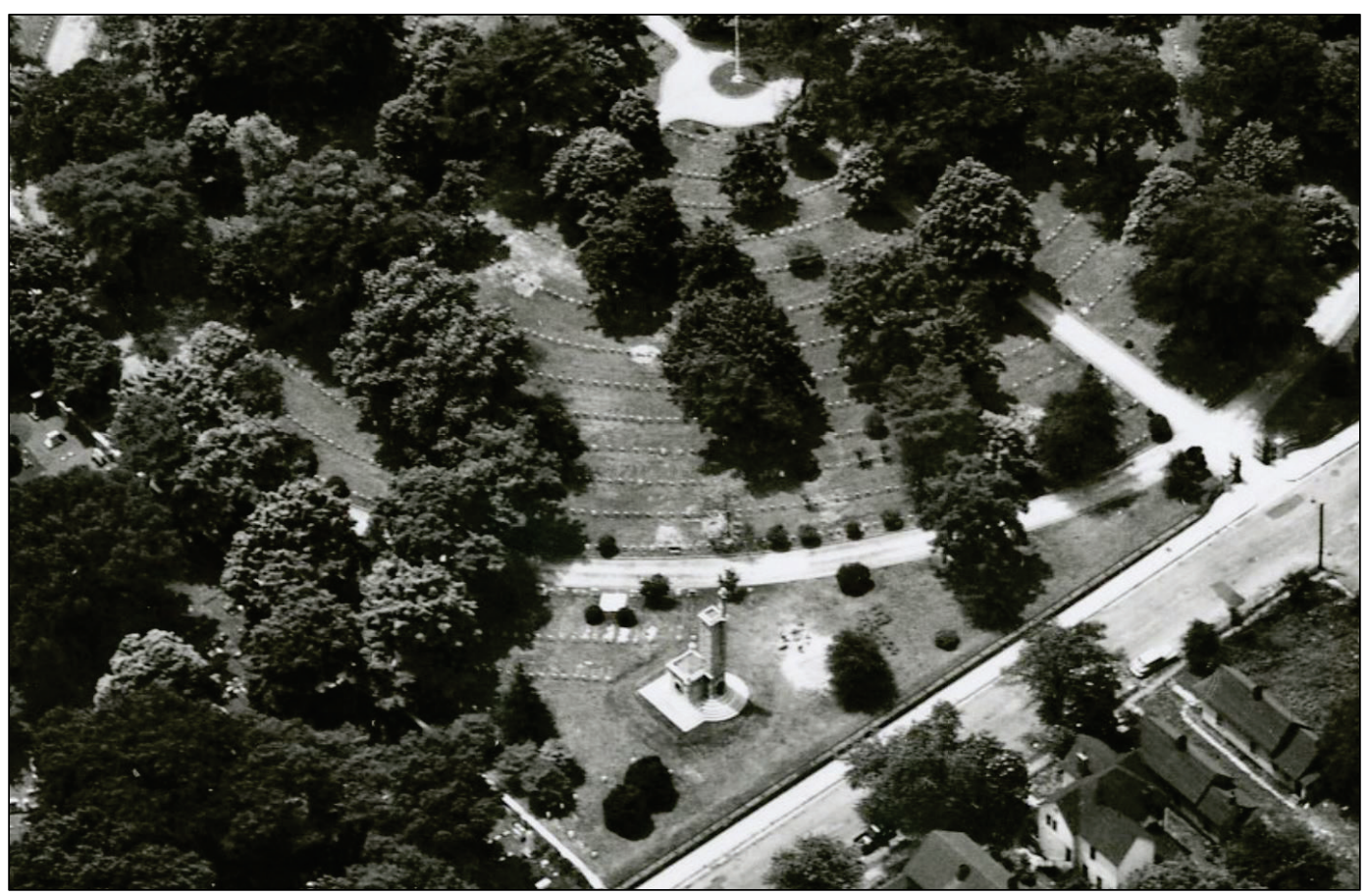


Figure 167. View to the southeast of the Union Soldier Monument, 1945 (VA NCA Archives, Washington, DC).

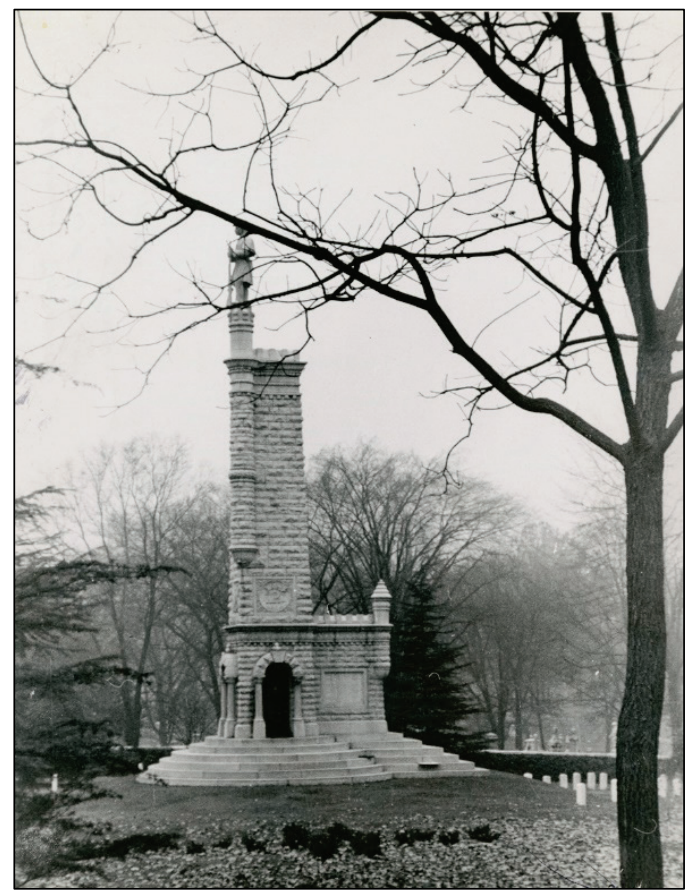

Figure 168. View to the northwest from the Union Soldier Monument towards the Tyson Gate, 1953 (VA NCA Archives, Washington, DC).

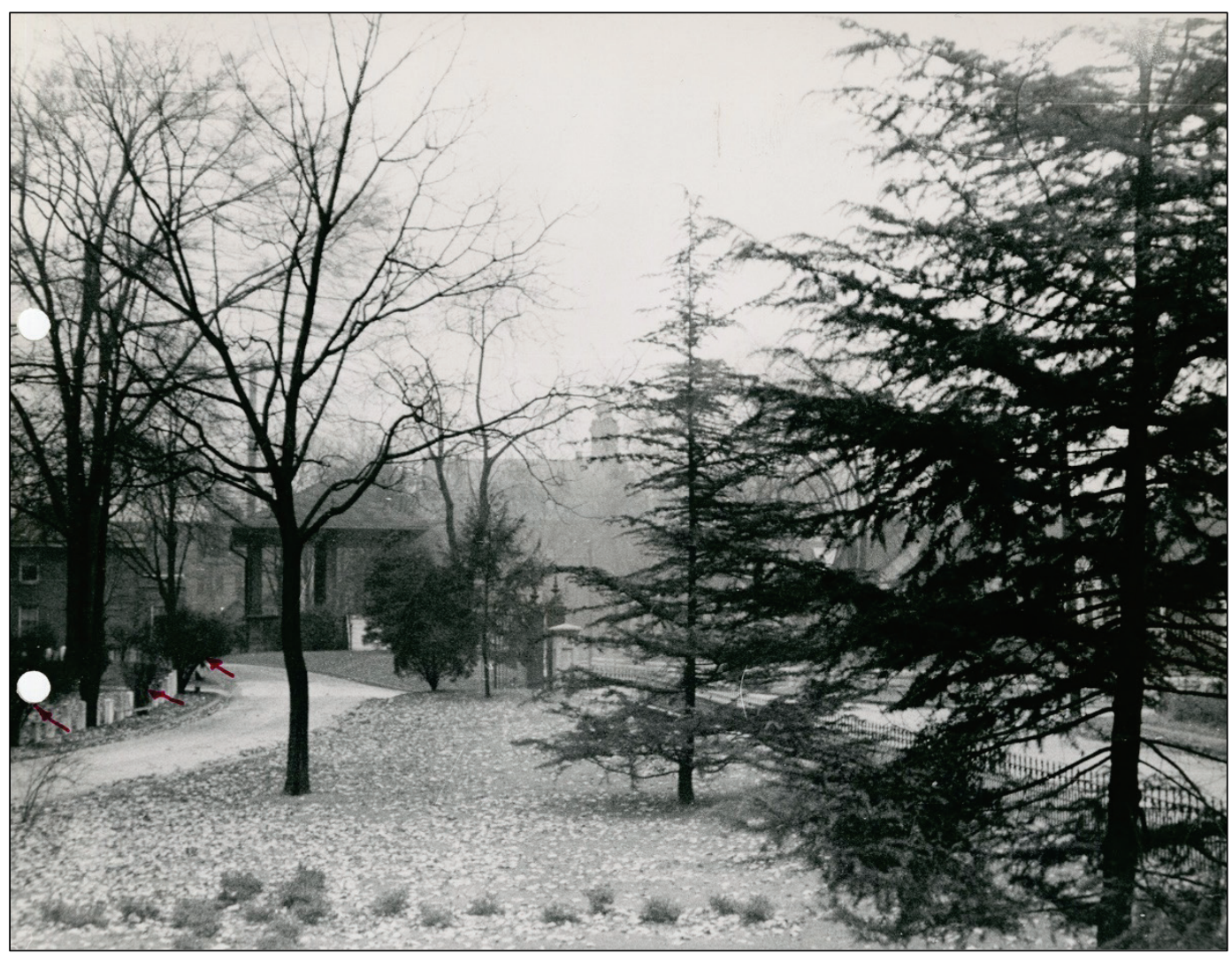




\subsubsection{1971 map}

The map from 1971 does not have landscaping depicted on it, but what it does show is that eight new rows of graves were added in between the existing 13 rows from the Civil War era for a total of 21 rows. Outer A and Section X are completely laid out although there are many unused grave sites (Figure 169). The curbing has been erased from the drawing on either side of the east-west drive, but the curbing along the circle drive remained (Figure 170).

Figure 169. Inner A, Outer A, and Section X as depicted on a portion of the 1971 map (VA NCA Archives, Washington, DC).

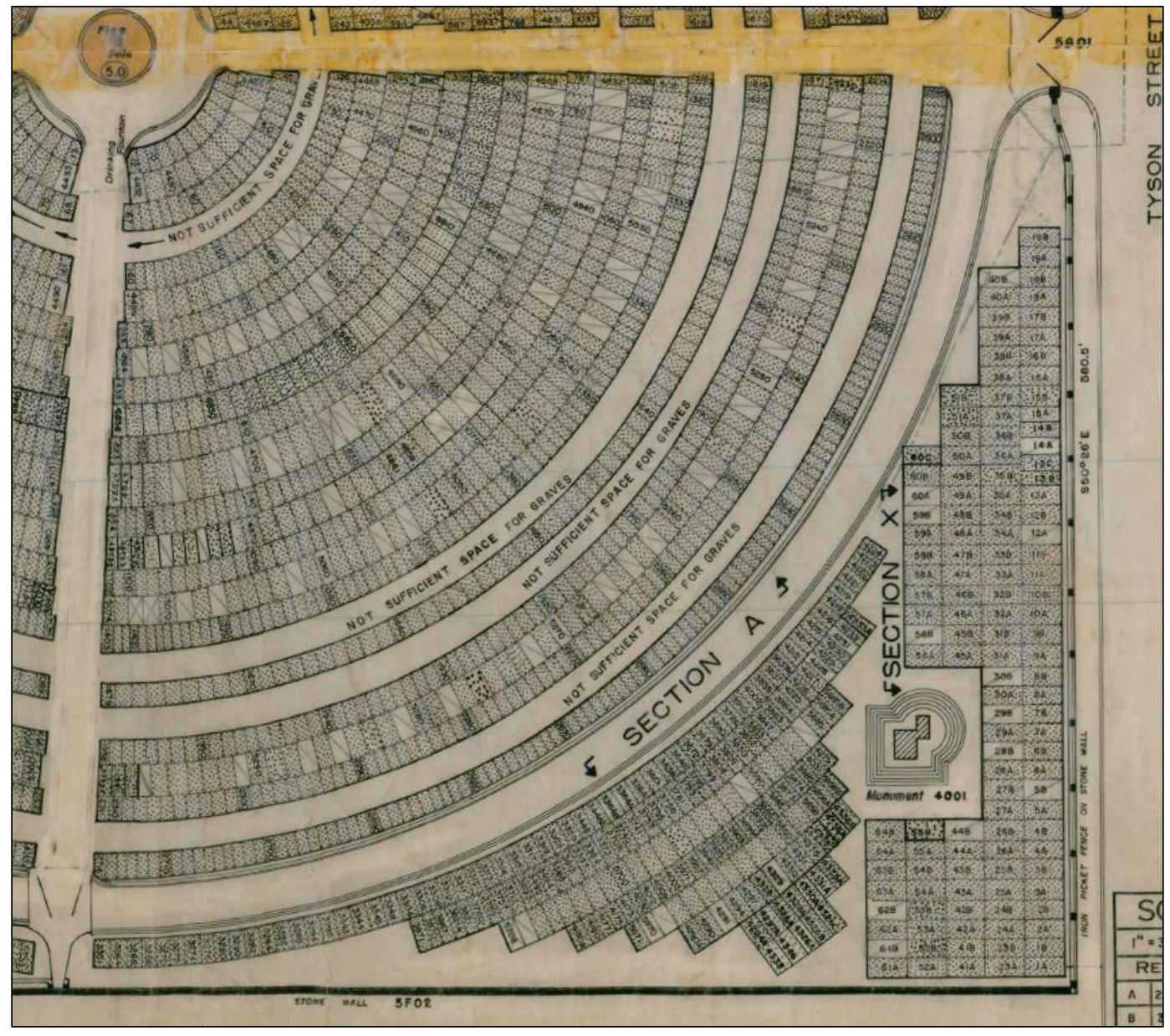


Figure 170. View to the northeast along the circle drive towards the Union Soldier Monument, 1989 (VA NCA Archives, Washington, DC).

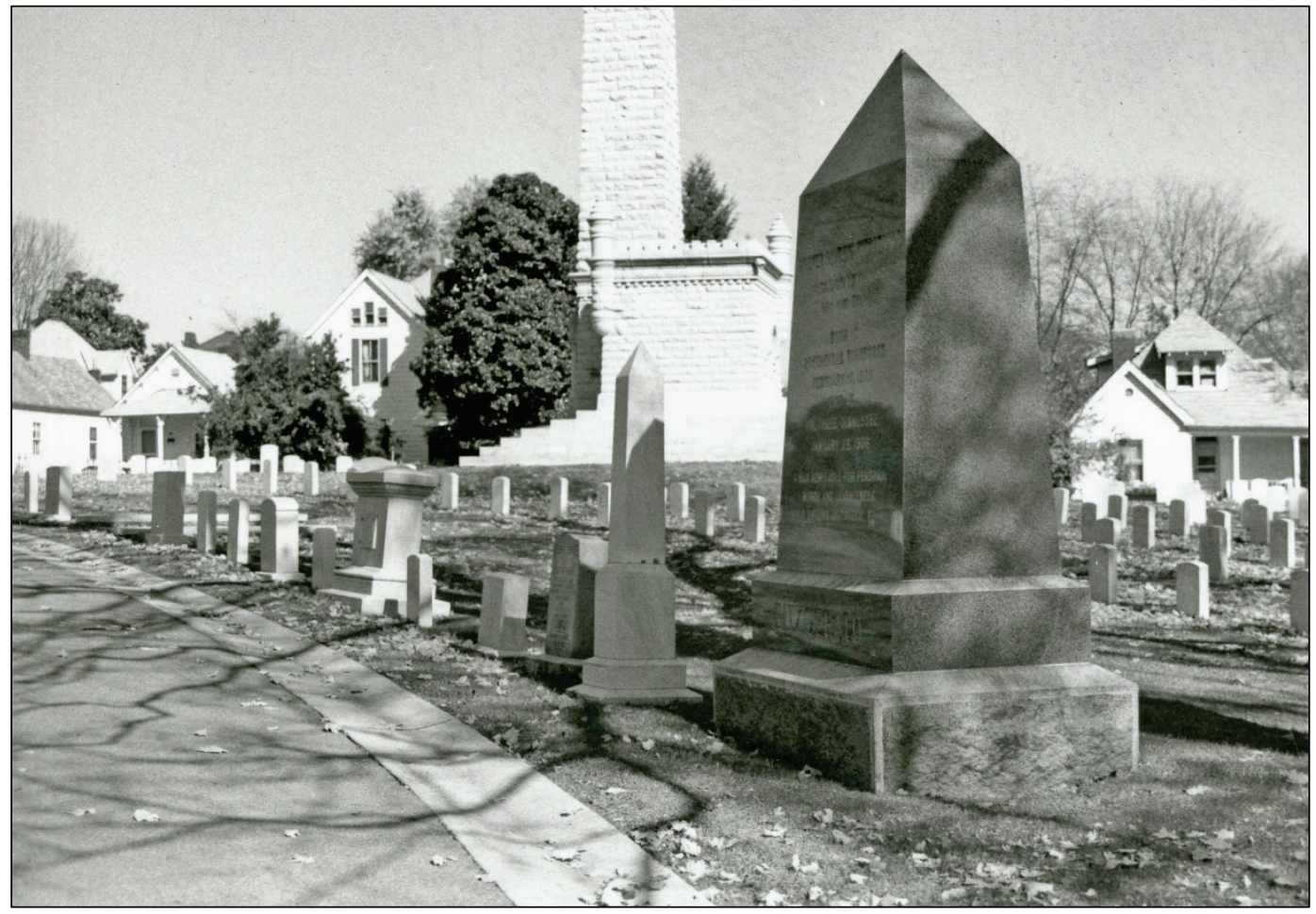

\subsubsection{2019 map}

The map from 2019 does have landscaping depicted on it, and it shows that one new row of graves was added to Inner A for a total of 22 rows. Outer A and Section $\mathrm{X}$ are mostly filled with interments. The east-west drive that connected the two gates from the cemetery's inception is now filled with gravesites leaving only the circle drive and the north-south drive (Figure 171). Figures 172 through 181 show scenes throughout Inner A.

An analysis of the trees in Inner A, Outer A, and Section X has one Black Walnut (Juglans nigra), two Flowering Dogwood (Cornus florida), one Norway Spruce (Picea abies), two American Hollies (Ilex Americana), one Crepe Myrtle (Lagerstroemia sp.). 
Figure 171. Inner A, Outer A, and Section $X$ as depicted on a portion of the 2019 map (VA NCA Archives, Washington, DC).

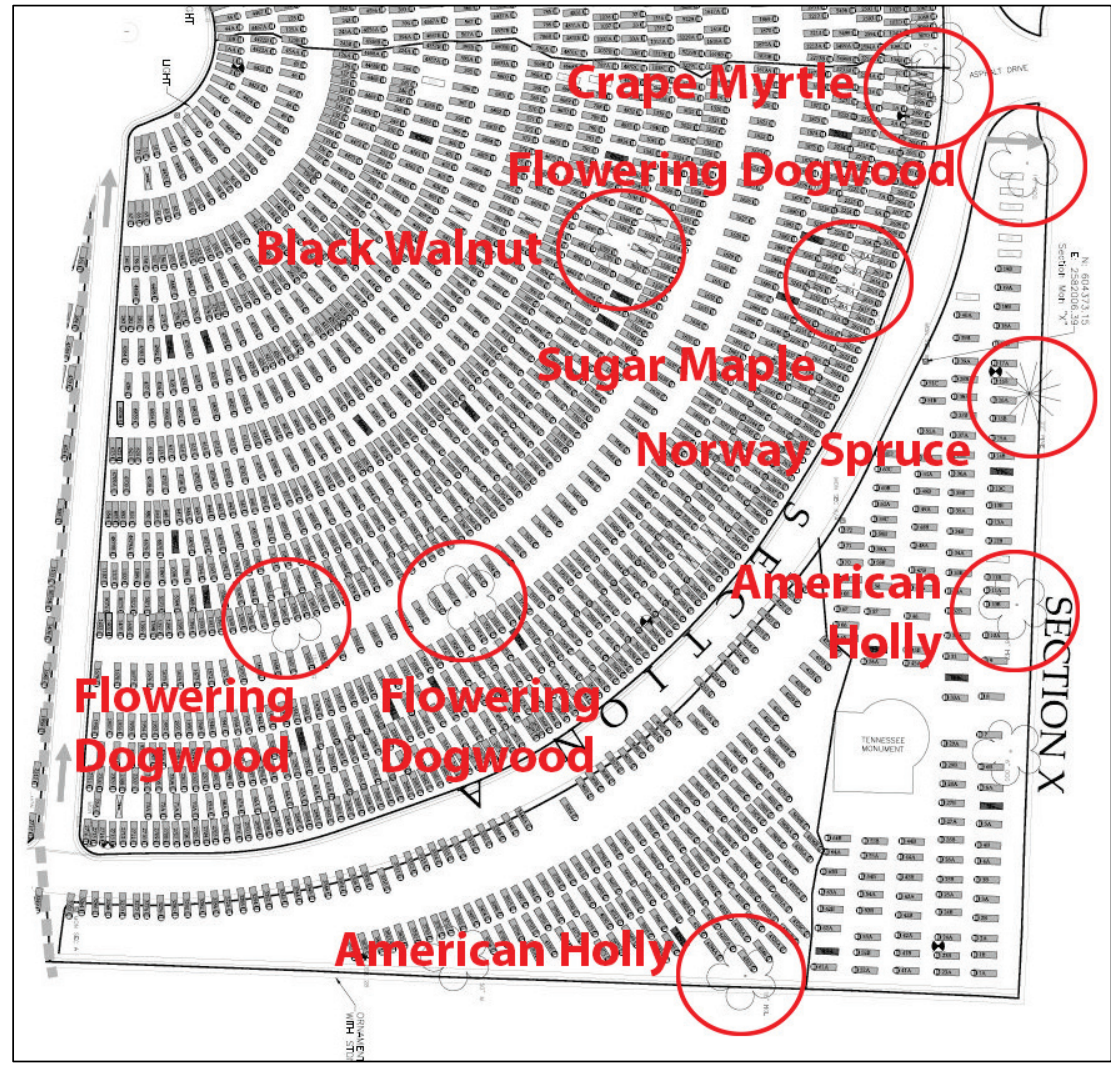

Figure 172. Looking west across Inner A at the Highlanders Memorial and graves with the flagstaff in the background (ERDC-CERL, 2019).

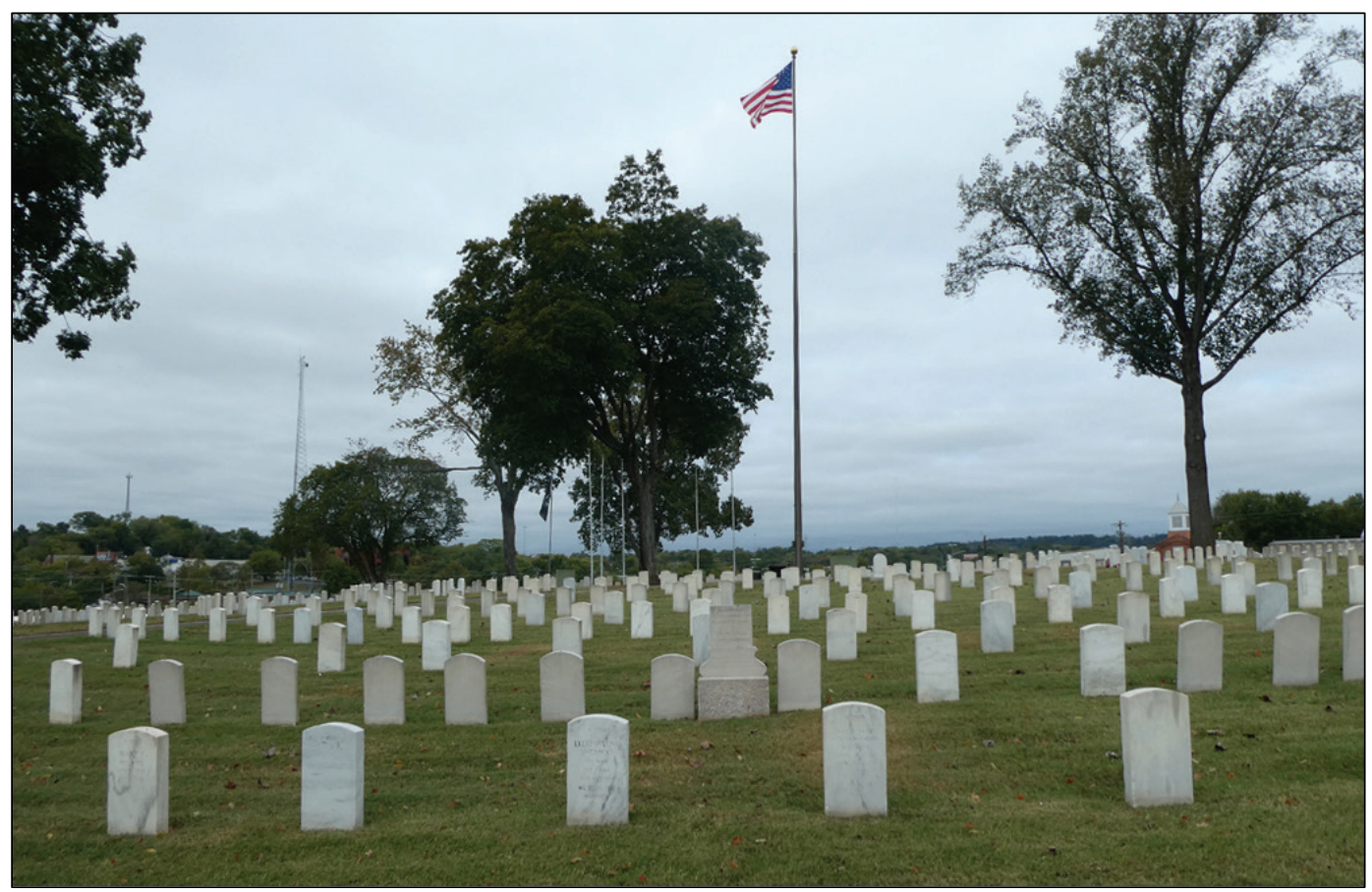


Figure 173. Looking west at the back of the Highlanders Memorial (ERDC-CERL, 2019).

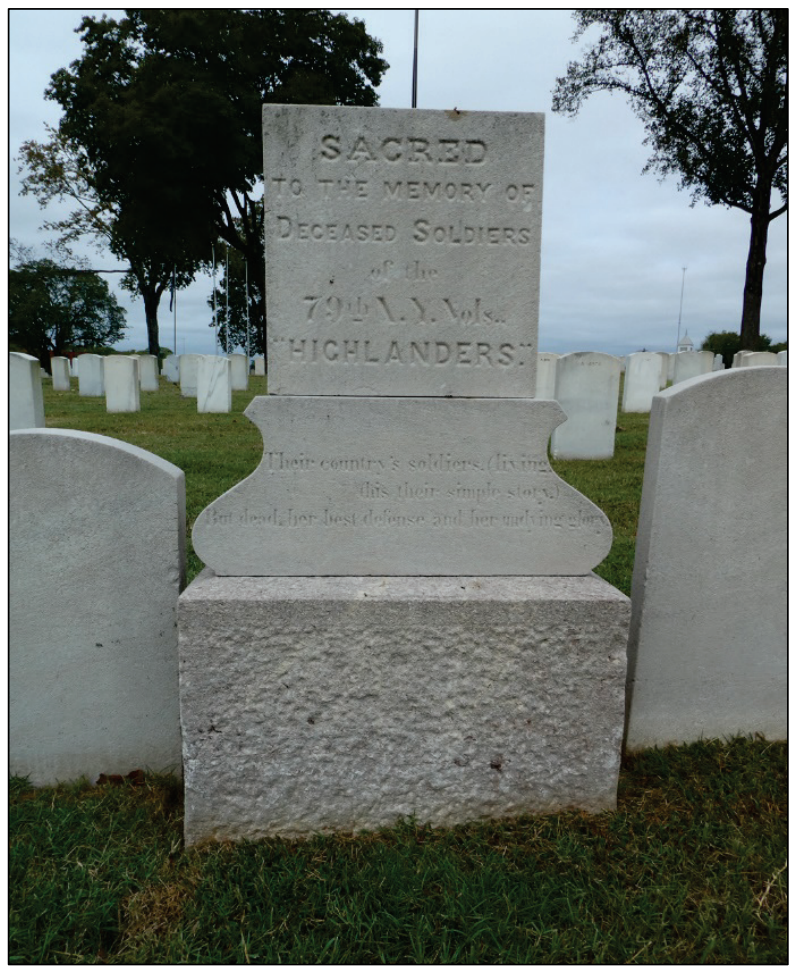

Figure 174. Looking east at the front of the Highlanders Memorial (ERDC-CERL, 2019).

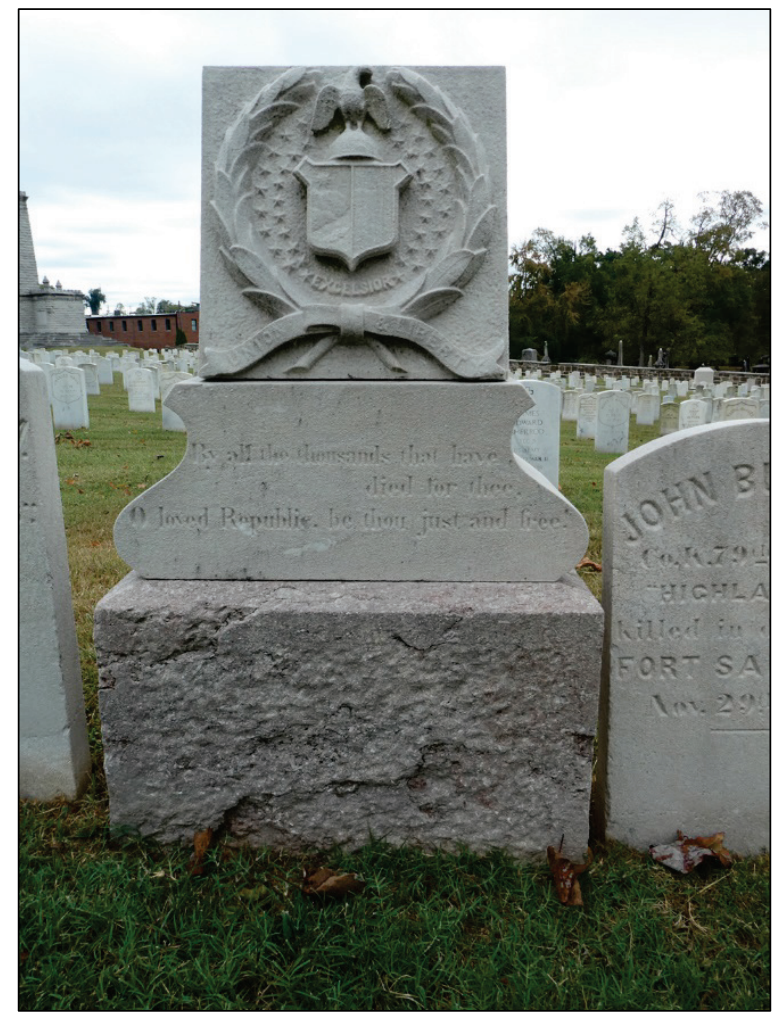


Figure 175. Looking east across Inner A towards the Union Soldier Monument (ERDC-CERL, 2019).

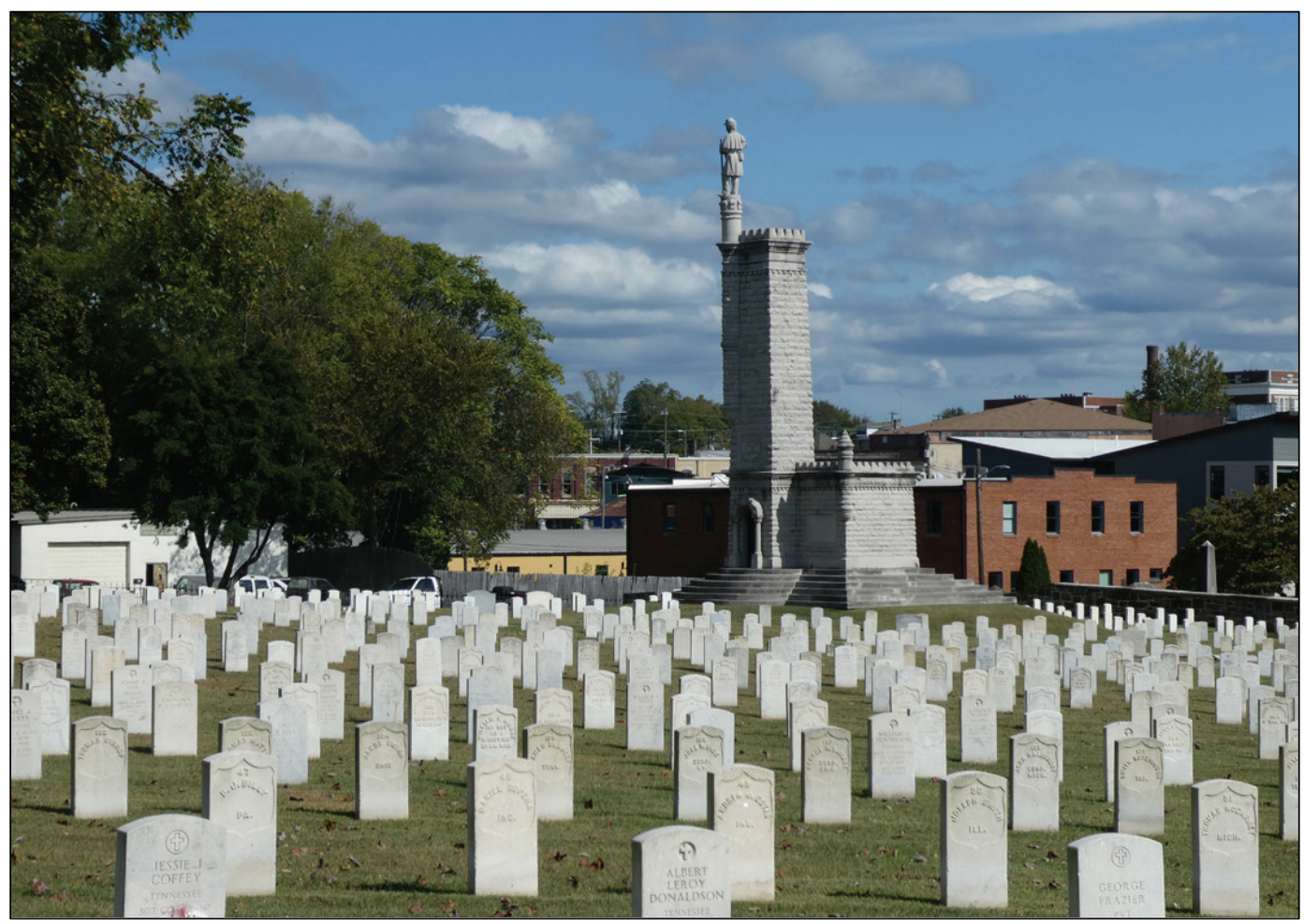

Figure 176. Looking southwest at the wall between the Knoxville National Cemetery and the Old Gray Cemetery where it intersects with the sidewalk along Tyson Street (ERDC-CERL, 2019).

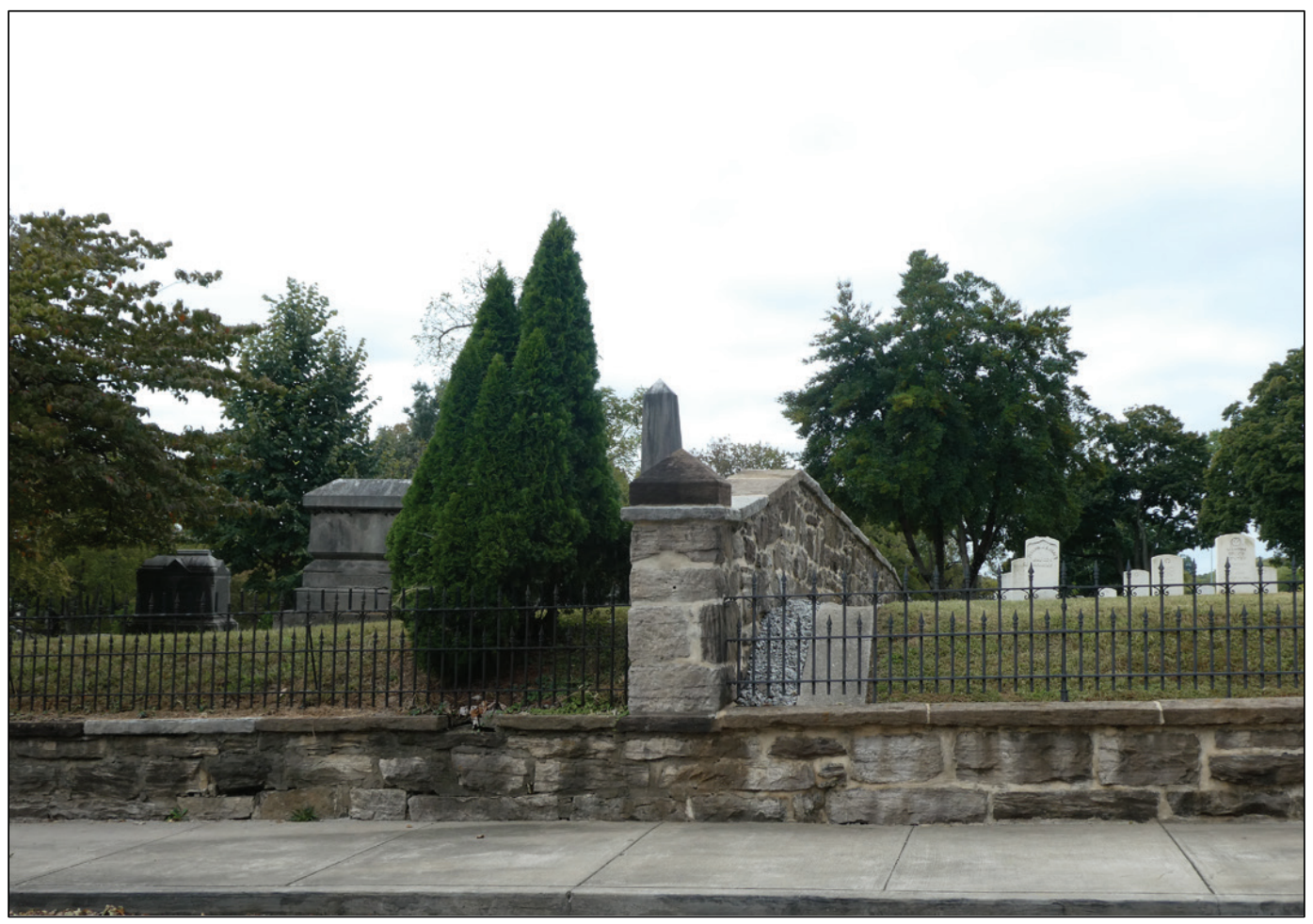


Figure 177. Looking southeast at the Dogwood in the foreground and the Norway Spruce in the middle with the Union Soldier Monument in the background in Section X (ERDC-CERL, 2019).

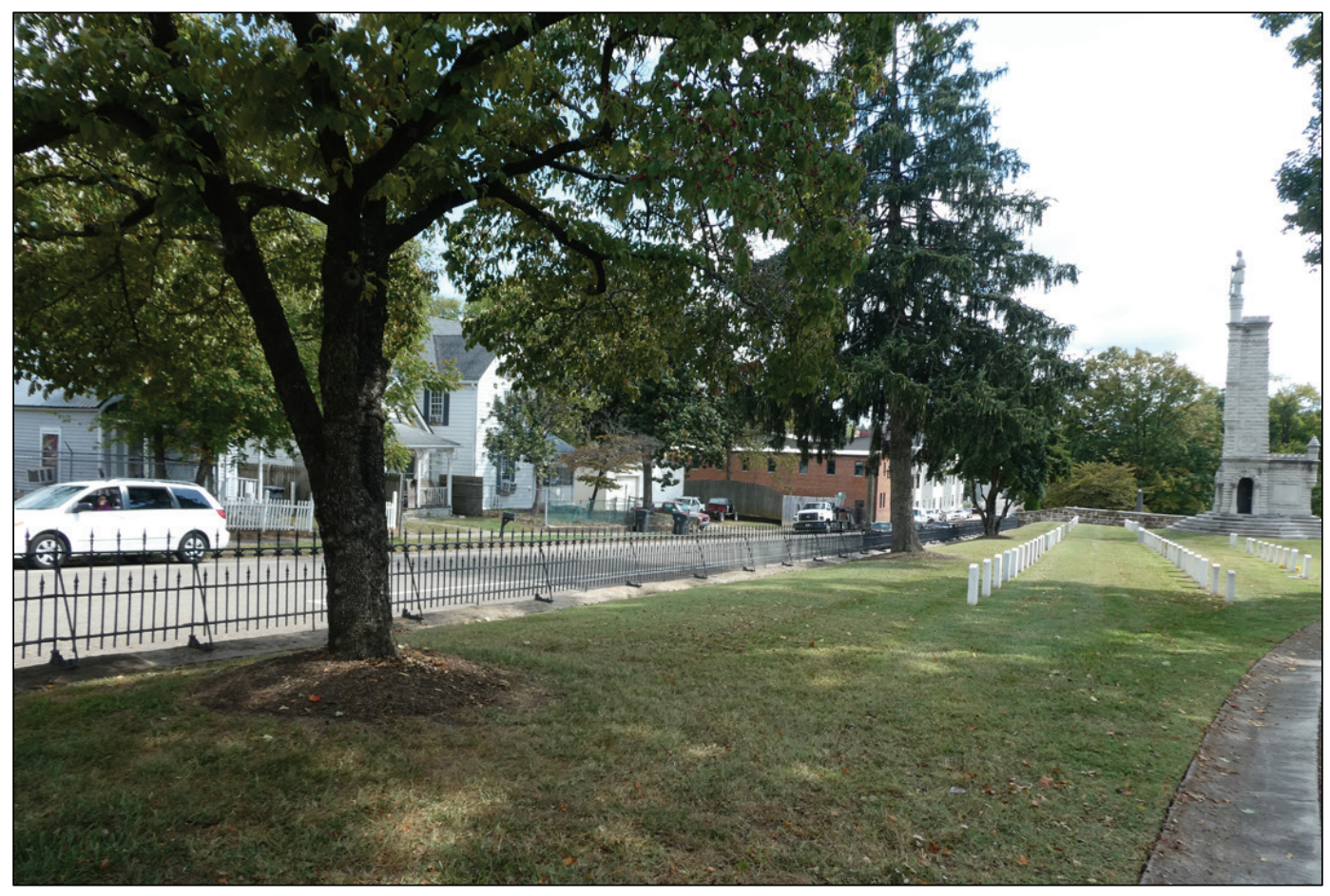

Figure 178. Looking southeast across Inner A at two Crepe Myrtles at the location where the east-west drive once intersected with the circle drive (ERDC-CERL, 2019).

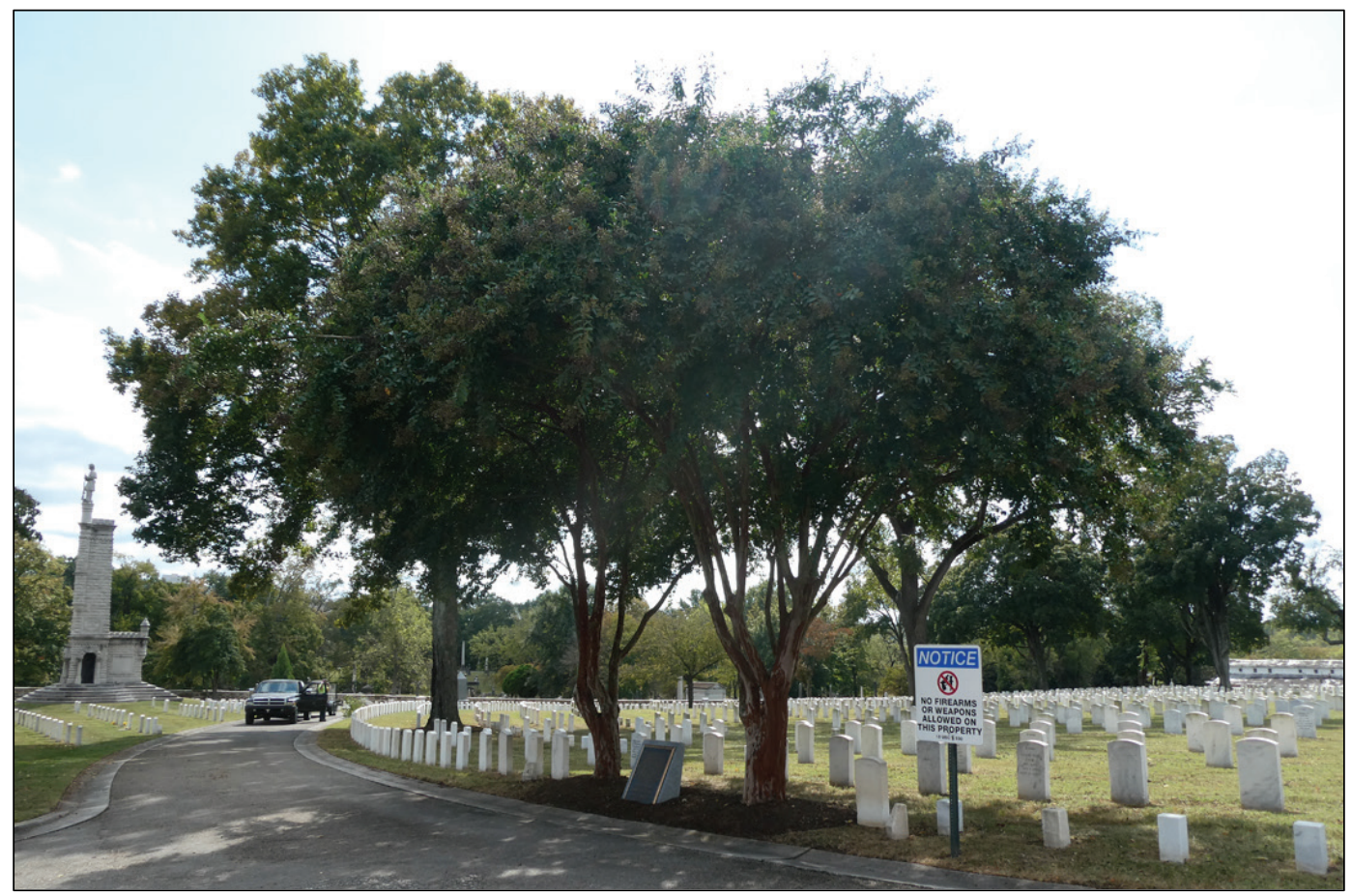


Figure 179. Looking southeast at the American Holly tree at the stone wall between the Knoxville National Cemetery and the Old Gray Cemetery in Outer A (ERDC-CERL, 2019).

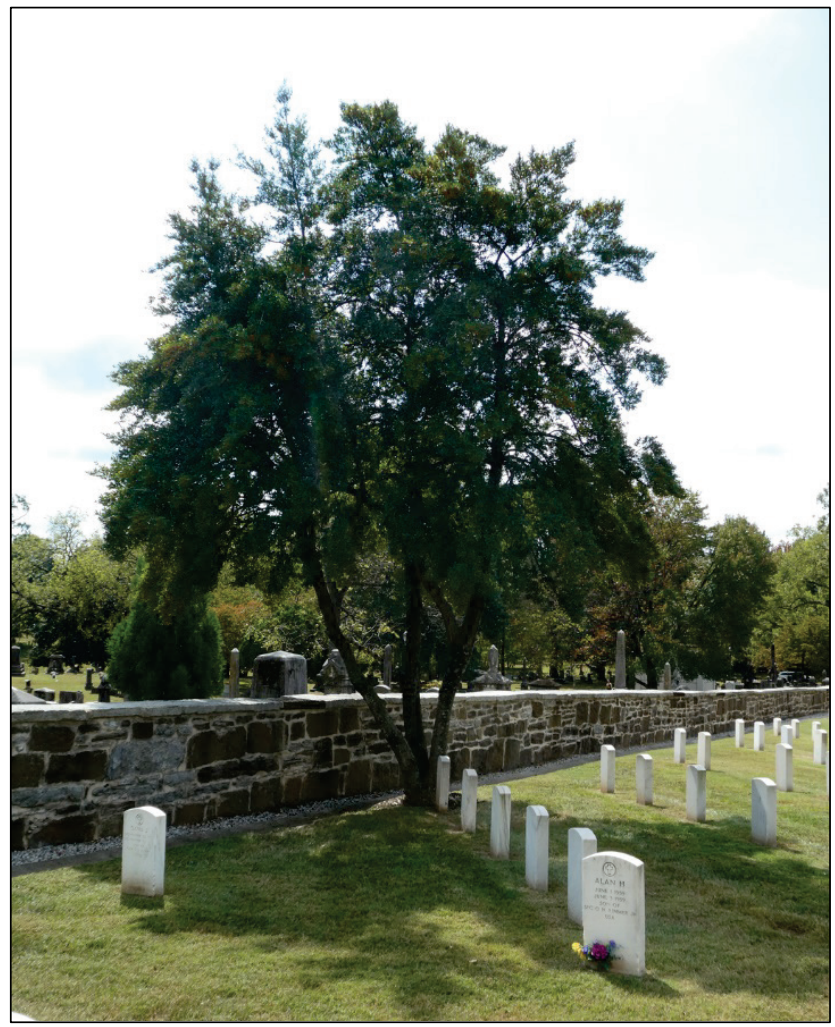

Figure 180. Looking northwest at one of the Flowering Dogwoods in Inner A (ERDC-CERL, 2019).

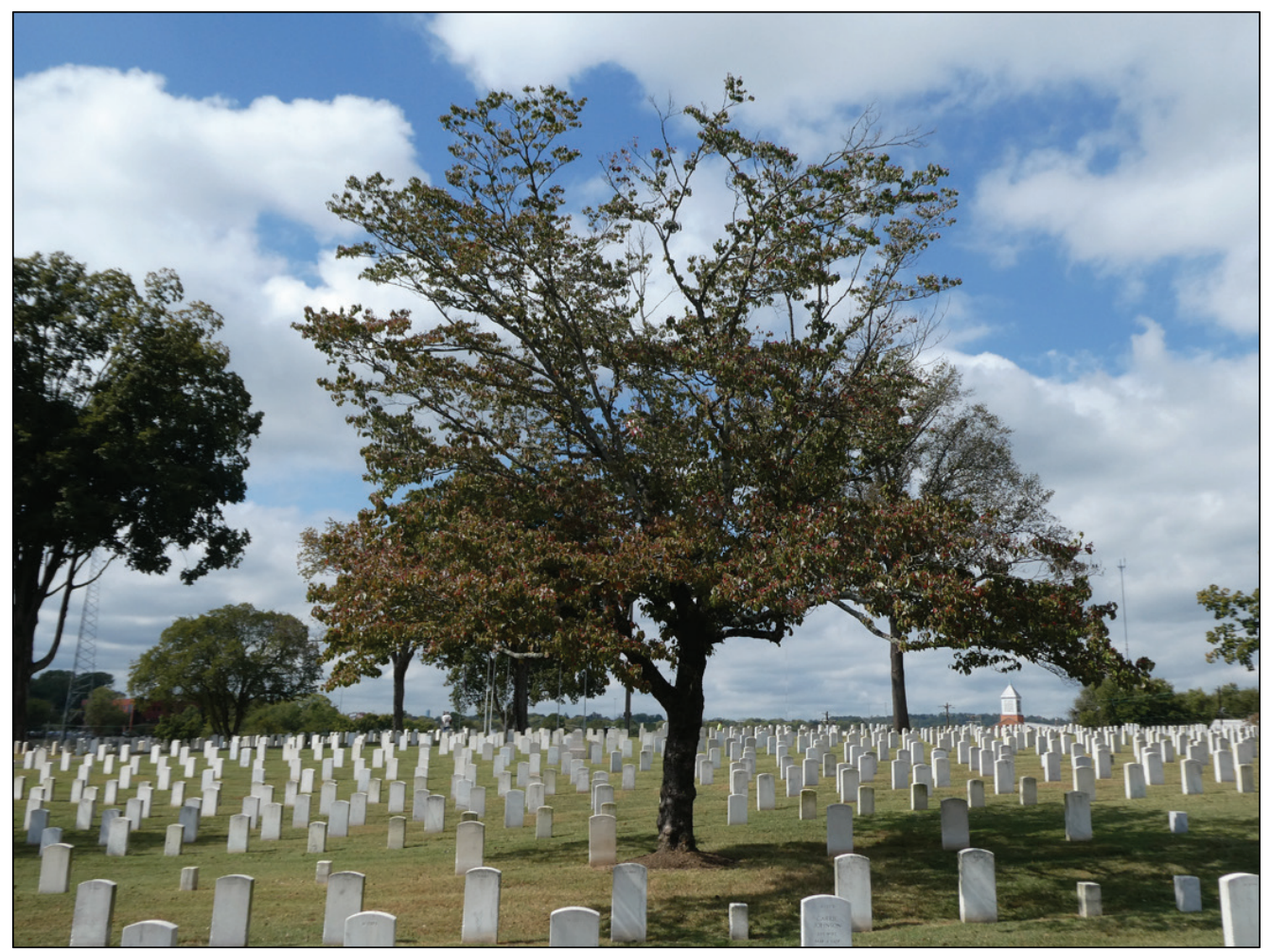


Figure 181. Looking northwest at the Black Walnut tree in Inner A (ERDC-CERL, 2019).

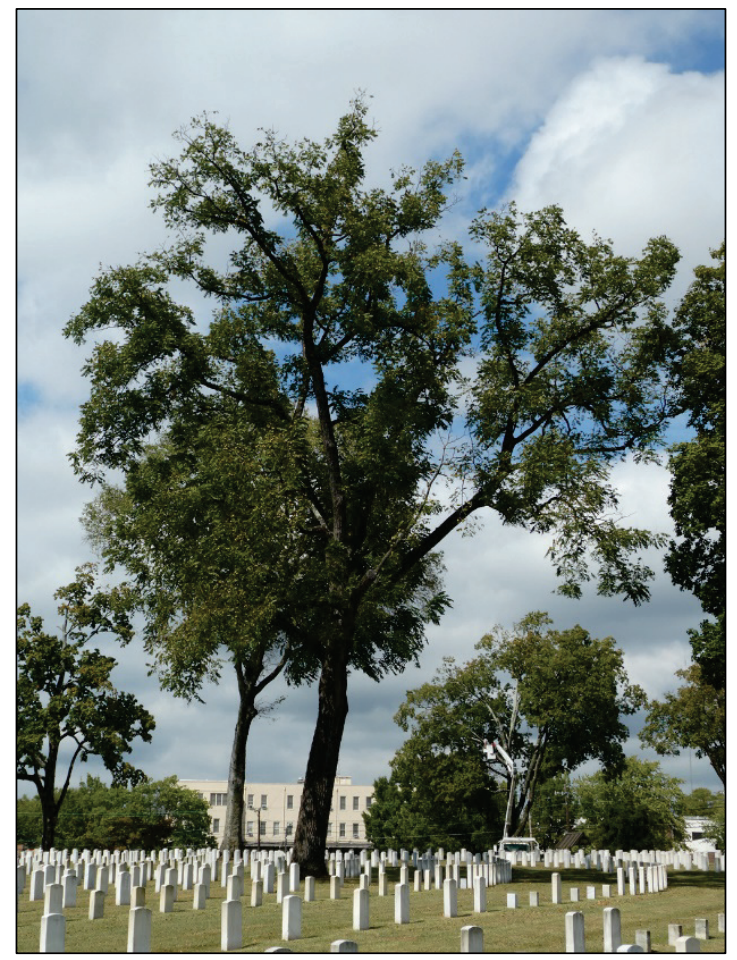

\subsubsection{Burial register summary}

According to records from fall 2019, Section A has 3,070 burial spaces. Of those, 811 are from the Civil War with 149 of them Unknown Soldier burials. The remaining burials in Section A are from the 2oth and 21st centuries, with the most recent in 2019.

In Section X, there are a total of 192 burials with most of them being from WWII through the 1990s. There are several group burials located in Section X from WWII.

\subsubsection{Inner B}

The Inner B section of the cemetery is an original burial area of the cemetery (Figure 182). The ground slopes up from the circle drive, which is at $905^{\prime}$ elevation to the flagpole, which is at $915^{\prime}$. 
Figure 182. Inner B as depicted on P.M. Radford's drawing, 1869 (NARA, Washington DC, RG92).

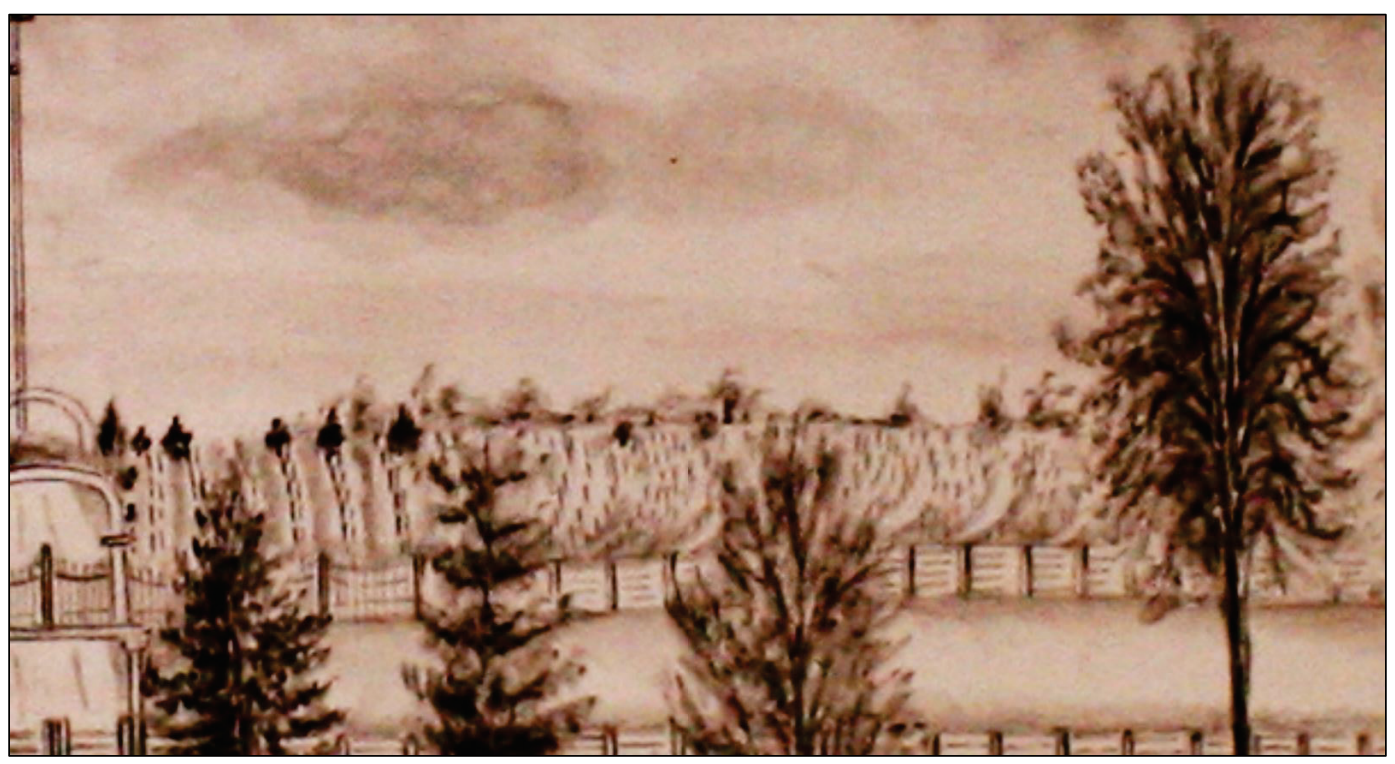

\subsubsection{1869 map}

The 1869 map drawn by P.M. Radford shows 13 concentric rows of radiating out from the center within the circle drive with the graves of Black soldiers on the outermost row for Inner B (Figure 183). There is a $14^{\text {th }}$ row on the outside of the circle drive. This map does not show any landscaping.

Figure 183. Inner B as depicted on P.M. Radford's map, 1869 (NARA, Washington DC, RG92).

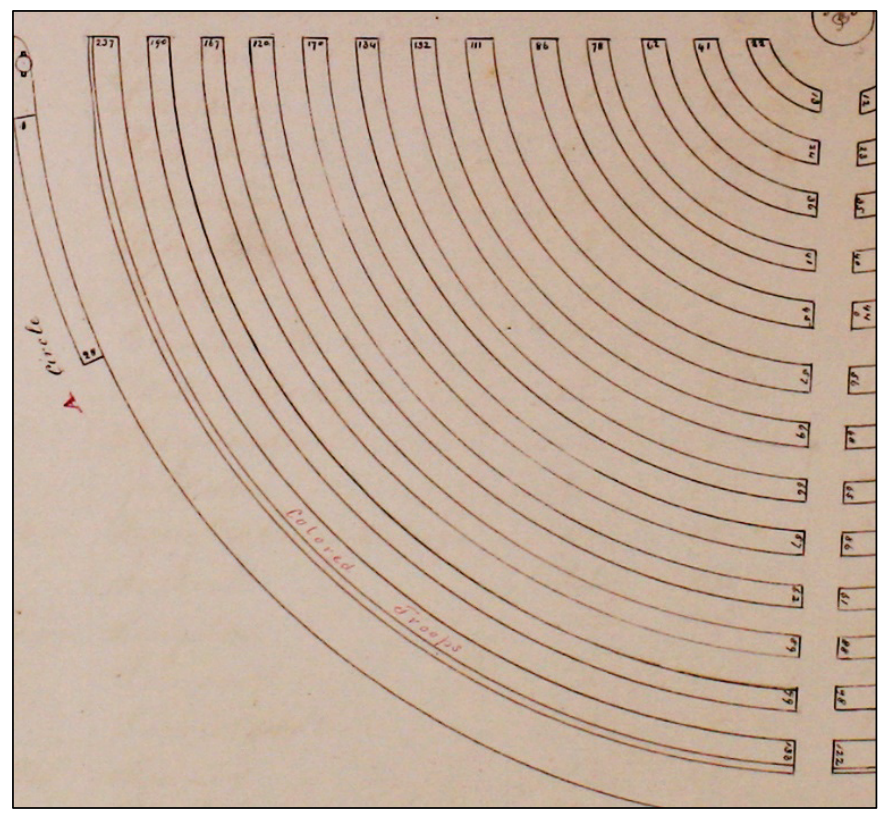




\subsubsection{1892 map}

The map from 1892 still has 13 concentric rows of graves radiating out from the center but does not show any graves on the outside of the circle drive. The graves of Black soldiers are not shown on this map. The map also shows that there was a siege gun monument close to the circle drive, and the burial plot for Superintendent Thomas Ridge and his family (both of these are discussed in the Outer B section). There are deciduous trees and evergreen shrubs spread throughout the section (Figure 184).

Figure 184. Inner B as depicted on a portion of the 1892 map (VA NCA Archives, Washington, DC).

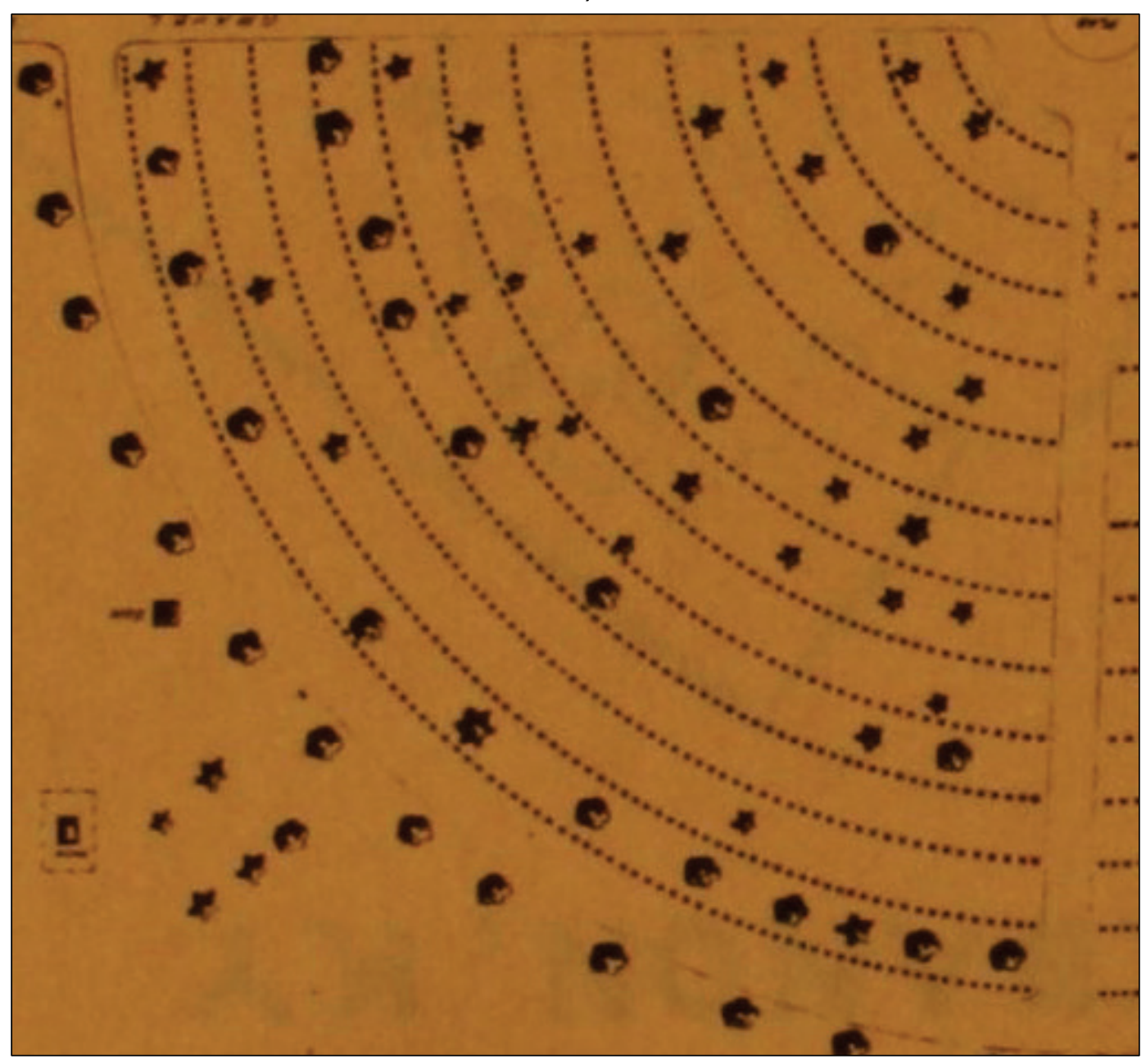

\subsubsection{1909 map}

The map from 1909 is an update of the 1892 map, but there are no differences between the 1892 and 1909 maps for Inner B (Figure 185). Figure 186 was a popular view of the flagstaff from the circle drive in 1908. 
Figure 185. Inner B as depicted on a portion of the 1909 map (NARA, Washington DC, RG92).

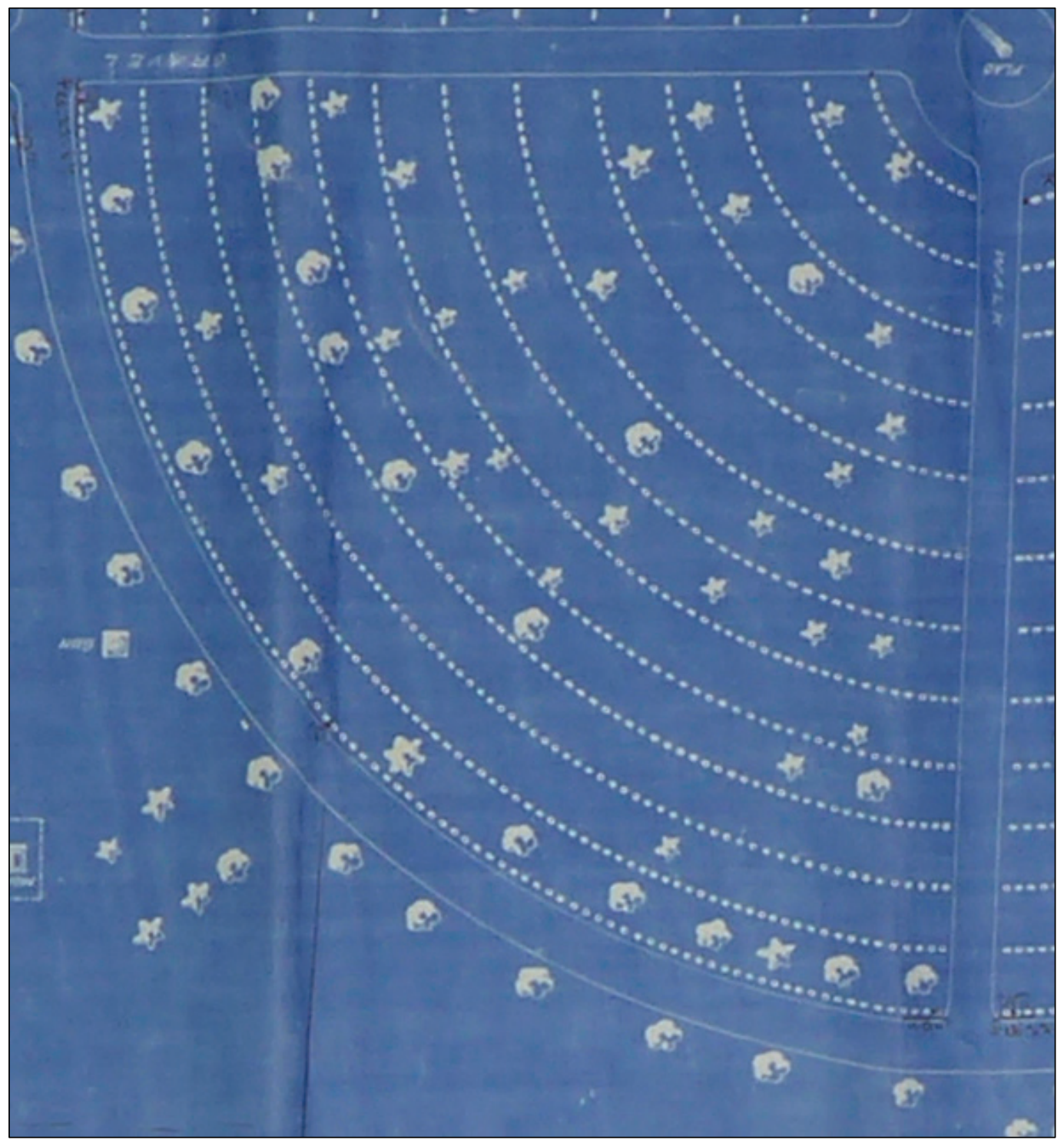


Figure 186. View to the northeast of the of the east-west drive from the circle drive with Inner C on the left and Inner B on the right, 1908 (NARA College Park RG92-CA).

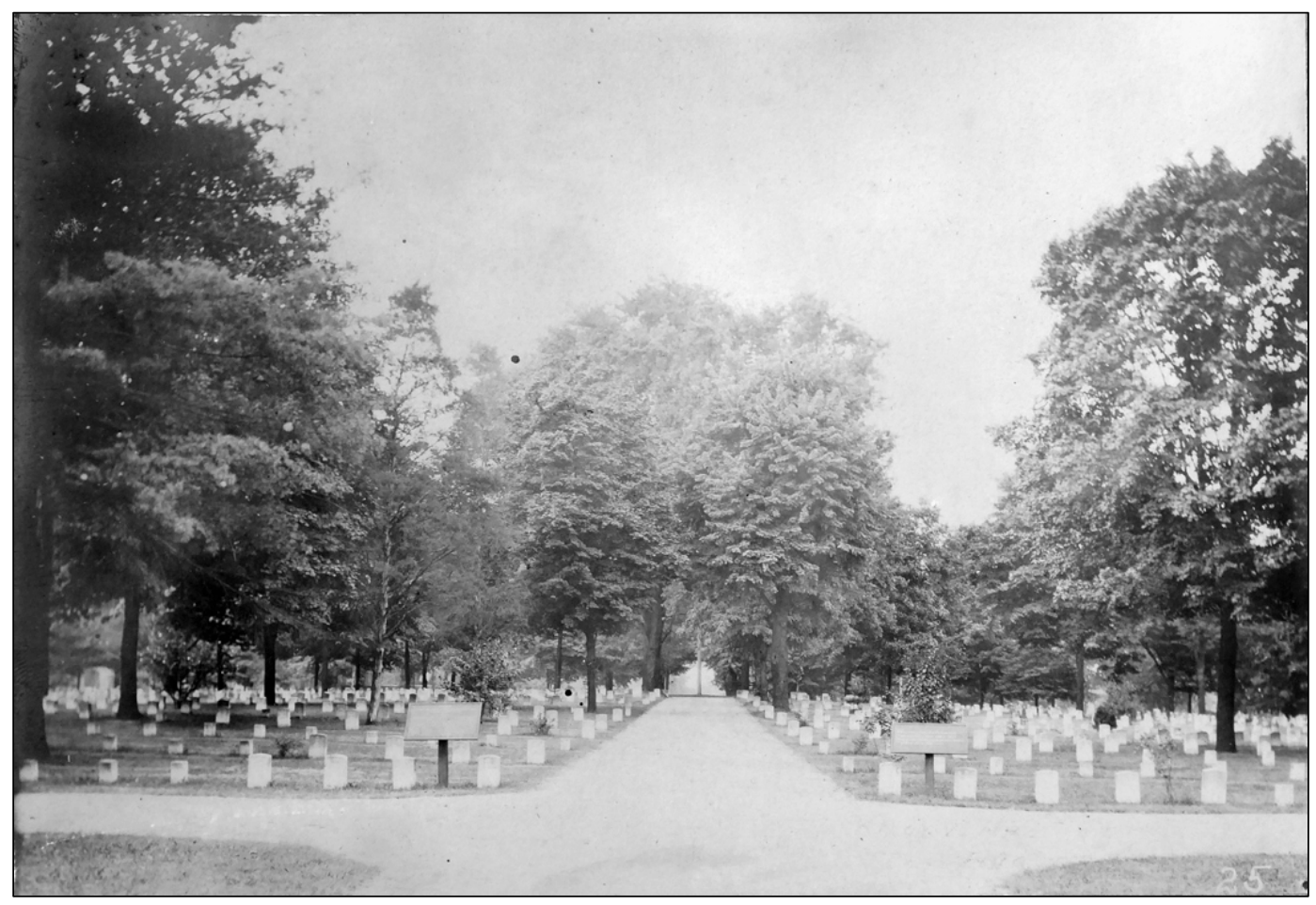

\subsubsection{1947 map}

The map from 1947 is the first map that has the species of trees indicated on it. The map also shows that there are graves on the outside of the circle drive. The map still has 13 concentric rows of graves radiating out from the center (Figure 187). There were 13 Maples and one Wild Cherry. The 1947 map only has trees shown and listed, but an aerial from 1948 shows that Inner B had quite a number of shrubs spread throughout the section including along the road (Figure 188). Photographs from 1953 also show quite a few shrubs along the circle drive (Figures 189 and 190). 
Figure 187. Inner B as depicted on a portion of the 1947 map with types of trees (NARA, Washington DC, RG15).

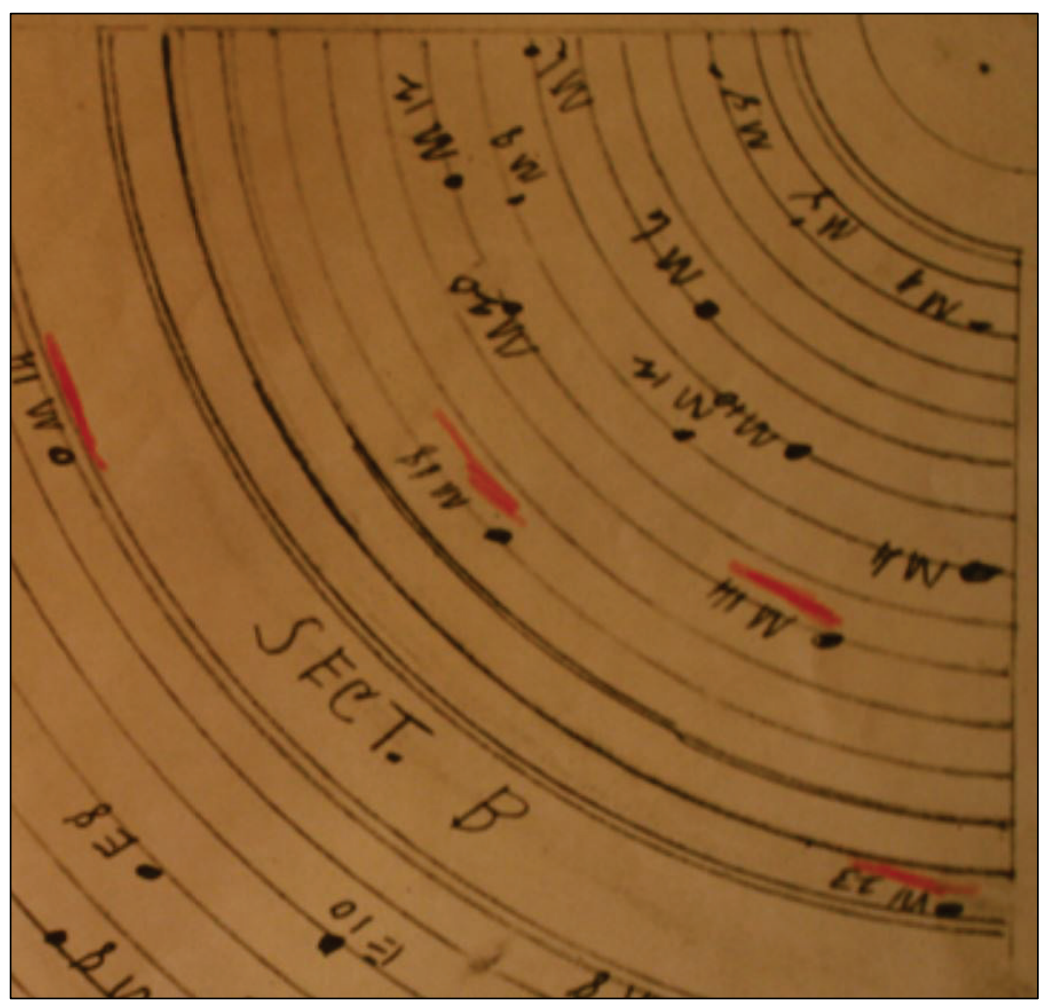

Figure 188. Aerial view of Inner B showing extensive tree cover, 1948 (HALS-TN-2, Library of Congress).

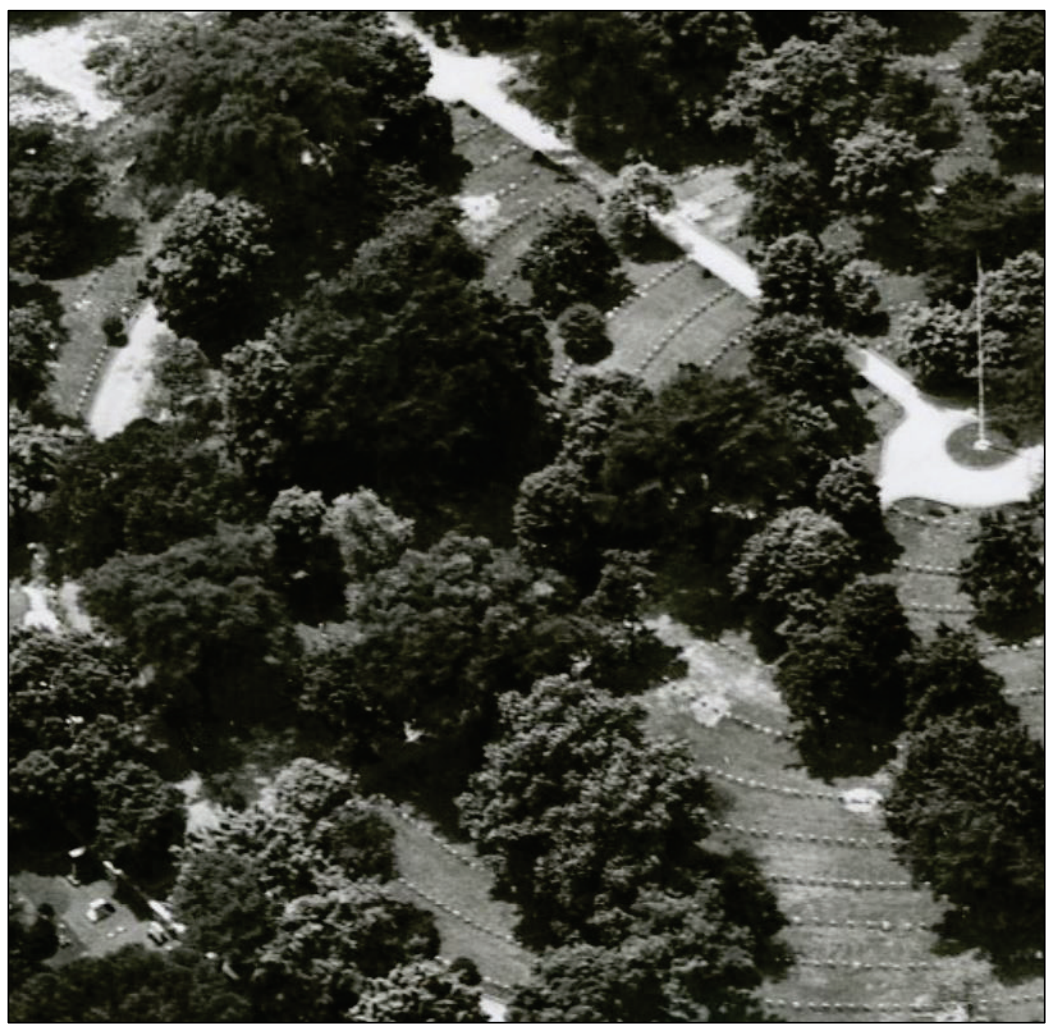


Figure 189. View to the southeast along the circle drive with Inner B on the left with shrubs along road, 1953 (VA NCA Archives, Washington, DC).

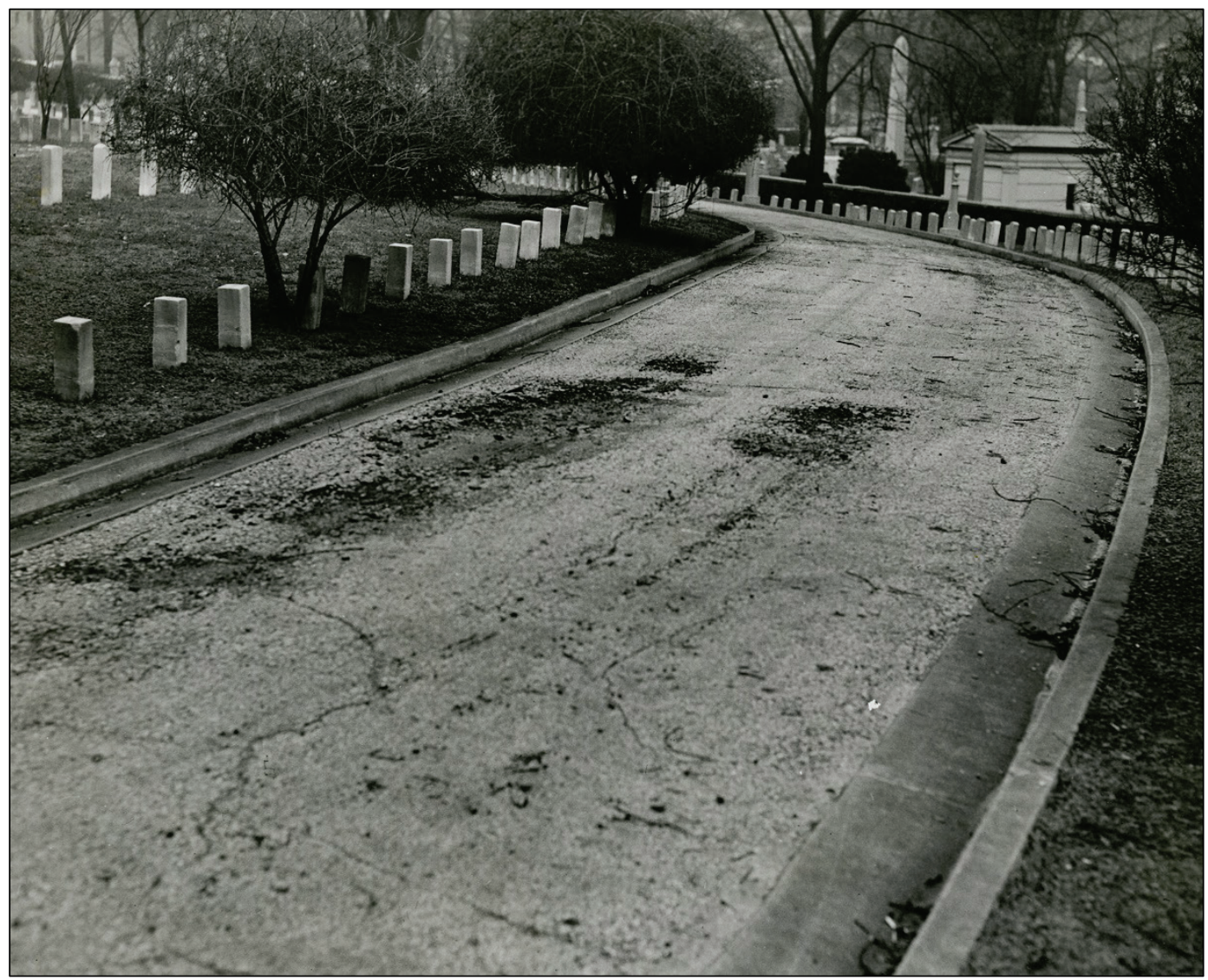

Figure 190. View to the northeast along the circle drive with Inner B on the left with shrubs along road, 1953 (VA NCA Archives, Washington, DC).

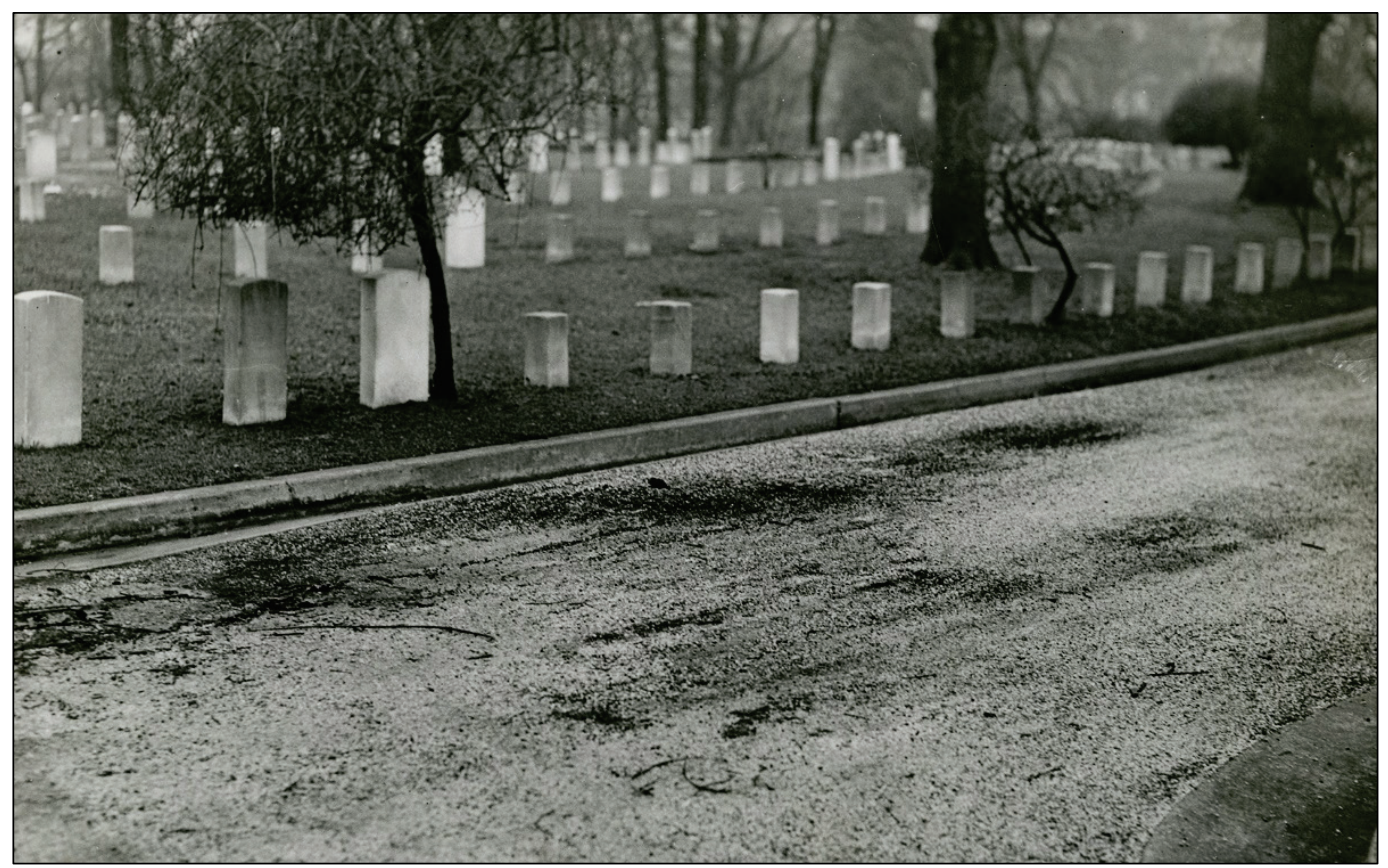




\subsubsection{1971 map}

The map from 1971 does not have landscaping depicted on it, but what it does show is that eight new rows of graves were added in between the existing 13 rows from the Civil War era for a total of 21 rows (Figure 191). The curbing has been erased from the drawing along both sides of the east-west drive. Curbing along the circle drive and the north-south drive had not been removed (Figures 192 and 193).

Figure 191. Inner B as depicted on a portion of the 1971 map (VA NCA Archives, Washington, DC).

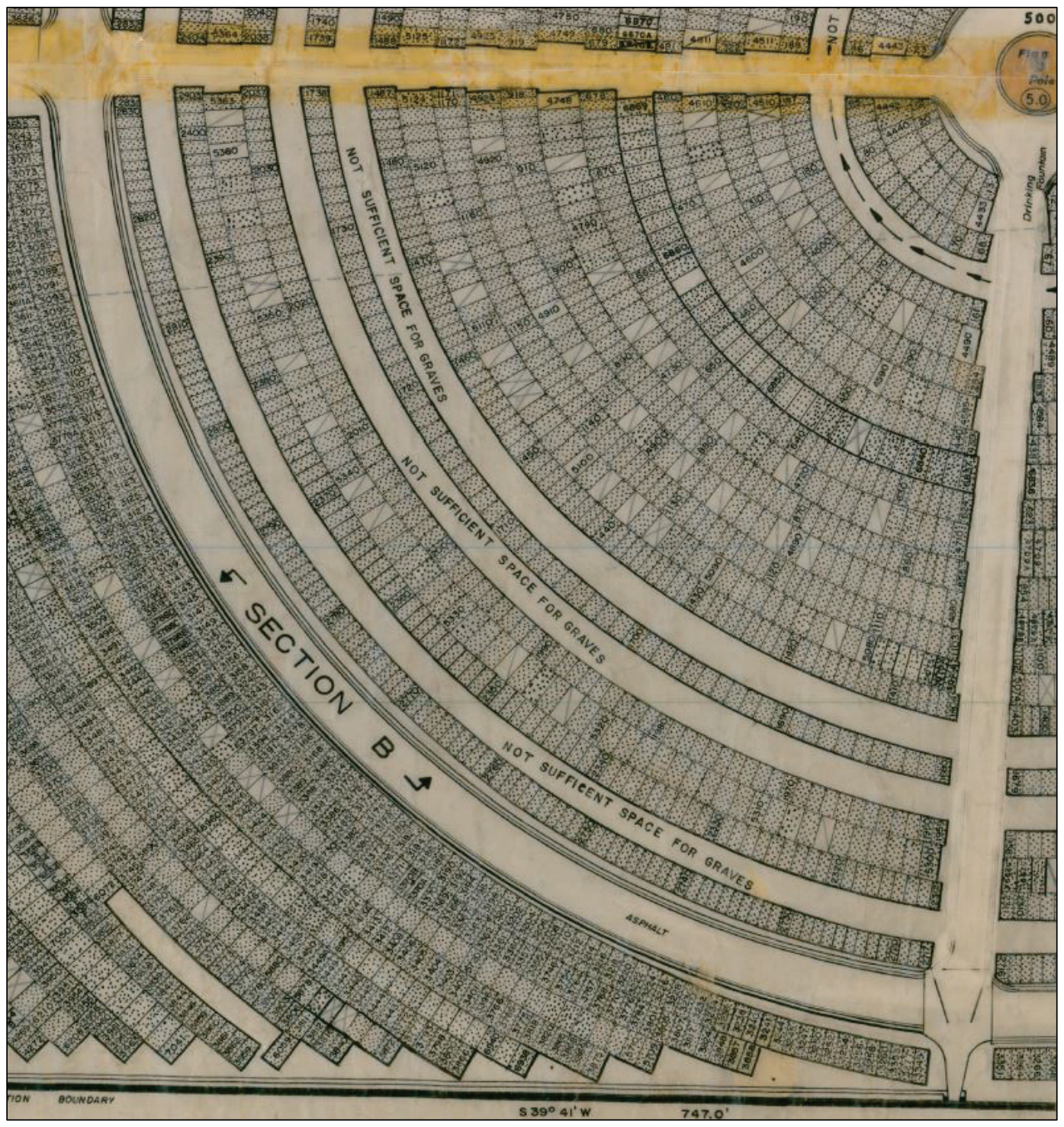


Figure 192. View to the northwest along the intersection of the circle drive and the northsouth drive [Inner B is on the left and Inner A is on the right], 1989 (VA NCA Archives, Washington, DC).

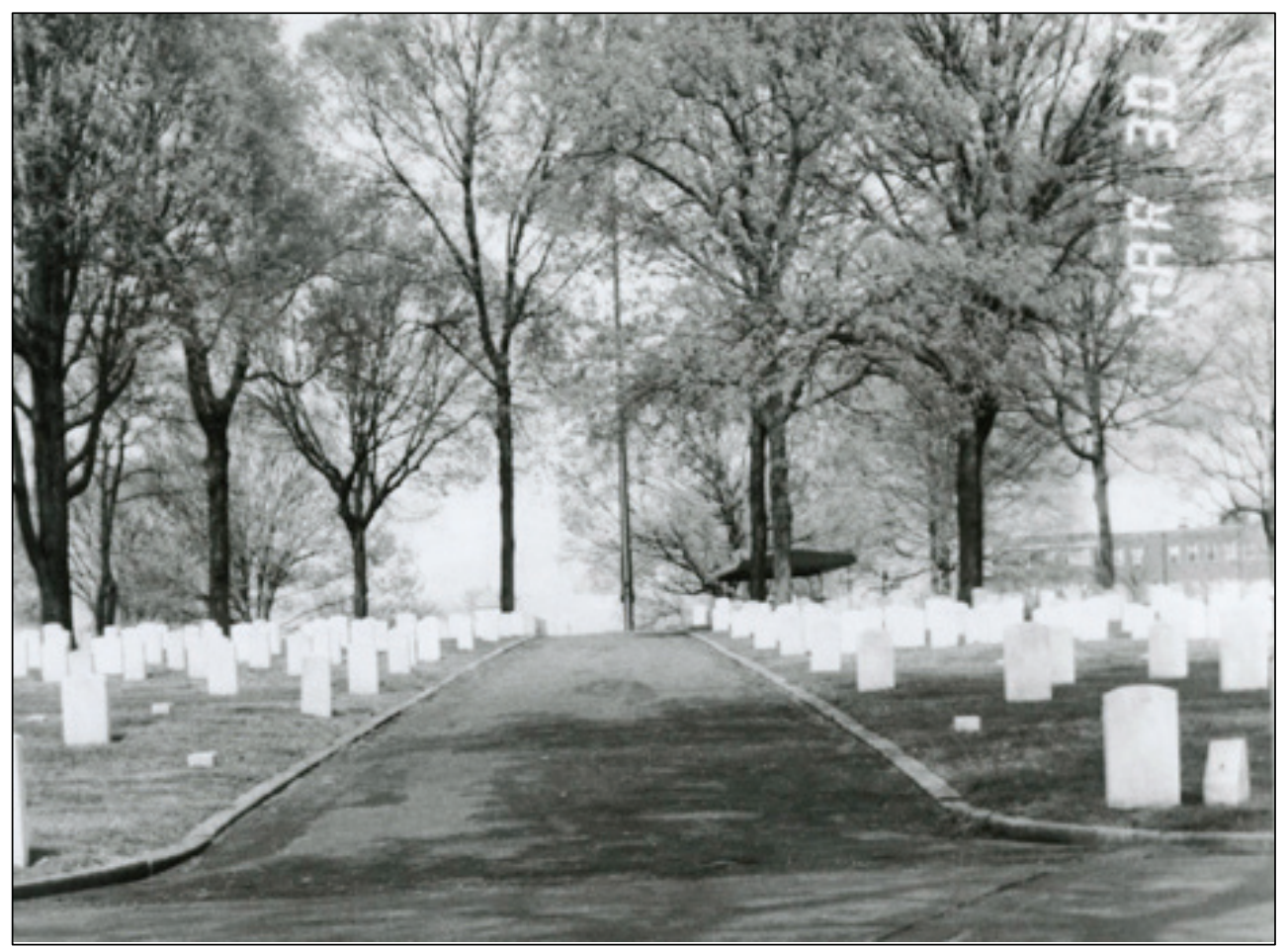

Figure 193. View to the northeast along the circle drive with Inner B on the left and Outer B on the right, 1989 (VA NCA Archives, Washington, DC).

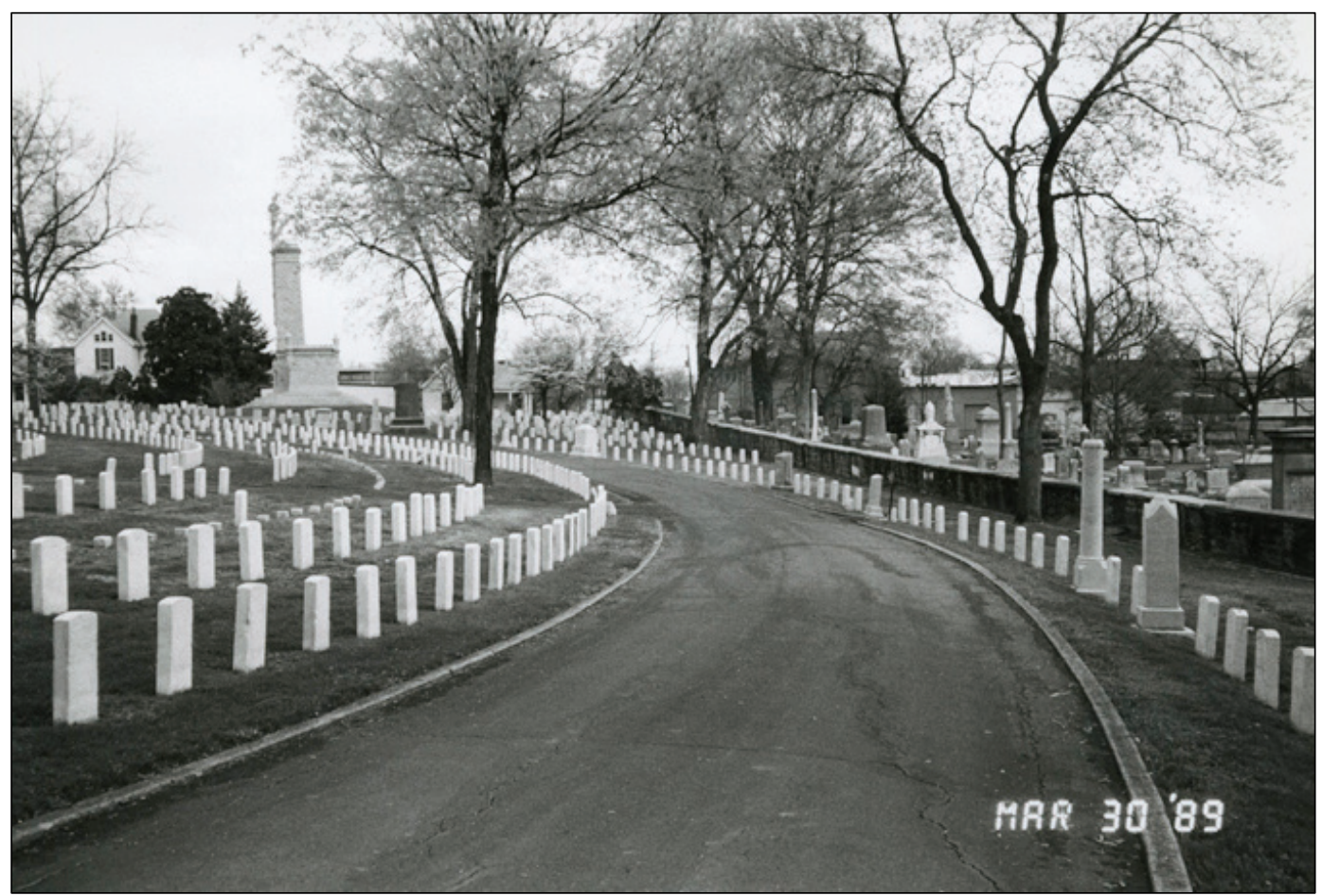




\subsubsection{2019 map}

The map from 2019 does have landscaping depicted on it, and it shows that one new row of graves was added to Inner B for a total of 22 rows. The eastwest drive that connected the two gates from the cemetery's inception is now filled with gravesites leaving only the circle drive and the north-south drive (Figure 194). Figures 195 through 200 show scenes throughout Inner B.

An analysis of the trees in Inner B has four Sugar Maples (Acer saccharum).

Figure 194. Inner B as depicted on a portion of the 2019 map (VA NCA Archives, Washington, DC).

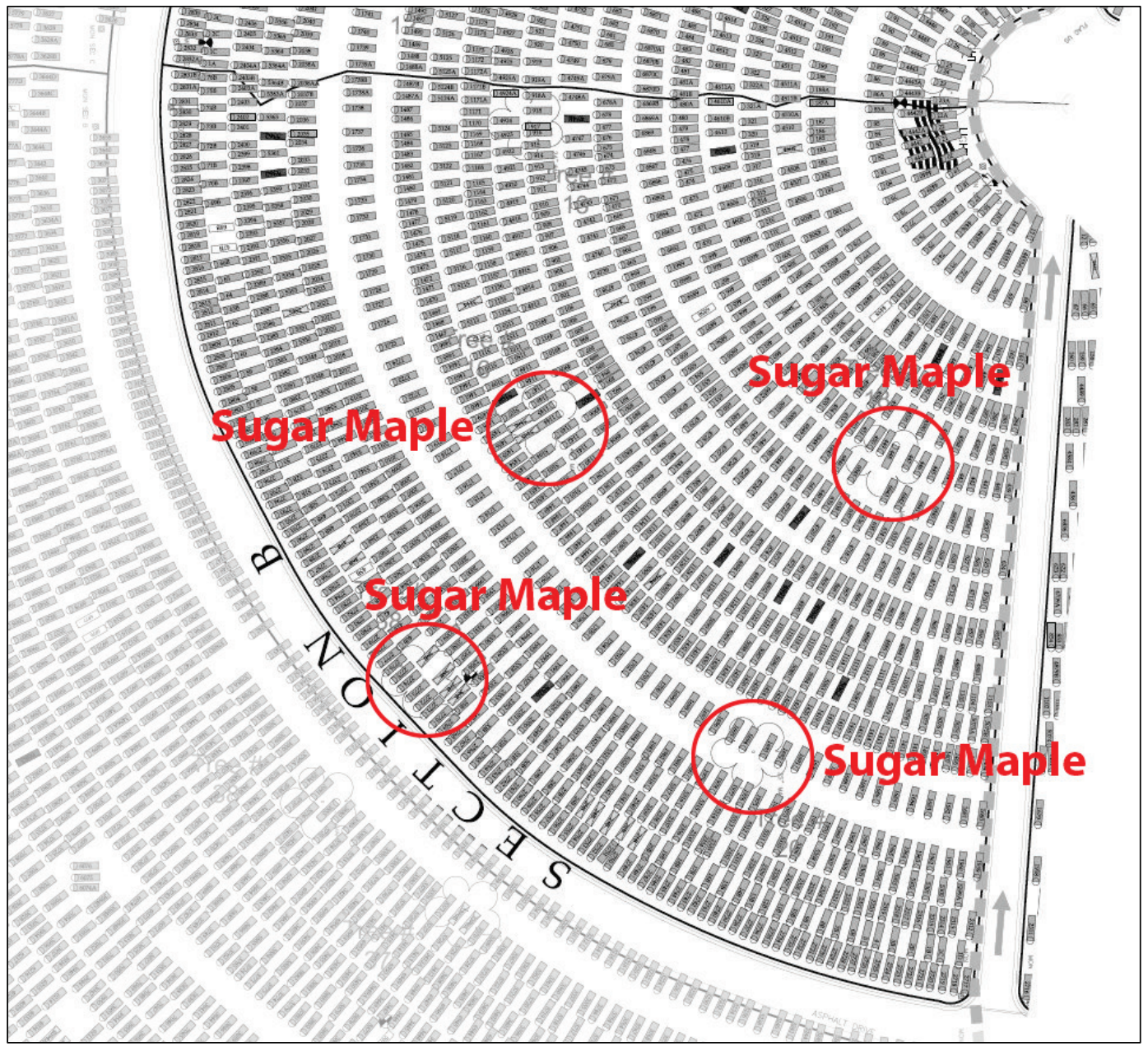


Figure 195. Looking northwest with Inner B on the left and Inner A on the right and the eastwest drive with the flagstaff in the background (ERDC-CERL, 2019).

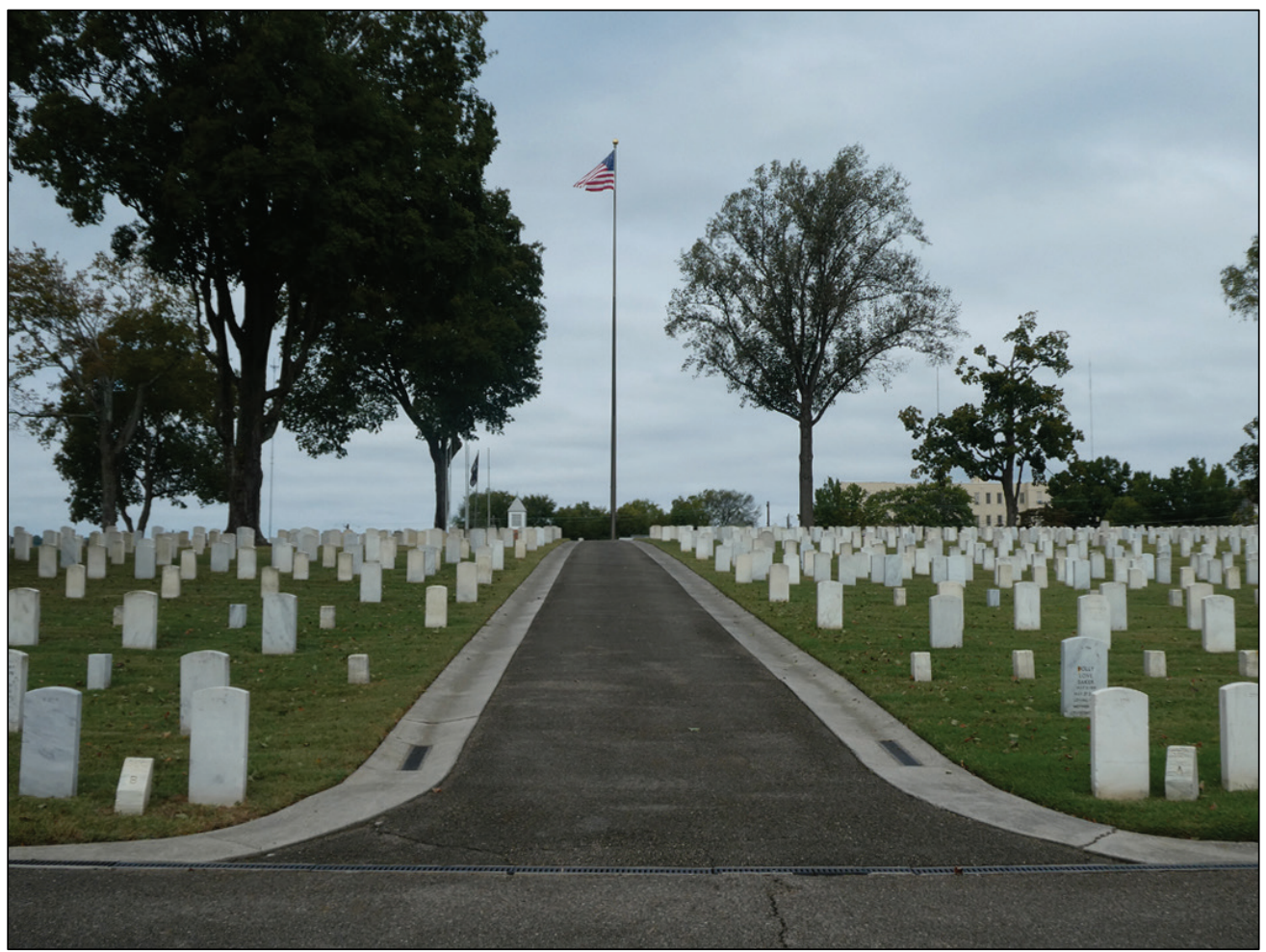

Figure 196. Looking north across Inner B with a Sugar Maple (ERDC-CERL, 2019).

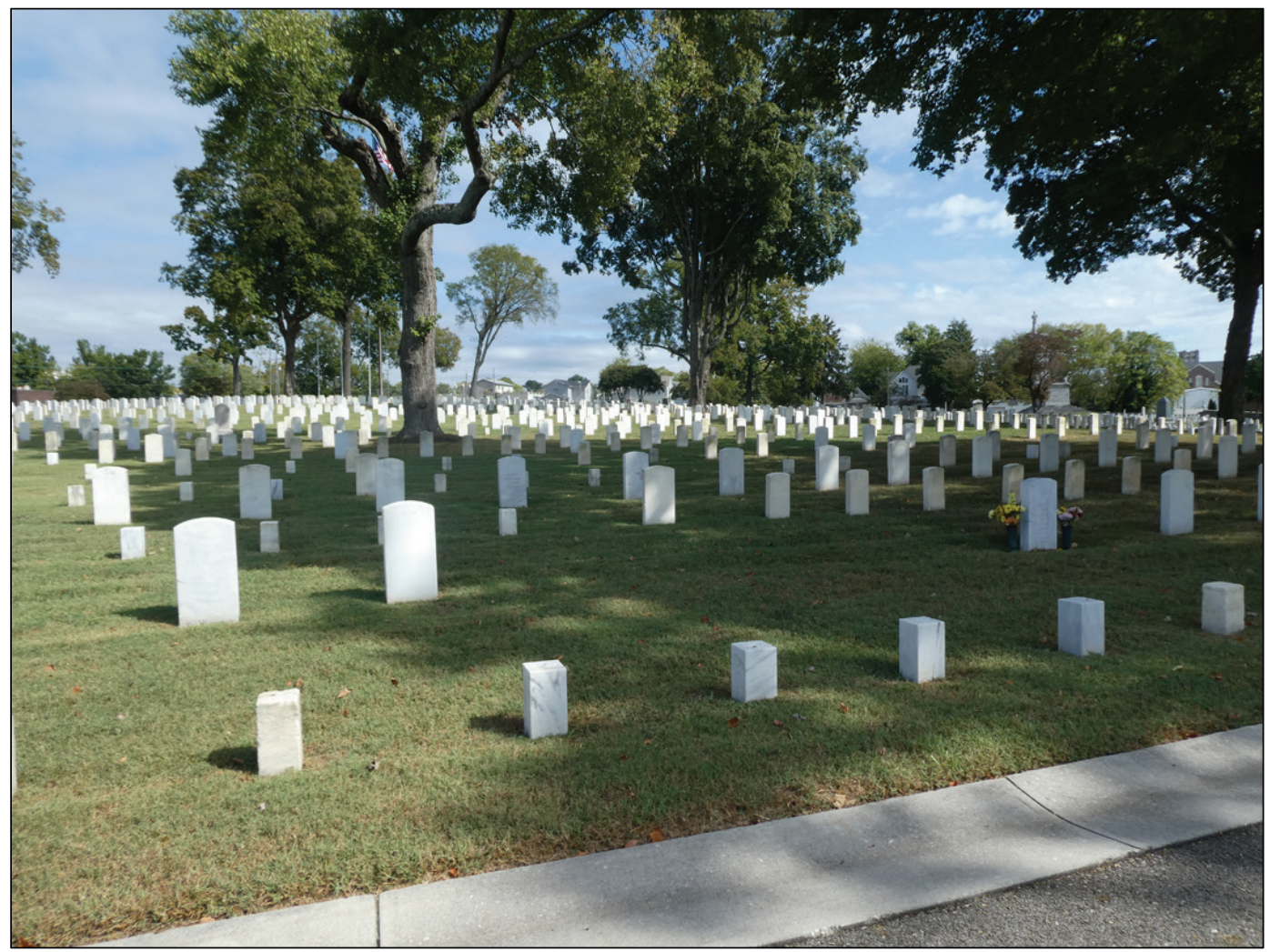


Figure 197. Looking north at a Sugar Maple in Inner B (ERDC-CERL, 2019).

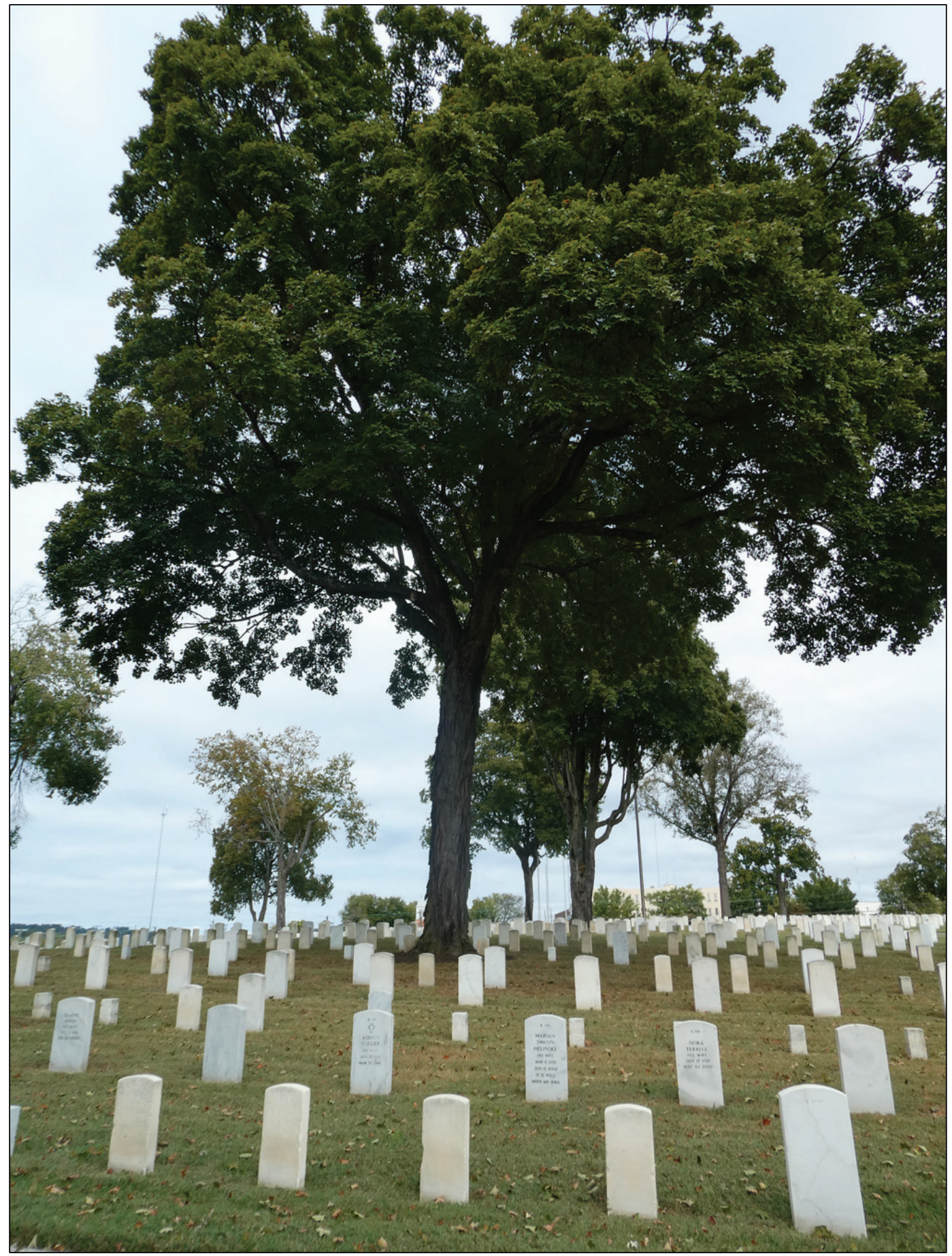


Figure 198. Looking southeast along the circle drive with Inner B on the left and Outer B on the right (ERDC-CERL, 2019).

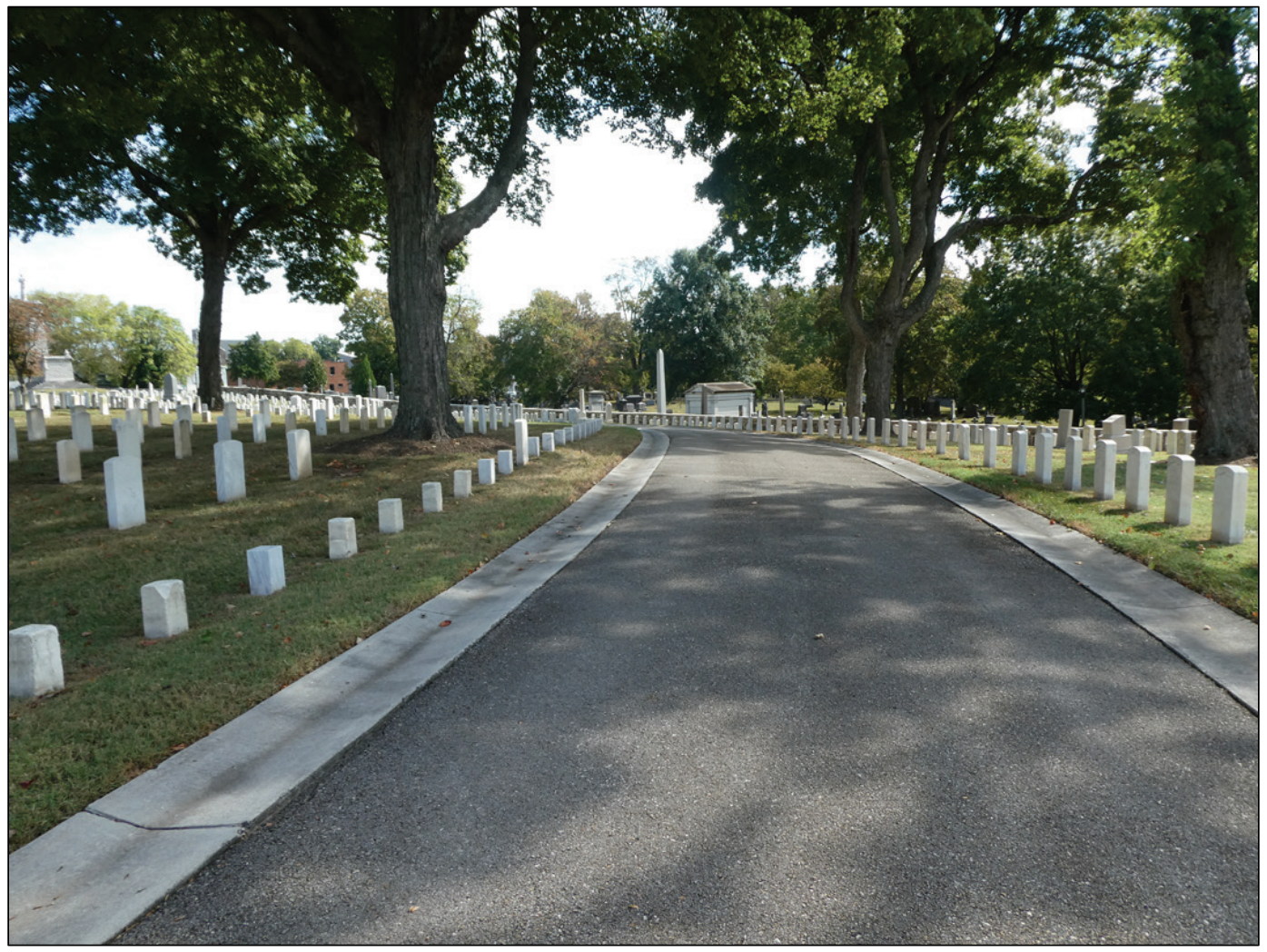

Figure 199. Looking northeast from the circle drive at the former location of the east-west drive with Inner $C$ on the left and Inner on the right (ERDC-CERL, 2019).

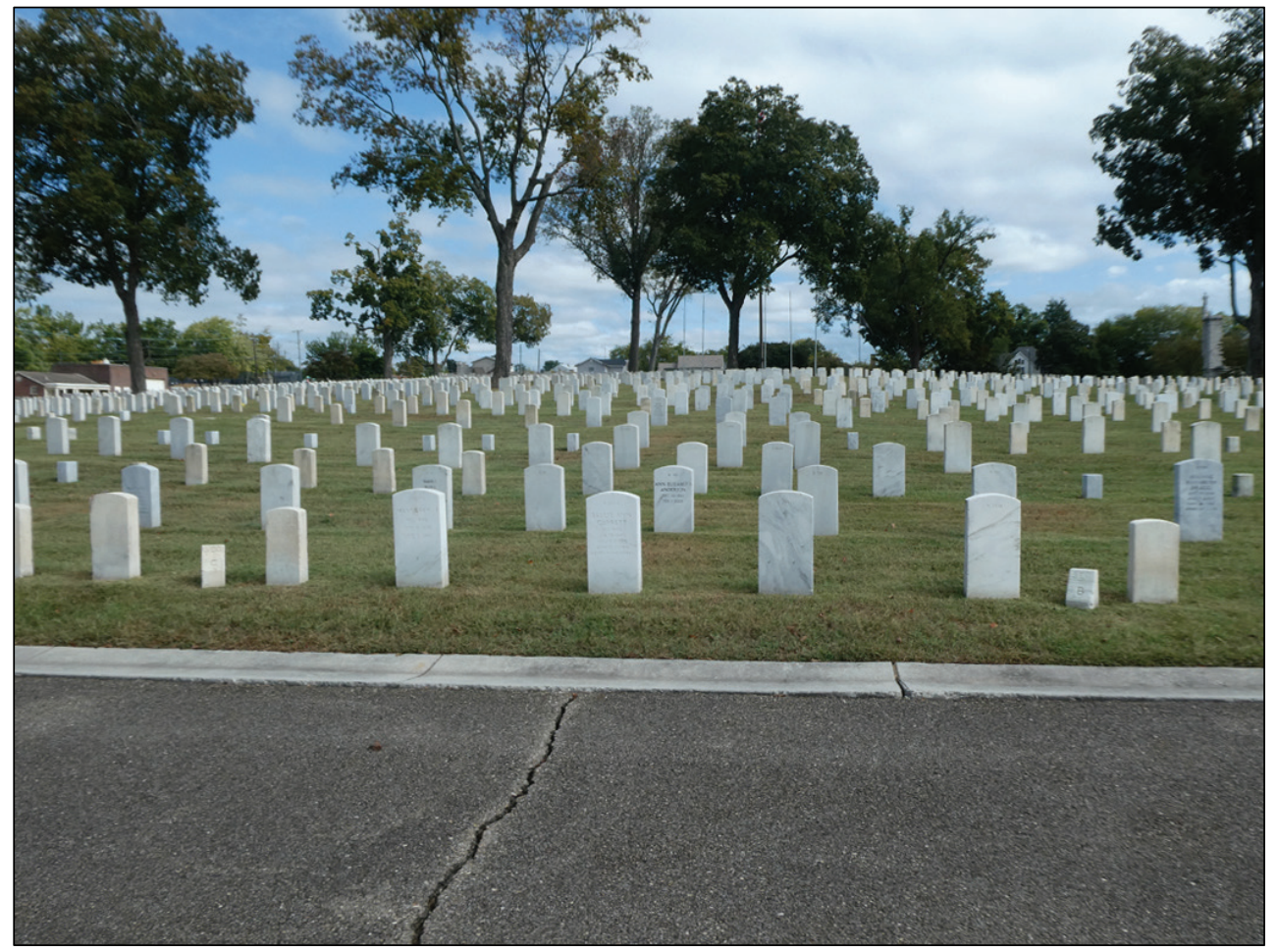


Figure 200. Looking south from the flagstaff across Inner B (ERDC-CERL, 2019).

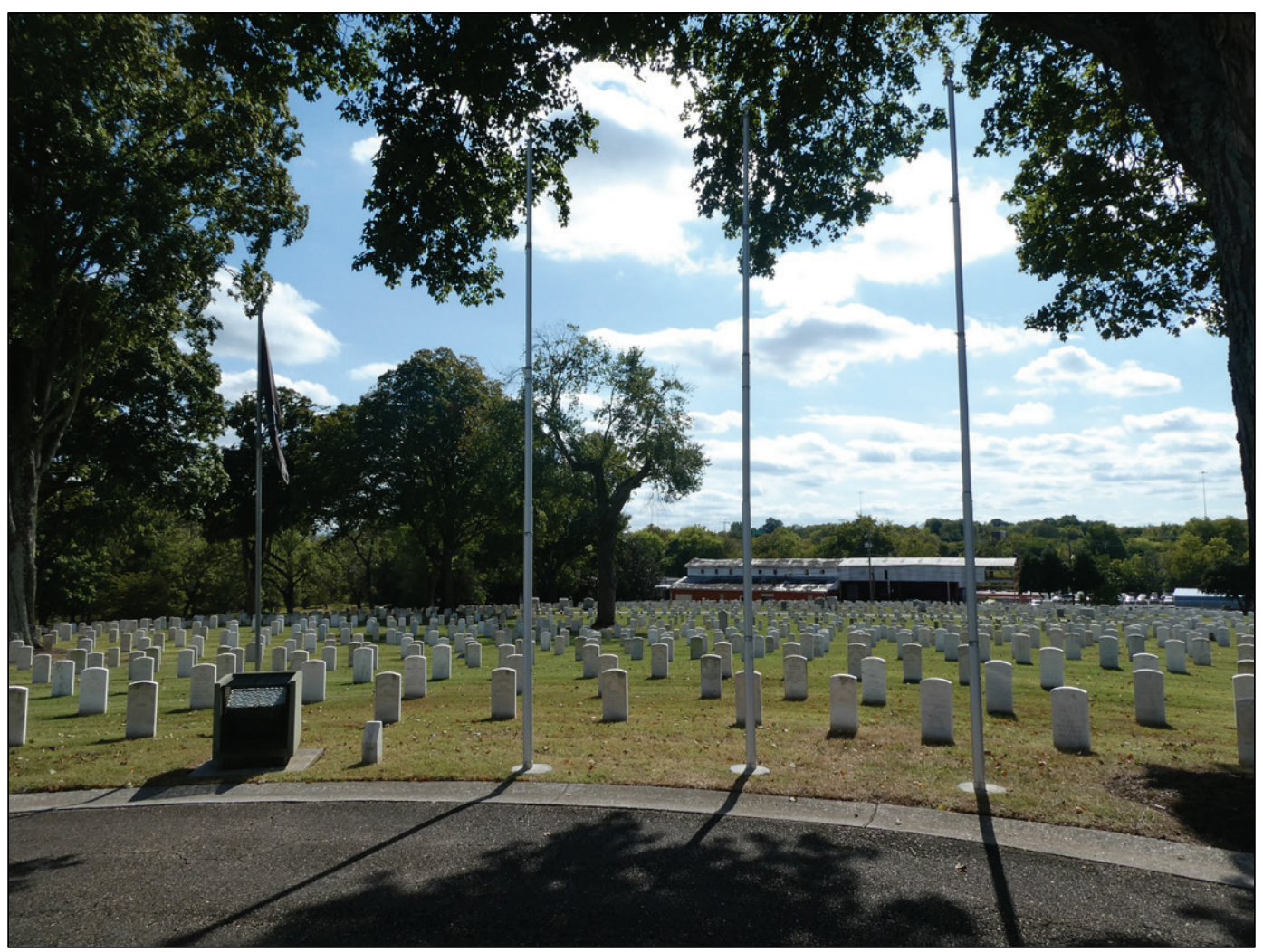

\subsubsection{Burial register summary}

According to records from fall 2019, Section B has 3,070 burial spaces. Of those, 761 are from the Civil War with 283 of them Unknown Soldier burials. The remaining burials in Section B are from the 2oth and 21st centuries, with the most recent in 2019. The burial list does not separate Inner B from Outer B.

\subsubsection{Inner C}

The Inner $\mathrm{C}$ section of the cemetery is an original burial area of the cemetery (Figure 201). The ground slopes up from the circle drive, which is at $899^{\prime}$ elevation to the flagpole, which is at $915^{\prime}$. 
Figure 201. Inner C as depicted on P.M. Radford's drawing, 1869 (NARA, Washington DC, RG92).

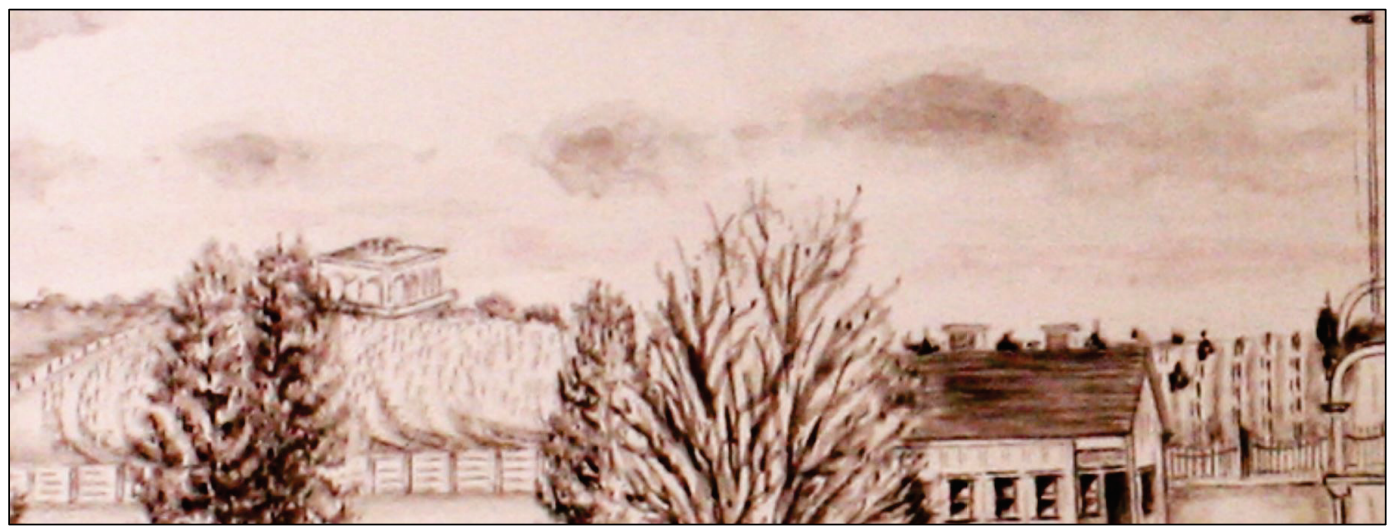

\subsubsection{1869 map}

The 1869 map drawn by P.M. Radford shows 13 concentric rows of radiating out from the center within the circle drive with the graves of Black soldiers on the outermost row for Inner $C$ (Figure 202). There is a $14^{\text {th }}$ row on the outside of the circle drive. This map does not show any landscaping.

Figure 202. Inner C as depicted on P.M. Radford's map, 1869 (NARA, Washington DC, RG92).

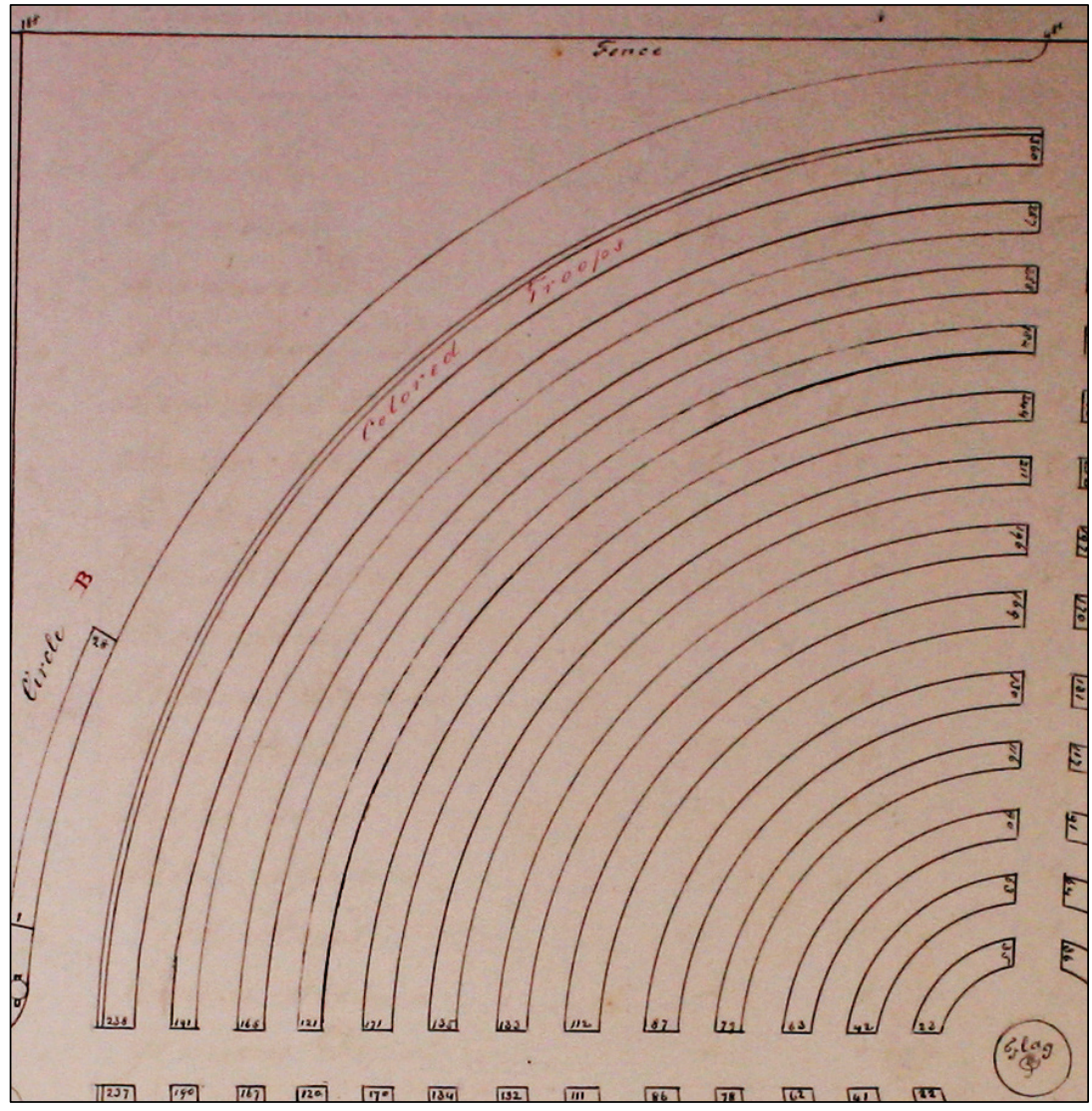




\subsubsection{1892 map}

The map from 1892 still has 13 concentric rows of graves radiating out from the center but does not show any graves on the outside of the circle drive (Figure 203). The graves of Black soldiers are not shown on this map. The map also shows that there was a siege gun monument close to the circle drive (this is discussed in the Outer $\mathrm{C}$ section). There are deciduous trees and evergreen shrubs spread throughout the section.

Figure 203. Inner $C$ as depicted on a portion of the 1892 map (VA NCA Archives, Washington, DC).

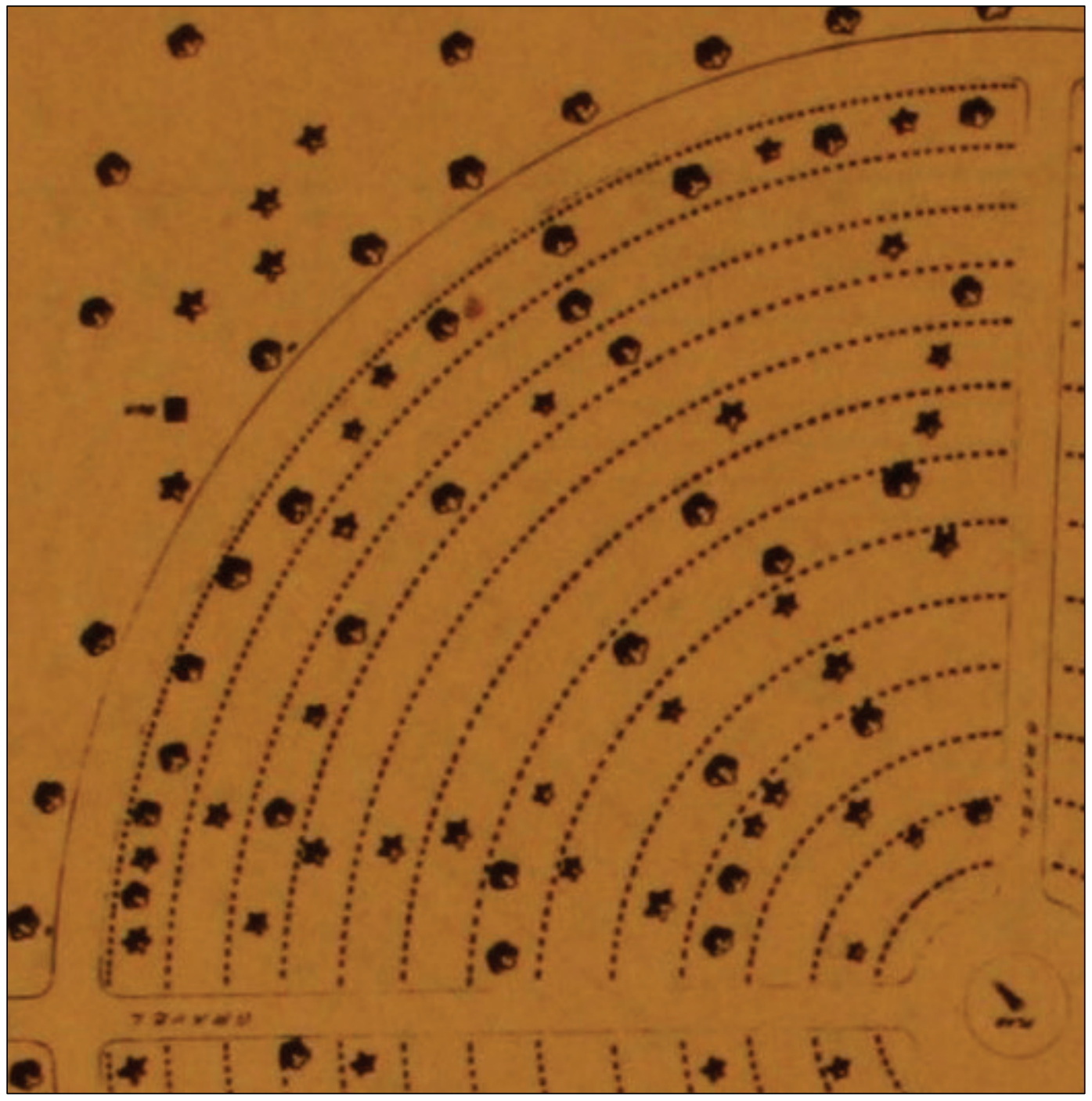

\subsubsection{1909 map}

The map from 1909 is an update of the 1892 map, but there are no differences between the 1892 and 1909 maps for Inner C (Figure 204). 
Figure 204. Inner C as depicted on a portion of the 1909 (NARA, Washington DC, RG92).

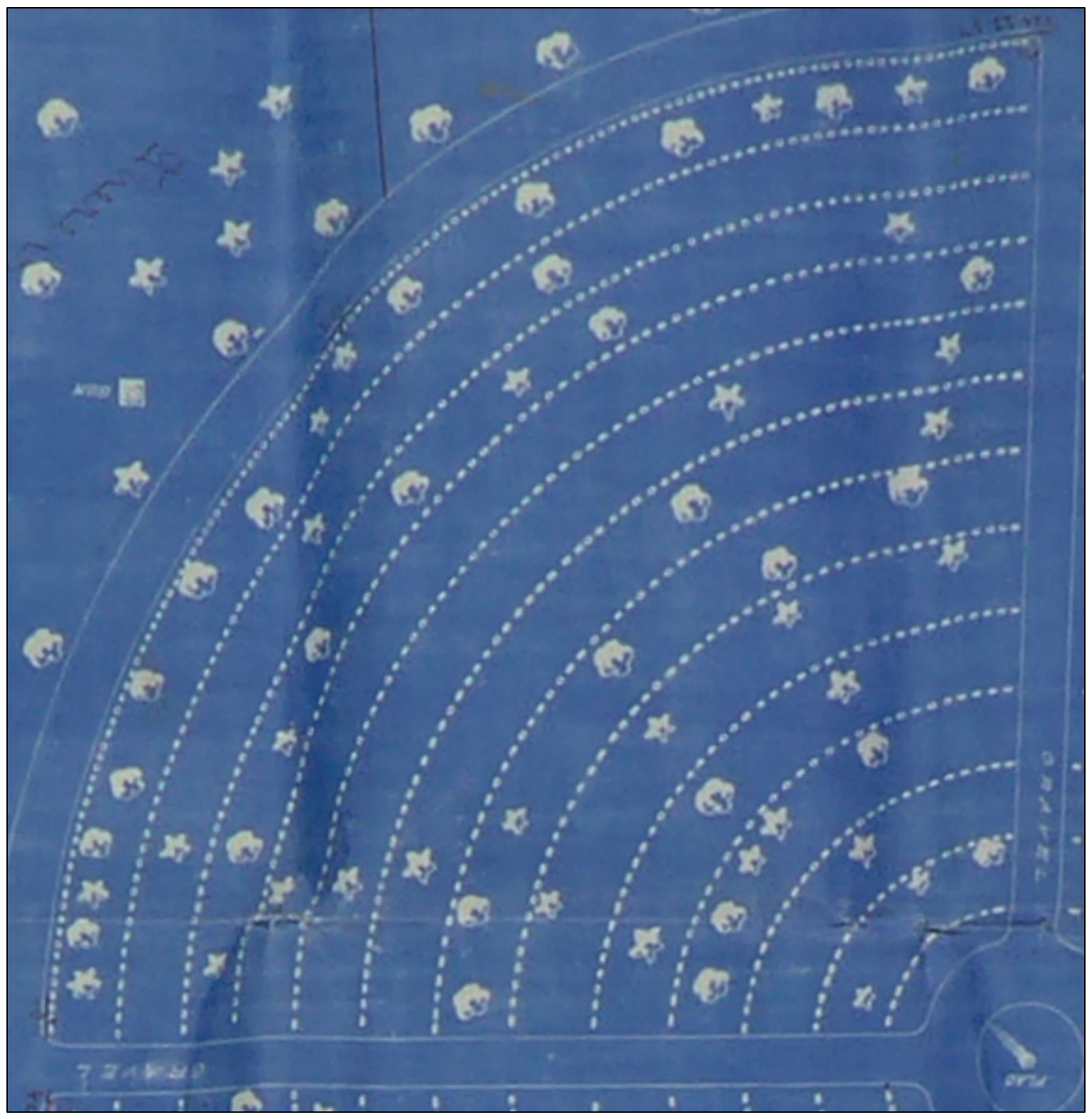

\subsubsection{1947 map}

The map from 1947 is the first map that has the species of trees indicated on it. The map also shows that there are graves on the outside of the circle drive. The map still has 13 concentric rows of graves radiating out from the center (Figure 205). There were eight Maples, one Wild Cherry, three Elms, and one Catalpa. The 1947 map only has trees shown and listed, but an aerial from 1948 shows that Inner $C$ had quite a number of shrubs spread throughout the section (Figure 206). A 1953 photographs shows a large shrub at the intersection of the north-south drive and the circle drive (Figure 207). 
Figure 205. Inner $C$ as depicted on a portion of the 1947 map with types of trees (NARA, Washington DC, RG15).

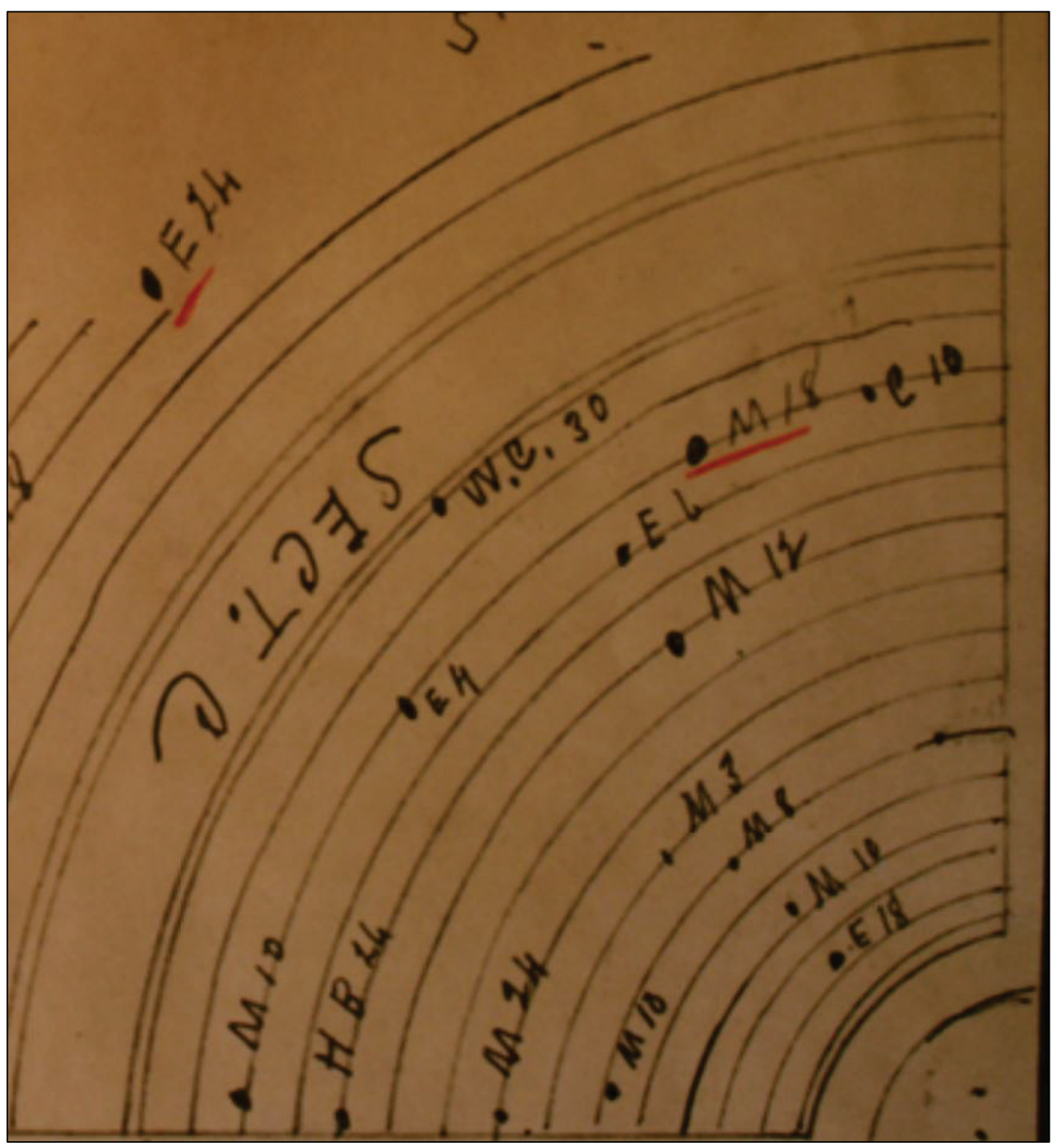

Figure 206. Aerial view of Inner C showing extensive tree cover, 1948 (HALS-TN-2, Library of Congress).

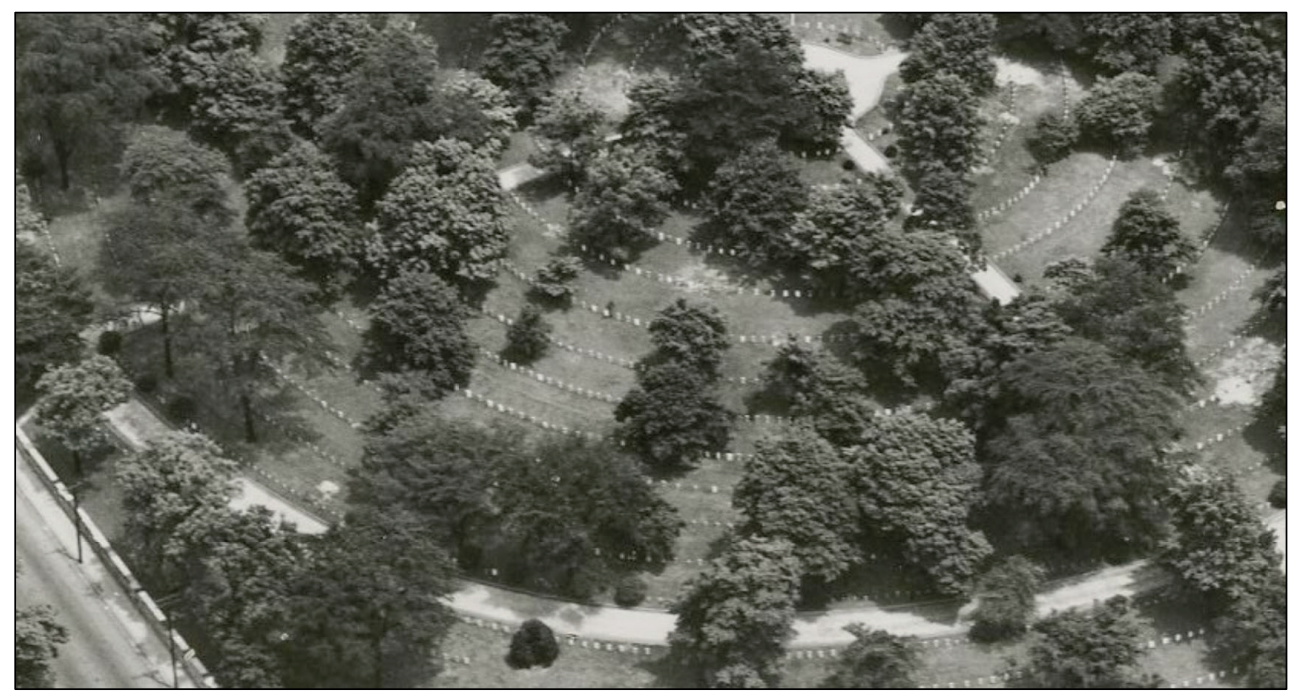


Figure 207. View to the southeast of the intersection of the north-south drive and the circle drive with Section D on the left and Inner C on the right, 1953 (VA NCA Archives, Washington, DC). Note the accent shrub at the intersection.

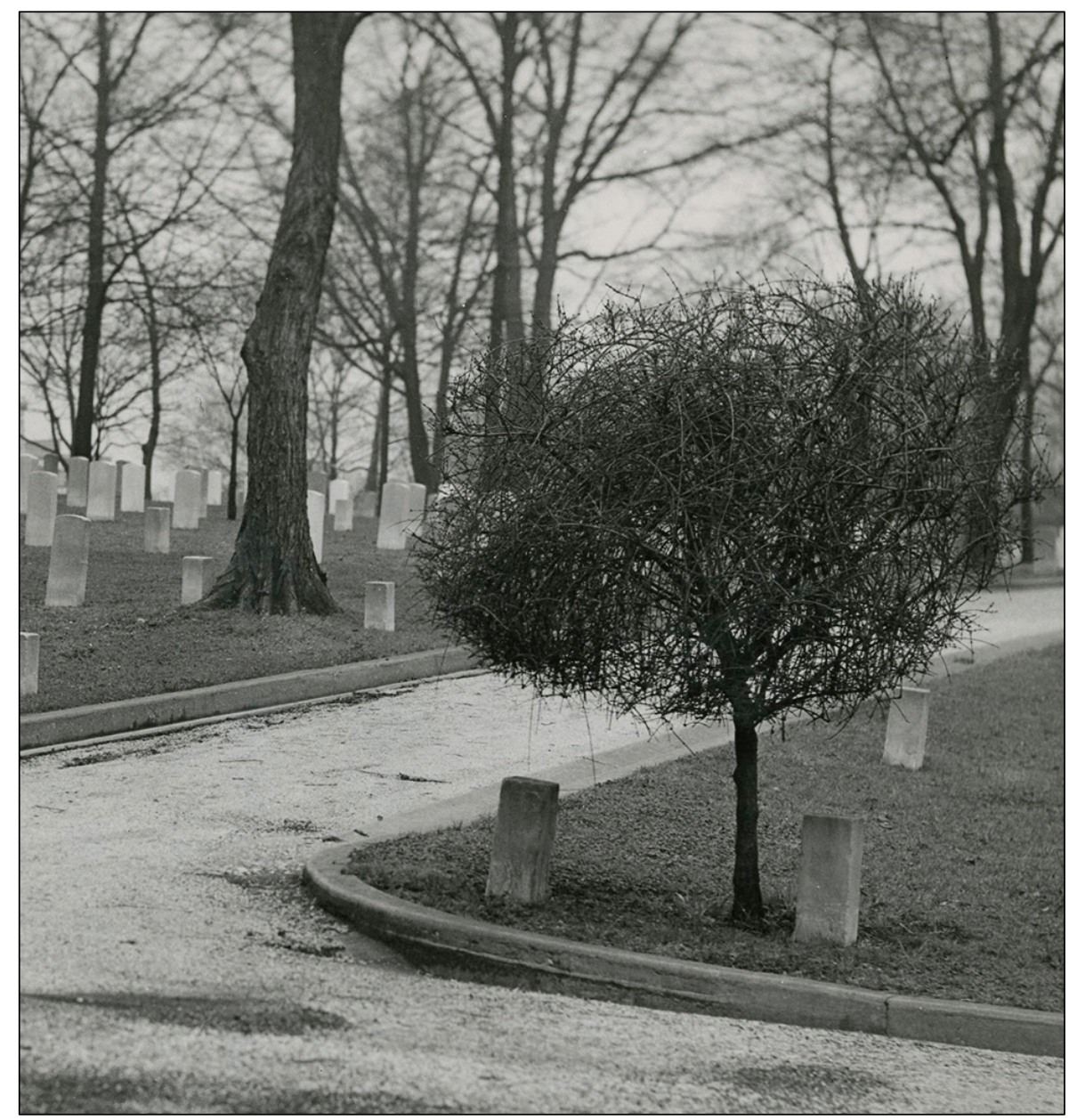

\subsubsection{1971 map}

The map from 1971 does not have landscaping depicted on it, but what it does show is that eight new rows of graves were added in between the existing 13 rows from the Civil War era for a total of 21 rows (Figure 208). The curbing has been erased from the drawing along both sides of the east-west drive. Curbing along the circle drive and the north-south drive had not been removed (Figures 209 and 210). 
Figure 208. Inner C as depicted on a portion of the 1971 map (VA NCA Archives, Washington, $\mathrm{DC})$.

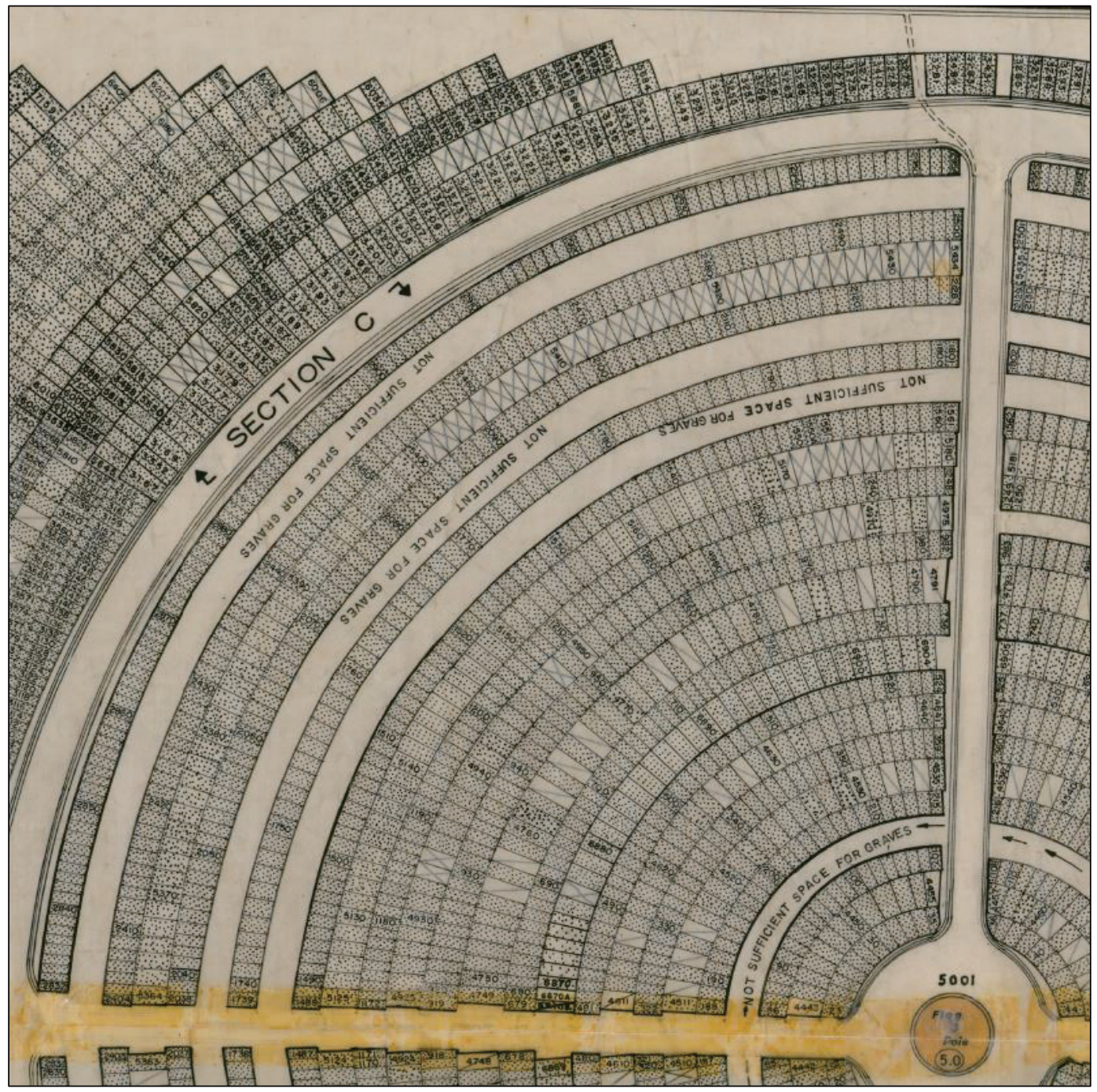


Figure 209. View to the south along the circle drive with Inner C shown in the center, 1989 (VA NCA Archives, Washington, DC).

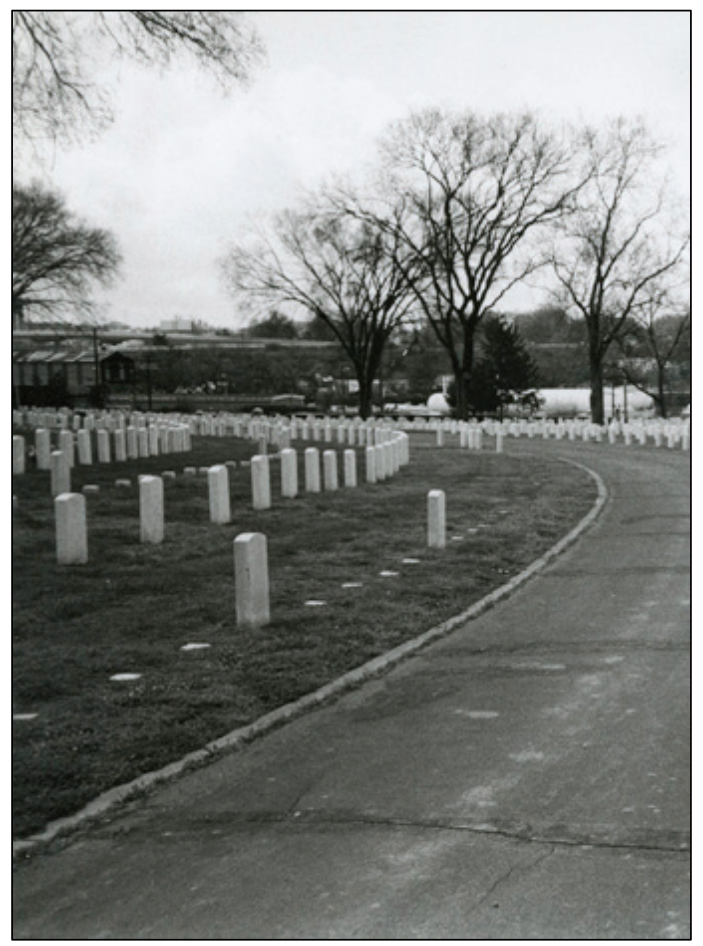

Figure 210. View to the southeast up the north-south drive with Section $D$ on the left and Inner C on the right, 1989 (VA NCA Archives, Washington, DC).

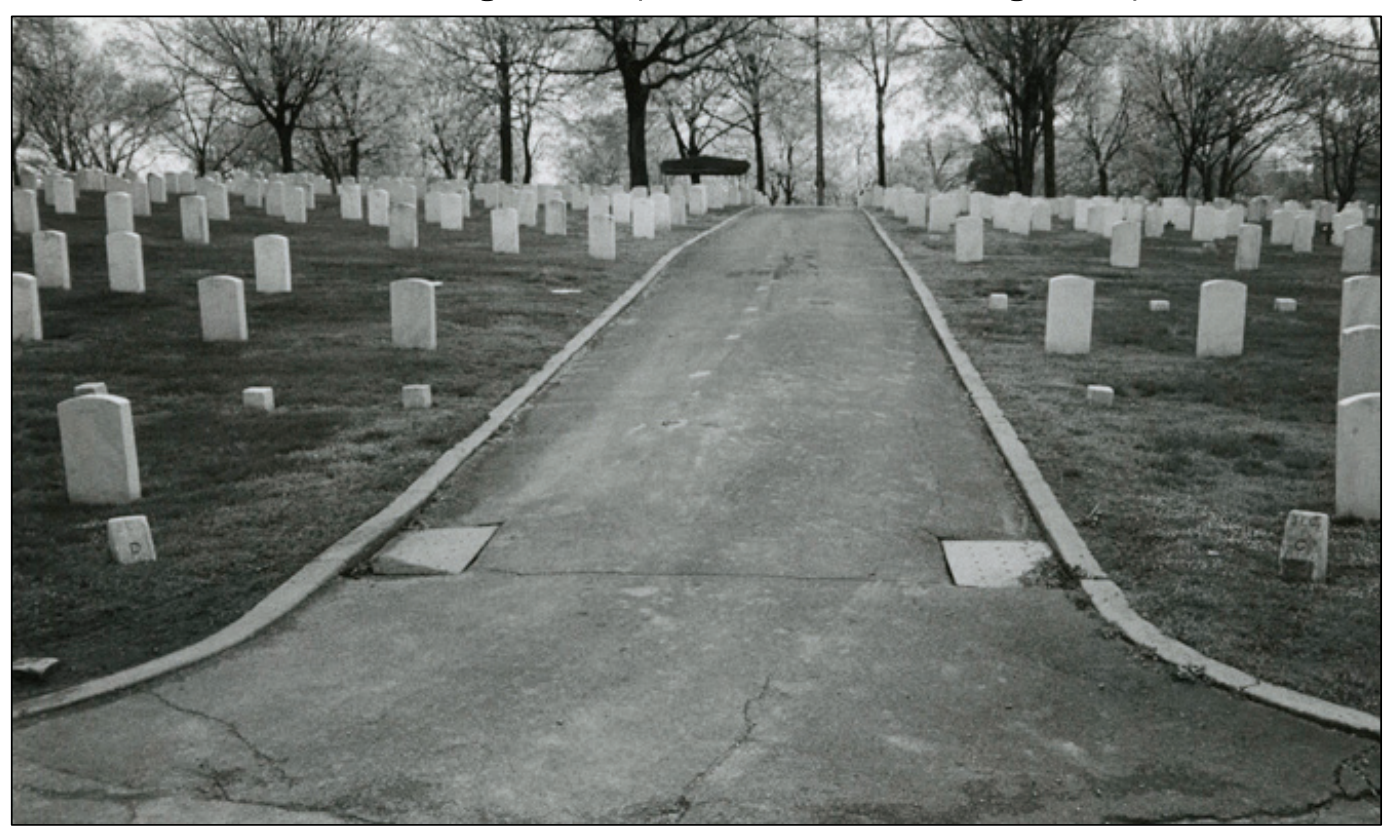

\subsubsection{2019 map}

The map from 2019 does have landscaping depicted on it, and it shows that one new row of graves was added to Inner $\mathrm{C}$ for a total of 22 rows. The east- 
west drive that connected the two gates from the cemetery's inception is now filled with gravesites leaving only the circle drive and the north-south drive (Figure 211). Figures 212 through 214 show scenes throughout Inner C.

An analysis of the trees in Inner $\mathrm{C}$ has one Sugar Maple (Acer saccharum) and two Red Maples (Acer rubrum).

Figure 211. Inner $\mathrm{C}$ as depicted on a portion of the 2019 map (VA NCA Archives, Washington, DC).

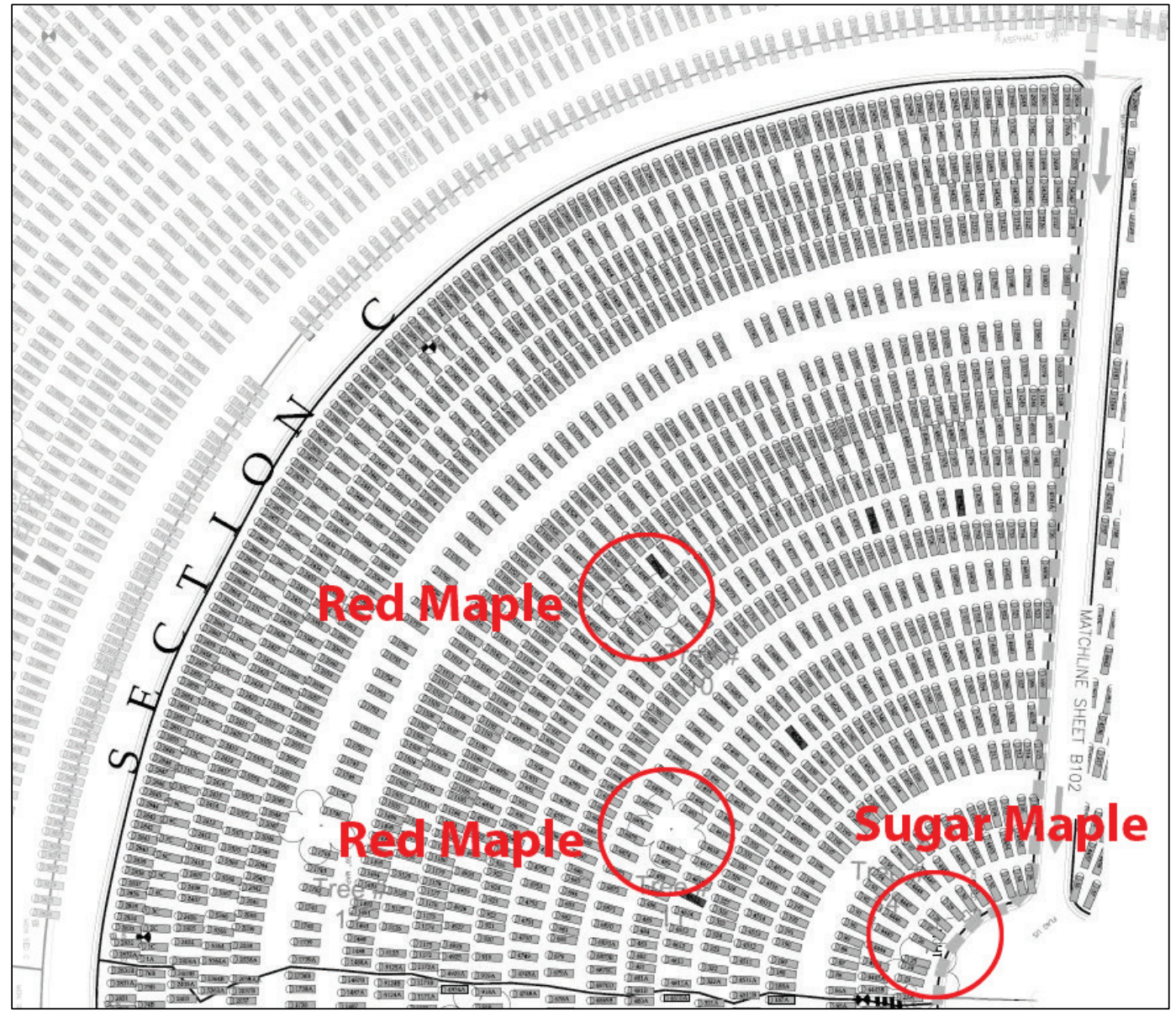


Figure 212. Looking north along the circle drive with Inner C on the right (ERDC-CERL, 2019).

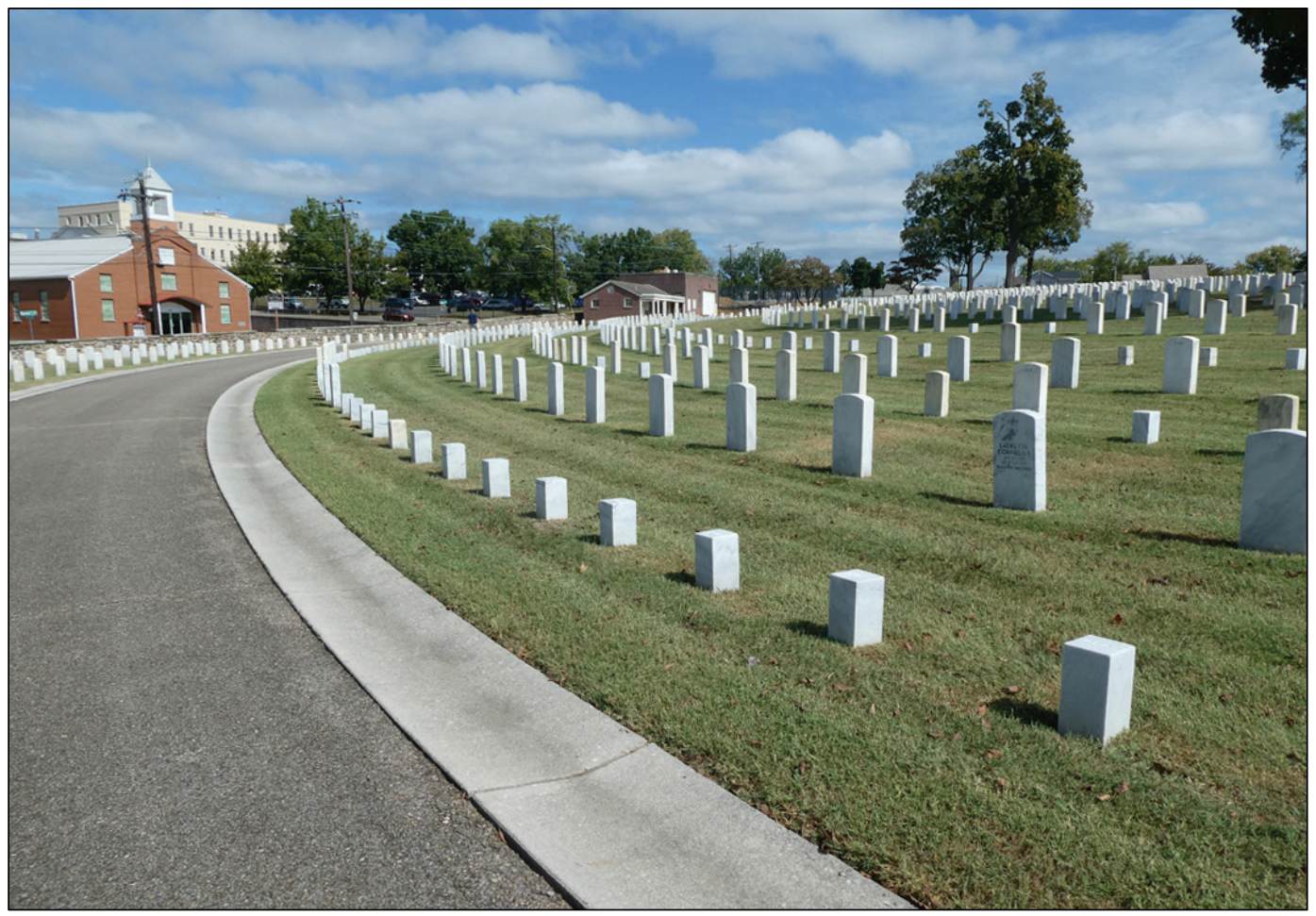

Figure 213. Looking south along the circle drive with Inner C on the left (ERDC-CERL, 2019).

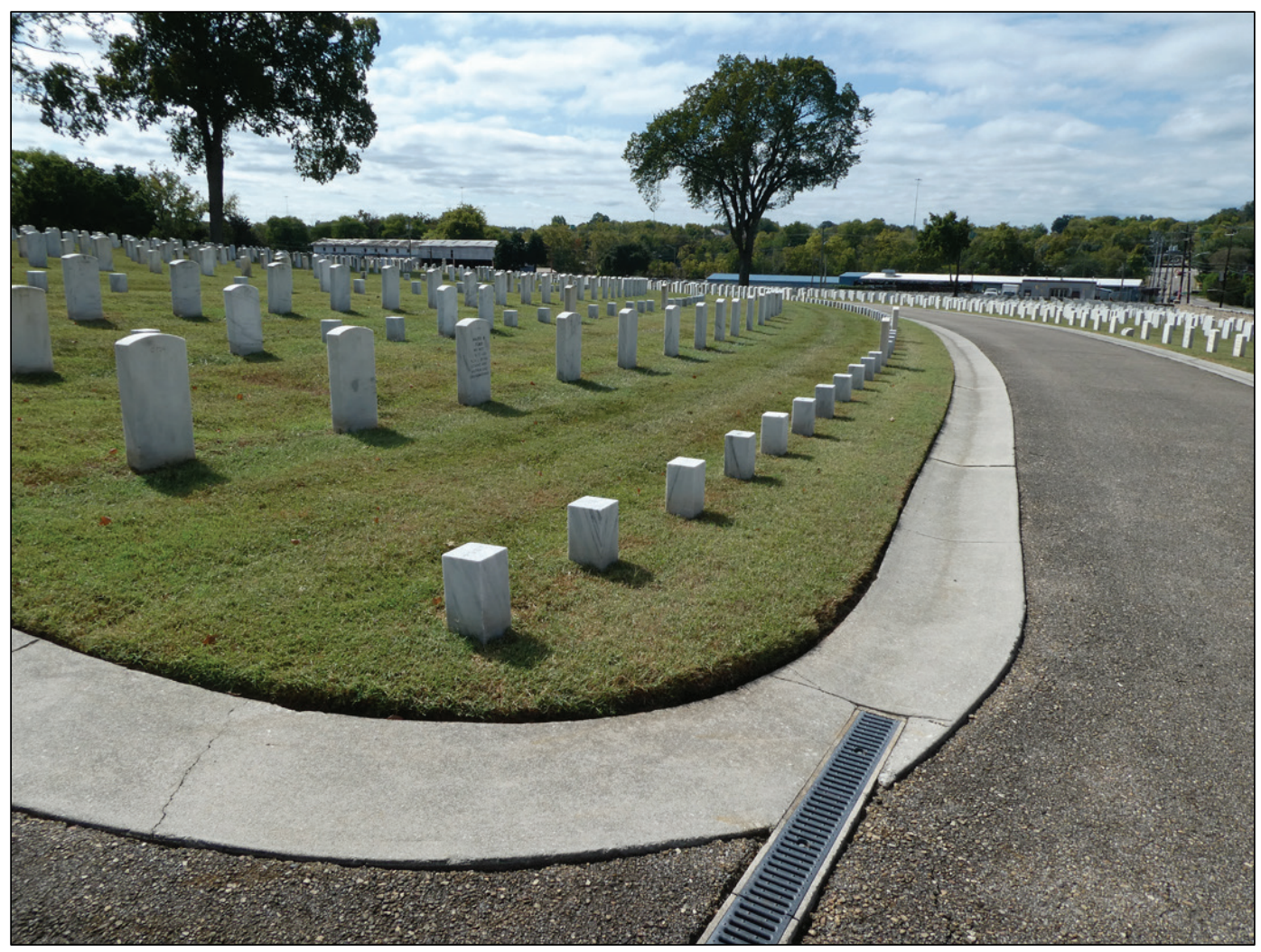


Figure 214. View to the southeast up the north-south drive with Section $D$ on the left and Inner C on the right (ERDC-CERL, 2019).

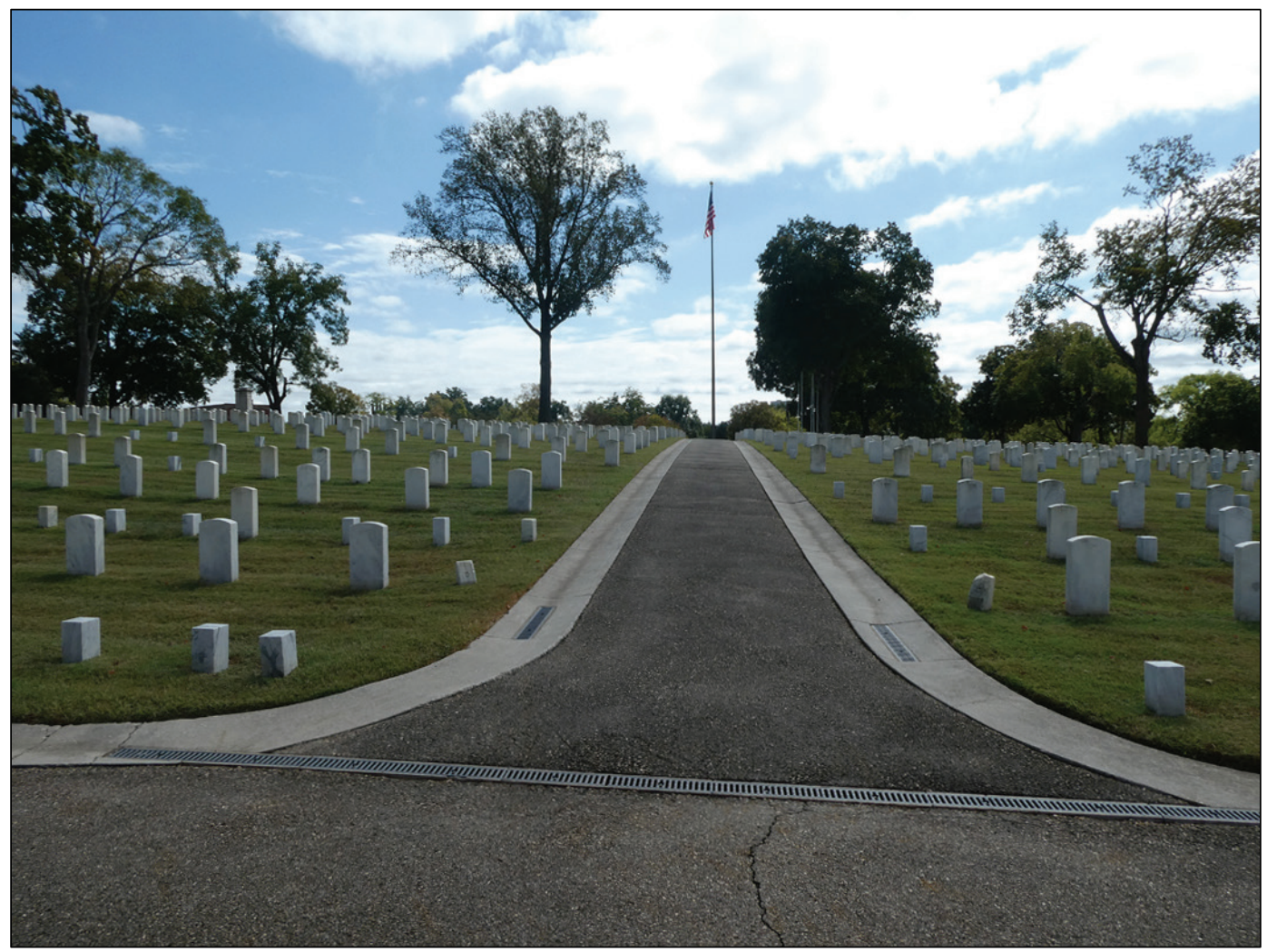

\subsubsection{Burial registry summary}

According to records from fall 2019, Section C has 3,164 burial spaces. Of those, 826 are from the Civil War with 360 of them Unknown Soldier burials. The remaining burials in Section B are from the 2oth and 21st centuries, with the most recent in 2018. There is one burial from 1890. The burial list does not separate Inner $\mathrm{C}$ from Outer $\mathrm{C}$.

\subsubsection{Section D}

The Section D area of the cemetery is an original burial area of the cemetery. The ground slopes down from the circle drive, which is at 922' elevation to the flagpole, which is at $915^{\prime}$.

\subsubsection{1869 map}

The 1869 map drawn by P.M. Radford shows 13 concentric rows of radiating out from the center within the circle drive with the graves of Black soldiers on the outermost row for Section D (Figure 215). This map does not show any landscaping. 
Figure 215. Section D as depicted on P.M. Radford's map, 1869 (NARA, Washington DC, RG92).

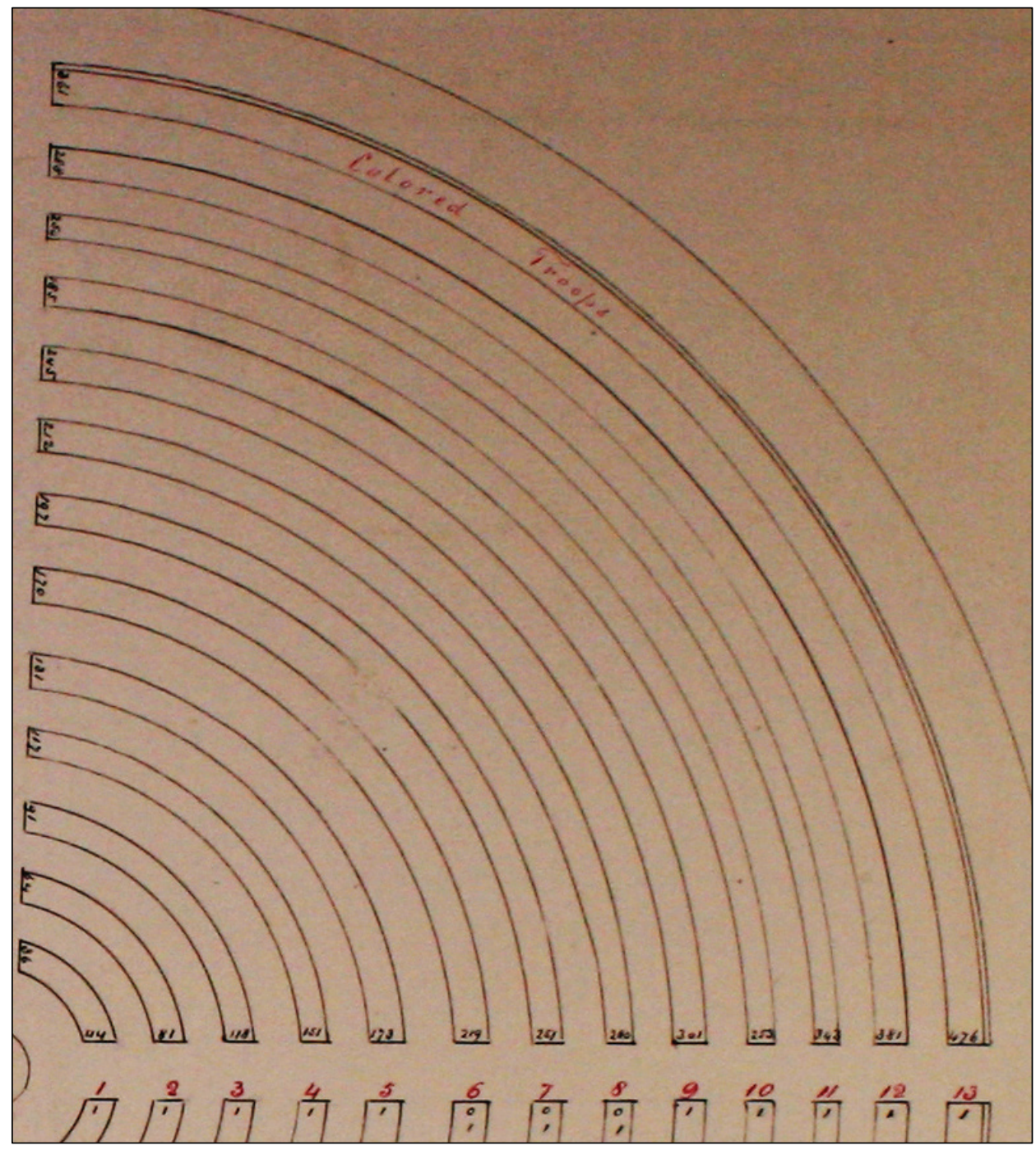

\subsubsection{1892 map}

The map from 1892 still has 13 concentric rows of graves radiating out from the center. The graves of Black soldiers are not shown on this map. There are deciduous trees and evergreen shrubs spread throughout the section (Figure 216). 
Figure 216. Section D as depicted on a portion of the 1892 map (VA NCA Archives, Washington, DC).

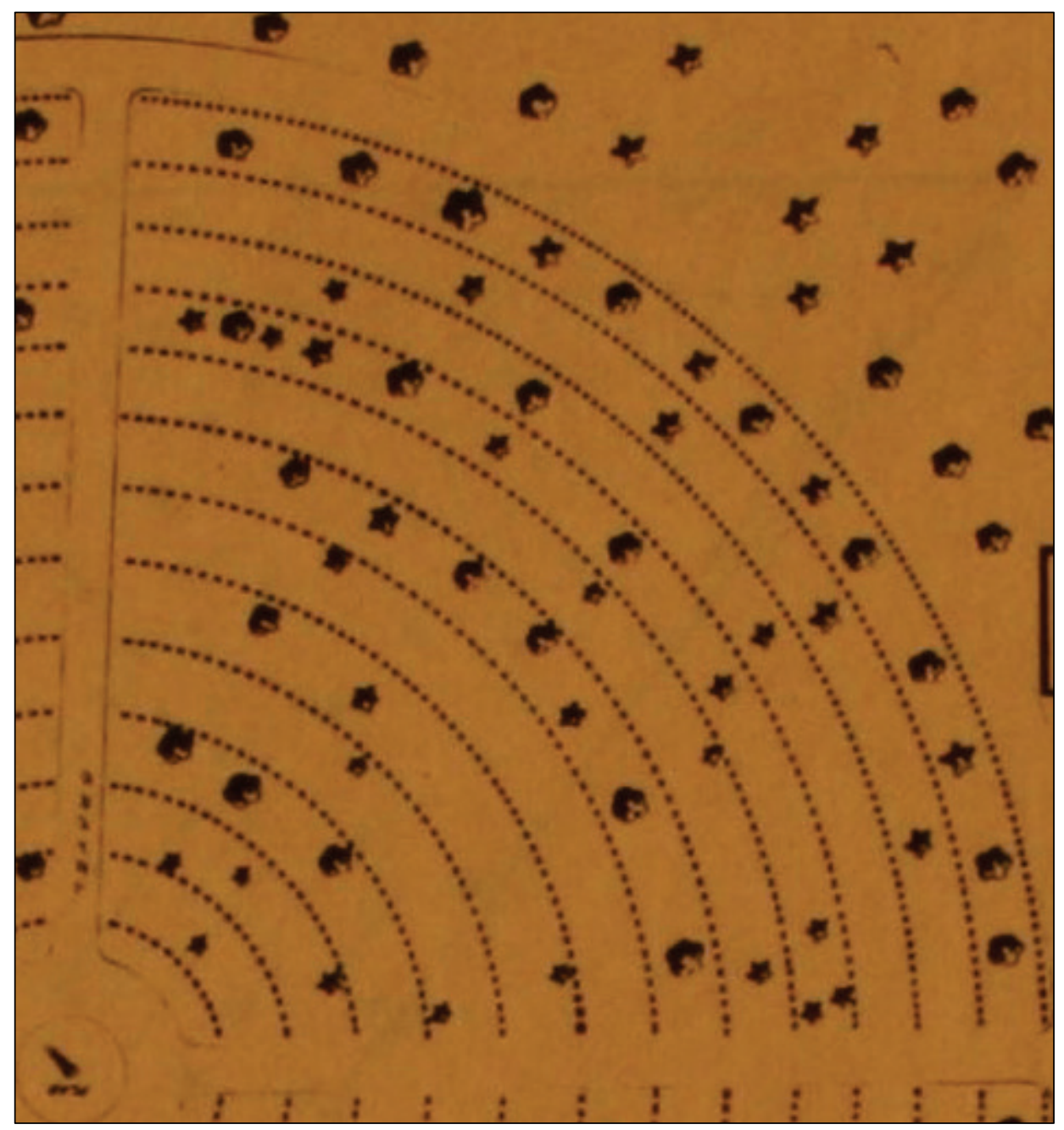

\subsubsection{1909 map}

The map from 1909 is an update of the 1892 map, but there are no differences between the 1892 and 1909 maps for Section D (Figure 217). 
Figure 217. Section D as depicted on a portion of the 1909 map (NARA, Washington DC, RG92).

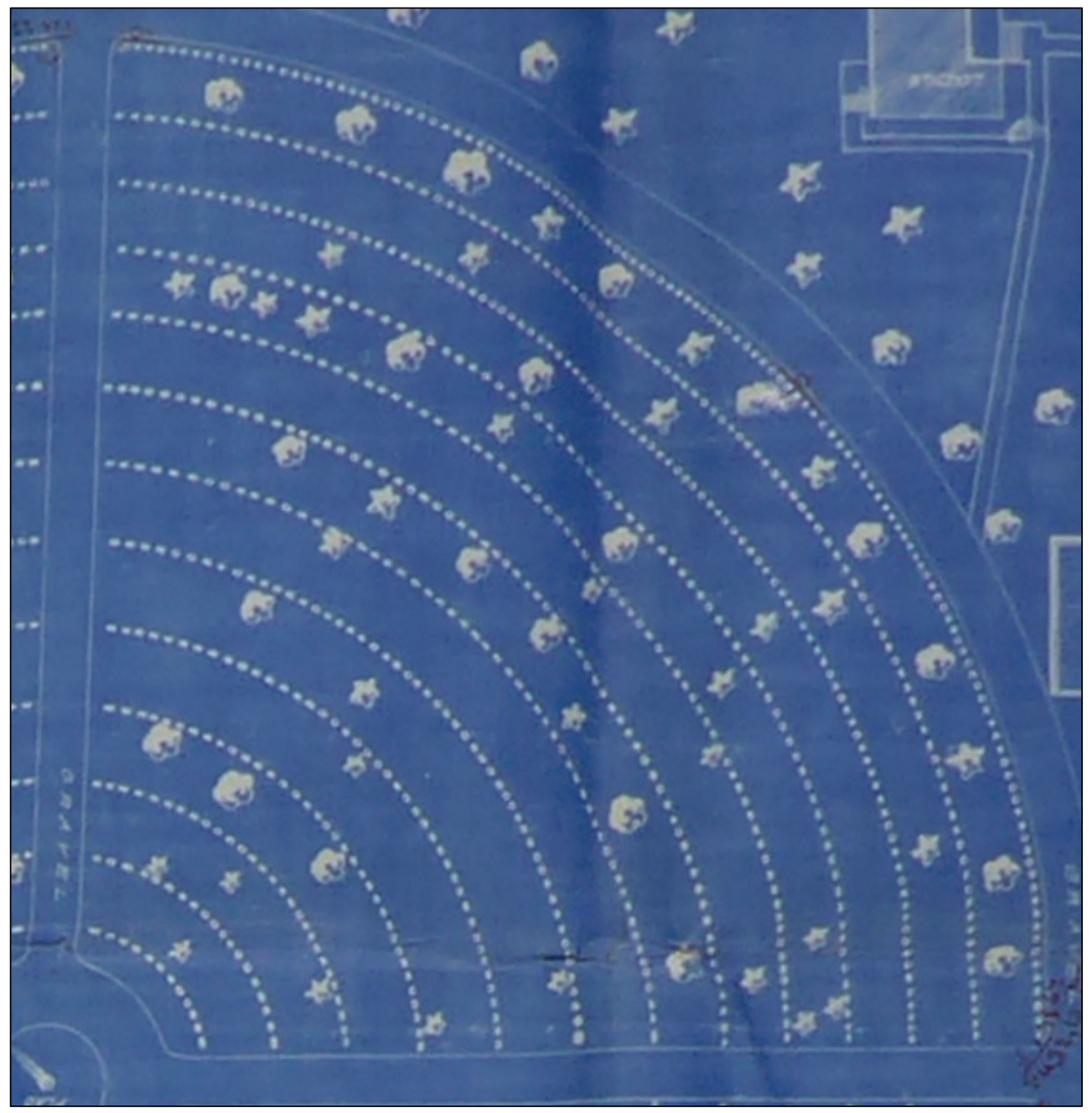

\subsubsection{1947 map}

The map from 1947 is the first map that has the species of trees indicated on it. The map still has 13 concentric rows of graves radiating out from the center (Figure 218). There were eight Maples, one Magnolia, and one Catalpa. The 1947 map only has trees shown and listed, but an aerial from 1948 and a photograph from 1953 show that Section D had an extensive tree cover (Figure 219 and Figure 220). 
Figure 218. Section D as depicted on a portion of the 1947 map with types of trees (NARA, Washington DC, RG15).

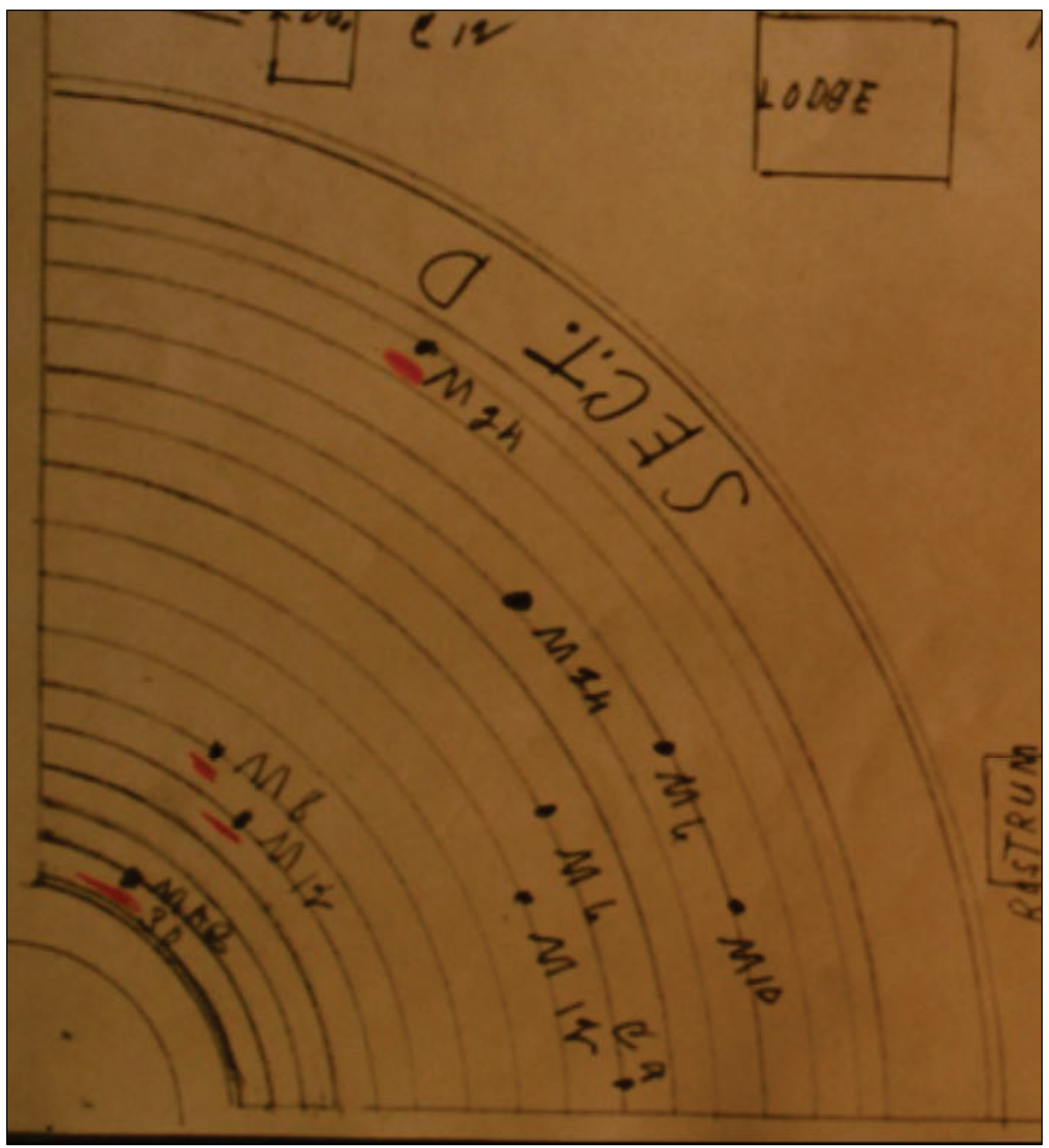


Figure 219. Aerial view of Section D showing extensive tree cover, 1948 (HALS-TN-2, Library of Congress).

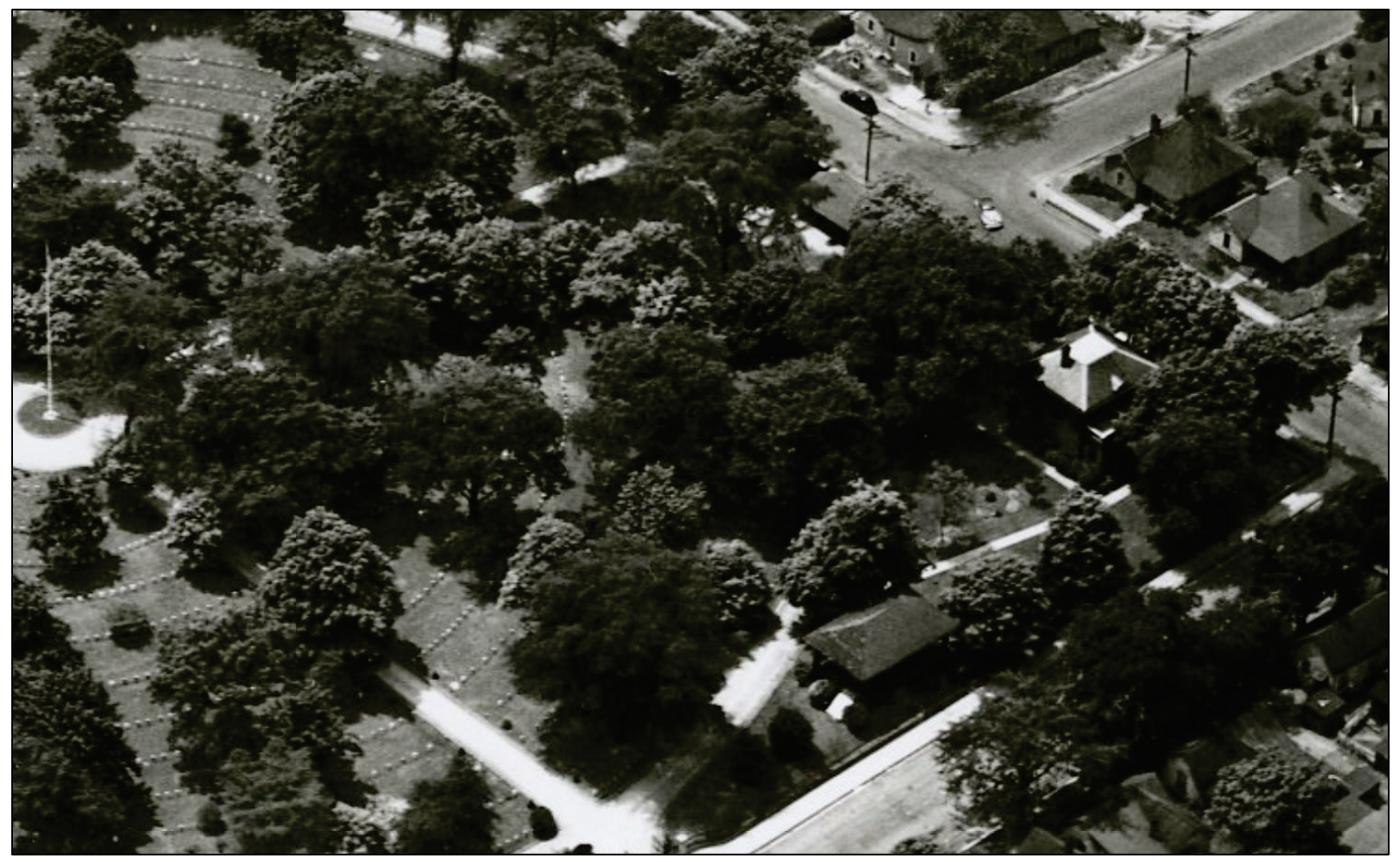

Figure 220. View to the north of Section $D$ from where the circle drive intersects with the north-south drive, 1953 (VA NCA Archives, Washington, DC).

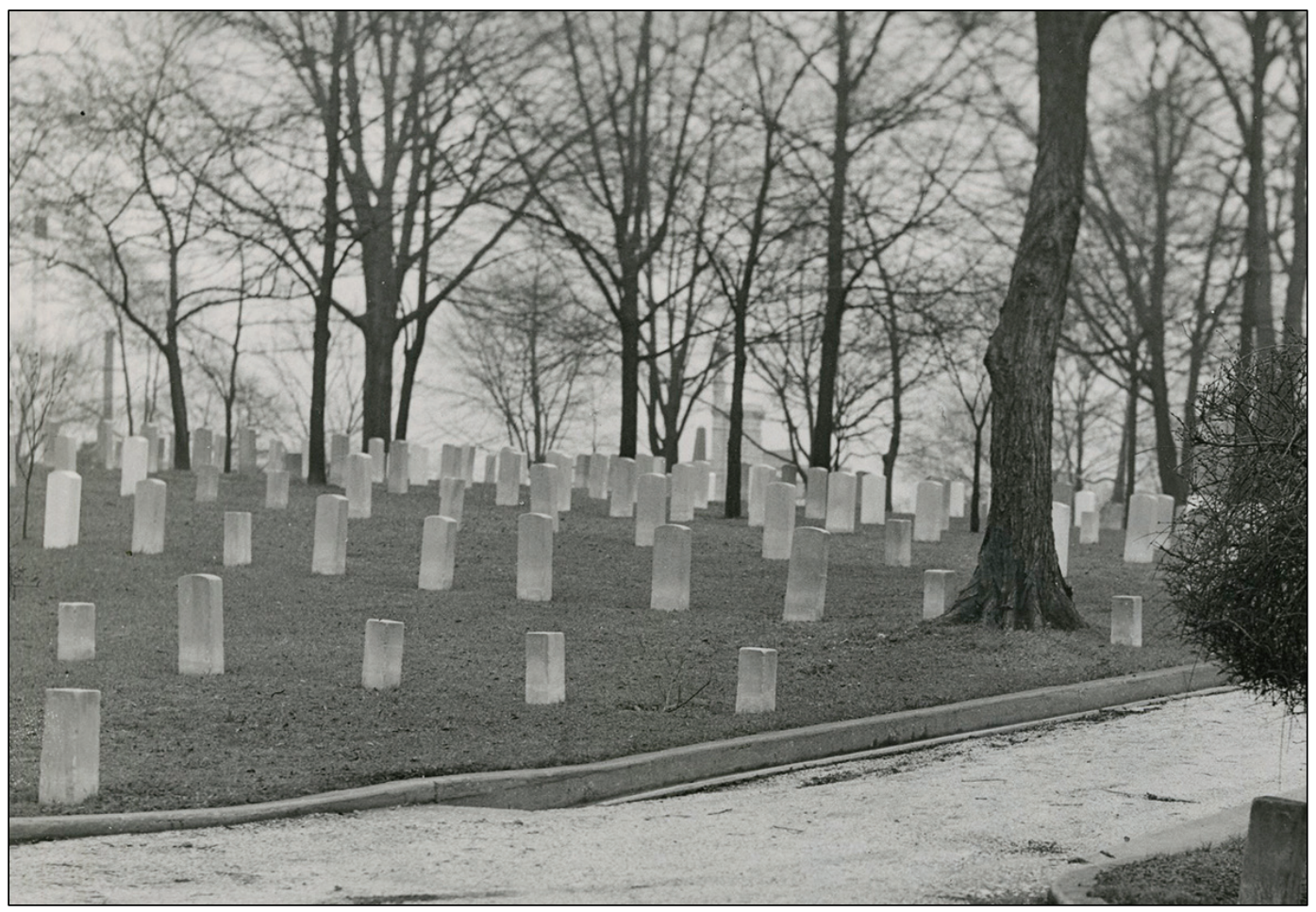




\subsubsection{1971 map}

The map from 1971 does not have landscaping depicted on it, but what it does show is that seven new rows of graves were added in between the existing 13 rows from the Civil War era for a total of 20 rows (Figure 221). The curbing has been erased from the drawing along both sides of the east-west drive. Curbing along the circle drive had not been removed (Figure 222).

Figure 221. Section D as depicted on a portion of the 1971 map (VA NCA Archives, Washington, DC).

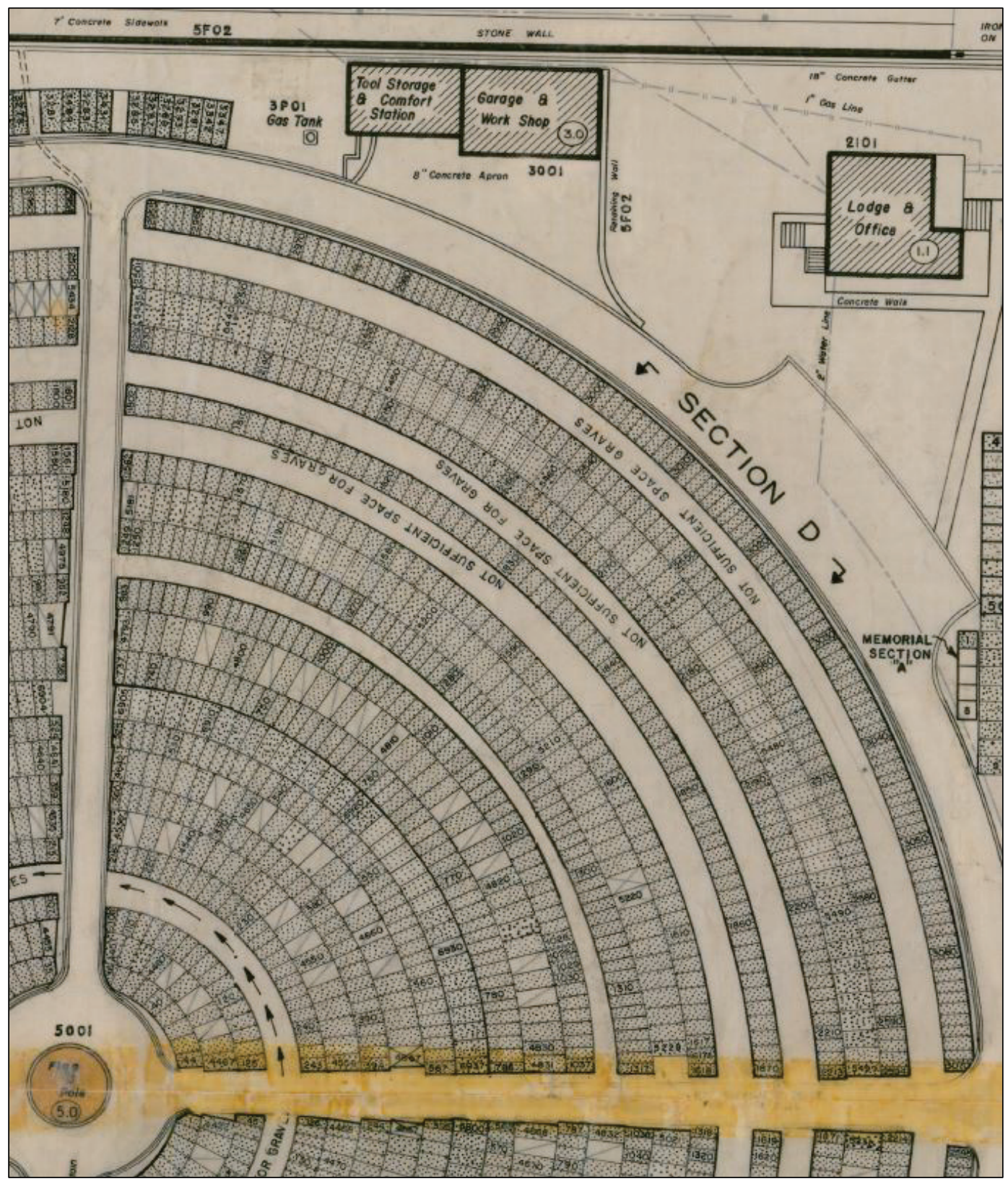


Figure 222. View to the southwest towards Section $D$ with a portion of Section $Y$ in the foreground, 1989 (VA NCA Archives, Washington, DC).

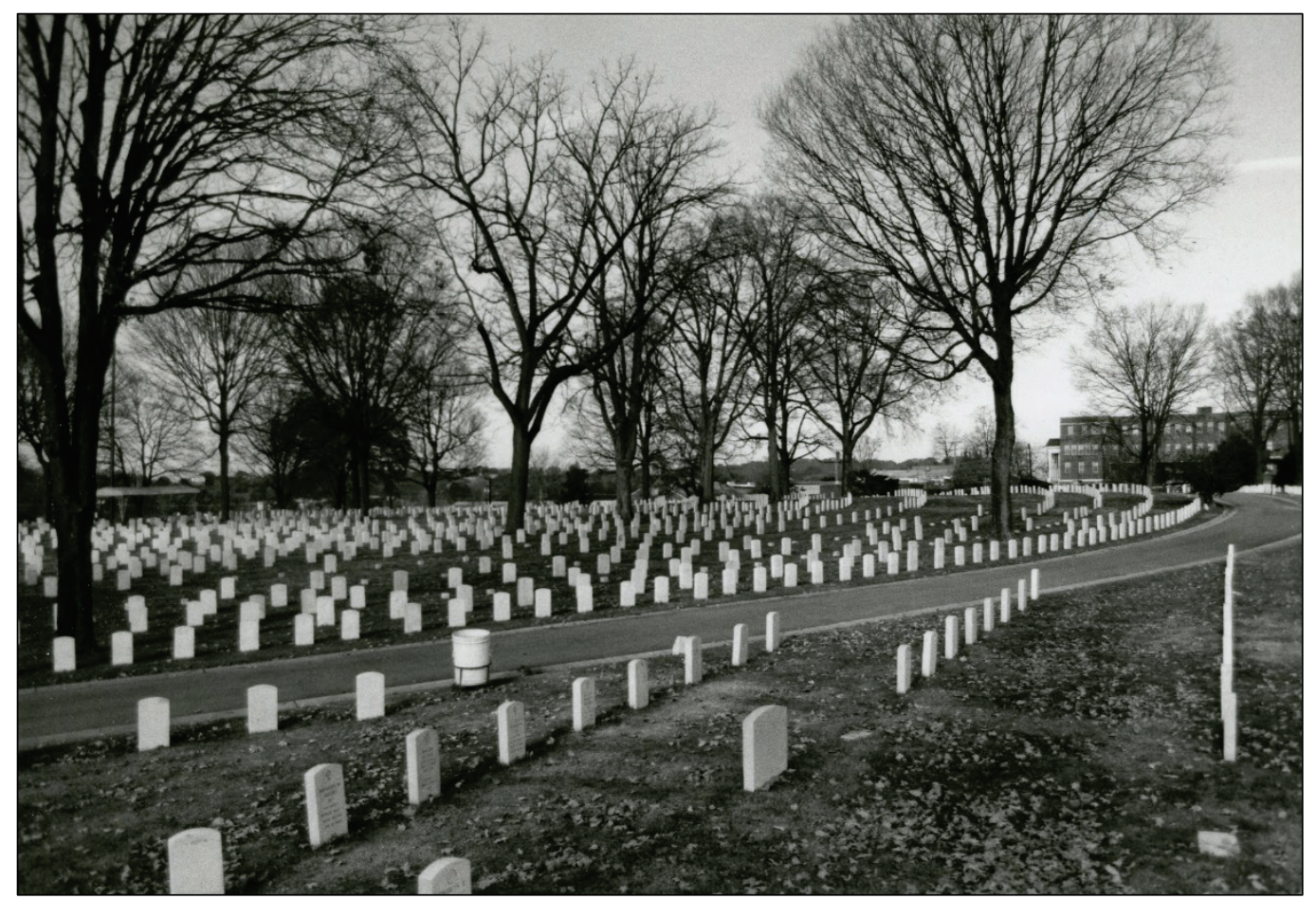

\subsubsection{2019 map}

The map from 2019 does have landscaping depicted on it, and it shows that two new rows of graves was added to Section $\mathrm{D}$ for a total of 22 rows. The east-west drive that connected the two gates from the cemetery's inception is now filled with gravesites leaving only the circle drive and the north-south drive (Figure 223). Figures 224 through 227 show scenes throughout Inner D.

An analysis of the trees in Inner B has four Sugar Maples (Acer saccharum), one White Poplar (Populus alba), two Flowering Dogwoods (Cornus florida), and one Crepe Myrtle (Lagerstroemia sp.). 
Figure 223. Section D as depicted on a portion of the 2019 map (VA NCA Archives, Washington, DC).

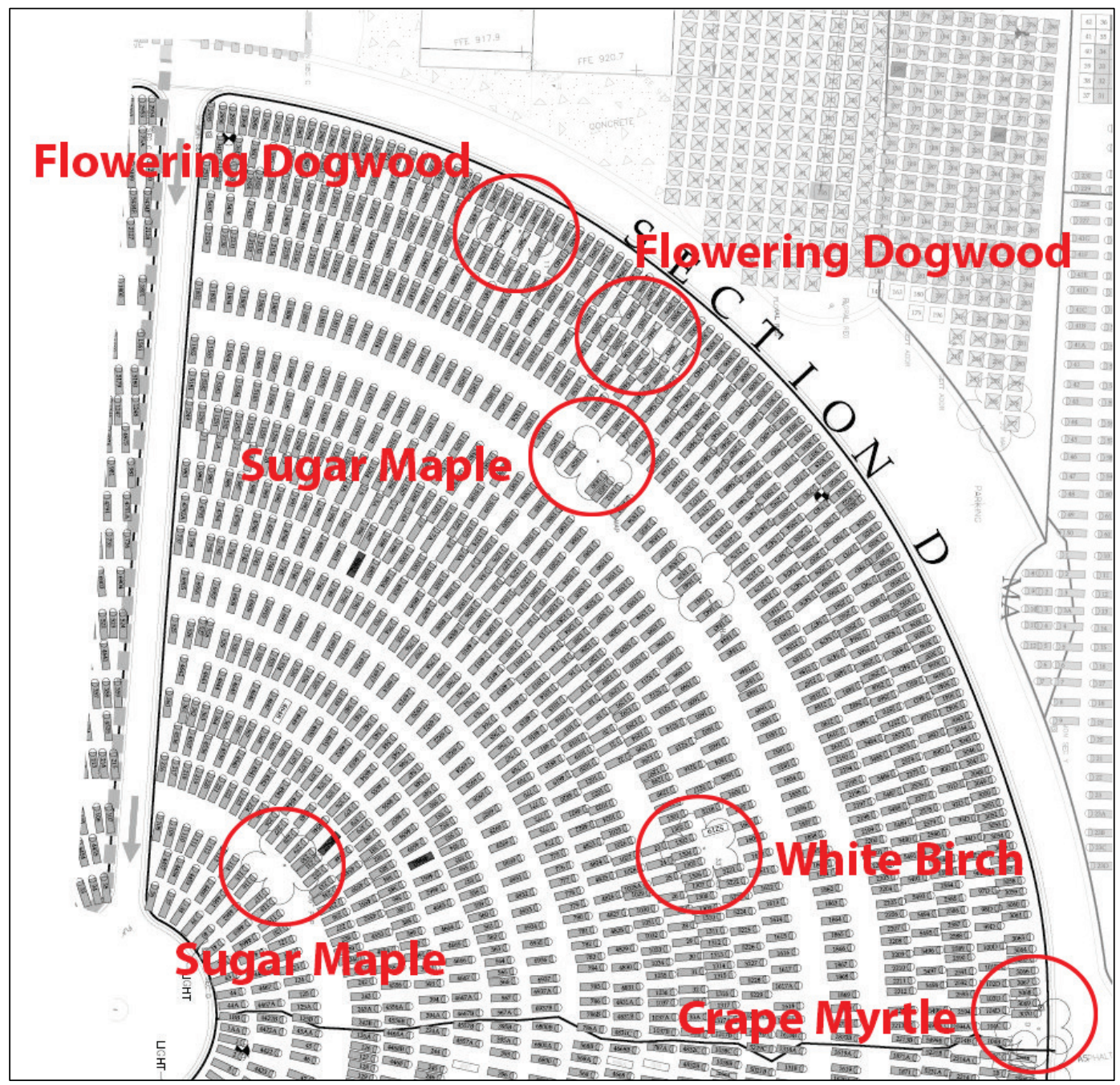


Figure 224. Looking east along the circle drive with Section D in the center (ERDC-CERL, 2019).

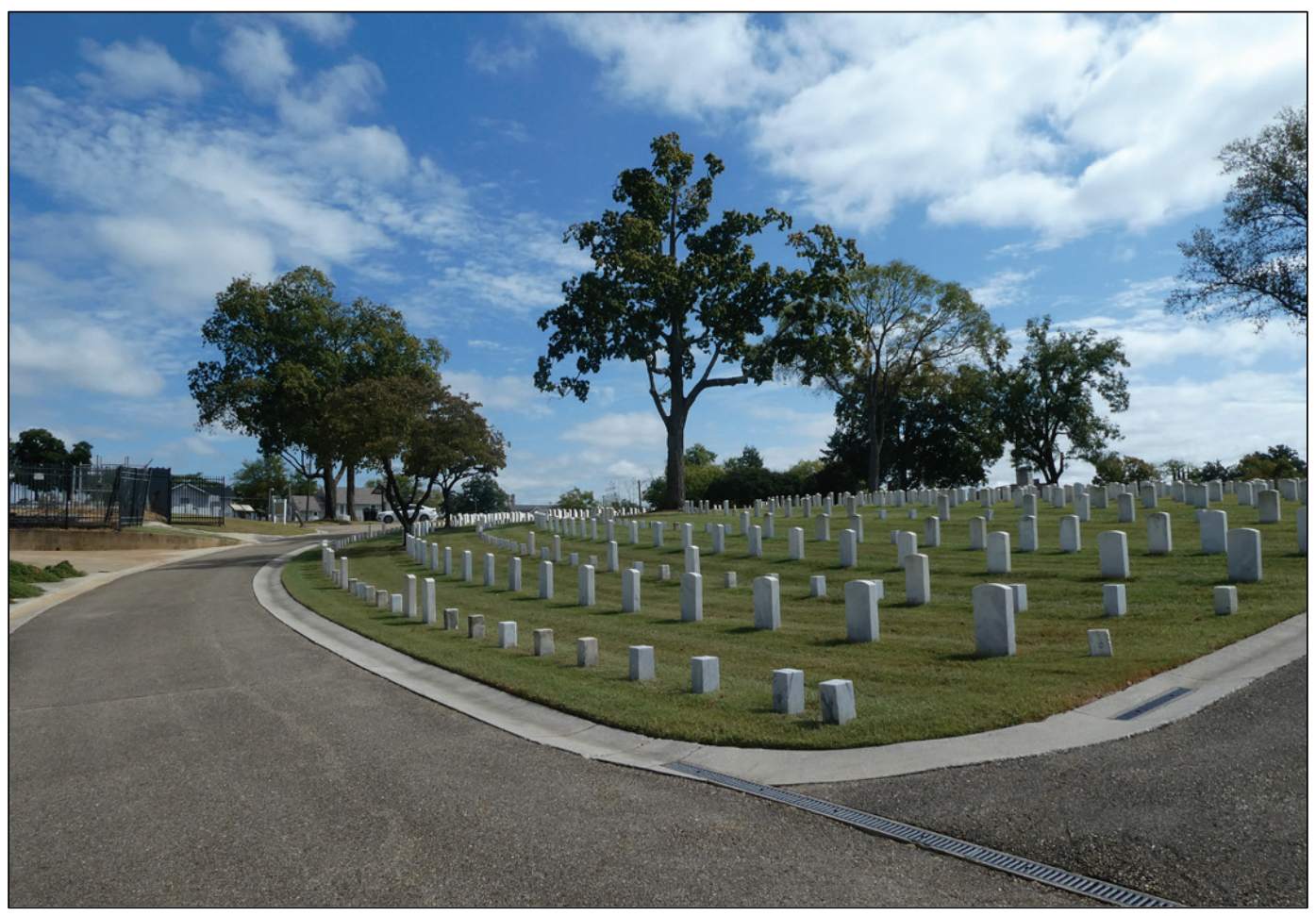

Figure 225. Looking west across Section D (ERDC-CERL, 2019).

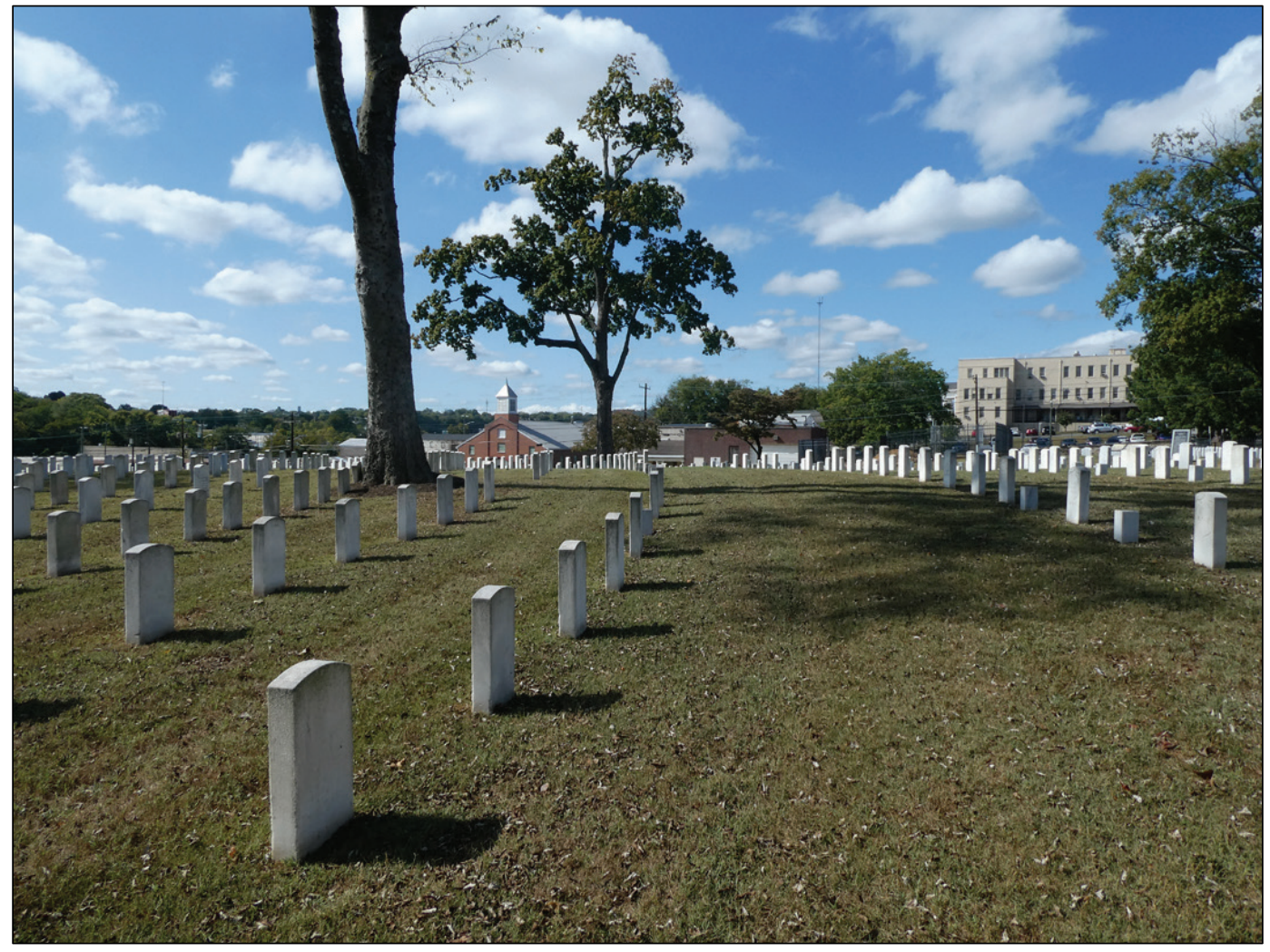


Figure 226. Looking southwest from the Tyson Gate with Section A on the left and Section D on the right (ERDC-CERL, 2019).

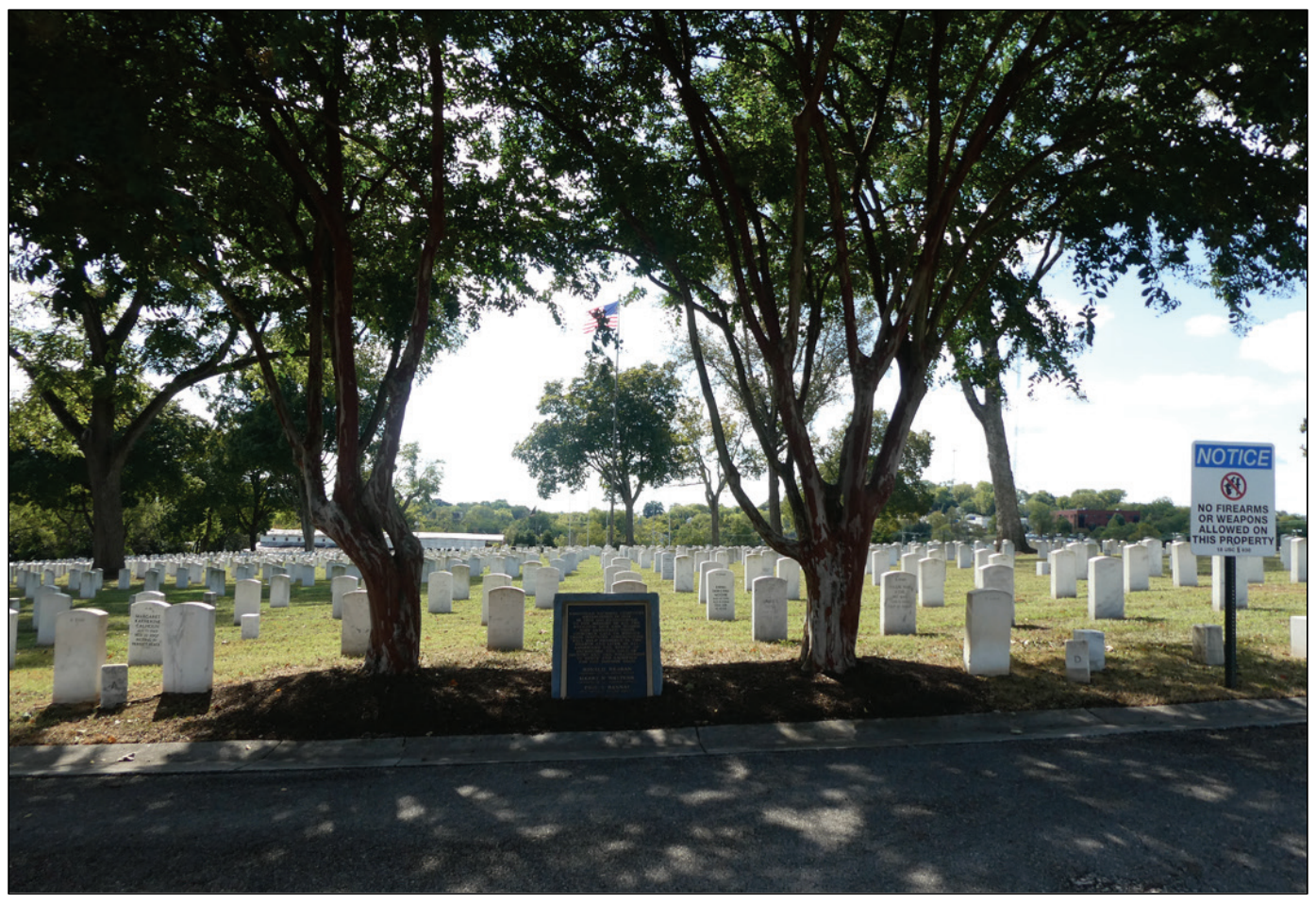

Figure 227. Looking south from the flagstaff across Section D (ERDC-CERL, 2019).

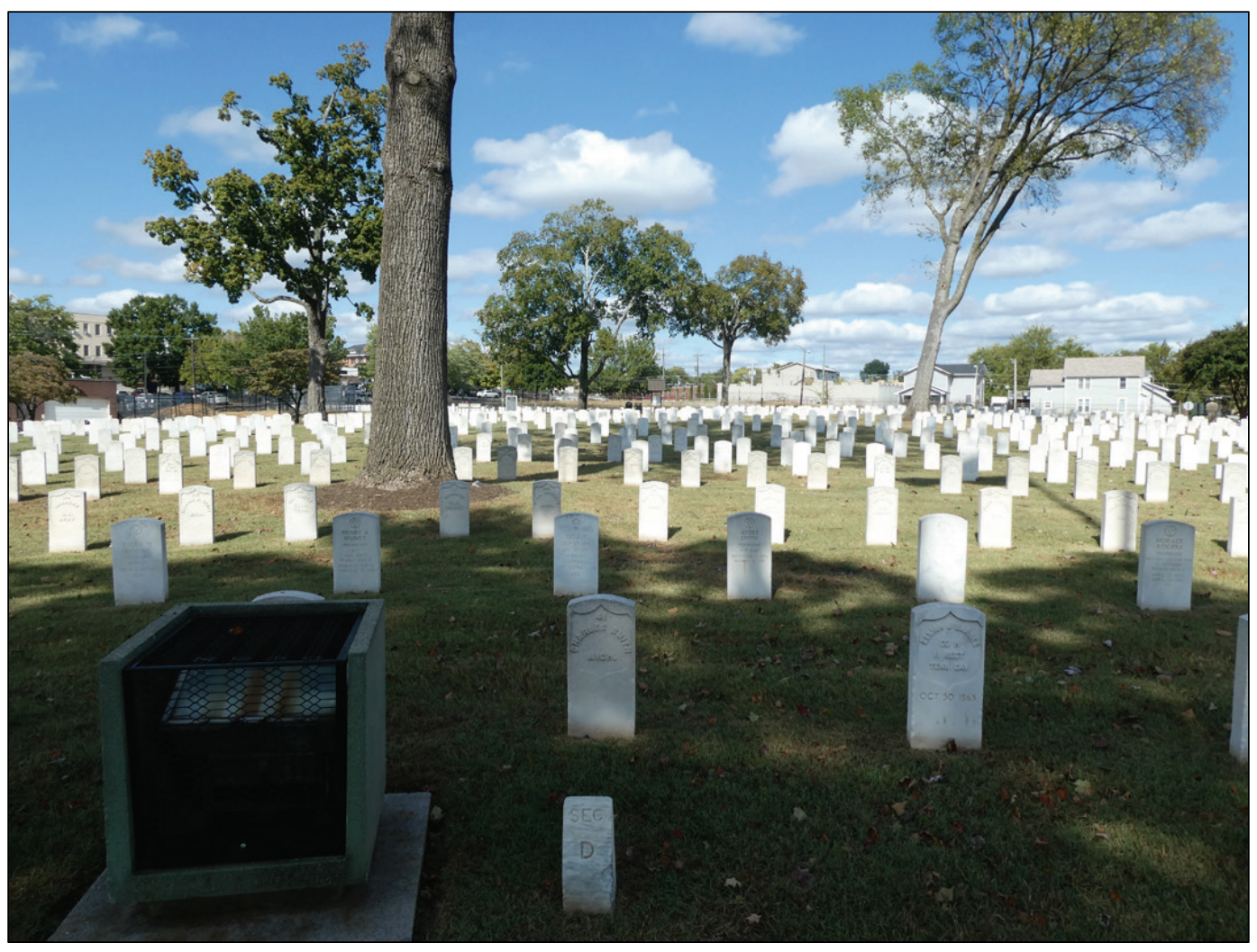




\subsubsection{Burial register summary}

According to records from fall 2019, Section D has 1,255 burial spaces. Of those, 726 are from the Civil War with 295 of them Unknown Soldier burials. The remaining burials in Section D are from after WWII through the 21st centuries, with the most recent in 2018.

\subsubsection{Outer B}

The Outer B section of the cemetery was not planned for burials. It was empty in the 1869 sketch of the cemetery (Figure 228). The ground slopes from $905^{\prime}$ at the circle drive down to $892^{\prime}$ at the south corner of the cemetery.

Figure 228. Outer B as depicted on P.M. Radford's drawing, 1869 (NARA, Washington DC, RG92).

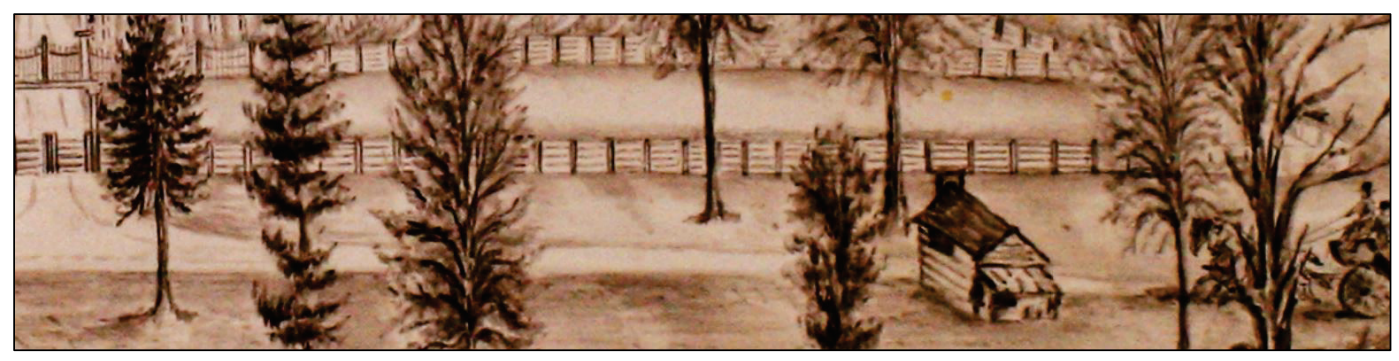

\subsubsection{1869 map}

The 1869 map drawn by P.M. Radford shows the entire area as vacant except that a wood rail fence divides the burial area of the circle from the rest of Outer B (Figure 229). There is one row of graves shown on the outer side of the circle drive. This map does not show any landscaping. 
Figure 229. Outer B as depicted on P.M. Radford's map, 1869 (NARA, Washington DC, RG92).

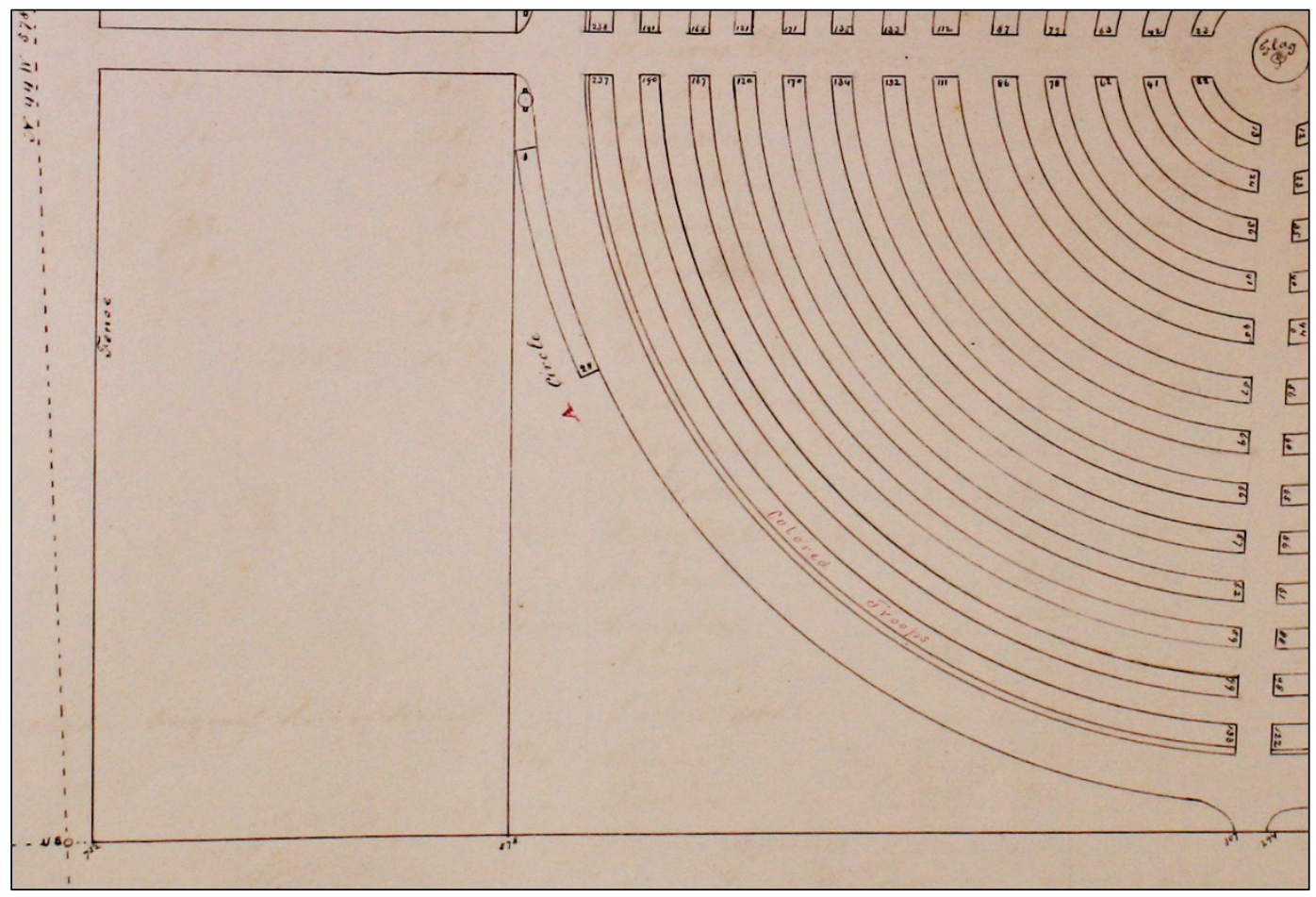

A plan from 1874 shows the new stone superintendent's lodge and wood tool shed and privy (Figure 230). The plan has marked that the ground between the lodge and the stables was leveled and shows a berm to the northeast of the stables. The stone wall along Cooper Street is shown with Osage Orange clippings, and the wood rail fence is marked with Osage Orange clippings as well. There is a large flower bed at the Cooper Gate. 
Figure 230. Detail of a plan showing the stone superintendent's lodge and brick stables, 1874 (NARA, Washington DC, RG9).

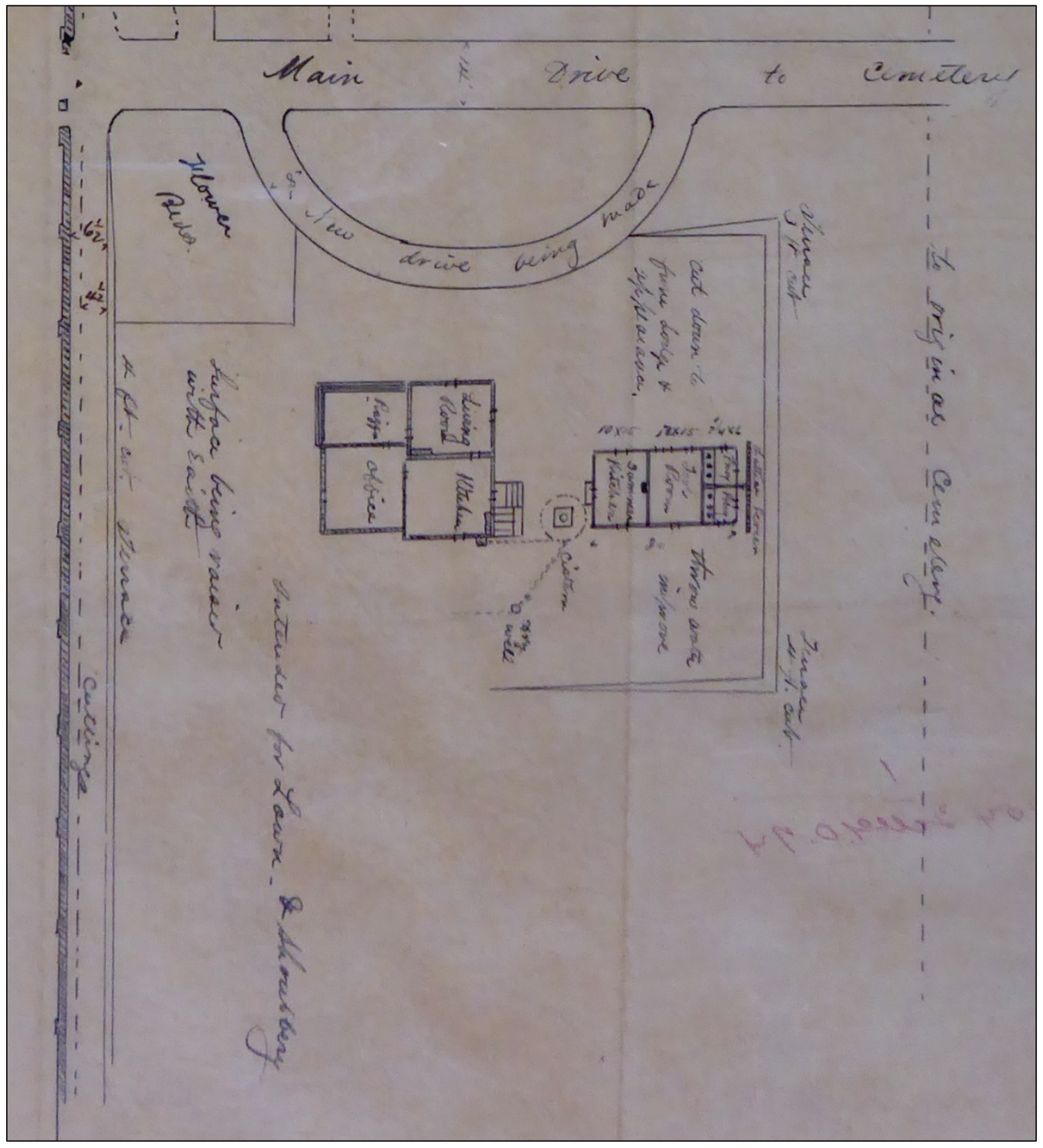

\subsubsection{1892 map}

The map from 1892 does not show much has changed from the 1874 map (Figure 231). The stone superintendent's lodge is on the southeast side of the east-west drive (Figure 232). A semi-circular driveway accessed the front of the lodge from the east-west drive with shrubs and trees planted within the half circle driveway. To the northeast of the lodge was the wood tool shed and privy. To the southeast of the tool shed was a large arbor and further out was a five-pointed star planting bed with each point having an evergreen shrub. A stone wall bounds the area on the southwest and 
southeast, while a wood fence bounds the area on the northeast. The wall and fence are lined with deciduous trees (presumably Osage Orange) there are few other trees shown in the lodge area. There are deciduous trees and evergreen shrubs spread throughout the area between the wood fence and circle drive with the circle drive lined with deciduous trees. This map does not show any graves outside the circle drive; however, there is the burial plot for the two sons of Superintendent Thomas Ridge who died in the 1870 s near the wood fence and a siege gun monument (Figure 233) near the circle drive.

Figure 231. Outer B as depicted on a portion of the 1892 map (VA NCA Archives, Washington, DC).

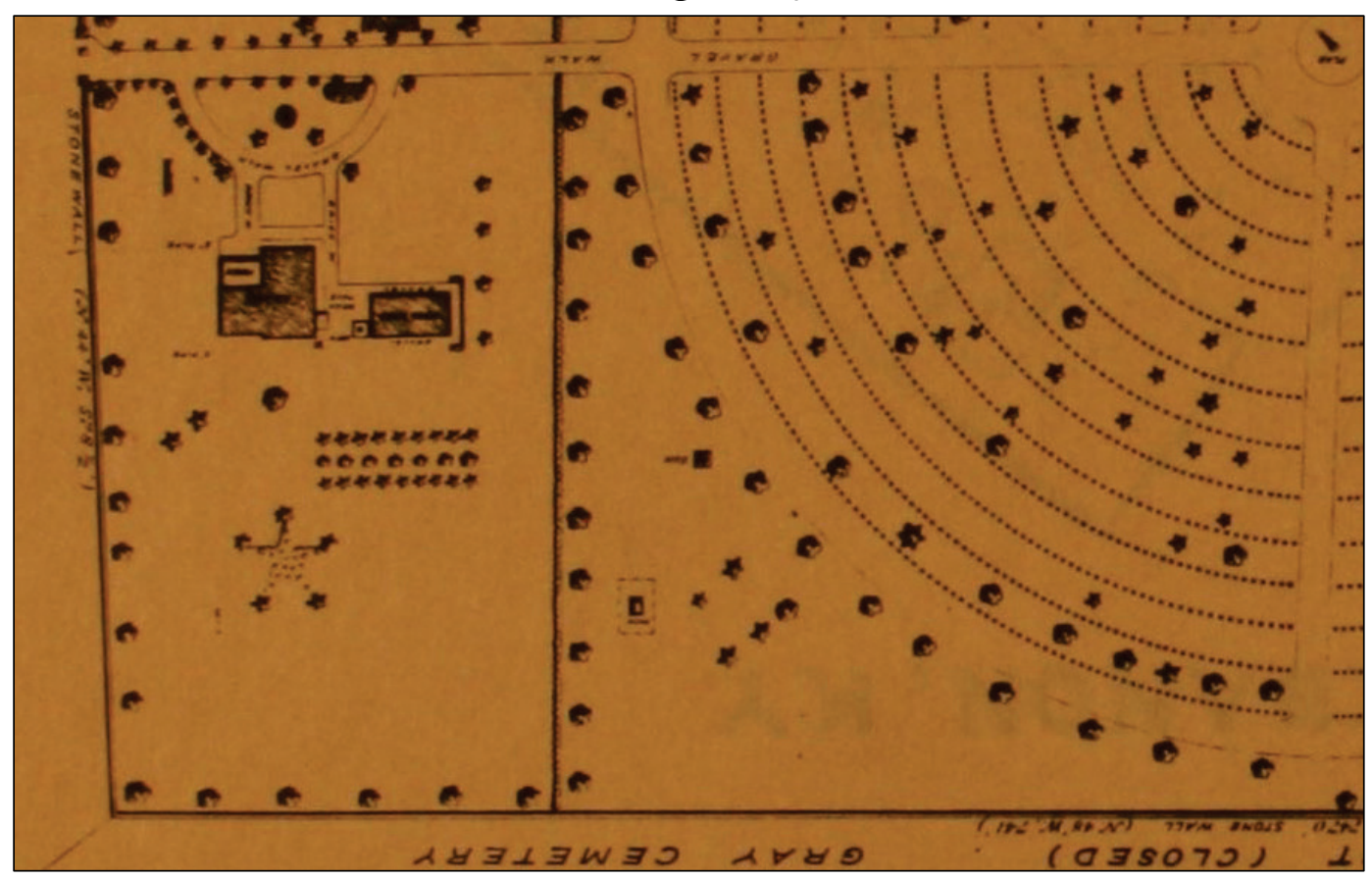


Figure 232. View to the southeast of the stone superintendent's lodge, 1908 (NARA College Park RG92-CA). Note low ground cover around house foundation.

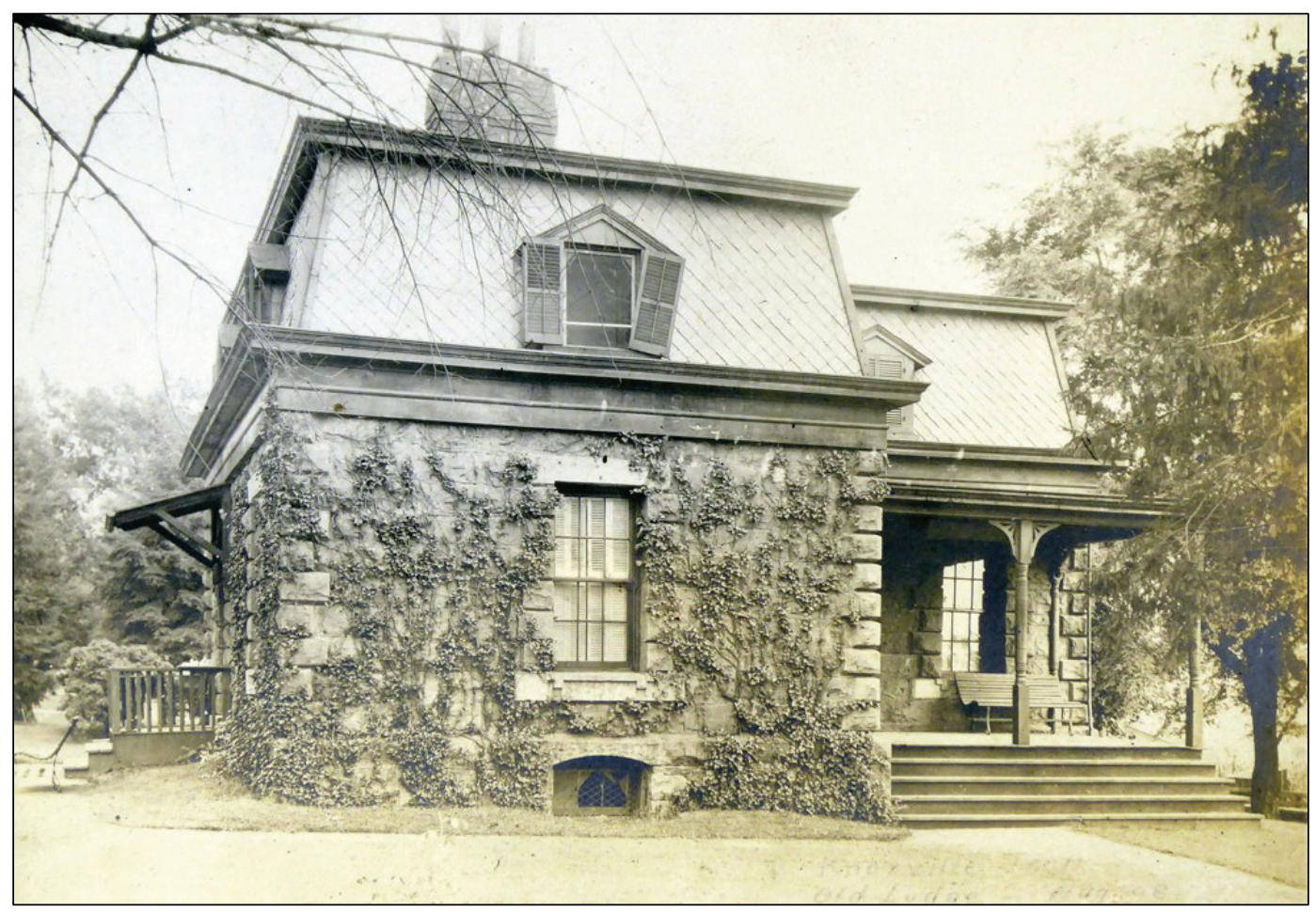

Figure 233. Postcard view of the siege gun monument in Outer B near the circle drive, c.1910 (University of Tennessee, Knoxville, Library digital collections “Images of East

Tennessee"). Note the variety of evergreen and deciduous trees and shrubs.

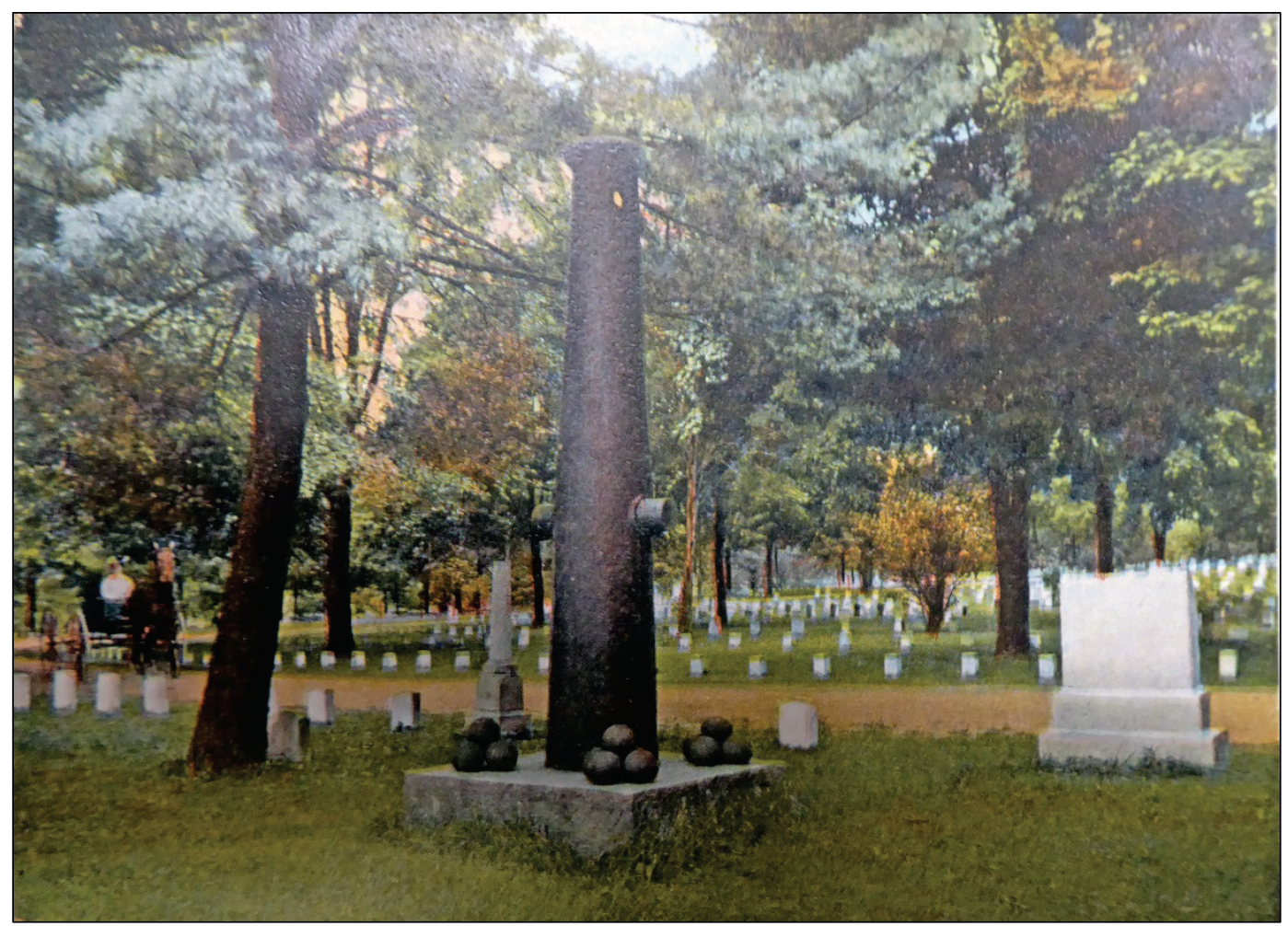




\subsubsection{1909 map}

The map from 1909 is an update of the 1892 map (Figure 234). A brick stable replaced the wood tool shed and privy in 1898 in approximately the same location (Figure 235). There is a handwritten note that 300 graves can fit southeast of the arbor. The wood fence has been erased. The star shaped planting bed with five evergreens is "x'ed" out. The 1909 map also has a new superintendent's lodge up in the northeast area of the cemetery, but the old one was not marked for demolition on this map. The Ridge family plot is still by itself, but Thomas Ridge's wife was added to the plot in 1902.

Figure 234. Outer $B$ as depicted on a portion of the 1909 map shows the stone superintendent's lodge and brick stable (NARA, Washington DC, RG92).

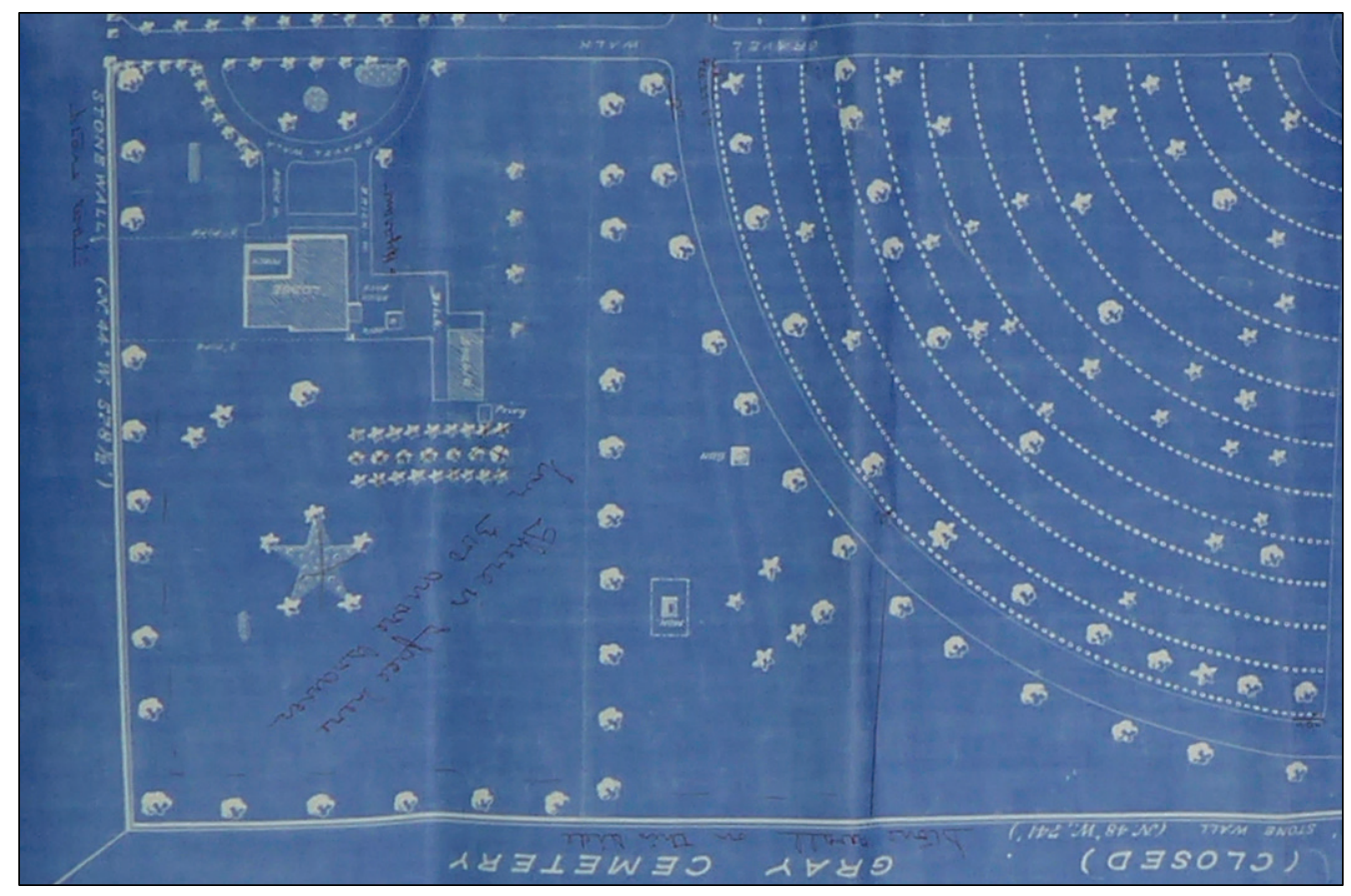


Figure 235. View to the northeast of the brick stable, 1908 (NARA College Park RG92-CA).

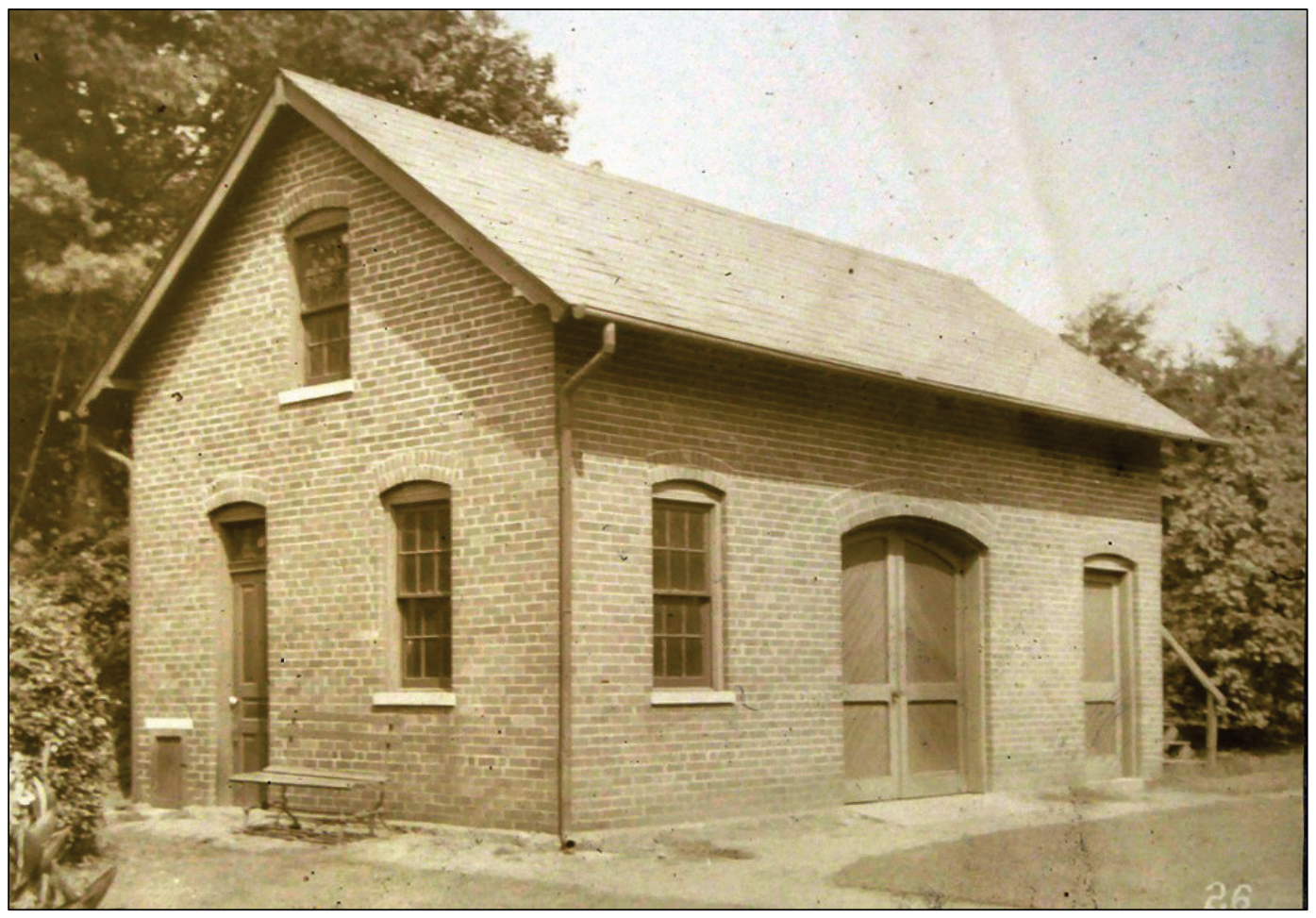

\subsubsection{1947 map}

The map from 1947 is the first map that has the species of trees indicated on it. The map also shows that there are graves on the outside of the circle drive all the way towards the Cooper Street wall (Figure 236). While not shown on the map, the Superintendent Ridge family plot was filled with the burial of Thomas Ridge in 1918; the four headstones face directly northeast and are not in line with the other graves in that row. There were four Maples, three Elms, and 13 Catalpa. The Catalpas are right inside the stone wall. The 1947 map only has trees shown and listed, but an aerial from 1948 shows that Outer B had quite a number of shrubs especially in the south corner near the stone wall (Figure 237).

The Cooper Gate was mostly not used as the main entrance and had been moved to the Tyson Gate around the same time as the brick superintendent's lodge was constructed in 1907 (Figure 238). The stone lodge was demolished sometime after 1909 and before 1935, and the brick stable was demolished in 1935. A small brick restroom building was constructed in 1935 utilizing structural elements from the recently demolished brick stable (Figure 239). It was demolished by 1948. It is unknown when the siege 
gun monuments were removed from Outer B, but from the available record, it was at some point between 1909 and the 1940 .

A planting plan for Outer B from 1966 (Figure 240) has eight Sugar Maple (Acer saccharum), two Eastern Redbud (Cercis canadensis), two Purple Crabapple (Malus sp.), five Redflowering Dogwood (Cornus florida var.), four American Elm (Ulmus americana), two Deodar Cedar (Cedrus deodara), one Silver Maple (Acer saccharinum), two White Pine (Pinus strobus), one Smoothleaf Elm (Ulmus minor), two American Holly (Ilex americana), three Red Maple (Acer rubrum), one Black Walnut (Juglans nigra), and three Silktree Albizzia (Albizia julibrissin). The 1966 planting plan also shows that burial areas extended out to the walls.

Figure 236. Outer $B$ as depicted on a portion of the 1947 map with types of trees and the small restroom building marked as a rectangle (NARA, Washington DC, RG15).

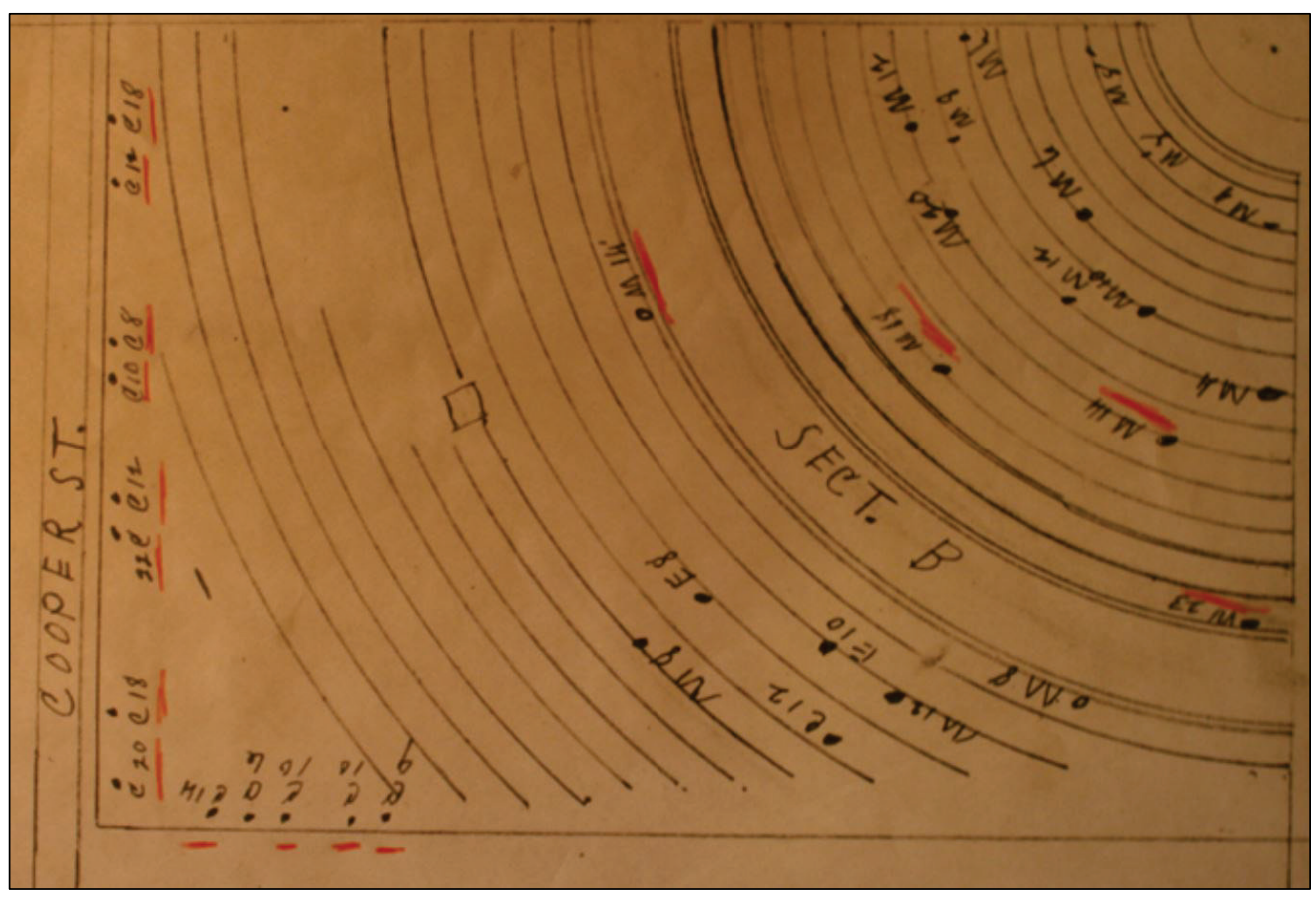


Figure 237. Aerial view of Outer B showing little tree cover in the section close to the stone wall but there are a large group of shrubs in the southwest corner, 1948 (HALS-TN-2, Library of Congress).

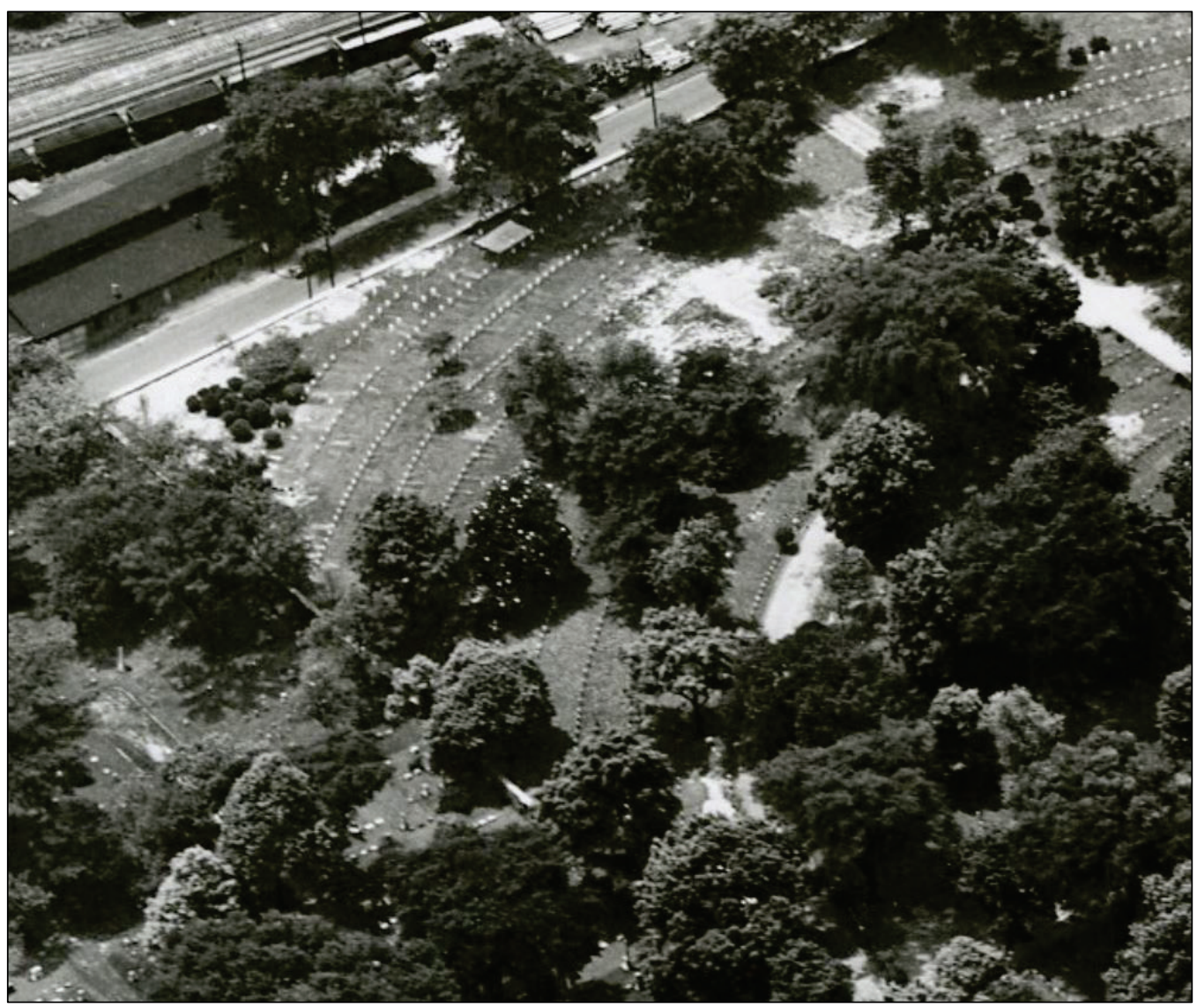

Figure 238. View to the southwest of the Cooper Gate, 1946 (VA NCA Archives, Washington, $\mathrm{DC})$.

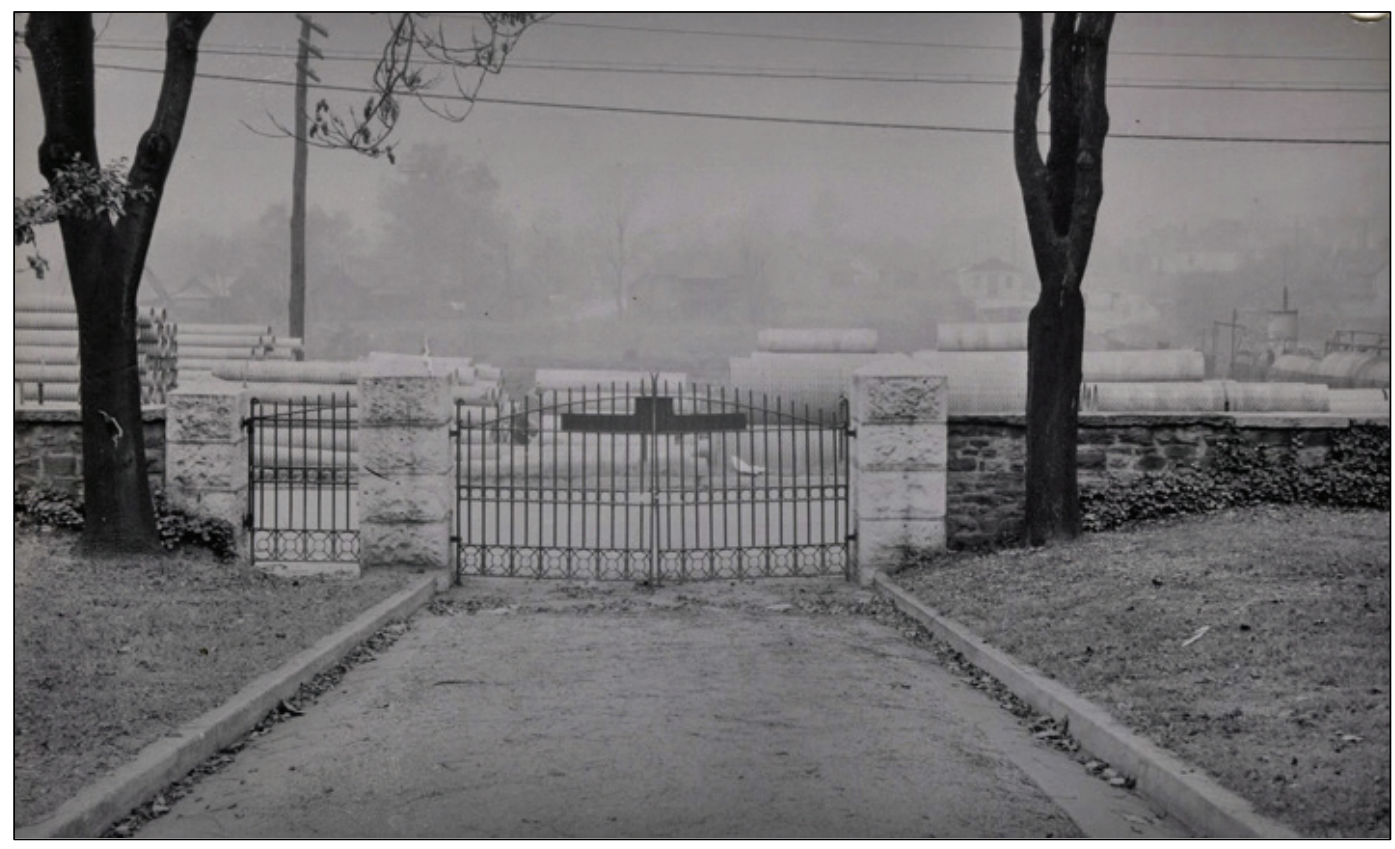


Figure 239. Looking east at the small restroom building in Outer B, unknown date (VA NCA Archives, Washington, DC).

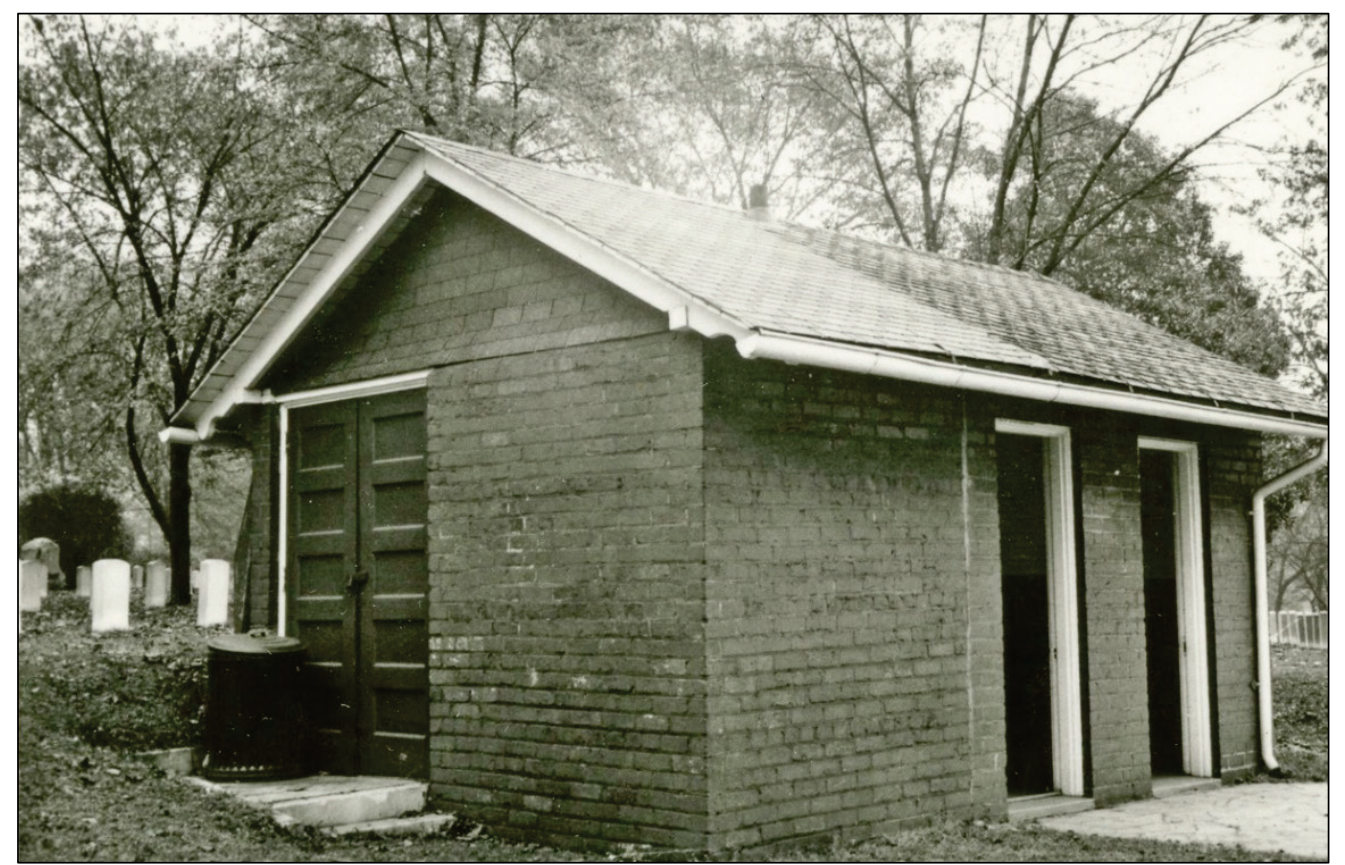

Figure 240. Outer B planting plan as depicted on a portion of the 1966 map (VA NCA Archives, Washington, DC).

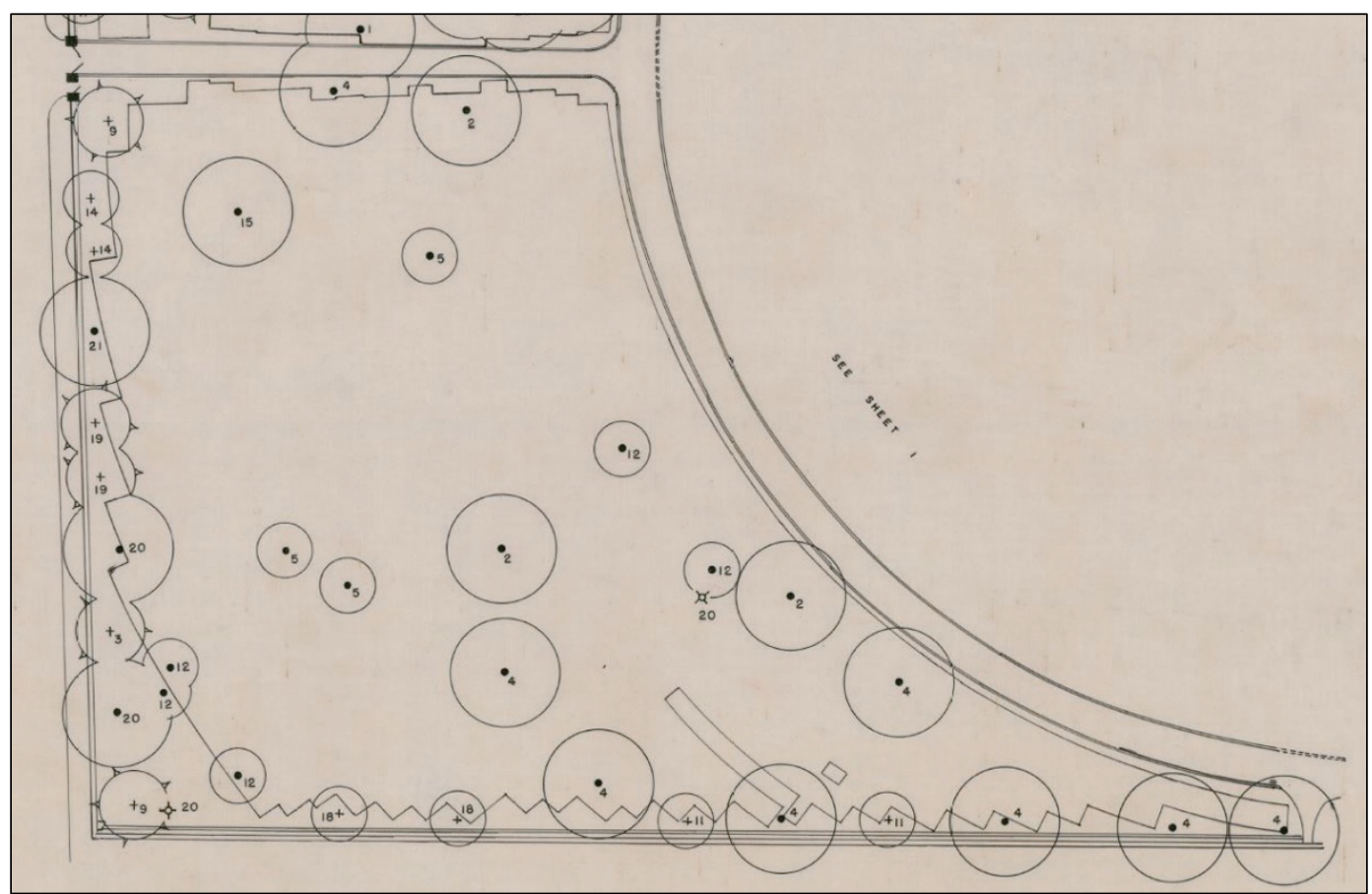




\subsubsection{1971 map}

The map from 1971 does not have landscaping depicted on it, but what it does show is 27 rows of graves (Figure 241). The curbing has been erased from the drawing along both sides of the east-west drive, but there was still curbing along the circle drive in 1953 (Figure 242).

Figure 241. Outer B as depicted on a portion of the 1971 map (VA NCA Archives, Washington, DC).

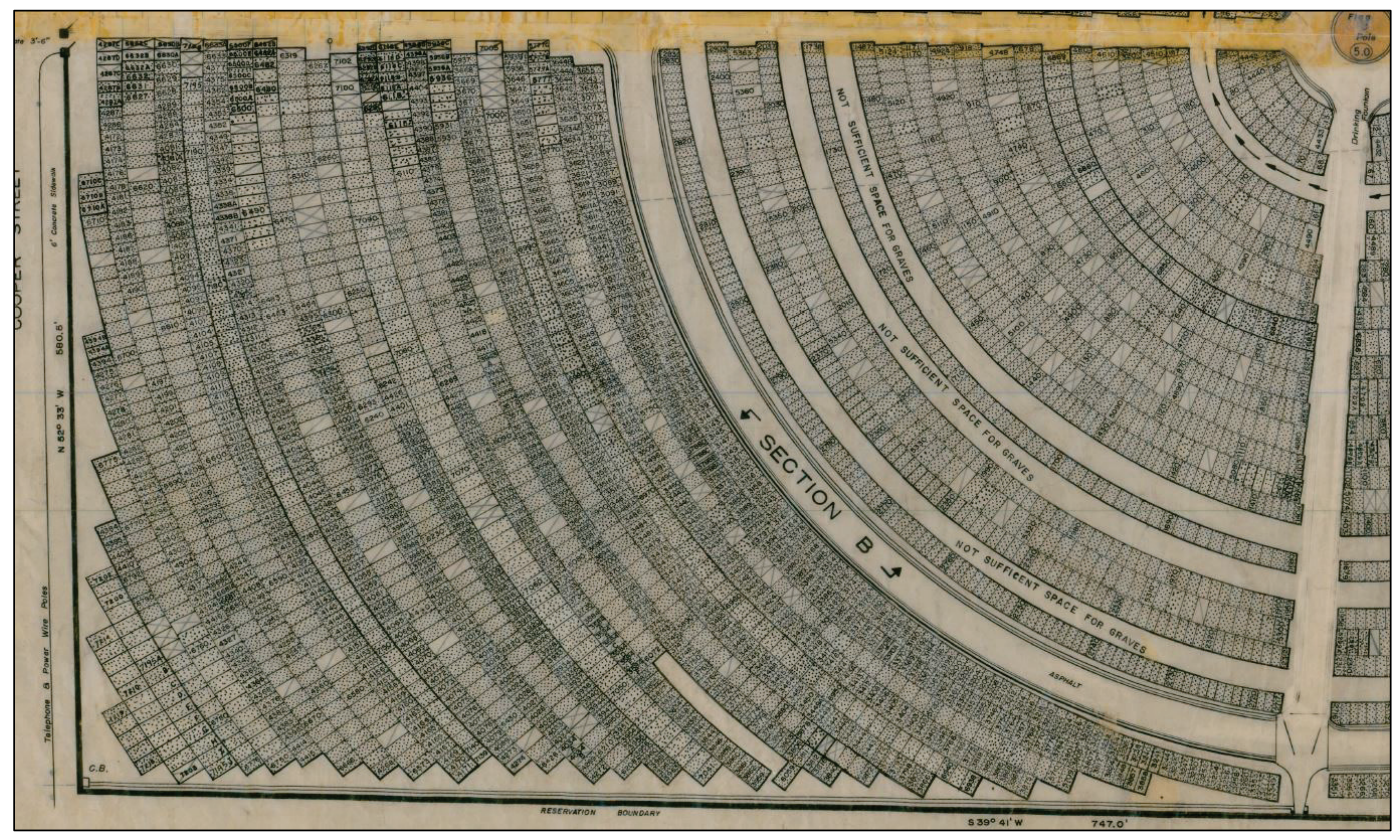


Figure 242. View to the east along the circle drive with Inner B on the left and Outer B on the right, 1989 (VA NCA Archives, Washington, DC).

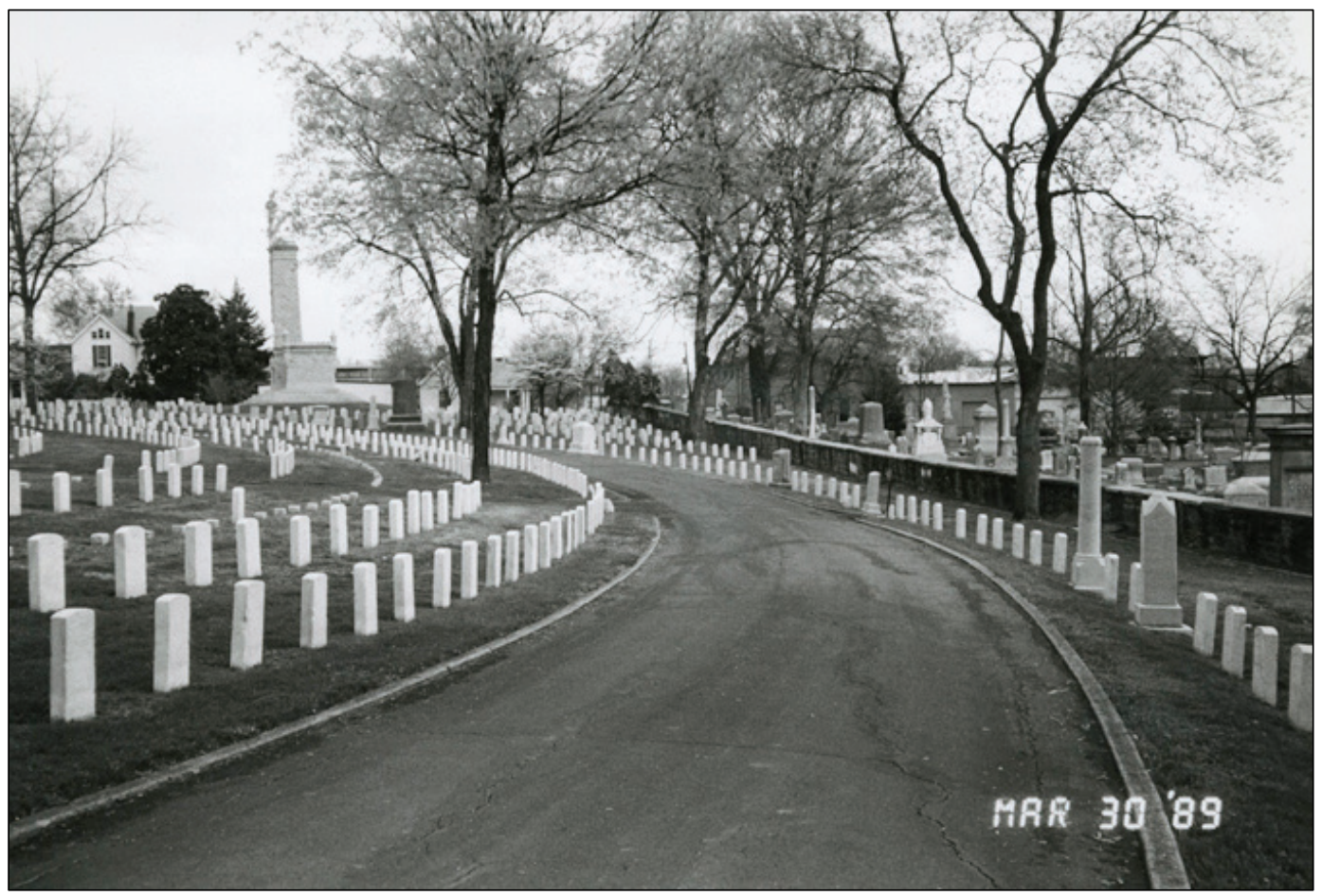

\subsubsection{2019 map}

The map from 2019 does have landscaping depicted on it, and it shows that Outer B still has 27 rows of graves that all take the shape of the circle drive. The east-west drive that connected the two gates from the cemetery's inception is now filled with gravesites leaving only the circle drive and the north-south drive (Figure 243). Figures 244 through 250 show scenes throughout Outer B.

An analysis of the trees in Outer B has two Sugar Maples (Acer saccharum), two Red Maples (Acer rubrum), and two American Holly (Ilex Americana). 
Figure 243. Outer B as depicted on a portion of the 2019 map (VA NCA Archives, Washington, DC).

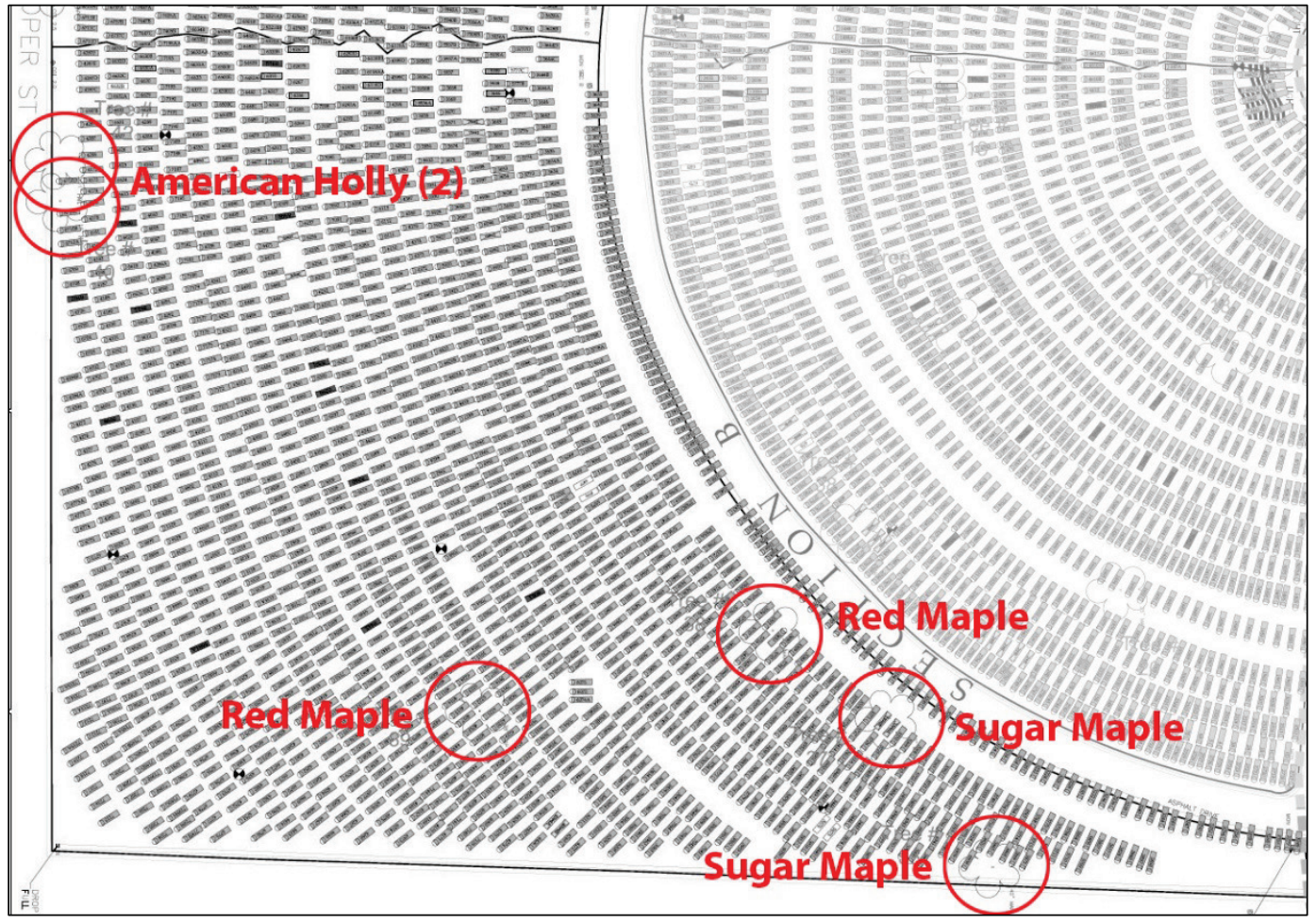

Figure 244. Looking southwest at the east edge of Outer B and the southwest stone wall on the left with the Old Gray Cemetery beyond (ERDC-CERL, 2019).

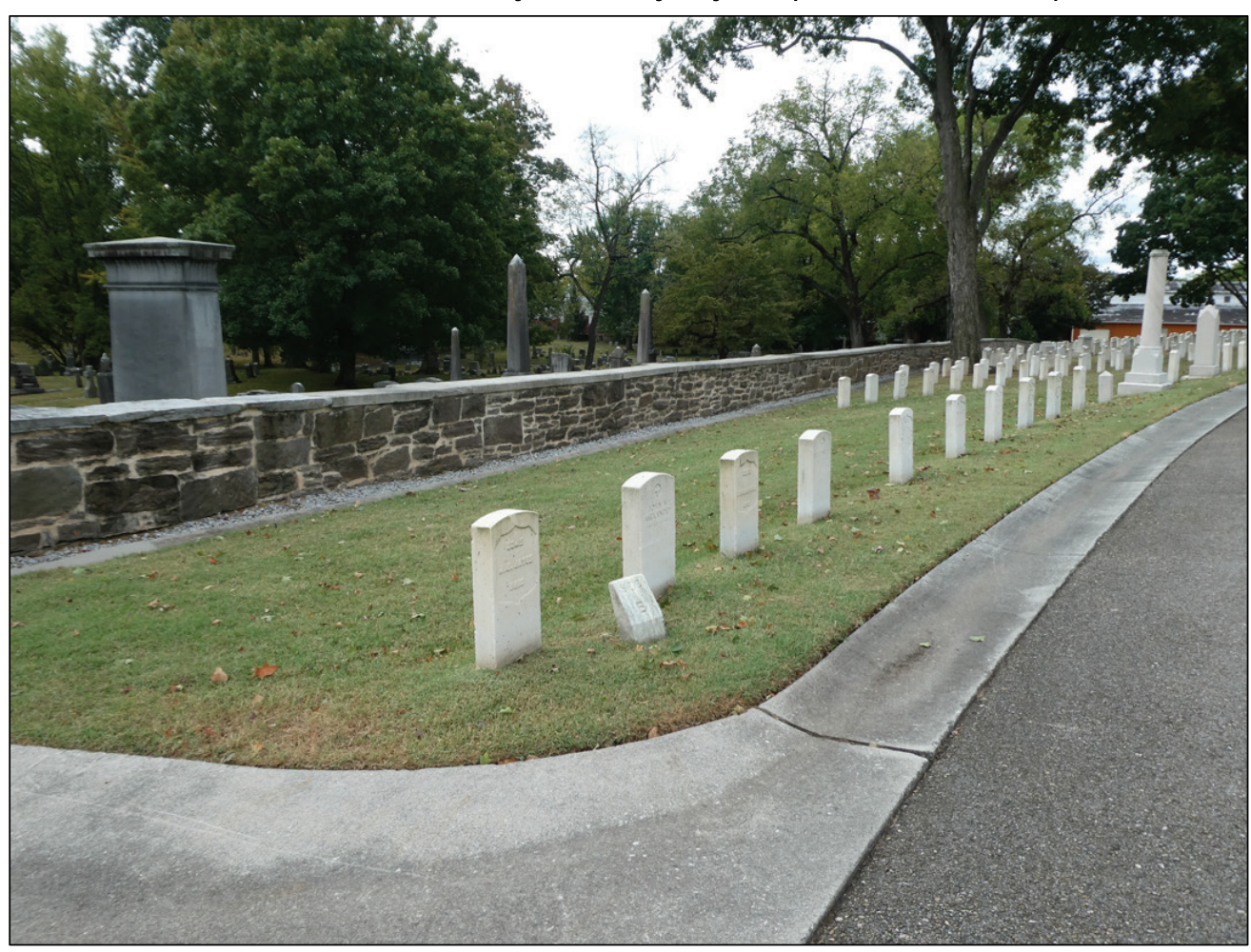


Figure 245. Looking south at the eastern portion of Outer B (ERDC-CERL, 2019).

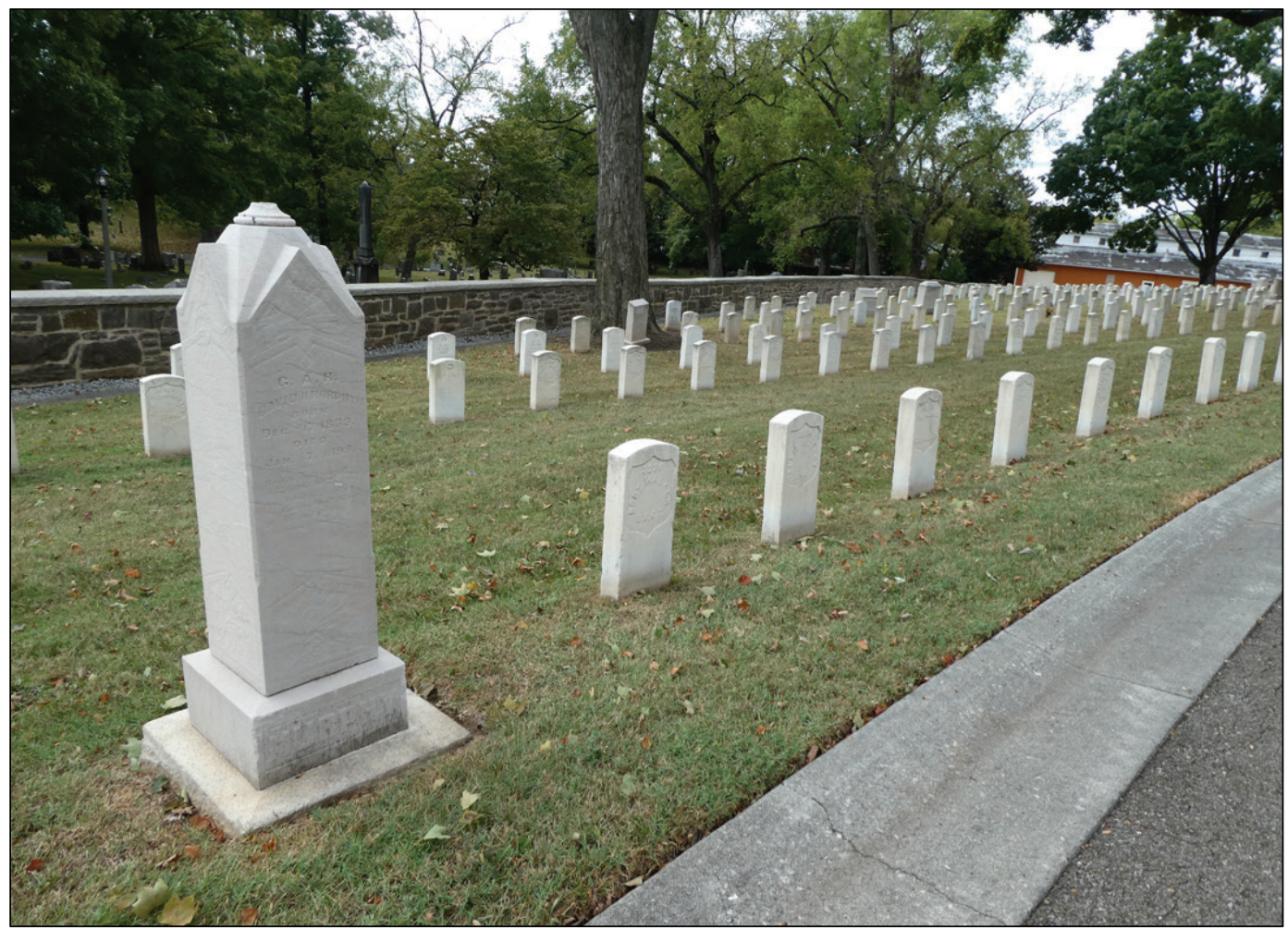

Figure 246. Looking southwest at the Superintendent Thomas Ridge burial plot in Outer B (ERDC-CERL, 2019).

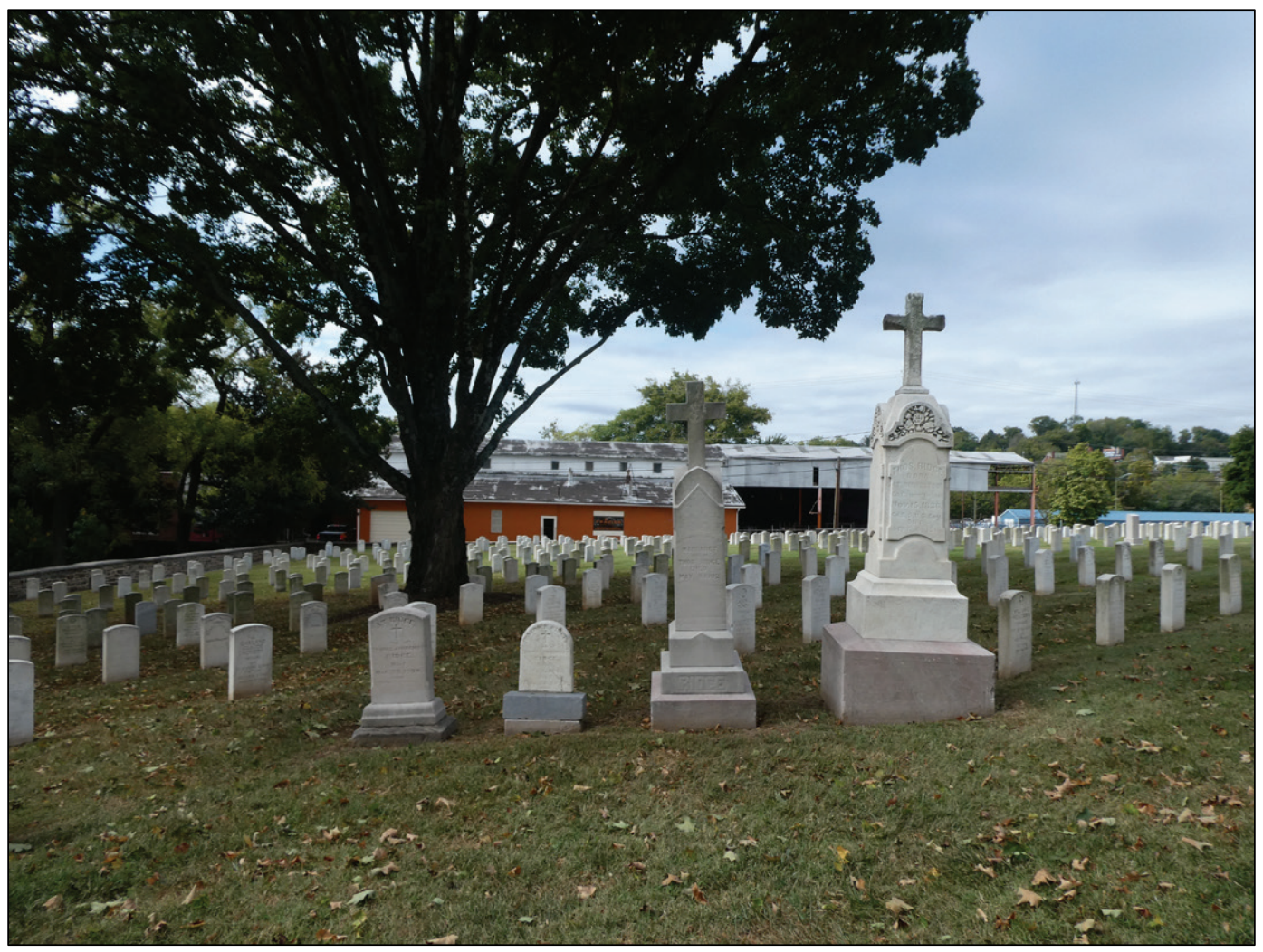


Figure 247. Looking south towards the southeast corner of Outer B (ERDC-CERL, 2019).

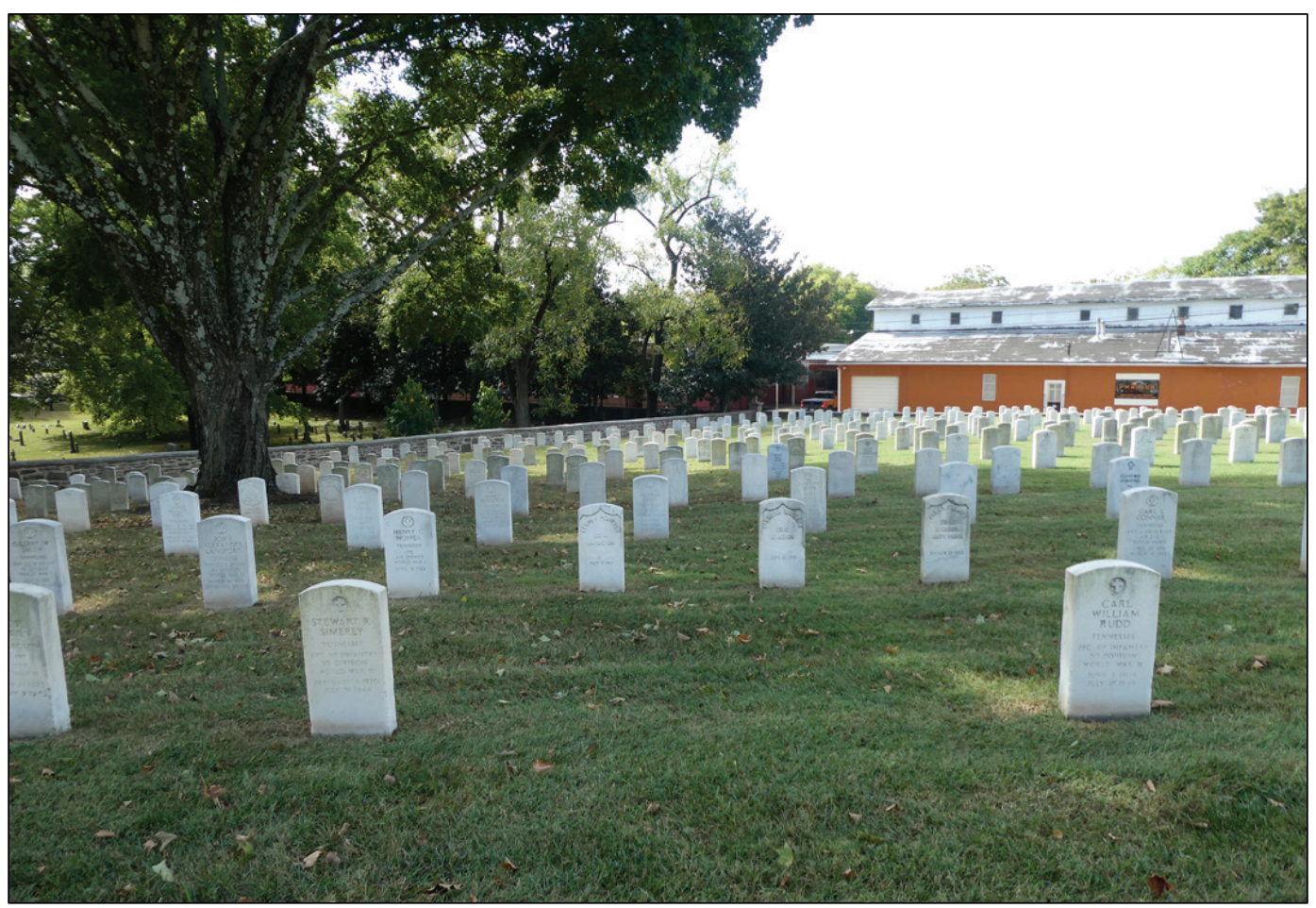

Figure 248. Looking northwest across Outer B (ERDC-CERL, 2019). Note very few trees are visible.

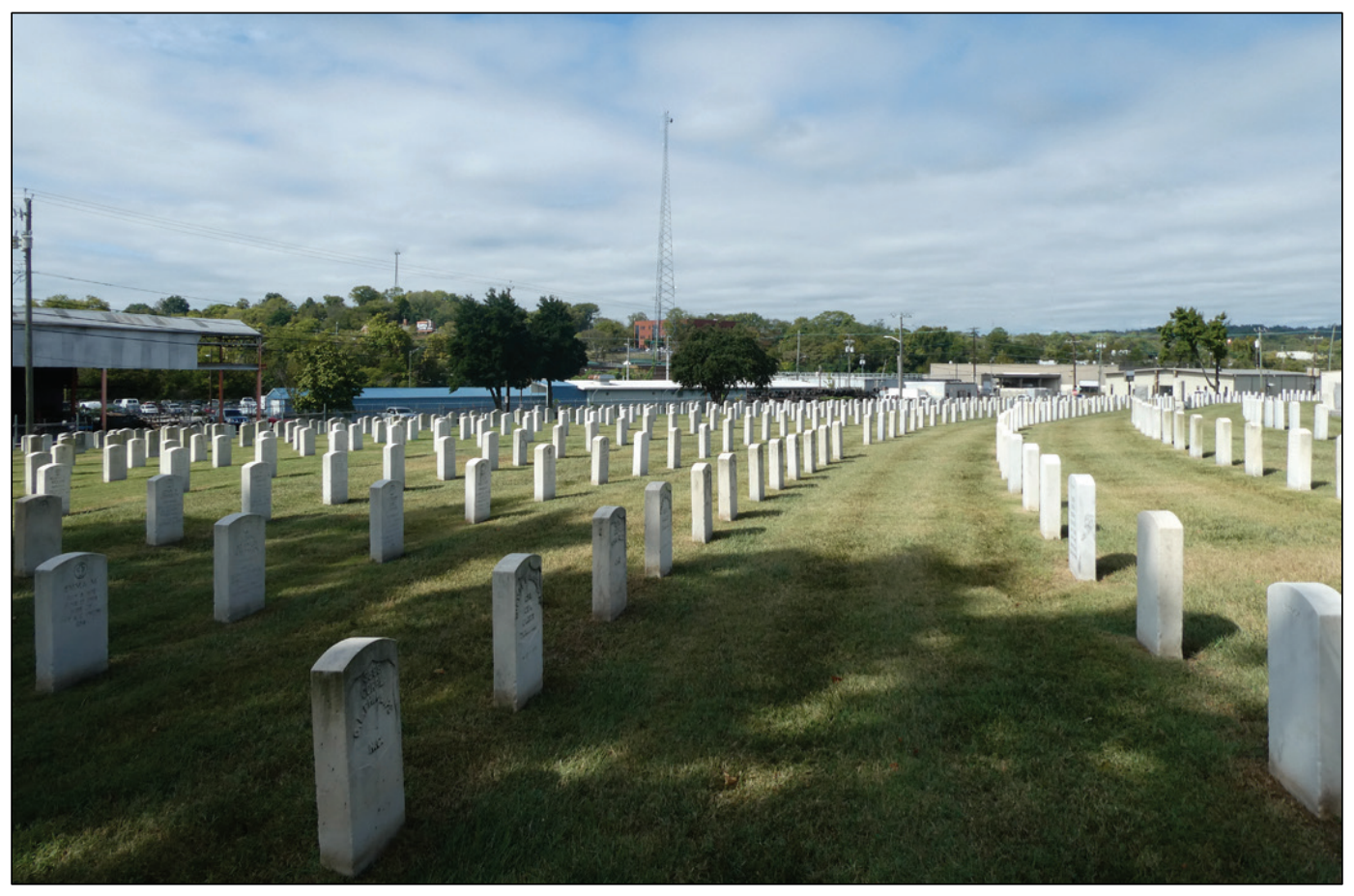


Figure 249. Looking southeast in Outer B at a Sugar Maple (ERDC-CERL, 2019).

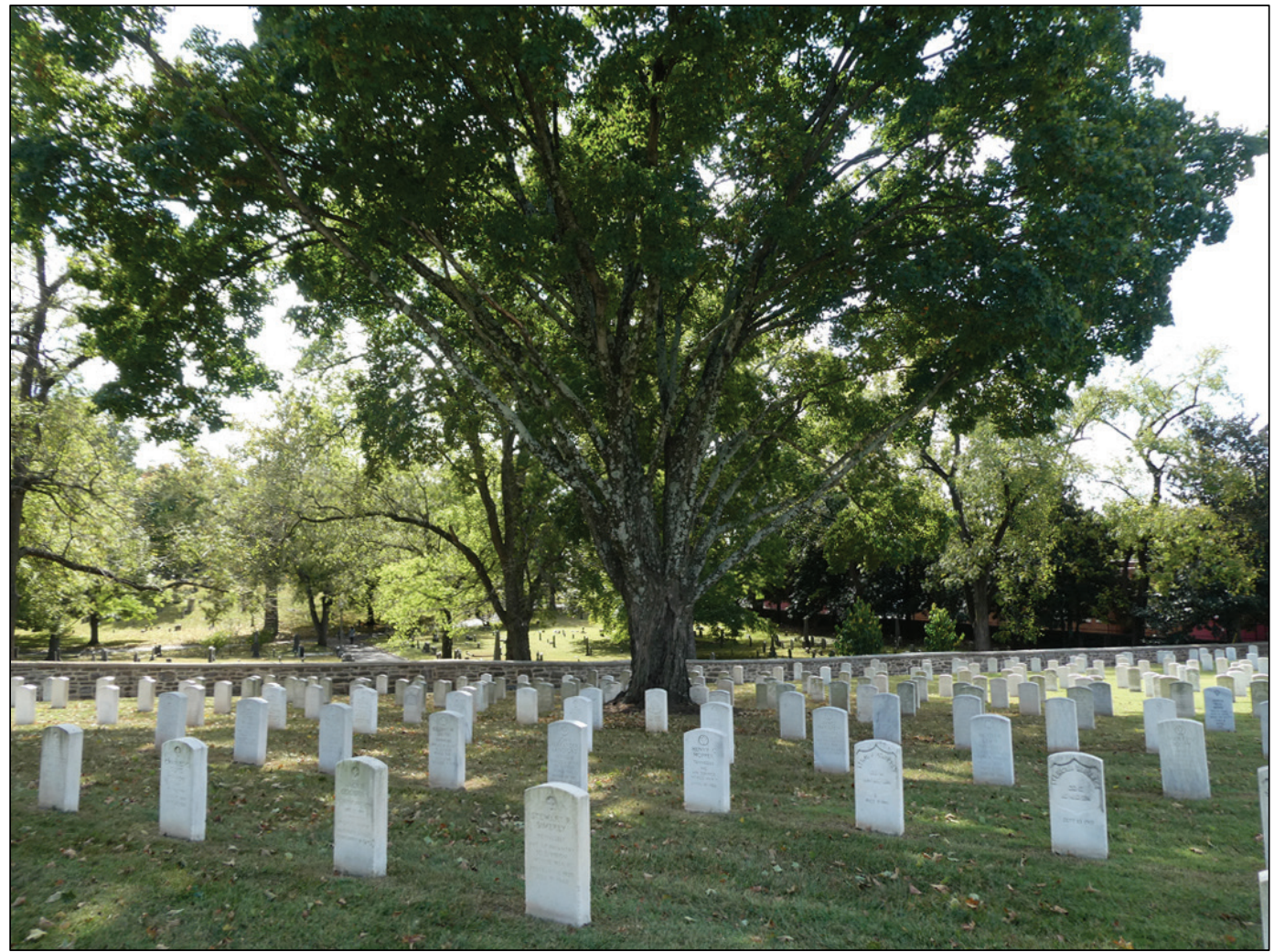

Figure 250. Looking southeast at the two American Holly trees along the Cooper Street wall, as well as a remnant of Cooper Gate on right (ERDC-CERL, 2019).

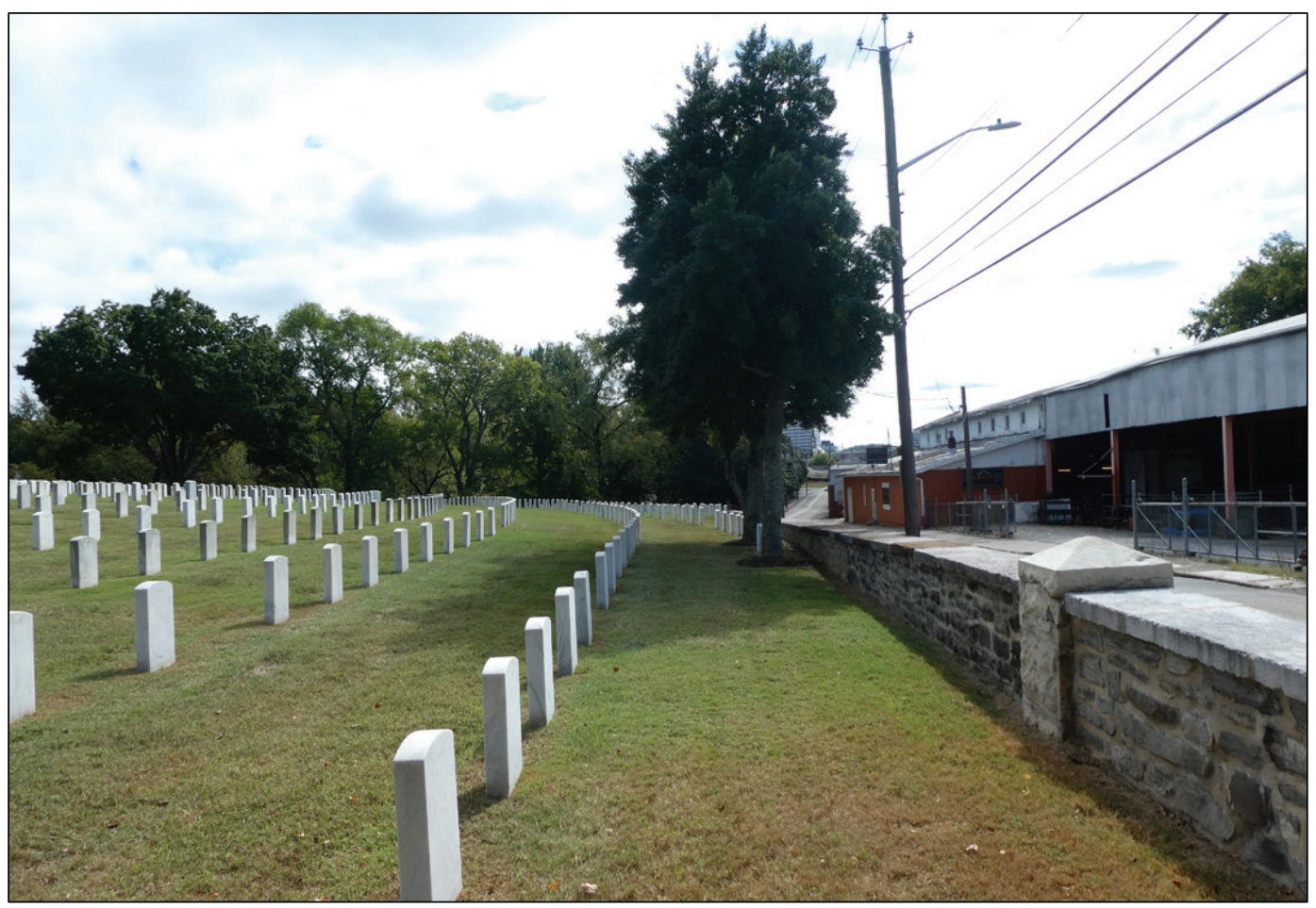




\subsubsection{Burial register summary}

See burial numbers for Inner B.

\subsubsection{Outer C}

The Outer C section of the cemetery was not planned for burials. It contained a wood superintendent's lodge next to the east-west drive and a barn near the northeast corner in the 1869 sketch of the cemetery (Figure 251). The ground slopes from $899^{\prime}$ at the circle drive down to $889^{\prime}$ at the west corner of the cemetery.

Figure 251. Outer C as depicted on P.M. Radford's drawing, 1869 (NARA, Washington DC, RG92).

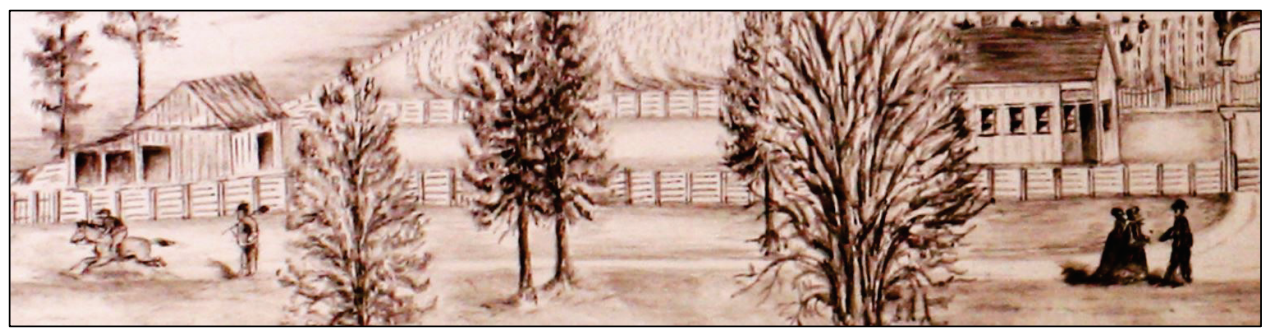

\subsubsection{1869 map}

The 1869 map (Figure 252) drawn by P.M. Radford shows a superintendent's lodge (Figure 253) and a barn, both constructed out of wood, in an area divided from the rest of the cemetery by a wood rail fence. There is one row of graves shown on the outer side of the circle drive. This map does not show any landscaping. 
Figure 252. Outer $C$ as depicted on P.M. Radford's map, 1869 (NARA, Washington DC, RG92).

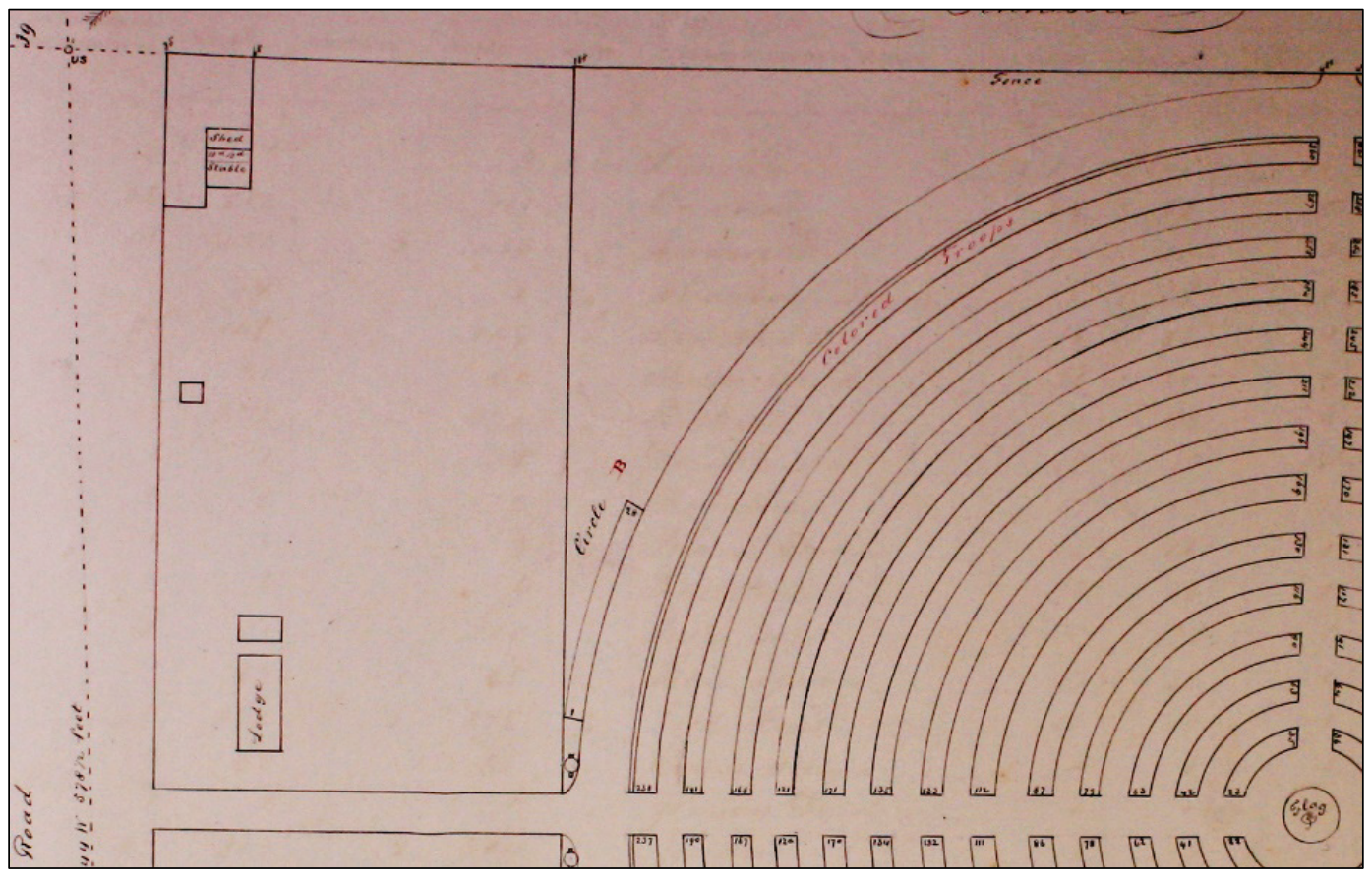

Figure 253. Front of the original wood lodge, 1874 (NARA, Washington DC, RG92).

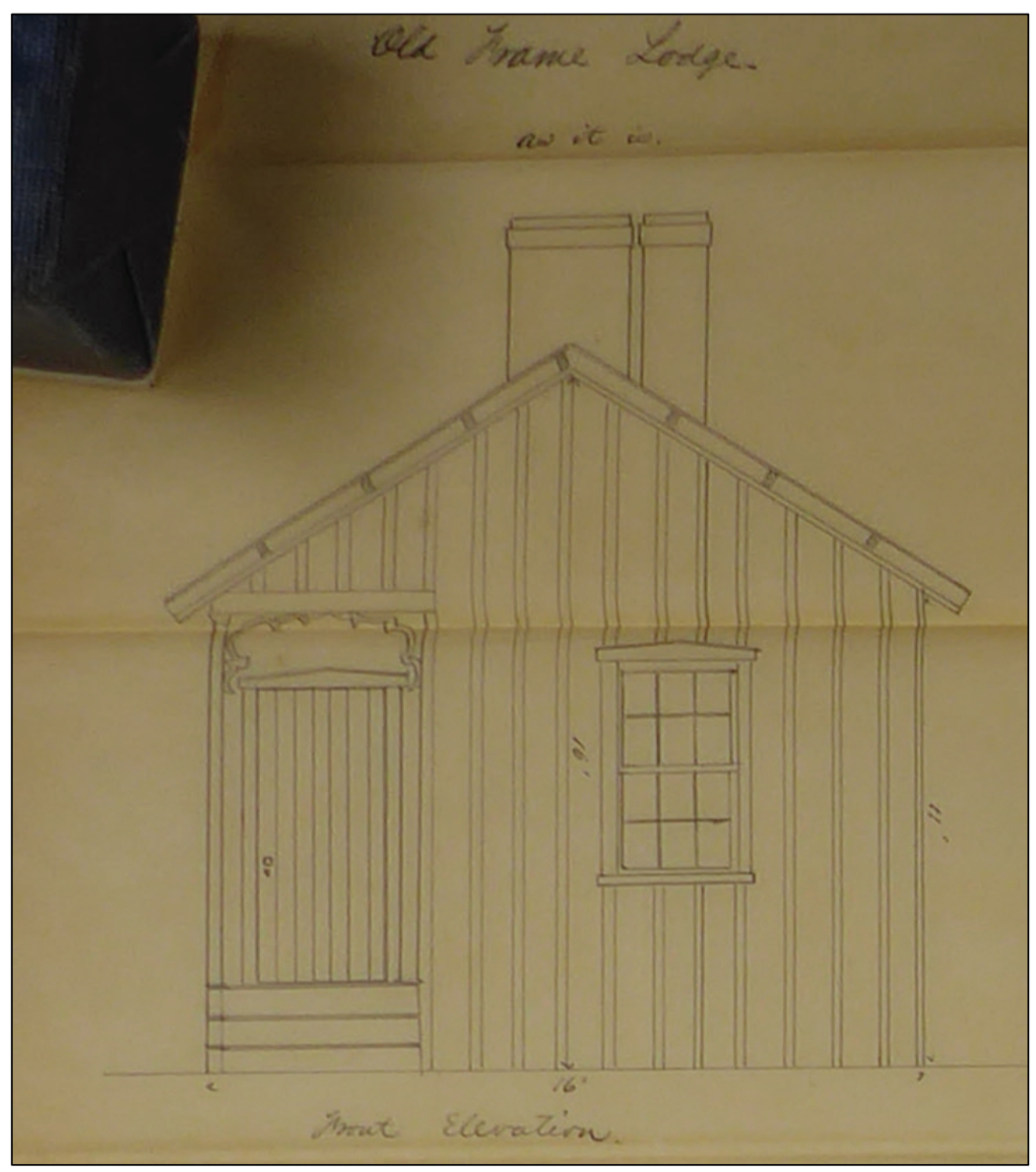


A plan from 1874 shows the old wood superintendent's lodge being moved south across the east-west drive and placed northeast of the new stone superintendent's lodge. It was transformed into a tool shed and privy. The stone wall along Cooper Street is shown with Osage Orange clippings, and the wood rail fence is marked with Osage Orange clippings as well.

\subsubsection{1892 map}

The map from 1892 has extensive changes from the 1869 map. All of the structures have been removed, and the area is open except for a few hedges. A stone wall bounds the area on the southwest and northwest, while a wood fence bounds the area on the northeast. The wall and fence are lined with deciduous trees (presumably Osage Orange). There are few other trees shown in the lodge area. There are deciduous trees and evergreen shrubs spread throughout the area between the wood fence and circle drive with the circle drive lined with deciduous trees. This map does not show any graves outside the circle drive; however, there is a siege gun monument near the circle drive (Figure 254).

Figure 254. Outer $C$ as depicted on a portion of the 1892 map (VA NCA Archives, Washington, DC).

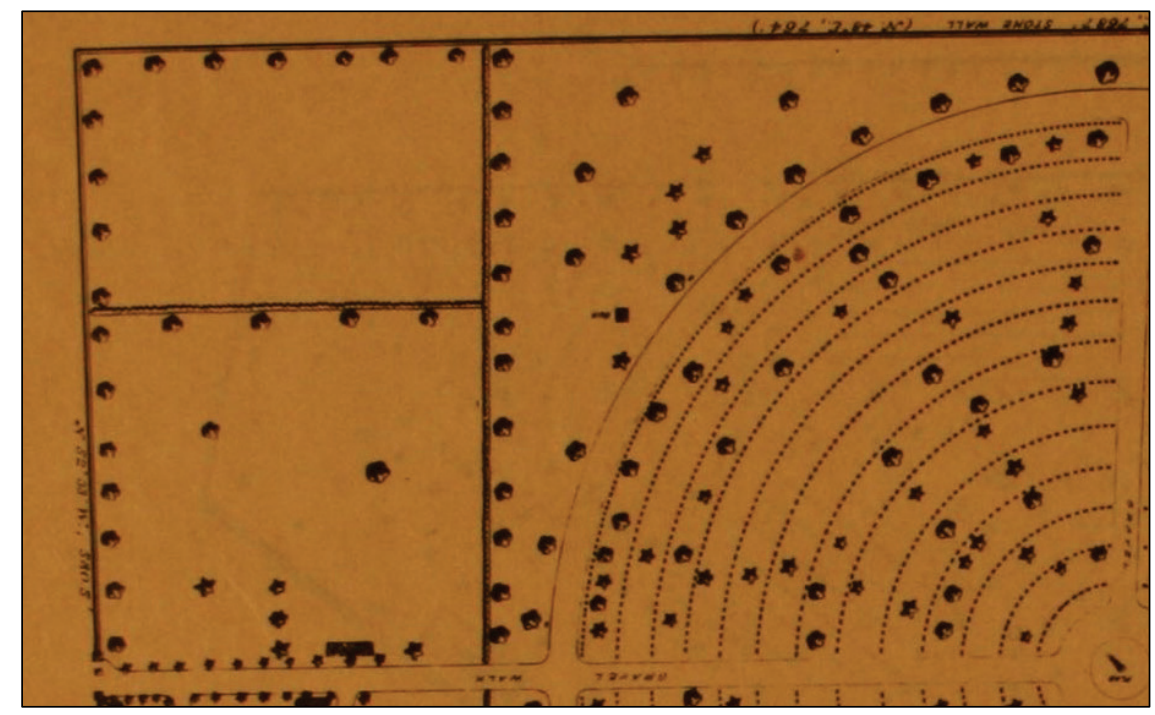

\subsubsection{1909 map}

The map from 1909 is an update of the 1892 map (Figure 255). There is a handwritten note that 700 graves can fit in the entire area. The wood fence has been erased, although the rows of trees are still visible. A planting bed along the east-west drive is marked for removal. 
Figure 255. Outer $\mathrm{C}$ as depicted on a portion of the 1909 map (NARA, Washington DC, RG92).

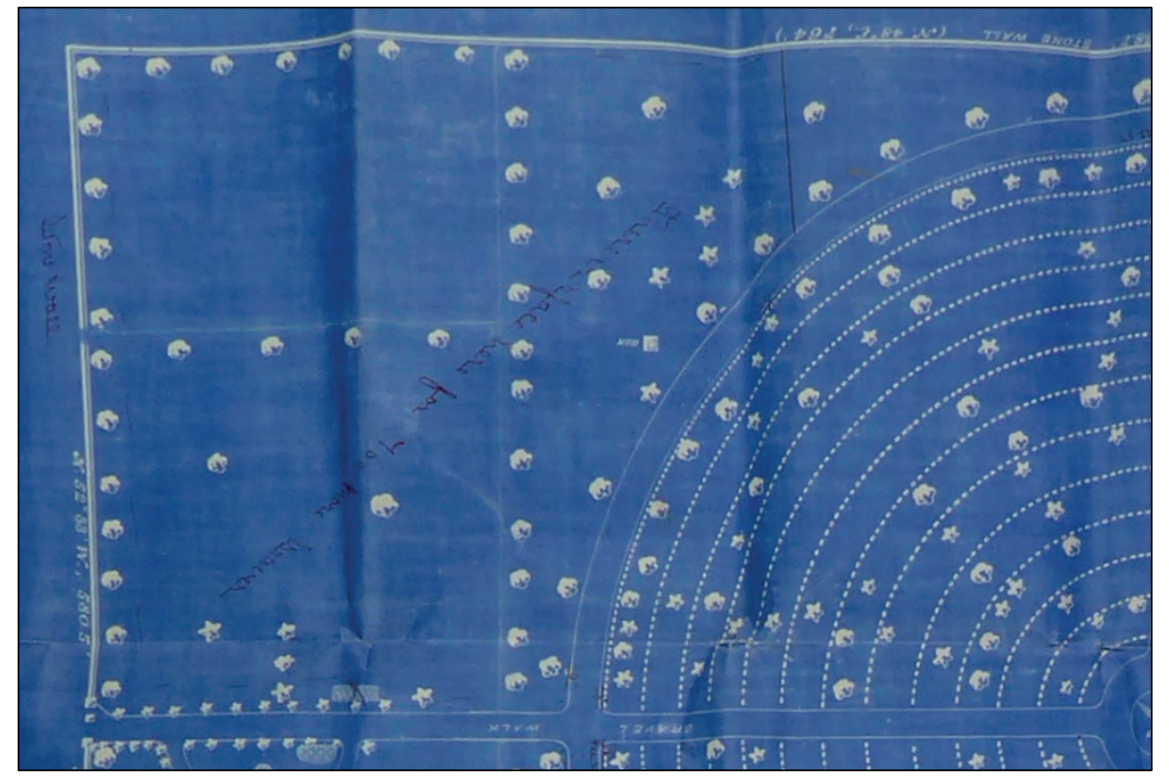

\subsubsection{1947 map}

The map from 1947 is the first map that has the species of trees indicated on it. The map also shows that there are graves on the outside of the circle drive halfway towards the Cooper Street wall (Figure 256). There was one Maple, one Elm, one Sycamore, and 14 Catalpa trees on the map. The Catalpas are right inside the stone wall. The 1947 map only has trees shown and listed, but an aerial from 1948 (Figure 257) shows that Outer C had a large tree near where the old wood lodge once stood, which appears to be an American Elm according to the 1966 planting plan. It is unknown when the siege gun monuments were removed from Outer B, but from the available record, it was at some point between 1909 and the 1940 .

A planting plan for Outer C from 1966 (Figure 258) has 11 American Elms (Ulmus Americana), three White Pines (Pinus strobus), two European White Birch (Betula pendula), three Norway Maples (Acer platanoides), one Katsuratree (Cercidiphyllum japonicum), four Red Flowering Dogwoods (Cornus florida var.), three Smoothleaf Elm (Ulmus minor), two Purple Crabapples (Malus sp.), three Southern Magnolias (Magnolia grandiflora), four Japanese Crabapples (Malus floribunda), one Black Walnut (Juglans nigra), two Shadblow Serviceberry (Amelanchier canadensis), one Deodar Cedar (Cedrus deodara), two Silver Maples (Acer saccharinum), one Blue Atlas Cedar (Cedrus atlantica 'Glauca'), one Silktree Albizzia (Albizia julibrissin), and two Sugar Maples (Acer saccharum). 
The 1966 planting plan also shows that a large section of Outer $\mathrm{C}$ had not been planned for burials yet.

Figure 256. Outer $C$ as depicted on a portion of the 1947 map with types of trees (NARA, Washington DC, RG15).

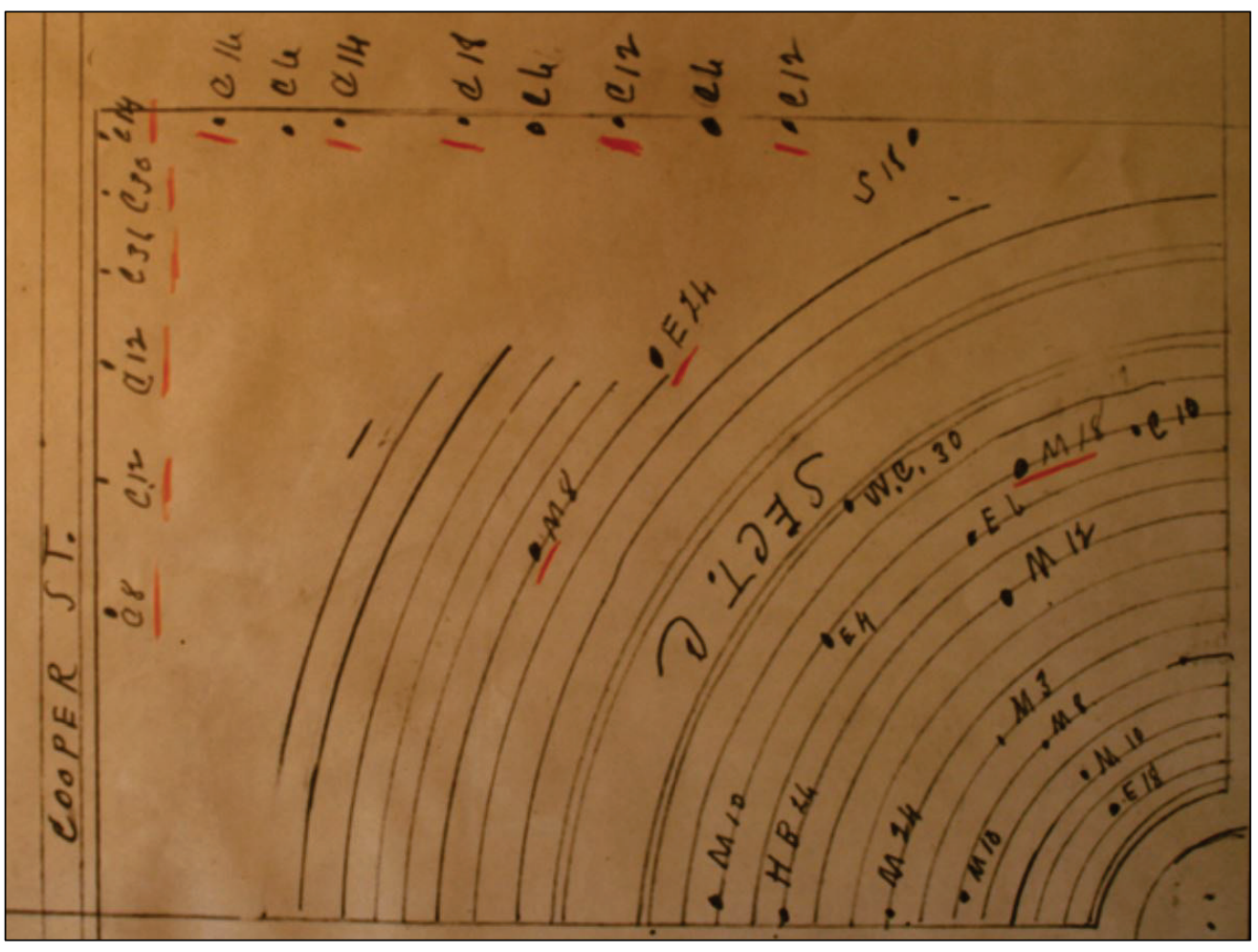

Figure 257. Aerial view of Outer C showing tree cover in Outer C, 1948 (HALS-TN-2, Library of Congress).

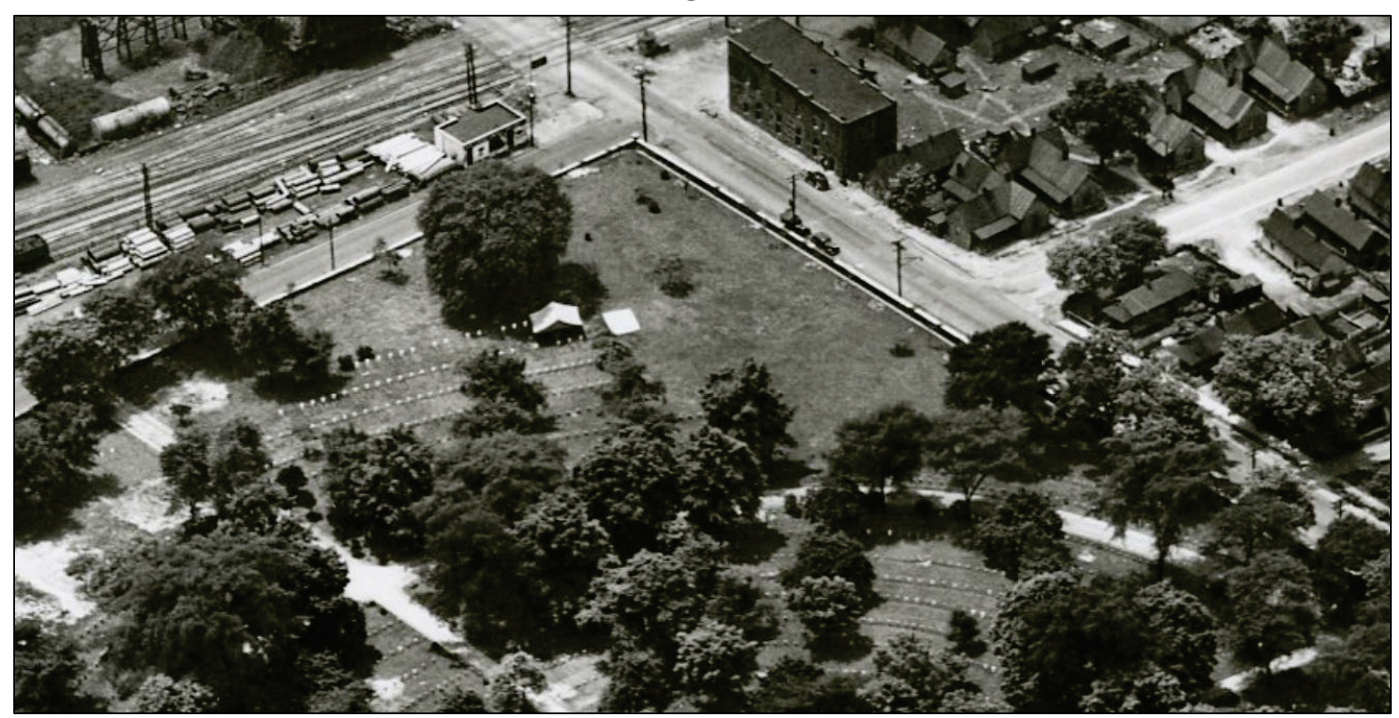


Figure 258. Outer C planting plan as depicted on a portion of the 1966 map (VA NCA Archives, Washington, DC).

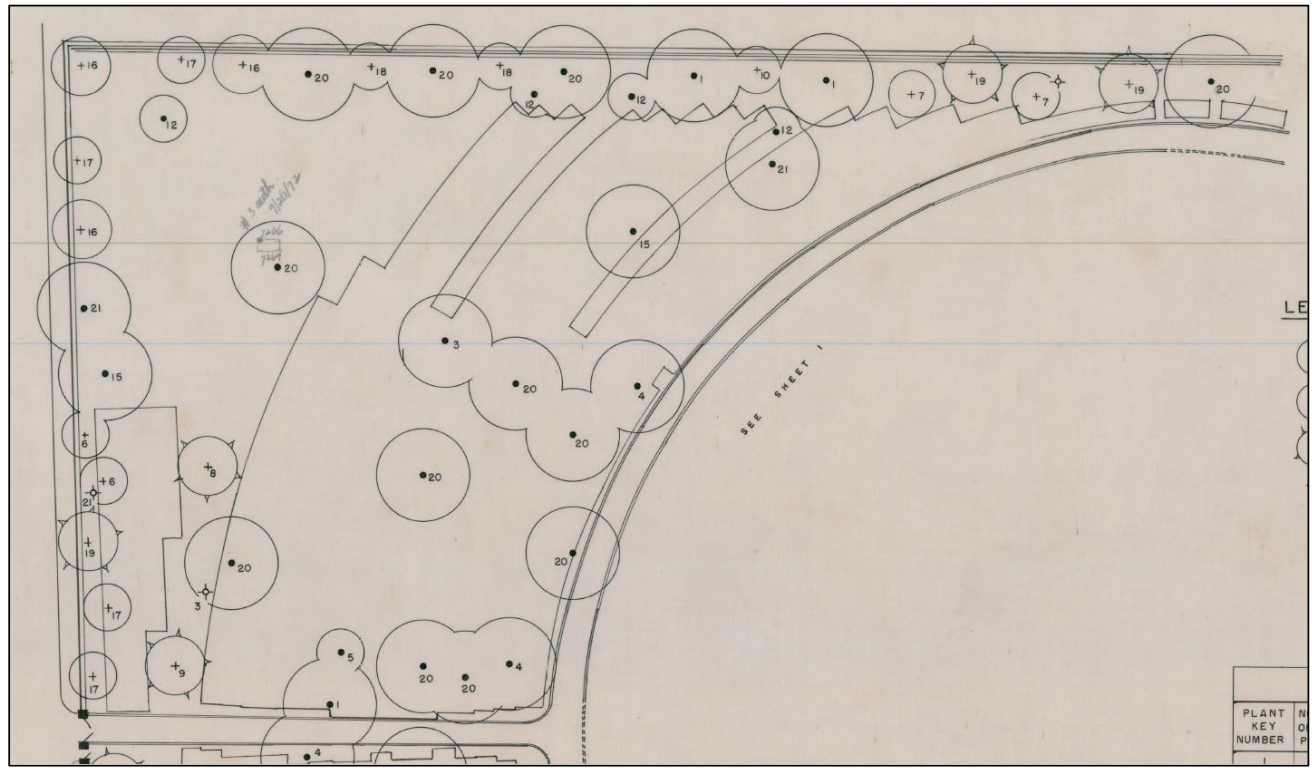

\subsubsection{1971 map}

The map from 1971 does not have landscaping depicted on it, but what it does show is that eight new rows of graves were added in between the existing graves from the Civil War era for a total of 16 rows parallel to the road (Figure 259). An additional 17 rows were added or planned parallel to the perimeter fence. Figures 260 and 261 are general views of Outer C from this period.

Figure 259. Outer $\mathrm{C}$ as depicted on a portion of the 1971 map (VA NCA Archives, Washington, DC).

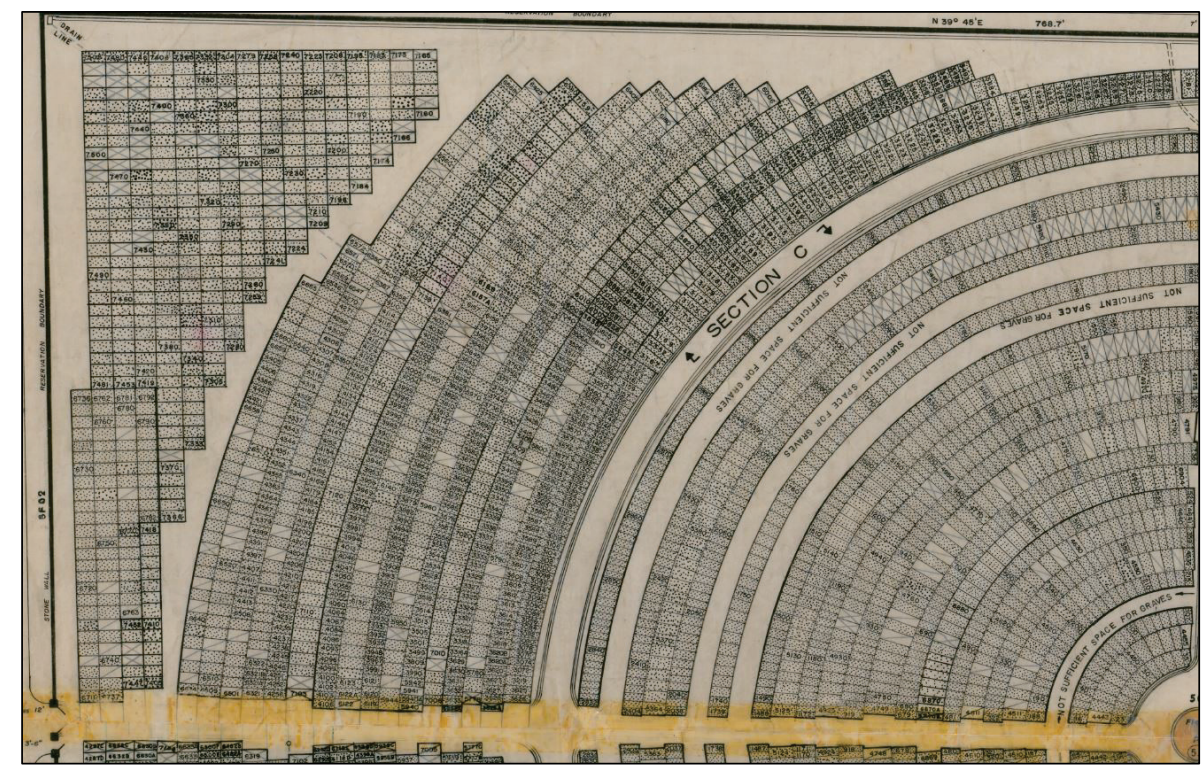


Figure 260. View to the southwest in Outer C along the stone wall, 1989 (VA NCA Archives, Washington, DC).

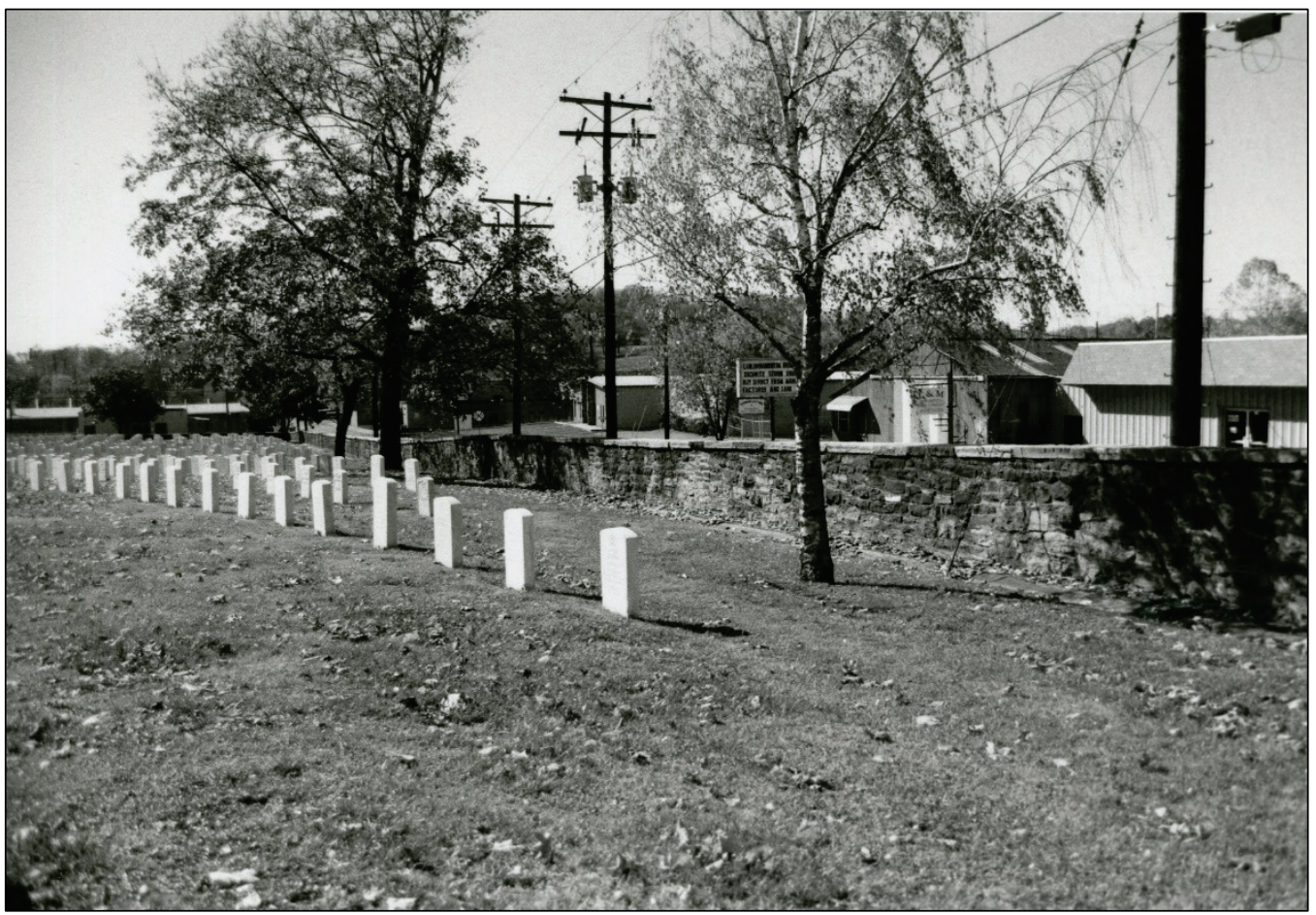

Figure 261. View to the northwest across Outer C, 1989 (VA NCA Archives, Washington, DC).

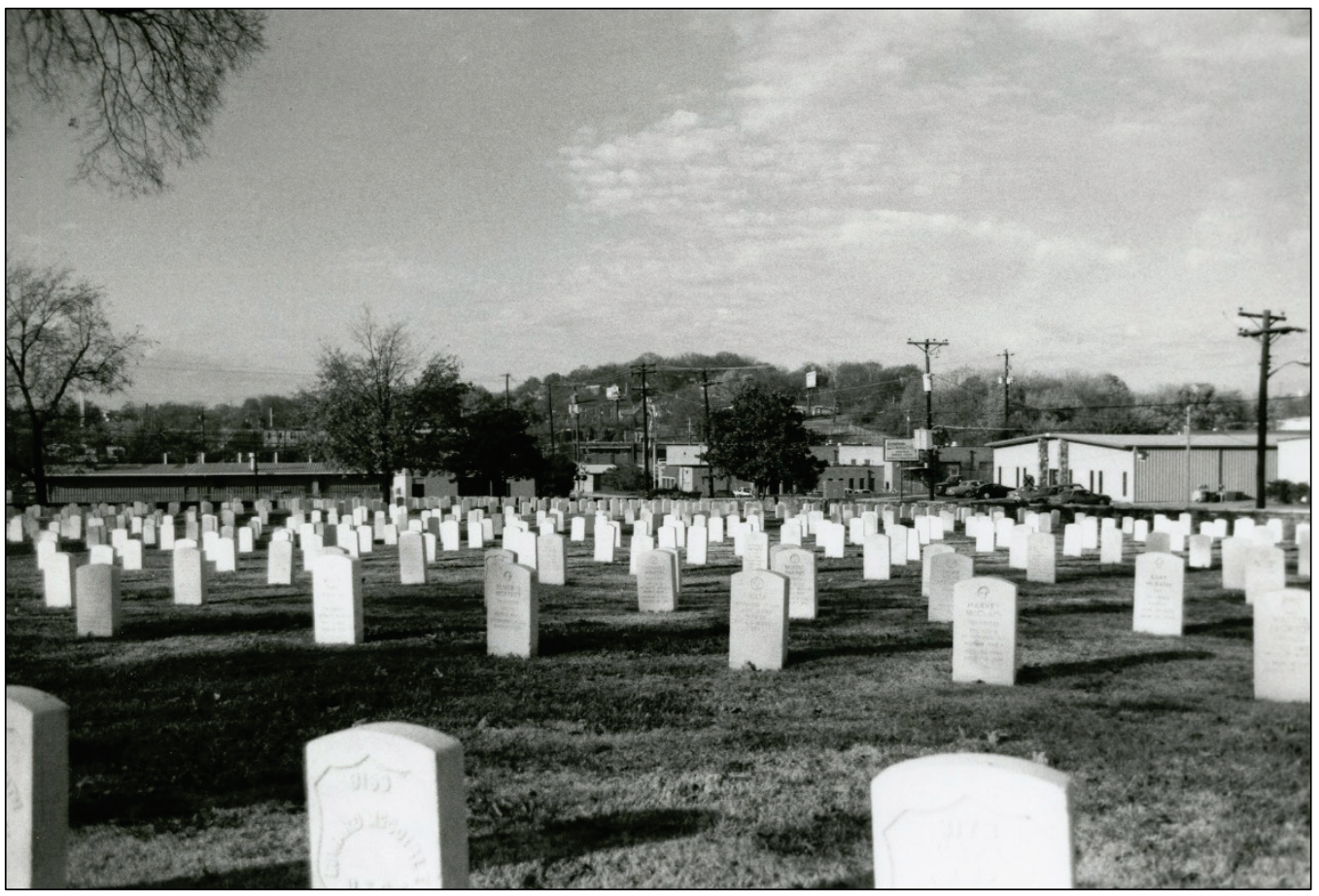




\subsubsection{2019 map}

The map from 2019 does have landscaping depicted on it. It shows that Outer $\mathrm{C}$ now has 16 rows of graves, and the rows take the shape of the circle drive and 17 rows of graves parallel with the Cooper Street wall. The east-west drive that connected the two gates from the cemetery's inception is now filled with gravesites, leaving only the circle drive and the northsouth drive (Figure 262). Figures 263 to 265 show scenes throughout Outer C.

An analysis of the trees in Outer C has one American Elm (Ulmus americana), one Sugar Maple (Acer saccharum), and one Crepe Myrtle (Lagerstroemia sp.).

Figure 262. Outer $C$ as depicted on a portion of the 2019 map (VA NCA Archives, Washington, DC).

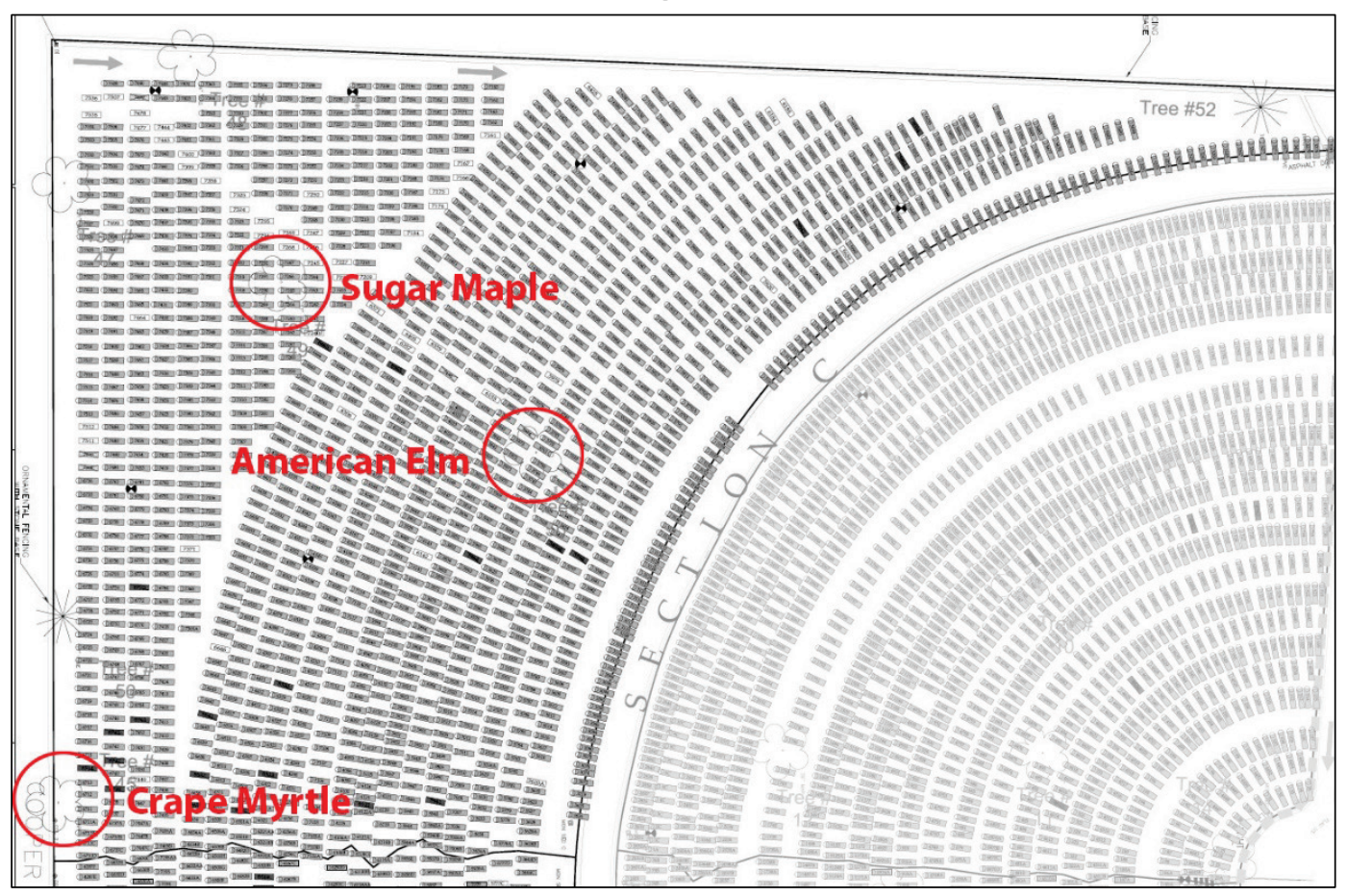


Figure 263. Looking southwest at the eastern edge of Outer C (ERDC-CERL, 2019).

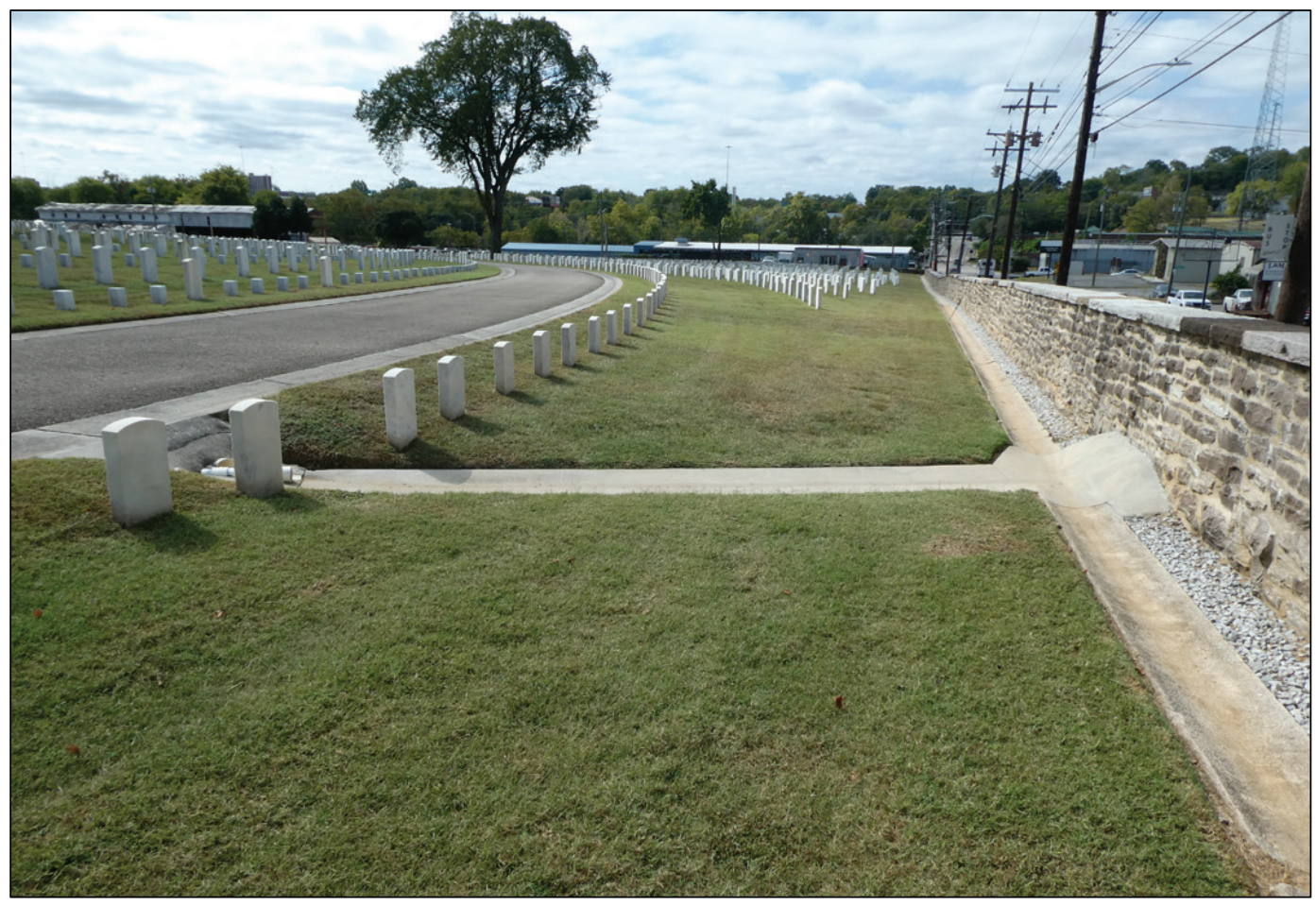

Figure 264. Looking west in Outer $C$ at the Crepe Myrtle in Outer C, note pylons for the old Cooper Gate along the wall (ERDC-CERL, 2019).

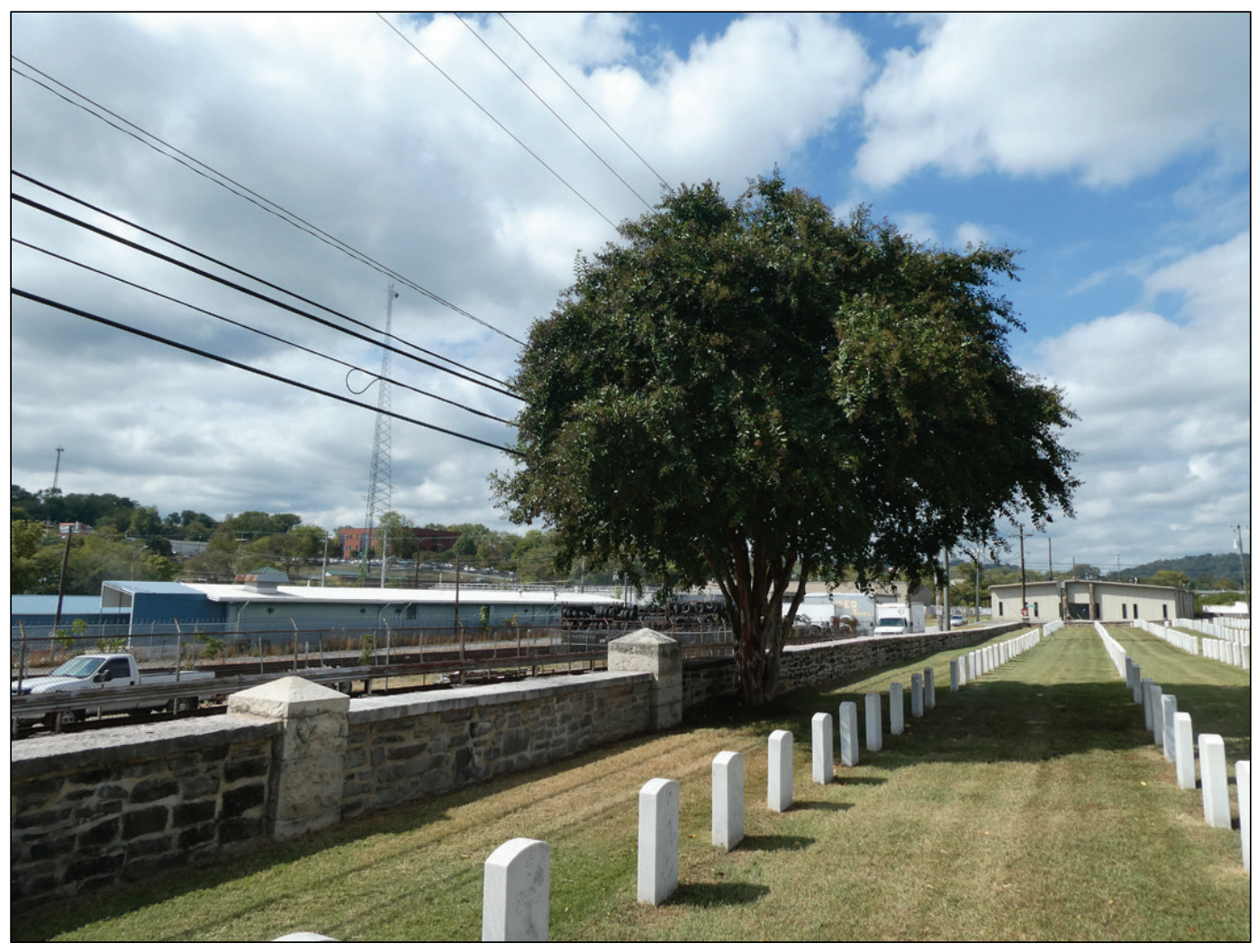


Figure 265. Looking northwest in Outer $\mathrm{C}$ at the Sugar Maple on the left and the American Elm on the right (ERDC-CERL, 2019).

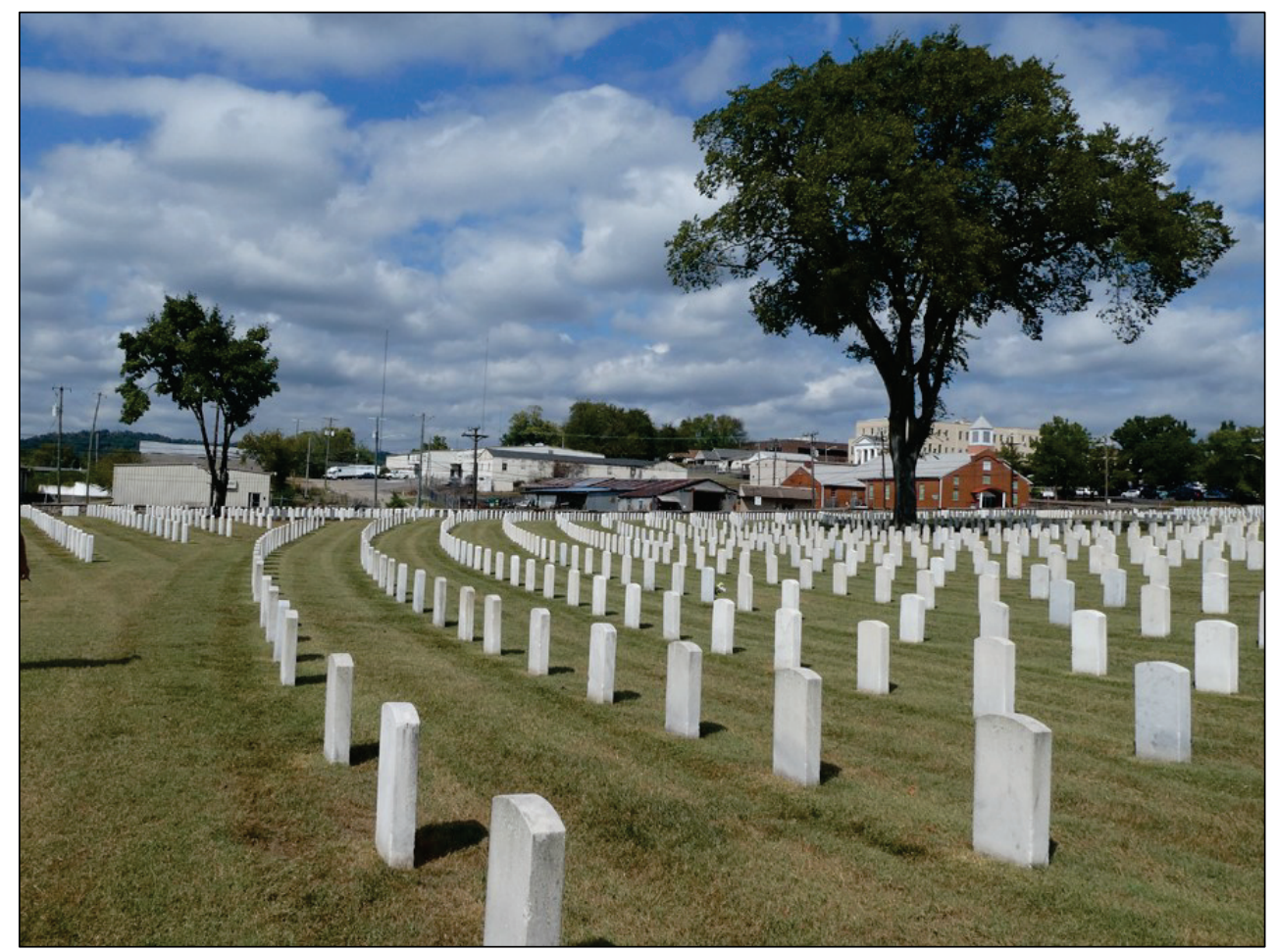

\subsubsection{Burial register summary}

See burial numbers for Inner C.

\subsubsection{Northeast}

The northeast section of the cemetery is the smallest of the areas within the cemetery and contained most of the public and service areas of the cemetery when the main entrance to the cemetery switched to Tyson Street from Cooper Street after the brick superintendent's lodge was constructed in 1907. It consists of the area outside the circle drive.

\subsubsection{1869 map}

The 1869 map drawn by P.M. Radford does not have anything located in the northeast section outside the circle drive (Figure 266). 
Figure 266. The Northeast section as depicted on P.M. Radford's map, 1869 (NARA, Washington DC, RG92).

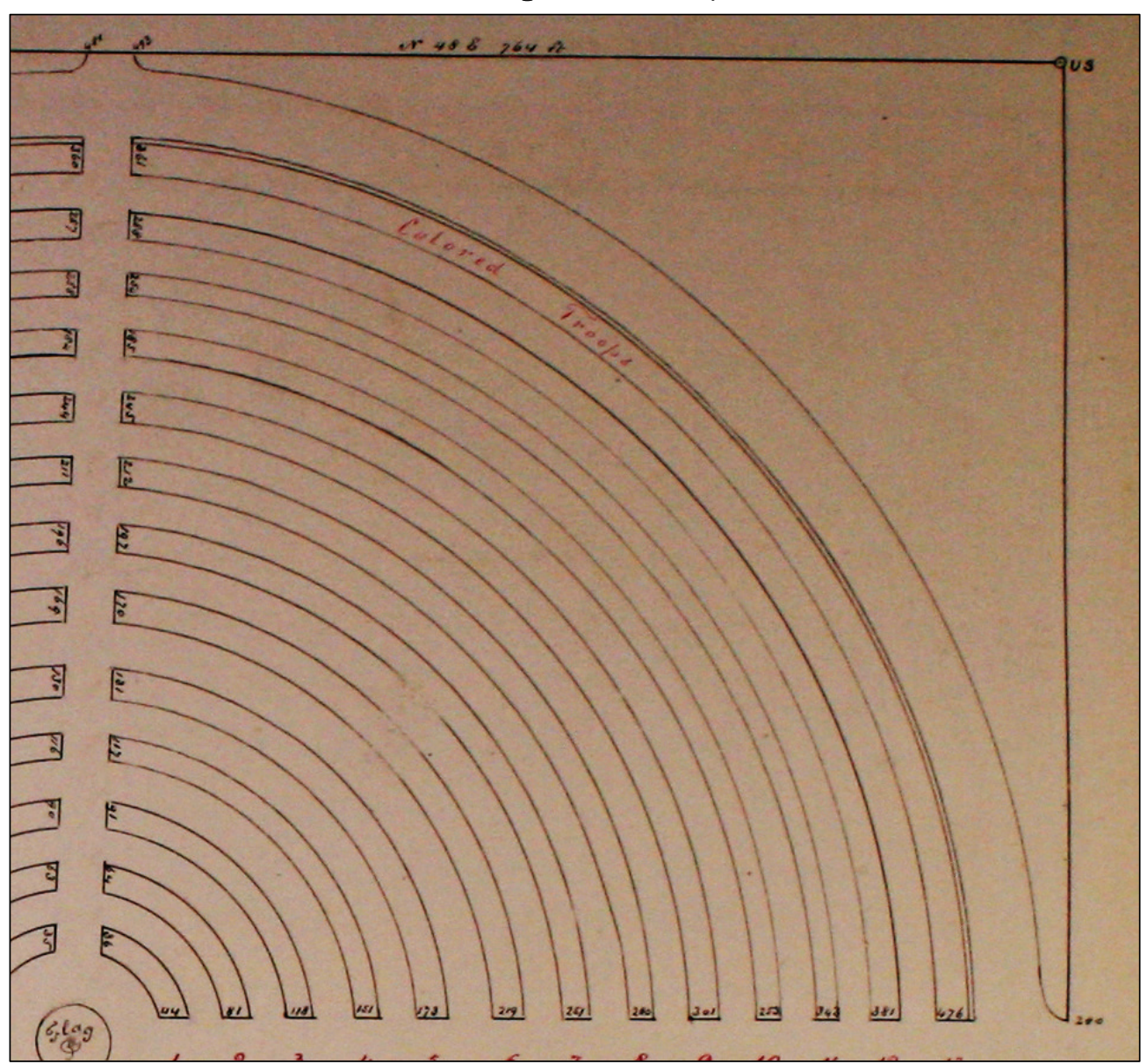

\subsubsection{1892 map}

The map from 1892 shows the northeast section as open except for the rostrum, which was constructed in 1879. There is a mixture of deciduous and evergreen trees in the area with both stone walls lined with deciduous trees (Figure 267). 
Figure 267. The Northeast section with the rostrum as depicted on a portion of the 1892 map (VA NCA Archives, Washington, DC).

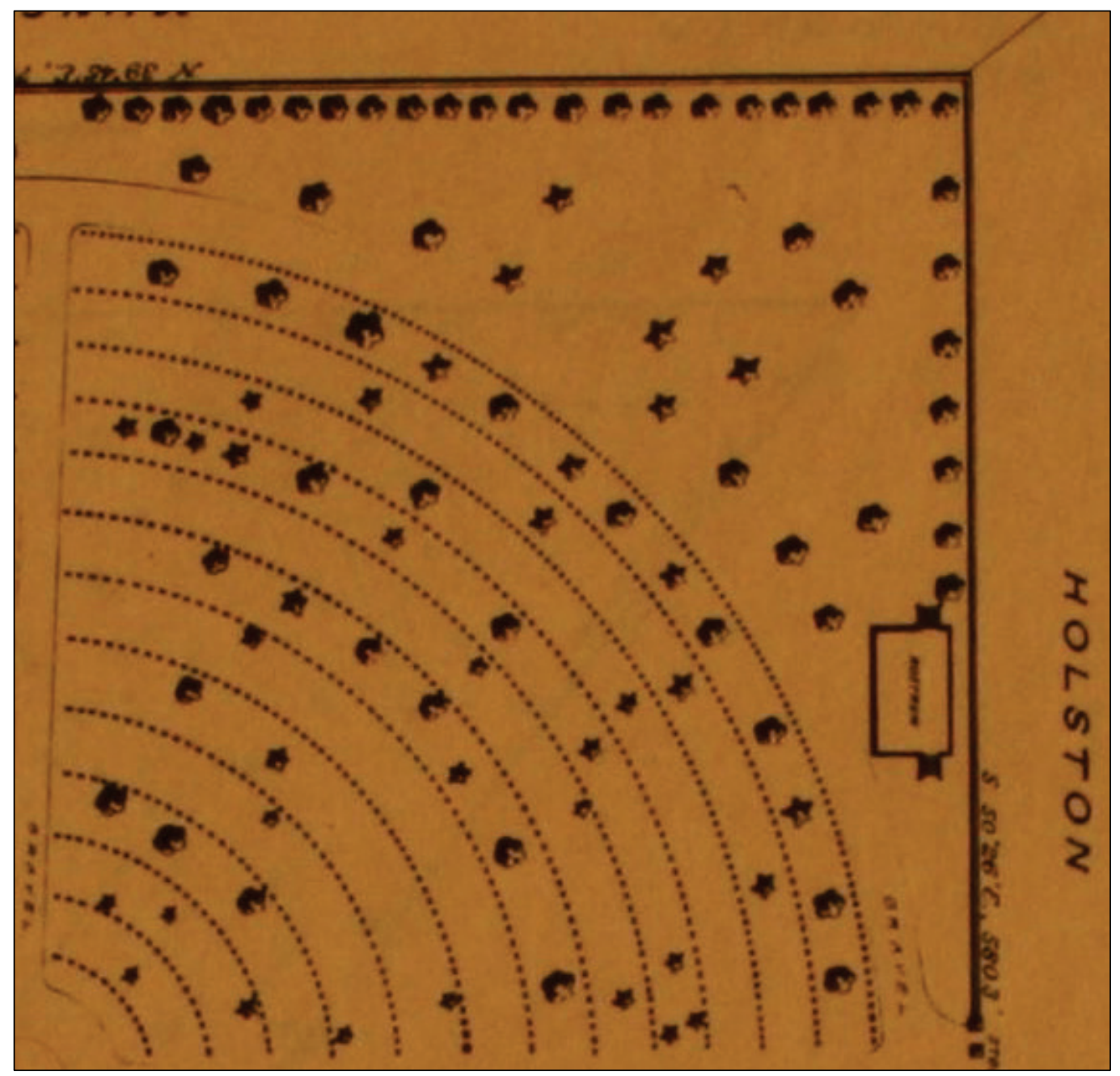

\subsubsection{1909 map}

The map from 1909 is an update of the 1892 map, and it does not show any difference in the landscaping (Figure 268). It does show the addition of the brick superintendent's lodge, which was constructed in 1907 (Figure 269). The lodge fronts out onto Tyson Street and has sidewalks that connect it to the circle drive and to the Tyson Street sidewalk. A new pedestrian opening was cut into the stone wall for this gate. The rostrum and the Tyson Gate are the other two dominating elements in the northeast (Figures 270 and 271). 
Figure 268. The Northeast section as depicted on a portion of the 1909 map showing the location of the rostrum and the brick superintendent's lodge outside the circle drive (NARA, Washington DC, RG92).

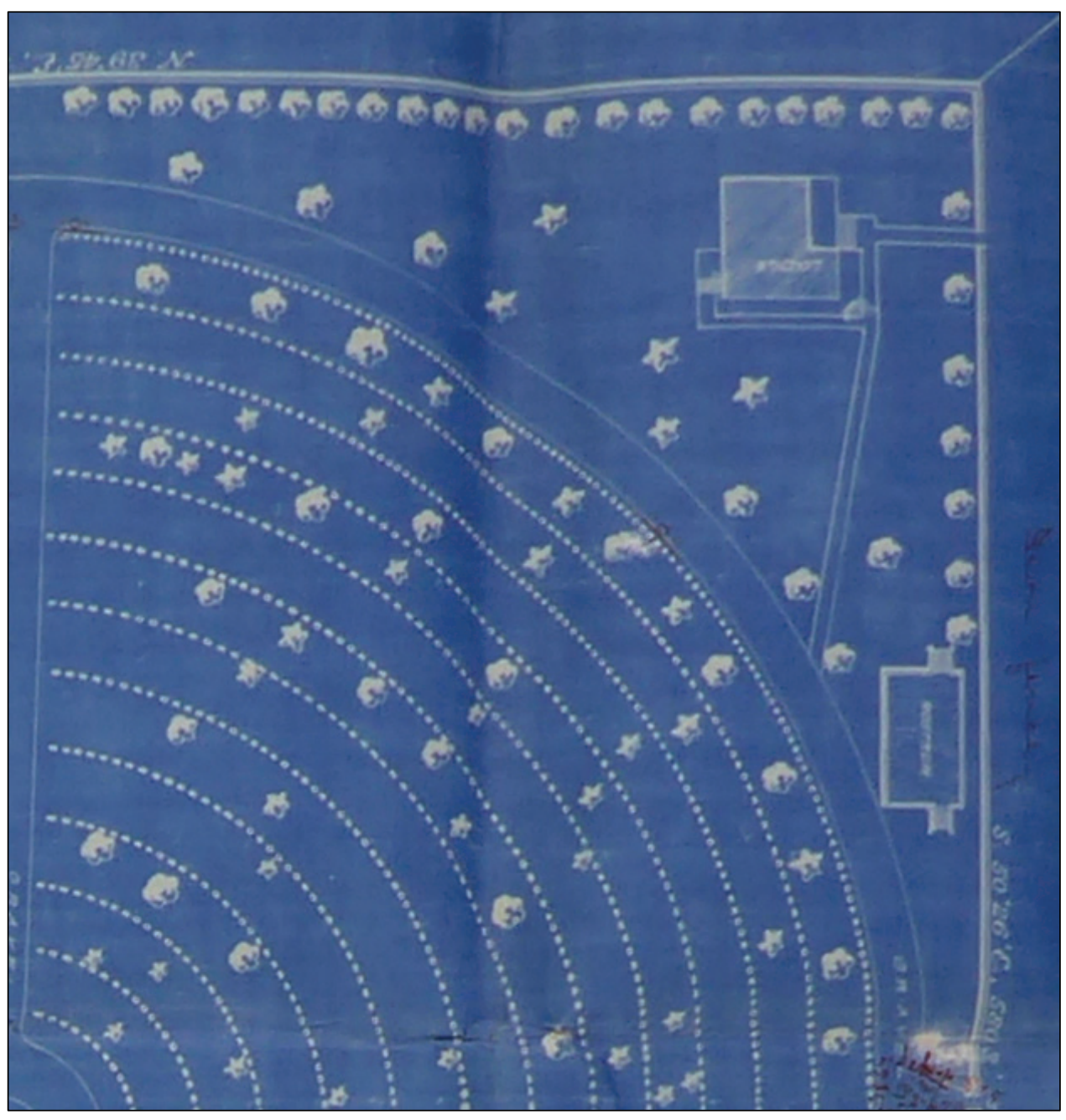


Figure 269. View to the west of the brick superintendent's lodge, 1908 (NARA College Park RG92-CA).

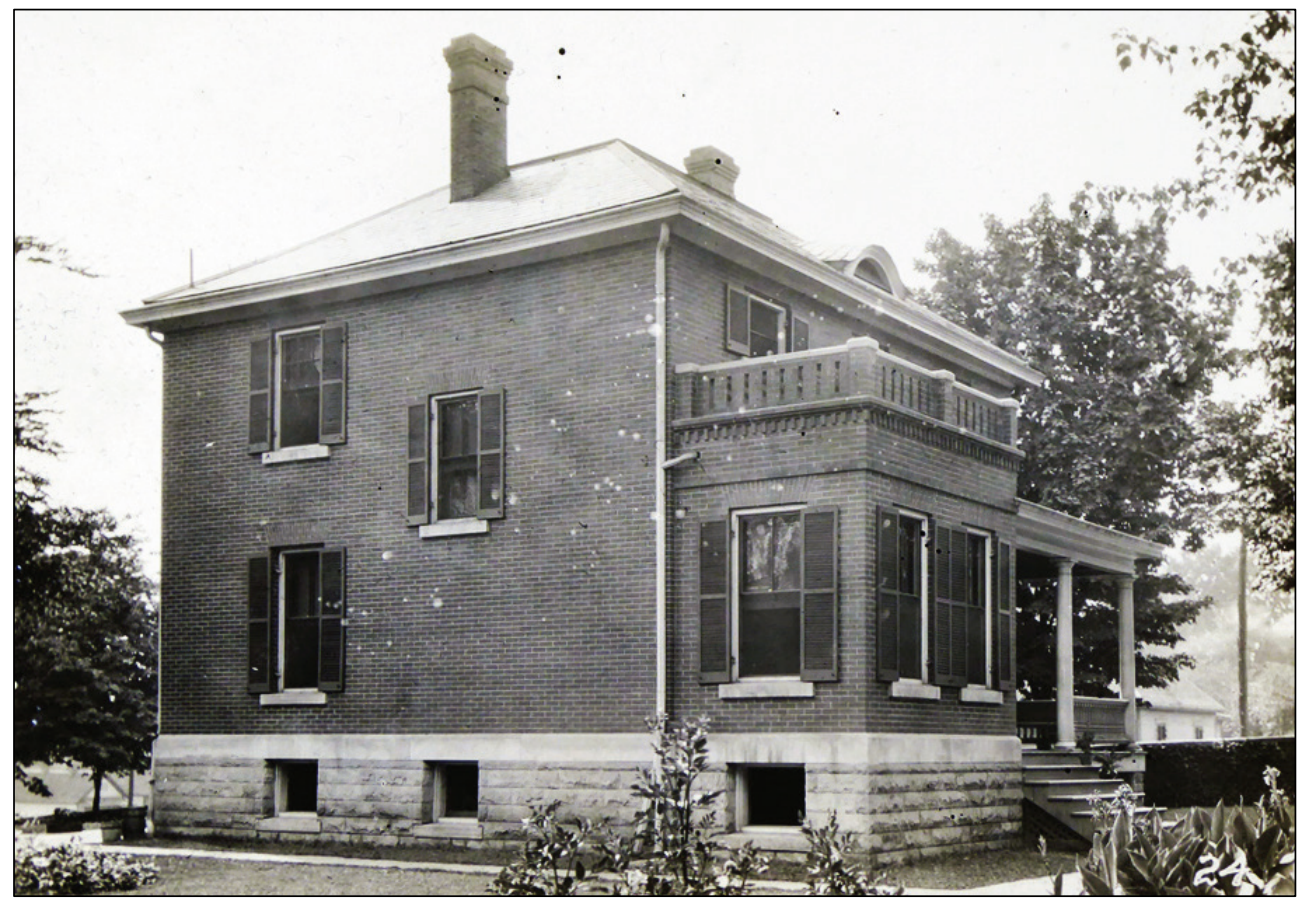

Figure 270. View to the northwest of the rostrum, 1908 (NARA College Park RG92-CA).

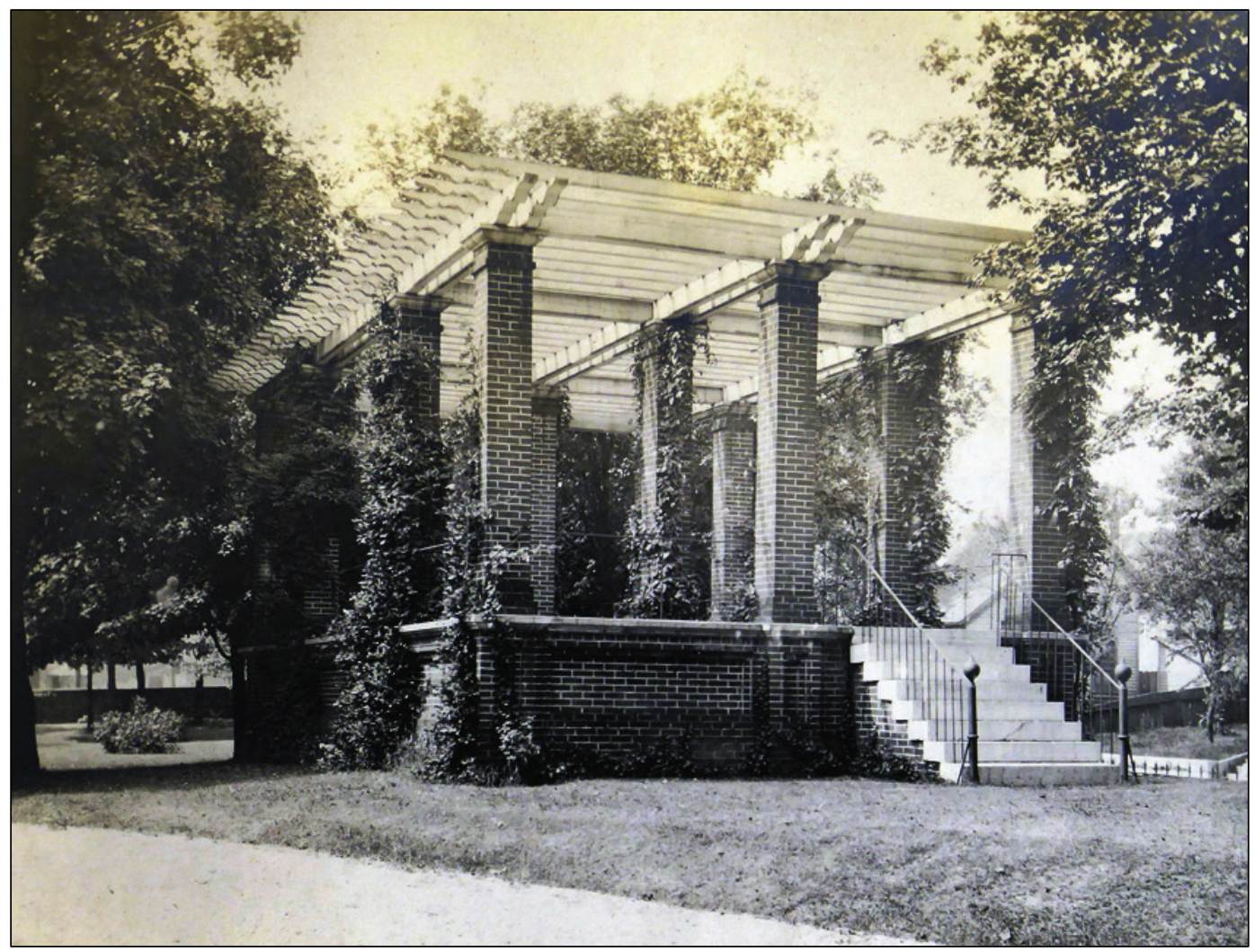


Figure 271. View to the west of the Tyson Gate, trees, and rostrum, 1908 (NARA College Park RG92-CA).

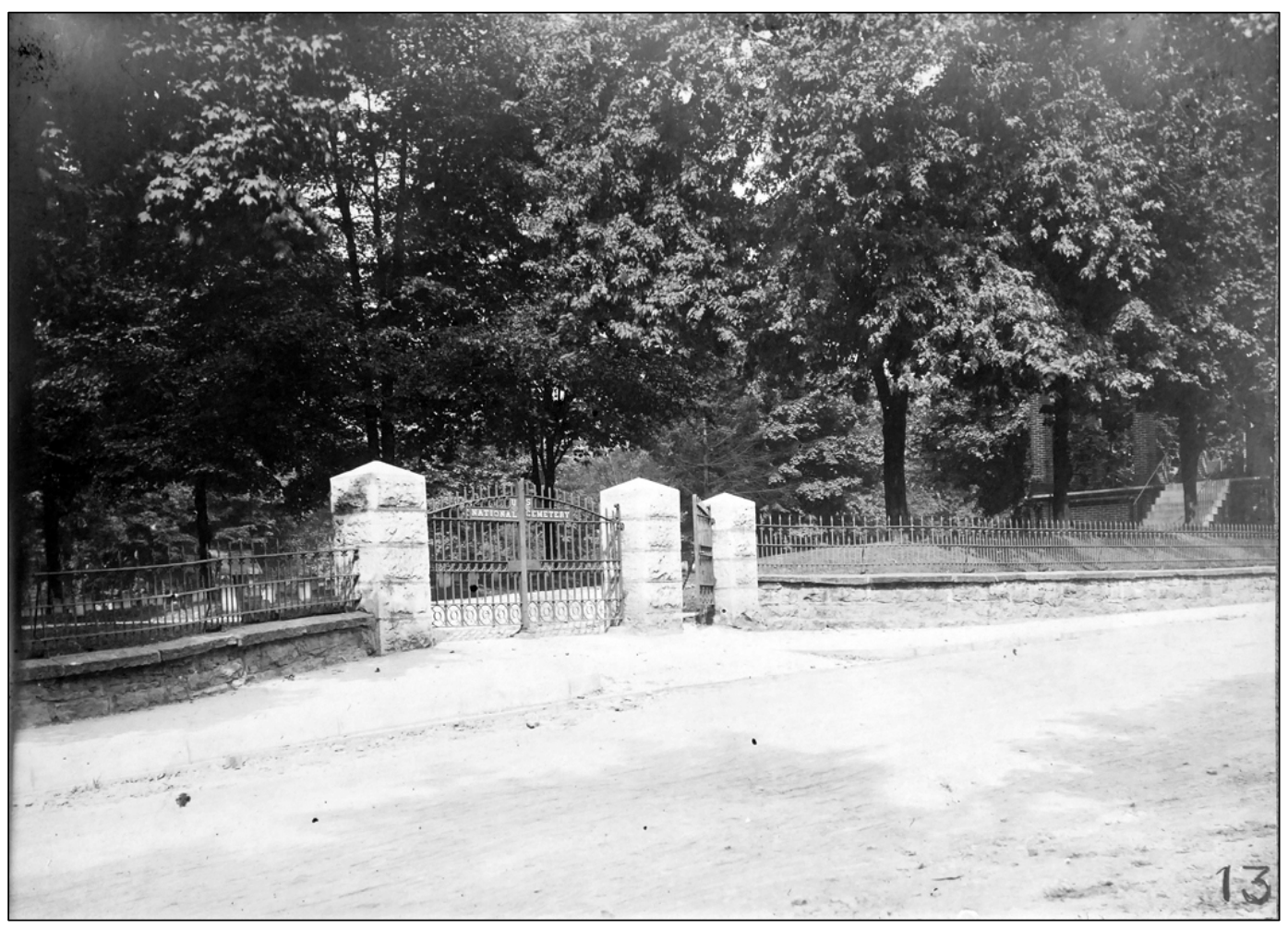

\subsubsection{1947 map}

The map from 1947 is the first map that has the species of trees indicated on it (Figure 272). The map also shows that there are no graves on the outside of the circle drive, but there is a restroom and utility building constructed in 1936 (Figure 273), the brick superintendent's lodge (Figure 274), and the rostrum (Figure 275, Figure 276, and Figure 277). There were two Maples along the walls, and one Catalpa near the utility building. The 1947 map only has trees shown and listed, but an aerial from 1948 shows that the Northeast area had quite a number of trees and shrubs compared to what the map shows (Figure 278). A large, brick garage was added to the northeast of the restroom and utility building in 1949 (Figure 279). The Tyson Gate was changed as well (Figure 280). The rostrum's roof was removed in 1958 (Figure 281). Foundation plantings were evident surrounding all of the buildings, especially the brick superintendent's lodge (Figure 282). 
Figure 272. The Northeast section as depicted on a portion of the 1947 map with types of trees (NARA, Washington DC, RG15).

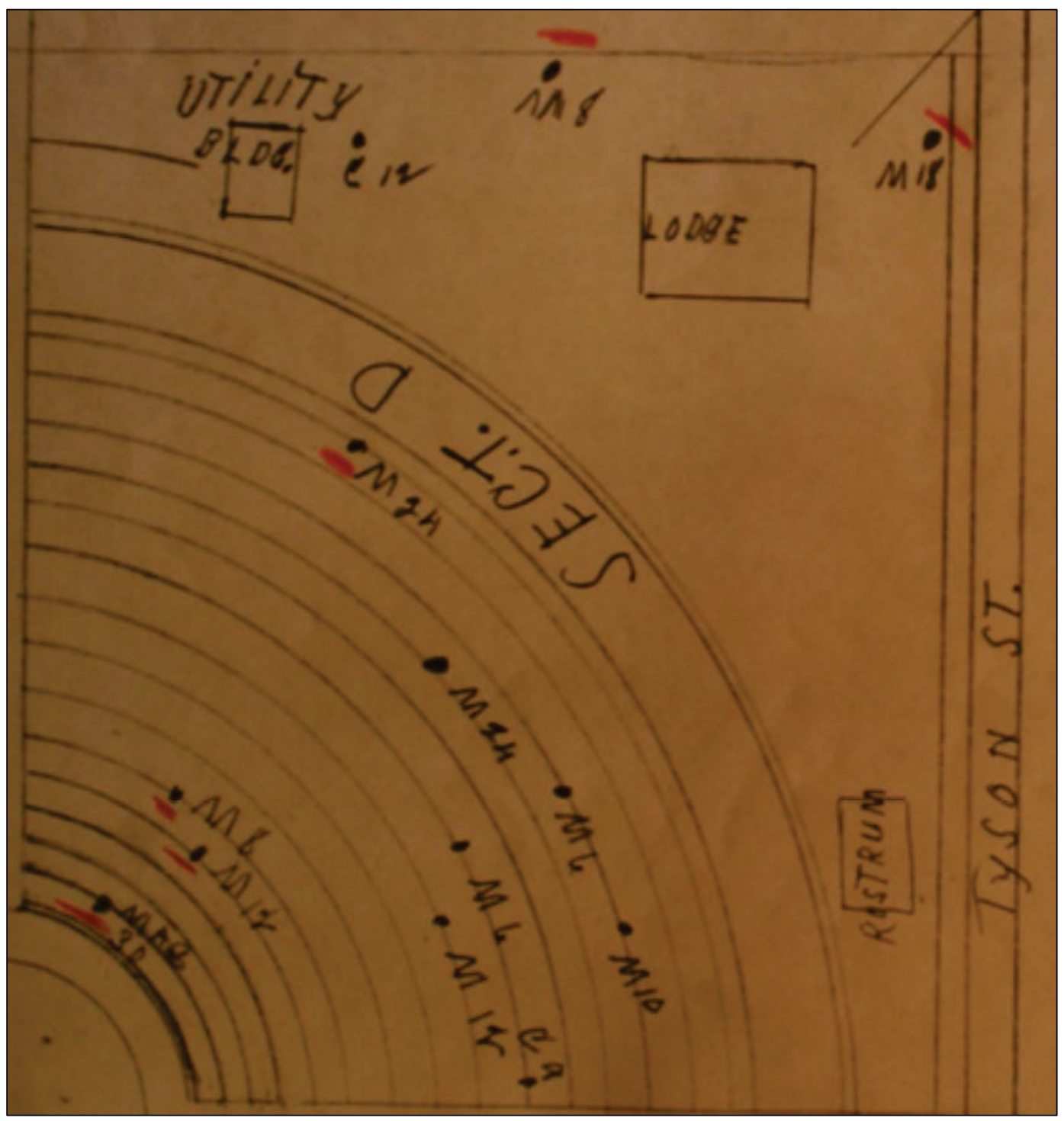


Figure 273. Restroom and utility building, 1949 (NARA, Washington DC, RG15).

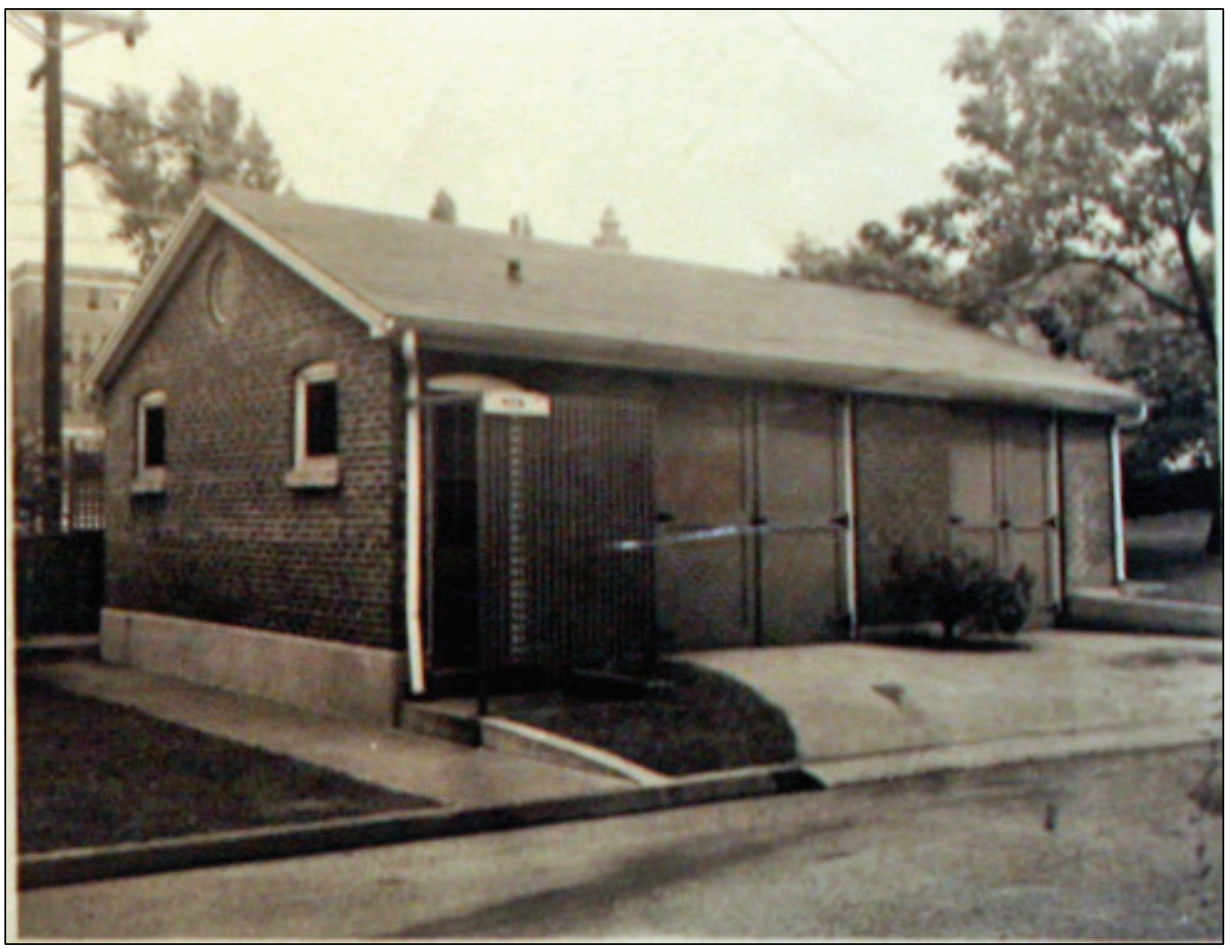

Figure 274. View to the southwest of the brick superintendent's lodge showing the pedestrian gate, 1961 (VA NCA Archives, Washington, DC).

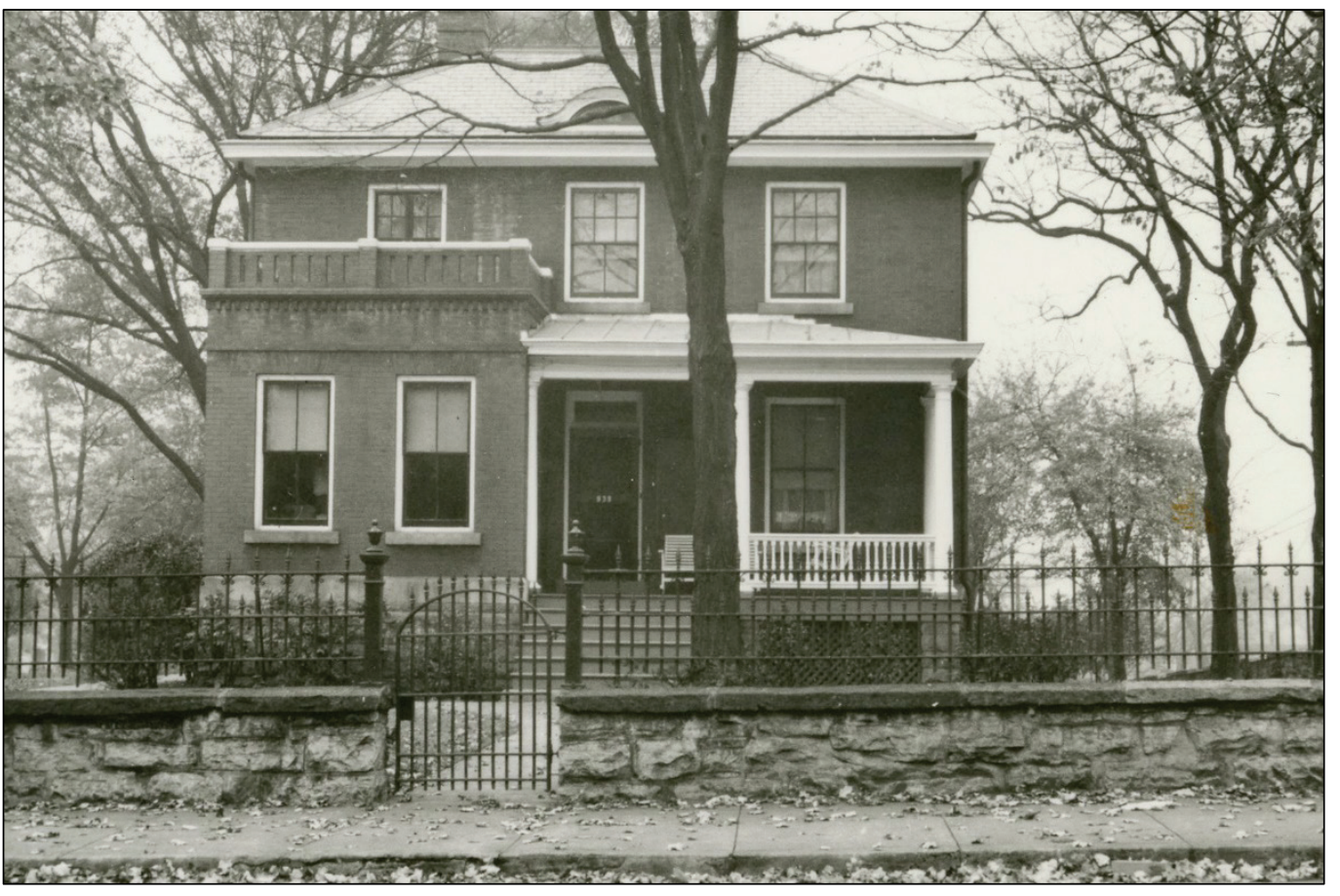


Figure 275. View to the northeast from the utility building to the rostrum, 1953 (VA NCA Archives, Washington, DC).

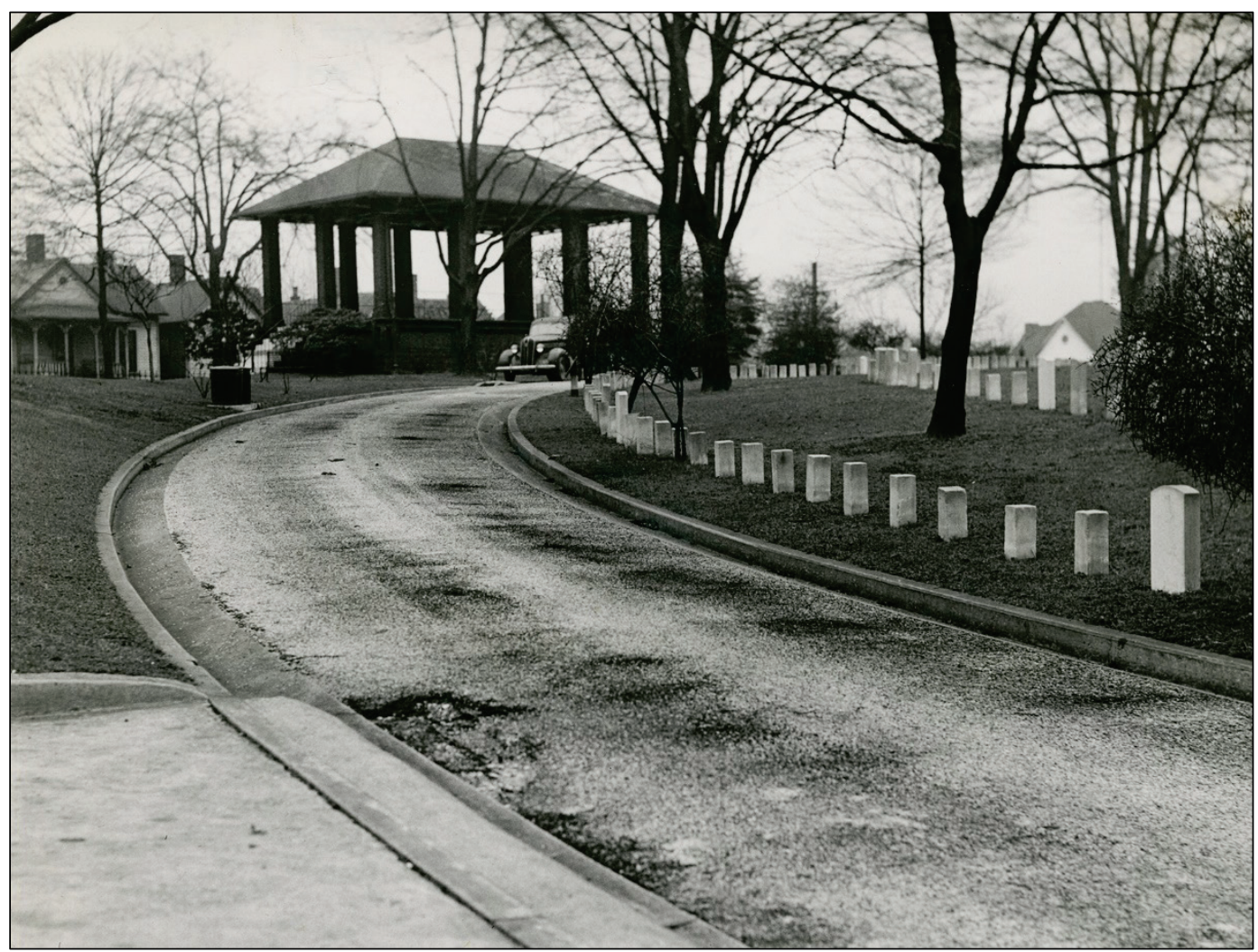

Figure 276. View to the northeast of the rostrum showing shrubs along foundation, 1953 (VA NCA Archives, Washington, DC).

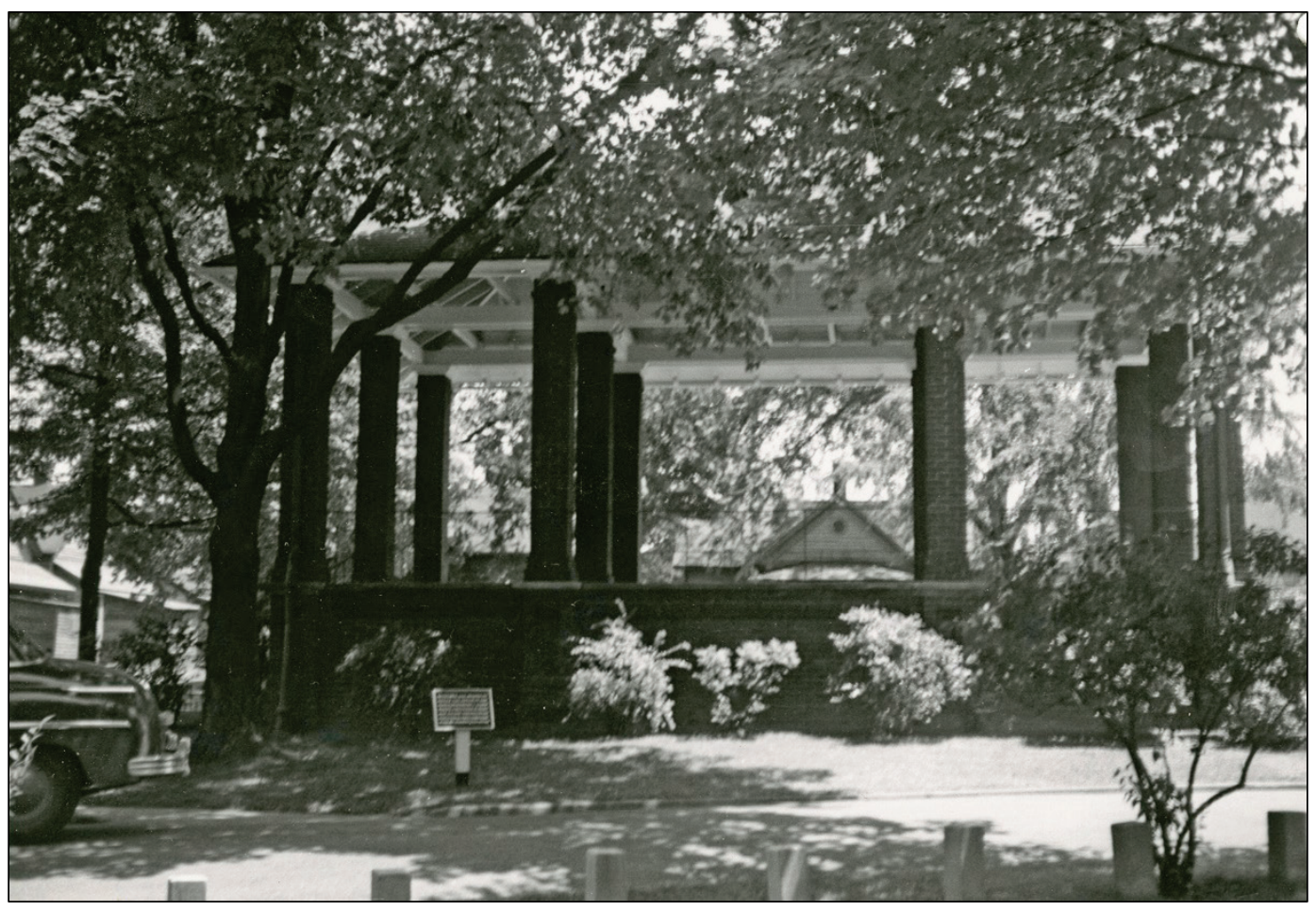


Figure 277. View to the north of the rostrum, circa 1950s (VA NCA Archives, Washington, DC).

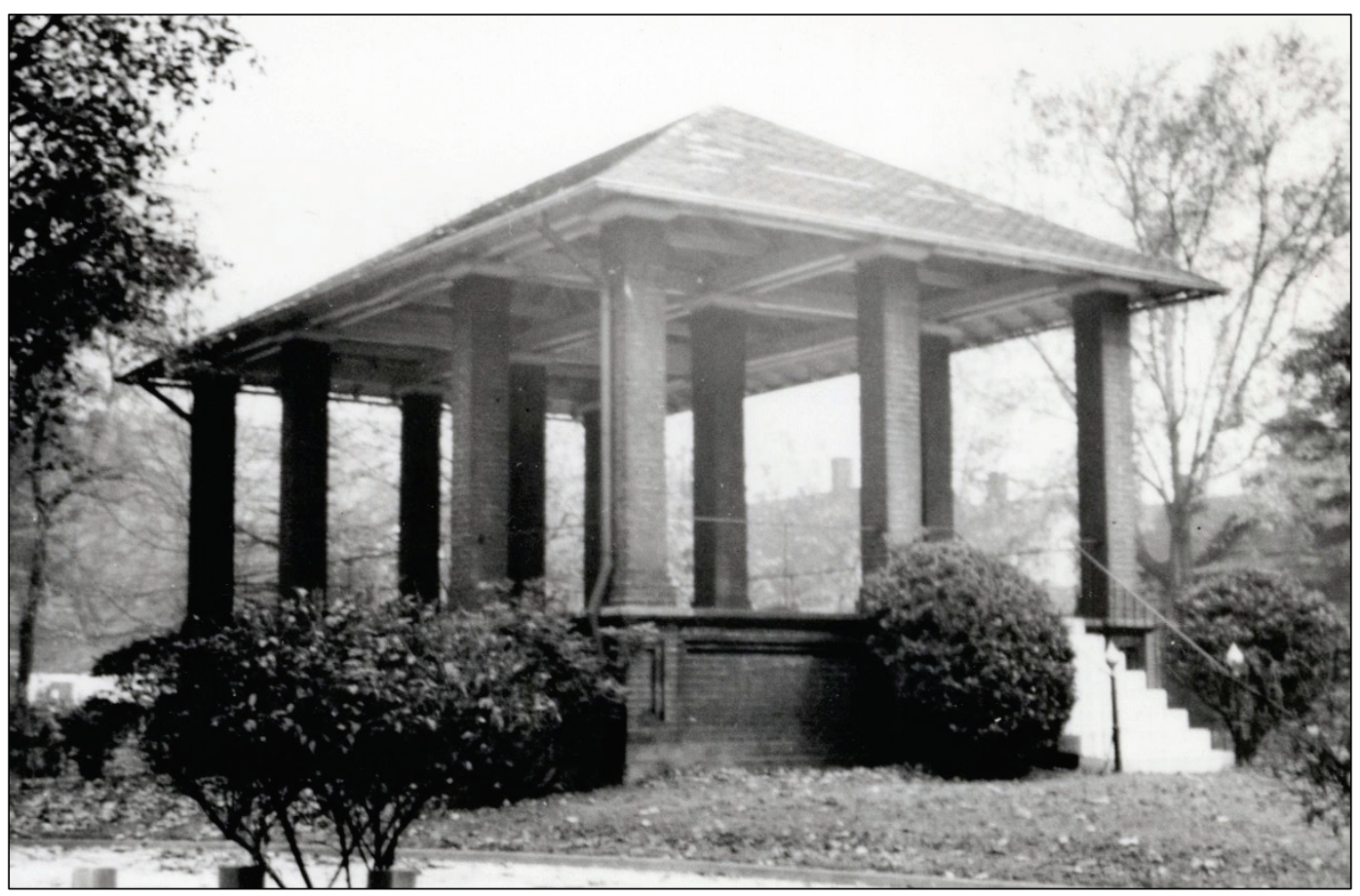

Figure 278. Aerial view of the Northeast section showing extensive cover surrounding the rostrum and brick superintendent's lodge, 1948 (HALS-TN-2, Library of Congress).

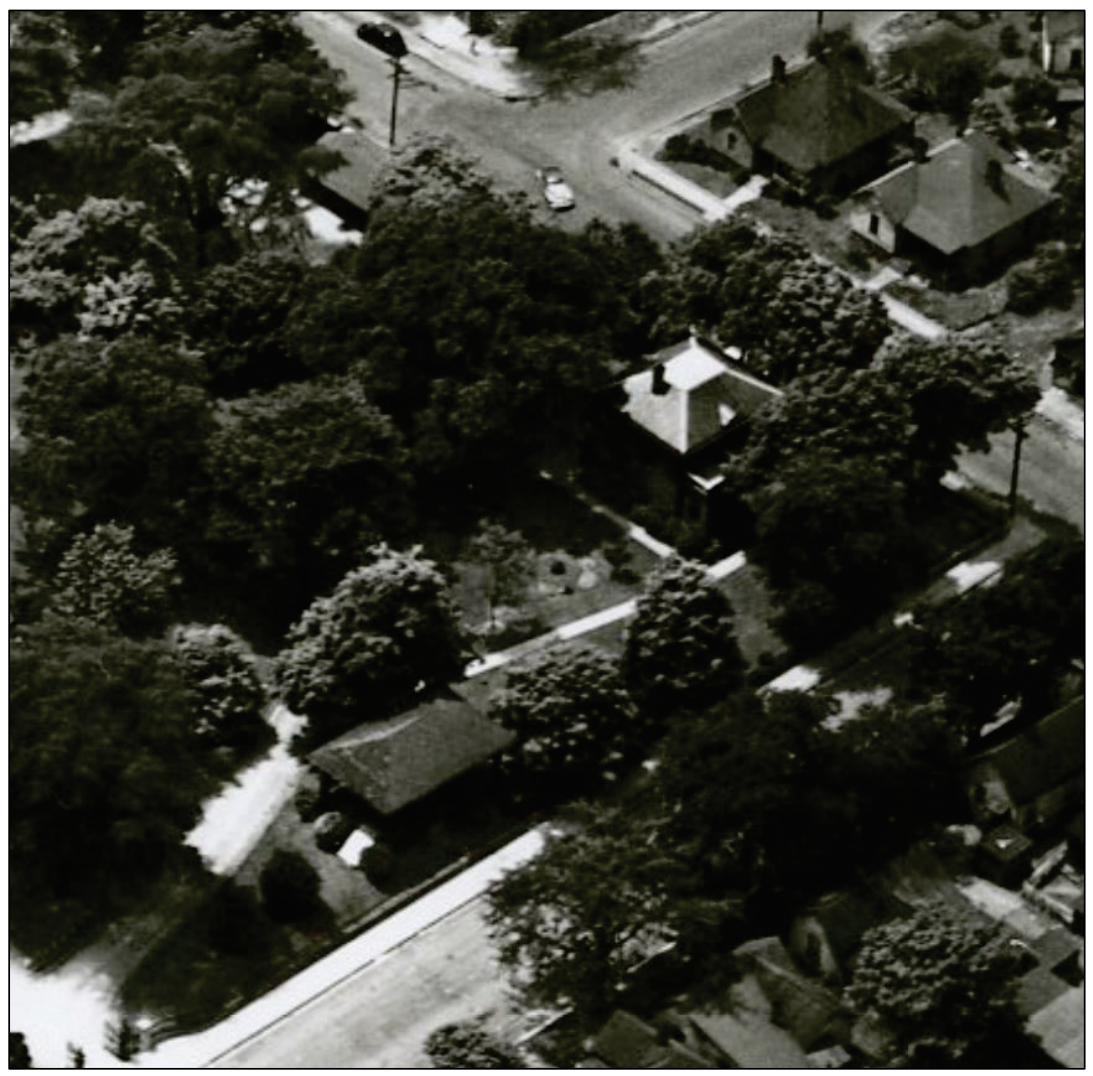


Figure 279. View to the southwest in the Northwest area of the brick utility building, 1949 (VA NCA Archives, Washington, DC). Note the shrub in the foreground.

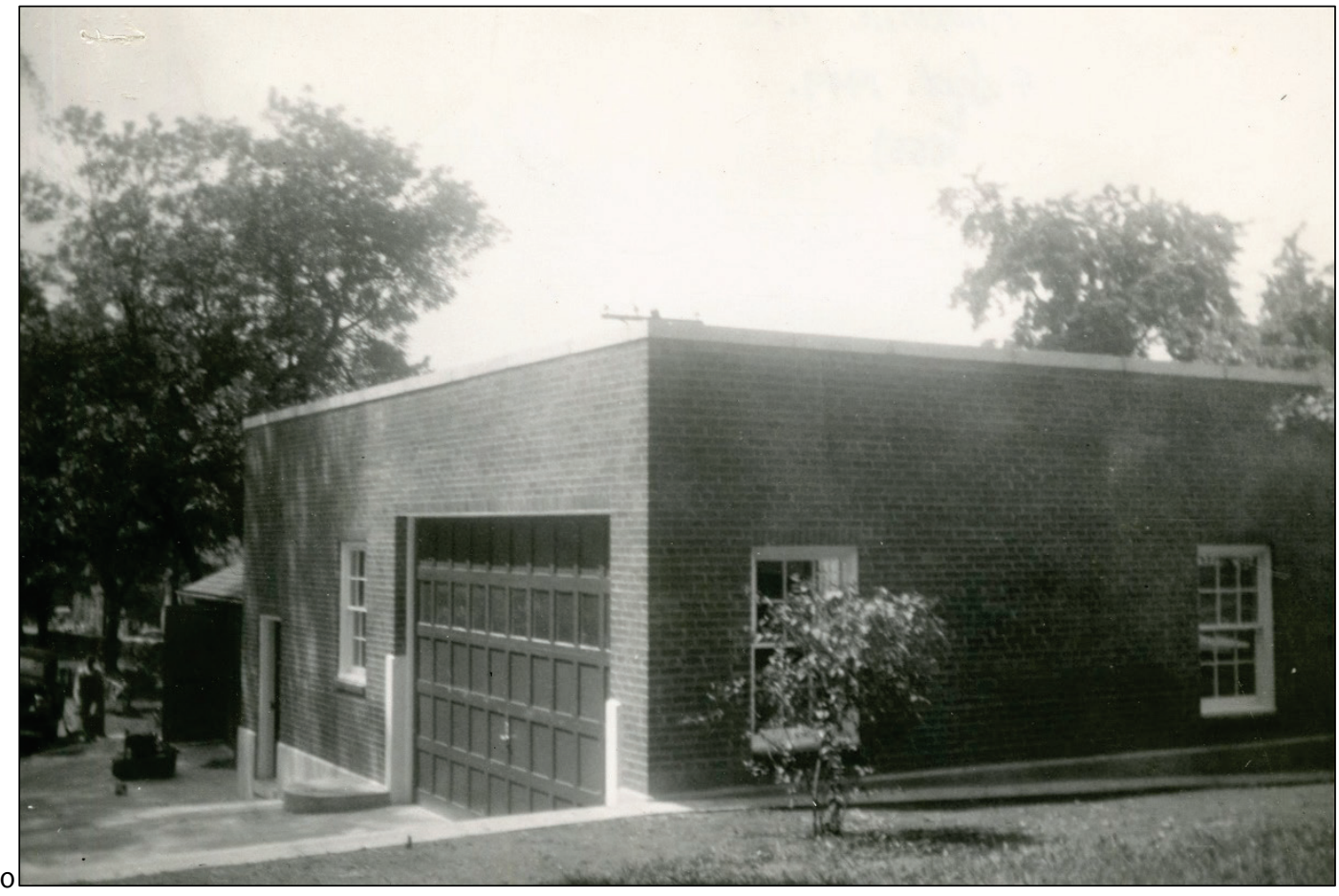

Figure 280. View to the southwest of the Tyson Gate, 1953 (VA NCA Archives, Washington, $\mathrm{DC})$.

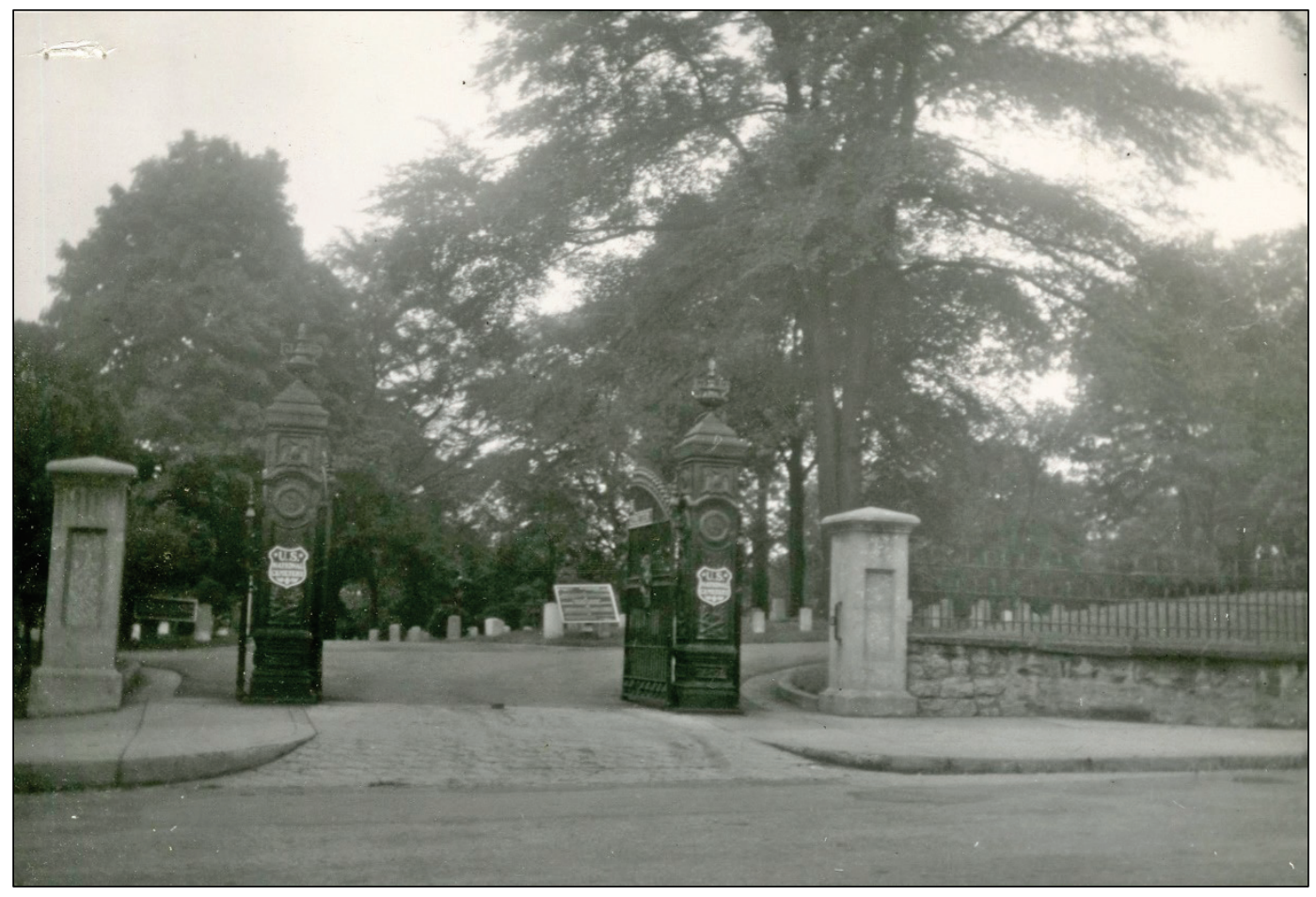


Figure 281. Rostrum without a roof, circa 1958 (NARA, Washington DC, RG15).

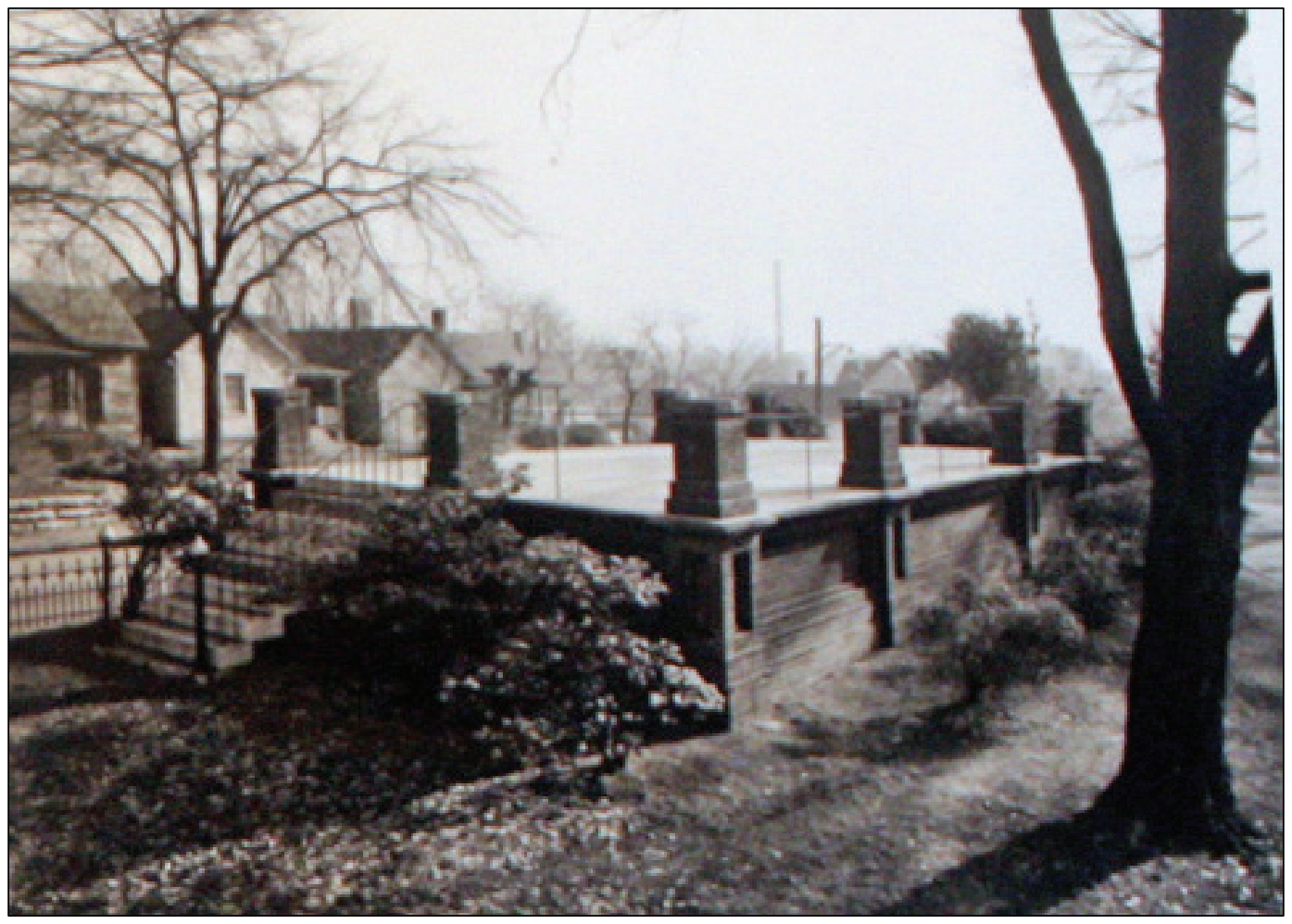

Figure 282. View to the south of the corner concrete pylon and brick superintendent's lodge, 1961 (VA NCA Archives, Washington, DC).

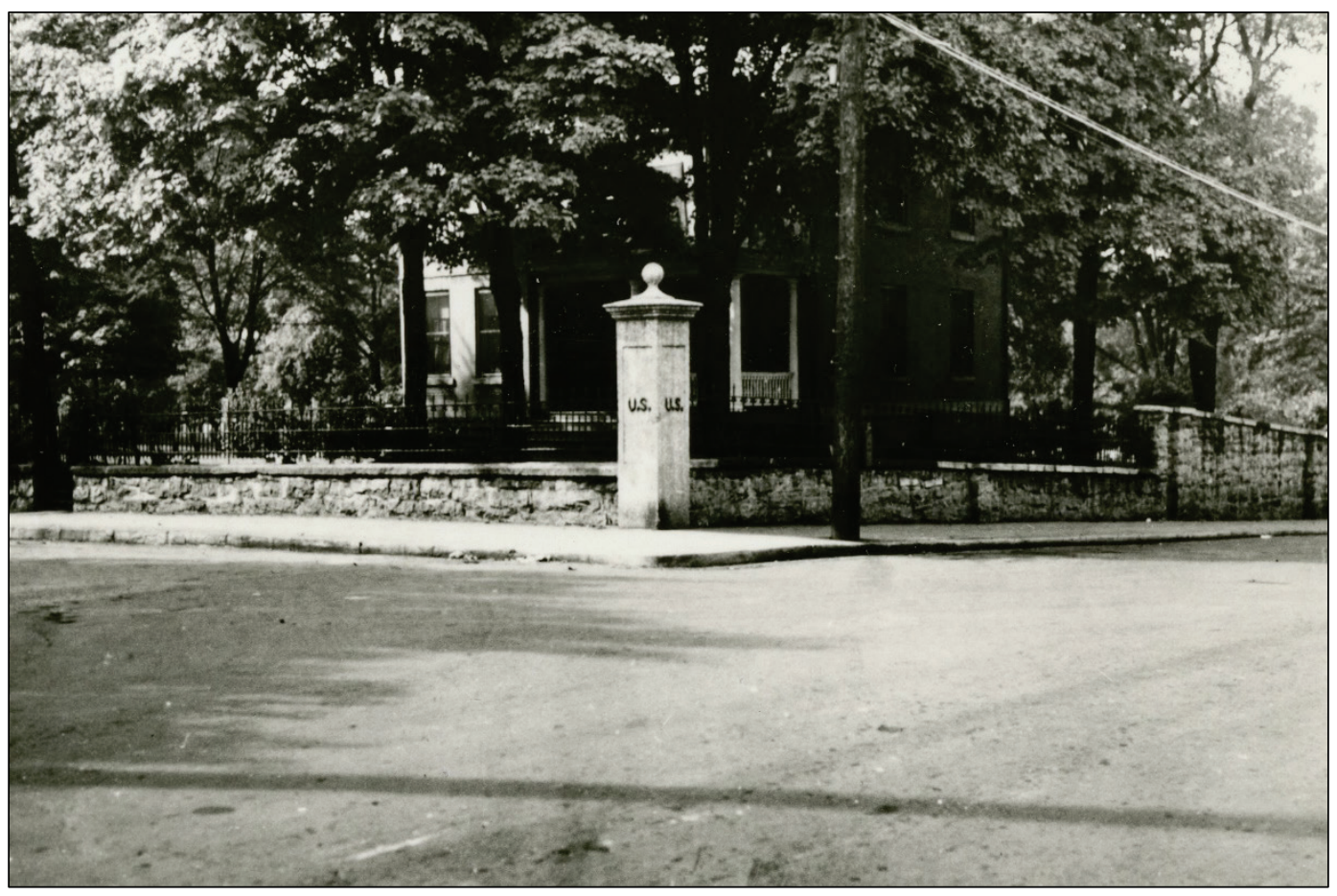


A planting plan for the brick superintendent's lodge from 1966 (Figure 283) has the lodge fronted by two Saucer Magnolias (Magnolia $\times$ soulangeana) and two Redflowering Dogwoods (Cornus florida var.) on the southeast side of the lodge. The north corner of the lodge had foundation plantings of one Foster Holly (Ilex $\times$ attenuata 'Fosteri') surrounded by two Burford Chinese Hollies (Ilex cornuta 'Burfordii'), three Pfitzer Compact Junipers (Juniperus $\times$ pfitzeriana), and four Zabel Common Laurelcherries (Prunus laurocerasus 'Zabeliana'). The southeast side of the lodge had foundation plantings of five Browns Anglojap Yew (Taxus x media), three Littleleaf Japanese Hollies (Ilex crenata 'Compacta'), and three Holly Osmanthus' (Osmanthus heterophyllus). The rear yard of the lodge was separated from the rest of the area by a wood, basket-weave fence. The 1966 planting plan also shows that the Northwest area had not been planned for burials yet.

Figure 283. Planting plan for the brick superintendent's lodge as depicted on a portion of the 1966 map (VA NCA Archives, Washington, DC).

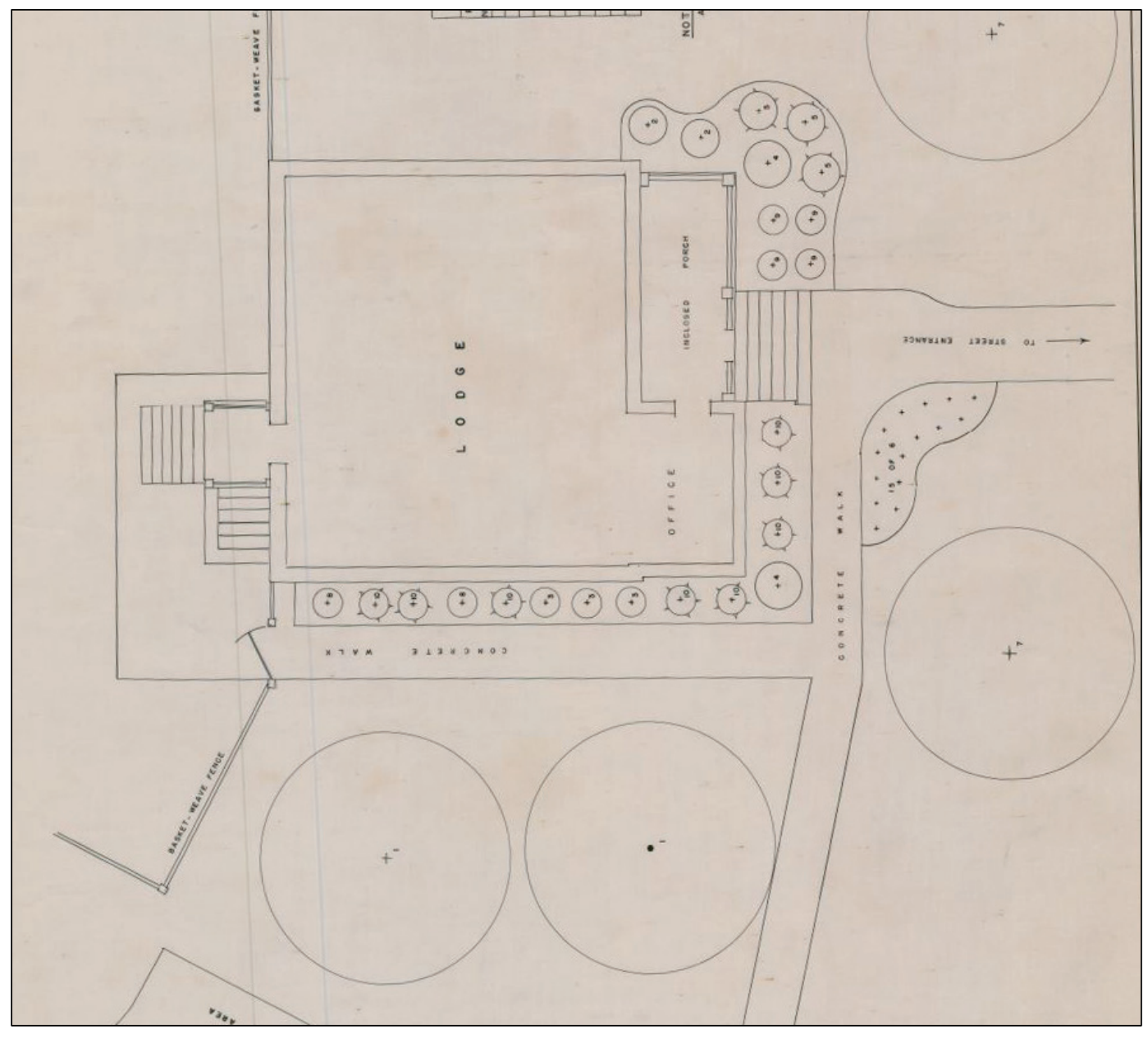




\subsubsection{1971 map}

The map from 1971 does not have landscaping depicted on it, but what it does show is that the rostrum was demolished (1960). In its place are three new rows of graves for a new Section $Y$ and a new Memorial Section (Figure 284). Lattice was added to the front of the restroom building in 1987 (Figure 285). The area lost most of its formality and planting with the demolition of the rostrum (Figure 286). The brick superintendent's lodge was demolished in 1993.

Figure 284. Northeast section as depicted on a portion of the 1971 map (VA NCA Archives, Washington, DC).

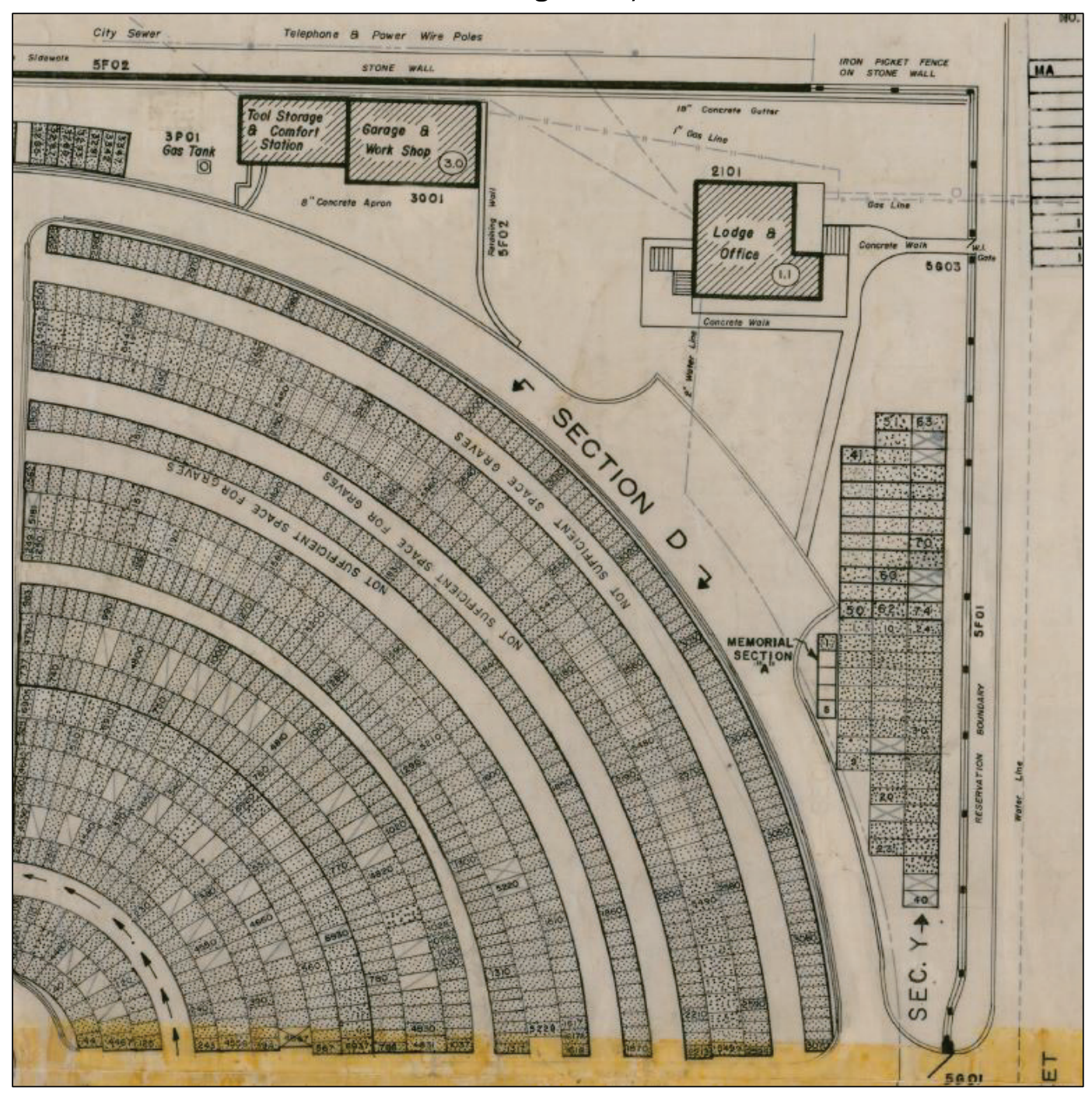


Figure 285. View to the northwest of the restroom building showing creeping junipers and evergreen shrubs planted in front, 1989 (VA NCA Archives, Washington, DC).

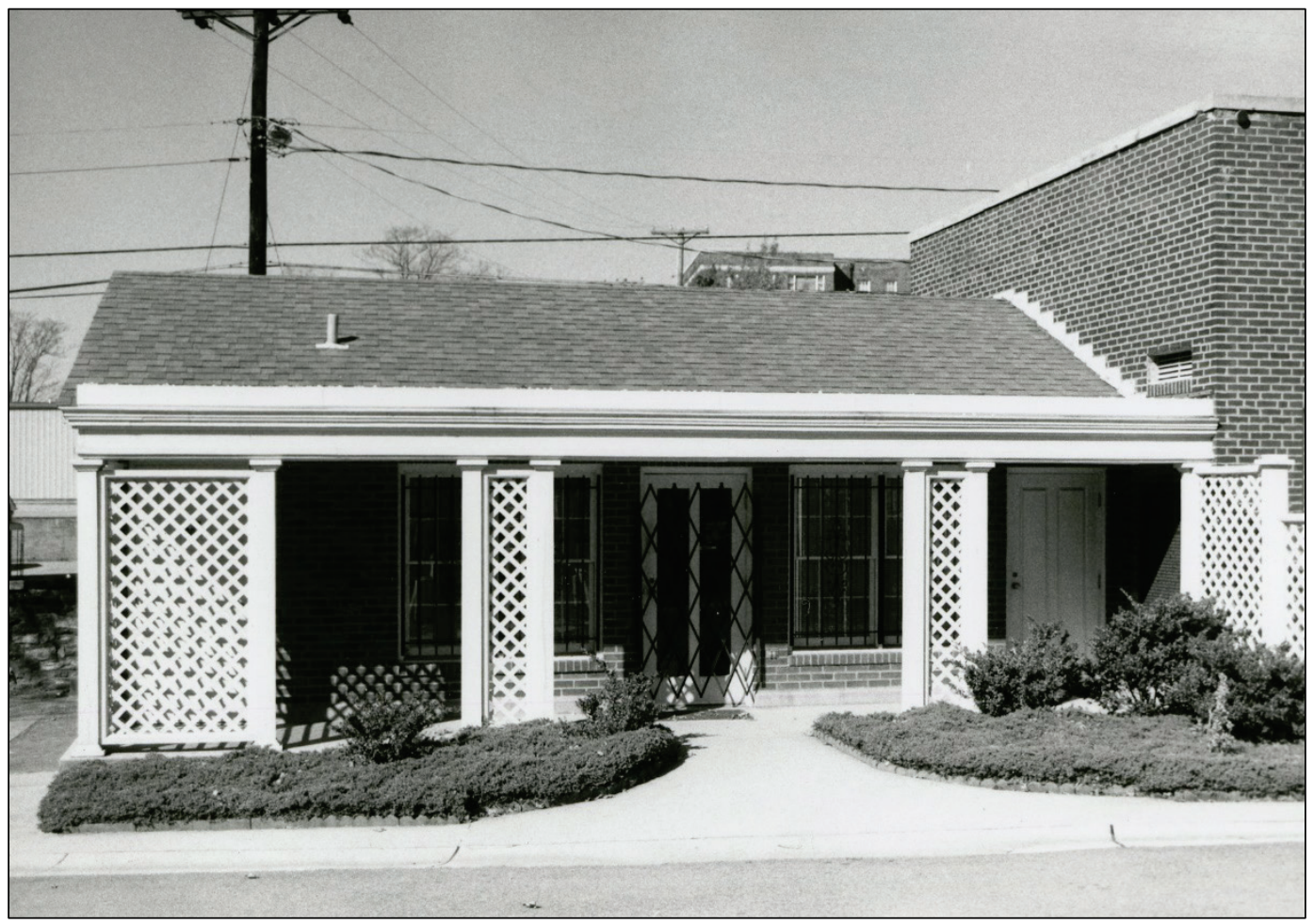

Figure 286. View to the northwest along the circle drive towards the Section $\mathrm{Y}$ with the Tyson Gate on the right, 1989 (VA NCA Archives, Washington, DC).

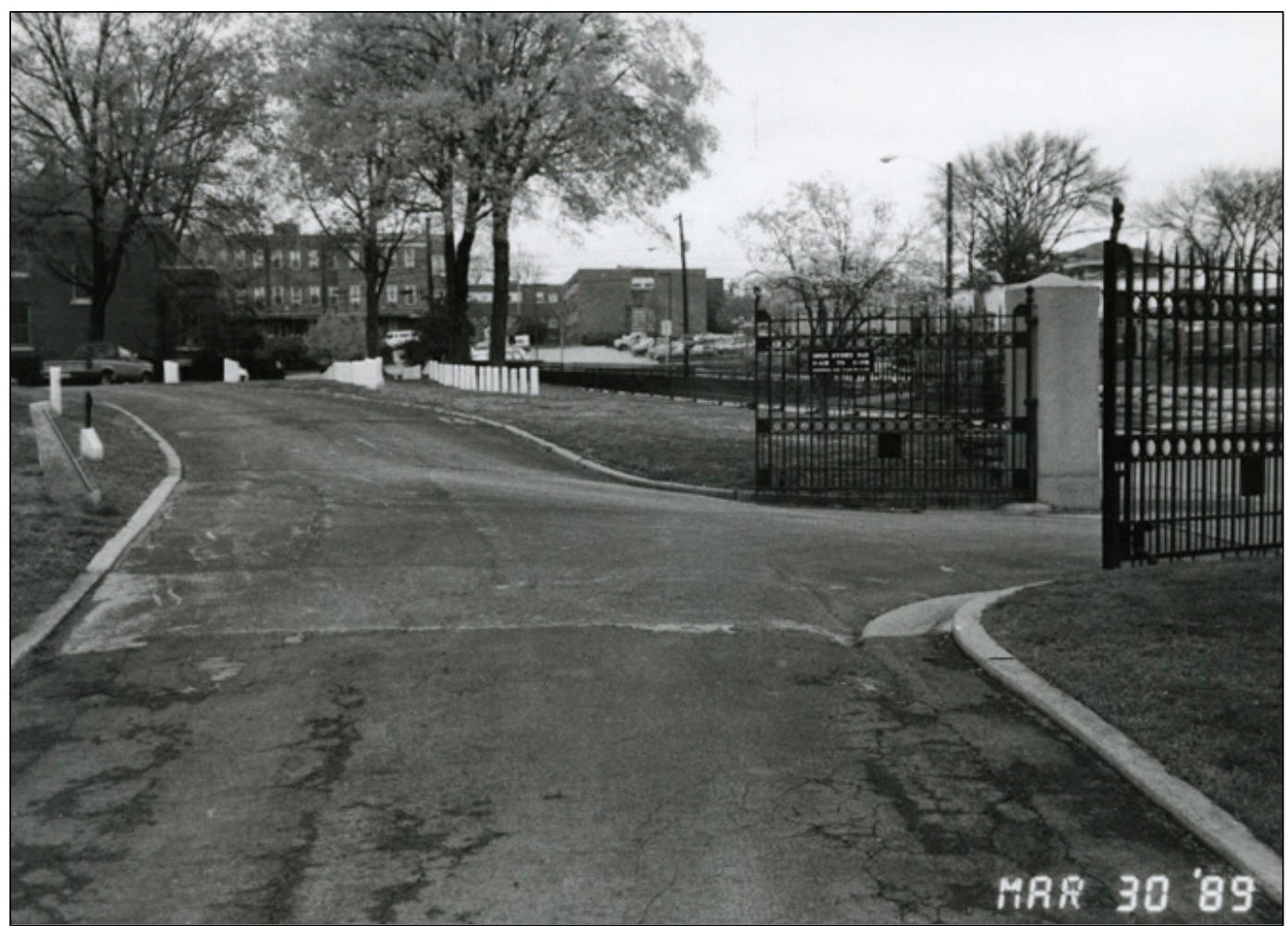




\subsubsection{2019 map}

The map from 2019 does have landscaping depicted on it, and it shows that the brick superintendent's lodge area is now filled with an extension of the burial area for Section Y and two new areas, Section CS and CS-2 (Figure 287). The area between Section CS and the brick utility building, which is currently used for landscape waste, has been plotted for graves as well, but it is not part of Section CS. The Northwest area is the primary location for all cemetery information and memorials. Figures 288 through 296 show scenes throughout the Northwest area.

An analysis of the trees in the Northwest area has two Sugar Maples (Acer saccharum) and two American Hollies (Ilex americana).

Figure 287. The Northwest area as depicted on a portion of the 2019 map (VA NCA Archives, Washington, DC).

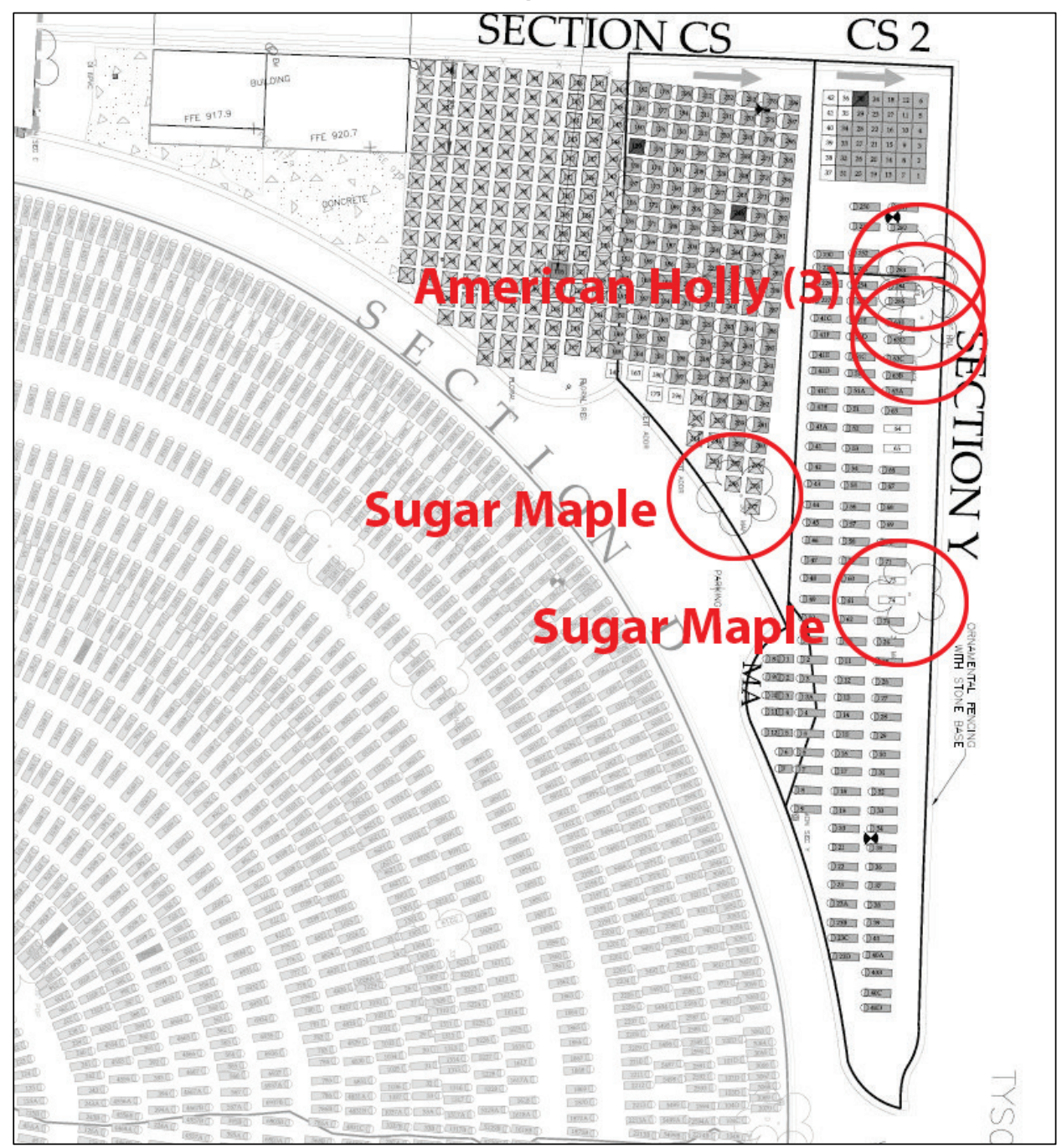


Figure 288. Looking northeast at the southwest edge of the Northwest area with the restroom building and creeping juniper plantings (ERDC-CERL, 2019).

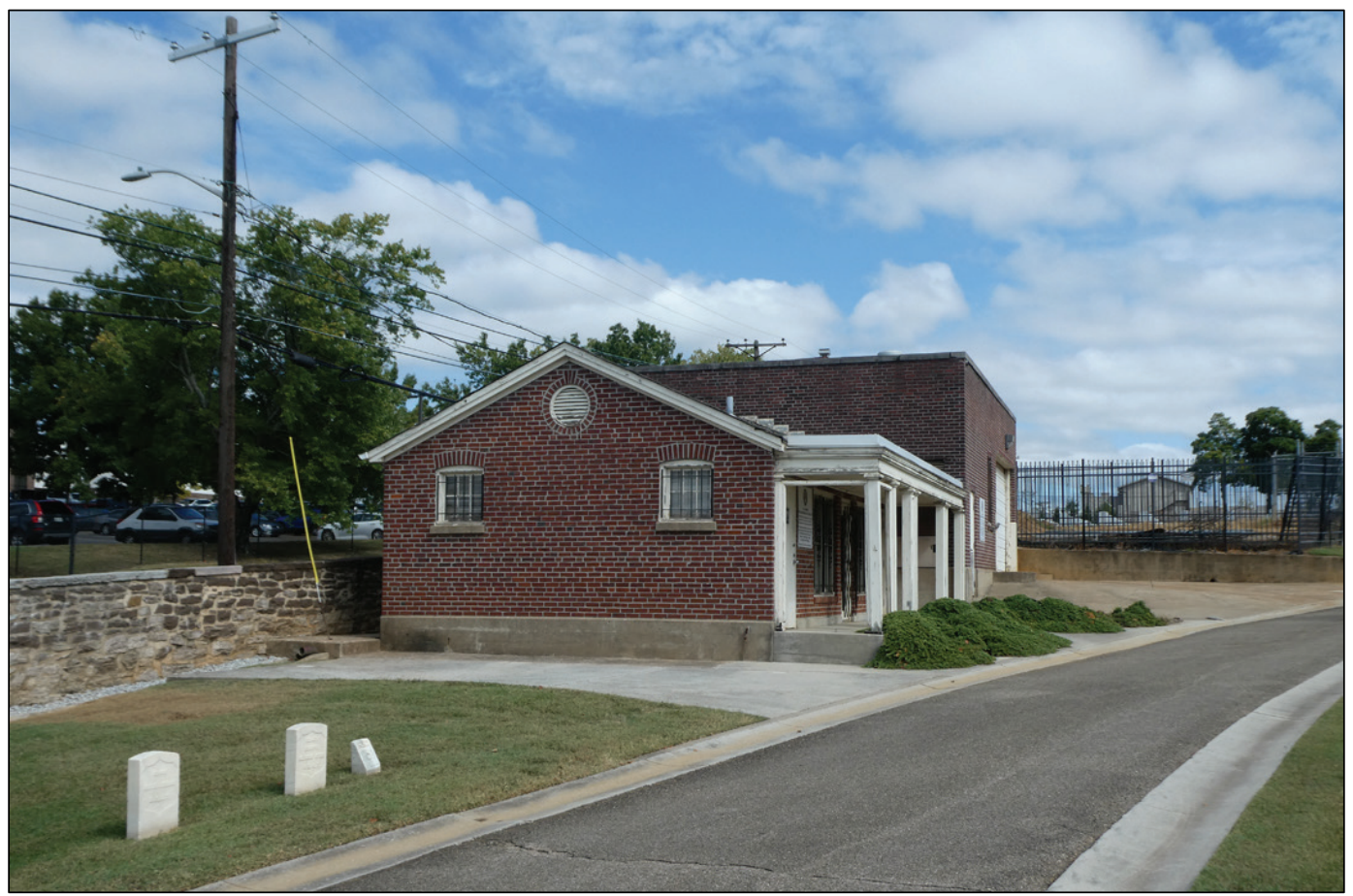

Figure 289. Looking northwest at the restroom building on the left and the utility building on the right in the Northwest area (ERDC-CERL, 2019).

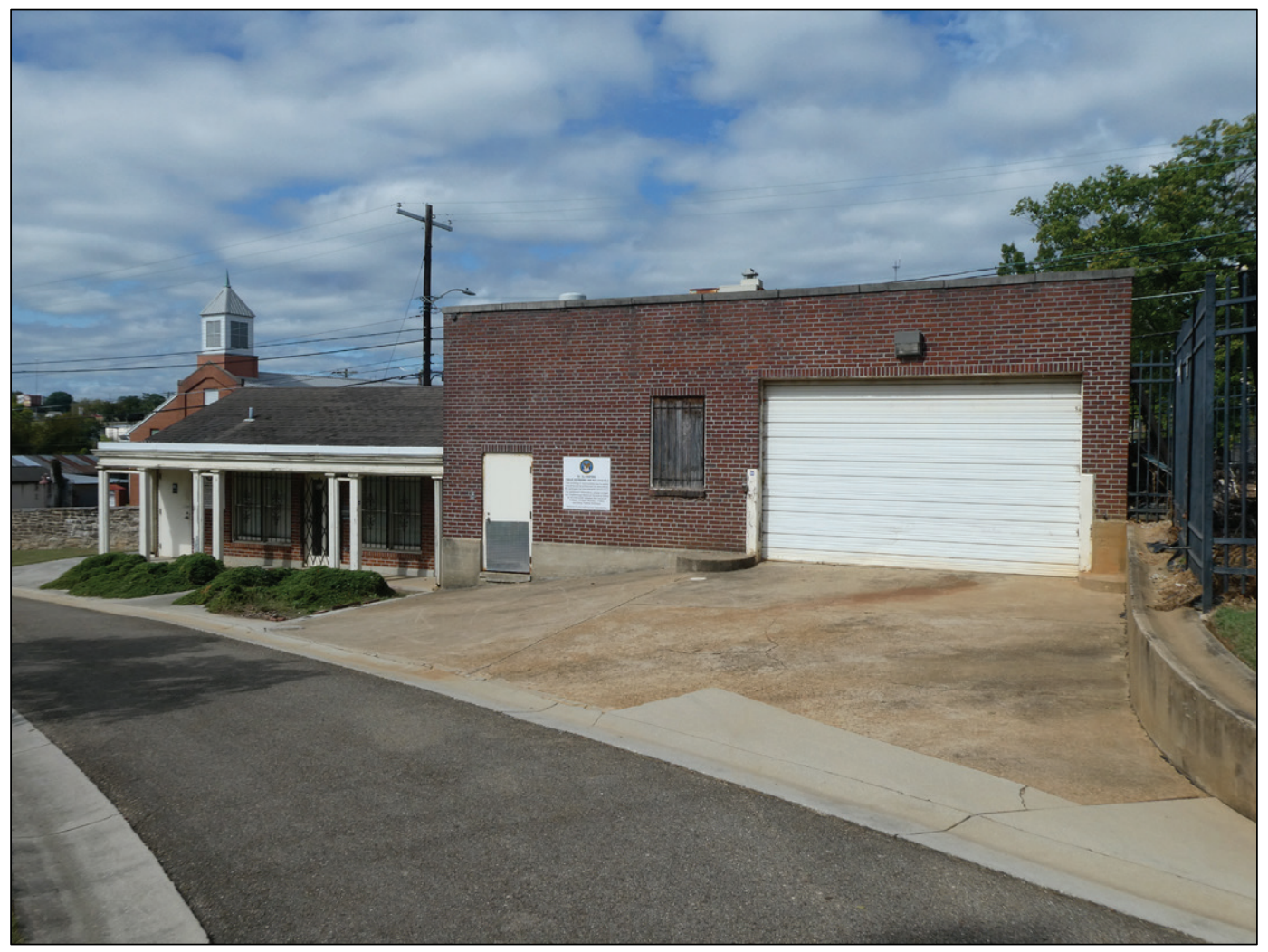


Figure 290. Looking northwest at the fenced landscape waste area in the Northwest area (ERDC-CERL, 2019).

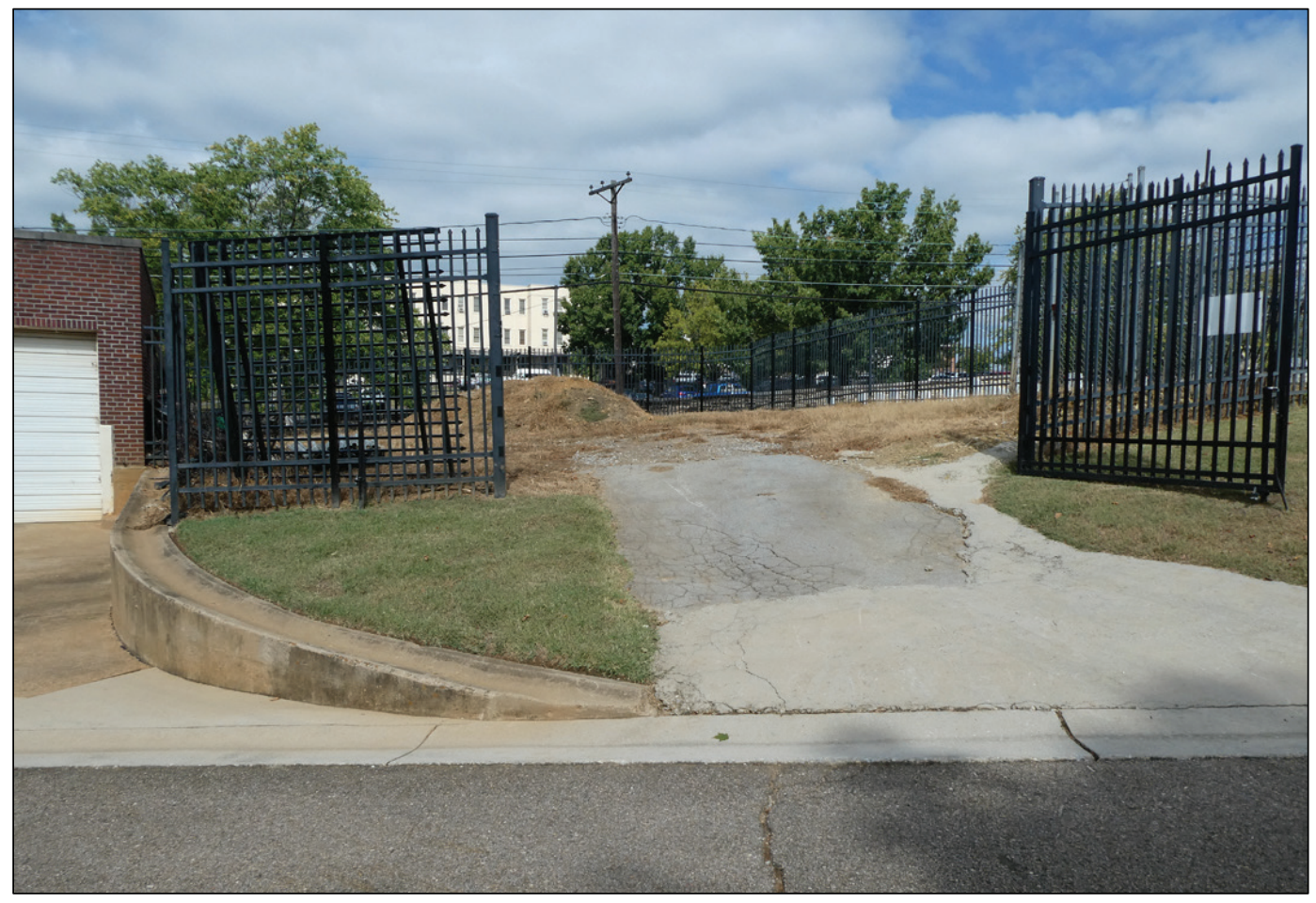

Figure 291. Looking northwest at the parking area in the Northwest area (ERDC-CERL, 2019).

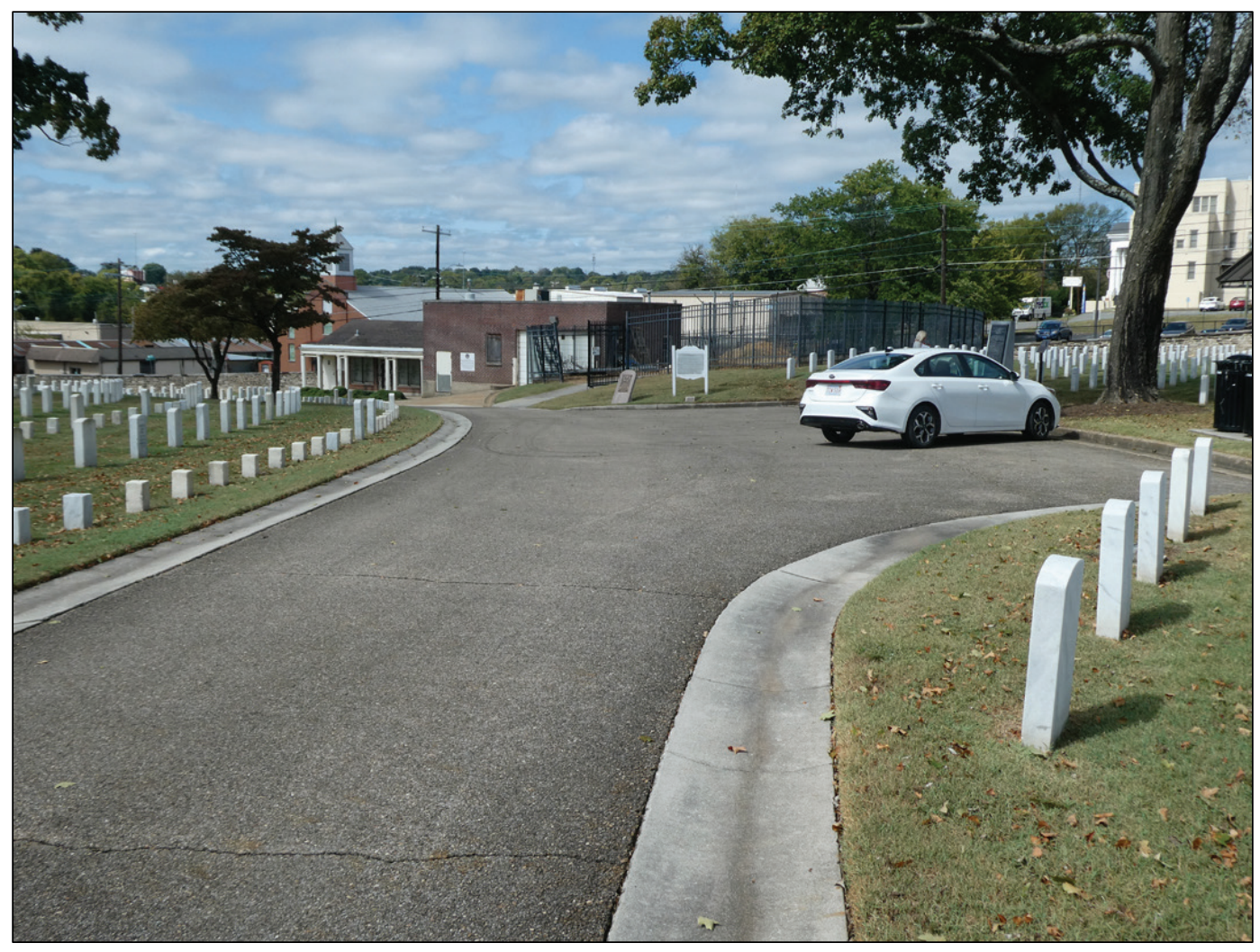


Figure 292. Looking north at the Gettysburg Address monument in the Northwest area (ERDC-CERL, 2019).

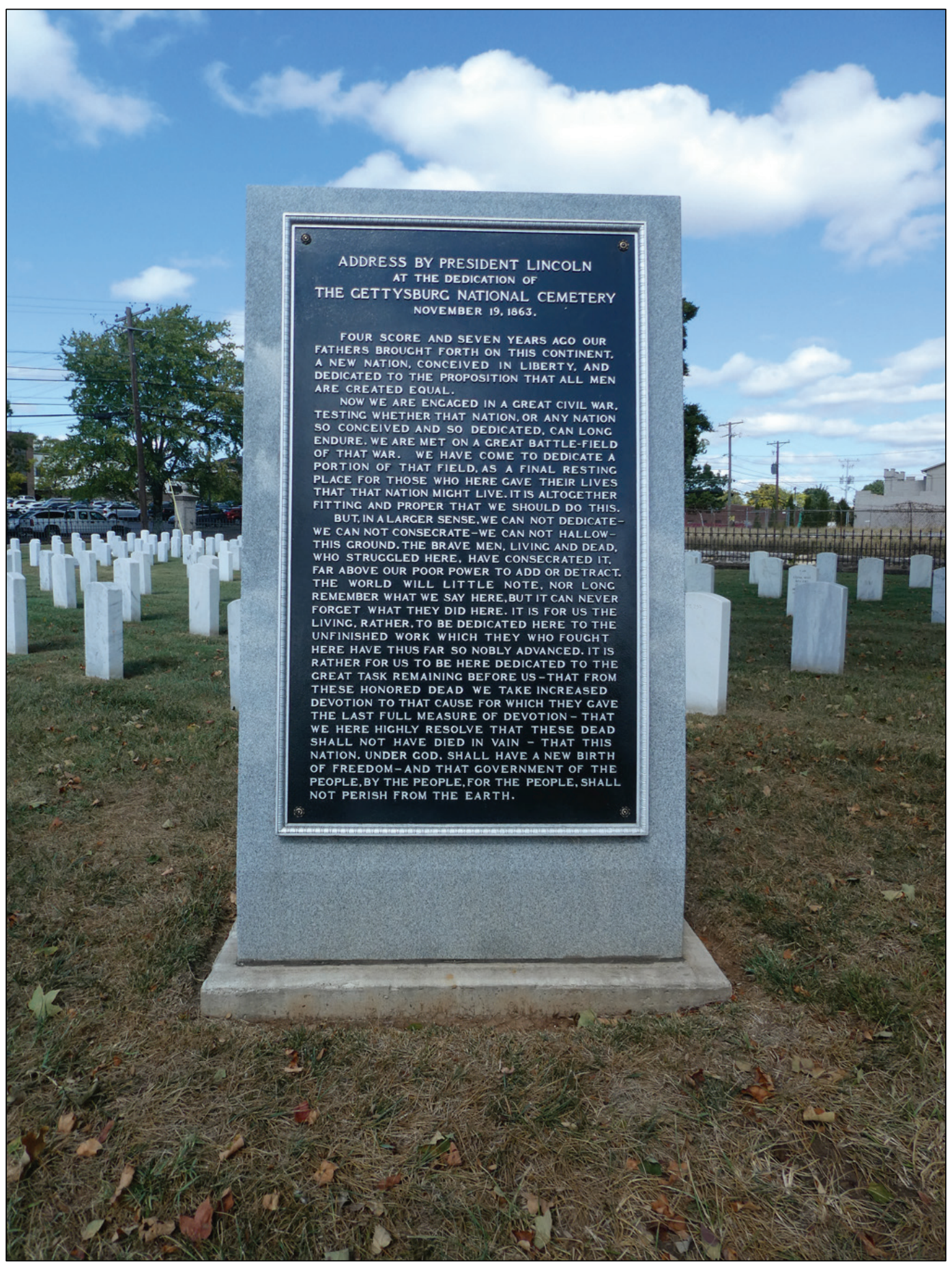


Figure 293. Looking northeast at the Memorial Area in front and Section $Y$ in the rear (ERDCCERL, 2019).

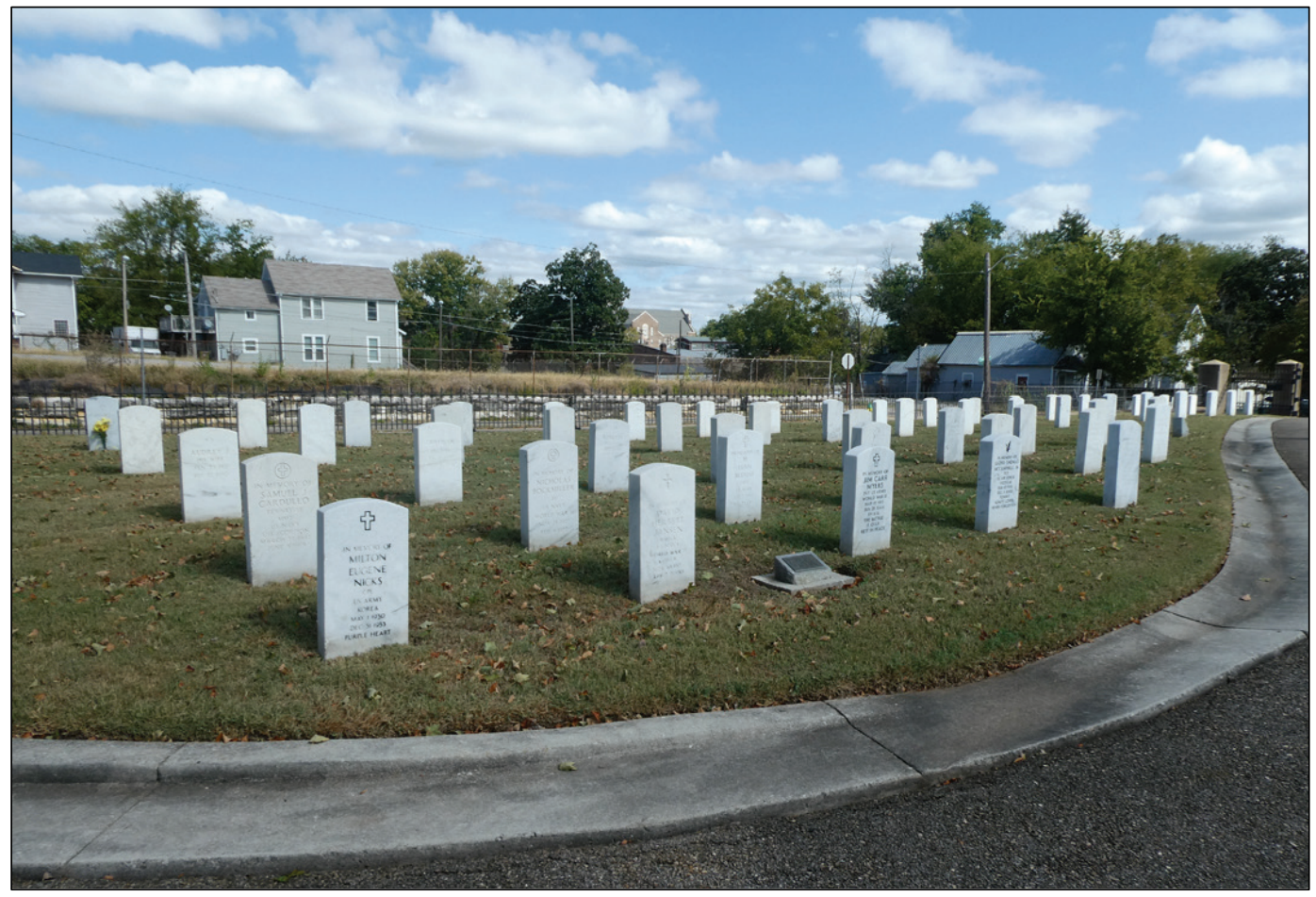

Figure 294. Looking northwest at the southeast edge of the Northwest area with Section $Y$ in the foreground (ERDC-CERL, 2019).

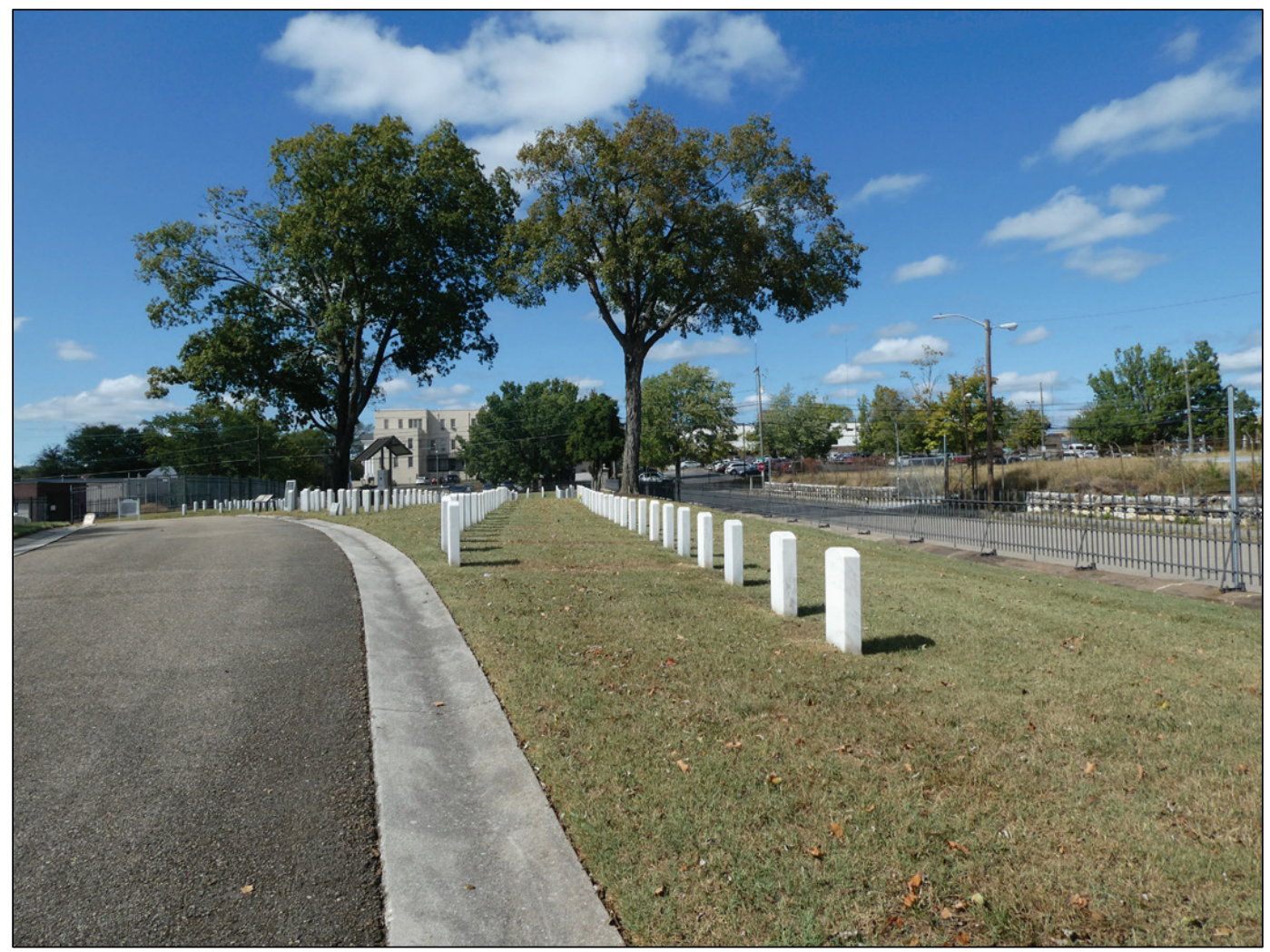


Figure 295. Looking southwest at the former location of the brick superintendent's lodge [note former lodge pedestrian gate with light colored stone cap] (ERDC-CERL, 2019).

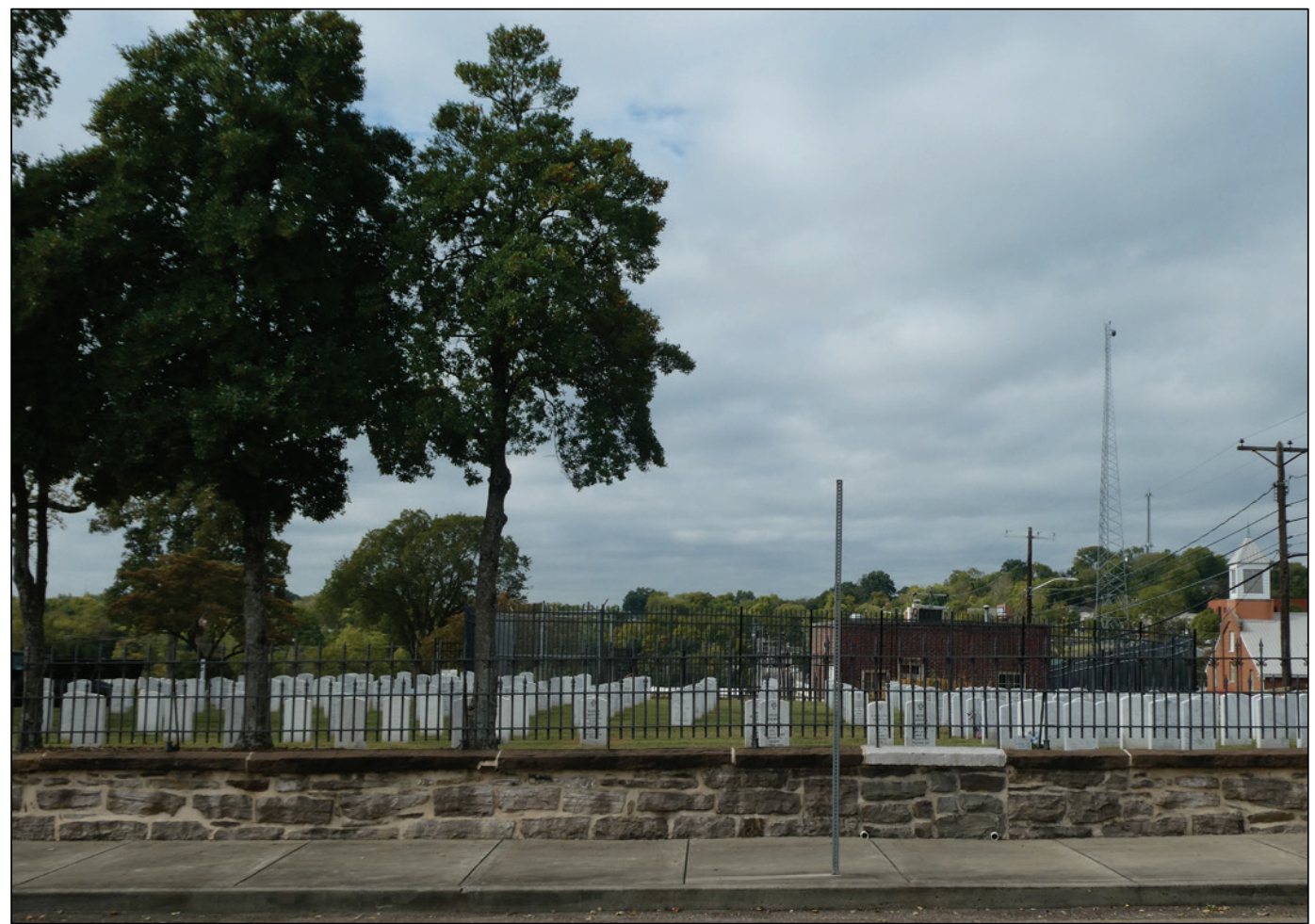

Figure 296. Looking south at the corner concrete pylon and Section CS-2 (ERDC-CERL, 2019).

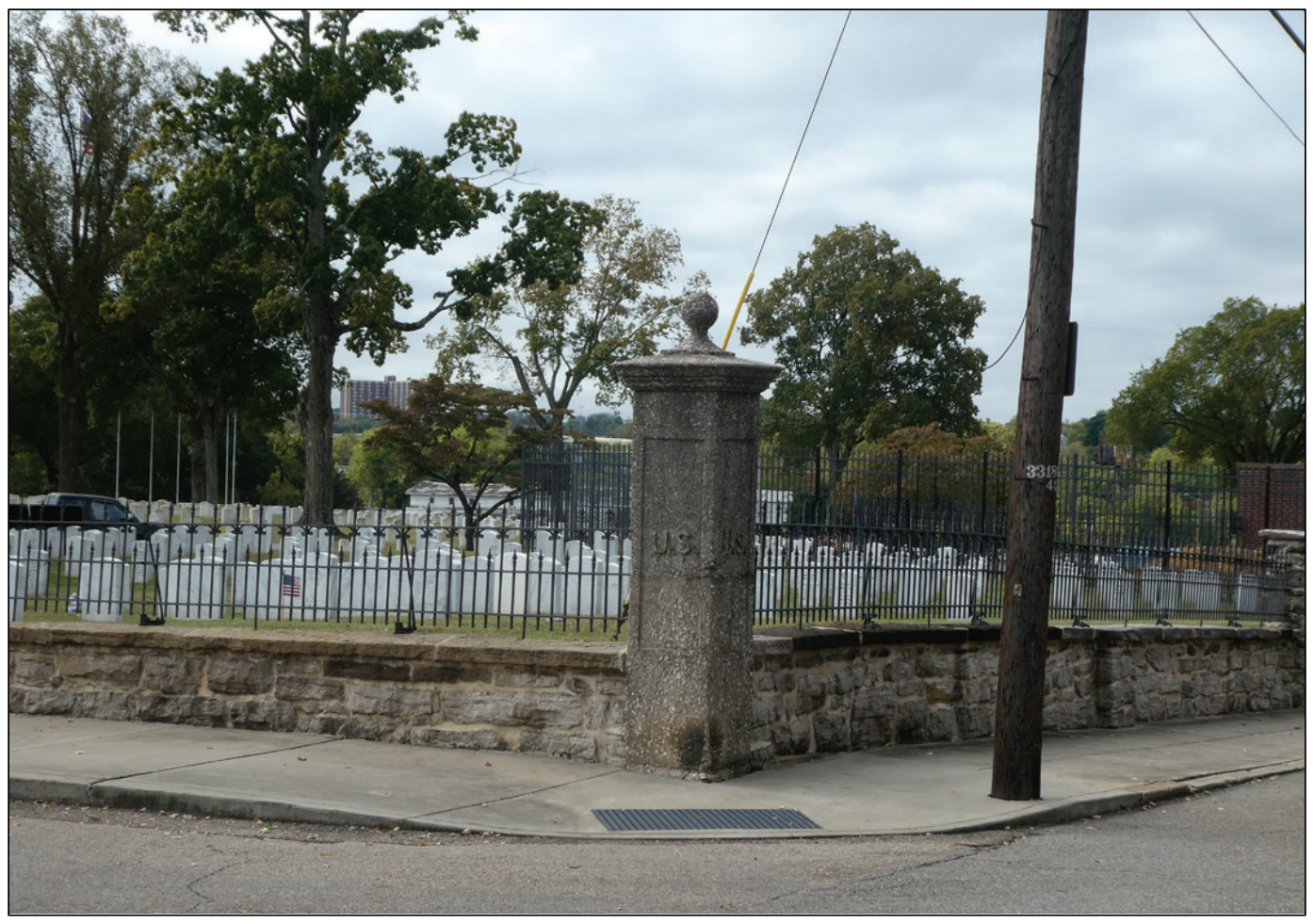




\subsubsection{Burial register summary}

The Northeast section of the cemetery has four separate burial sections: $Y$, MA, CS, and CS-2. Section Y has 155 burial spaces with interments spanning the 1960 s through 2010s. The Memorial Area (MA) has 11 burial spaces with interments dates from WWII through the 2010s. Section CS has 315 burial spaces with all burials in the $21^{\text {st }}$ century; this section still has space for more burials. Section CS-2 has 46 burial spaces all from the 2010 .

\subsubsection{Flagstaff}

The flagstaff at Knoxville National Cemetery is located on the center of the eastern side of the property. The north-south drive incorporates the flagstaff with a large circular paved area. An east-west drive was removed between 1985 and 1995. The original flagstaff was replaced in 1875, then replaced in 1940 and again in 1946. It is unknown if this is the current flagstaff.

\subsubsection{Preliminary plan}

The flagstaff and the circle drive have been the primary design for the cemetery since its founding.

\subsubsection{1869 map}

The 1869 map by P.M. Radford shows a flagstaff at the center (Figure 297), and the drawing that he did has a flagstaff as the prominent feature along the east-west drive from Cooper Street (Figure 298). 
Figure 297. The flagstaff at the center of the circle on the 1869 map (NARA, Washington DC, RG92).

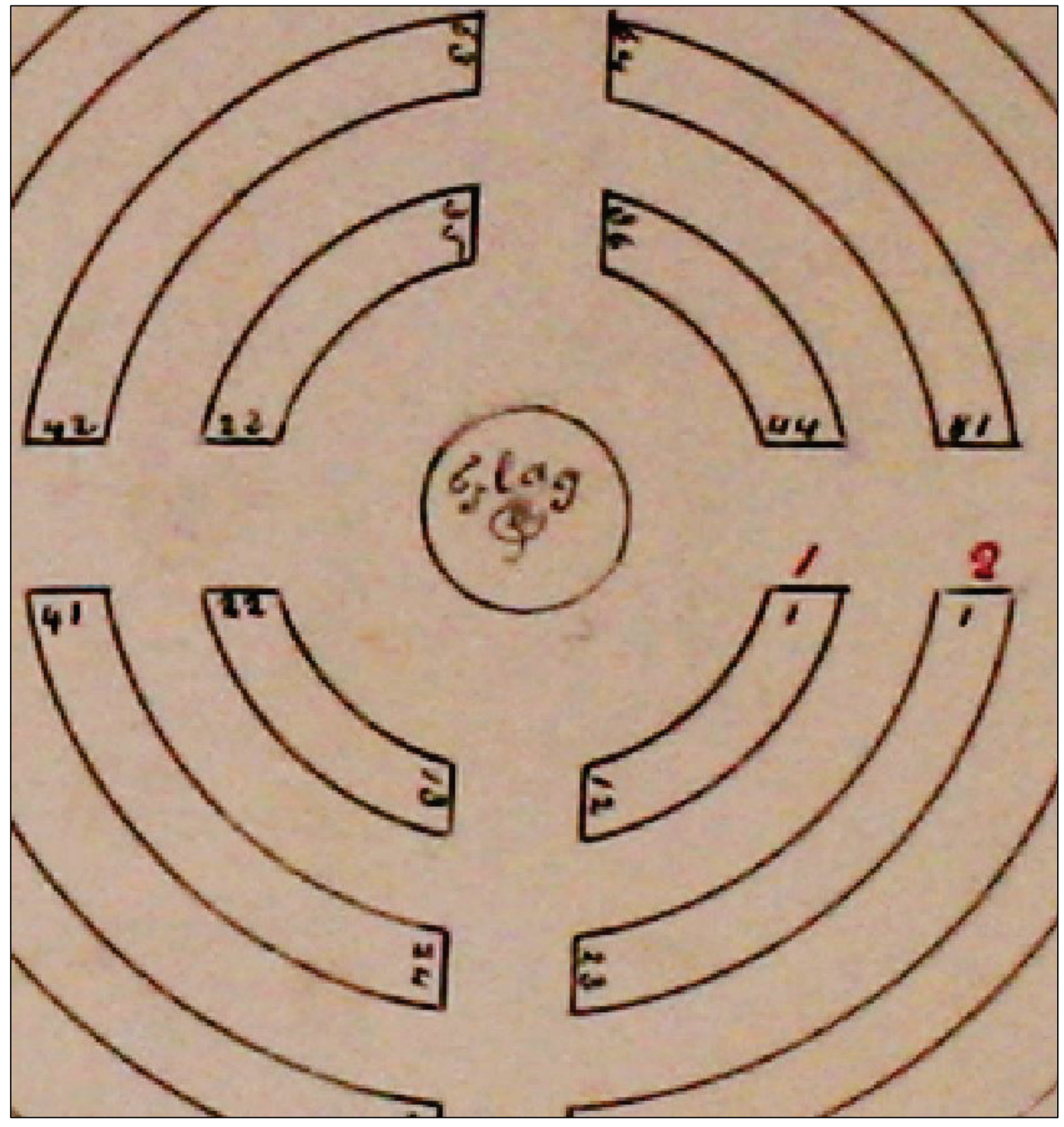


Figure 298. Looking northeast at a drawing of the wood fence along Cooper Street, 1869 (NARA, Washington DC, RG92).

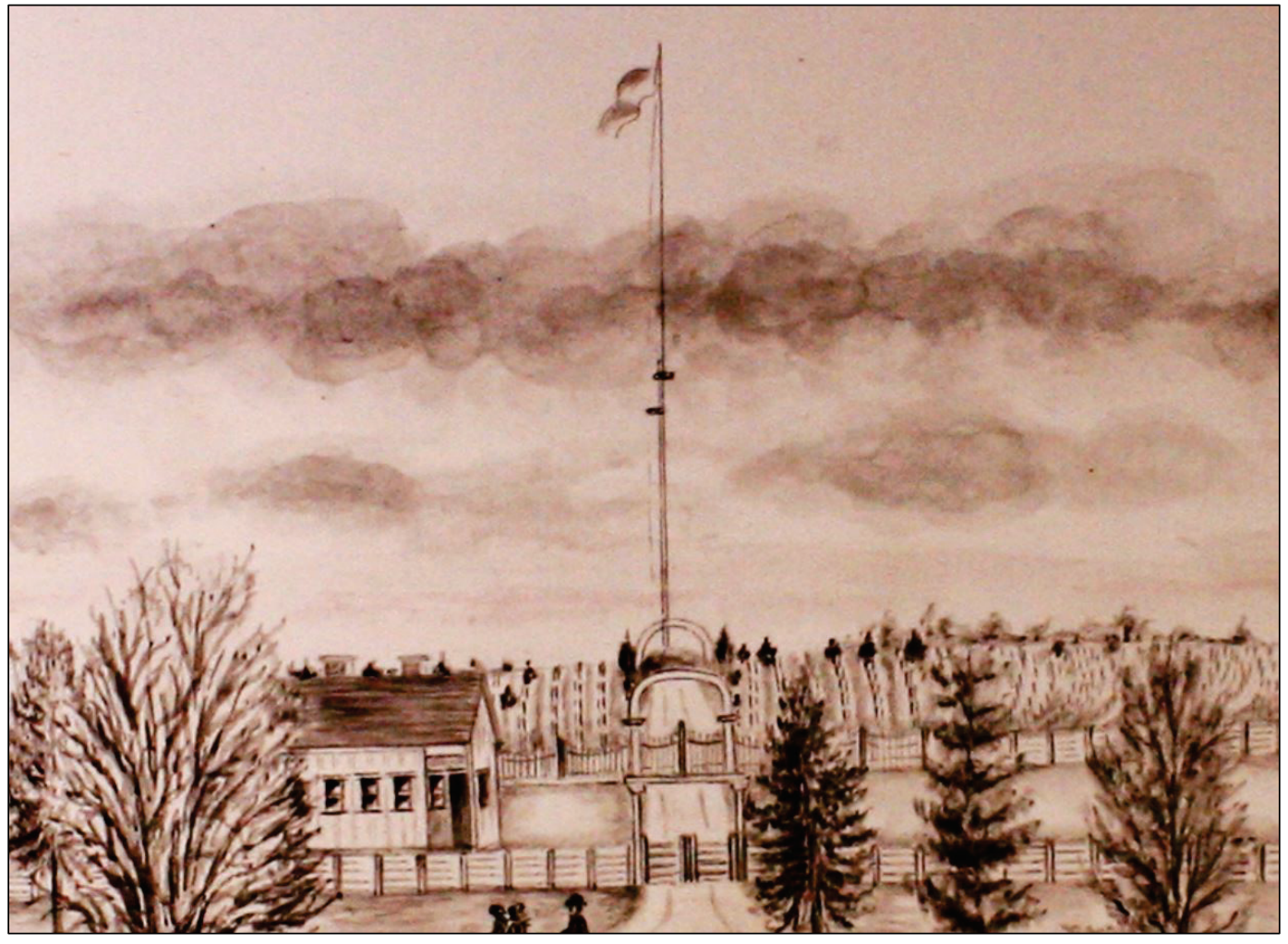

\subsubsection{1892 map}

While the 1892 map does have trees and shrubs depicted throughout the cemetery, there is no vegetation surrounding the flagstaff (Figure 299). It does appear that a curb surrounded the flagstaff. 
Figure 299. Plan of the flagstaff on the 1892 cemetery plan (VA NCA Archives, Washington, DC).

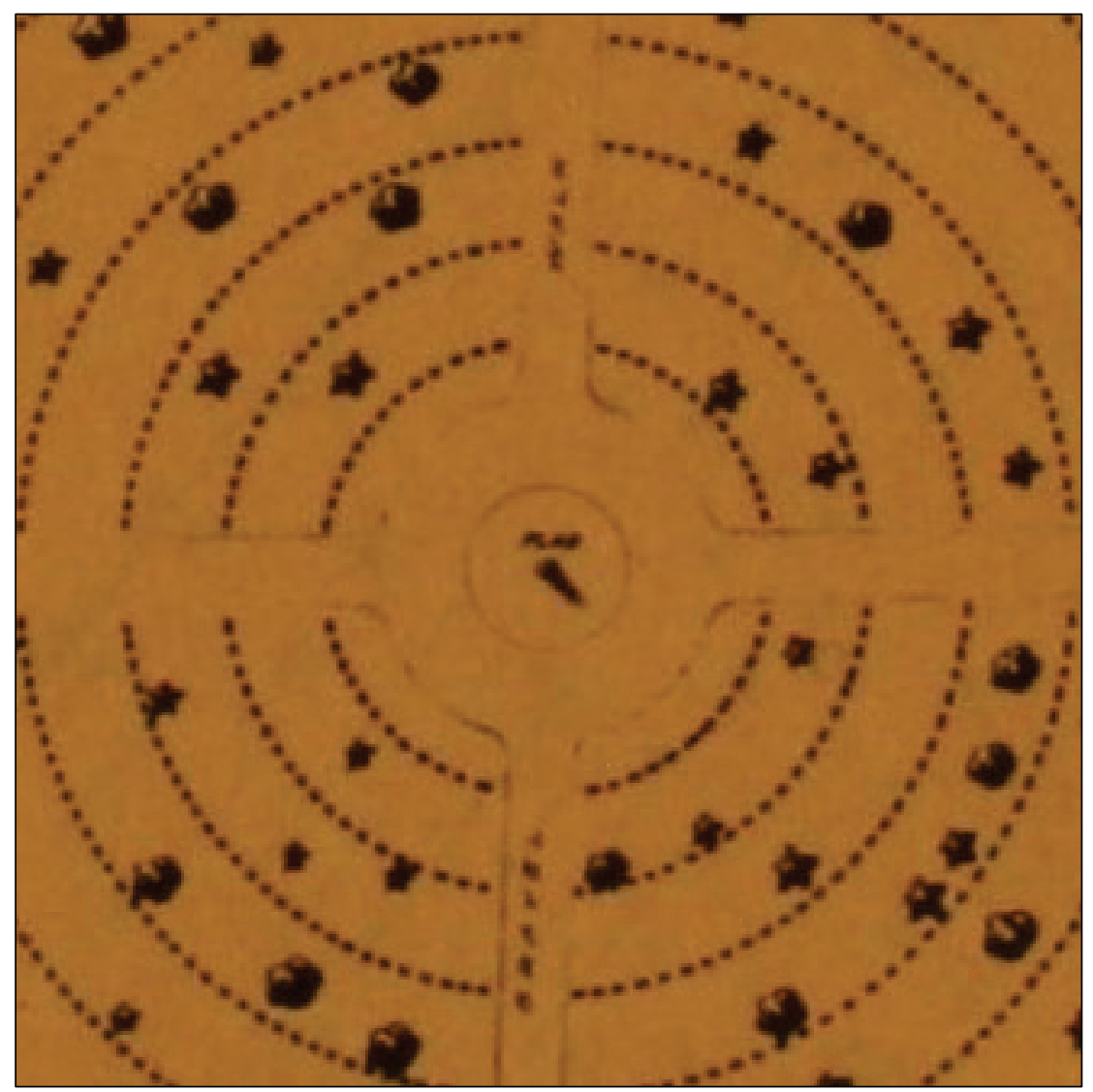

\subsubsection{1909 map}

The 1909 map does not have any vegetation surrounding the flagpole, but the curb is shown.

\subsubsection{1947 map}

The 1947 map does not have any vegetation surrounding the flagpole, but the curb is shown. An aerial from 1948 shows that grass surrounded the flagstaff (Figure 300), and this is confirmed by a photograph from 1953 (Figure 301). 
Figure 300. Aerial view of the flagstaff circle, 1948 (HALS-TN-2, Library of Congress).

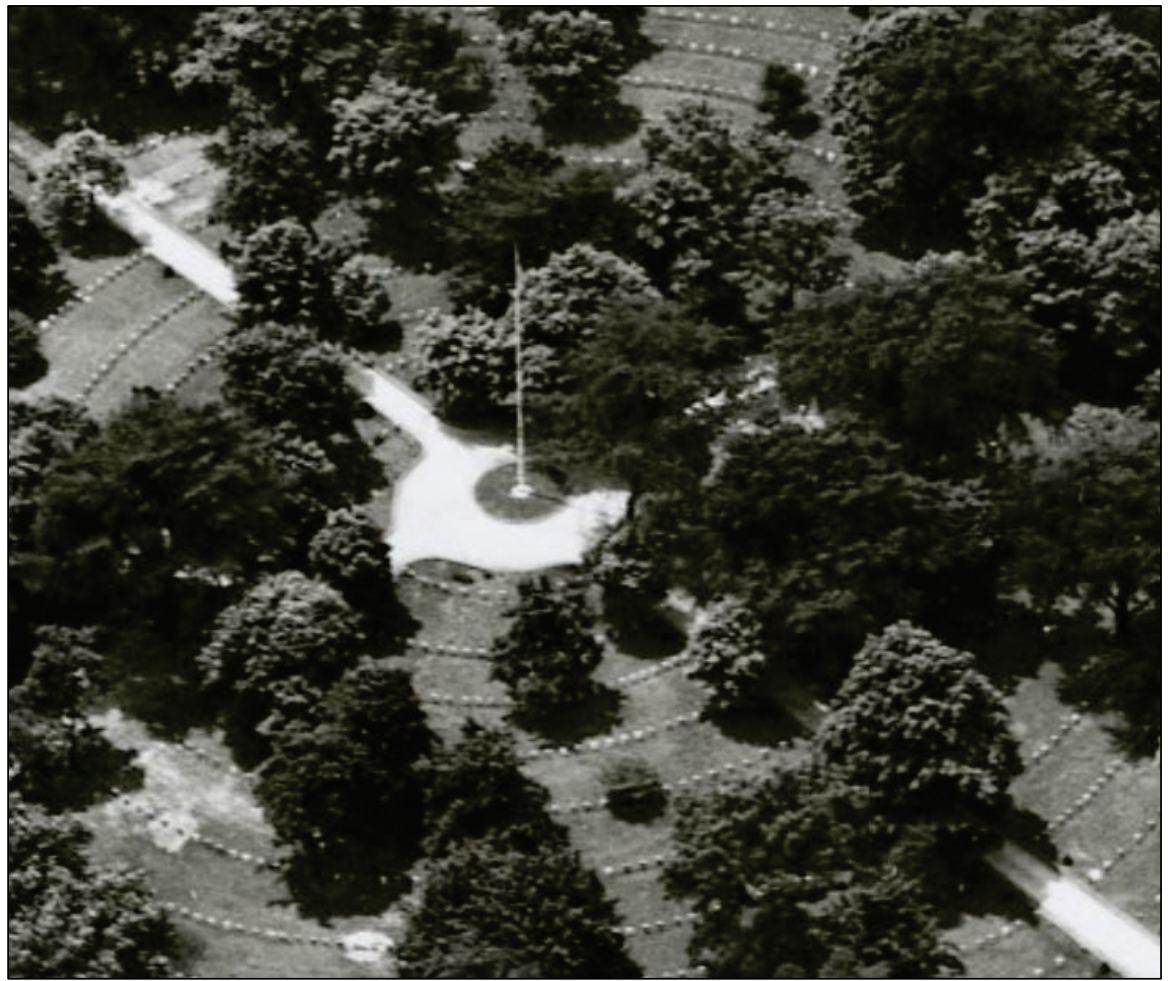

Figure 301. Looking northeast over the flagstaff circle towards the Tyson Gate, 1953 (VA NCA Archives, Washington, DC).

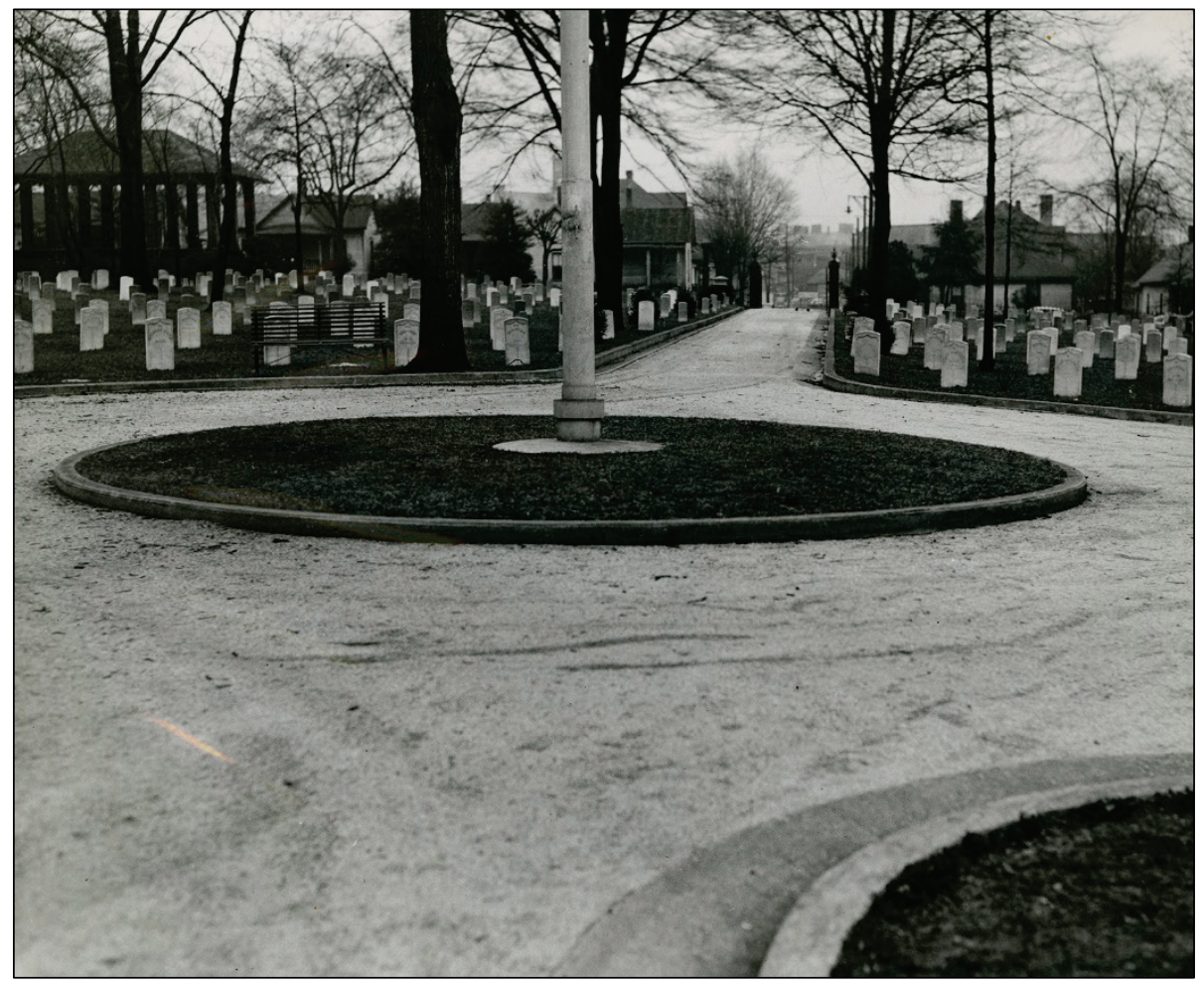




\subsubsection{1971 map}

The 1971 map does not have any vegetation surrounding the flagpole, but the curb is shown.

\subsubsection{2019 map}

The map from 2019 does have landscaping depicted on it, but it does not show any landscaping around the flagstaff. The entire flagstaff circle is paved with asphalt except for a small bit of concrete in which the flagstaff is anchored (Figure 302).

Figure 302. Looking northwest at the flagstaff circle showing that there is no vegetation or curb (ERDC-CERL, 2019).

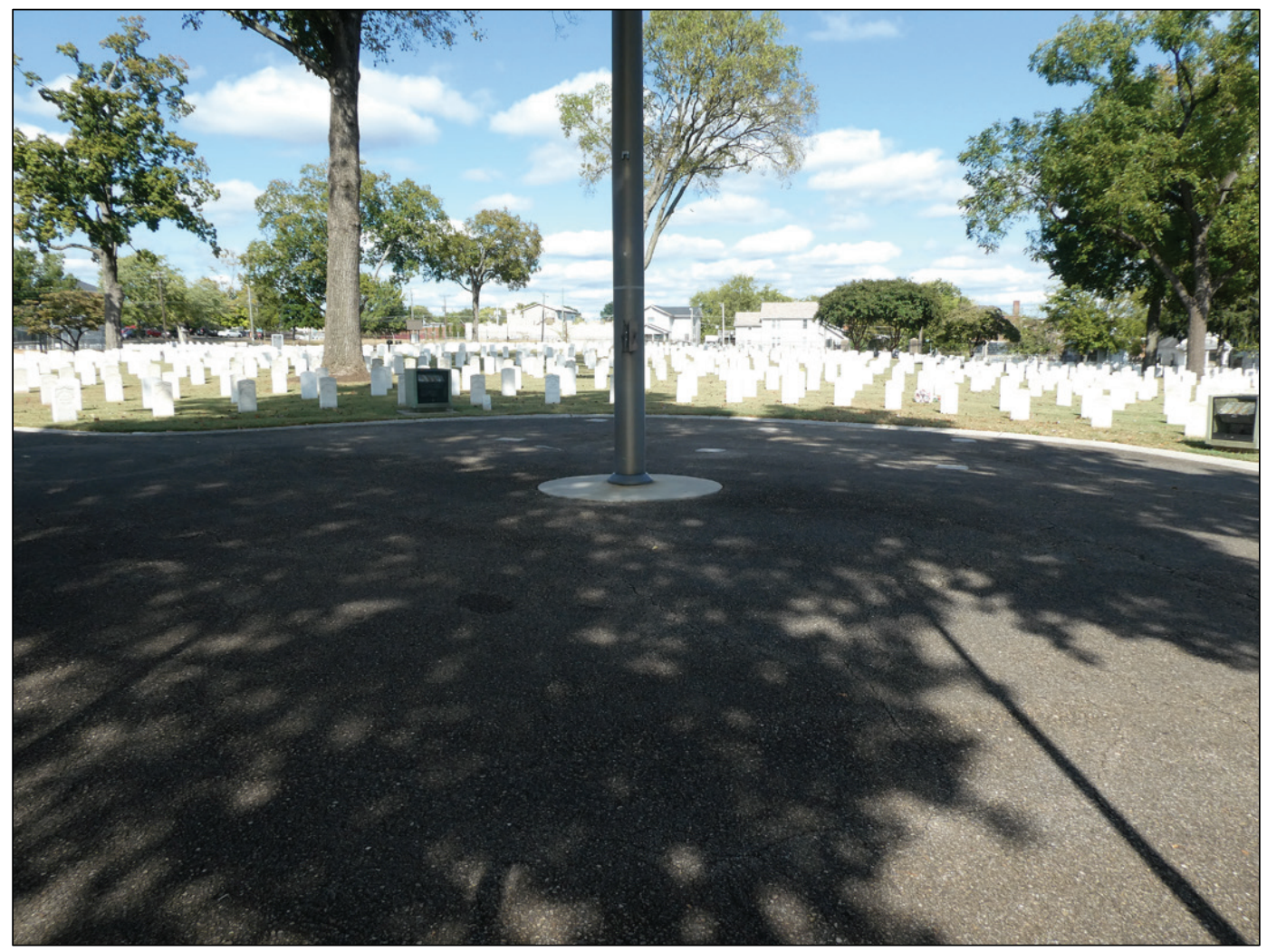




\subsection{Views and viewsheds}

Views of a site and viewsheds through a site are important components of historic landscapes. Views and viewsheds are how all landscape features are seen as a complementary whole. A landscape, such as Knoxville National Cemetery, was designed to emphasize certain views of the site that had aesthetic qualities that would make them memorable. The viewsheds at Knoxville National Cemetery have changed over the years as the main entrance to the cemetery was shifted from Cooper Street to Tyson Street and the former main east-west axis was removed and filled with graves. From the new main entrance, significant views included views from the entrance gate left towards the Union Soldier Monument, straight to the flagstaff, and right to the rostrum and lodge. Secondary views and viewsheds were from the flagstaff out towards the four quadrants.

\subsubsection{View northeast from Cooper Gate toward flagstaff}

Originally, the design and layout of Knoxville National Cemetery reinforced one significant viewshed, that of entering at the Cooper Gate and looking up the slope to the prominent flagstaff (Figure 303). This view was impacted in 1907 when the brick superintendent's lodge was constructed on Tyson Street and the Tyson Gate became the main entrance. This view was lost when the former main east-west axis road was removed and filled with graves and the entrance gate filled in (Figure 304). 
Figure 303. View northeast from the Cooper Gate in 1869 (NARA, Washington DC, RG92).

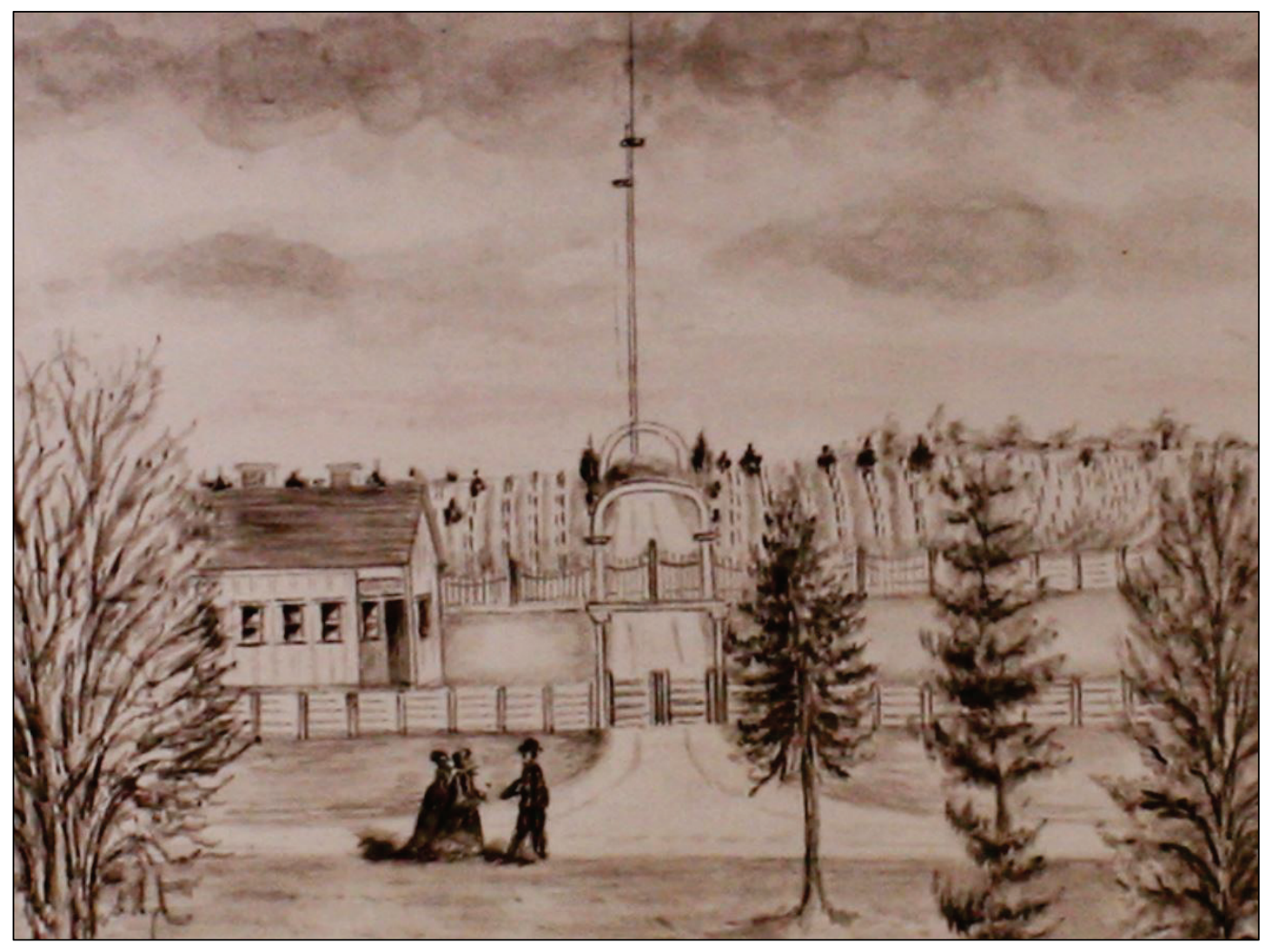

Figure 304. View northeast toward former Cooper Gate and flagstaff (ERDC-CERL, 2019).

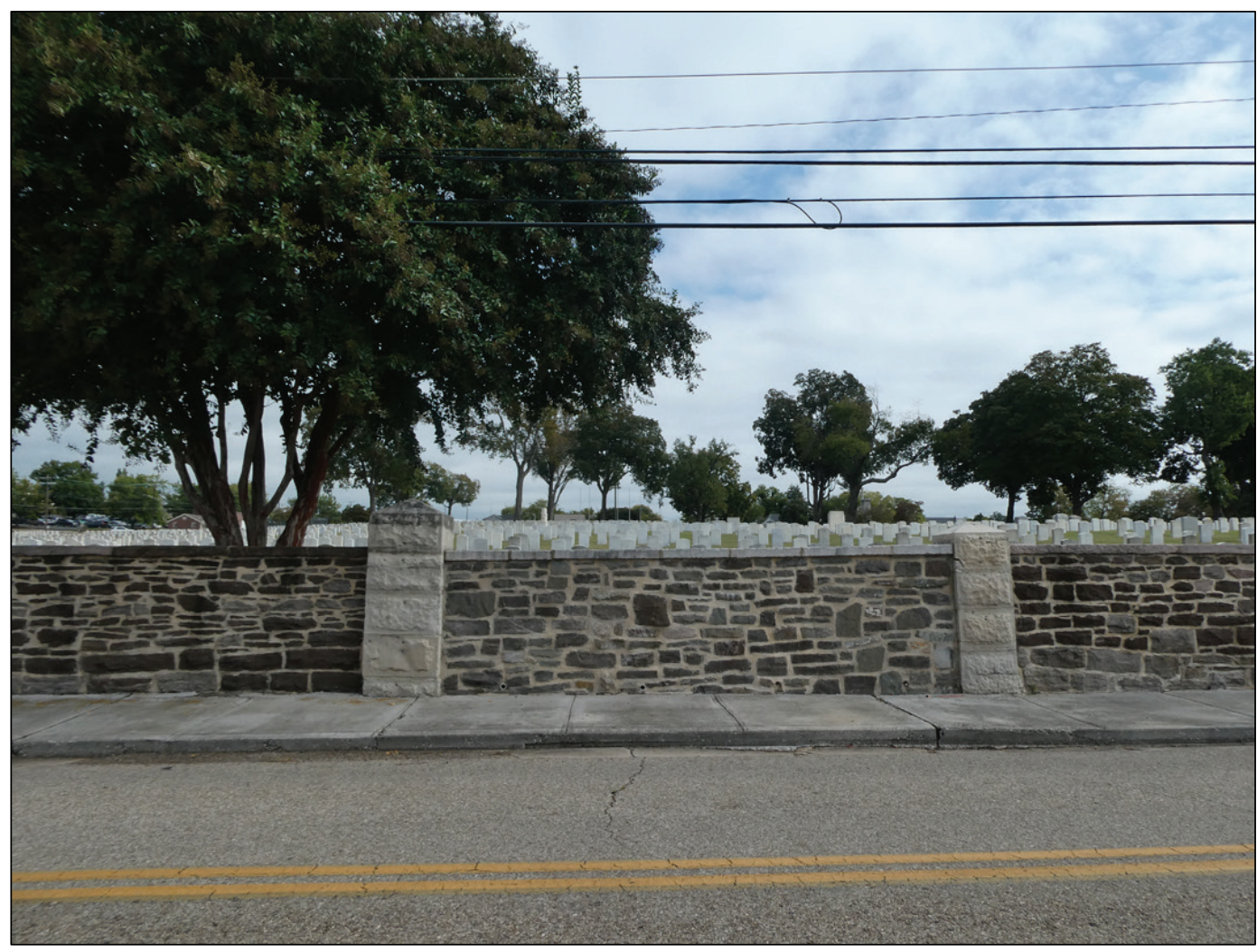




\subsubsection{View southwest from the Tyson Gate}

When Tyson Gate was transformed into the main entrance, this view was enjoyed by all that entered the cemetery during the $20^{\text {th }}$ Century (Figure 305). This view was impacted when the former main east-west axis road was removed and filled with graves and the Crepe Myrtle trees were planted in front of the flagstaff (Figure 306).

Figure 305. View southwest from the Tyson Gate in 1908 (NARA College Park, RG92-CA and ERDC-CERL).

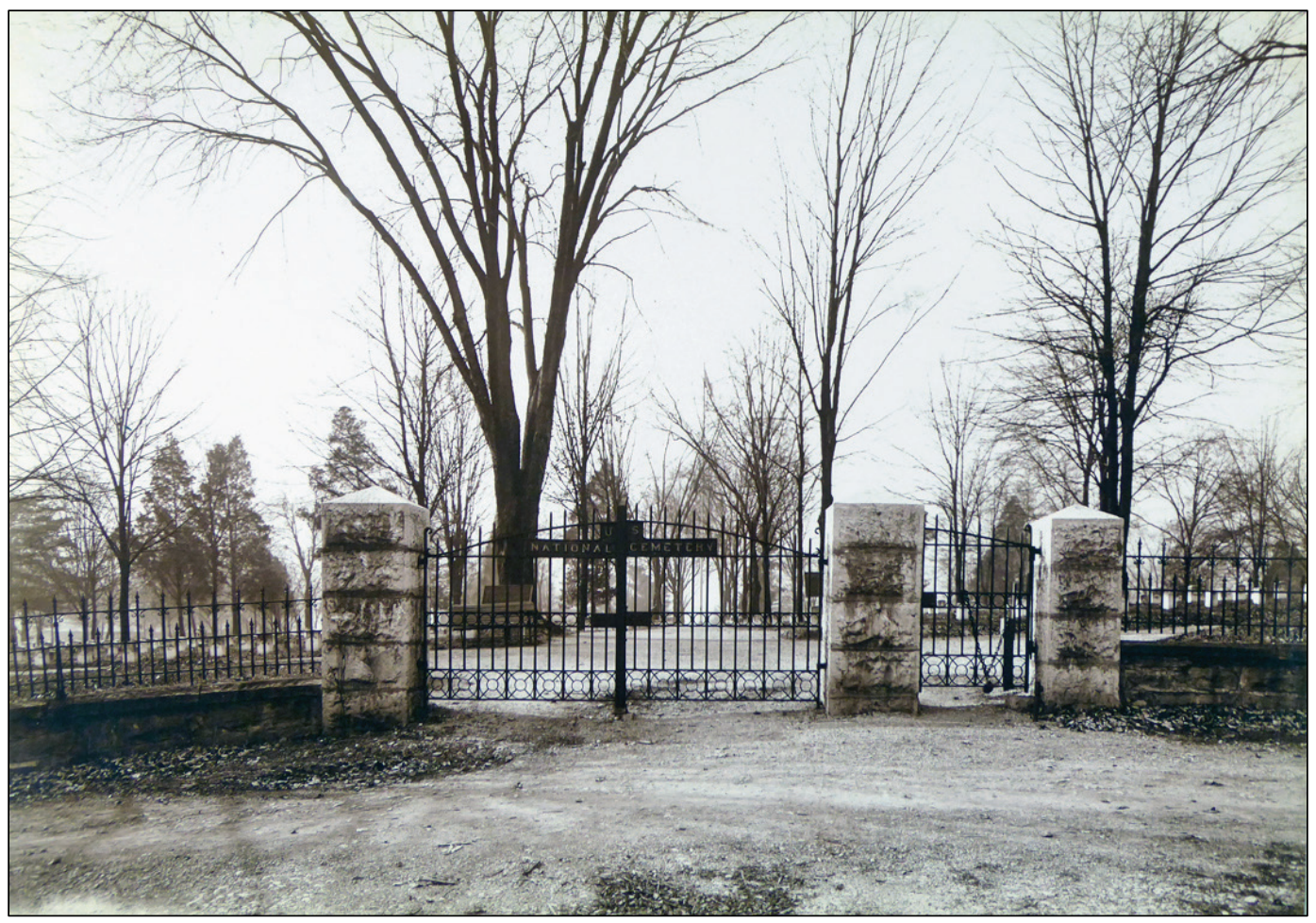


Figure 306. View southwest from the Tyson Gate in 2019 (ERDC-CERL).

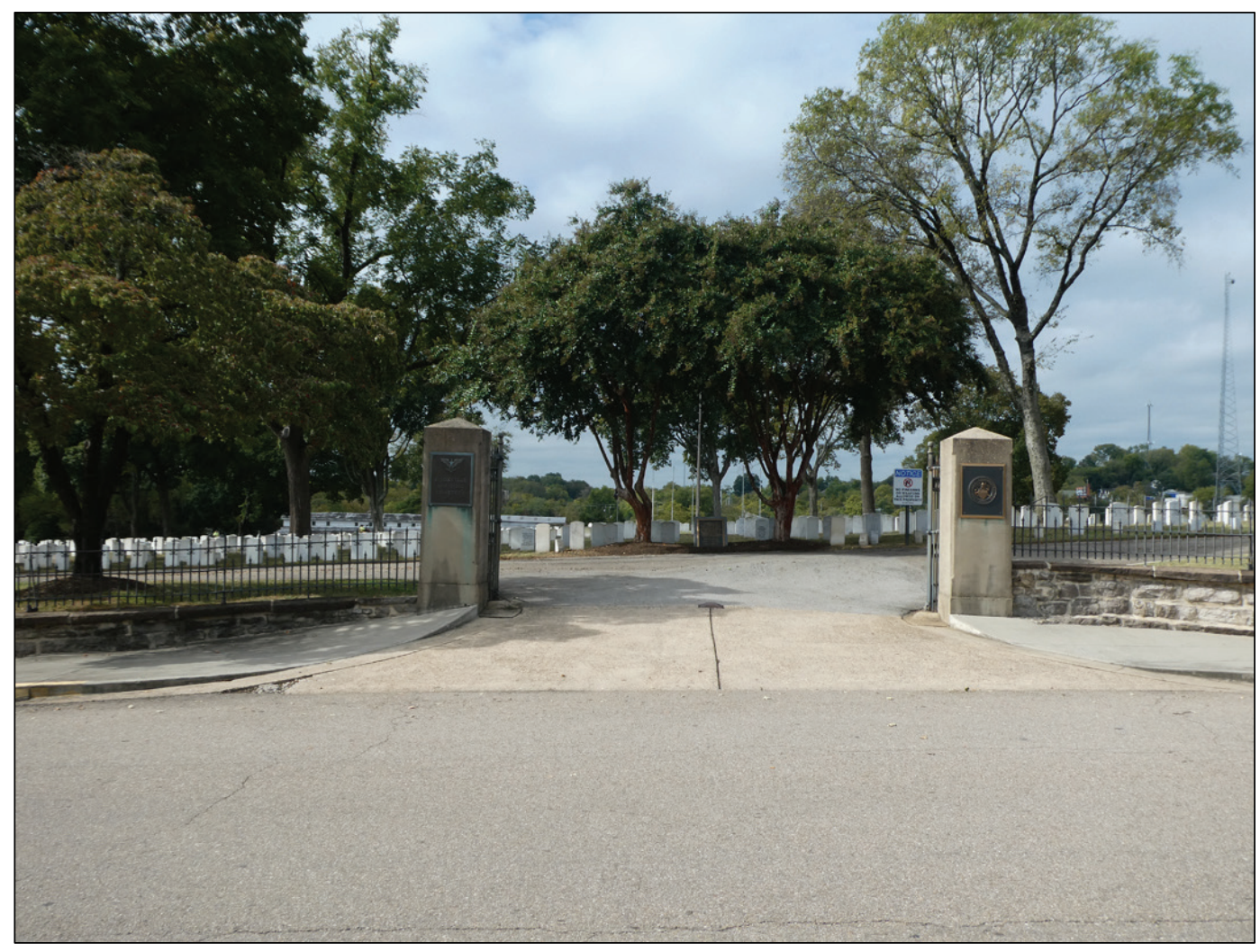

\subsubsection{View southeast from Tyson Gate towards Union Soldier Monument}

When Tyson Gate was transformed into the main entrance, this view of the impressive Union Soldier Monument was enjoyed by all that visited the cemetery (Figure 307). Other than the loss of some of the vegetation, the view still has integrity (Figure 308). 
Figure 307. View southeast from the Tyson Gate towards the Union Soldier Monument in c.1910 (University of Tennessee, Knoxville, Library digital collections “Images of East Tennessee").

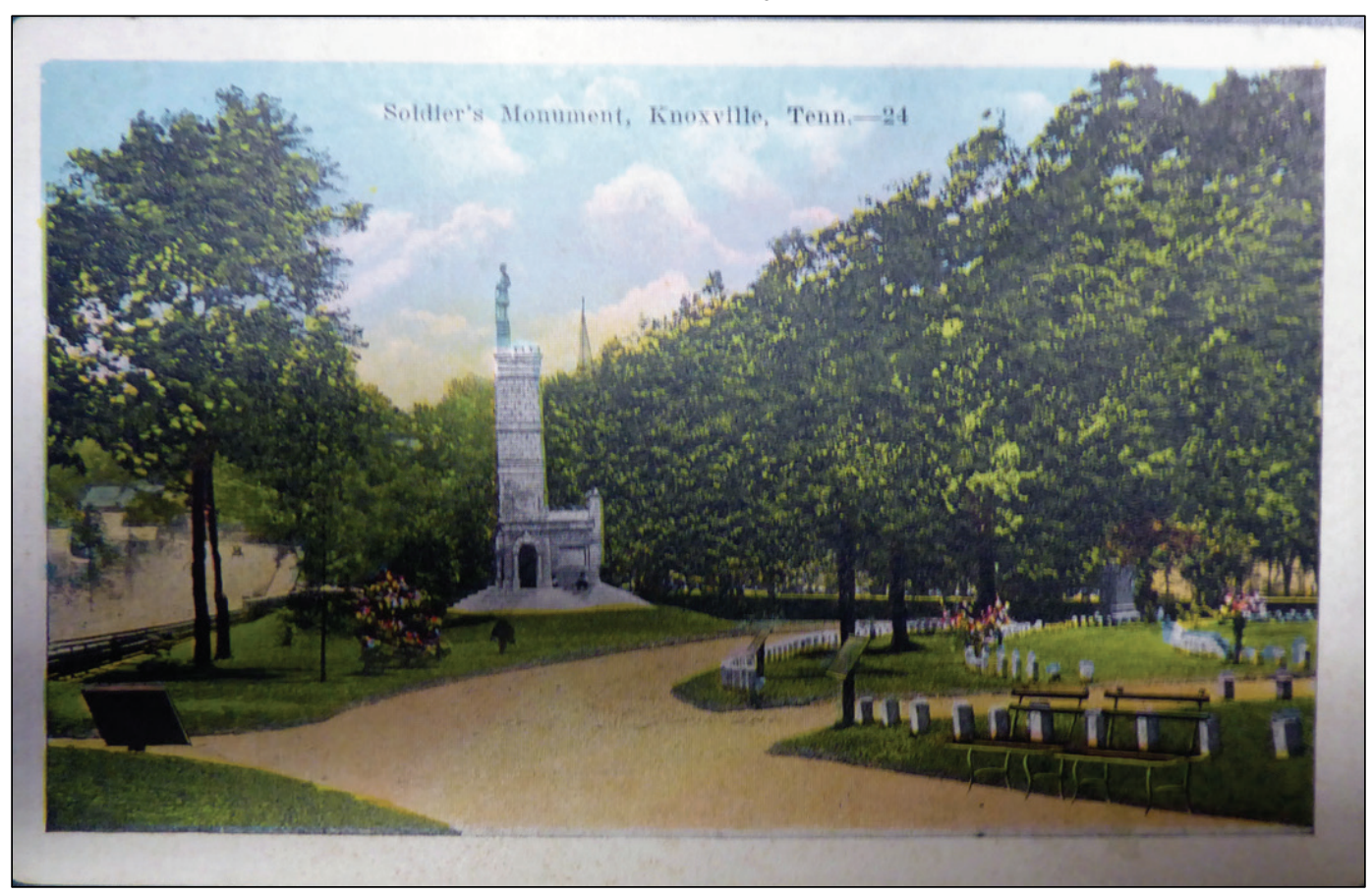

Figure 308. View southeast from the Tyson Gate towards the Union Soldier Monument in 2019 (ERDC-CERL).

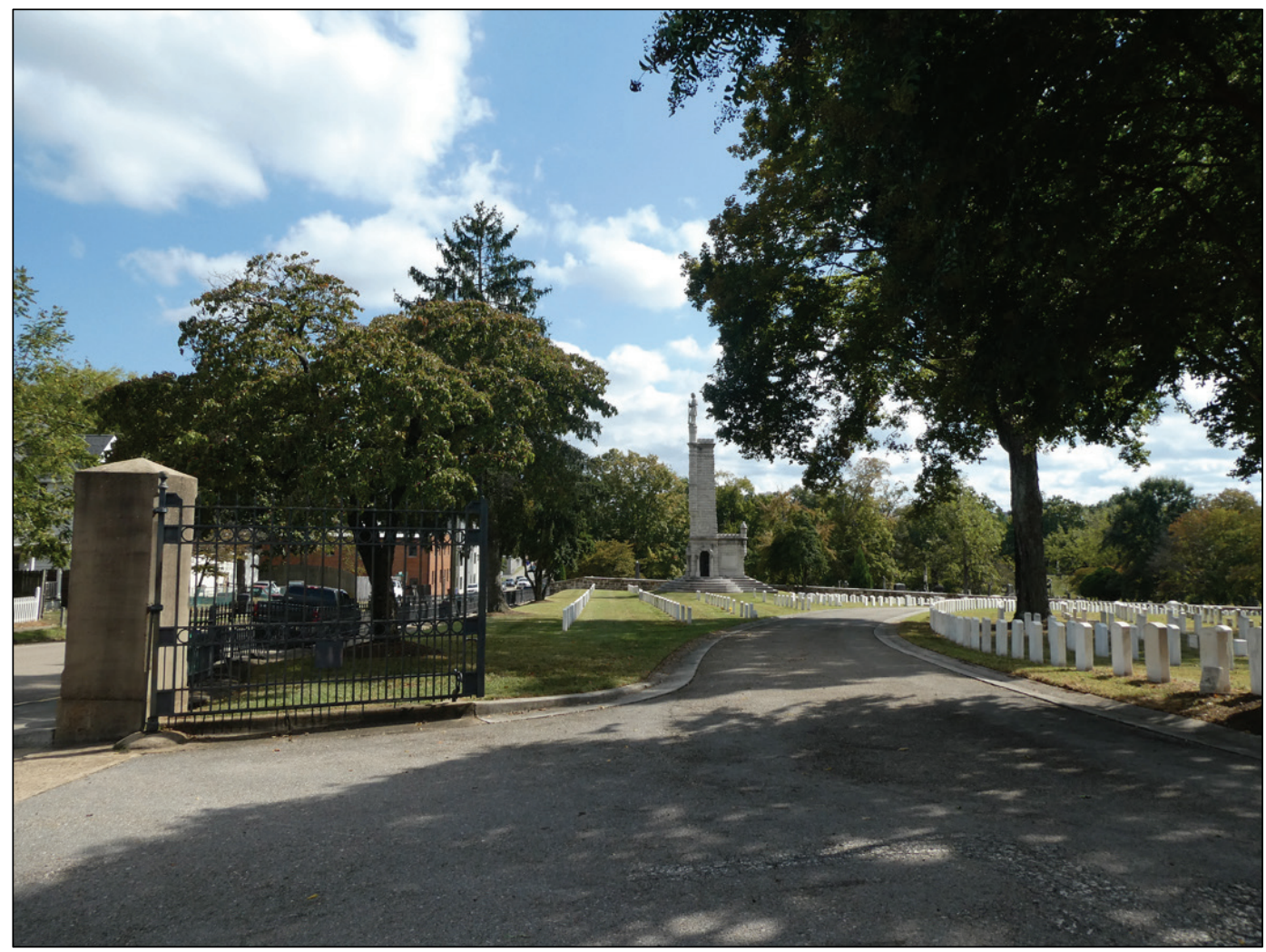




\subsubsection{View northwest from the Tyson Gate}

Once a significant view for visitors to the cemetery (Figure 309), after the loss of both the rostrum and the lodge, this view no longer retains its integrity (Figure 310).

Figure 309. View northwest from the Tyson Gate towards the rostrum in c.1910 (University of Tennessee, Knoxville, Library digital collections “Images of East Tennessee").

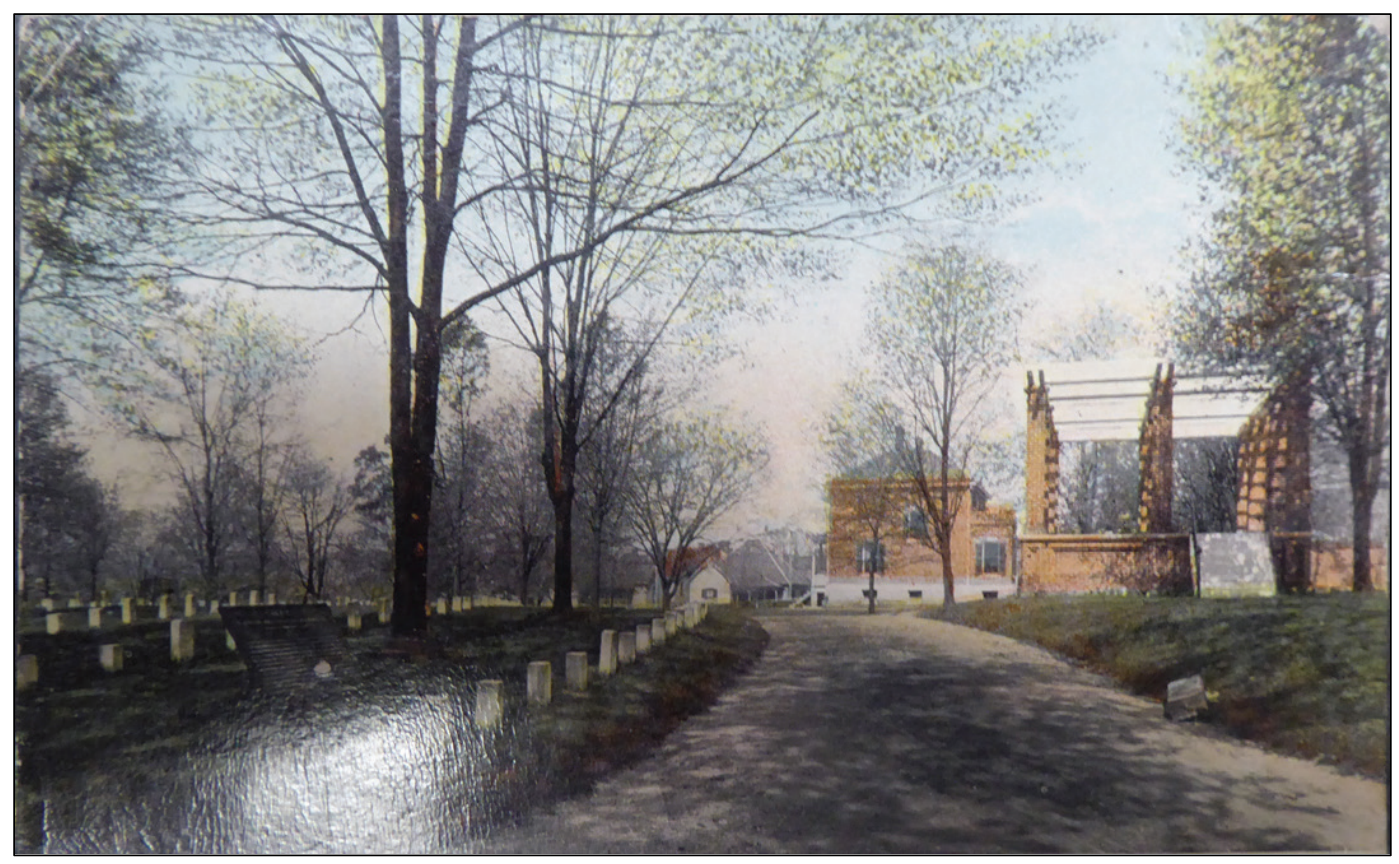


Figure 310. View northwest from the Tyson Gate towards the former site of the rostrum (ERDC-CERL, 2019).

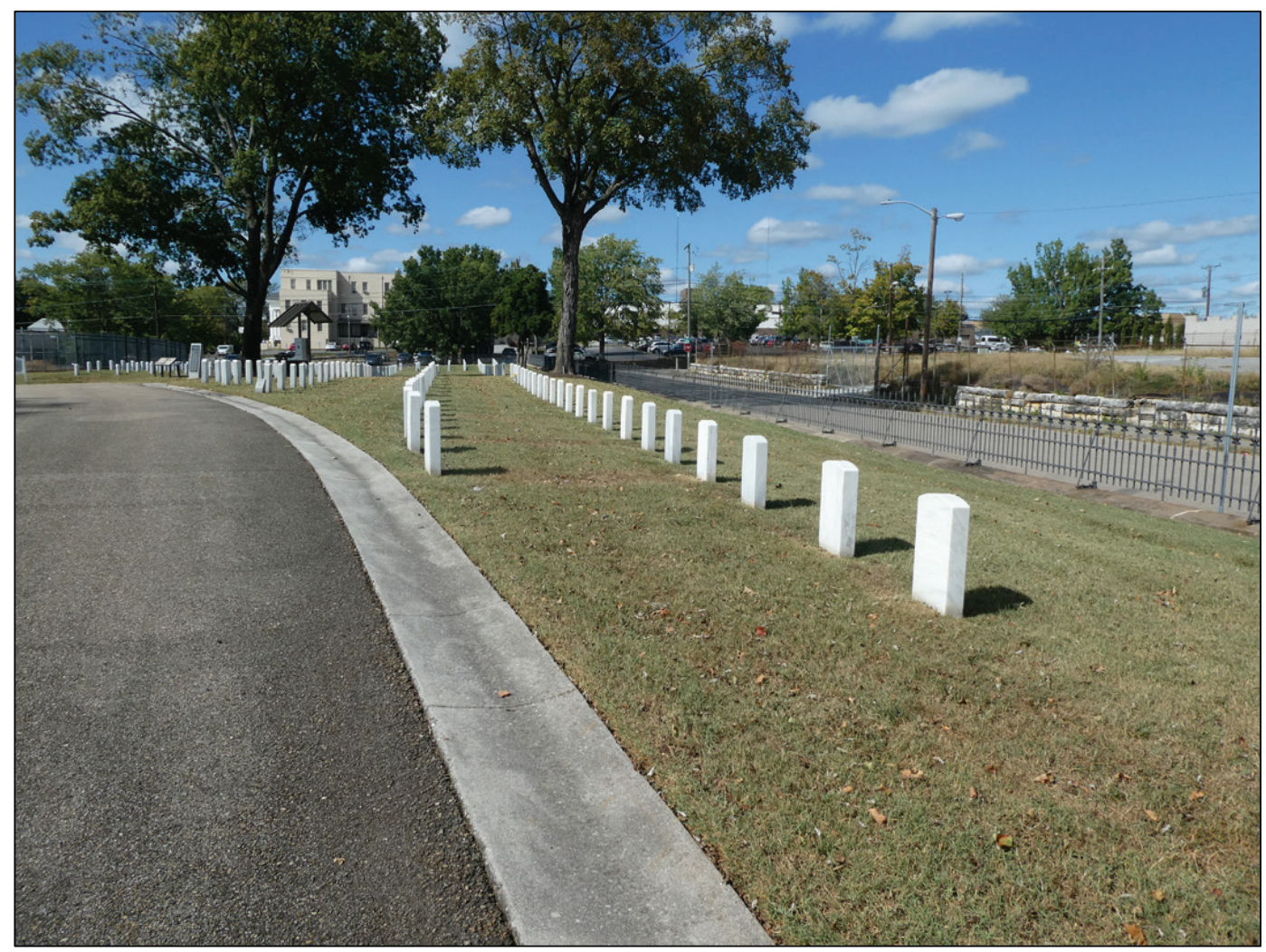

\subsubsection{View northeast from circle drive towards flagstaff}

Even after the main gate was moved to Tyson Street, views back toward the flagstaff as one circled the drive were significant (Figure 311). This view was impacted when the former main east-west axis road was removed and filled with graves and no visual path remained (Figure 312). 
Figure 311. View northeast from the circle drive towards the flagstaff with Section $C$ on the left and Section B on the right in 1908 and 2019 (NARA College Park, RG92-CA and ERDCCERL).

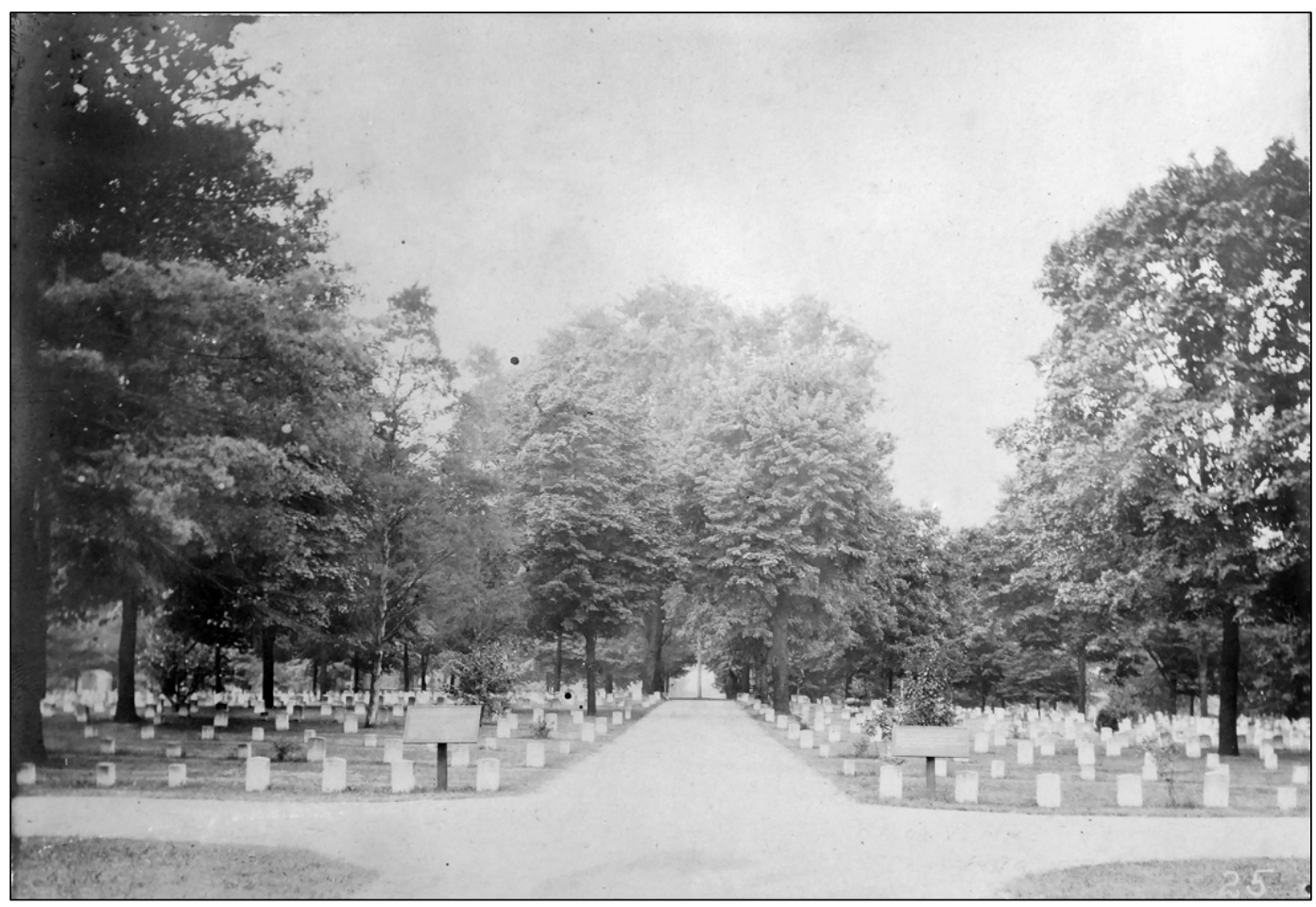

Figure 312. View northeast from the circle drive towards the flagstaff with Section $C$ on the left and Section B on the right in 2019 (ERDC-CERL).
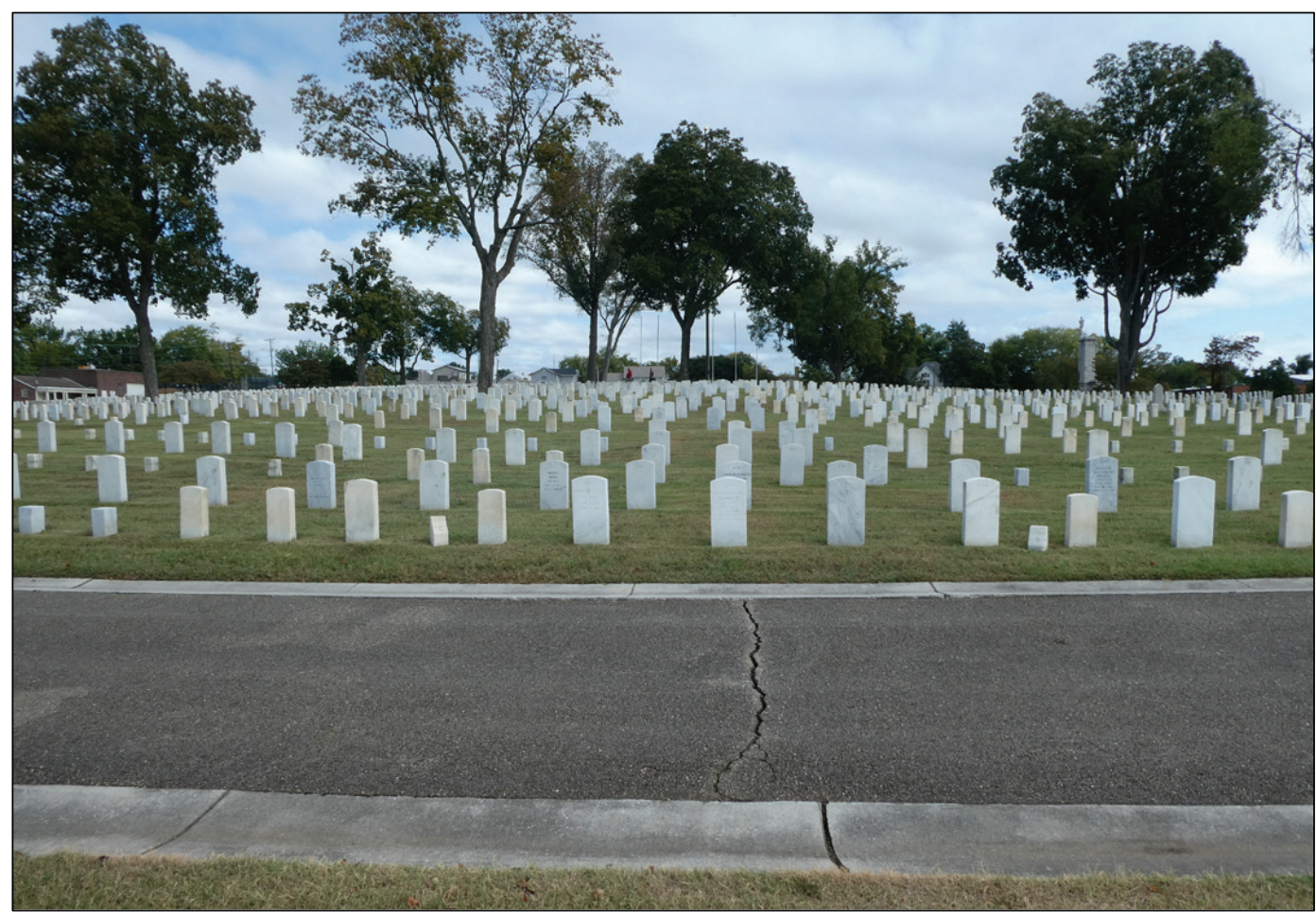


\subsubsection{View southeast from flagstaff towards the Old Gray Cemetery}

While a historic photograph of this view was not located, there has always been a strong visual connection between the two cemeteries. The green backdrop of the trees at Old Gray Cemetery over the wall adds to the peacefulness of the Knoxville National Cemetery (Figure 313).

Figure 313. View southeast from the flagstaff towards the Old Gray Cemetery (ERDC-CERL, 2019).

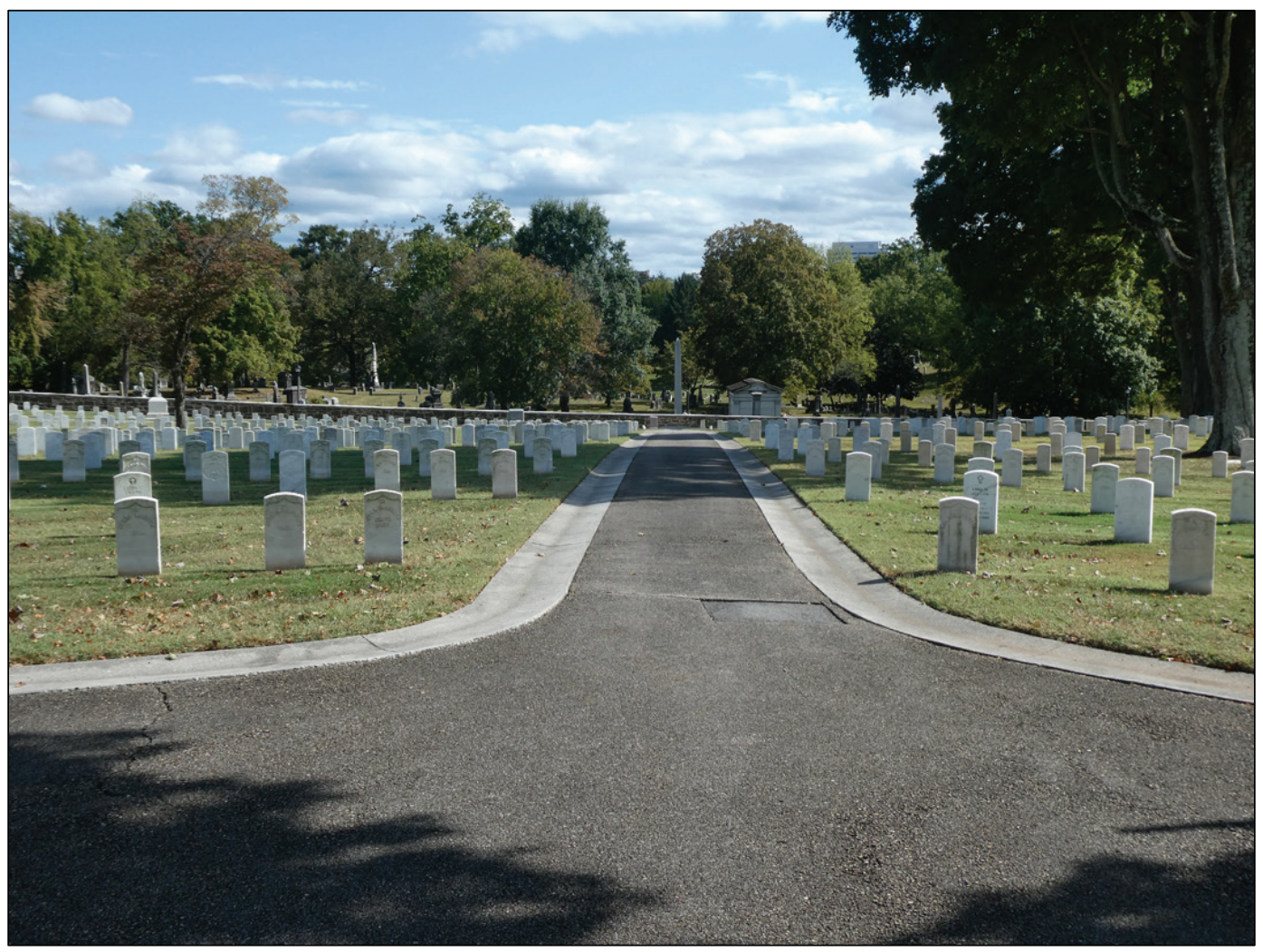

\subsection{Same-scale maps and aerials}

The development of Knoxville National Cemetery can be read through plans and aerial images of the site. Figure 314 shows a sequence of plans starting from left with the 1869 plan, 1892 plan, 1909 update, 1949 plan, 1971, and 2019. Figure 315 shows a sequence of aerial images from 1948 through 2019. The aerial images show overall changes to the cemetery landscape through 6 decades. Note that the 1985 and 2019 images show the site during fall or winter, when the leaves have fallen off the deciduous trees, and this difference makes a vegetation density comparison across the images somewhat difficult. 
Figure 314. Sequence of maps for Knoxville National Cemetery 1869, 1892 [Left to Right, top row], 1906, 1949 [Left to Right, middle row], 1971, and 2019 [Left to Right, bottom row] (various sources).

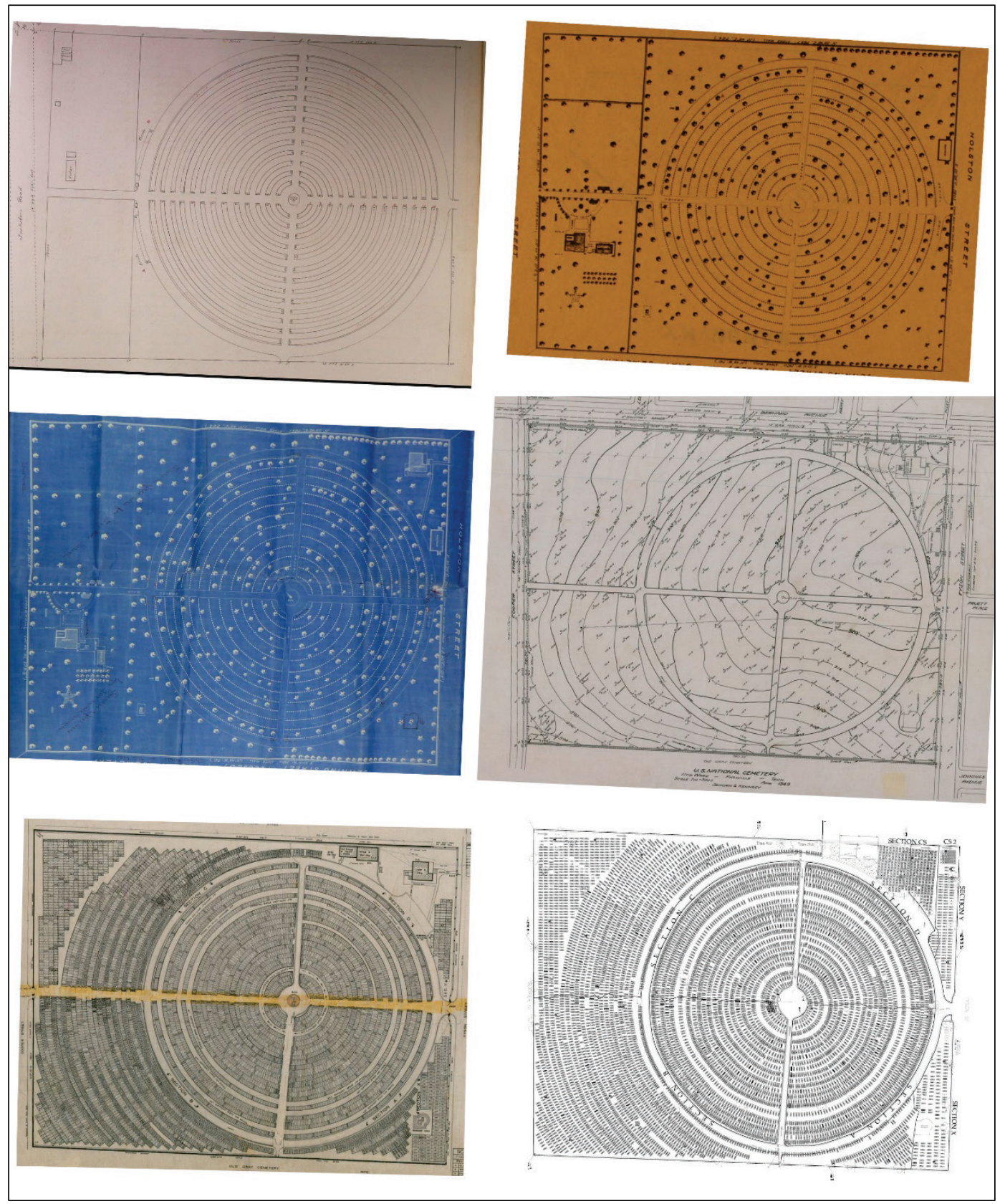


Figure 315. Sequence of aerial images from left to right, 1948, 1969, 1985, 1995, 2019

(HALS-TN-2, Library of Congress, city of Knoxville, and Google).
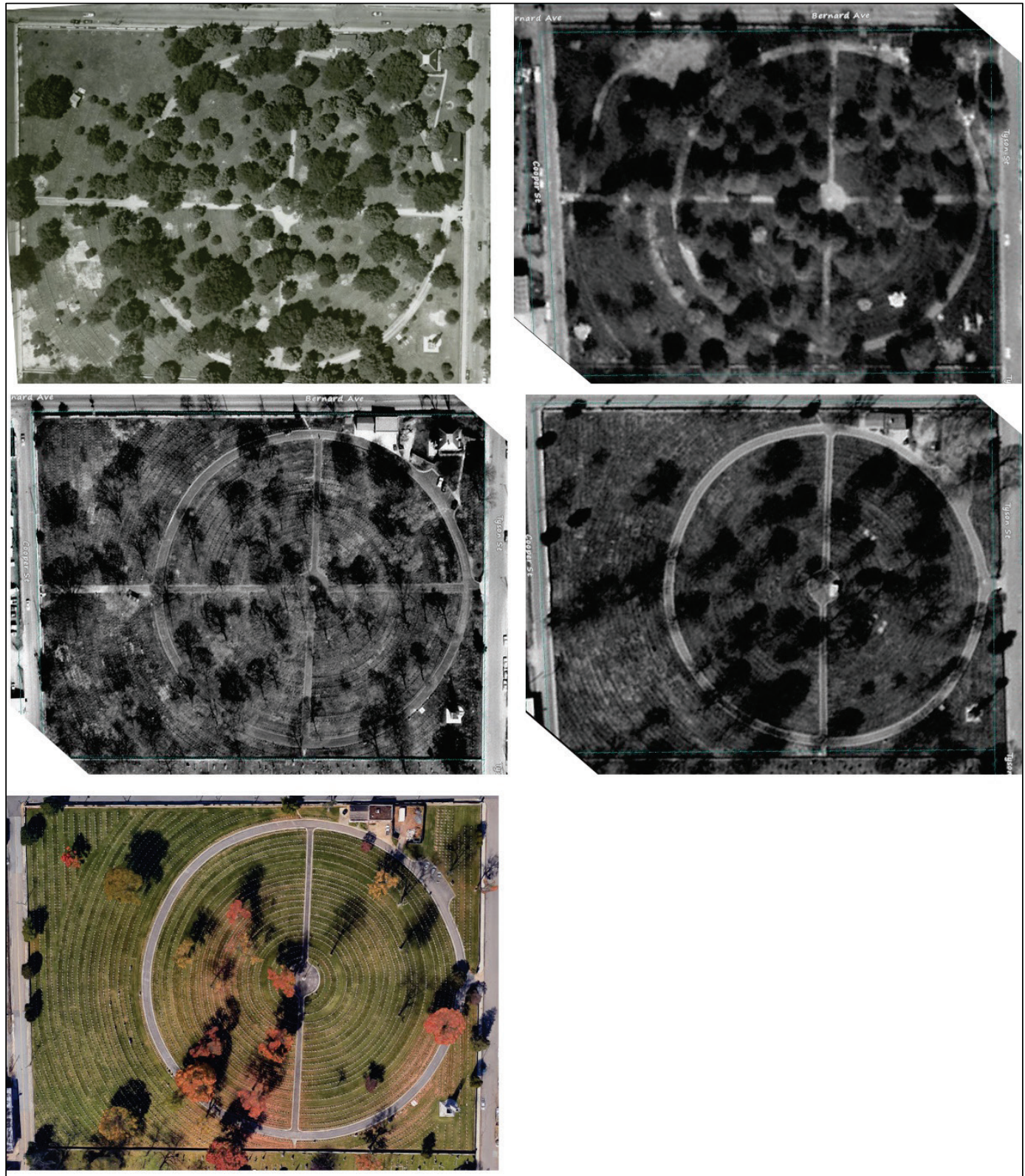


\section{Summary and Recommendations}

\subsection{Landscape features}

The Knoxville National Cemetery was designed by Assistant Quartermaster Captain H.S. Chamberlain in 1863. The original design was characterized by a circle of plots bisected into quarters by carriageways. The cemetery was bordered by a stone wall. The service areas once located on the southwest side of the cemetery were relocated to the north corner of the cemetery. The flagpole is located in the center of the circle. The main entrance once located on Cooper Street was relocated to Tyson Street, and the Cooper Street entrance was closed.

\subsubsection{Character-defining landscape features}

Key character-defining landscape features that reflect the design intent of the cemetery include the following:

- The organization of programmatic areas within the cemetery: the bereaved and visitor support services clustered in the north corner, the memorial area near the main entrance, and the flagstaff at the center of the cemetery.

- Circular layout of the burial sections.

- Circle drive.

- Northwest-southeast cross paved roadway (cross drive) that encircles the flagpole.

- Flagstaff at the center of the circle.

- Deciduous trees arrayed throughout the site, providing areas of shade and the feeling of open and enclosed spaces. Evergreen and flowering trees used as accents.

- Uniform and regularly spaced white marble headstones.

- View from the main entrance southwest toward the flagstaff.

- View from the main entrance southeast toward the Union Soldier Monument.

- View from the flagstaff southeast into Old Gray Cemetery. 


\subsubsection{Character-defining buildings and structures}

Key character-defining buildings and structures include the following:

- Union Soldier Monument (1906, 60' tall, crenulated stone tower, memorial chamber, ornate iron gates, stained-glass window).

- Restroom building (1936, rectangular-shaped, clad in brick, gable roof, office and restrooms).

- Utility building (1949, rectangular-shaped, clad in brick, flat roof, garage bay).

- Perimeter stone wall (including metal fence that tops stone portions).

- Main entrance gate located on the northeast wall (two concrete piers support ornamented wrought-iron gates).

\subsection{Landscape treatment}

The Secretary of the Interior is responsible for establishing professional standards and providing advice on the stewardship of cultural resources listed on or as eligible for the NRHP. The Secretary's standards describe four basic approaches to the treatment of historic landscapes. ${ }^{236}$

\subsubsection{Restoration approach}

Restoration is the act or process of accurately depicting the form, features, and character of a property as it appeared at a particular period in time. This process includes reconstruction of missing features from the restoration period and removal of features from all other periods. The approach can be considered only when the property's significance during a particular period of time outweighs the loss of extant elements from other historical periods, when there is substantial physical and documentary evidence for the work, and when contemporary alterations and additions are not planned. 237

Restoration is not an appropriate approach for the Knoxville National Cemetery since changes to the cemetery have occurred over an extended period of time (1866-present), and the period of significance extends in perpetuity.

\footnotetext{
236 National Park Service, The Secretary of the Interior's Standards for the Treatment of Historic Properties with Guidelines for the Treatment of Cultural Landscapes, edited by Charles A. Birnbaum with Christine Capella Peters. (Washington, DC: U.S. Department of the Interior, National Park Service, 1996), 3.

237 Ibid., 89-90.
} 


\subsubsection{Reconstruction approach}

Reconstruction is the act or process of using new construction to depict a non-surviving site, landscape, building, structure, or object as it appeared at a specific period of time and in its historic location. The approach is appropriate only when the property's significance during a particular period of time outweighs the potential loss of extant features that characterize other historical periods. In addition, there must be substantial physical and documentary evidence for the work, and the work must be clearly identified as a contemporary re-creation. ${ }^{238}$

Reconstruction is a viable path for maintaining the Knoxville National Cemetery, since this report contains sufficient documentary evidence to reconstruct elements of the landscape that have changed or have been removed from the cemetery over the years-particularly the removed trees, shrubs, and other landscaping features such as benches and paving materials.

\subsubsection{Preservation approach}

Preservation involves applying measures to sustain the existing form, integrity, and materials of a historic property. This approach focuses on stabilizing and protecting extant historic resources, rather than replacing missing elements. It is appropriate when a historic property is essentially intact and does not require extensive repair or replacement; depiction at one particular period of time is not appropriate; and when continuing or new use does not require additions or alterations. ${ }^{239}$

Preservation is a potential management treatment for the Knoxville National Cemetery due to the large amount of intact resources.

\subsubsection{Rehabilitation approach}

Rehabilitation allows repairs, alterations, and additions necessary to enable a compatible use for a property as long as the portions or features that convey the historical, cultural, or architectural values are preserved. This approach is appropriate when depiction at one particular period of time is

\footnotetext{
238 Ibid., 127-129.

239 Ibid., 17-18.
} 
not appropriate, repair or replacement of deteriorated features is necessary, and alterations or additions are needed for a new use. ${ }^{240}$

Rehabilitation is appropriate for Knoxville National Cemetery as the landscape has changed over time, and repair/replacement has historically been necessary, particularly the stone perimeter wall.

\subsection{Management issues and recommendations}

The Knoxville National Cemetery is federally owned and operated by the NCA, and the cemetery is listed on the NRHP. As such, the NCA consults for all undertakings that affect the cemetery with the State of Tennessee Department of Archives and History (MDAH) Historic Preservation Division (HPD). The HPD serves as the State Historic Preservation Officer (SHPO) for consultation purposes.

\subsubsection{Management issues}

Current landscape management issues include the following:

- Visitors are unaware of the landscape design history of the cemetery.

- Current policy of not replacing trees in-kind has negatively impacted the design and feel of the cemetery, especially between the burial sections and the perimeter wall.

- Filling in of grass paths with burial plots has negatively impacted the central circle of plots and the grass paths that define them.

- Removal of hedges and shrubs has negatively impacted the design and feel of the cemetery.

- Lack of landscape plan listing tree species and age and estimated replacement date.

- Tree removal without replacement has led to a lack of tree diversity, and a lack of diversity can lead to massive loss from disease and/or pests.

- Lack of seating areas, which were provided historically.

- Lack of consistent signage in both placement and visual continuity.

- Seeming lack of a monuments and memorials placement plan/protocol and design standards.

- The vacancy of the maintenance and restroom buildings detracts from the cemetery's story. 
- Lack of a rostrum for a cemetery that previously had one also detracts from the cemetery's story.

\subsubsection{Historic landscape recommendations}

The following actions are recommended to address the issues outlined above in section 6.3.1:

- Develop a memorial and monument location plan.

- Develop a management plan that preserves the historic characteristics of the cemetery landscape and its features.

- Develop a planting plan based on historic vegetation planting patterns and plans.

- Review tree removal policy and consider renewing tree planting efforts.

- Review the Section 106 consultation procedures to make sure all undertakings that affect the landscape are included in the consultation process.

- Establish consistent maintenance guidelines for all buildings, structures, and objects.

- Develop a master plan for the next 25-year period.

- Update NCA real property and heritage asset list with corrected construction dates and NRHP eligibility codes. 


\section{Bibliography}

\section{Publications}

Bennett, Ann K. Knoxville-Knox County Metro Planning Commission. "National Register of Historic Places Registration Form - Old Gray Cemetery, Knoxville, Tennessee.” 14 December 1996. https://npgallery.nps.gov/GetAsset/57260983-9faf412e-b78c-7e27f69210ec.

"Ecoregions of Tennessee." http://ecologicalregions.info/data/tn/tn_front.pdf.

"Elevation Finder." https://www.freemaptools.com/elevation-finder.htm.

Harrison, Michael R. "National Cemeteries, Superintendent's Lodges." Historic American Buildings Survey (HABS) No. DC-46. Washington, DC: National Park Service, 2013.

Harrison, Michael R. "National Cemeteries, Rostrums." Historic American Buildings Survey (HABS) No. DC-47. Washington, DC National Park Service, 2013.

Historic American Landscapes Survey. "Lodges and Rostrums Data Recorded by HALS." 2013 Excel Spreadsheet. National Cemetery Administration, U.S. Department of Veterans Affairs, Washington, DC.

"Knoxville." https://en-us.topographic-map.com/maps/nsr/Knoxville/.

Loechl, Suzanne Keith, Susan I. Enscore, Megan Weaver Tooker, and Samuel A. Batzli, "Guidelines for Identifying and Evaluating Historic Military Landscapes." ERDC/CERL TR-09-6. Champaign, IL: ERDC/CERL, 2009.

McGinnis, Robert P. “Historic Cemeteries of Old Knoxville.” Knoxville, TN: selfpublished, 2017.

National Park Service. "National Register Bulletin \#15: How to Apply the National Register Criteria for Evaluation." Washington, DC: U.S. Department of the Interior, National Park Service, 1997.

National Park Service, National Register of Historic Places. "National Register Eligibility of National Cemeteries-a Clarification of Policy.” Washington, DC: NRHP, o8 September 2011. https://www.cem.va.gov/CEM/pdf/Final_Eligibility_of_VA_cemeteries_A_Clarification_of_Polic y_rev.pdf.

National Park Service. "The Secretary of the Interior's Standards for the Treatment of Historic Properties with Guidelines for the Treatment of Cultural Landscapes." Edited by Charles A. Birnbaum with Christine Capella Peters. Washington, DC: U.S. Department of the Interior, National Park Service, 1996.

Neely, Jack and Paul James. Knoxville’s National Cemetery. Knoxville, TN: Knoxville History Project, 2018. 
Poe, Orlando M. Occupation of East Tennessee and the Defense of Knoxville. Reprint of the 1889 edition published by Ostler Printing Co. of Detroit. Knoxville: East Tennessee Historical Society, 1963.

Price, Virginia B. "Historic American Landscapes Survey: Knoxville National Cemetery, Lodge.” HALS No. TN-2-A. Washington, DC: Department of the Interior, 2012.

Sammartino, Therese T. "Knoxville National Cemetery." National Register of Historic Places nomination form. Washington, DC: National Park Service, 1996.

Steere, Edward. "Early Growth of the National Cemetery System." Quartermaster Review, March-April 1953. https://www.qmfound.com/article/early-growth-of-thenational-cemetery-system/.

“Tennessee Planting Zones.” https://gilmour.com/tennessee-planting-zones.

U.S. Department of Agriculture. "Soil Survey of Knox County." https://www.nrcs.usda.gov/Internet/FSE_MANUSCRIPTS/tennessee/knoxTN2006/Knox_TN.pdf

U.S. Department of the Interior. "Knoxville National Cemetery, Knoxville, Tennessee." https://www.nps.gov/nr/travel/national_cemeteries/Tennessee/Knoxville_National_Cemetery.h tml.

U.S. Department of Veterans Affairs (VA), National Cemetery Administration (NCA). "Bivouac of the Dead." Washington, DC: NCA website, 2019. https://www.cem.va.gov/history/bivouac.asp.

. "History of Government Furnished Headstones and Markers." Washington, DC: VA, NCA, 2015. https://www.cem.va.gov/history/hmhist.asp.

. "New Gettysburg Address Tablets for National Cemeteries to Honor Abraham Lincoln Bicentennial." Washington, DC: VA, NCA, 2015. https://www.cem.va.gov/history/LincBic.asp.

U.S. Secretary of War, "Annual Report of the Secretary of War," 43rd Congress, 1st Session, Ex. Doc. No. 1, Part 6, (Washington, DC: Government Printing Office, 1873); National Cemetery Association, "History of Government Furnished Headstones and Markers," Washington, DC: Department of Veterans Affairs NCA, last updated 2015). https://www.cem.va.gov/history/hmhist.asp.

\section{Archival resources}

\section{NARA}

“Addition to Util. Bldg. on NE side." Real Property Form. U.S. National Cemetery, Knoxville, Tenn., 1961. Record Group 15 Records of the Veterans Administration, Entry A1-25 Department of Memorial Affairs, National Cemetery Historical File, Box 24, National Archives and Records Administration (NARA), Washington, DC.

Bellinger, J.B., Major and Quartermaster, U.S. Army. “Orders.” 24 May 1904. Record Group 92 Records of the Office of the Quartermaster General, Entry 601, Records Relating to Functions: Cemeterial, 1828-1929, NARA, Washington, DC. 
Bingham to Quartermaster General. Letter 19 November 1881. Record Group 92 Records of the Office of the Quartermaster General, Entry 576 General Correspondence and Reports Relating to National and Post Cemeteries ("Cemetery File"), 18651914, Box 22, Washington, DC.

"Brief to Major E.B. Kirk." 23 March 1888. Record Group 92 Records of the Office of the Quartermaster General, Entry 576 General Correspondence and Reports Relating to National and Post Cemeteries ("Cemetery File"), 1865-1914, Box 38, NARA, Washington, DC.

"Brief to Major E.B. Kirk.” 29 December 1888. Record Group 92 Records of the Office of the Quartermaster General, Entry 576 General Correspondence and Reports Relating to National and Post Cemeteries (“Cemetery File”), 1865-1914, Box 38, NARA, Washington, DC.

Campbell, J.A.M., Road Commissioner, Knoxville, Tennessee. "Right of Way for Holston Road.” 1886. Record Group 15 Records of the Veterans Administration, Entry A125 Department of Memorial Affairs, National Cemetery Historical File, Box 24, NARA, Washington, DC.

Carlton, Major C.H. "Report of an Inspection of the National Cemetery at Knoxville Tennessee." 23 November 1881. Record Group 92 Records of the Office of the Quartermaster General, Entry 576 General Correspondence and Reports Relating to National and Post Cemeteries ("Cemetery File"), 1865-1914, Box 38, NARA, Washington, DC.

Clarke, C.M., Civil Engineer, Quartermaster Department. Letter to the Quartermaster General, Quartermaster Department. 13 May 1874. Record Group 92 Records of the Office of the Quartermaster General, Entry 576 General Correspondence and Reports Relating to National and Post Cemeteries ("Cemetery File"), 1865-1914, Box 38, NARA, Washington, DC.

. Letter to Major B.C. Card, Quartermaster, U.S. Army. 25 June 1881. Record Group 92 Records of the Office of the Quartermaster General, Entry 576 General Correspondence and Reports Relating to National and Post Cemeteries (“Cemetery File"), 1865-1914, Box 38, NARA, Washington, DC.

. Letter to Major B.C. Card, Quartermaster, U.S. Army. 27 June 1881. Record Group 92 Records of the Office of the Quartermaster General, Entry 576 General Correspondence and Reports Relating to National and Post Cemeteries (“Cemetery File”), 1865-1914, Box 38, NARA, Washington, DC.

Damron, John. "Conveyance of Land." 10 June 1867. Record Group 15 Records of the Veterans Administration, Entry A1-25 Department of Memorial Affairs, National Cemetery Historical File, Box 24, NARA, Washington, DC.

Davis, W.H., Inspector General. Letter to Inspector General, Headquarters, U.S. Army, 16 April 1878. Record Group 92 Records of the Office of the Quartermaster General, Entry 649 Reports of Inspection-National Cemeteries, 1874-1883, Box 1, NARA, Washington, DC. 
Donelson, Lt. Col. D.K., Maj. M.J. Gill, and Chas. J. Dorman, Management \& Inspection Branch, Memorial Division, Quartermaster Corps. "Report of Official Travel." 10 October 1946. Record Group 15 Records of the Veterans Administration, Entry A1-25 Department of Memorial Affairs, National Cemetery Historical File, Box 24, NARA, Washington, DC.

Doolittle, L.S., Superintendent, Knoxville National Cemetery. Letter to Quartermaster General, U.S. Army. 27 April 1909. Record Group 92 Records of the Office of the Quartermaster General, Entry 576 General Correspondence and Reports Relating to National and Post Cemeteries ("Cemetery File"), 1865-1914, Box 38, NARA, Washington, DC.

Eddy, A.R., Chief Quartermaster, Department of the South. "Proposals.” 10 April 1871. Record Group 92 Records of the Office of the Quartermaster General, Entry 576 General Correspondence and Reports Relating to National and Post Cemeteries (“Cemetery File"), 1865-1914, Box 38, NARA, Washington, DC.

"Enclosing Walls and Fences." Real Property Form. U.S. National Cemetery, Knoxville, Tenn. 1967. Record Group 15 Records of the Veterans Administration, Entry A125 Department of Memorial Affairs, National Cemetery Historical File, Box 24, NARA, Washington, DC.

"Entrance Gates.” Real Property Form. U.S. National Cemetery, Knoxville, Tenn. 1962. Record Group 15 Records of the Veterans Administration, Entry A1-25 Department of Memorial Affairs, National Cemetery Historical File, Box 24, NARA, Washington, DC;

“Flagstaff.” Real Property Form. U.S. National Cemetery, Knoxville, Tenn. 1945. Record Group 15 Records of the Veterans Administration, Entry A1-25 Department of Memorial Affairs, National Cemetery Historical File, Box 24, NARA, Washington, DC.

"Flagstaff (cont'd).” Real Property Form. U.S. National Cemetery, Knoxville, Tenn. 1958. Record Group 15 Records of the Veterans Administration, Entry A1-25 Department of Memorial Affairs, National Cemetery Historical File, Box 24, NARA, Washington, DC.

Folsom, Brevet Major C.W., Assistant Quartermaster. "Inspection Report of Cemeteries at Knoxville Tennessee.” 4 April 1867. Record Group 92 Records of the Office of the Quartermaster General, Entry 576 General Correspondence and Reports Relating to National and Post Cemeteries ("Cemetery File"), 1865-1914, Box 38, NARA, Washington, DC.

Gall, James Jr., Civil Engineer, Quartermaster Department. Letter to the Quartermaster General, Quartermaster Department. 16 February 1876. Record Group 92 Records of the Office of the Quartermaster General, Entry 576 General Correspondence and Reports Relating to National and Post Cemeteries ("Cemetery File"), 1865-1914, Box 38, NARA, Washington, DC.

. Letter to Colonel Rockwell, U.S. Army. 15 February 1878. Record Group 92 Records of the Office of the Quartermaster General, Entry 576 General Correspondence and Reports Relating to National and Post Cemeteries (“Cemetery File"), 1865-1914, Box 38, NARA, Washington, DC. 
."Report on Inspection of the Chattanooga and Knoxville National Cemeteries." 11 June 1878. Record Group 92 Records of the Office of the Quartermaster General, Entry 576 General Correspondence and Reports Relating to National and Post Cemeteries (“Cemetery File"), 1865-1914, Box 38, NARA, Washington, DC.

“Grounds.” Real Property Form. U.S. National Cemetery, Knoxville, Tenn. 1957-1970. Record Group 15 Records of the Veterans Administration, Entry A1-25 Department of Memorial Affairs, National Cemetery Historical File, Box 24, NARA, Washington, DC.

“Inspection Report, Knoxville Cemetery.” 28 August 1874. Record Group 92 Records of the Office of the Quartermaster General, Entry 649 Reports of InspectionNational Cemeteries, 1874-1883, Box 1, NARA, Washington, DC.

Jones, Matthew H., Quartermaster, Seventh Army. Letter to Quartermaster General, Washington, DC. 17 February 1947. Record Group 15 Records of the Veterans Administration, Entry A1-25 Department of Memorial Affairs, National Cemetery Historical File, Box 24, NARA, Washington, DC.

Keel, Owen H., Superintendent. Letter to Commanding General, Seventh Army. 14 February 1947. Record Group 15 Records of the Veterans Administration, Entry A1-25 Department of Memorial Affairs, National Cemetery Historical File, Box 24, NARA, Washington, DC.

. "Questionnaire-National Cemeteries." 28 May 1953. Record Group 15 Records of the Veterans Administration, Entry A1-25 Department of Memorial Affairs, National Cemetery Historical File, Box 24, NARA, Washington, DC.

“Knoxville National Cemetery Inspection.” November 1944. Record Group 15 Records of the Veterans Administration, Entry A1-25 Department of Memorial Affairs, National Cemetery Historical File, Box 24, NARA, Washington, DC.

“Knoxville Tenn. Nat. Cemetery \& Road." Undated. Record Group 15 Records of the Veterans Administration, Entry A1-25 Department of Memorial Affairs, National Cemetery Historical File, Box 24, NARA, Washington, DC.

"Knoxville, Tennessee, National Cemetery, (Second Class)." 1893. Record Group 15 Records of the Veterans Administration, Entry A1-25 Department of Memorial Affairs, National Cemetery Historical File, Box 24, NARA, Washington, DC.

“Knoxville, Tennessee, National Cemetery, (Second Class).” 1894. Record Group 15 Records of the Veterans Administration, Entry A1-25 Department of Memorial Affairs, National Cemetery Historical File, Box 24, National Archives and Records Administration, Washington, DC.

“Knoxville, Tennessee, Project 311, Landscape.” 2 August 1945. Record Group 15 Records of the Veterans Administration, Entry A1-25 Department of Memorial Affairs, National Cemetery Historical File, Box 24, NARA, Washington, DC.

Larson, H.B., Quartermaster Department. Letter to the Quartermaster General. 30 March 1877. Record Group 92 Records of the Office of the Quartermaster General, Entry 576 General Correspondence and Reports Relating to National and Post Cemeteries ("Cemetery File"), 1865-1914, Box 38, NARA, Washington, DC. 
"Letter to Major Kirk for a more exact estimate.” 17 December 1888. Record Group 92 Records of the Office of the Quartermaster General, Entry 576 General Correspondence and Reports Relating to National and Post Cemeteries (“Cemetery File”), 1865-1914, Box 38, NARA, Washington, DC.

"Letter to Major Scully." 6 January 1890. Record Group 92 Records of the Office of the Quartermaster General, Entry 576 General Correspondence and Reports Relating to National and Post Cemeteries ("Cemetery File"), 1865-1914, Box 38, NARA, Washington, DC.

Letter from Captain Russell Williams, Office of the Acting Quartermaster, Atlanta, GA to the Quartermaster General, Quartermaster Department, Washington, DC. 28 February 1880. Record Group 92 Records of the Office of the Quartermaster General, Entry 576 General Correspondence and Reports Relating to National and Post Cemeteries (“Cemetery File”), 1865-1914, Box 38, NARA, Washington, DC.

"Lodge.” Real Property Form. U.S. National Cemetery, Knoxville, Tenn. 1934. Record Group 15 Records of the Veterans Administration, Entry A1-25 Department of Memorial Affairs, National Cemetery Historical File, Box 24, NARA, Washington, DC.

Meigs, Montgomery C., Quartermaster General. Letter to Major A.R. Eddy, Chief Quartermaster, Department of the South. 20 June 1871. Record Group 92 Records of the Office of the Quartermaster General, Entry 576 General Correspondence and Reports Relating to National and Post Cemeteries (“Cemetery File"), 1865-1914, Box 38, NARA, Washington, DC.

. Letter to Lieutenant George S. Heys. 8 August 1878. Record Group 92 Records of the Office of the Quartermaster General, Entry 576 General Correspondence and Reports Relating to National and Post Cemeteries ("Cemetery File"), 18651914, Box 38, NARA, Washington, DC.

"Monthly Report of Superintendent of the National Cemetery at Knoxville, Tenn." November 1873 - June 1876. Record Group 92 Records of the Office of the Quartermaster General, Entry 643 Records Relating to Functions: Cemeterial, 1828-1929, Box 1, NARA, Washington, DC.

"National Cemetery." 1 August 1947. Record Group 15 Records of the Veterans Administration, Entry A1-25 Department of Memorial Affairs, National Cemetery Historical File, Box 24, NARA, Washington, DC.

“National Cemetery Data.” Knoxville National Cemetery. 5 October 1959. Record Group 15 Records of the Veterans Administration, Entry A1-25 Department of Memorial Affairs, National Cemetery Historical File, Box 24, NARA, Washington, DC.

Nicholson, M., Civil Engineer. Letter to Major J.W. Scully, Quartermaster Department. 24 December 1889. Record Group 92 Records of the Office of the Quartermaster General, Entry 576 General Correspondence and Reports Relating to National and Post Cemeteries ("Cemetery File"), 1865-1914, Box 38, NARA, Washington, DC. 
. Letter to Major J.W. Scully, Quartermaster Department. 5 March 1890. Record Group 92 Records of the Office of the Quartermaster General, Entry 576 General Correspondence and Reports Relating to National and Post Cemeteries (“Cemetery File”), 1865-1914, Box 38, NARA, Washington, DC.

Office of National Cemeteries. Letter to Quartermaster General, Quartermaster Department. 4 February 1875. Record Group 92 Records of the Office of the Quartermaster General, Entry 225 Consolidated Correspondence File, 1794-1915, Box 1058, NARA, Washington, DC.

Office of the Quartermaster General. Letter to Mr. Bearden and Mr. Patterson. 7 July 1873. Record Group 92 Records of the Office of the Quartermaster General, Entry 576 General Correspondence and Reports Relating to National and Post Cemeteries (“Cemetery File”), 1865-1914, Box 38, NARA, Washington, DC;

Owen, W.H., Quartermaster Corps. Letter to Lt. Colonel R.N. Batchelder, Deputy Quartermaster General. 7 May 1886. Record Group 92 Records of the Office of the Quartermaster General, Entry 576 General Correspondence and Reports Relating to National and Post Cemeteries (“Cemetery File"), 1865-1914, Box 38, NARA, Washington, DC.

. Manuscript notes. 9 February 1887. Record Group 92 Records of the Office of the Quartermaster General, Entry 576 General Correspondence and Reports Relating to National and Post Cemeteries ("Cemetery File"), 1865-1914, Box 38, NARA, Washington, DC.

"Plan of the National Cemetery at Knoxville Tennessee." 1866. Record Group 92 Records of the Office of the Quartermaster General, Entry 576 General Correspondence and Reports Relating to National and Post Cemeteries ("Cemetery File"), 18651914, Box 38, NARA, Washington, DC.

Quartermaster General's Office. "Remarks of the Quartermaster General on Report of the Soldiers Cemetery at Knoxville, Tenn.” April 1866. Record Group 92 Records of the Office of the Quartermaster General, Entry 576 General Correspondence and Reports Relating to National and Post Cemeteries ("Cemetery File"), 1865-1914, Box 38, NARA, Washington, DC.

"Questionnaire for Superintendents, Knoxville National Cemetery." 18 November 1958. Record Group 15 Records of the Veterans Administration, Entry A1-25 Department of Memorial Affairs, National Cemetery Historical File, Box 24, NARA, Washington, DC.

Ramage, William J. Letter to the Quartermaster General, U.S.A. 7 February 1896. Record Group 15 Records of the Veterans Administration, Entry A1-25 Department of Memorial Affairs, National Cemetery Historical File, Box 24, NARA, Washington, DC.

"Report of Brevet Major W. A. Wainwright, Office of Assistant Quartermaster." 24 July 1866. Record Group 92 Records of the Office of the Quartermaster General, Entry 576 General Correspondence and Reports Relating to National and Post Cemeteries ("Cemetery File"), 1865-1914, Box 38, NARA, Washington, DC. 
Ridge, Thomas. "Monthly Report of the Condition of Knoxville National Cemetery at Knoxville, Tenn, for the Month of September 1872." 1 October 1872. Record Group 92 Records of the Office of the Quartermaster General, Entry 576 General Correspondence and Reports Relating to National and Post Cemeteries ("Cemetery File"), 1865-1914, Box 38, NARA, Washington, DC.

, Superintendent. "Classified Statement of Interments in the Knoxville, Tenn. National Cemetery, June 30, 1875." Record Group 92 Records of the Office of the Quartermaster General, Entry 576 General Correspondence and Reports Relating to National and Post Cemeteries ("Cemetery File"), 1865-1914, Box 38, NARA, Washington, DC.

, Superintendent, Knoxville National Cemetery. Letter to Major J.W. Scully, Quartermaster Department. 7 December 1891. Record Group 92 Records of the Office of the Quartermaster General, Entry 576 General Correspondence and Reports Relating to National and Post Cemeteries (“Cemetery File”), 1865-1914, Box 38, NARA, Washington, DC.

“Roads.” Real Property Form. U.S. National Cemetery, Knoxville, Tenn. 1957. Record Group 15 Records of the Veterans Administration, Entry A1-25 Department of Memorial Affairs, National Cemetery Historical File, Box 24, NARA, Washington, DC.

“Roads (Cont'd).” Real Property Form. U.S. National Cemetery, Knoxville, Tenn. 1967. Record Group 15 Records of the Veterans Administration, Entry A1-25 Department of Memorial Affairs, National Cemetery Historical File, Box 24, NARA, Washington, DC.

Robbins, Captain S.M. "Report on National Cemetery Knoxville Tennessee.” 20 June 1877. Record Group 92 Records of the Office of the Quartermaster General, Entry 576 General Correspondence and Reports Relating to National and Post Cemeteries (“Cemetery File”), 1865-1914, Box 38, NARA, Washington, DC.

“Rostrum.” Real Property Form. U.S. National Cemetery, Knoxville, Tenn. 1932. Record Group 15 Records of the Veterans Administration, Entry A1-25 Department of Memorial Affairs, National Cemetery Historical File, Box 24, NARA, Washington, DC.

"Specifications for changes and additions to repairs of Cemetery road.” 11 January 1889. Record Group 92 Records of the Office of the Quartermaster General, Entry 576 General Correspondence and Reports Relating to National and Post Cemeteries (“Cemetery File"), 1865-1914, Box 38, NARA, Washington, DC.

Superintendent, Knoxville National Cemetery. "Questionnaire on Status and History of Cemetery.” to Quartermaster General, U.S. Army. 8 January 1889. Record Group 92 Records of the Office of the Quartermaster General, Entry 576 General Correspondence and Reports Relating to National and Post Cemeteries (“Cemetery File”), 1865-1914, Box 38, NARA, Washington, DC.

“Superintendent's Lodge (Cont'd).” Real Property Form. U.S. National Cemetery, Knoxville, Tenn. 1957. Record Group 15 Records of the Veterans Administration, Entry A1-25 Department of Memorial Affairs, National Cemetery Historical File, Box 24, NARA, Washington, DC. 
Swords, Major General Thomas, Assistant Quartermaster General, Department of the Cumberland, United States Army. "Consolidated Monthly Report of Progress on the National Cemeteries in the Department of the Cumberland for the Month of January 1968.” January 1868. Record Group 15 Records of the Veterans Administration, Entry A1-25 Department of Memorial Affairs, National Cemetery Historical File, Box 24, NARA, Washington, DC.

"Tool Room and Public Toilets." Real Property Form. U.S. National Cemetery, Knoxville, Tenn. undated. Record Group 15 Records of the Veterans Administration, Entry A1-25 Department of Memorial Affairs, National Cemetery Historical File, Box 24, NARA, Washington, DC.

Townsend, E.D., Adjutant General, War Department. "General Orders No. 6.” 18 June 1873. Record Group 92 Records of the Office of the Quartermaster General, Entry 576 General Correspondence and Reports Relating to National and Post Cemeteries ("Cemetery File"), 1865-1914, Box 38, NARA, Washington, DC;

"Utility Building." Real Property Form. U.S. National Cemetery, Knoxville, Tenn. 1963. Record Group 15 Records of the Veterans Administration, Entry A1-25 Department of Memorial Affairs, National Cemetery Historical File, Box 24, NARA, Washington, DC.

“Utility Building No. 2.” Real Property Form. U.S. National Cemetery, Knoxville, Tenn. Undated. Record Group 15 Records of the Veterans Administration, Entry A1-25 Department of Memorial Affairs, National Cemetery Historical File, Box 24, NARA, Washington, DC

"Veteran to Fill Final Grave in Old Cemetery." The Knoxville Journal, 20 April 1973. Record Group 15 Records of the Veterans Administration, Entry A1-25 Department of Memorial Affairs, National Cemetery Historical File, Box 24, NARA, Washington, DC.

Wainwright, W.A. "Report on Conditions of the Knoxville Soldiers Cemetery." 11 May 1866. Record Group 92 Records of the Office of the Quartermaster General, Entry 576 General Correspondence and Reports Relating to National and Post Cemeteries ("Cemetery File”), 1865-1914, Box 38, NARA, Washington, DC.

Wainwright, W.A. "Historical Report of the National Cemetery at Knoxville, East Tennessee.” 25 January 1867. Record Group 92 Records of the Office of the Quartermaster General, Entry 576 General Correspondence and Reports Relating to National and Post Cemeteries ("Cemetery File"), 1865-1914, Box 38, NARA, Washington, DC.

War Department. "Questionnaire for Superintendents.” 1 March 1909. Record Group 92 Records of the Office of the Quartermaster General, Entry 576 General Correspondence and Reports Relating to National and Post Cemeteries (“Cemetery File”), 1865-1914, Box 38, NARA, Washington, DC.

Whitman, Brevet Major E.B., Superintendent National Cemeteries, Assistant Quartermaster. "Report on National Cemeteries No 10, Knoxville." 11 November 1867. Record Group 92 Records of the Office of the Quartermaster General, Entry 576 General Correspondence and Reports Relating to National and Post Cemeteries ("Cemetery File"), 1865-1914, Box 38, NARA, Washington, DC. 
Letter to Brevet Major General Thomas Swords. 5 August 1868. Record Group 92, Records of the Office of the Quartermaster General, Entry 576 General Correspondence and Reports Relating to National and Post Cemeteries (“Cemetery File”), 1865-1914, Box 22, NARA, Washington, DC.

."Report of E.B. Whitman, Superintendent National Cemeteries, Dept. of the Cumberland, Embracing Explorations of Battle fields, Cemeteries, and places where Union Dead were interred, Selection, Establishment, and Completion of National Cemeteries with Tables of Mortuary Statistics, Views and Plans.” Louisville, KY: Mil. Div. of the Tennessee. 10 May 1869. Record Group 92 Records of the Office of the Quartermaster General, Entry 646 Report of E.B. Whitman 1868, Box 1, NARA, Washington, DC.

Wolf, J.L. Letter to Superintendent, Knoxville National Cemetery. 12 February 1947. Record Group 15 Records of the Veterans Administration, Entry A1-25 Department of Memorial Affairs, National Cemetery Historical File, Box 24, NARA, Washington, DC.

\section{National Cemetery Administration collection}

"Application for General Operating Expense Construction and Repair Project and Minor Construction Project: Knoxville National Cemetery." 9 January 1985. Folder: "Knoxville National Cemetery Project No. 788-855-002-FY86," NCA Archives, Washington, DC.

Beller, Bob R., Director, Cemetery Service, Veterans Administration. "Develop New Gravesites, Project No. 788-855-001.” 17 September 1984. Folder: "Knoxville National Cemetery - General," NCA Archives, Washington, DC.

. Memorandum to Director, Office of Planning, Veterans Administration. 3 January 1986. Folder: "Knoxville National Cemetery - General," NCA Archives, Washington, DC.

. "Trip Report Response - Knoxville and Mountain Home National Cemeteries." 21 November 1986. Folder: "Knoxville National Cemetery Project No. 788-855002-FY86," NCA Archives, Washington, DC.

Cannon, Curtis L. "Report of Contact." 26 February 1986. Folder: "Knoxville National Cemetery - General," NCA Archives, Washington, DC.

Cemetery Branch, Office, Chief of Support Services, Department of the Army. "Knoxville National Cemetery, Knoxville, Tennessee, Planting Plan.” 19 May 1966. Plan Number ML-148.1, Sheet 1 of 2, VA, NCA Archives.

- “Knoxville National Cemetery, Knoxville, Tennessee, Planting Plan.” 19 May 1966. Plan Number ML-148.1, Sheet 2 of 2, VA, NCA Archives.

Ebel, Wilfred L. "Trip Report.” 16 June 1988. Folder: "Knoxville National Cemetery General," NCA Archives, Washington, DC.

"EMIS Construction Program - Estimate Worksheet Project VG21P-1772." 13 March 1985. Folder: "Develop New Gravesites Project," VA NCA Archives, Washington, DC. 
“Historical Summary.” 11 January 1936. Folder: Audit No. 462, NCA Archives, Washington, DC.

Jensen, Margaret B., Technical Service Division. "Trip Report - Knoxville National Cemetery.” 26 February 1988. Folder: "Knoxville National Cemetery Project No. 788-855-002-FY86," NCA Archives, Washington, DC.

“The Knoxville Cemeteries.” Knoxville Daily Tribune. 14 August 1881. In Folder:

"Knoxville," VA NCA Archives, Washington, DC.

"Knoxville National Cemetery Lodge Technical Assessment."17 February 1988. Folder: "Knoxville National Cemetery Project No. 788-855-002-FY86," NCA Archives, Washington, DC.

"Many Graves Are Added to U.S. Cemetery." Knoxville News-Sentinel. 1948. In Folder: "Knoxville," VA, NCA, Washington, DC.

Memorandum, Field Operations, NCA. 19 April 1990. Folder: "Knoxville,” NCA Archives, Washington, DC.

Mollenhoff, Gjore J., Historic Preservation Officer. Letter to Herbert L. Harper, Tennessee Historical Commission. 13 January 1986. Folder: "Knoxville National Cemetery - General," NCA Archives, Washington, DC.

"National Cemetery Data: Knoxville N/C." 1978. Folder: "Knoxville National Cemetery General," NCA Archives, Washington, DC.

Rapp, Roger R., Director, Field Operations, Veterans Administration. Letter to Director, VA Medical Center, Mountain Home, TN. 12 April 1989. Folder: "Knoxville National Cemetery Project No. 788-855-002-FY86," NCA Archives, Washington, DC.

"Soldiers' Tomb-Stones.” Knoxville Daily Tribune. 6 April 1876. In Folder: “Knoxville,” VA NCA Archives, Washington, DC.

"South Atlantic Division Historical File Summary." Undated. Folder: Audit No. 462, NCA Archives, Washington, DC.

"VA Construction Project Management Information Report." 12 June 1986. Folder: "Knoxville National Cemetery Project No. 788-855-002-FY86," NCA Archives, Washington, DC.

Vaughn \& Melton, Engineers-Architects. "Preliminary Engineering Report: Resurface Roads, Knoxville National Cemetery, Knoxville, Tennessee.” 19 April 1989. In Folder: 'Knoxville National Cemetery, FY89 Minor Resurface Roads," VA NCA Archives, Washington, DC.

Veterans Administration, National Cemetery Division. "150 th Anniversary National Cemeteries of the Civil War 2012 planner.” 2011. NCA Archives, Washington, DC.

Veterans Administration. "Design Requirements for Renovate Maintenance Building at Knoxville National Cemetery." 5 November 1984. Folder: "Knoxville National Cemetery Project No. 788-855-002-FY86," NCA Archives, Washington, DC. 
Veterans Administration. "Knoxville National Cemetery." 1977. Folder: "Knoxville National Cemetery - General," NCA Archives, Washington, DC.

\section{Other sources:}

Hooker, William E. III. E-mail correspondence with Susan Enscore, ERDC-CERL. 25 June 2020.

"Ridge." The Knoxville Journal and Tribune. 6 September 1918. In the East Tennessee History Center McClurg Collection, Knoxville, Tennessee.

Undated newspaper clipping in the East Tennessee History Center McClurg Collection, Knoxville, Tennessee.

University of TN Knoxville, Special Collections Library, Harold S. Fink Papers, 19591970. Box 2, Folder: Folder IX, MS-779, "Knoxville National Cemetery, Old Gray Cemetery," 1966. 


\section{Acronyms and Abbreviations}

\begin{tabular}{|l|l|}
\hline Abbreviation & Term \\
\hline ERDC-CERL & $\begin{array}{l}\text { Engineer Research and Development Center, Construction Engineering } \\
\text { Research Laboratory }\end{array}$ \\
\hline G.A.R. & Grand Army of the Republic \\
\hline HPD & Historic Preservation Division \\
\hline MA & Memorial Area \\
\hline MDAH & (State of Tennessee) Department of Archives and History \\
\hline MIA & Missing in action \\
\hline NARA & National Archives and Records Administration \\
\hline NCA & National Cemetery Administration \\
\hline NCS & National Cemeteries System \\
\hline NHPA & National Historic Preservation Act of 1966 \\
\hline NRHP & National Register of Historic Places \\
\hline POW & Prisoner of war \\
\hline SHPO & State Historic Preservation Officer \\
\hline
\end{tabular}




\section{Unit Conversion Factors}

\begin{tabular}{|l|c|l|}
\hline Multiply & By & To Obtain \\
\hline acres & $4,046.873$ & square meters \\
\hline feet & 0.3048 & meters \\
\hline gallons (U.S. liquid) & $3.785412 \mathrm{E}-03$ & cubic meters \\
\hline inches & 0.0254 & meters \\
\hline square feet & 0.09290304 & square meters \\
\hline square yards & 0.8361274 & square meters \\
\hline yards & 0.9144 & meters \\
\hline
\end{tabular}




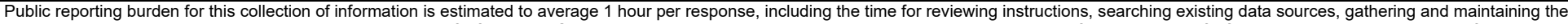

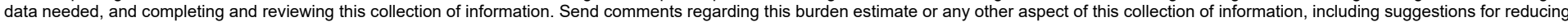

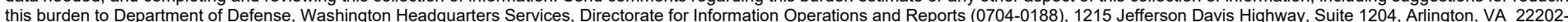

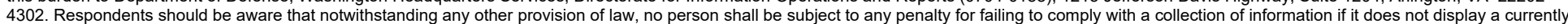
valid OMB control number. PLEASE DO NOT RETURN YOUR FORM TO THE ABOVE ADDRESS.
1. REPORT DATE (DD-MM-YYYY)
2. REPORT TYPE Final
March 2021

\section{TITLE AND SUBTITLE}

Historic Landscape Inventory for Knoxville National Cemetery

Susan I. Enscore, Adam D. Smith, and Megan W. Tooker

\section{5d. PROJECT NUMBER}

467132

5e. TASK NUMBER

5f. WORK UNIT NUMBER

8. PERFORMING ORGANIZATION REPORT NUMBER

ERDC/CERL TR-21-11

U.S. Army Engineer Research and Development Center (ERDC)

Construction Engineering Research Laboratory (CERL)

PO Box 9005

Champaign, IL 61826-9005

\section{SPONSORING / MONITORING AGENCY NAME(S) AND ADDRESS(ES)}

10. SPONSOR/MONITOR'S ACRONYM(S)

U.S. Department of Veterans Affairs

National Cemetery Administration

Washington, DC 20420

11. SPONSOR/MONITOR'S REPORT NUMBER(S)

\section{DISTRIBUTION / AVAILABILITY STATEMENT}

Approved for public release; distribution is unlimited.

\section{SUPPLEMENTARY NOTES}

\section{ABSTRACT}

This project was undertaken to provide the U.S. Department of Veterans Affairs National Cemetery Administration with a cultural landscape survey of Knoxville National Cemetery. The 9.8-acre cemetery is located within the city limits of Knoxville, Tennessee, and contains more than 9,000 burials. Knoxville National Cemetery was placed on the National Register of Historic Places on 12 September 1996, as part of a multiple-property submission for Civil War Era National Cemeteries.

The National Cemetery Administration tasked the U.S. Army Engineer Research and Development Center-Construction Engineering Research Laboratory (ERDC-CERL) to inventory and assess the cultural landscape at Knoxville National Cemetery through creation of a landscape development context, a description of current conditions, and an analysis of changes over time to the cultural landscape. All landscape features were included in the survey because according to federal policy on National Cemeteries, all national cemetery landscape features are considered to be contributing elements.

\section{SUBJECT TERMS}

National cemeteries--United States, Knoxville (Tenn.), Historic preservation, Landscape protection, Cultural property--Protection

\section{SECURITY CLASSIFICATION OF:}

a. REPORT
Unclassified

\section{b. ABSTRACT}

Unclassified

17. LIMITATION
OF ABSTRACT
SAR

C. THIS PAGE

Unclassified
8. NUMBER OF PAGES

334 19a. NAME OF RESPONSIBLE PERSON

19b. TELEPHONE NUMBER

(include area code) 